Fall 1977

\title{
1977 Miracle Yearbook
}

\section{Cedarville College}

Follow this and additional works at: https://digitalcommons.cedarville.edu/yearbooks

Part of the Higher Education Commons, Organizational Communication Commons, and the Public Relations and Advertising Commons

\section{Recommended Citation}

Cedarville College, "1977 Miracle Yearbook" (1977). Yearbooks. 5.

https://digitalcommons.cedarville.edu/yearbooks/5

This Book is brought to you for free and open access by DigitalCommons@Cedarville, a service of the Centennial Library. It has been accepted for inclusion in Yearbooks by an authorized administrator of DigitalCommons@Cedarville. For more information, please contact digitalcommons@cedarville.edu. 


\section{MJRACLE}

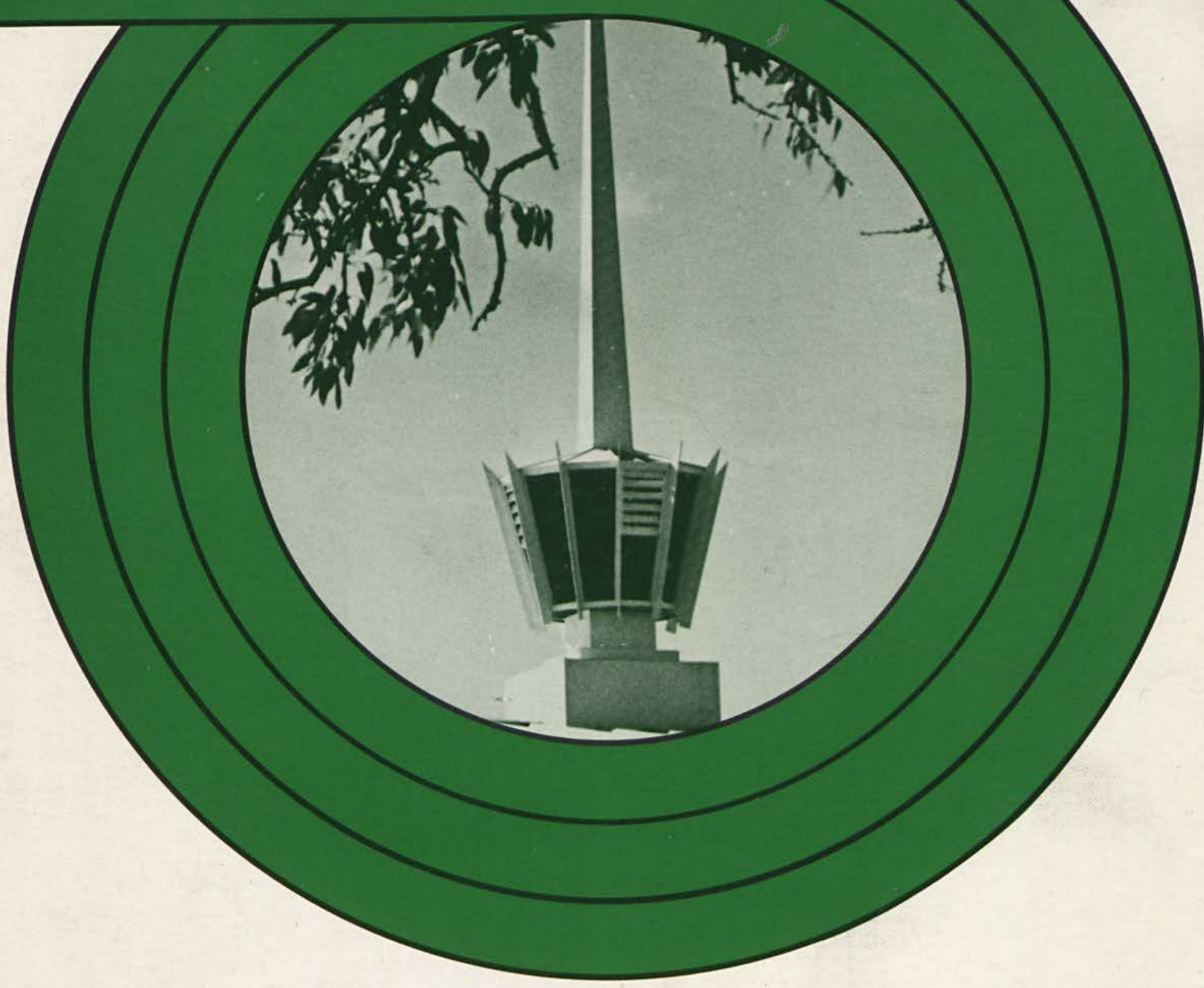



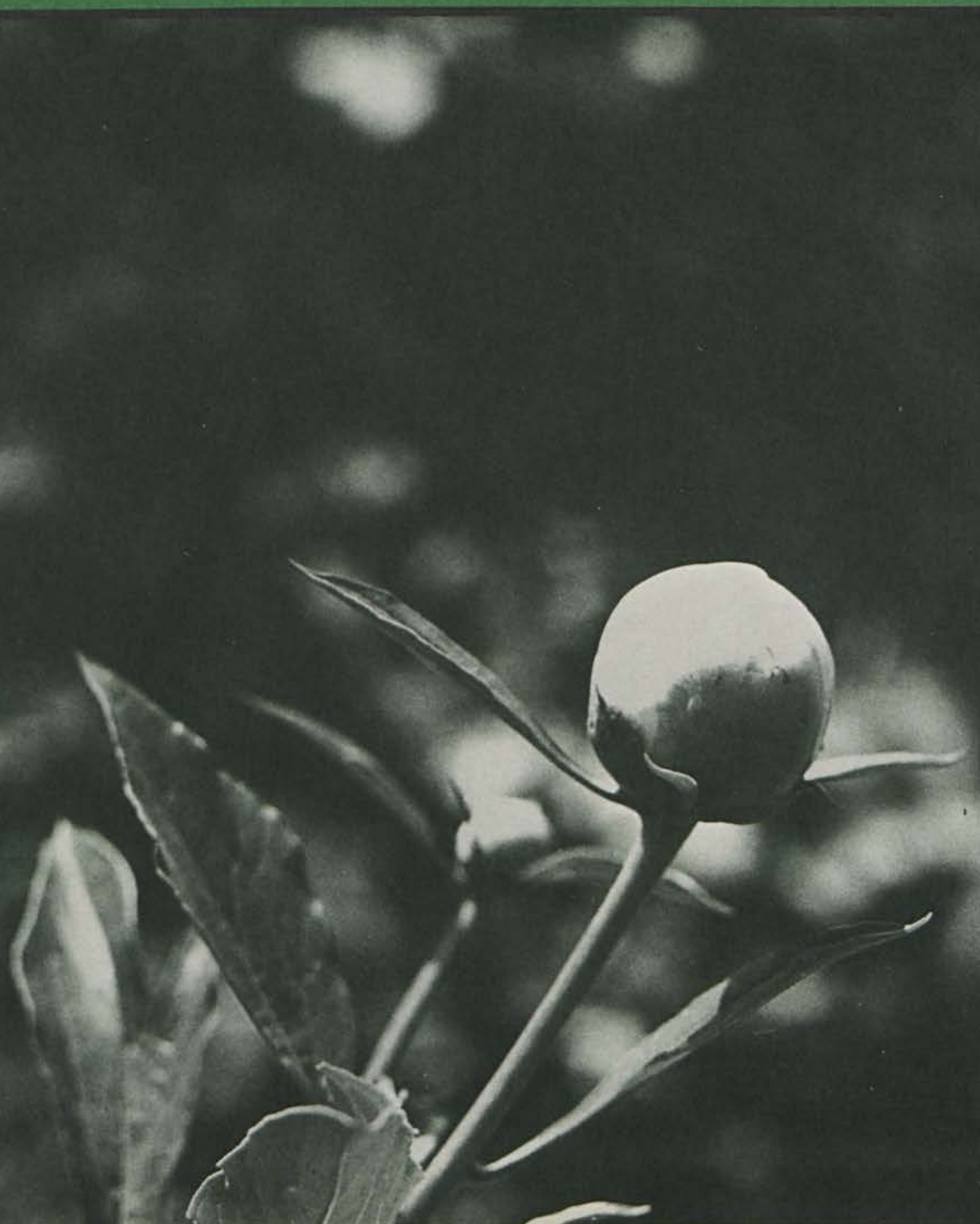
Be still,

and know that $J$ am God 


\section{The}
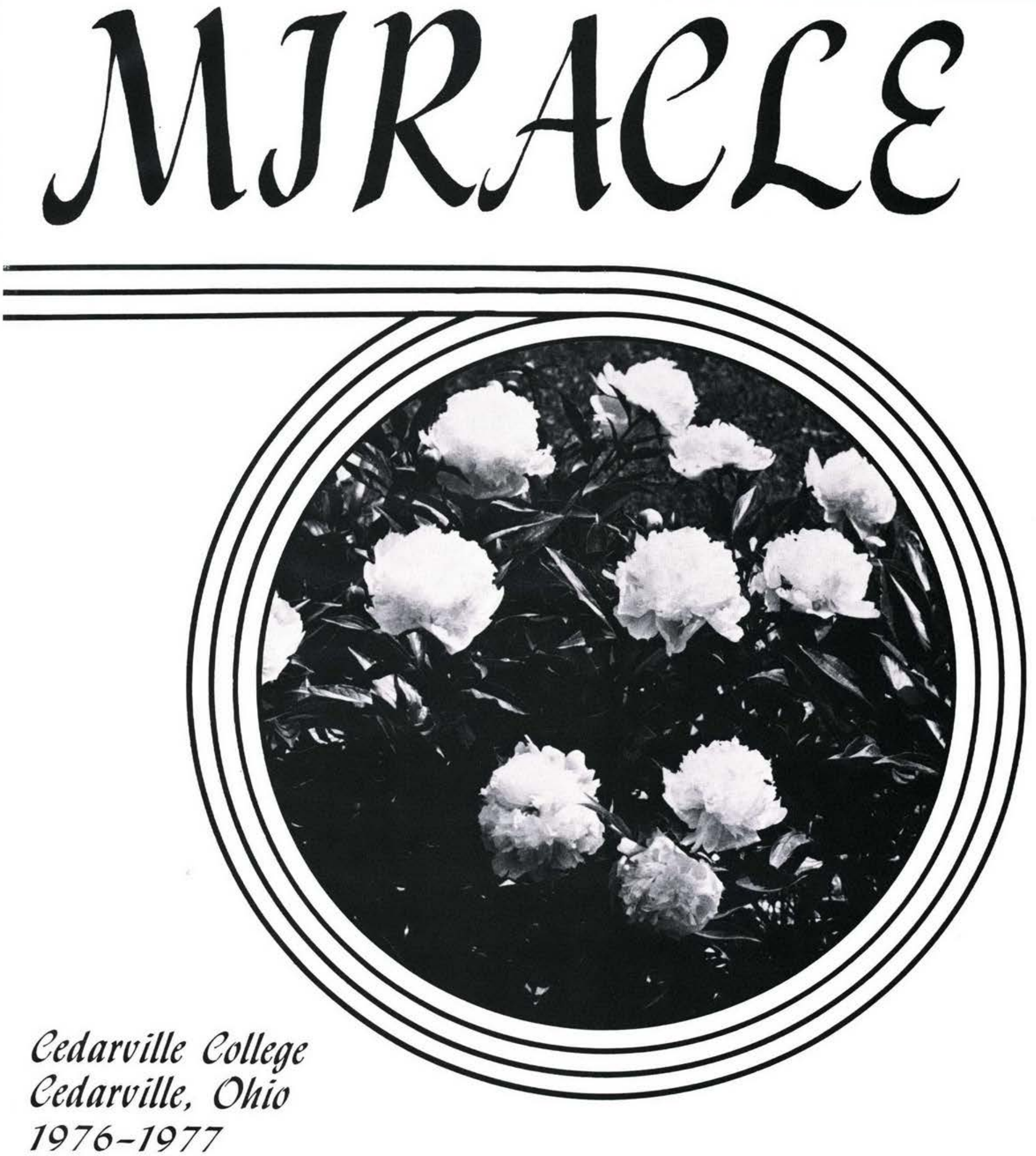


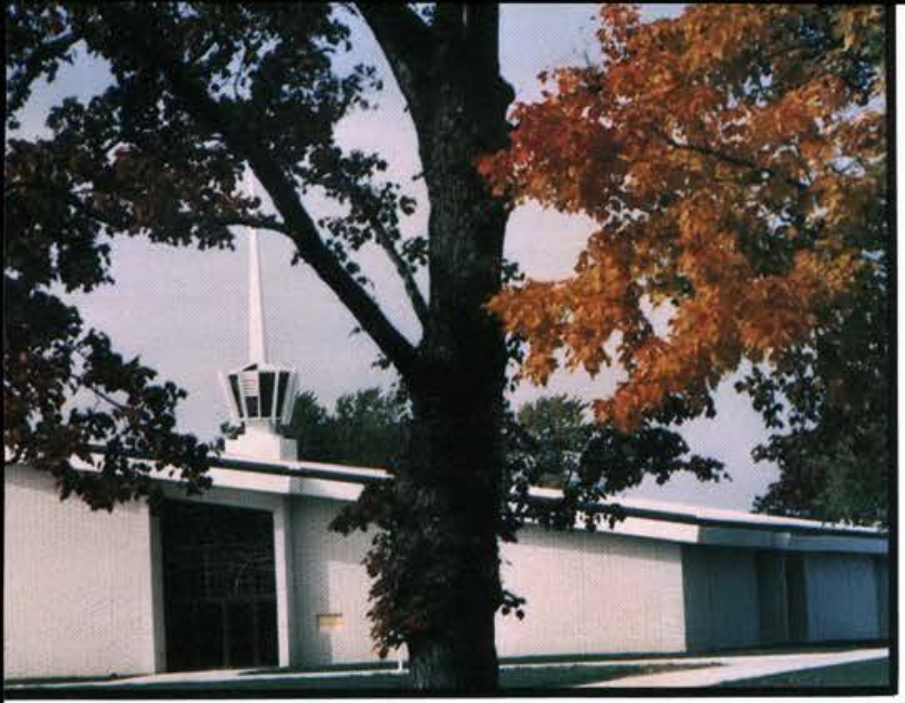

\section{जा}

CEDARVILLE C OLLEGE

A BAPTIST COLLEGE

OF ARTS AND SCIENCES

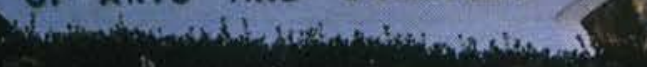

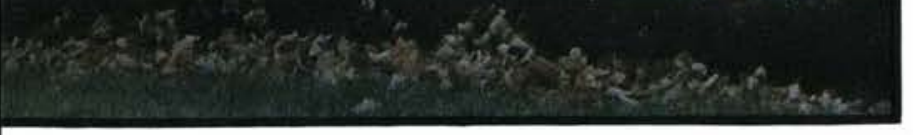

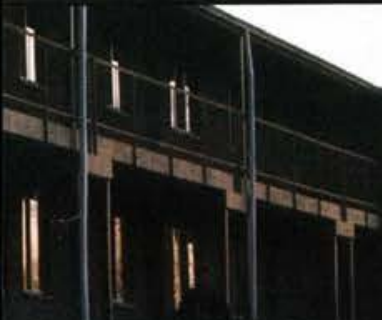
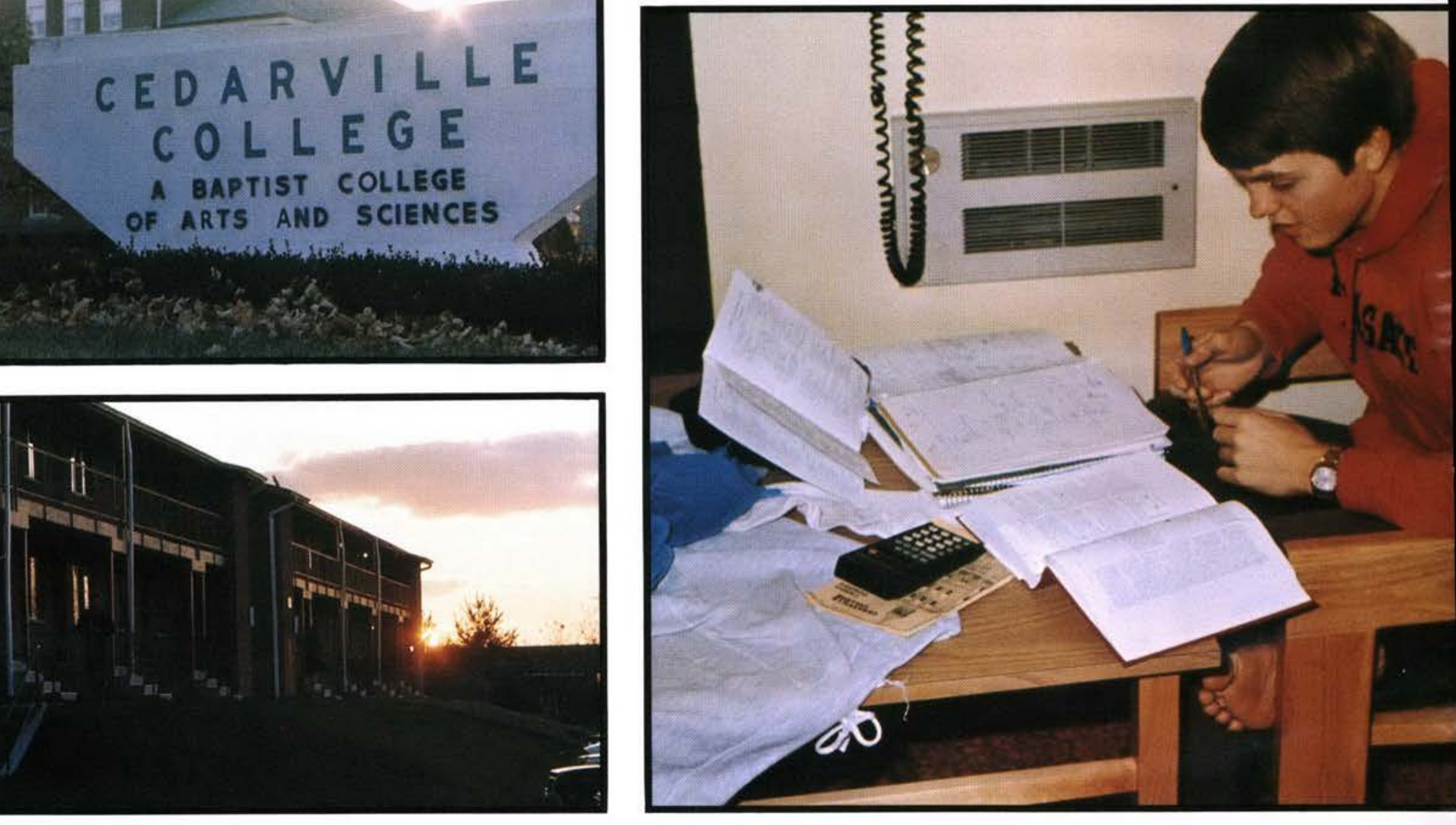

s.

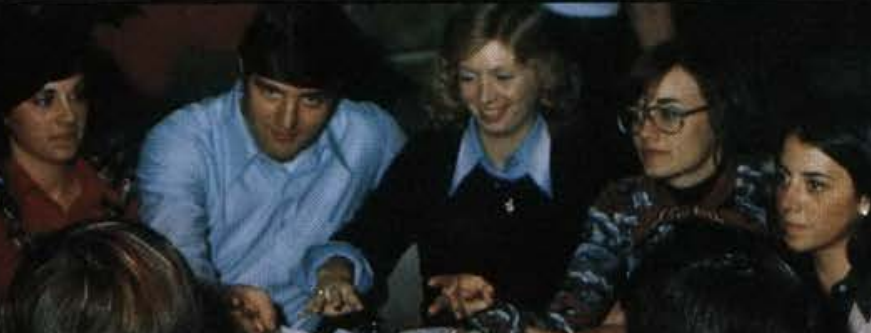

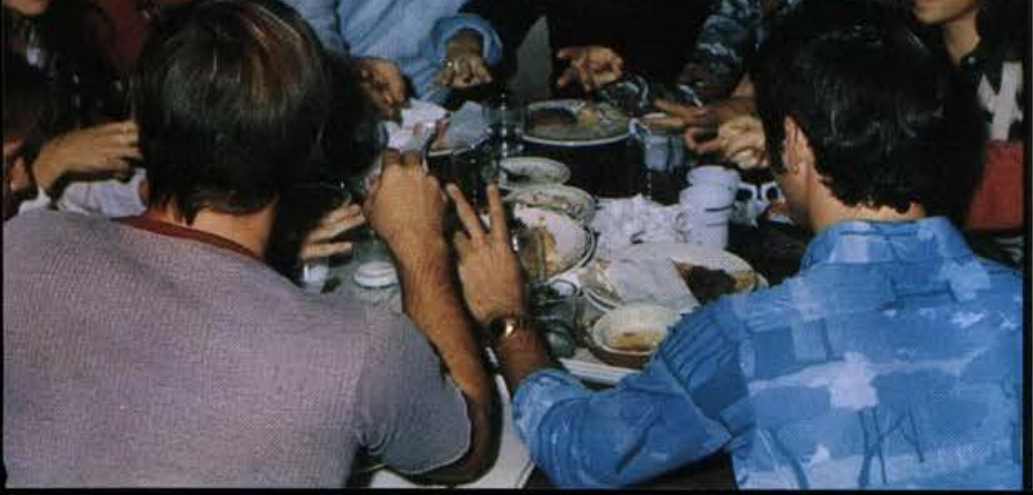

\section{8}

हो
हो

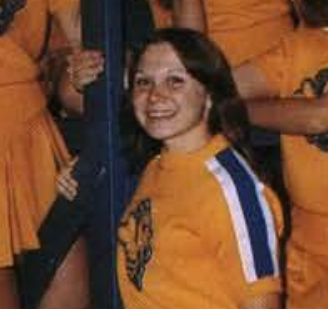




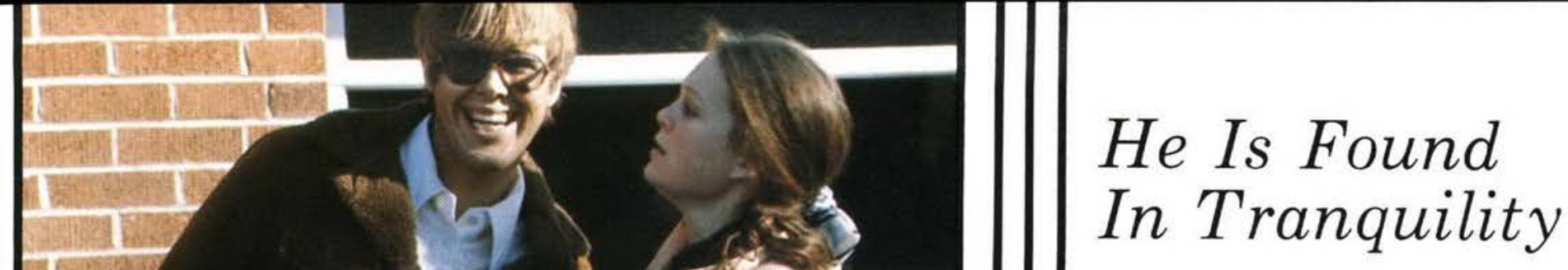

Psalm 47:10 says: "Be still and know that I am God: I will be exalted among the heathen, I will be exalted in the earth." In strolling through the woods, sitting by a lake, or gazing at the stars one is involved in reflecting upon the beauty of God's creation. All of these actions require a certain stillness, a quietness of the soul to truly appreciate the Person and the Work of the Creator. To know God better, a person turns from the business of his daily life, and takes time to worship the true God the powerful, almighty Creator God.

One who has been a college student can cite specific events as to what constitutes a basic day on a college campus. Classes and studies occupy a major portion of one's time. Extracurricular activities are considered important for they provide opportunities in which to become better acquainted with classmates, roommates, and future mates?! Yet, there is a time set aside for "getting away" — whether it be to John Bryan State Park, Indian Mound, or wherever - just to enjoy the beauty of the outdoors.

It is to the aspect of the free time, the quiet time, that the 1977 MIRACLE Staff seeks to expand and develop the student's life. A busy world, a turning world ... in it we find God to be the still point. 


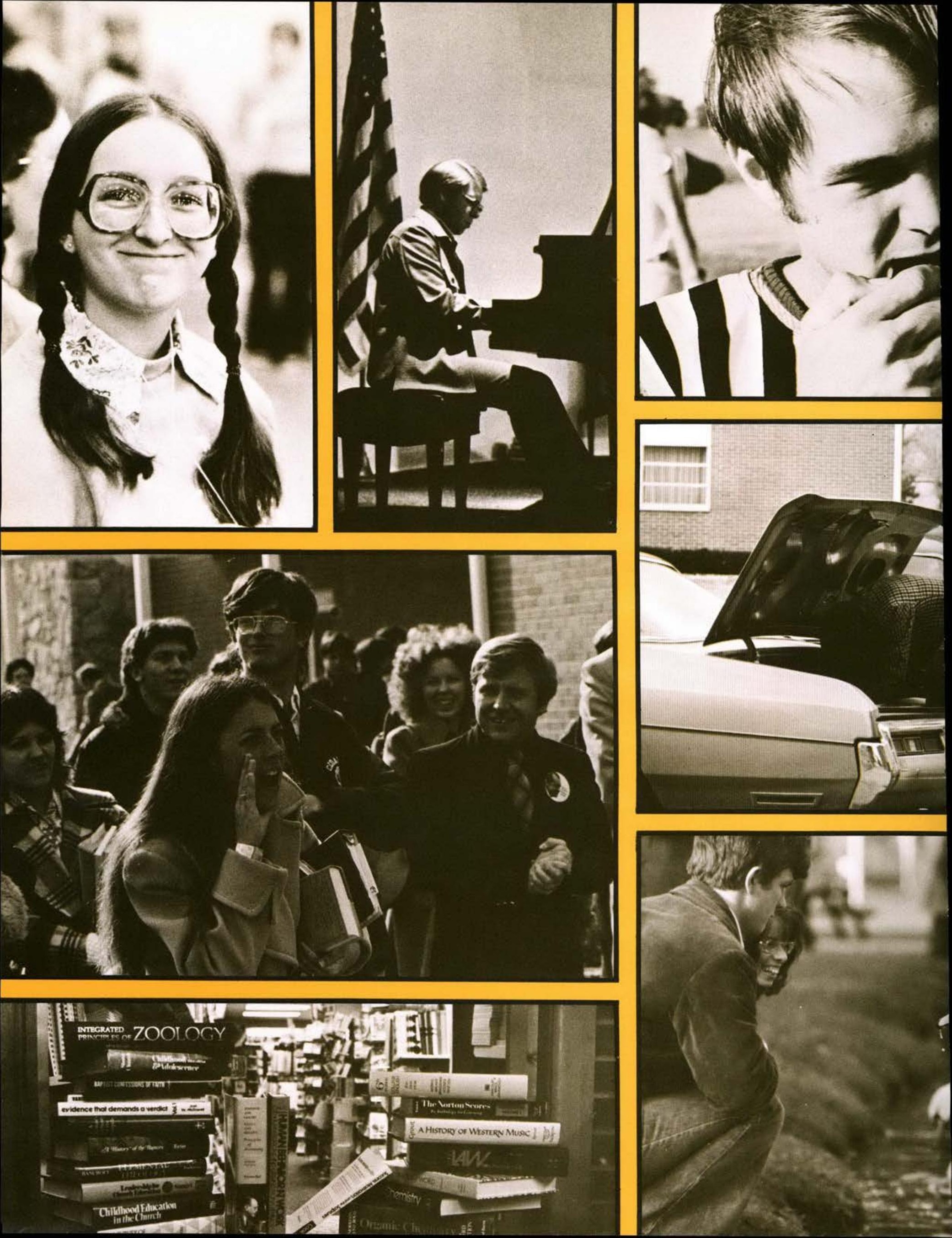




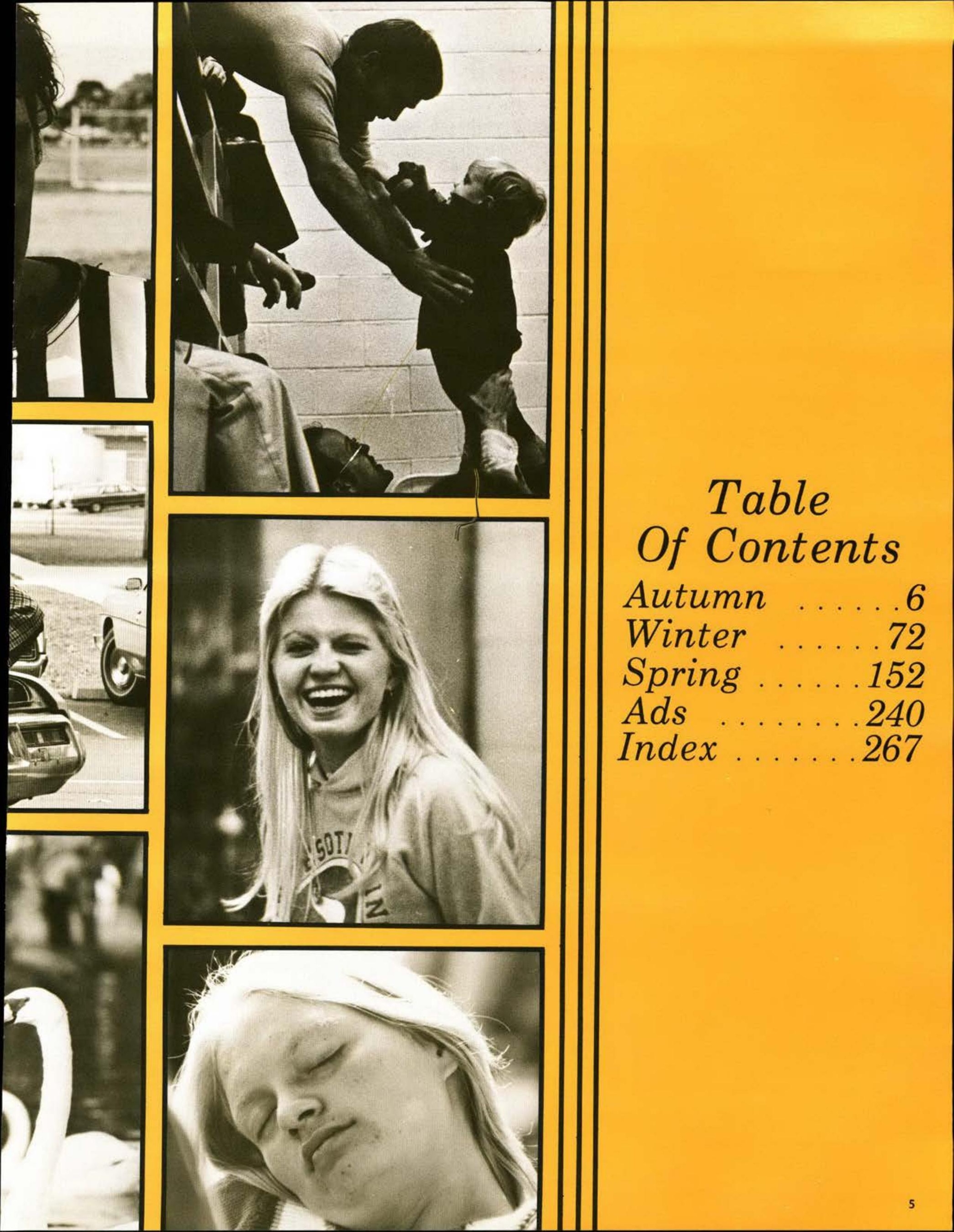



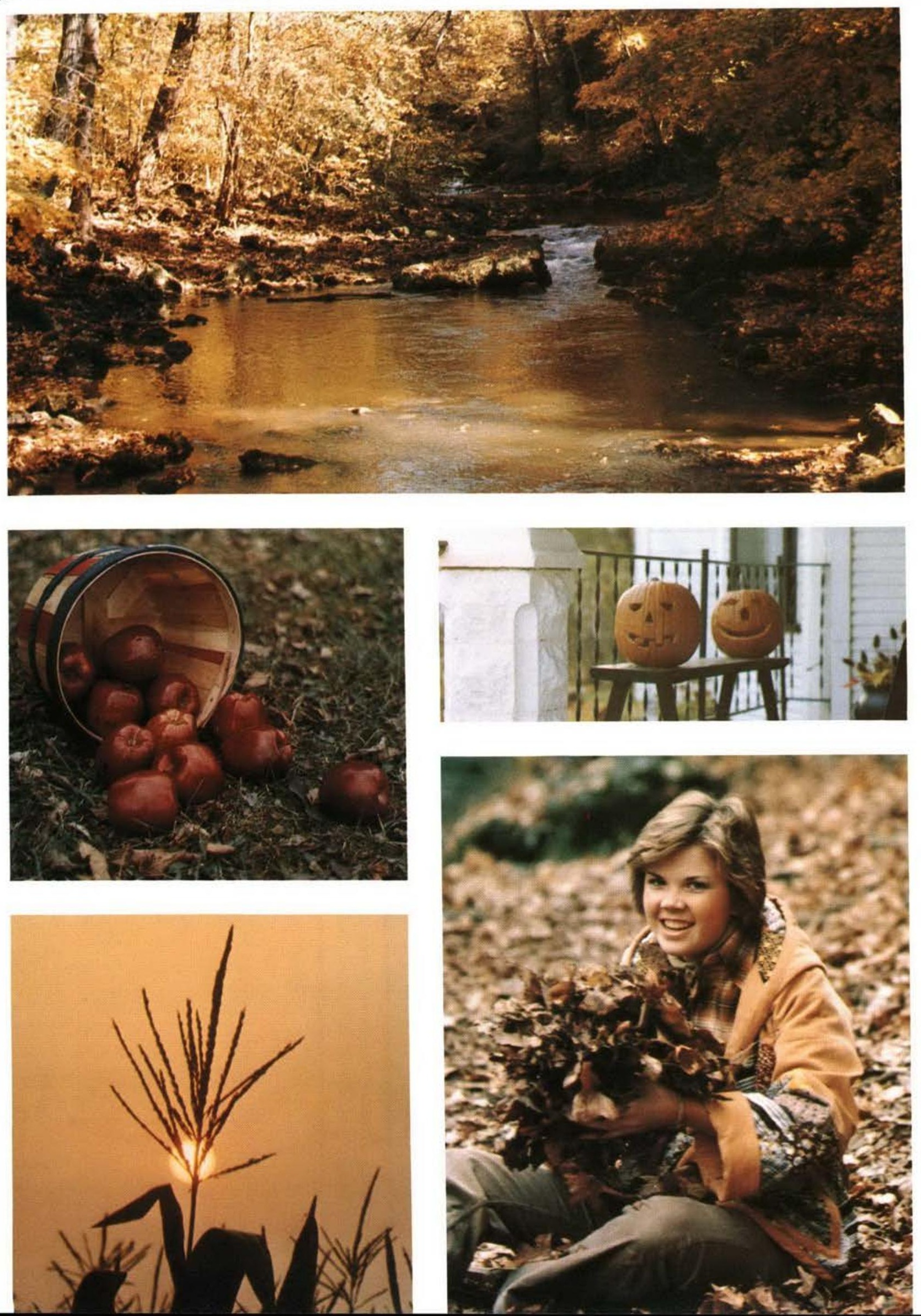


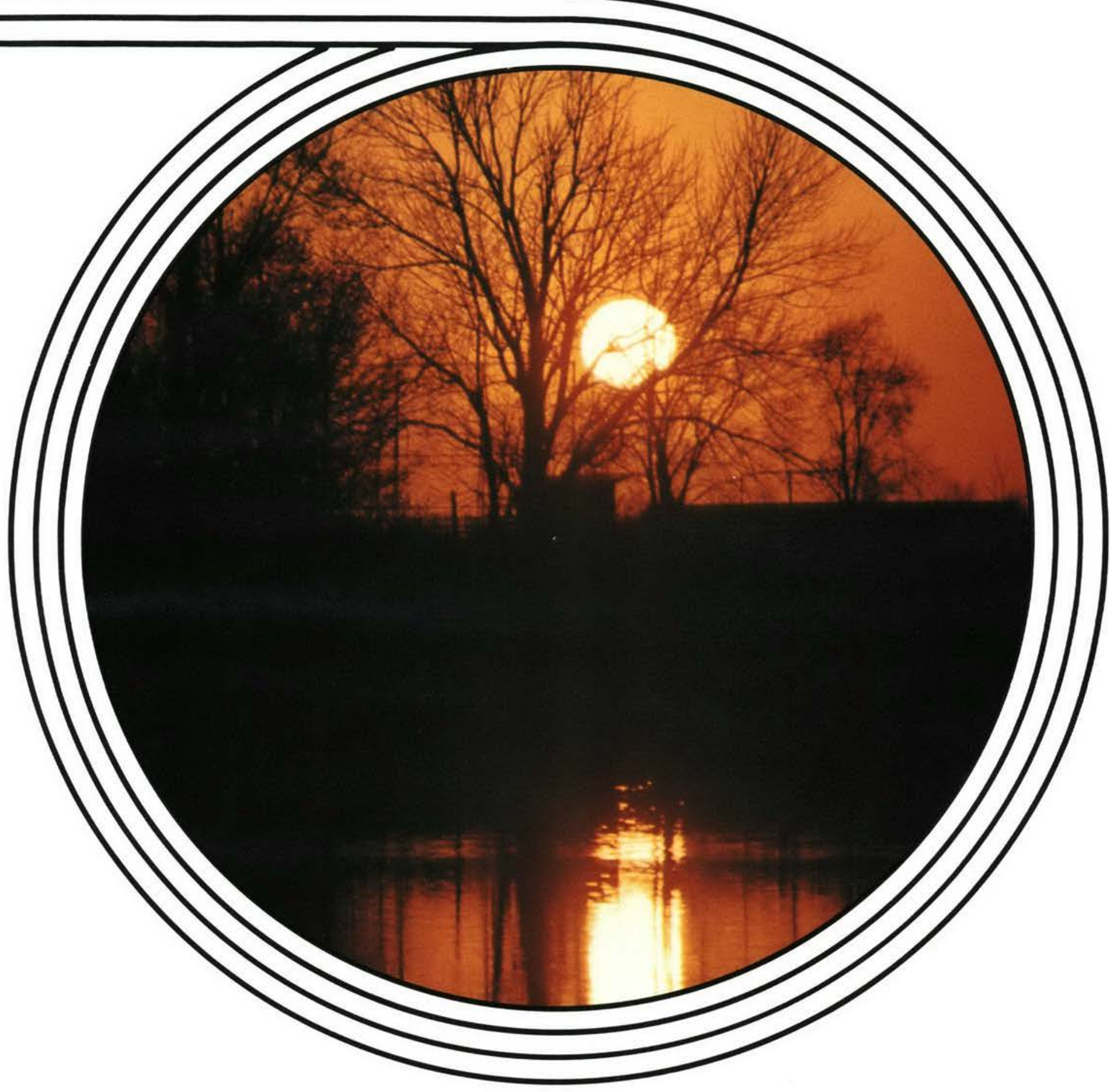

$$
\mathcal{A} \tau \mathcal{U} \mathcal{M}
$$




\section{College Week Is A Break From Tradition}

Trying something new this year, the administration of Cedarville College institutes College Week, at which time no classes are held during the entire week. Fall Bible Conference is held at the beginning of the school year during new student orientation. Two speakers with diverse backgrounds herald the truths of God's Word in the beautiful new chapel. Rev. David Jeremiah, pastor of the Blackhawk Baptist Church in Fort Wayne, Indiana speaks on "Success as a Christian". Delivering his message on "The Holy Spirit" is Dr. Truman Dollar, pastor of the Kansas City Baptist Temple in Missouri. Along with attending meetings, students are kept busy with registration, an all-school social, question/answer session with several trustees, a bonfire, soccer game, and dorm meetings.

1. Diana Rae and Kris Anderson help to serve tacos during a get-together for new students.

2. Returning college students listen intently to one of the first sermons in the new chapel.

3. Terry Broach and Sherri Jones share a happy moment at the all-school picnic held on the first Saturday back at school.

4. Two freshmen discover that blindfolded may not be the neatest way to eat, but it sure is a lot of fun!

5. David and Jim Jeremiah enjoy a light moment with their father, who proves that the President of the college can laugh too! 6. Debbie Dixon, Barry Heagy, and Marlene Bleeker scan the SBP Book Sale for a special bargain.

7. Barton Case performs the familiar task of crossing off his chapel number, with the ever-patient help of Deb Blackburn and Sheryle Tichenor.

8. President Jeremiah and Dr. Truman Dollar pass the time of day after a chapel service.
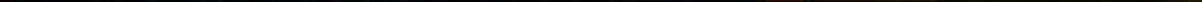

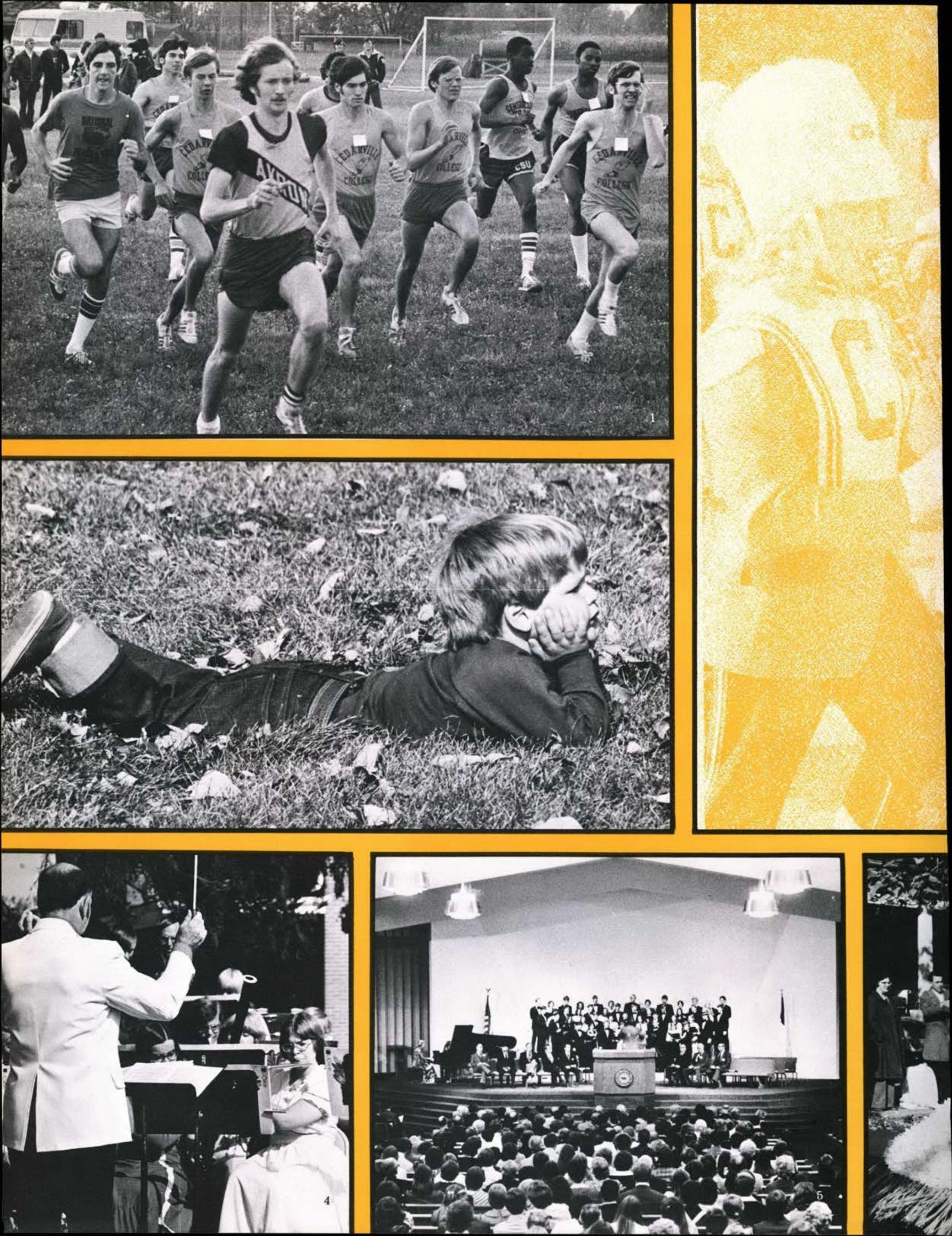


\section{Students Of Cedarville Go Political}

It is time once again to choose the President of Cedar What, a mock election held in conjunction with the national elections. Running this year for the Conservative Party are Dr. James Phipps and Dr. Jack Riggs. Challenging them are the Liberalists, headed by Dr. Al Monroe and Dr. David Matson. Fighting for women's rights to vote, a third party called the Liberty Belles and led by Dr. Sharon Biddle and Mrs. Pat Dixon is organized. Tension mounts during the week of November 8-13 as each candidate campaigns for his party. Political rallies are held every morning in front of the Student Center Gym Building. The candidates offer the students everything, including moustaches! The anticipated day finally comes - the day when the students vote for their favorite candidate. On November 13 at $6: 30$ p.m. the Cedar

1. Uncle $\mathrm{Al}$, surrounded by a squadron of his "secret service men," rallies support. 2. The blue and gold uniforms of Monroe supporters become a familiar sight.

3. Anarchist Guy Felmlee is caught while attempting to blow up the ad building.

4. April Brazelton and John Dailey break a wishbone to determine the outcome of the election.

5. Ringing a bell is Dr. Sharon Biddle - her spokes "person" is Pat Dixon.

6. Lori LaHaye and Lydia West exhibit "spirit-controlled temperaments".

7. Affected by the cry for Tender Loving Care, faculty women join Biddle's Belles.

8 . The banquet is the last place to campaign before the election.

9. The Conservatives demonstrate that civil disobedience must be punished by hanging Guy Felmlee.

10. Evidence of Biddle activity, shown by Dr. Riggs, reveals their work.

11. Monroe campaign manager, Tim Pasma, suffers severe wounds from a shootout with Phipps' manager, Mike Cuffman. 12. A plea for a "Grass Roots in Government" is echoed by Dr. Phipps.
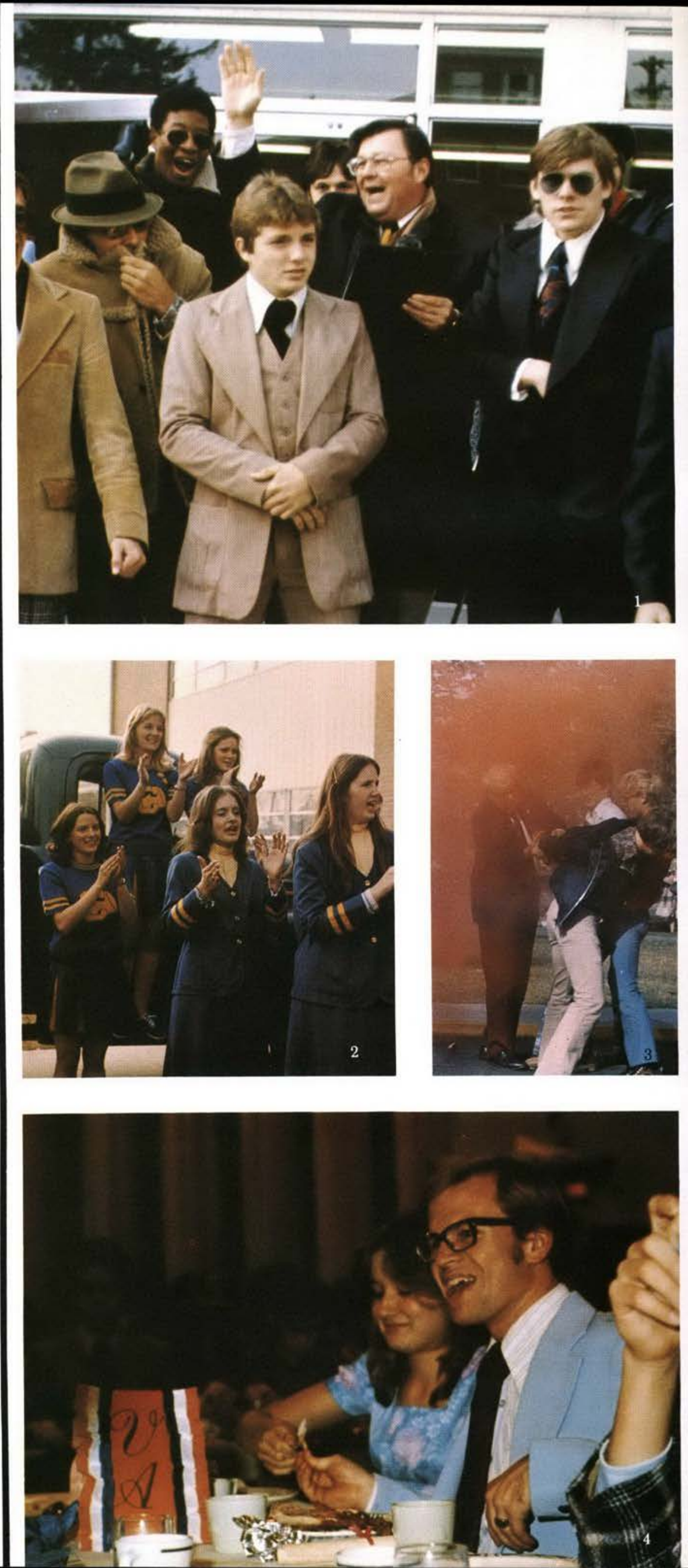


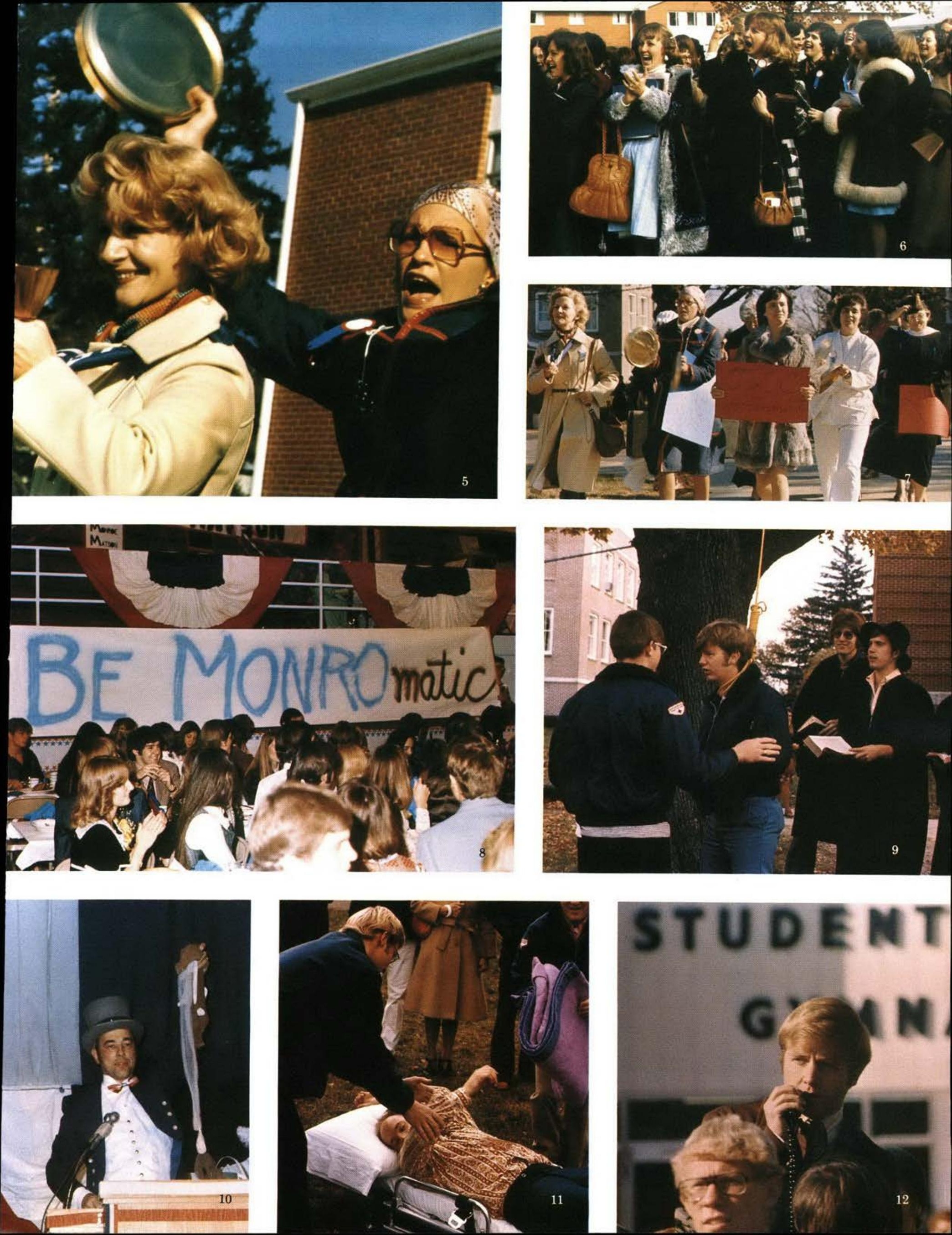




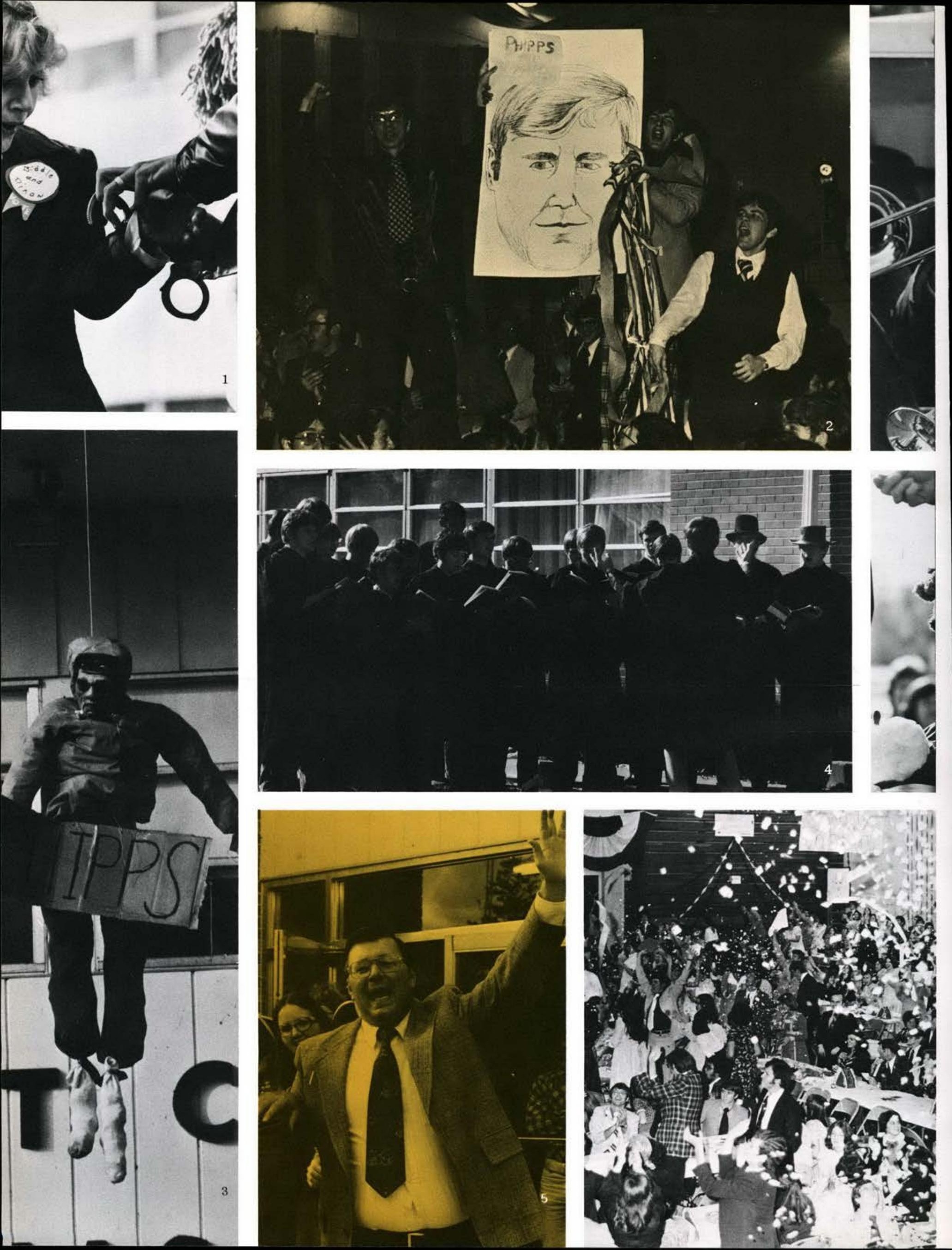



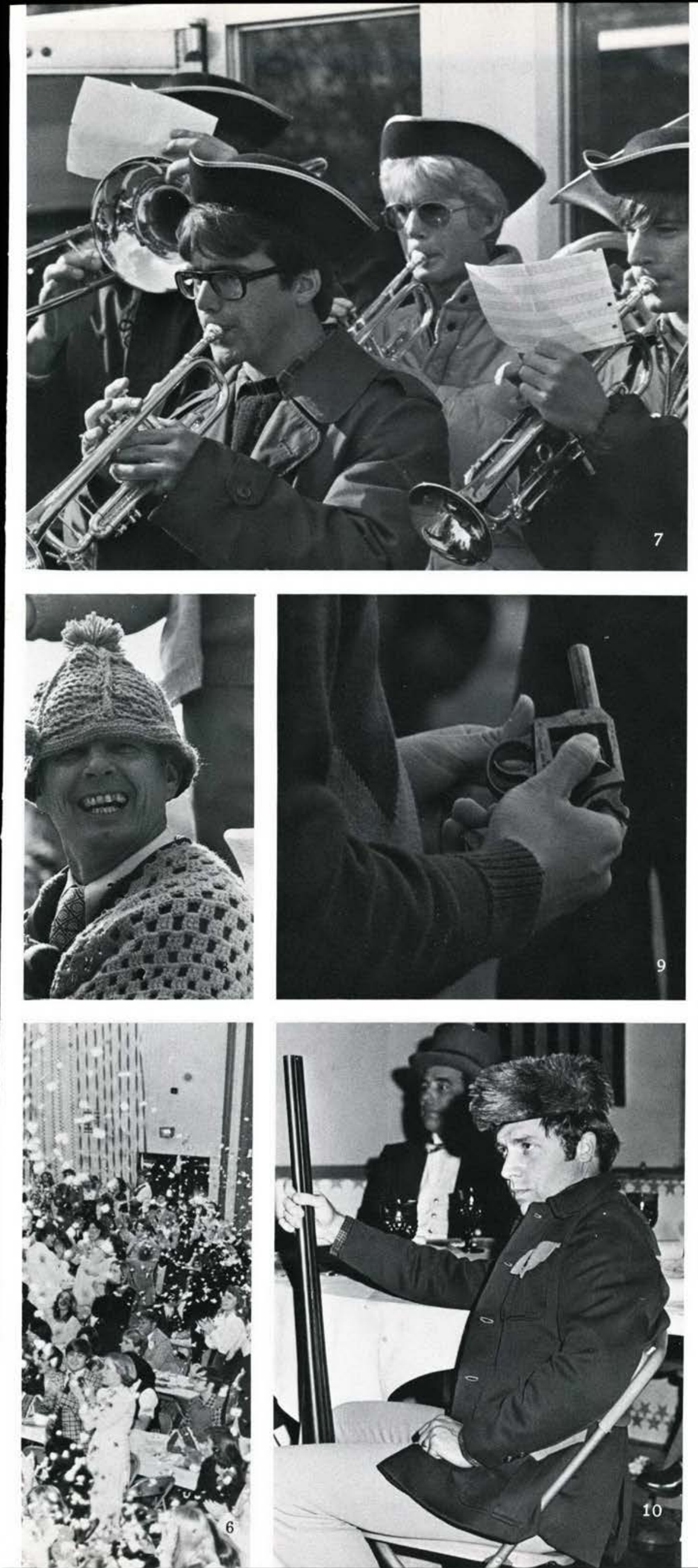

What Banquet, sponsored by $\mathrm{Al}$ pha Chi, begins. Each of those attending the banquet are escorted into the gymnasium and are taken to a table designated as one of the original thirteen colonies. After everyone is seated, a welcome speech by the President of Alpha Chi, Chuck Elliott, begins the banquet. The meal is served, and following it, a demonstration for women suffrage begins in the back of the gym. The women are refused the right to vote. Action is taken by the members of the Liberty Belles, and the male Presidential candidates are abducted! A compromise is made, and the candidates are returned, at which time the vote for the next Cedar What President is taken. After a show of hands by the students, Dr. Al Monroe and Dr. David Matson of the Liberalist Party are announced as the new President and Vice-President, respectively, of Cedar What. The Liberals give a victory speech, but Dr. James Phipps of the losing Conservative Party has the last word: "I hope you get what you got!'

1. Dr. Biddle is aghast when handcuffed. 2. A group of loyal supporters make their preferance known.

3. A grim-faced dummy hangs from the S.C.G.

4. Black-robed choir members, a sign of the Conservative Party, cry for women to "repent" and stay out of politics.

5 . Uncle $\mathrm{Al}$ is frequently heard campaigning.

6. The banquet is not the typical

Cedarville banquet, where dates quietly discuss the classes they are taking. Quite contrary, one must yell to be heard.

7. The brass band becomes a sign of Dr. Monroe's appearance.

8. Is this the true Dr. Johnson?

9. It becomes necessary to use guns to maintain law and order.

10. While the band plays Daniel Boone's theme song, Dr. Phipps plays his part. 


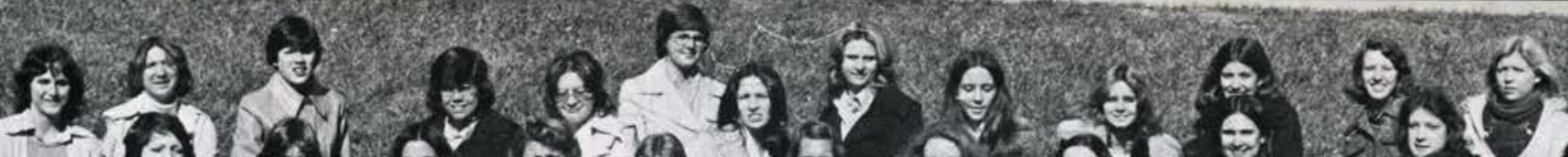
6.

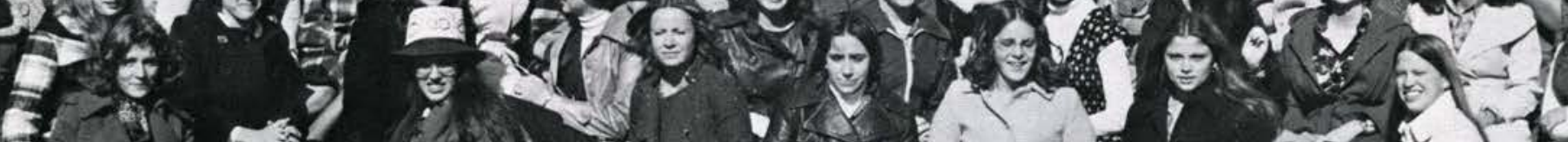
$\lim _{-3}, x^{2}$ 
(ii.

c.
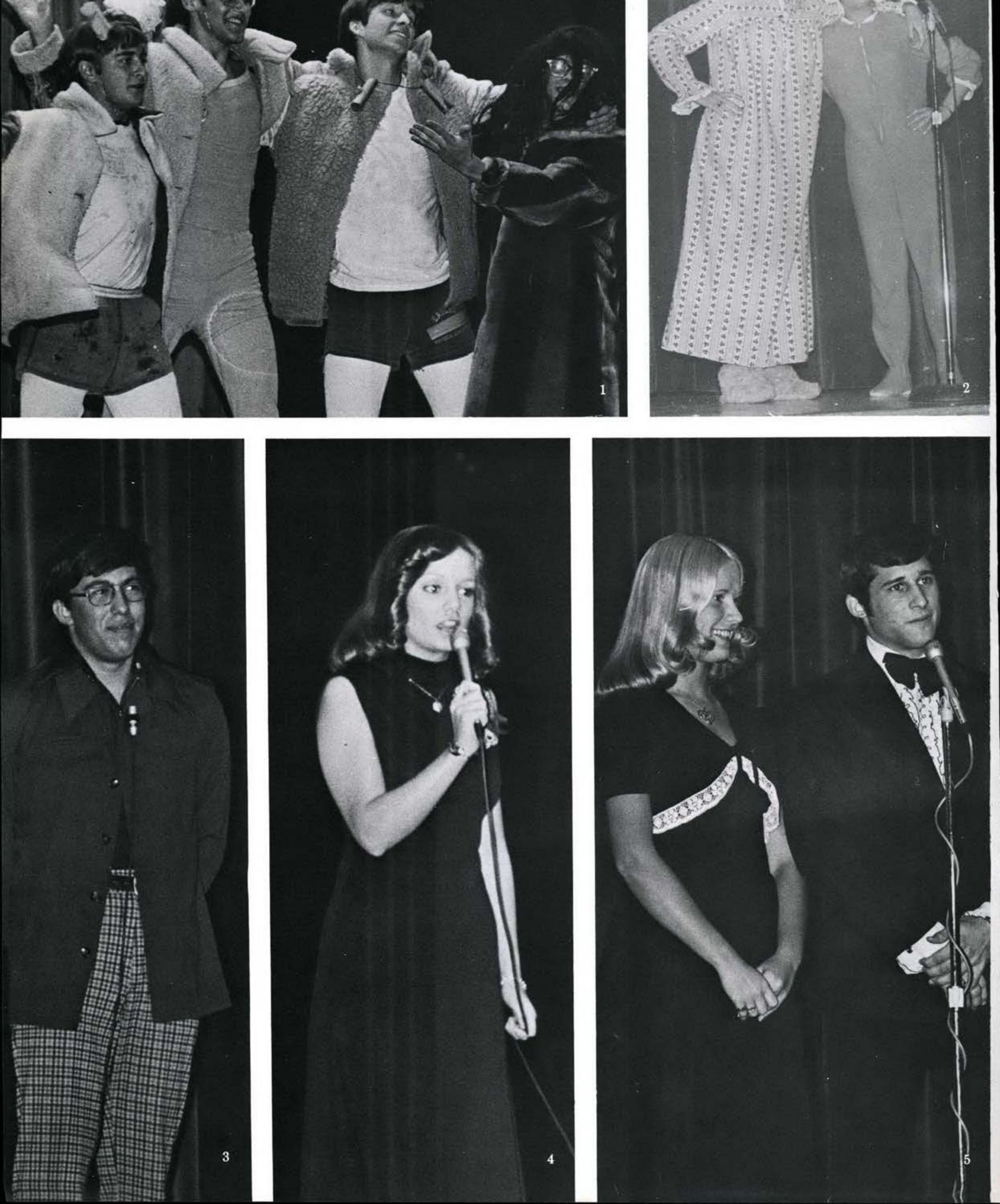


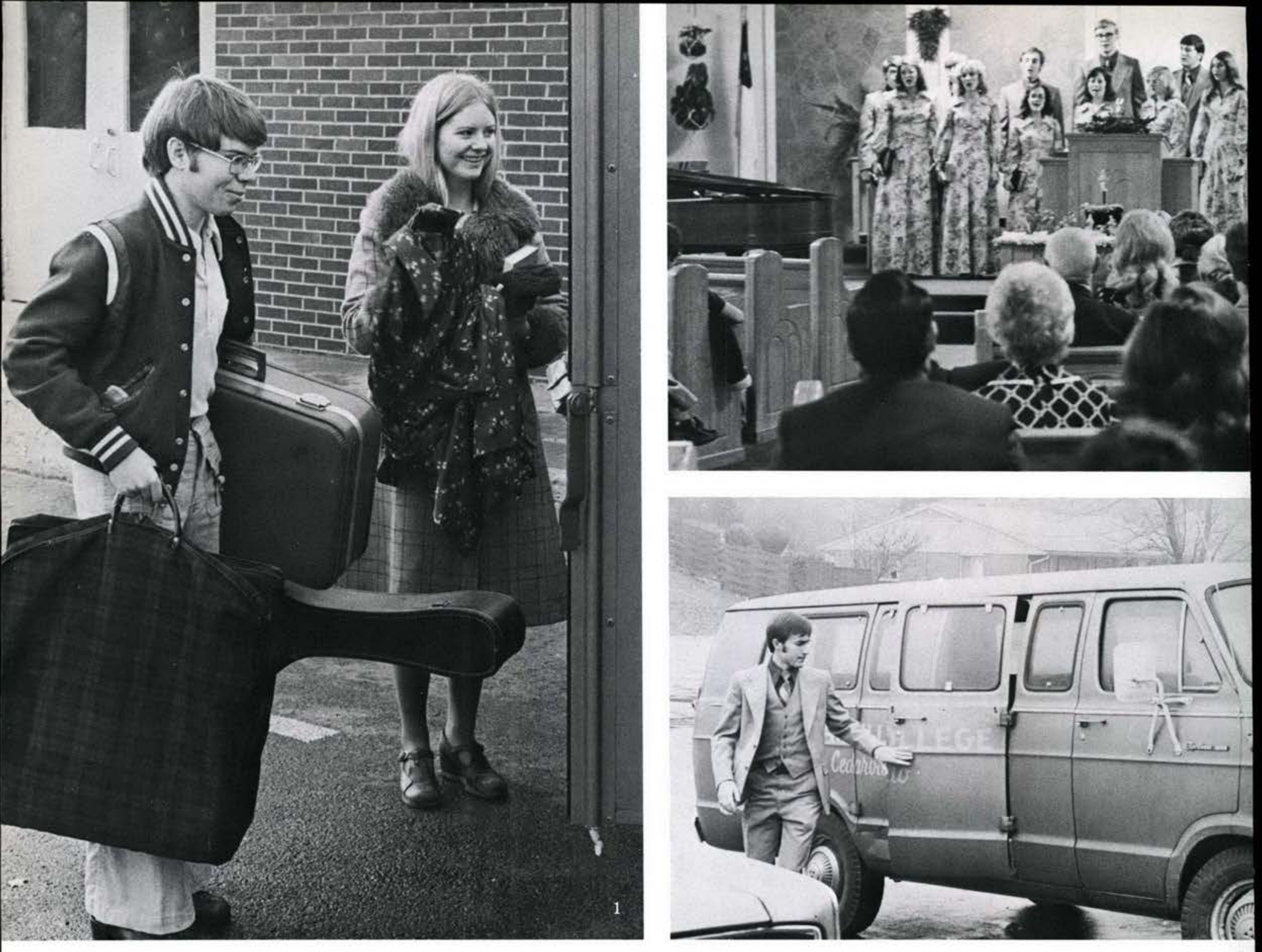



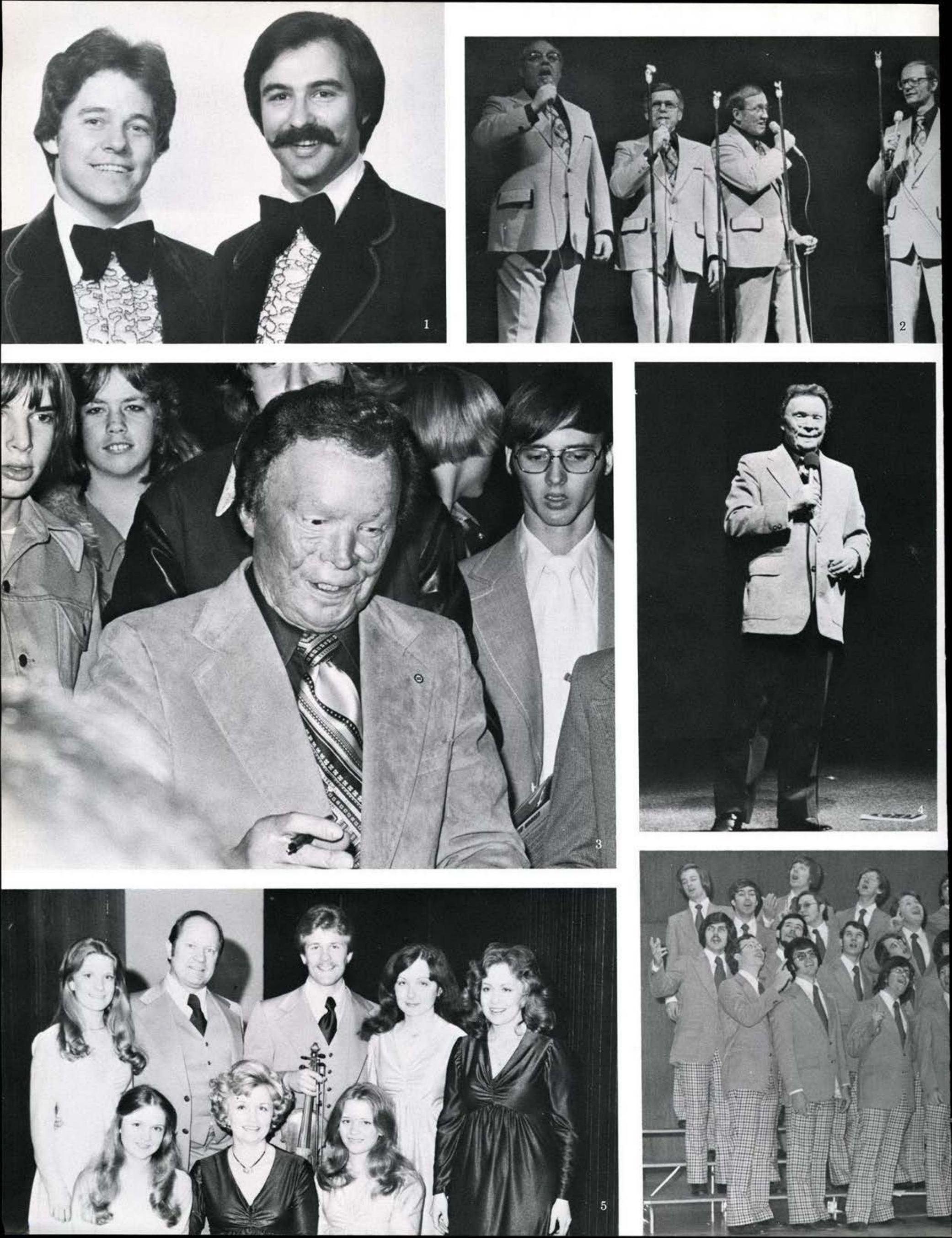

1

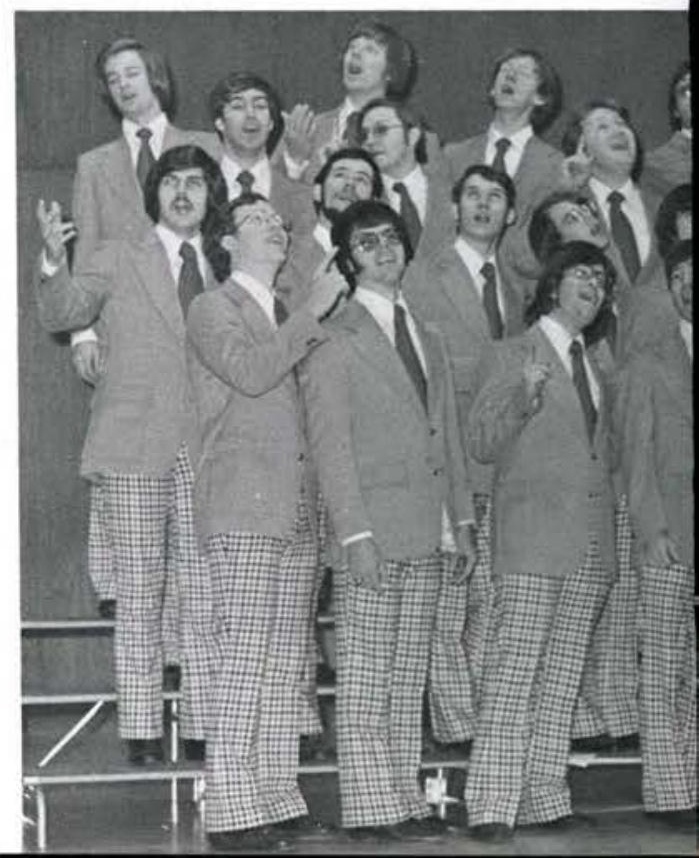



Entertainment

Russell Kirk Bicentennial Lectureship

\section{BBC Quartet}

Ohio State Men's Glee Club

Melody Four

Maxine Hancock Lectureship

Murk Family

Pete Carlson

Dr. John Reed

\section{7}

19,20

Jan 11-14

Feb 19

22

Mar 4

8,9

Apr 15

May 3

6

12

20

Nielson and Young

Stuart and Tyson

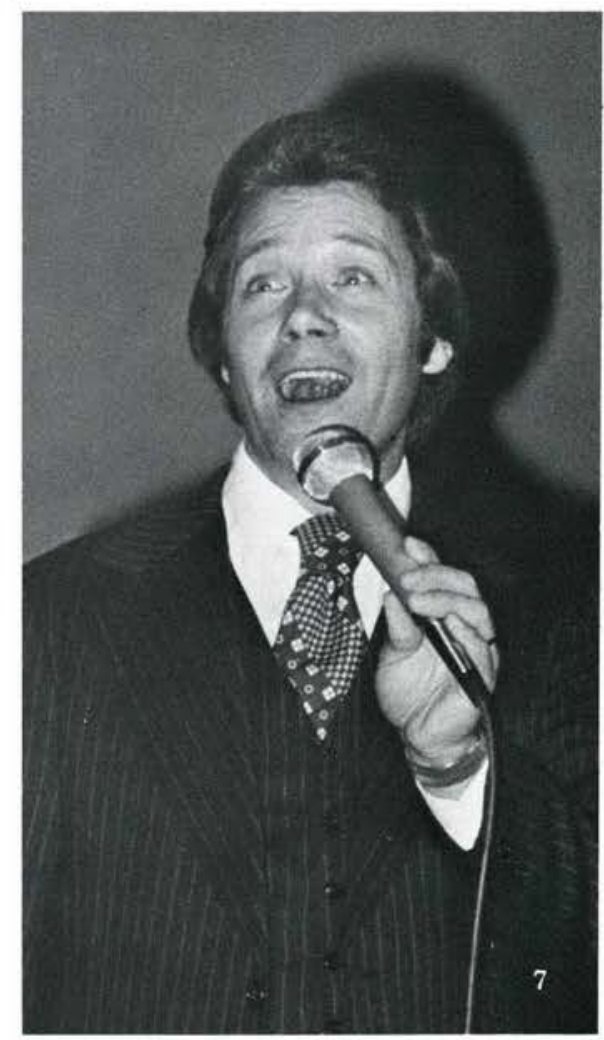

The Student Activities Office at Cedarville College provides many and varying artists for students throughout the school year. Performers include orators and musicians of many sorts.

1. Stuart and Tyson pose for a portrait. 2. The Melody Four Quartet entertains both young and old in the Cedarville College Chapel.

3. After his performance Merrill Womach signs autographs for his fans.

4. Merrill Womach is a singing testimony of God's grace.

5. The attractive Murk Family perform at the Gamma Chi Banquet.

6. It's Don Wyrtzen at the piano--

7. And Steve Boalt at the microphone.

8. The Ohio State Men's Glee Club keeps the audience awake the whole evening.

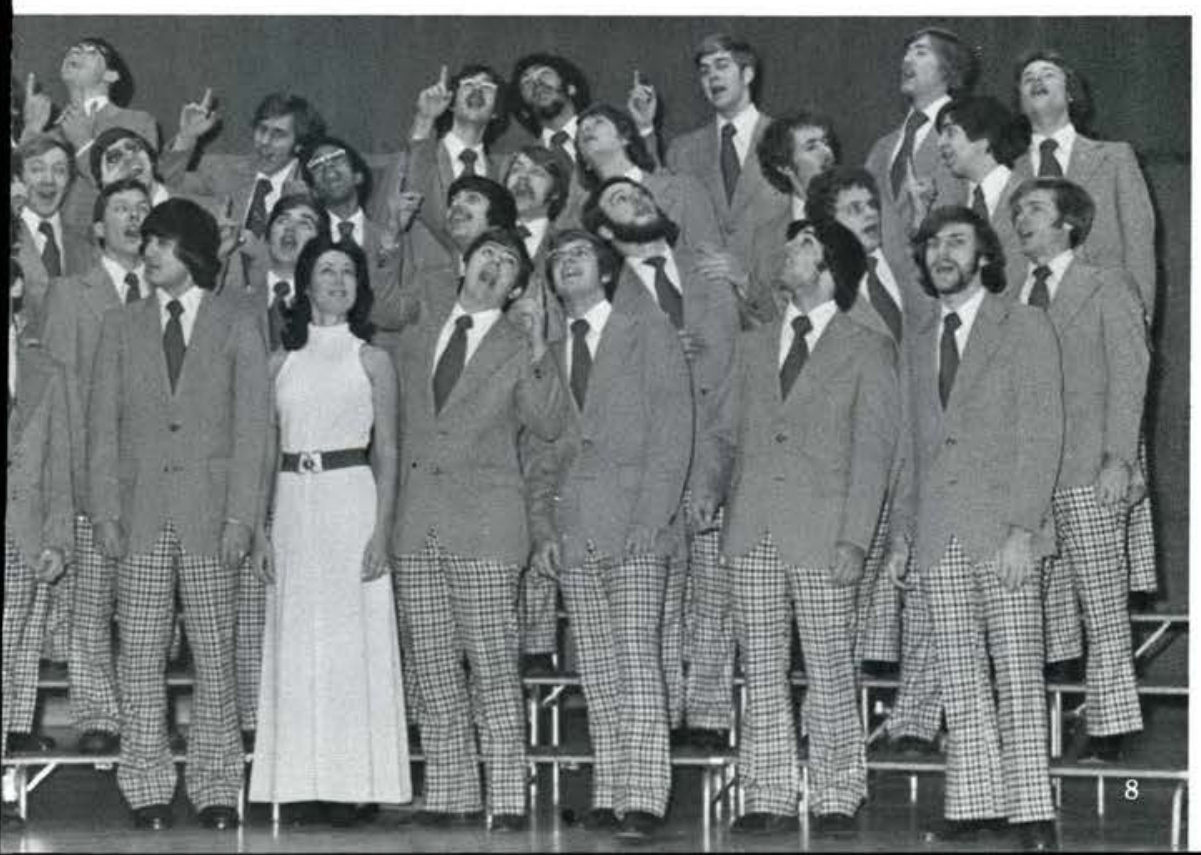




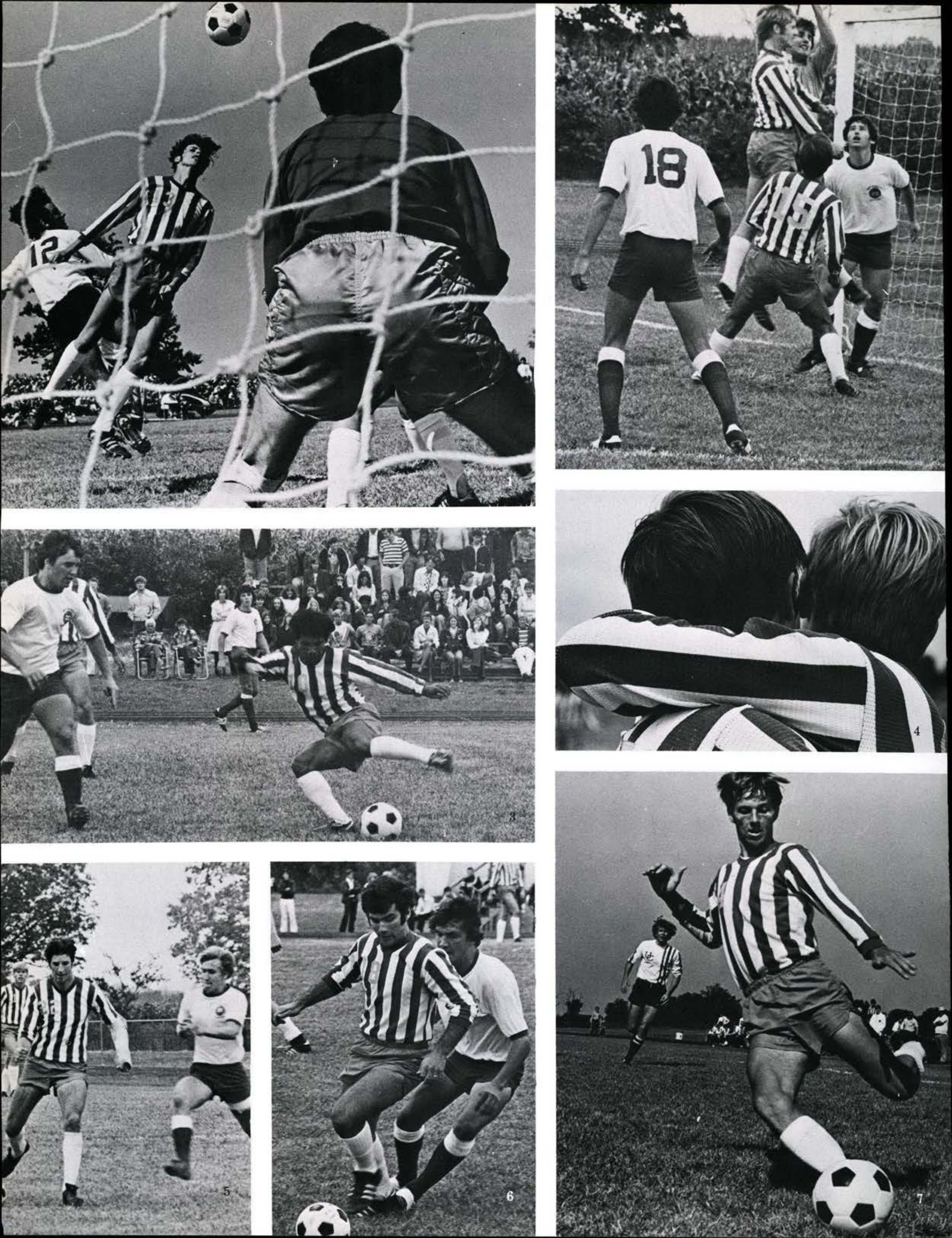


1. Evandro Batista prepares to cross the ball to the right wing.

2. Don Hare seeks to maintain possession against a Wittenberg defender.

3 . Right wing Dave Stoner would be helpless without the use of his tongue.

4. Joe Jenkins feints left and passes right to

a fellow Jacket.

5. Leading scorer Tom Benefiel puts a little finesse in his move.

6 . The soccer ball, die Fusbol, el Futebol.

7. Don Bartemus makes a mid-air return of a kick by the opposition.

8. Merle Ziegler outdistances his opponent and regains control of the ball.

9. The 1976 Jackets were 10-4-1 on the year: FRONT ROW: R. Clark, B. Belleman, C. Auwarter, T. Benefiel, P. Kester, D. Stoner, E. Batista, J. Jenkins, D. Jarvis, D. Bartemus, D. Hare, W. Gifford; BACK ROW: D.

Noble, M. Mignard, D. Ellington, W. Allen, T. Stoner, M. Ziegler, K. Howard, W. Gifford, G. Ellington, T. Cook, G. Donaldson, D. Scott, R. Auwarter, Coach McGillivray.
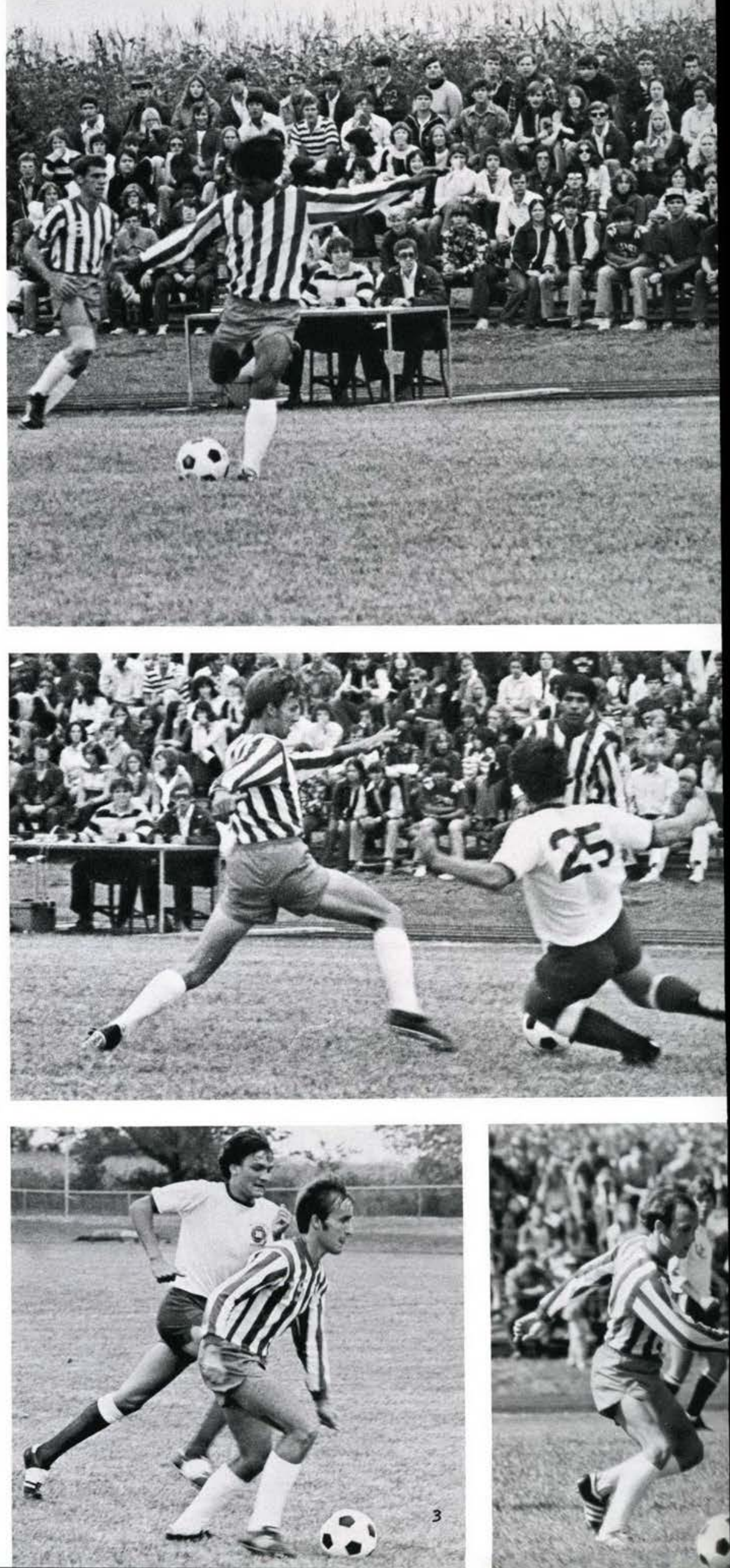
2ै.

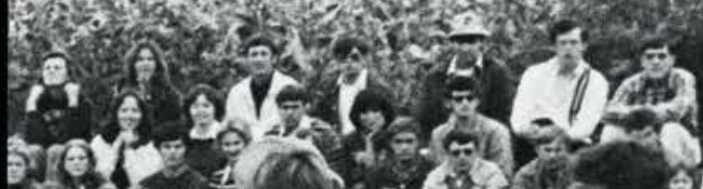

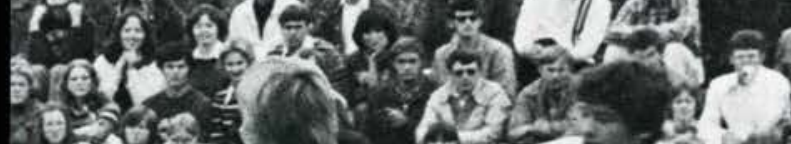
Tos $\mathrm{g}$ - 5 $1,3 \sqrt{3}, 2-m$ of

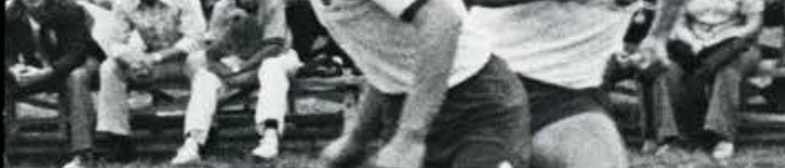
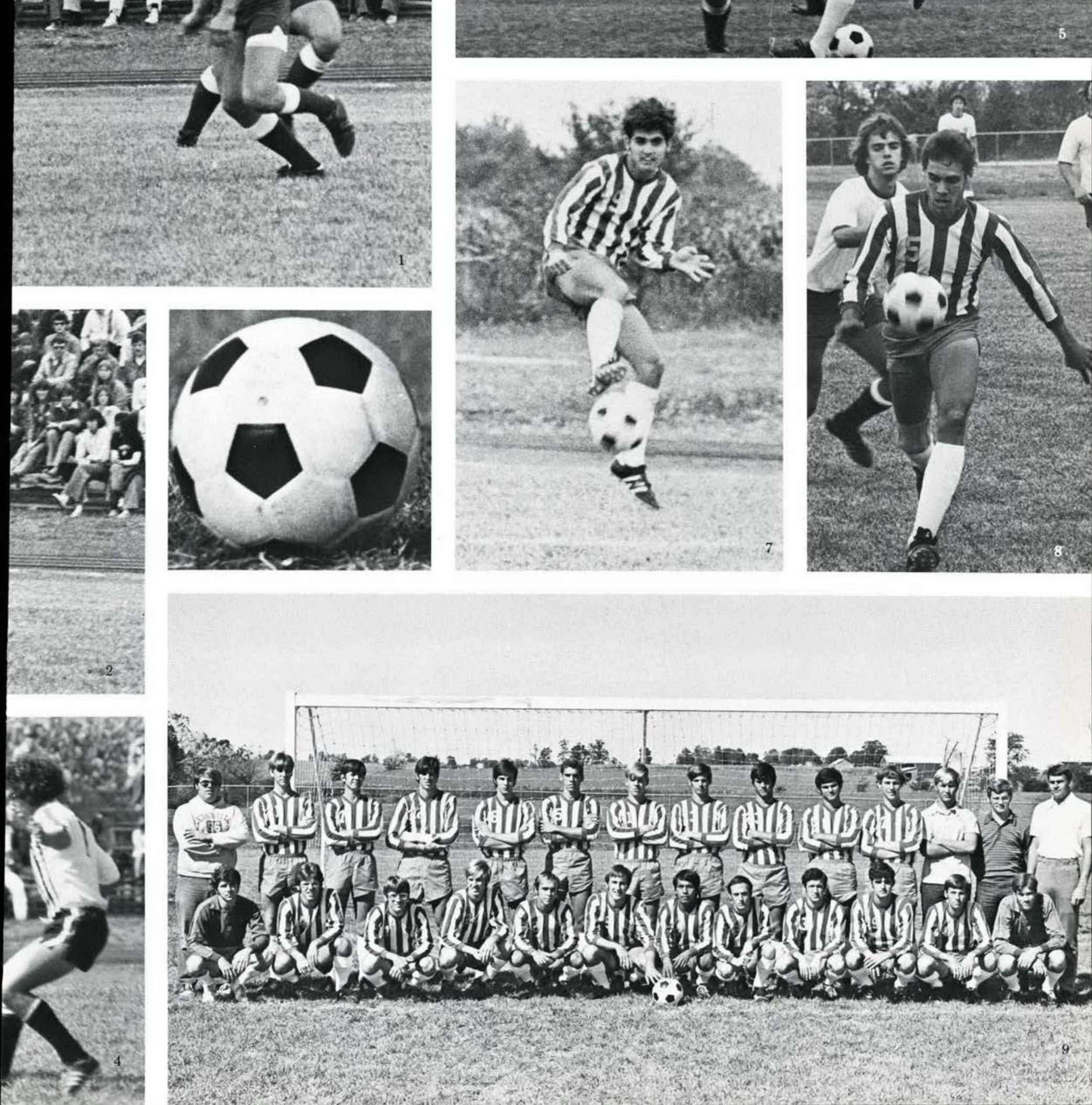


\section{All-American Heads Cross Country}

The story for the cross country squad this year is Brian Hull. Brian wins seven meets and clearly dominates NAIA competition in the state of Ohio. $\mathrm{He}$ outdistances the field in the District \#22 meet and places 20th at the NAIA National meet which is good enough to earn All-American honors and he is still a sophomore in eligibility.

The squad is not merely a one-man show, though, as Senior Paul Budnik, Freshman Dale Shaw, and Senior Ron Thomas, all turn in strong performances. The Jackets as a team combine to win the Earlham Invitational, the NCCAA District 3 meet, and place third in the national NCCAA meet.

With Hull and Shaw back next year, as well as the addition of Henslin, Colas, and Yater, Cedarville looks to be extremely strong, and hopes to battle with Malone and Rio Grande for a berth to nationals.

1. Joel Gehrke, Bruce Henslin, and Steve Crymble "psych-up" before the race. 2. The 1976 Cross Country team: FRONT ROW: Ron Thomas, Paul Budnik; BACK ROW: Coach King, Bruce Henslin, Brian Hull, Craig Colas, Dale Shaw.

3. Brian Hull and Dale Shaw dress down and flash pre-meet smiles.

4. Victorious in the meet, Ron Thomas, Brian Hull, and Paul Budnik cross the finish line hand-in-hand.

5. Brian Hull accepts his All-American honors at the banquet after the NAIA National meet.

6. Jacket runners hold on to their lead as they round Cedar Lake.

7. Mark Shaver finishe 'he tiresome five mile course.

8. Coach King updates team scoring at a home meet. 


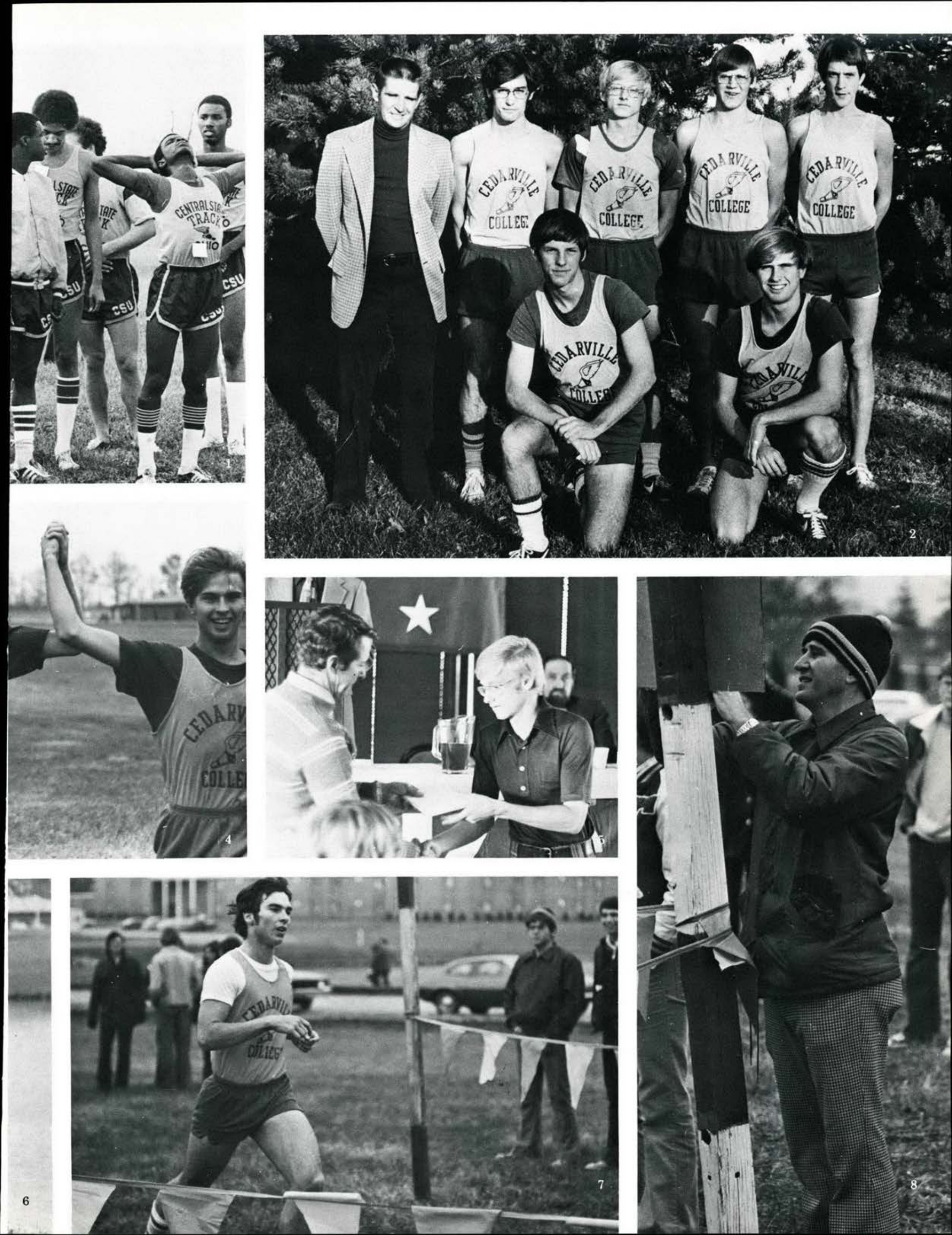



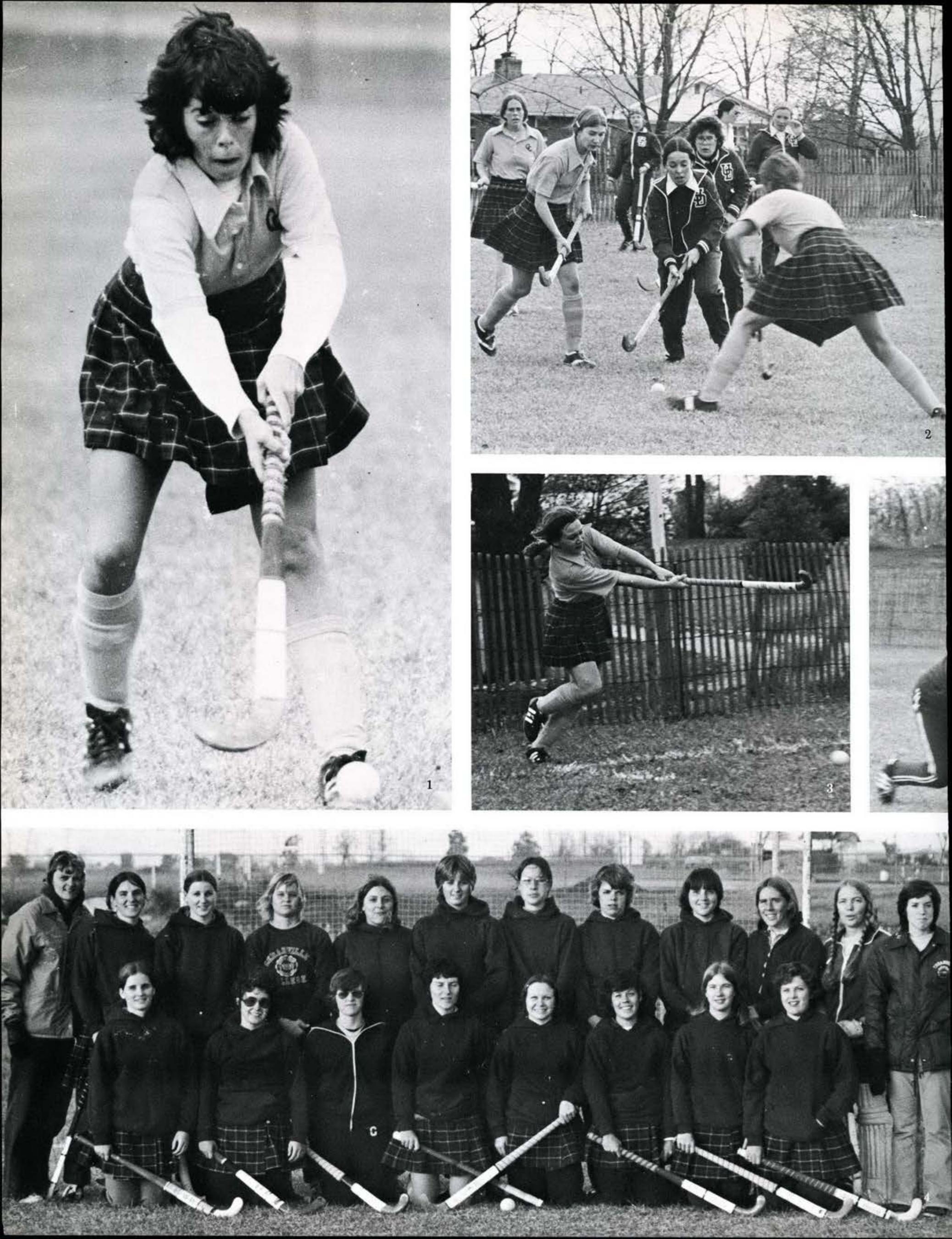


\section{Spikers Net Twenty-One Wins}

With a record of 21 wins and 12 losses, this year's varsity team has its best season in the history of Cedarville College. Regrettably, the team is not able to participate in State competition due to a mixup. For the first time, however, they are invited to the Earlham Tournament. They completely overwhelm the other competitors, which results in a first place win, making this the highlight of the season.

This year's captains are Roni Crum and Judie Cross. Next year's prospects look good in spite of the loss of Roni Crum, Becky DeLancey, Denice DeMars, and Jo Priola. The J.V. team is coached by Elaine Brown, a player - coach. Their season record is 3 wins and 6 losses. Several strong players emerge which will make promising additions to next year's varsity team.

1. Strategy and advice is given by the coach while the team meets in a huddle.

2. Judie Cross sets the ball for the impending spike.

3. The players stress good sportsmanship, regardless of the outcome.

4. Roni Crum clenches her fists in a tense moment.

5. Gazing intently, Jo Priola watches her team in action.

6. The J.V. Team: BACK ROW: C. Lancaster, N. Snook, K. Turner, E. Brown, L. Penquite, Dr. Kearney; FRONT ROW: L. Bruening, S. Taylor, P. Holmes, D. Sands, J. Priola.

7. Racing for the ball, Rachel Norton gets there in time.

8. Brenda Hobar takes a drink before reentering the game.

9. The Varsity Team: BACK ROW: C. Lancaster, R. Norton, B. DeLancey, V. Totman, E. Brown, Dr. Kearney; FRONT ROW: D. DeMars, B. Hobar, R. Crum, J. Cross, M. Park, J. Priola

10. A well-executed set by Denise DeMars makes the next point possible. 


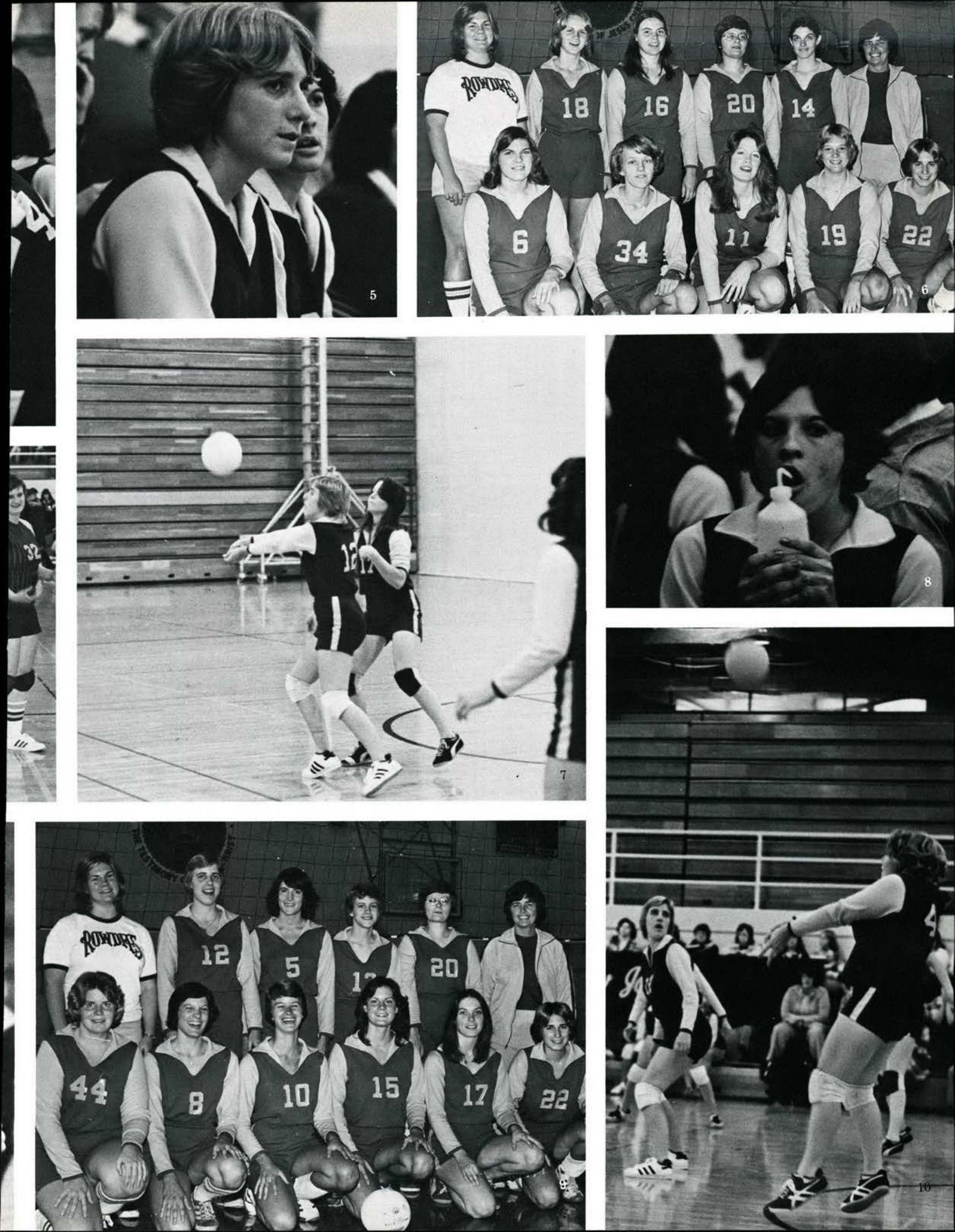




\section{Fall \\ Intramurals Boast Several New Activities}

Intramurals have always been an integral part of college life here at the 'Ville. This year Rob Seymour has done an excellent job in providing sports opportunities to a full capacity. In the fall, flag football dominates the scene. Off-campus captures the crown with an undefeated season, beating Upper Williams in a closely contested, well-played finale.

For the first time, a cross-country run is offered, and Warren Gifford trots off with top honors. Womens' volleyball is also a major part of the program this year, with a tournament and league play offered for the ladies.

1. Steve Stairs staunchly defends his quarterback, Carl Zelonis.

2. Even teammates flinch when Joyce Klamm returns a shot.

3. The determination of Steve Stairs causes Cal Searles to think quickly.

4. With his back to the camera, Steve Stump runs his pattern, awaiting a pass from Cal Searles.

5. With the ball tucked away, Wes Rowe looks for opposition up- field.

6. Kathy Kearby displays her patented "lightning" serve.

7. Deb Stahl calmly spikes a volley.

8. The Carr offense lines up for a play, with Steve Uyenishi in command.

9. The victorious Off-Campus squad, shown moments after narrowly defeating the second place team, Upper Williams: FRONT ROW: T. Flowers, D. LaBelle, B. Williams, M. Landis; BACK ROW: R. McCracken, C. Stephens, F. Vitt, M. Mary, J. Iseminger.
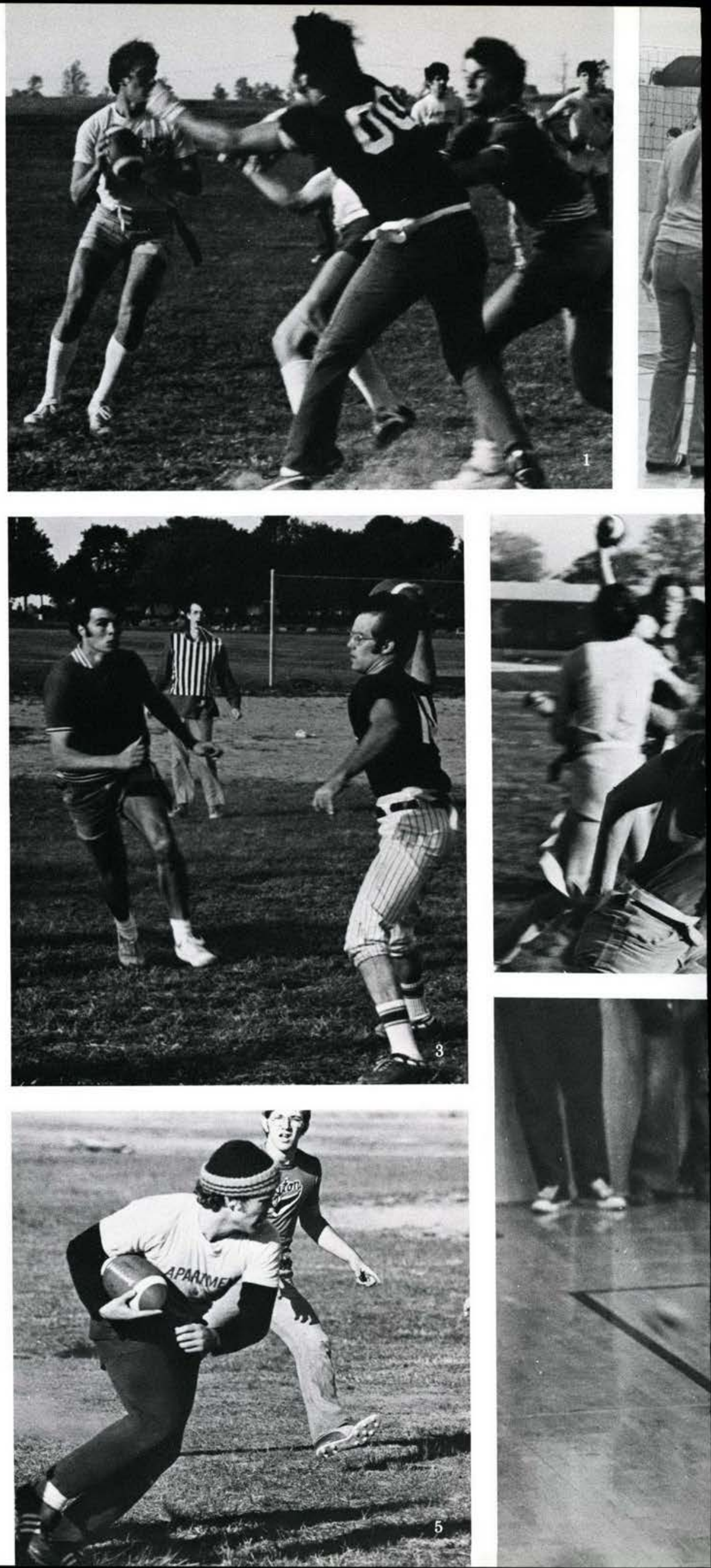


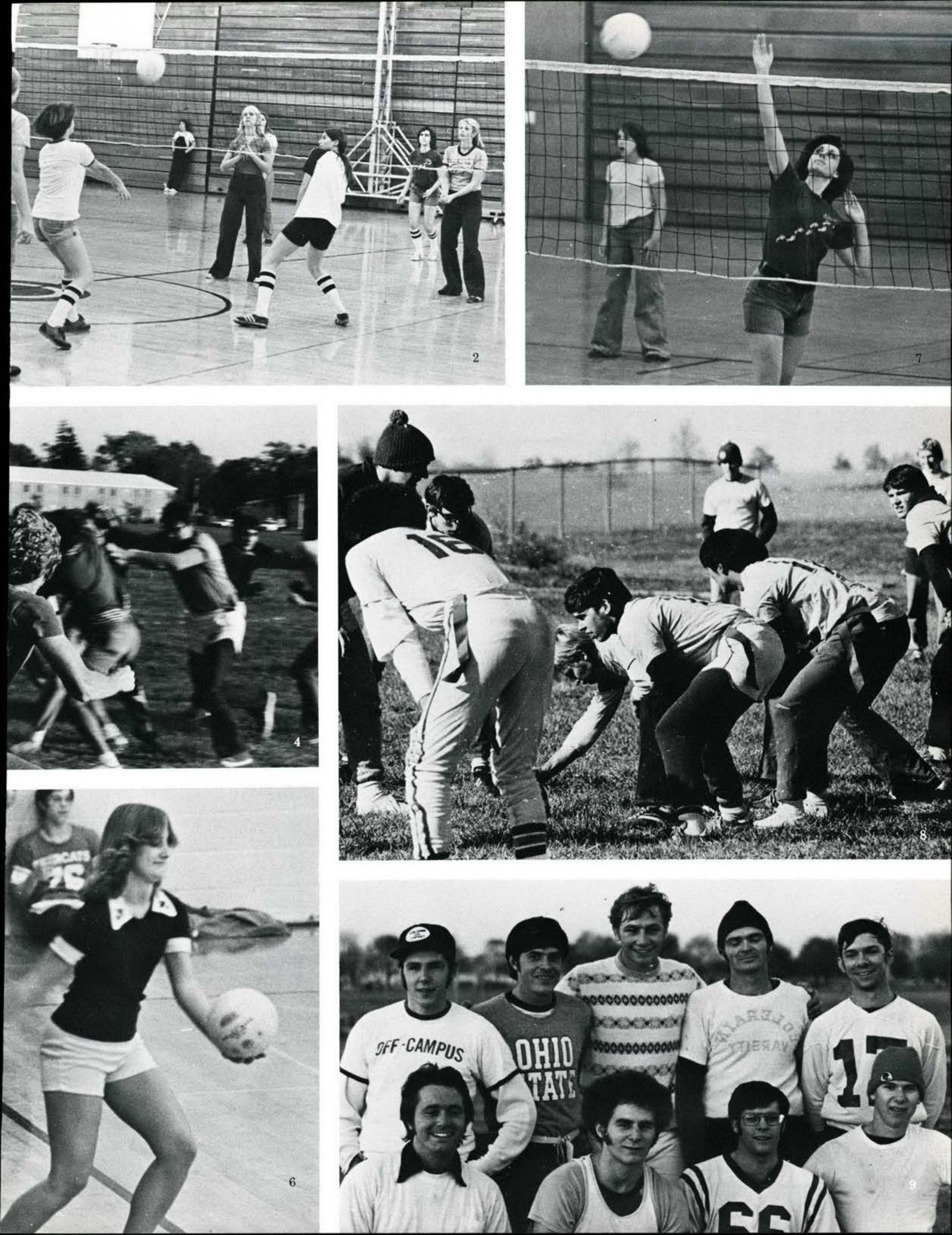




\section{New Faces Line The Hallways}

Returning upperclassmen are greeted by 412 bright and shining new faces, known as the Freshman Class. The freshmen invade the campus and are influential in making history for the 1977 school year. Tradition is broken as they did not have the "opportunity" to go through initiation. The class sponsors many activities of which the biggest event is Evacuation Weekend held in February. During the freezing cold winter, they enjoy swimming in an indoor- heated pool at Hueston Woods. Money making events include selling " $\mathrm{Ce}$ darville" pens and freshman class shirts.

1. Mike O'Quinn and Jeff Waldo are lullabied to sleep by Brahms.

2. Her wainful look is a sure sign of an empty mailbox.

3. The smiles are those of the Freshman Class Officers: Dan Green (Treasurer) Dawn Jansen (Secretary), Craig Colas (President), Keith Willhite (Vice President), Sheryl Scoggins (Student Senate), Mala Biggs (Student Senate). Not pictured - Kevin Browne (Chaplain), Nate Rehn (Student Senate).
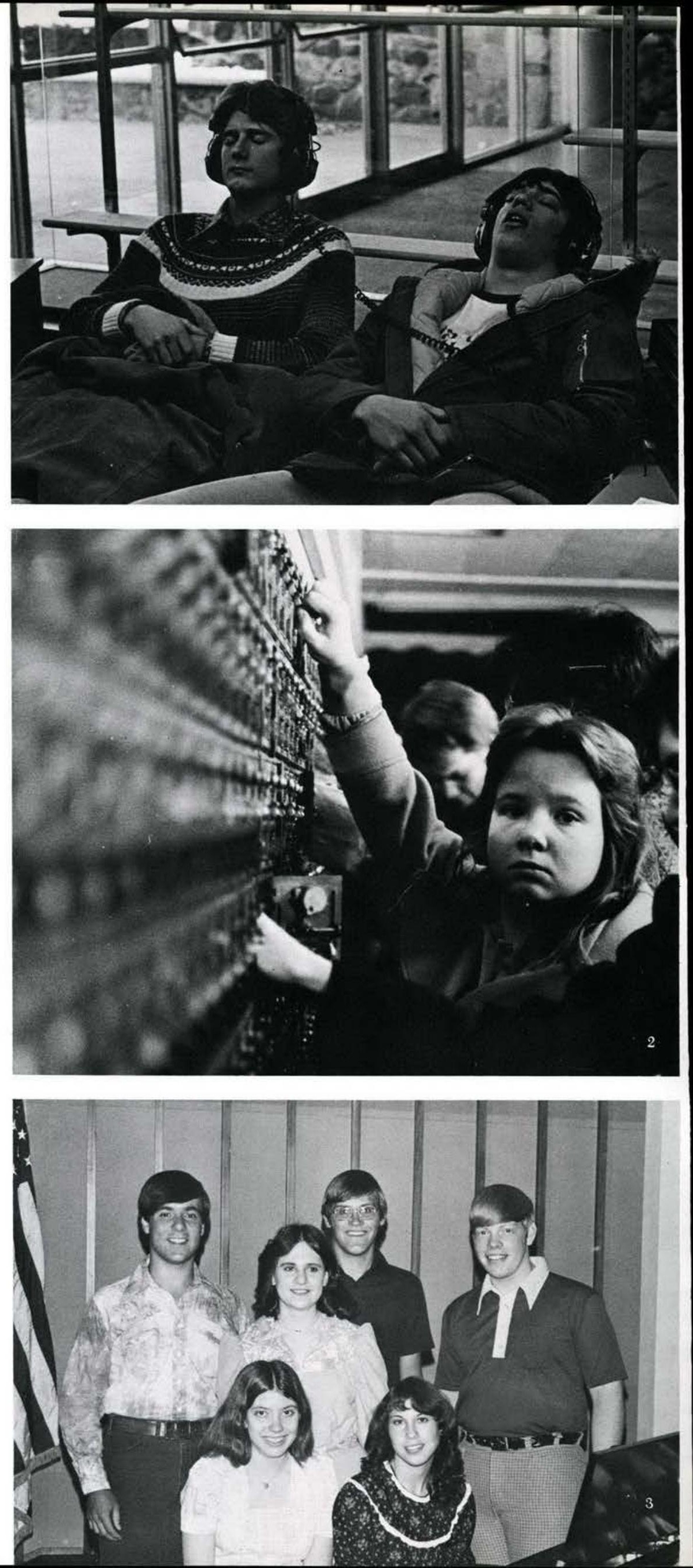

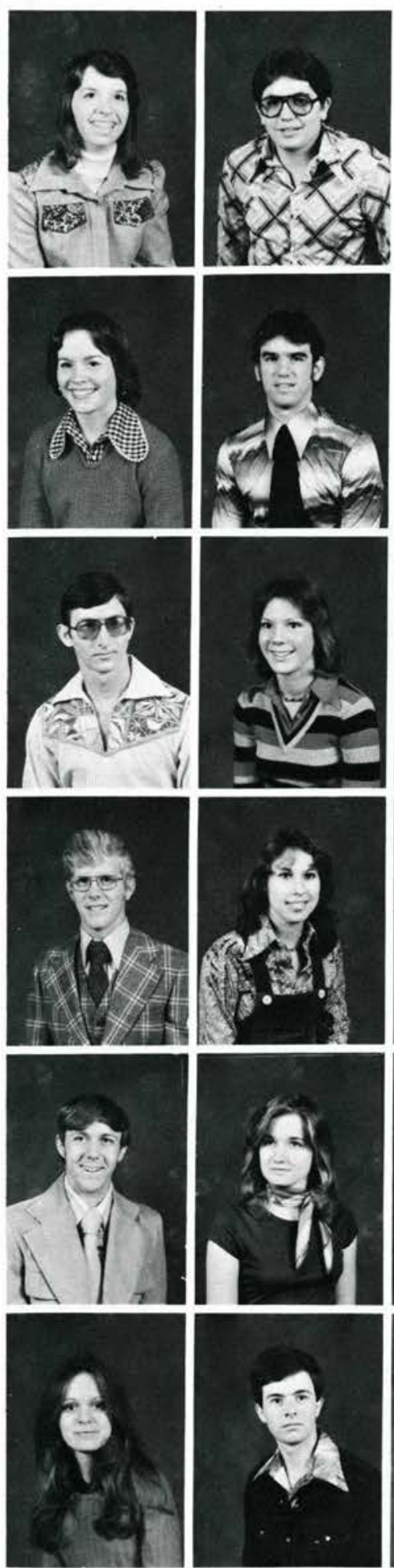

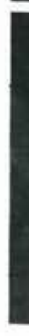
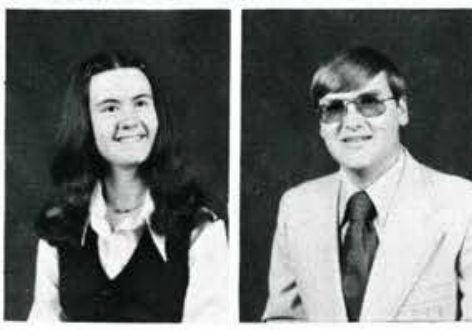
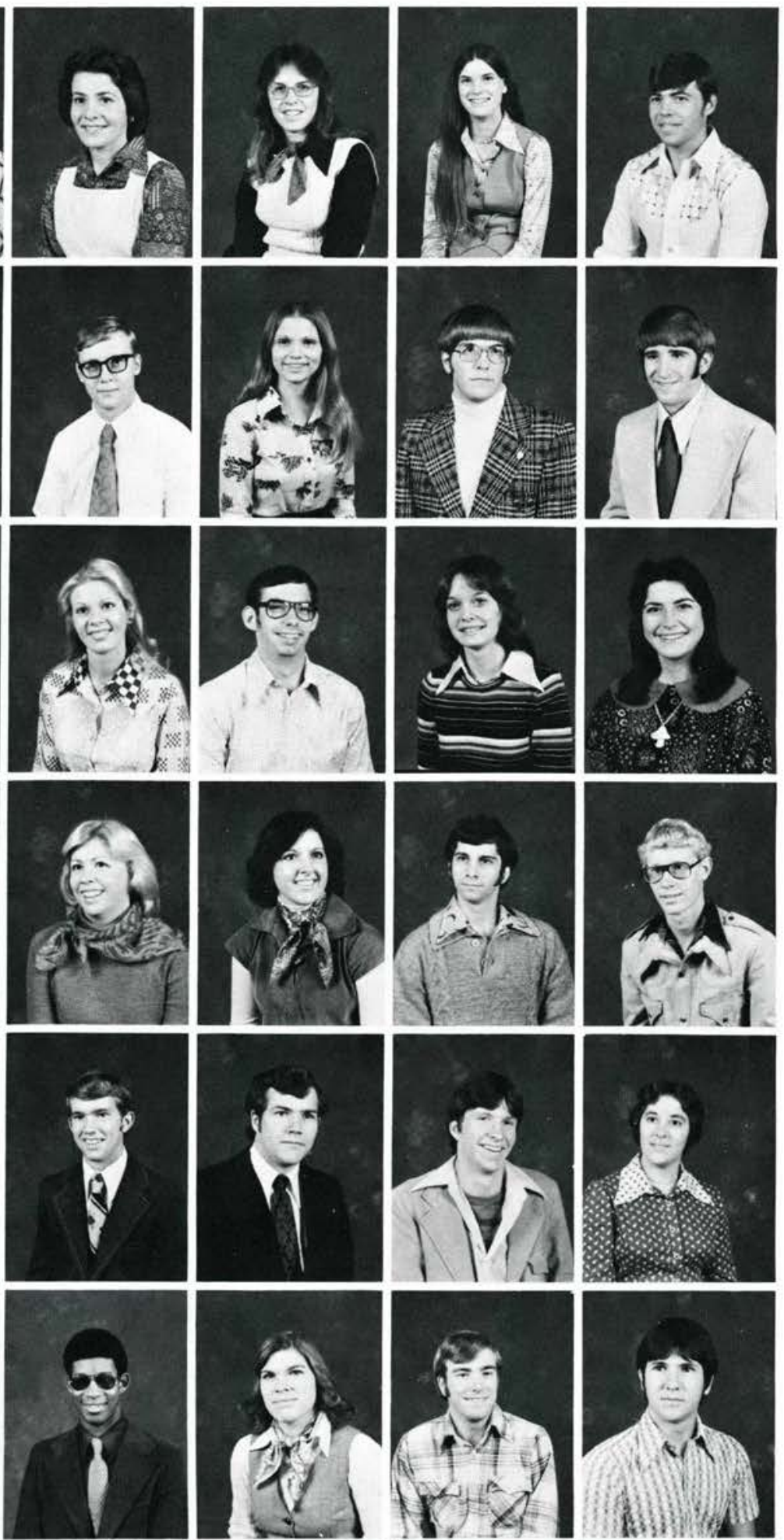
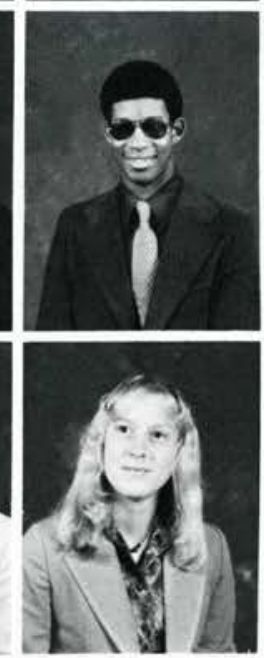
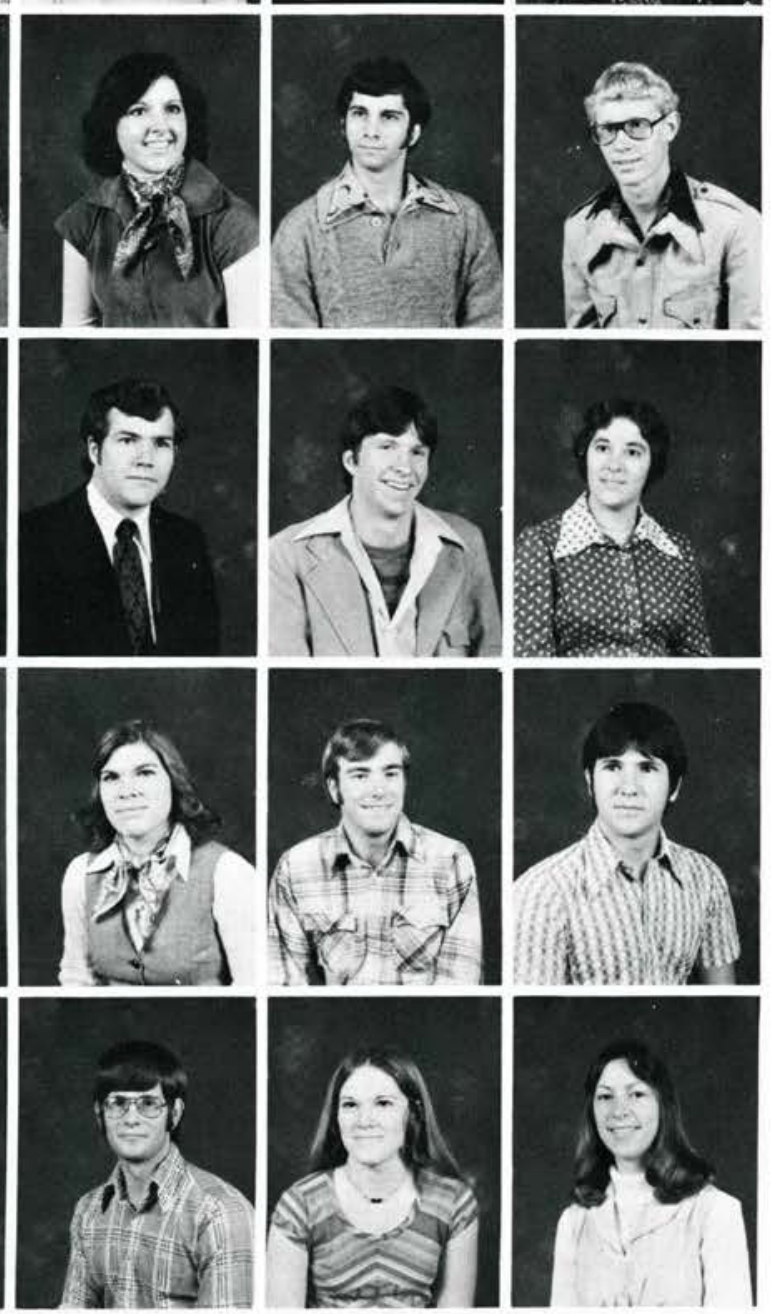

Nancy Abels

Jeff Acker

Barbara Adams

Cathy Adkins

Deborah Aeshleman

Tom Aitken

Diana Jo Amsden

Ken Andrus

Richard Atkinson

Pam Axiotis

Scott Bahorik

Bill Baldwin

Michael Barnett

Sharon Barrett

Becky Becker

Scott Beight

Beth Beikert

Barbara Bernstein

Dan Betts

Mala Biggs

Sandy Bonzo

Ruth Anne Book

John Bowers

Greg Brace

Terry Brammer

April Brazelton

Mike Bresson

Joe Brewer

John Briggs

Kathy Brower

Judy Brown

Steve Brown

Kevin Browne

Laurie Bruening

Lou Bunker

Don Burns

Joyce Butcher

Mike Butler

Vicki Butler

Brian Cafferty

Jan Callan

Lorraine Carr 
Bill Carroll Joyce Cartwright Cindy Castle

Scott Chandler

Dale Christian Ken Churchward

Victoria Clarke Pam Coates Craig Colas Rita Collingsworth Tammy Combs Richard Connors

David Conrad Stephen Coombs Kent Craig Nora Crandall Dave Cremean Janice Croy

Tammi Danec Tom Danube Joe Dariano

Debbie Dautel

Terea Davey Tim Davis

Ginny Decker Paul DeLange Julia DenOtter

Cindy Denny Cherie DePew Cheryl Douglass

Tim Dowd Ida Ehrman Goeffrey Ellington
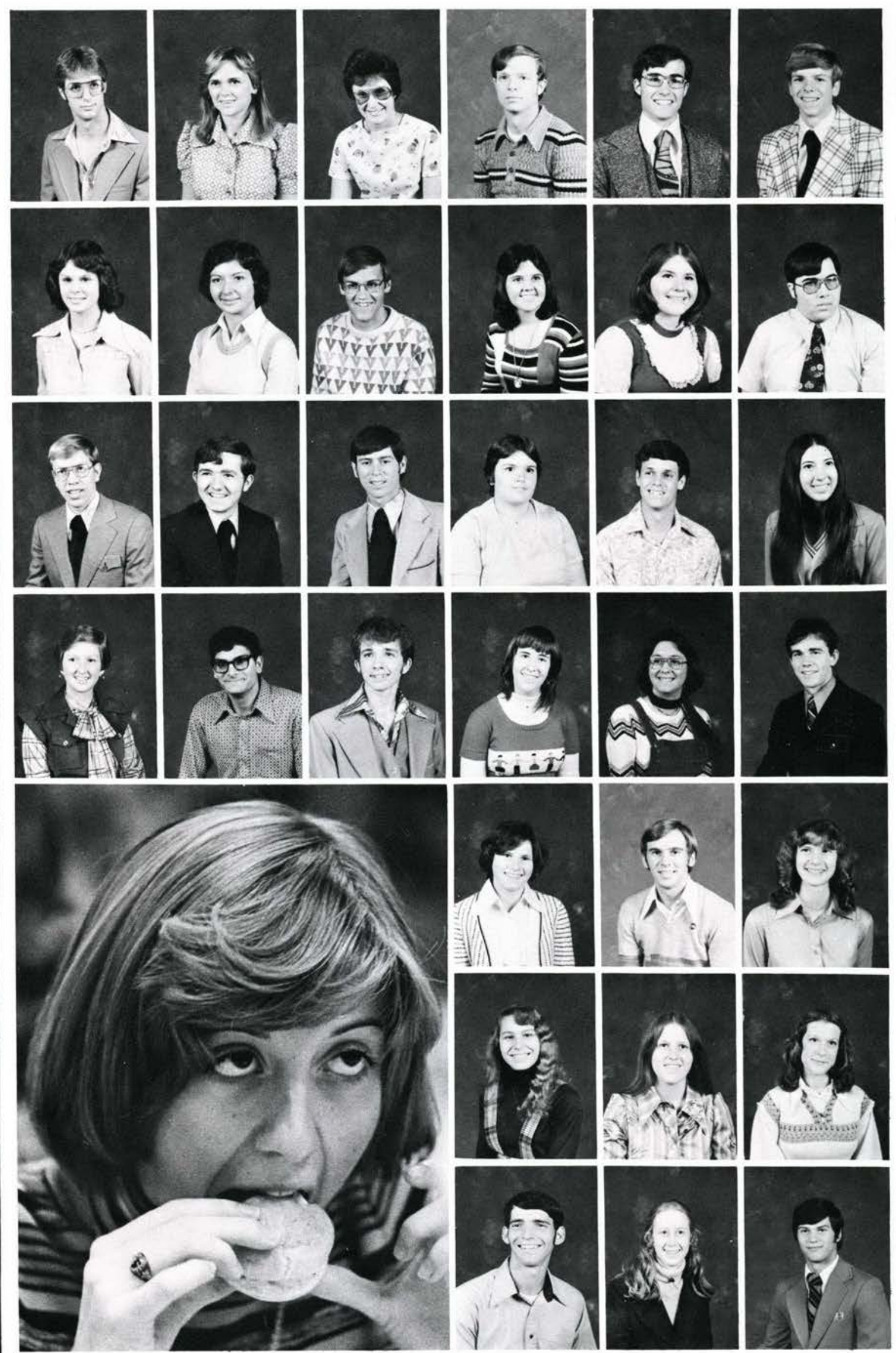

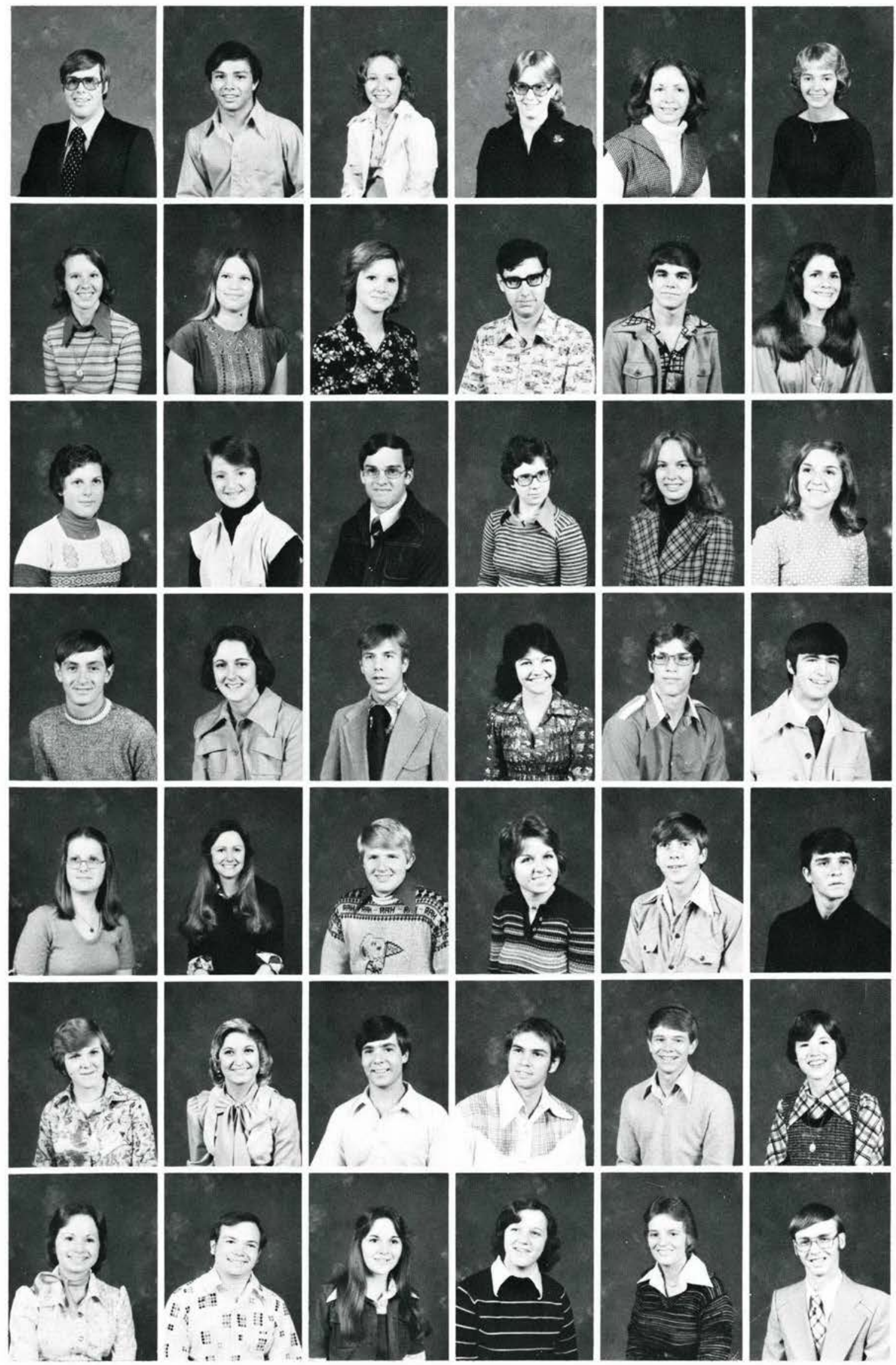
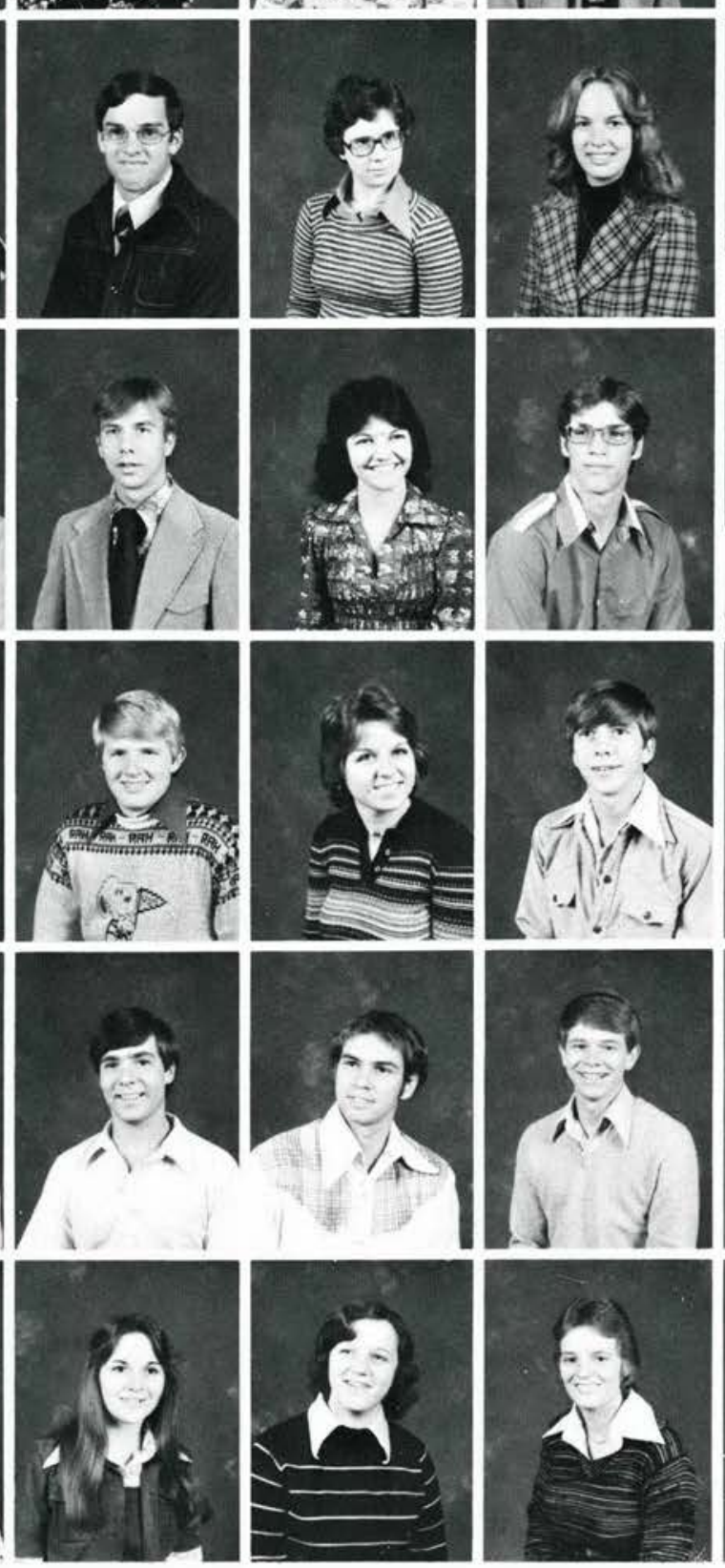
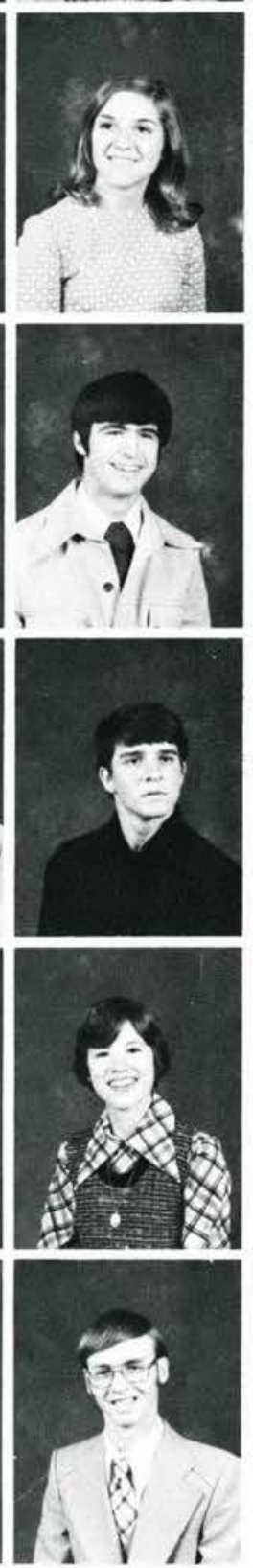

Dave Ellis

Erech England

Pat Farmwald

Kim Faull

Ann Fava

Sue Felts

Ruth Fenton

Margie Filmer

Rita Fletcher

Lawrence Flood

Ron Floyd

Darla Forrest

Kristen Frey

Elizabeth Fuller

Dan Fullmer

Jan Funtik

Elizabeth Galbraith

Teresa Galbreath

Gary Gallian

Vanessa Gardner Joel Gehrke

Paulette Gettle

Wynn Gifford

Allen Gilbert

Brenda Gilbert

Debbie Gillenwater

Frank Gillespie

Bonnie Gilmour

Roger Glidden

Gary Gromacki

Linda Grafton

Faith Grahl

Daniel Green

Dann Green

Andy Grenier

Marsha Greve

Cindy Grisham

Mark Grisham

Debbie Groves

Bonnie Guenther

Pam Hammond

Steve Hancock 
David Hanson Joel Hanson Randi Hargis Rick Harley Bonnie Harrison Denise Harrison

Charles Hatfield Kevin Hathaway Bill Hayes Steve Hayes Cecilia Hawkins Cathy Heatly

Dave Heffernan Kim Henderson Tim Henderson Judy Henson Kim Hermansky Cheryl Herron

Sarah Highbee Paul Hill

Scott Hinks John Hitchcock

Brenda Hobar Brenda Howard

Timothy Howard Greg Howe Carolyn Huffman

Margaret Hunt Cindy Jacobs

Brenda James

Dawn Jansen Rob Jenkins Susan Jenkins

Francine Jerisk

Brad Johnson Charlene Johnson

David Johnson Jill Johnson Marilyn Johnson Martha Johnson Cindy Jones Mark Jones
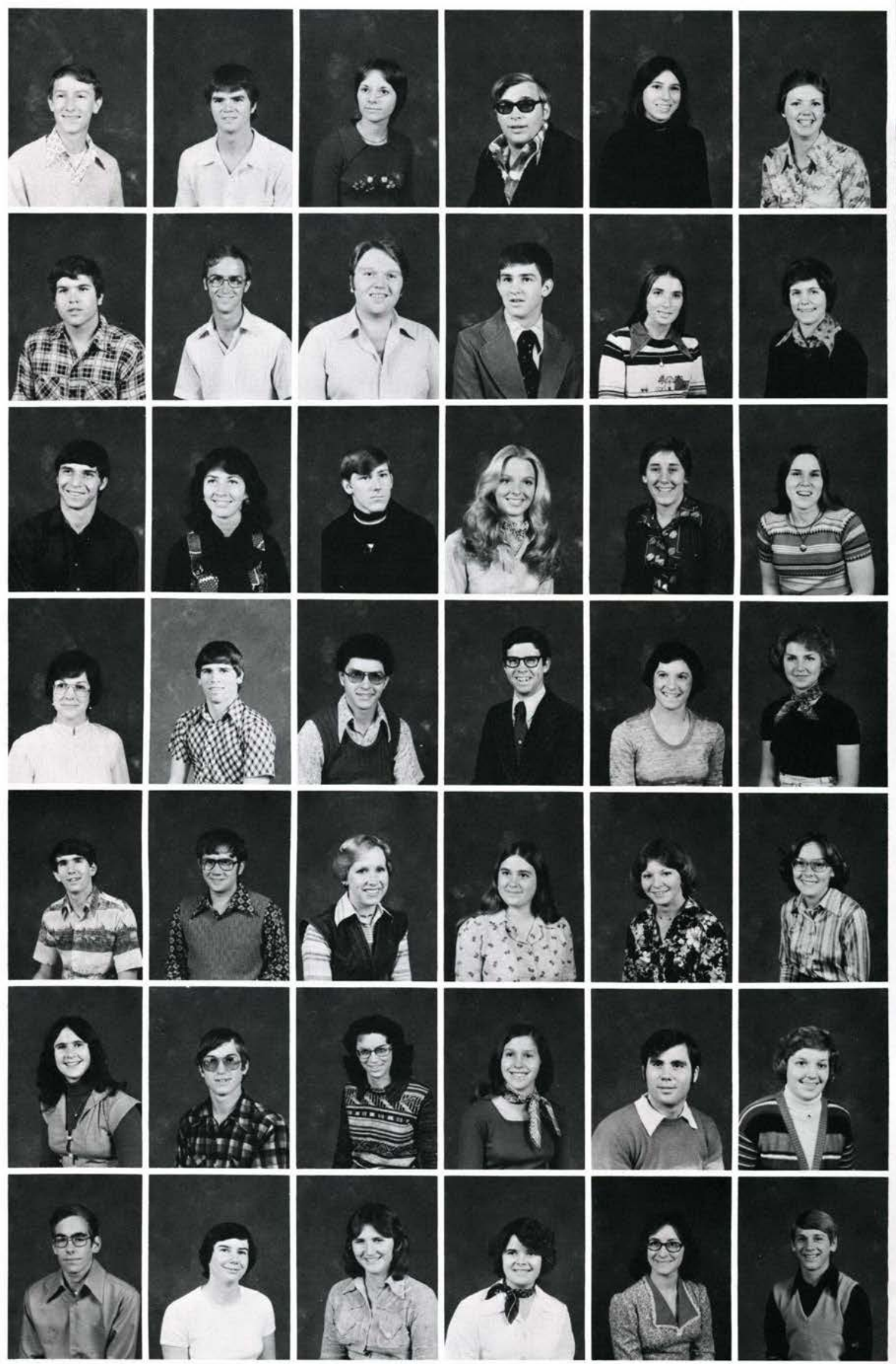

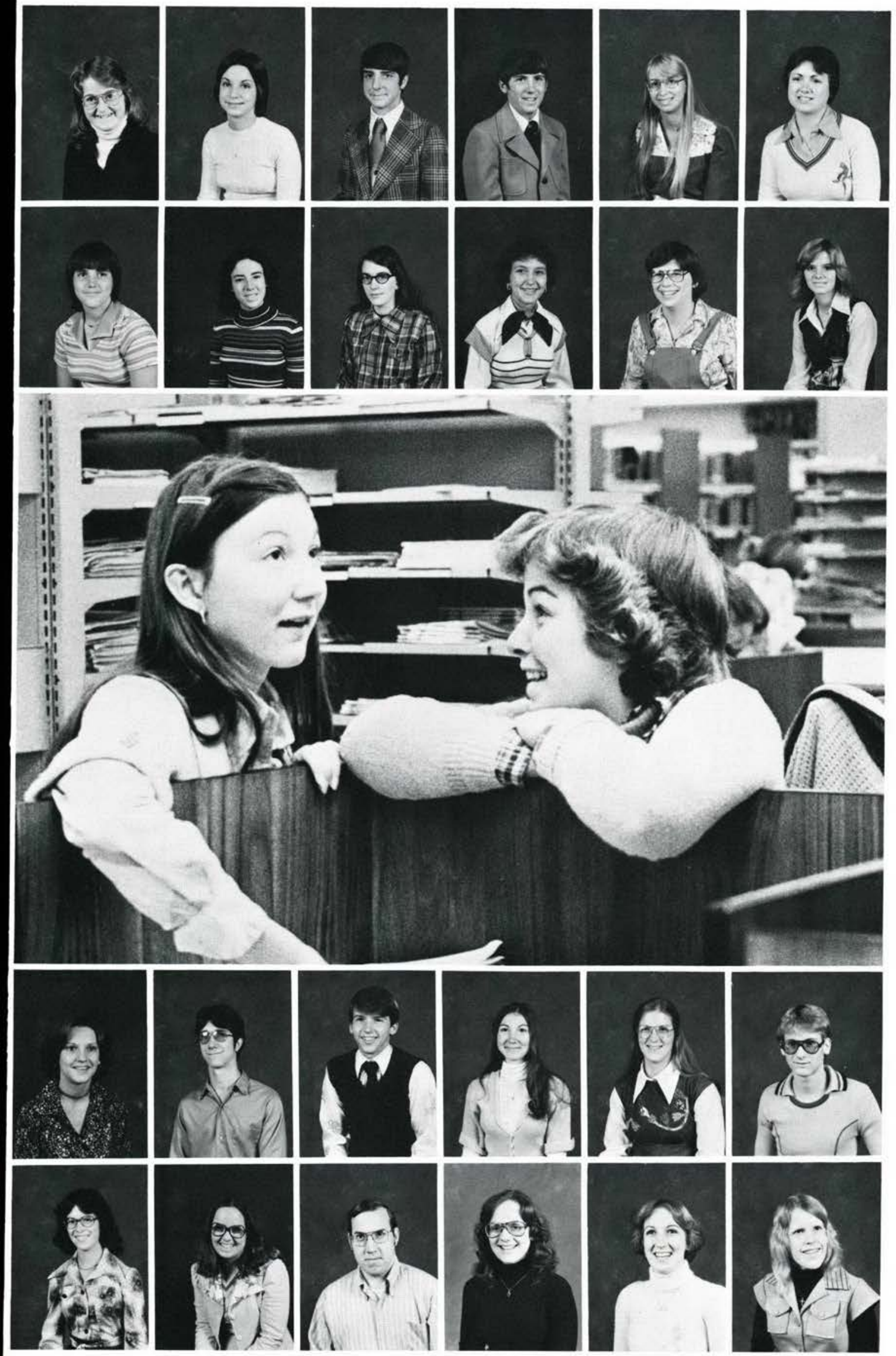

Peggy Kamphausen

Kristine Karsian

Kim Kauffman

Bob Kaufman

Ruth Kehus

Cheryl Keller

Sue Kelp

Susan Kerrigan

Debra Keys

Kristi Kimball

Colleen Kinney

JoAnn Kiser
Joyce Klamm

Joe Kobalka

David Polk

Paula Kozma

Gladys Krause

Dick Krewson

Mary Krick

Katherine Kuhn

John Kuhn

Linda Kurschel

Lori LaHaye

Betsy Lane 
Karen Langford

Karen Lapp

Valerie Larson

Dave LaRue

Debbie Lawrence

Fonda Leach

Jim Leightenheimer

Dorretta Lenox

Frances Levering

Sharon Levin

Tim Lewis

Nancy Lightner

Doug Lillback

Nick Linamen

Mark Lones

Nathan Longnecker Jim Luce

Byron Major

Promode Malaker Julie Marihugh

Cindy Martin

Ruth Martin Debbie Mast

Kevin Masters

Lisa Matheny

Stanley Mathews

Margie Mayo
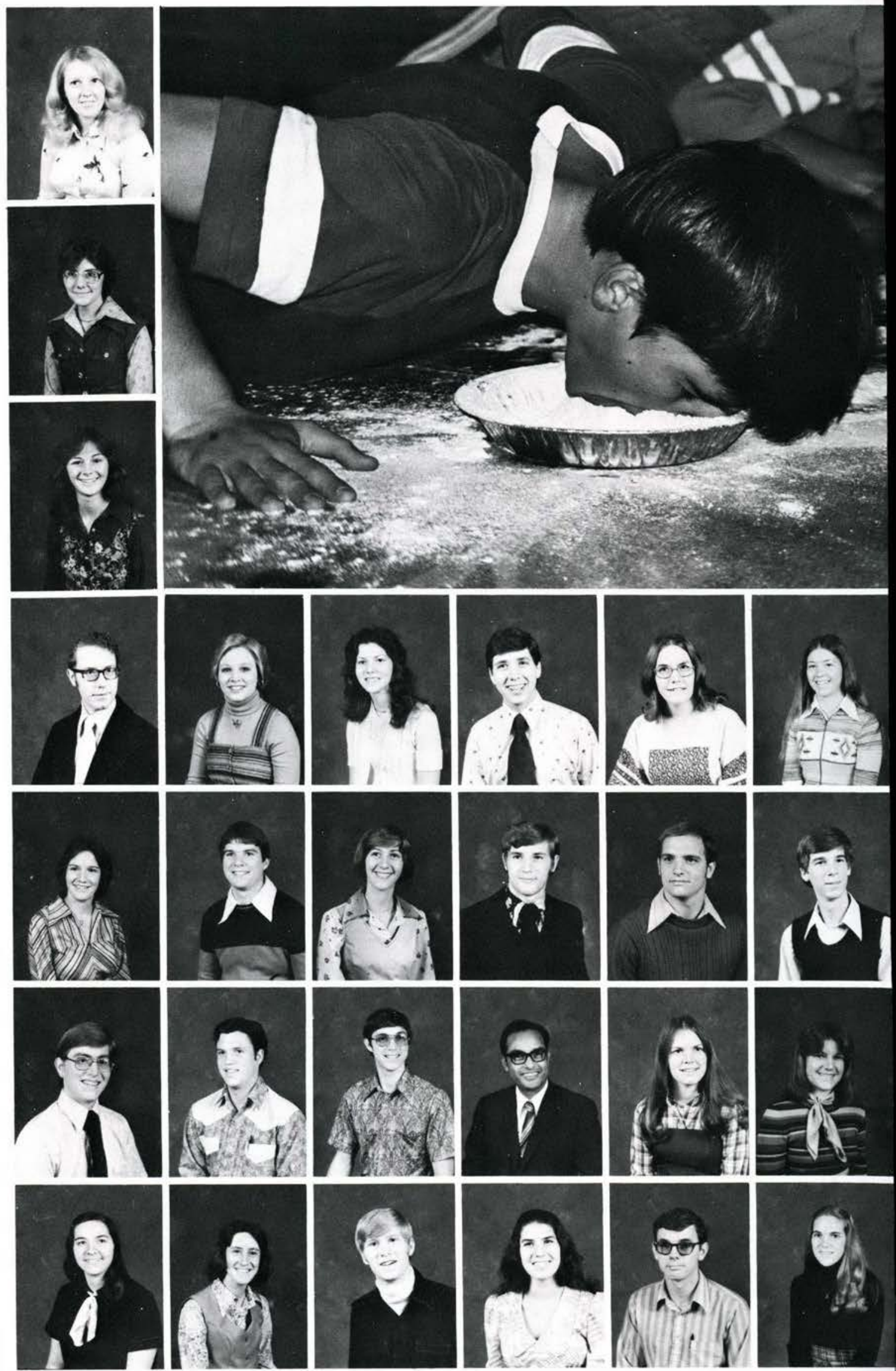

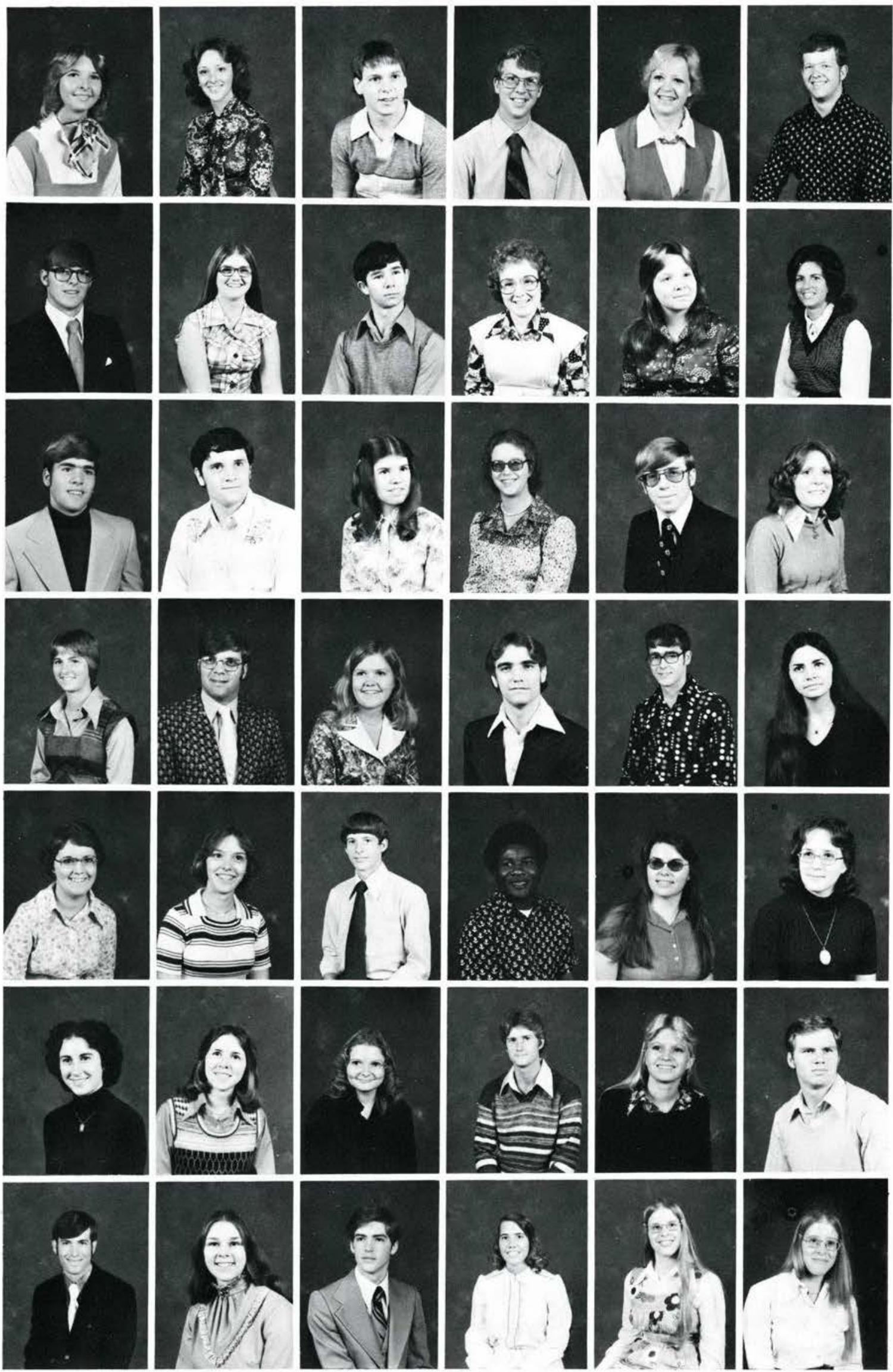
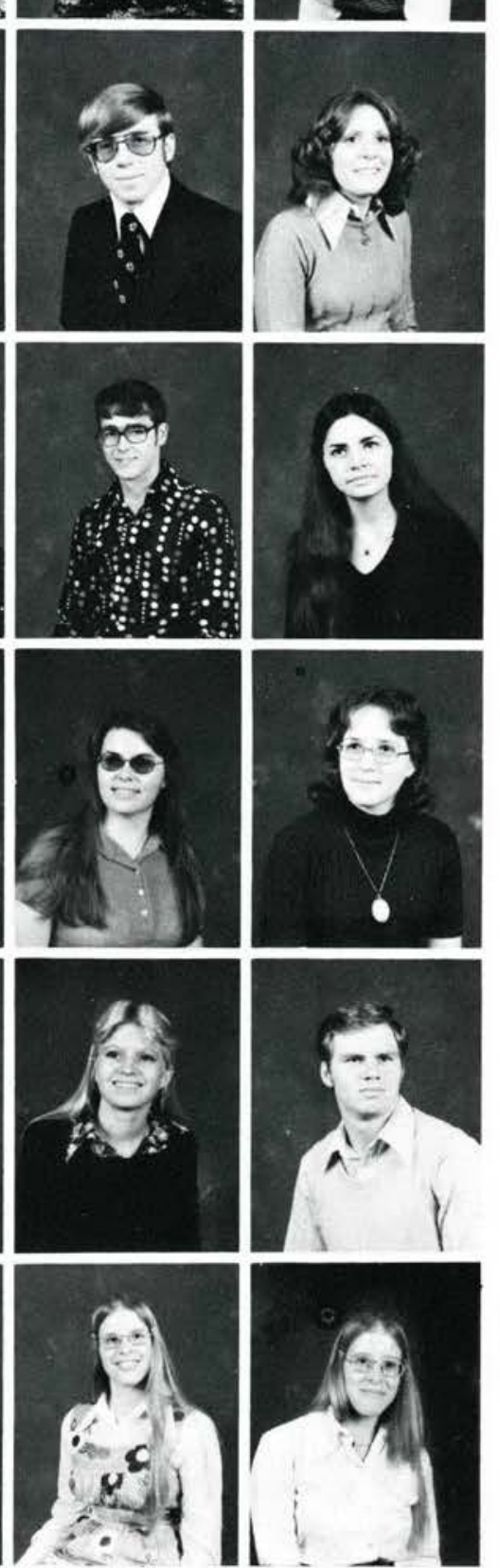
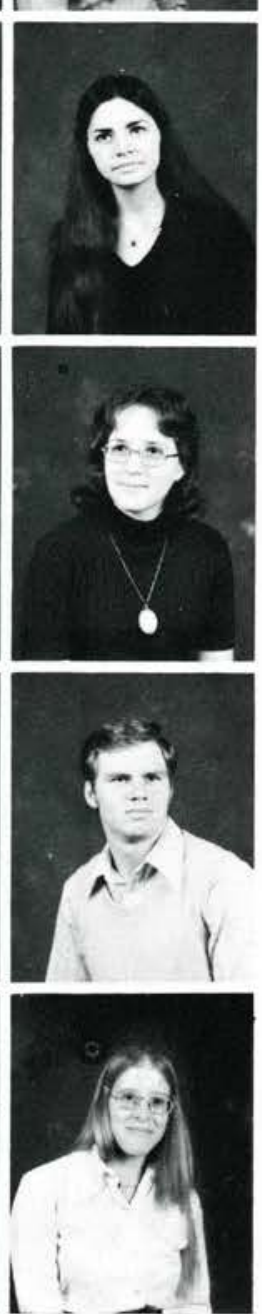

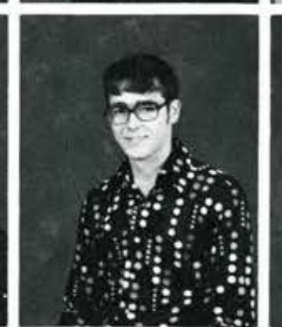

Brenda McBride

Michelle McClure

Gerry McCracken

Paul McCullough

Debra McDonald

Edwin McDonald

Dan McGhee

Connie McLane

Edwin McLouth

Karen McMurray

Leah Menninger

Pat Michalski

Roger Michel

Brad Milbauer

Cindy Miller

Leah Miller

Douglas Mitchell

Patti Molin

Diane Moore

Paul Moore

Rayanne Moore

David Morris

Douglas Morton

Avis Mucha

Debbie Myers

Carolyn Napier

James Neely

Samuel Nelson

Ruth Northcutt

Kathy Oakes

Judy Ockert

Renae Olden

Leslie Oliver

Mike O'Quinn

Kathy Osborn

Daniel Otto

William Pack

Donna Partridge

Don Parvin

Lynda Patton

Karen Payne

Kathy Payne 
Kelly Payne

Landa Penquite

Mark Peters

Ann Phillips

Frank Polley

Judy Peterson

Richard Peterson

Mark Pierce

Don Pippin

Daniel Poole

Kathy Price

Jody Pruitt

Charles Radcliff

Lee Randall

Debbie Rapinchuck

Cindy Rasmussen

Darlene Repp

Nate Rehn

Debbie Reid

Rick Reinhart

Janice Reu

Joan Rhodes

Lee Richards

Doug Richardson

Wanda Rife

Brian Riggs

Christine Robinson

Irv Rollman

Becky Rupe

Joyce Sagraves

Robert Salter

Chris Salzman

Clyde Sarver

Rhoda Schatz

Twila Schatz

Debbie Schieber

Paul Schmutzler

Terri Schofield

Mark Schuchard JoAnn Schwerthofer

Sheryl Scoggins

Marcia Seger
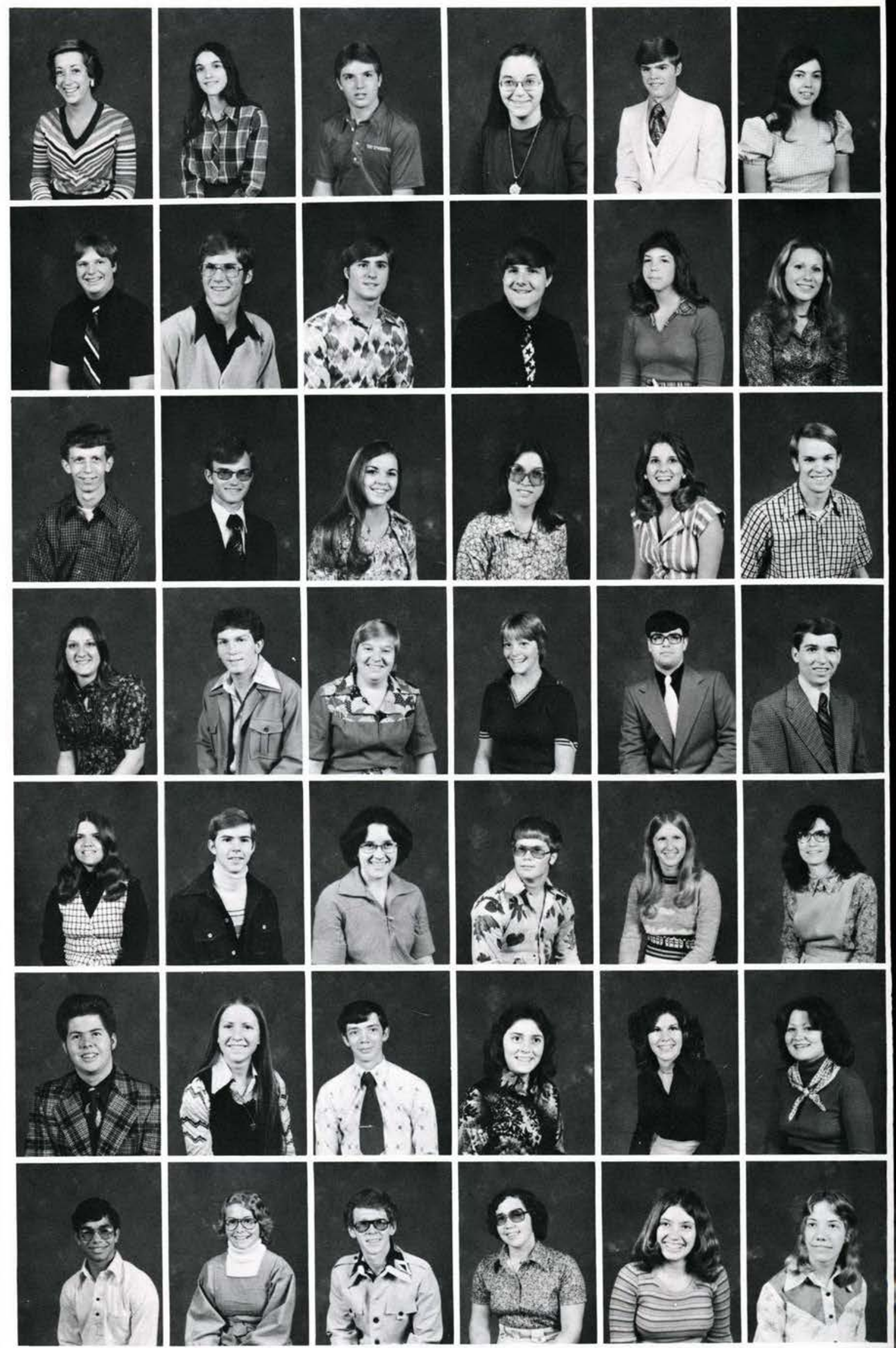
Steve Swayze Sheryle Tacderan Shawn Taylor Jane Tedeschi Nayda Terkildsen Steve Terlouw

Nancy Tillman Darlene Tillson Barry Tindall Kathy Titus Stacy Towle Dave Treese

Kathy Turner Nancy Unroe Mariene Vail Debbie Van Ryn Joel Veldt

Diane Vernon

Matt Vincent Kim Waites Jearl Ward Virginia Ward Doug Weimer Kathy Weller

Brad West Danette Wetzel Tom Whiting Joyce Willetts Keith Wilhite Carol Williams

John Williams Lynn Williams Allen Woodruff Ken Woods Michele Wozniak Dale Wurstner

Sharon Wurstner Eric Wyse Tom Yater Joy Yhap Janice Yoder Amy Young
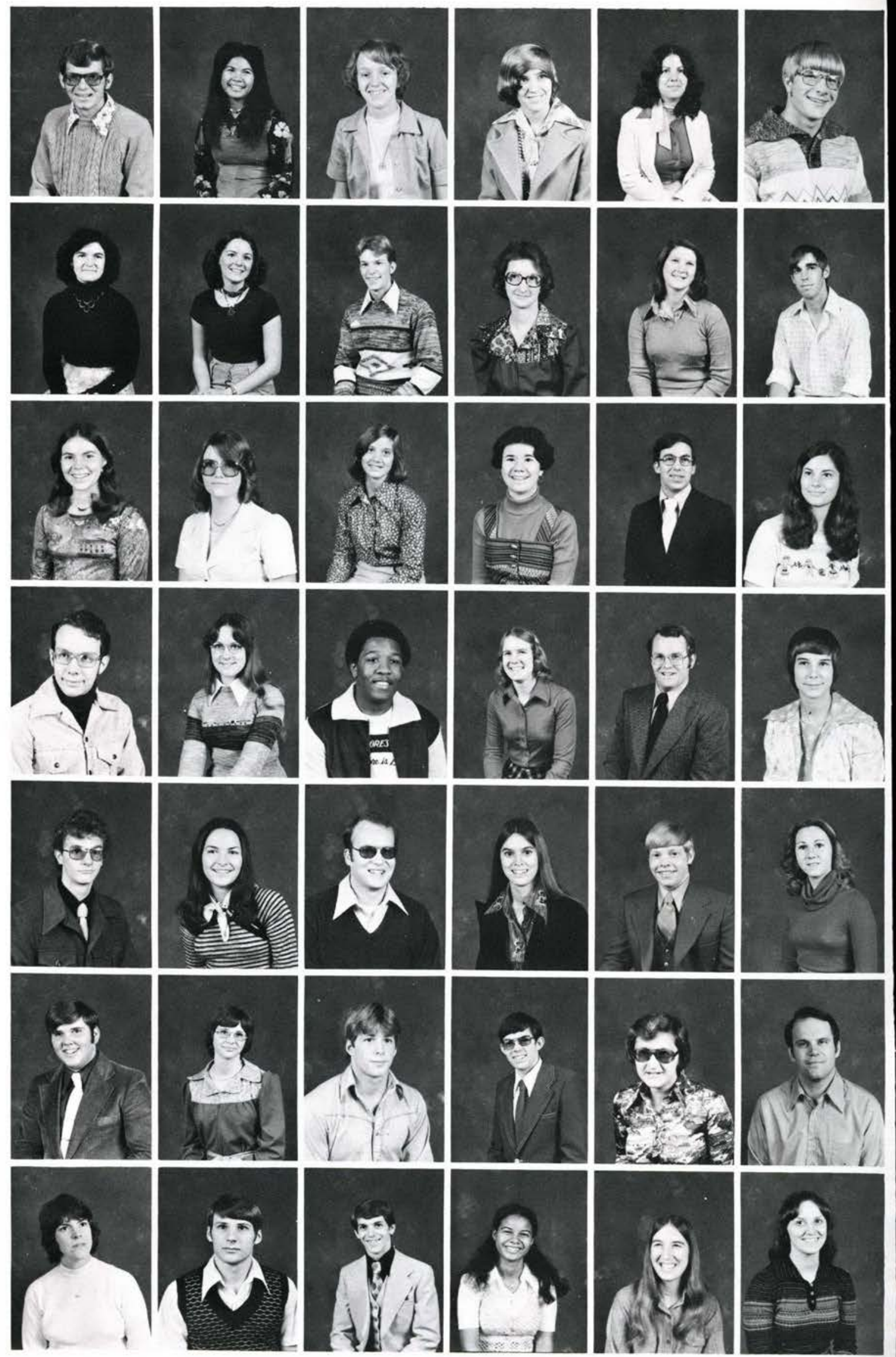
Daniel Abbott Jim Abercrombie Bill Abernathy

Warren Allan John Allen John Alvey

Crystal Anderson Dean Anderson Joyce Anderson Kris Anderson John Andrew Karin Angel

Kathy Armstrong Jane Arthur Paula Arvay Edward Babcock Tom Baily Pam Baker

Cindy Banner Jim Barrett Jeff Bean

Norman Benson

Mike Bentley

Beth Blackburn

Deb Blackburn Sue Board

Denise Bond Jay Borck

Terry Broach Becki Brown

Scott Browne Jan Bubel

Vicki Burleson Janice Byers

Randy Cagwin Randy Campbell

Cheryl Carey

Sharon Cartan Guthrie Chamberlain Sondra Champlin Jeff Conklin Gary Connors
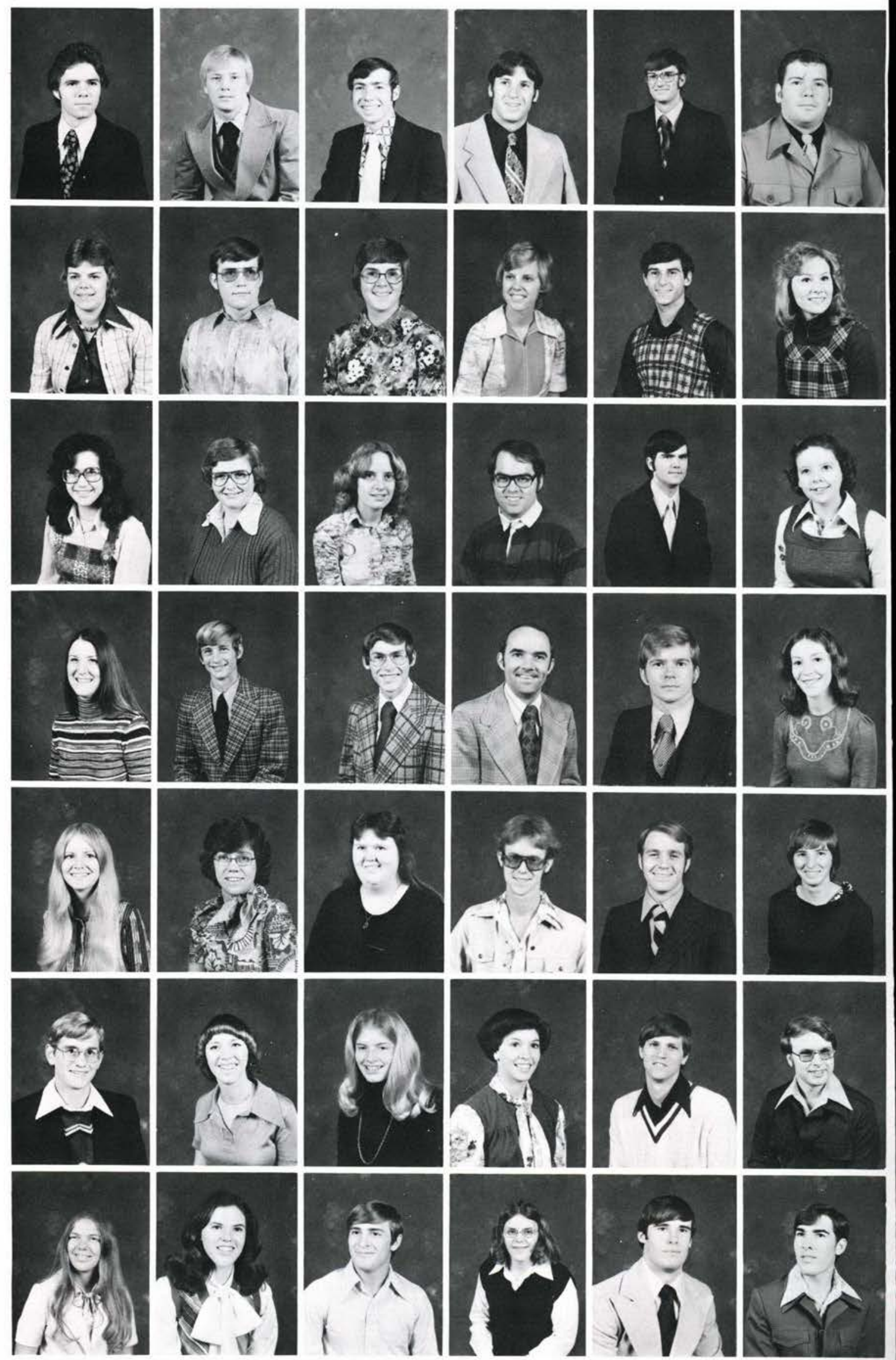

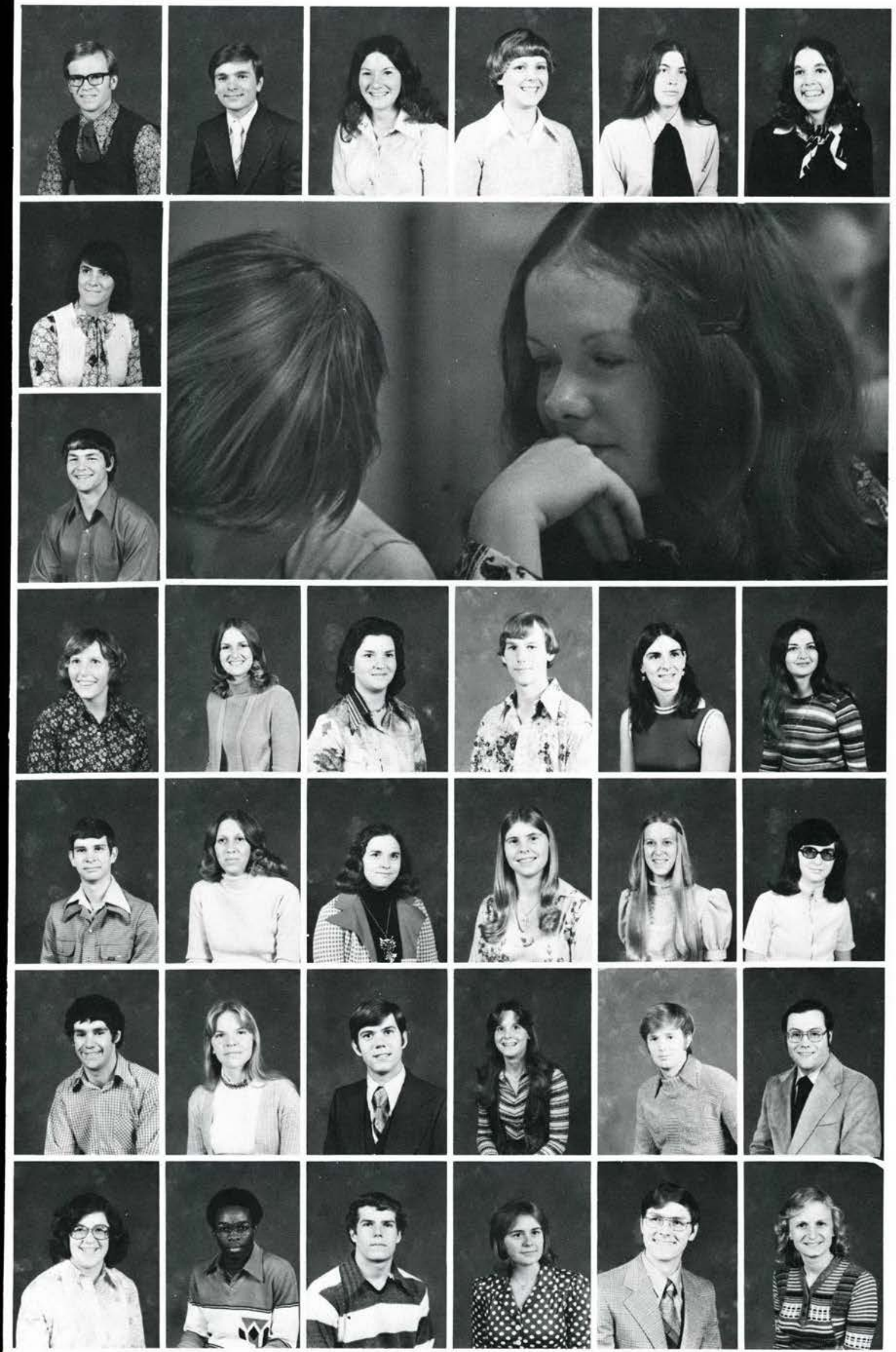
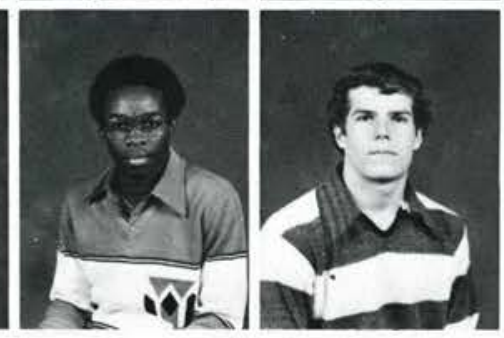

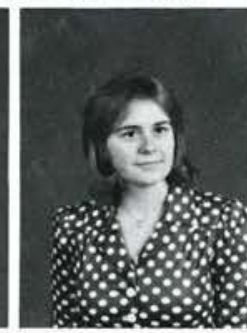

Paula Flint

James Footman

Dave Francis

Jane Frederick

Paul Freeman

Merry Freshney

Janice DeYoung

Lou Ann DeYoung

Debbie Dixon

Gordon Donaldson

Lynne Donnelly

Becky Driscoll

Dave Drozek

Eileen Dugan

Karen Duncan

Karen Dyer

Loretta Earnhart

Janet Ebel

Paul Edwards

Linda Eissens

Dave Ellington

Donna Evans

William Felmlee

Ned Fertig

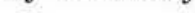


Carey Fullmer Barbi Geshay Kevin Grier

Fred Greetham David Gregory Elaine Gregory

Dewayne Grooms Gary Gross Karen Haga

Cindy Hall Jane Hansen Robert Hanson Judi Harkless

Dana Hazel Mark Highman

Dwain Hill Gary Hinkle Donald Huffman Joel Hunter James Jamison Dianne Jones

Sherri Jones Dan Kaffenbarger Jan Kaufman

Kathy Kearbey Denise Kelso William Kessler

Michael Kessel Mark Kirby Desiree Kirk Debbie Kitchen Rick Krejci Patti Kriel
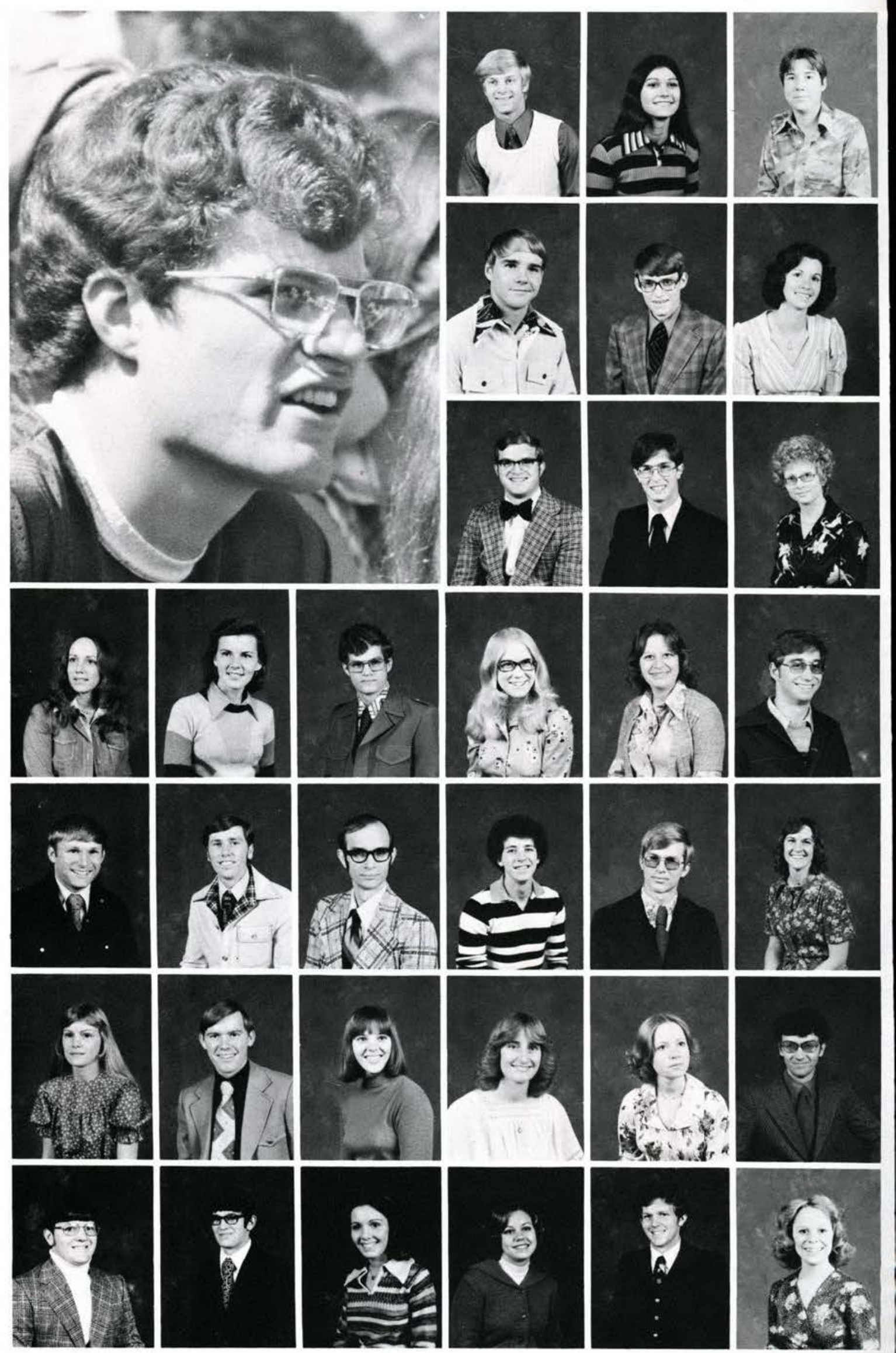


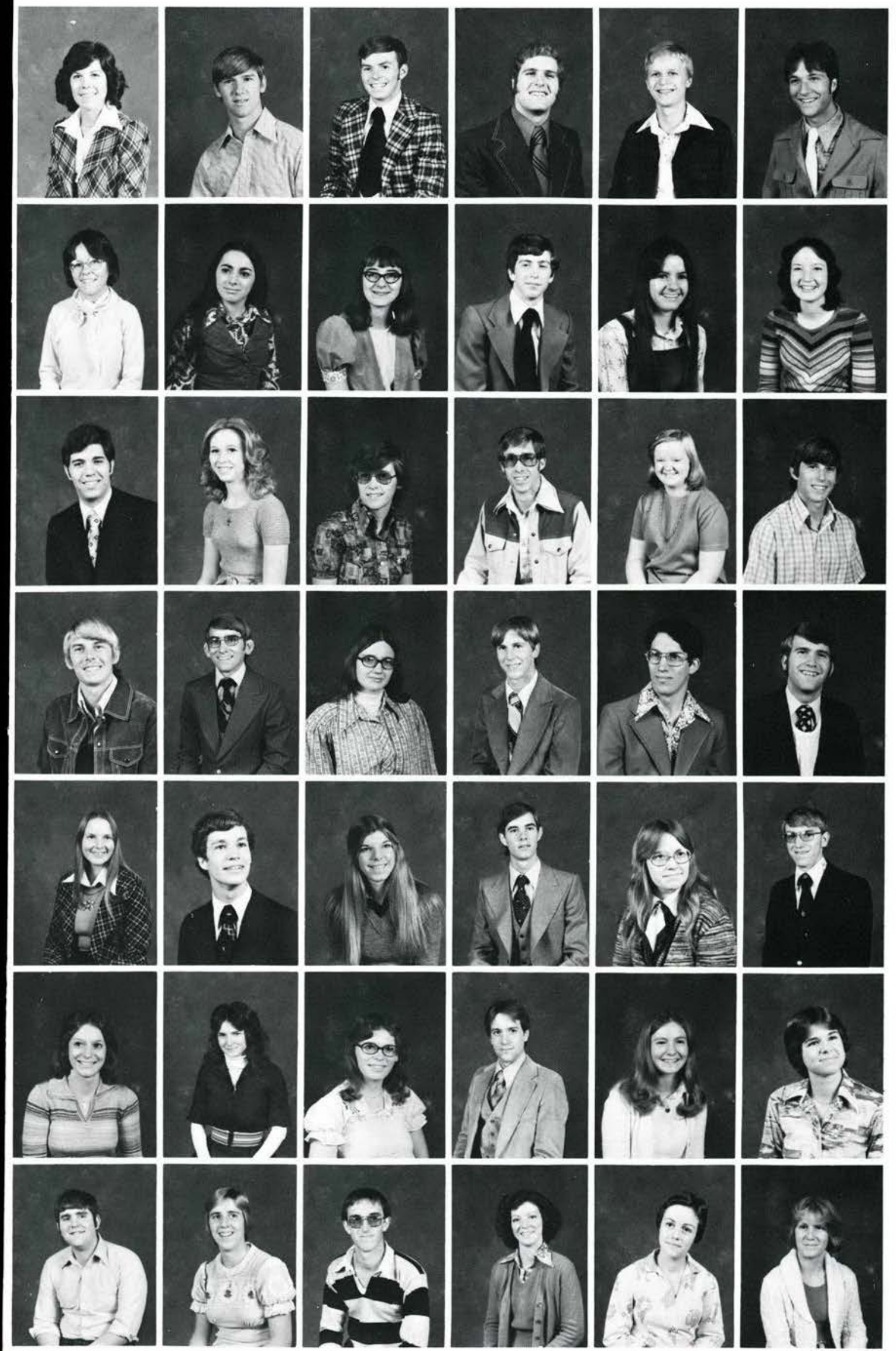

Sue Kuntzelman

Mark Landis

Bill Lanphier

Jerry Lantz

Mark Larson

Fred Laxton

Jo Leeke

Leslie Leyland

Sally Logsdon

Joel Longnecker

Janet Lowis

LuAnn Luers

Vance Maloney

Donna Marland

Dawn Marvin

Rick McClendon

Lisa McClure

Brian Medlock

Ron Medlock

Dave Messenger

Joyce Metzler

Mike Mignard

Brian Miller

Craig Miller

Darlene Miller

Phil Miller

Sharon Moberly

John Mohler

Jane Moore

Alan Morgan

Cheryl Morris

Dianne Muirhead

Cheryl Mull

Steve Myers

Lori Neal

Brenda Neally

Randy Neff

Rachel Norton

Tim O'Neal

Cindy Orrick

Lisa Overturf

Linda Parke 
Mark Patterson

Nancy Payne

Jim Perry

Sue Scott

Karen Seymour

Claire Phillips

Sharon Shaw

Melanie Smith

Rachel Smith

Ronda Smith

Jeff Pinson

Cindy Poskey

John Potter

Beth Prentice

Marty Pressau

Karen Price

Vera Price

Jane Prugh

Gaye Putman

Ed Rarick

Mike Ratzlaff

Marilyn Rayburn

Ellen Redinger

Cynthia Reed

Patricia Reynolds Judi Riter

Lloyd Roberts

Dave Rogers

Joe Rohde

Marcia Romein

Barb Roth

Betty Rousch

Clark Ruh

Tommy Ruiz

Debbie Sanderlin

Dorene Sands

Dean Scott

Martha Sprano

Terry Stanaway

Joan Surso

Cindy Strickland

Mark Streitmatter
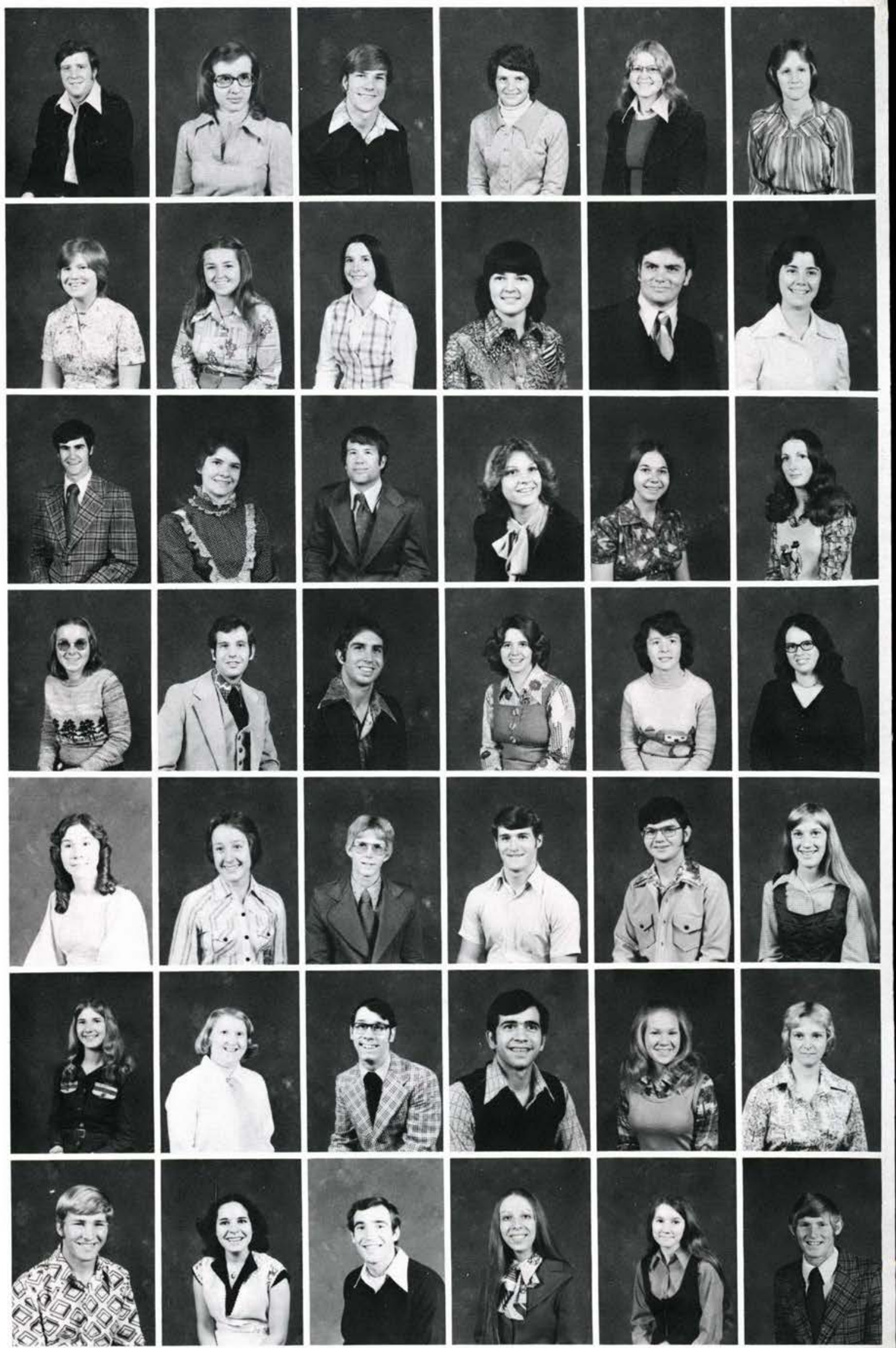


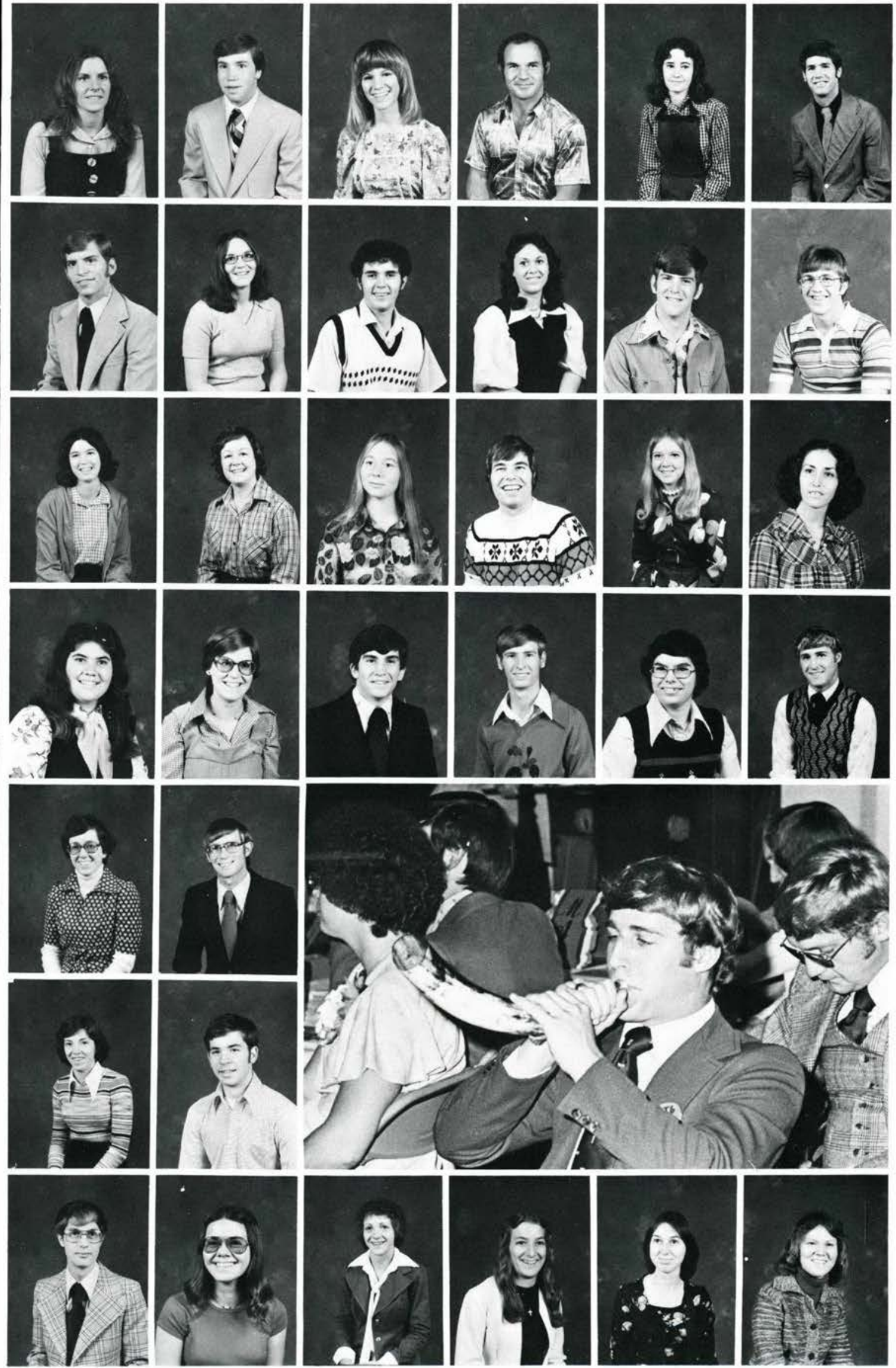

Gwena Sweeney

Dan Taylor

Priscilla Taylor

Tate Salmons

Sherri Thomas

Stephen Thompson

Warren Throckmorton

Sheryle Tichenor

Stephen Titus

Debbie Toro

Larry Twigg

Bob Ulrich

Sharalee Utley

Peggy Van der Hoeven

Julie Vogel

Randy Wagner

Ruth Wagner

Tina Wagner

Carol Walker

Kay Walker

Jeff Warix

Alan Webber

Karen Webster

Dale West

Claudia Whitestine

Bob Winward

Karen Wildermuth

Steve Willsey

Dave Woodall

Cindy Wright

Renee Wuebben

Leona Yater

Jan Zachary

Susan Zink 


\section{Junior Class Reaches For Rapport}

Having good communications between officers and students is the Junior Class's goal. Proof of this desire is seen in the questionnaires given to Juniors. All are asked to indicate which class activities they prefer. From this, all activities are determined, including a roller skating party, a bowling party, and an outdoor activity. The Junior Class endeavors to include the rest of the school in all their activities. Good organization is being emphasized in the efforts spent on the Junior-Senior Banquet.

1. Junior Class Officers: Richard Young (Chaplain), Bruce Henslin (Student Senate), Marty Shaw (President), Lila Terlouw (Secretary), Kurt Harding (Vice President). Not pictured Irene Taylor (Treasurer). and Dan Wickman (Student Senate).

2 . Beauty is in the eye of the beholder, or so hopes Dan Dunn.

3. To Cherie Watts, the library is more than just a place to read books.

4. Tom Williams chats before chapel.
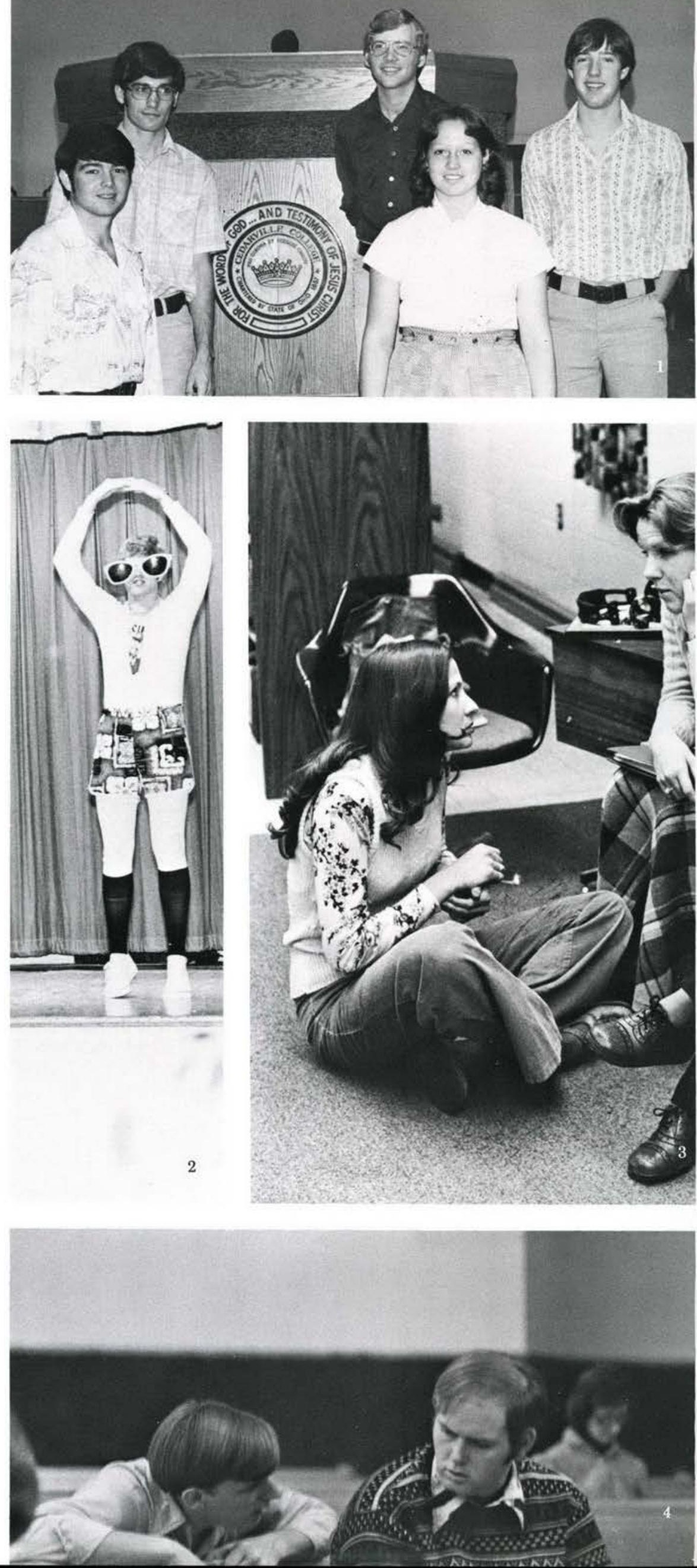

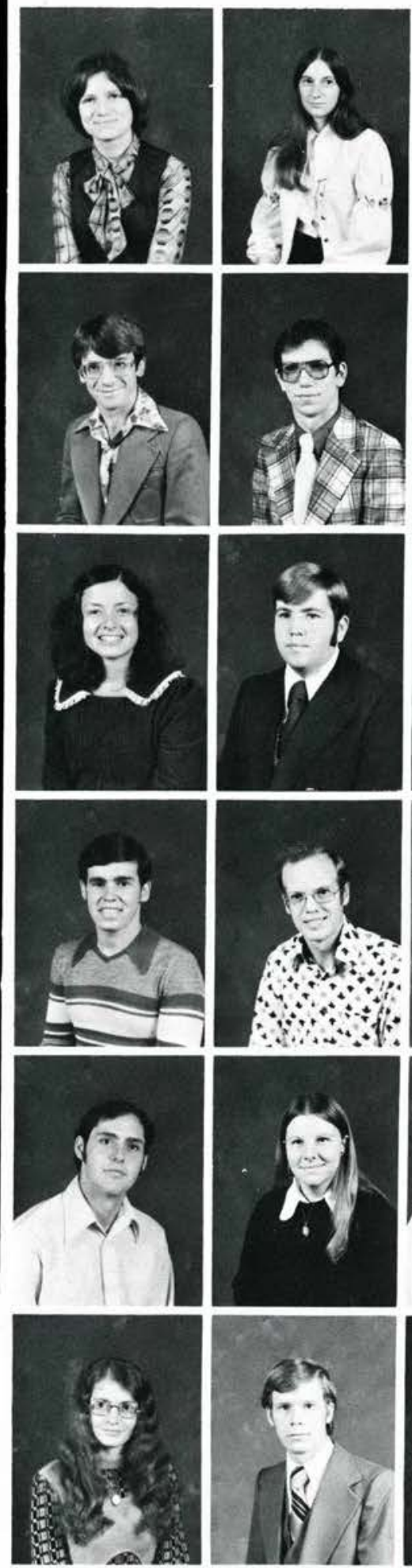

\section{r}
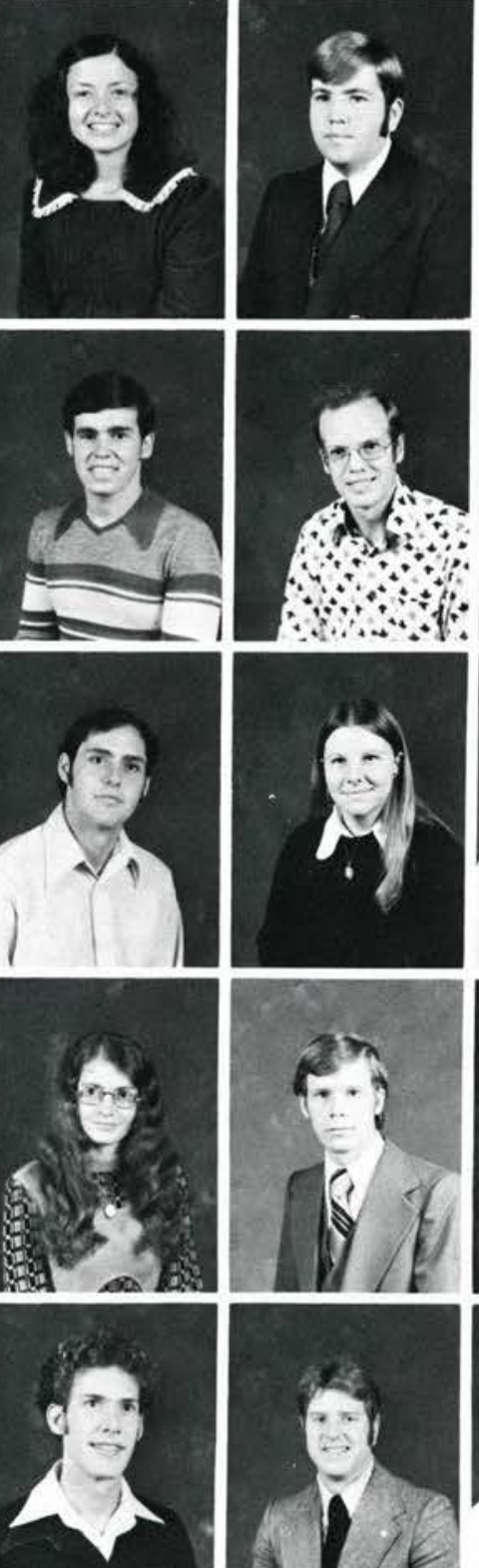
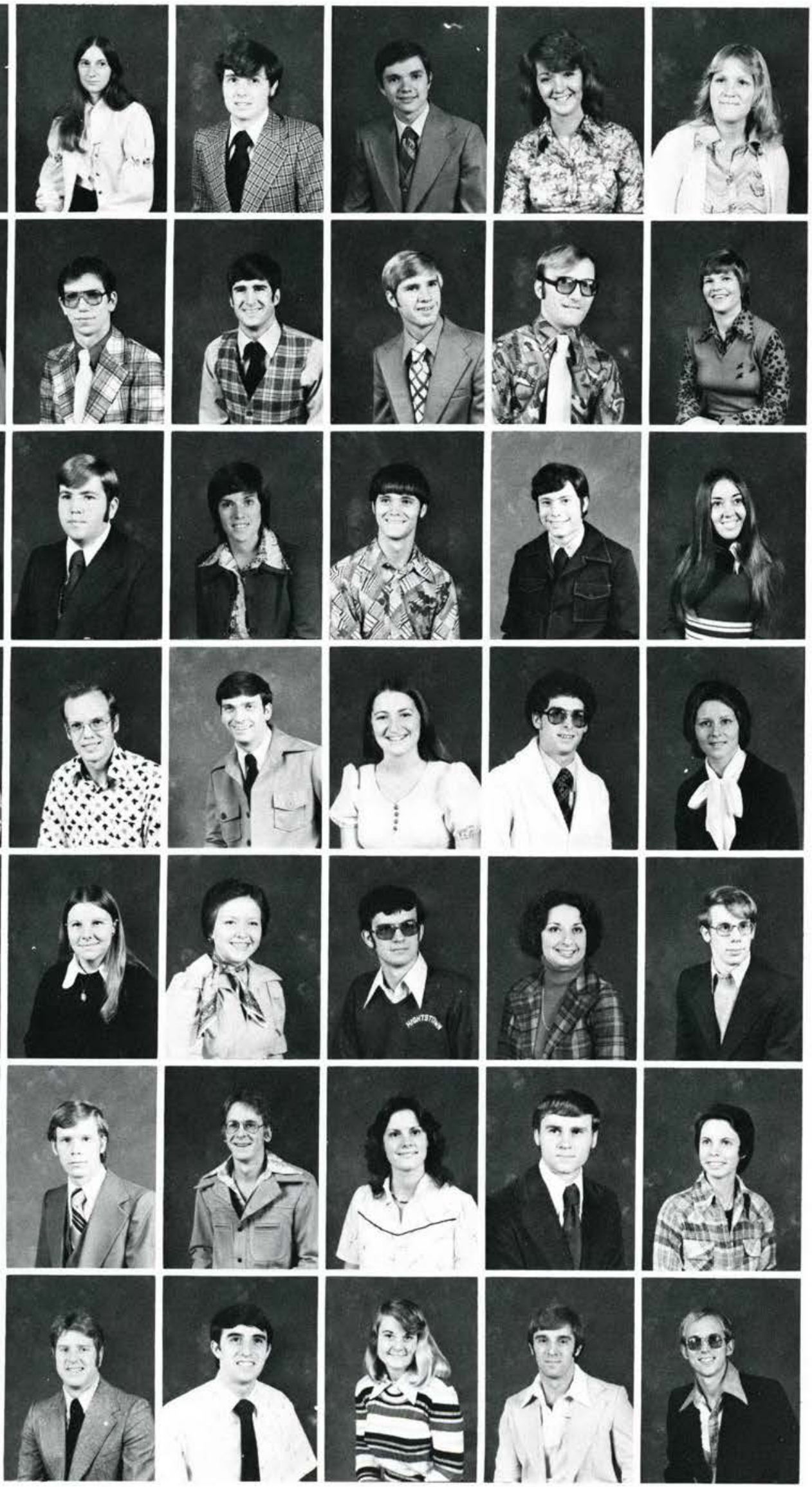

Rachel Courtsal

Mark Cowell

Jeff Cowen

Judy Cross

Mike Cuffman

Pam Dalby

John Dannenberg

Mike Davenport

Jeff Davis

Sandy Dawson

Dan Dedic

Ed DeLange 
Diane DeNicola

David Denny

Nancy Drake

Dan Dunn

Sallie Fogle Rosalie Eaton Mary Emery Elizabeth Engdahl Jessilon English Judy Erickson

Linda Ernst Ken Erny Vernon Esham Laura Everett Debbie Festag Karen Fetzer

Bryan Few Dennis Few Bruce Fleming Robert Foreman Mary Forsten Wendy Freeburger
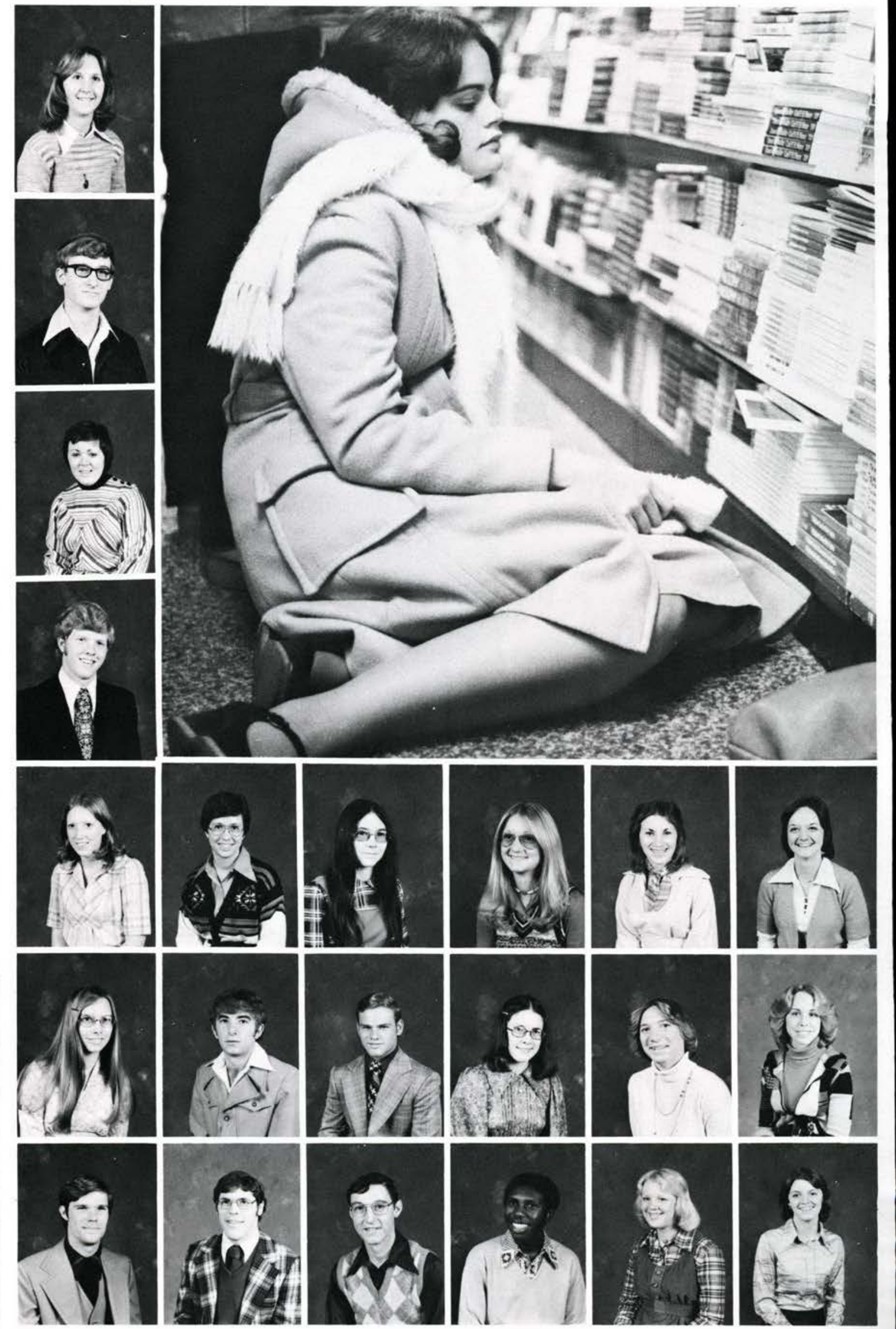

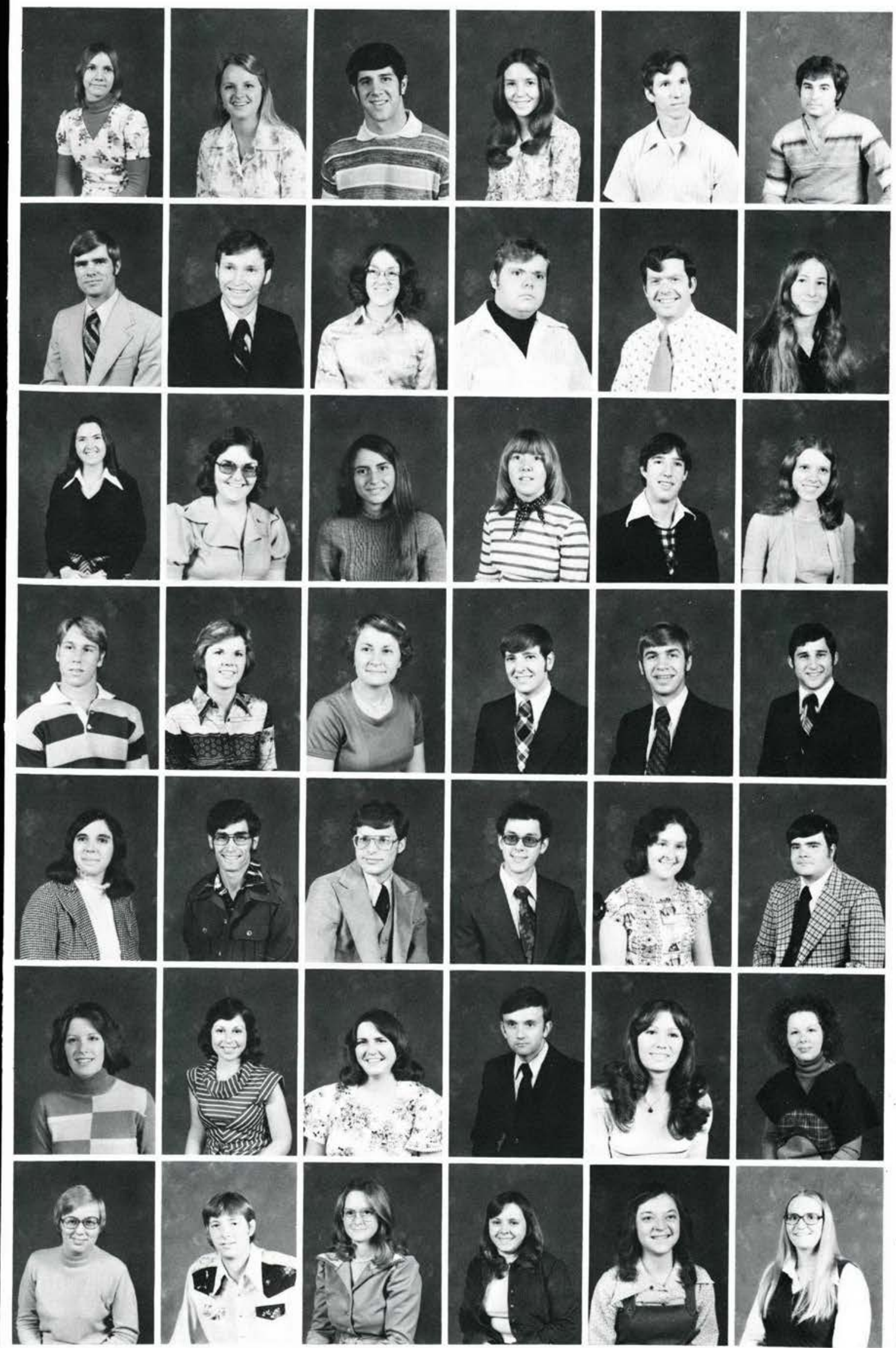
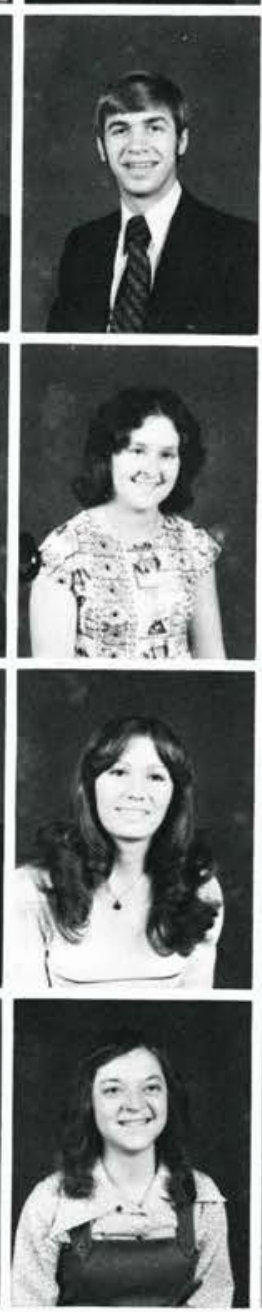
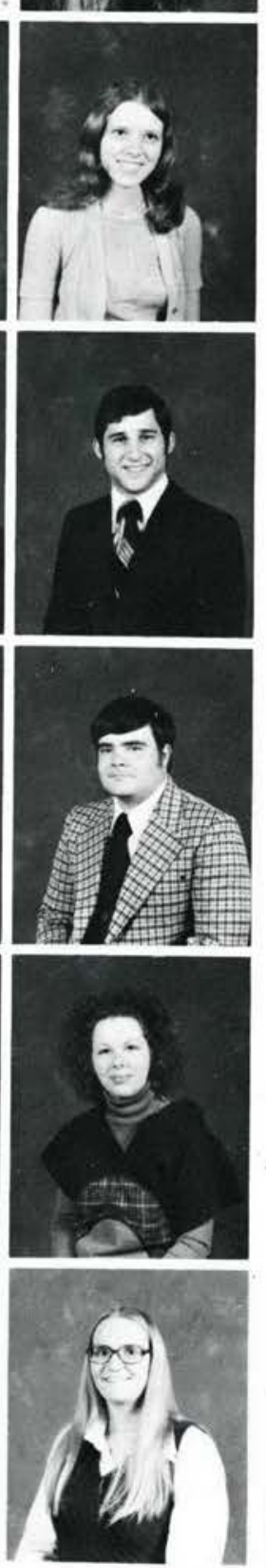

Sue French

Pat Gardner

Pete Gardner

Denise Gawthrop

David Gilbert

William Gilmour

Keith Glassey

David Glenney

Sandra Glenney

Paul Godby

Wayne Godby

Linda Gradish

Karen Gray

Carol Green

Kathy Green

Becky Hamer

Kurt Harding

Carla Hargis

Dan Harkleroad

Pam Harrison

Debbie Hattenfield

Steve Hoy

Doug Hazel

Barry Heagy

Ann Henning

Bruce Henslin

Dan Hicks

Dennis Hinks

Judy Hinks

Bert Holler

Pat Holmes

Marilyn Horne

Debbie Howard

Terrell Hudson

Mary Humbert

Heidi Humble

Denise Hunn

Mark Hunter

Cathy James

Dede James

Kathy Jones

Linda Jones 
Dave Joseph

Paul Kauffman

Kenneth Kerrigan

Alan King

Rochelle Kinkle

David Kisner

Judy Knudsen

Jayne Lambert

Keith Lambert

Carol Lancaster

Phil Leston

Ross Livingood

Guy Lloyd

Christine Lofgren

Grace Longnecker

Kathy Lord

Rich Luedeke

Vernon Lutman

Tom Lutz

David Lyons

Andrea MacDermaid

Lydia Mason

Dale Mattox

Michelle Mayo

Mark McDougal

Gene McMillen

Susann McMillen

Dave McMurray

Renee Meeker

Stephanie Mesner

Karen Metzger

Steve Miller

Thomas Mohler

Pam Monday

Diane Monts

Rebecca Myers

Jack Nace

Keith Namy

Janie Neely

Mike Nelson

Gary Nicholl

Dewey Noble
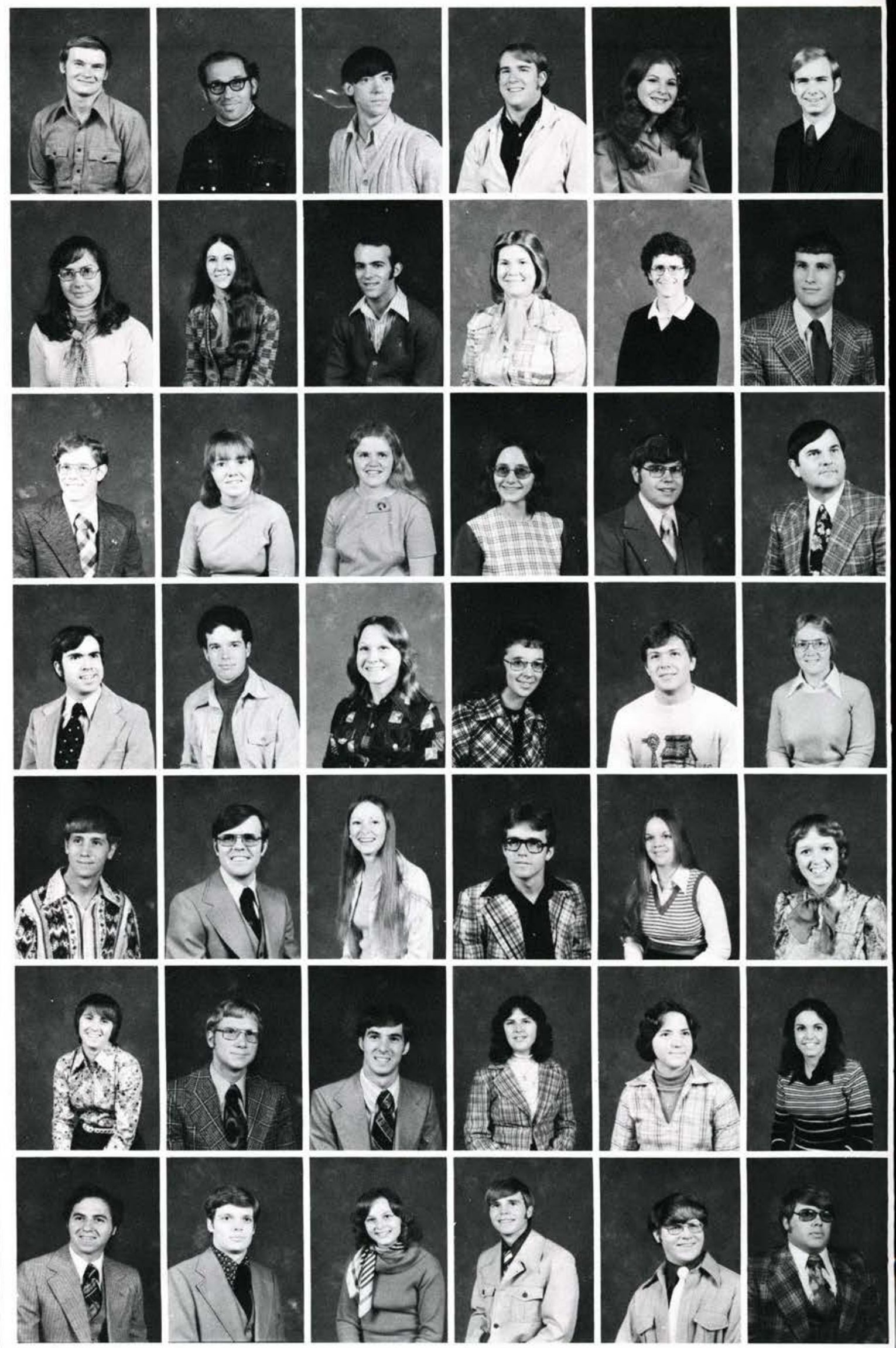


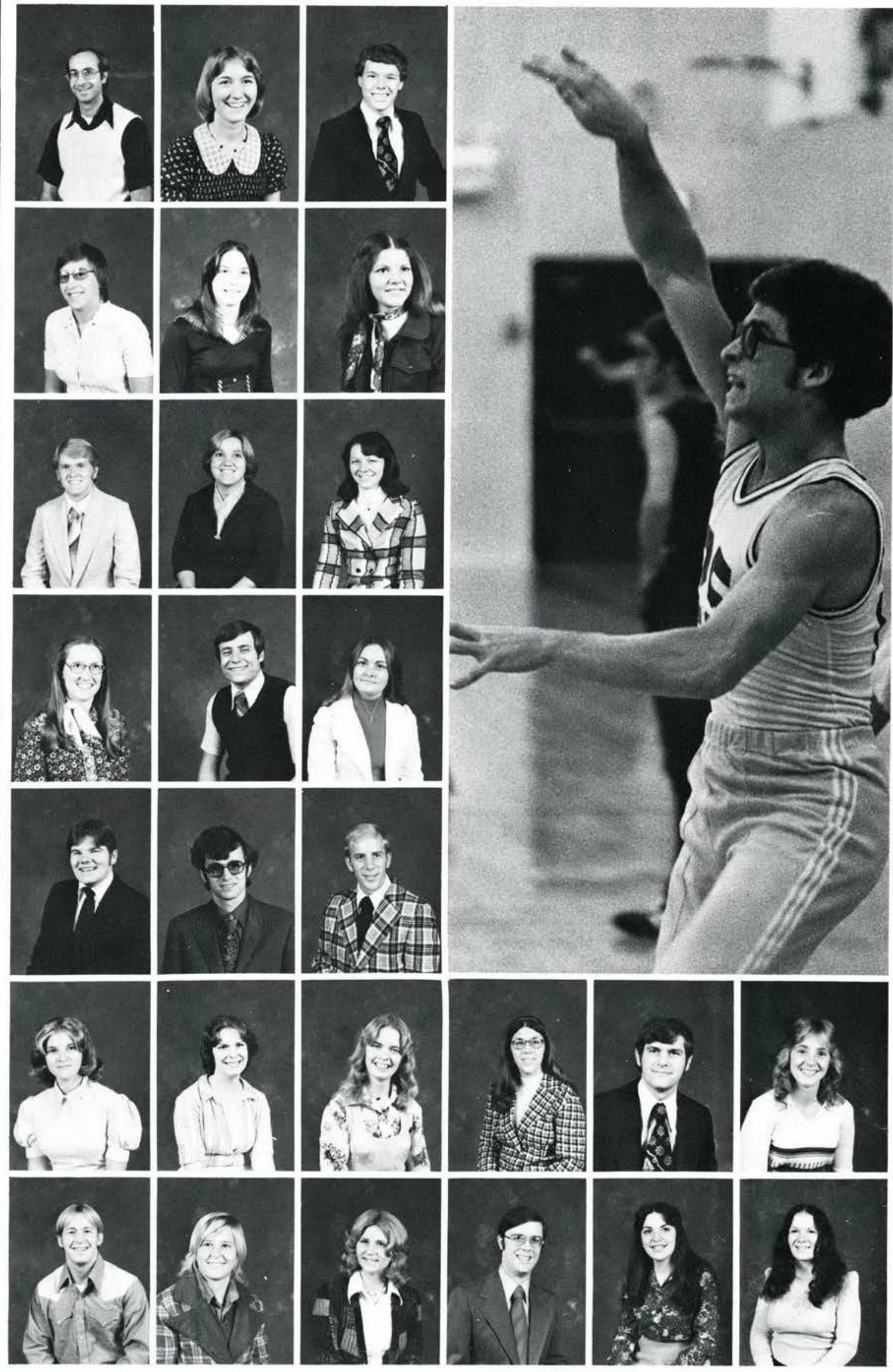

Paul North

Charlotte Olson

Dave Ormsbee

Laura Palmer

Micky Park

Evelyn Parker

Jay Patton

Sally Pearce

Roxanne Perry

Sue Perry

Mark Peterson Jeanne Pippin

Steve Poling Don Quinn Jon Raber

Debbie Ransom Chris Rees

Susie Regling Nancy Reitnauer Dave Rich

Janice Richards

Dave Riddle Laura Risser Deborah Robery Dave Rock Rhonda Rogers Cathy Rohm 
Bill Roloff Amy Ross

Wes Rowe

Tim Rowland

Larry Salyer

Debbie Schweitzer

Liz Schierwagen

Peggy Scott

Bryan Segerstrom

Becky Seldon

Marty Shaw

Melissa Shugars

Dawn Shumaker

Pete Slusher

Cathy Smith

Judy Smith

Dawn Spencer

Ruth Sprague

Mark Spradling Lyn Stauffer

Wayne St. Denis

Dennis Stickel

Loyd Stigers

David Stoner
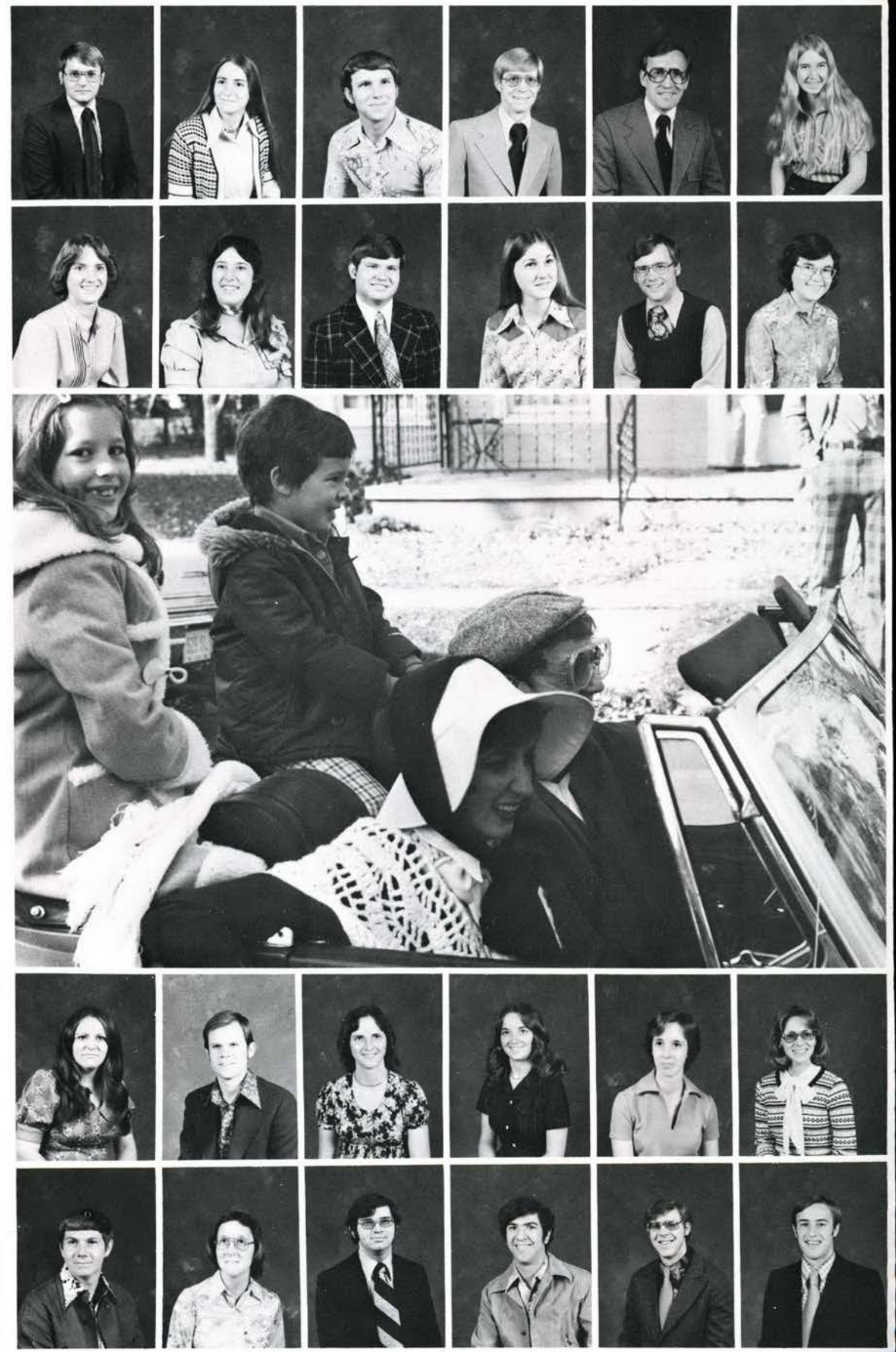


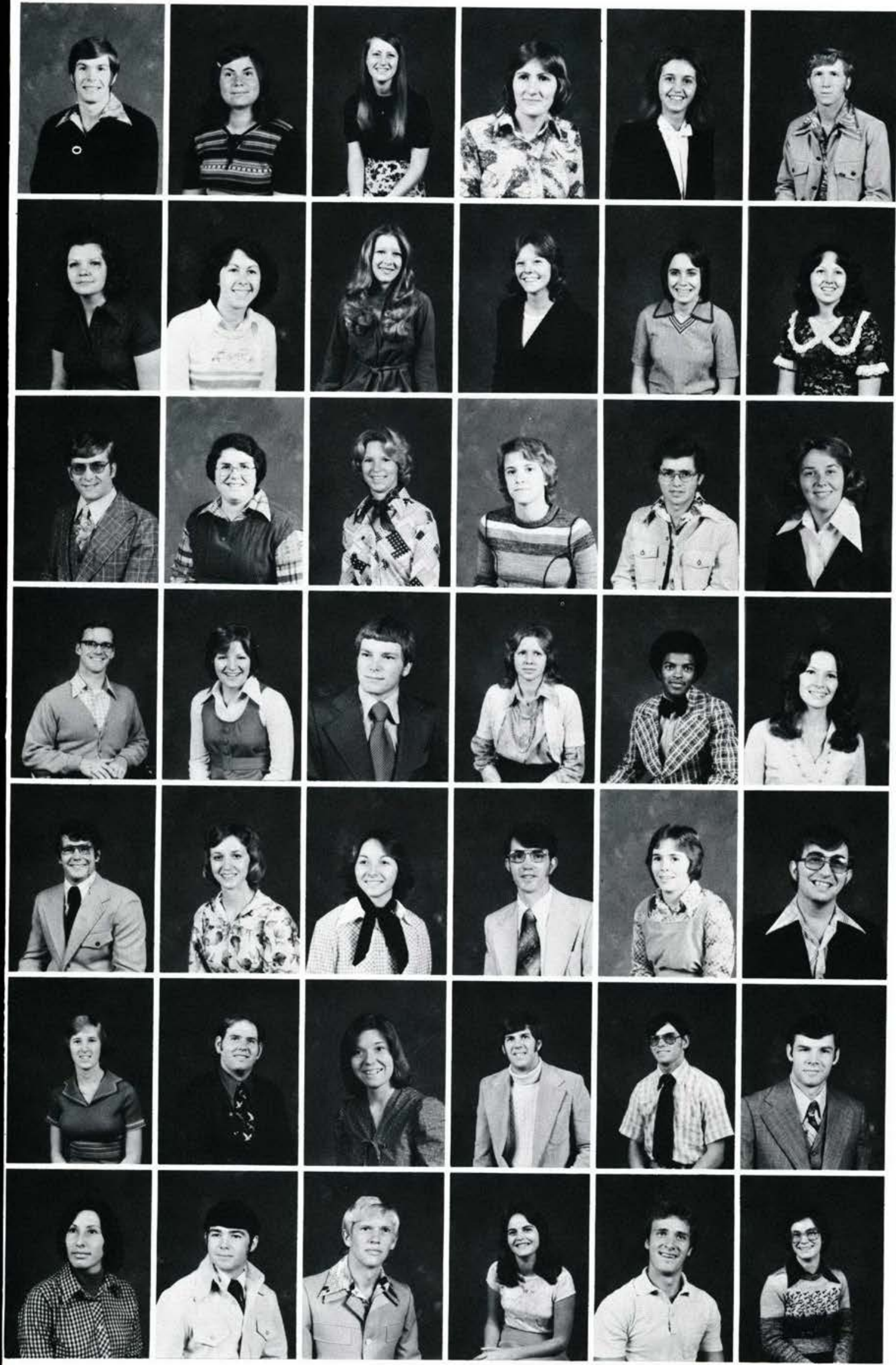

Tim Stoner

Debbie Storch

Becky Street

Marla Streitmatter

Linda Stuenzi

Steven Stump

Jenet Sullivan

Leigh Summerlin

Judy Tanner

Irene Taylor

Rhonda Taylor

Lila Terlouw

Alan Terwilleger

Debbie Thomas

Dorothy Toelcke

Valerie Totman

Jim Townsend

Pat Townsend

Paul Shenefield

Valerie VanCompernolle

Dave Wagner

Glenna Wagner

Kevin Waiters

Cherie Watts

Barry Weller

Lydia West

Joyce Wheeler

Brian Whitaker

Faith Whitelaw

Dan Wickman

Jan Willetts

Tom Williams

Robyn Wise

Dave Wood

Lee Wright

Russ Yoder

Rhonda Young

Richard Young

Gary Youngman

Debby Zaller

Carl Zelonis

Becky Ziemer 


\section{Students Show Concern For Children}

A new Christian service has sprouted on this campus; a puppet ministry. It is called "The Master's Muppets." This group goes from church to church, youth rally to youth rally, witnessing to others through a puppet show.

The AM group participating in the Old Soldiers and Sailors Orphanage Christian service are about twenty- five students in number. They assemble every Sunday morning at 8:30 to teach. The PM O.S.S.O. group meets at 6:00 every Sunday night. At the home, they greet the kids, sing, have devotions with them and special music is presented by one or more college students.

1. Judy Brown brings the Gospel to a young boy at the O.S.\&S.O. home.

2. Behind the scenes are Dale Christian, Bill Carroll, and Floyd Dallas.

3. O.S.\&S.O. Morning: FRONT ROW: B. Prentice, T. Danec, J. Marihugh, D. Groves, J. Brown, D. Kelso; BACK ROW: T. Shubert, D. Burns, T. Williams, P. Schnell, B. Humphrey, D. Johnson, F. Polley, T. Yater, J. Patton

4. O.S.\&S.O. Evening: BACK ROW: J. Ward, G. Hinkle, C. Jones, M. Johnson, D. Conrad, S. Browne, S. Glover; THIRD ROW: C. Searles, J. Yoder, S. Jenkins, K. Lapp, E. Shaffer, N. Linamen, R. Northcutt, T. Davis, D. Bond, S. Browning, C. Hall, D. Messenger; SECOND ROW: V. Burleson, C. Scoggins, C. Douglass, J. Moore, B. Guenther, J. Callan, C. Olson, K. Payne, D. Bresson, T. Broach, J. Johnson; FRONT ROW: C. Herron, G. Decker, D. Partridge, J. Ebel, C. Johnson, K. Langford, S. Beight, M. Pressau.

5. Puppet Ministry: FRONT ROW: F. Dallas, B. James K. Brower, D. Jansen, K. Smith, R. Taylor, J. Surso; SECOND ROW J. Cobb, B. Fuller, K. Steinhofer, K. Dun can, C. Kuhn, I. Ehrmann; BACK ROW: R Young, R. Meeker, R. Conners, B. Milbauer, B. Carroll, C. Orrick, D. Christian. 6. "Cowboy" Dale Christian tells a story from the old west.

7. The puppets not only entertain both young and old, but also relate Bible stories in a new and interesting way.

8. Bill Humphrey leads a Bible study with a group of boys at the O.S.\&S.O. home.
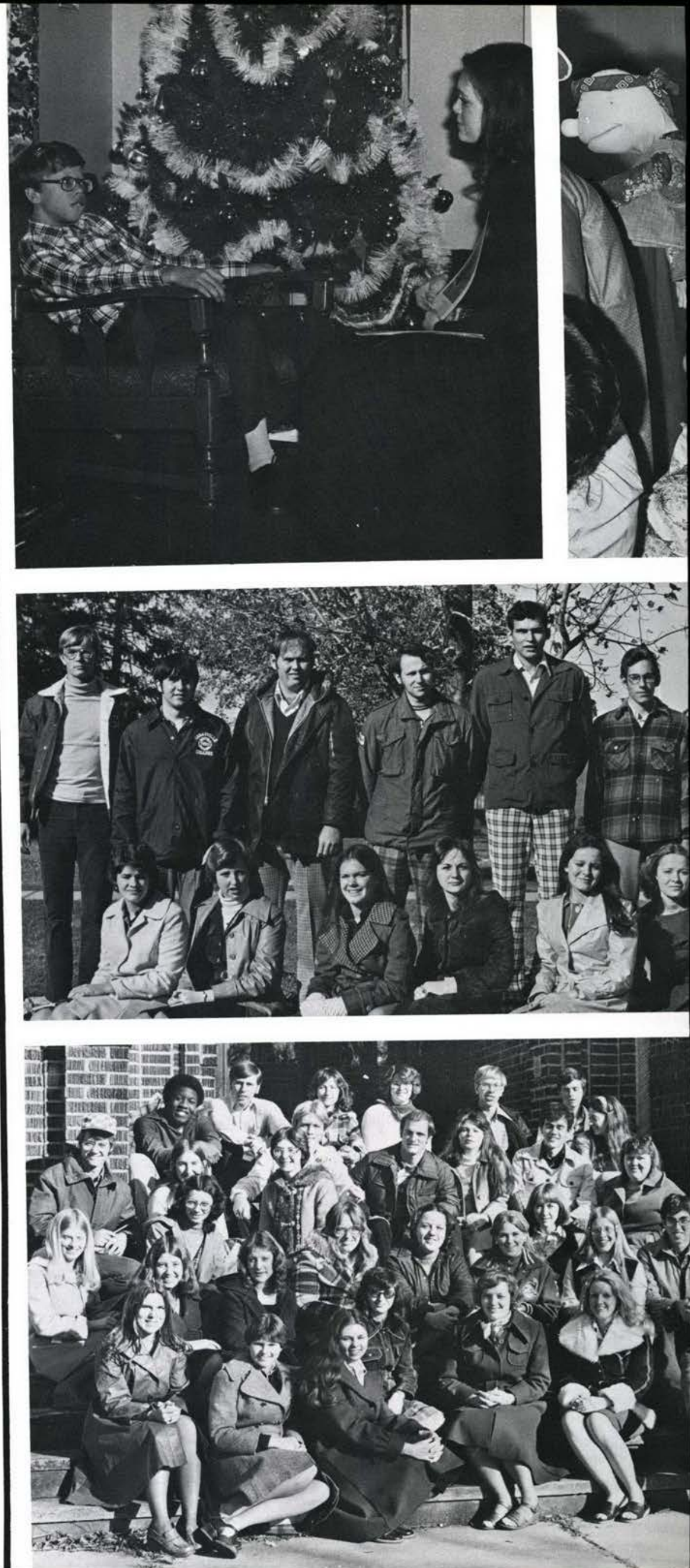


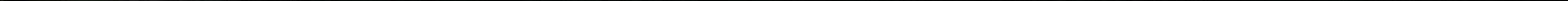




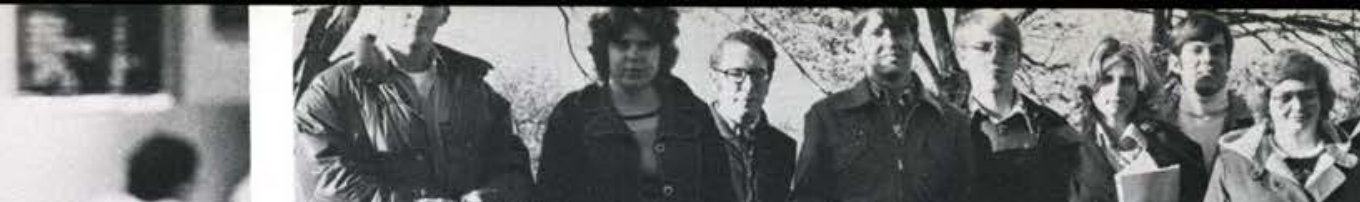

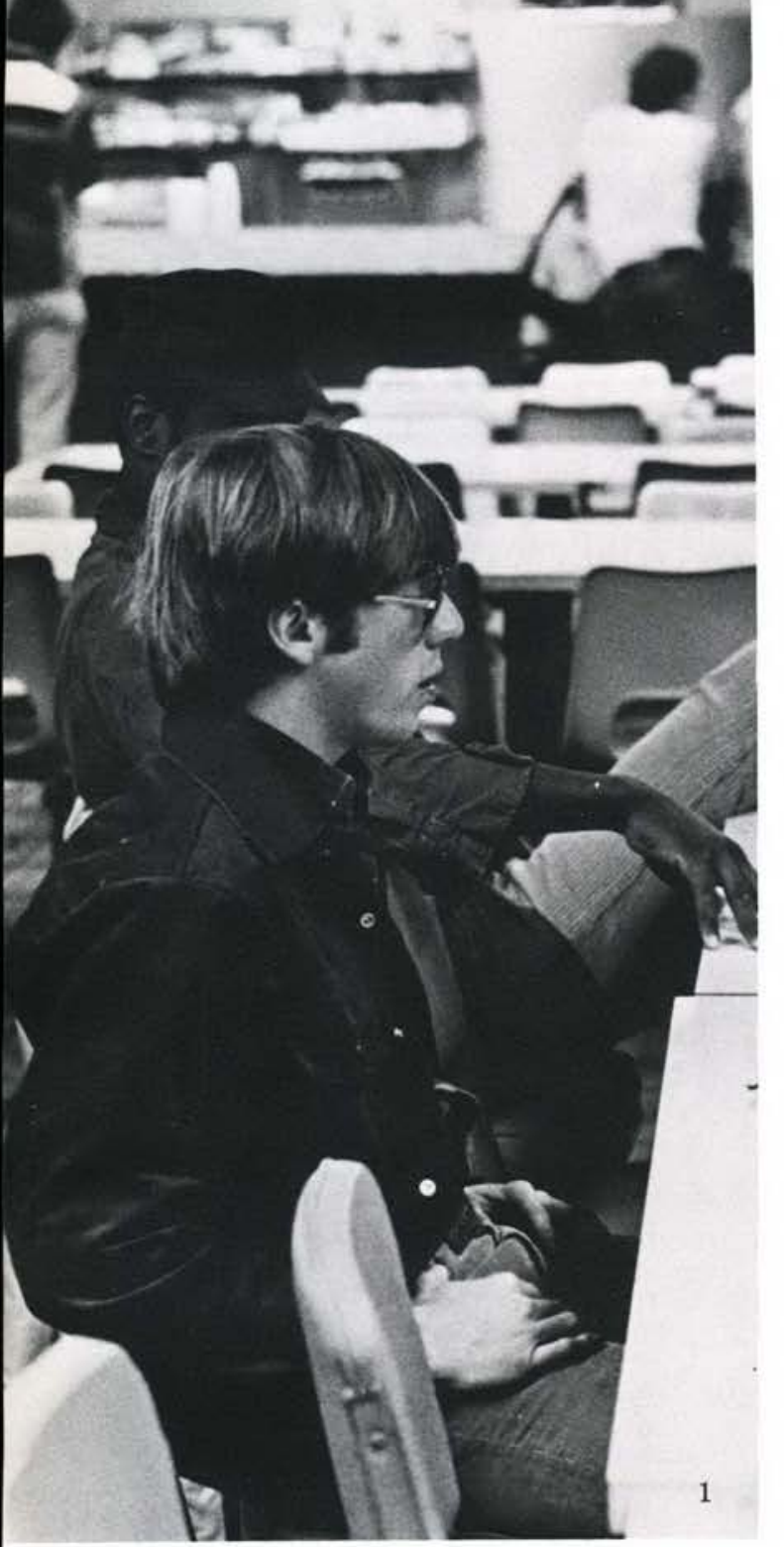

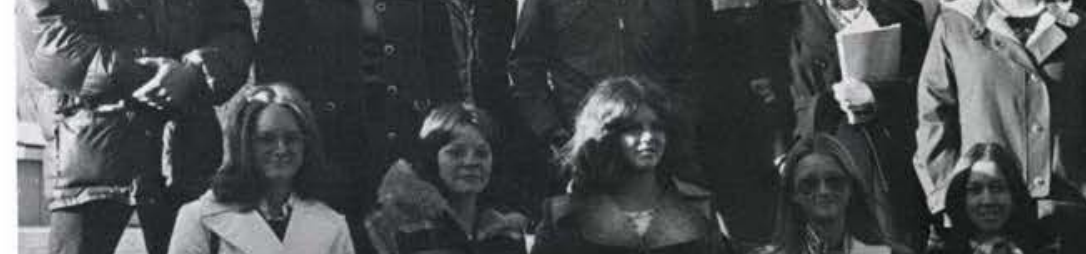
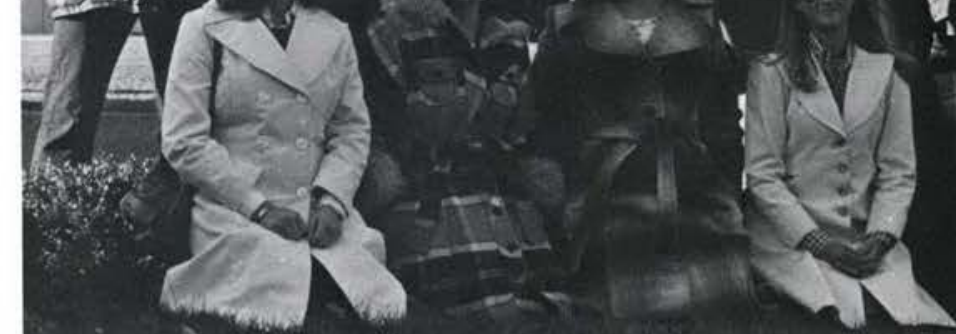

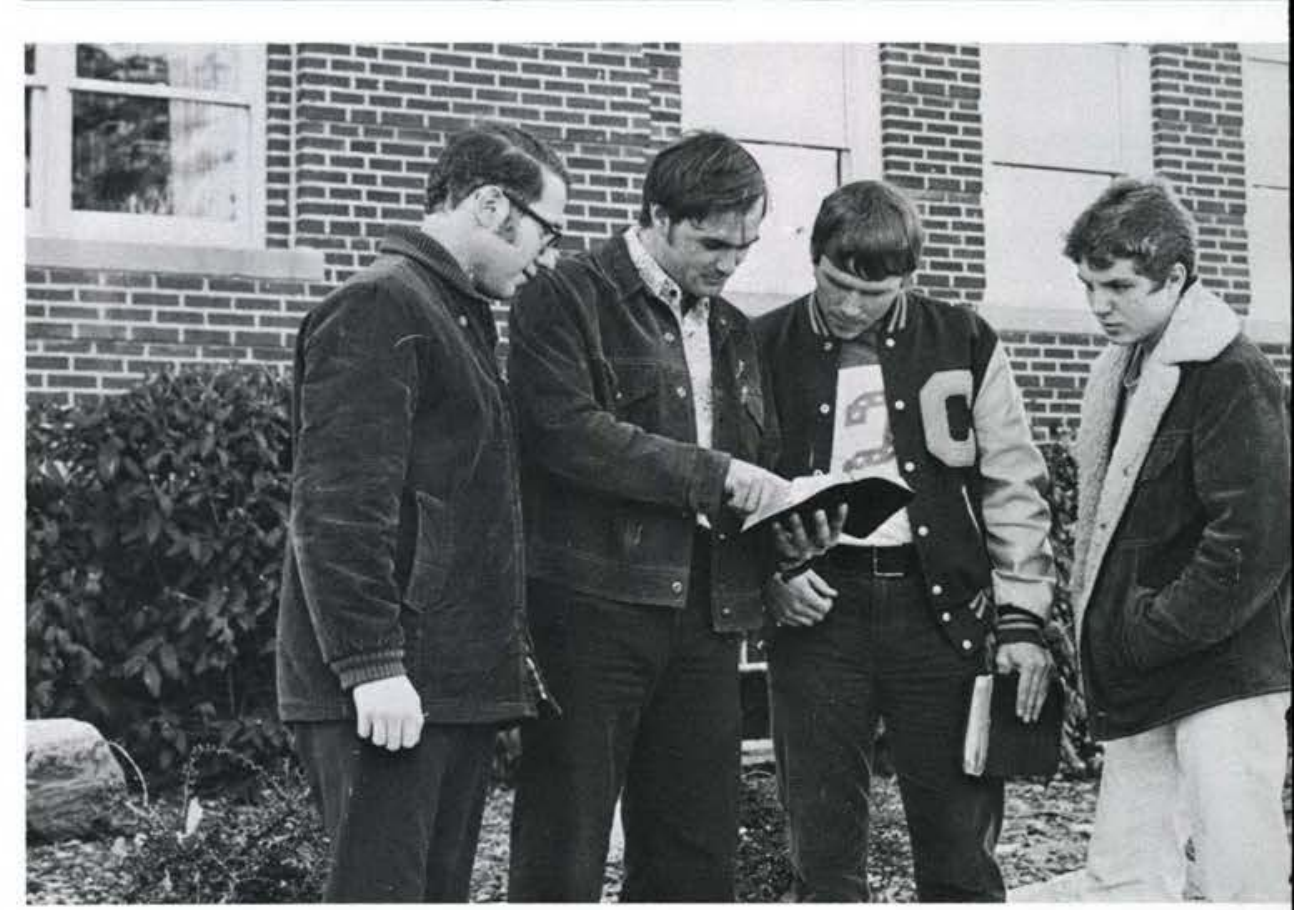

40

1

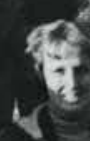
$+3$

(1) ${ }^{2} / 210$

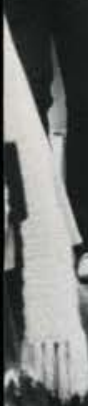
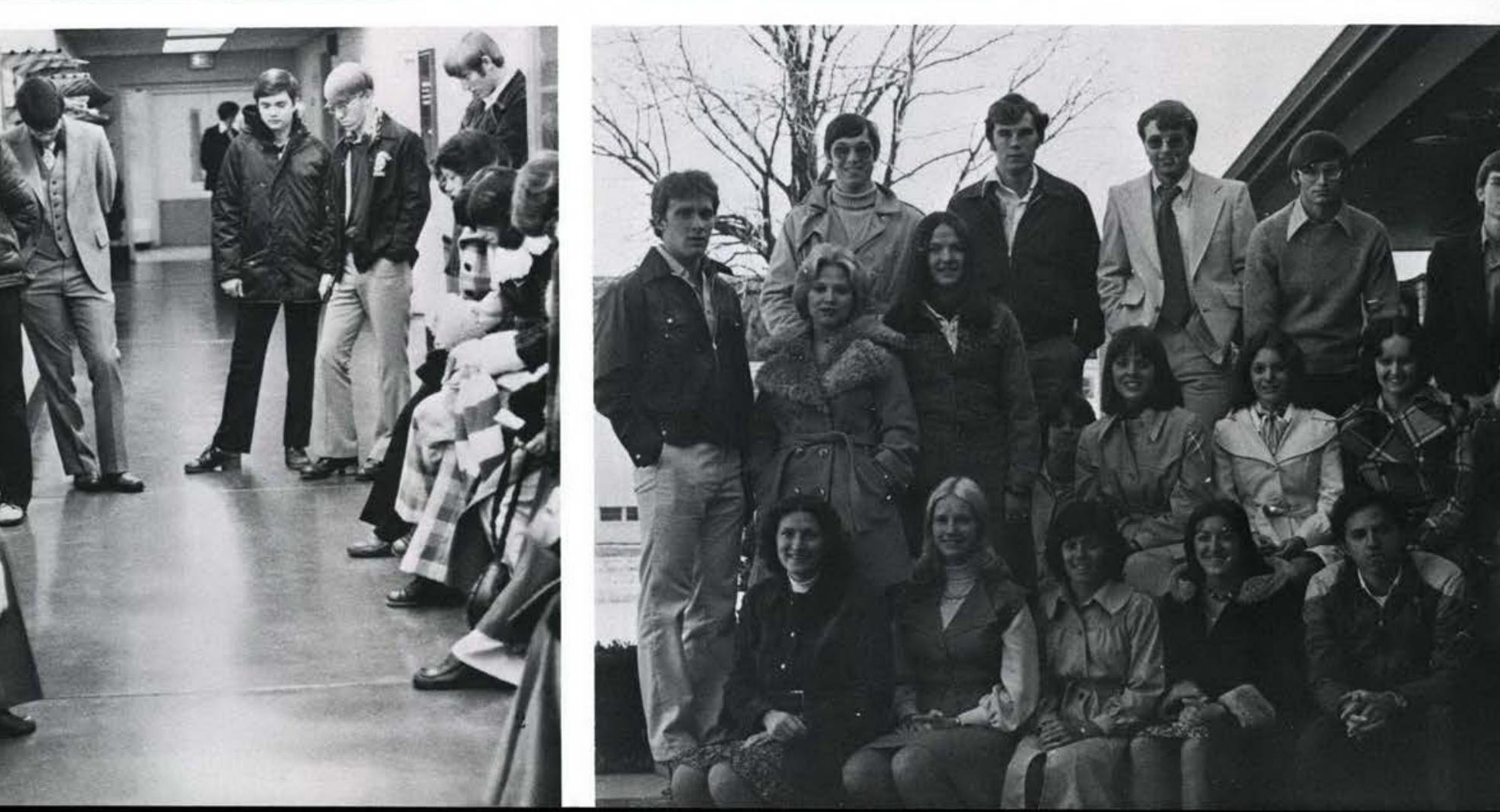

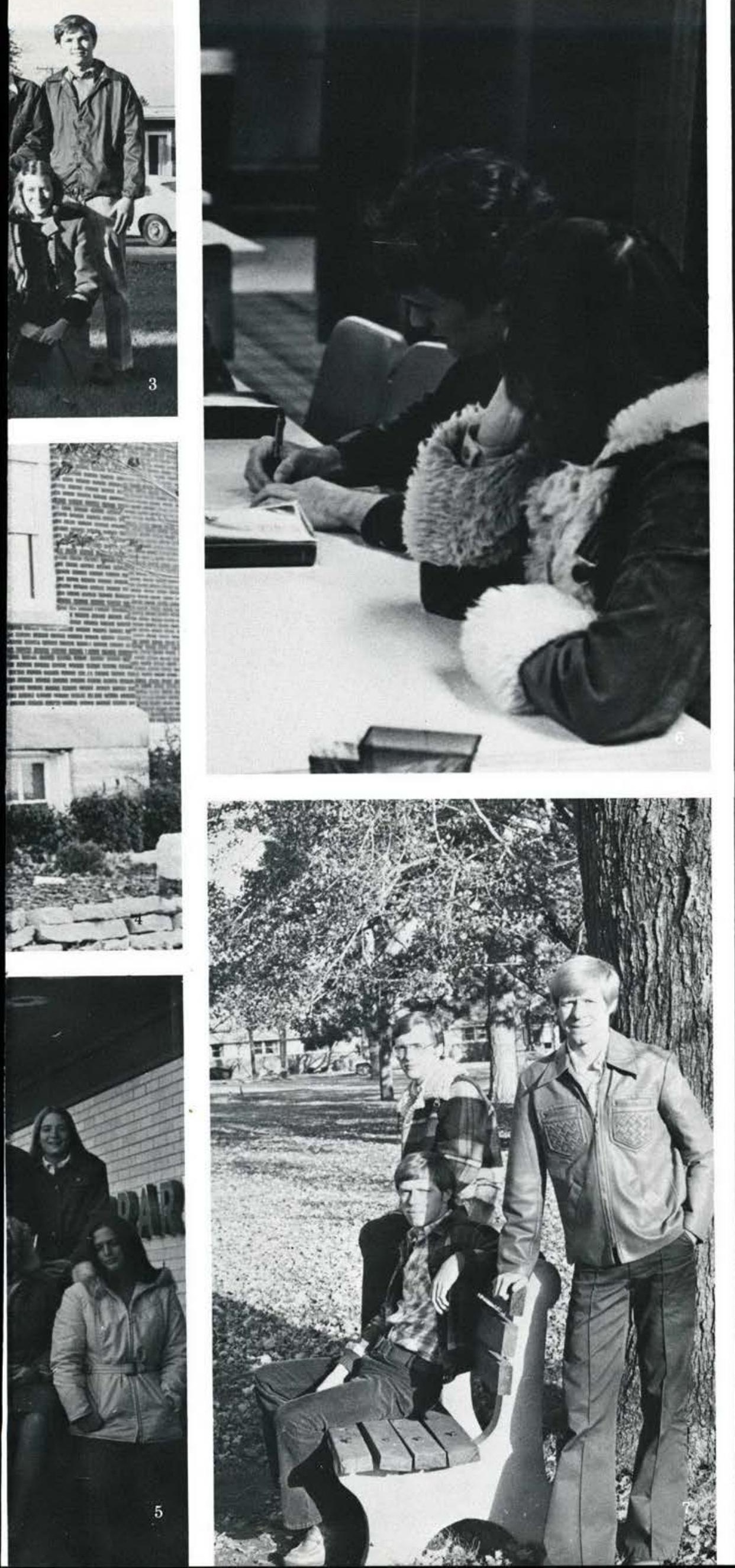

\section{Students'}

Outreach Includes All

Each week a large number of students travel to area detention homes and jails to tell boys and girls, men and women about Jesus and His love. There are three detention homes that students visit: Dayton Detention Home, Springfield Detention Home, and the Troy Rehabilitation Center. These ministries are good opportunities for Cedarville students to put into practice what they are learning from Bible classes and studies.

1. While at breakfast, Byron Major listens to instructions before leaving for the Dayton Detention Home.

2. The Springfield Detention Home group prays before leaving.

3. Springfield Detention Home: FRONT ROW: C. James, I. Taylor, E. Parker, E. Engdahl, G. Bushart, L. LaHaye, L. Yater; BACK ROW: D. Riddle, L. Lathrop, D. LaRue, S. Hoy, A. Morgan, D. Robery, D. Ellington, J. Arthur, K. Erny, M. Nelson, K. Amstutz.

4. Troy Detention Home: D. LaRue, J. Wyman, W. Rowe, M. Peters.

5. Dayton Detention Home: FRONT ROW: C. Morley, A. Hilmes, S. Kuntzelman, K. Sollenne, J. Nace; SECOND ROW: C. Zelonis, D. Lawrence, D. Wetzel, B. Neally, J. Kaufman, C. Morris, M. Waddle, M. Forsten, L. Aitken; BACK ROW: B. Major, S. Stairs, R. Campbell, P. Smith, D. Riedel, A. Ross.

6. Carl Zelonis prepares for service at the Dayton Detention Home.

7. Jail Service: M. Shaw, S. Rowland, T. Rowland. 

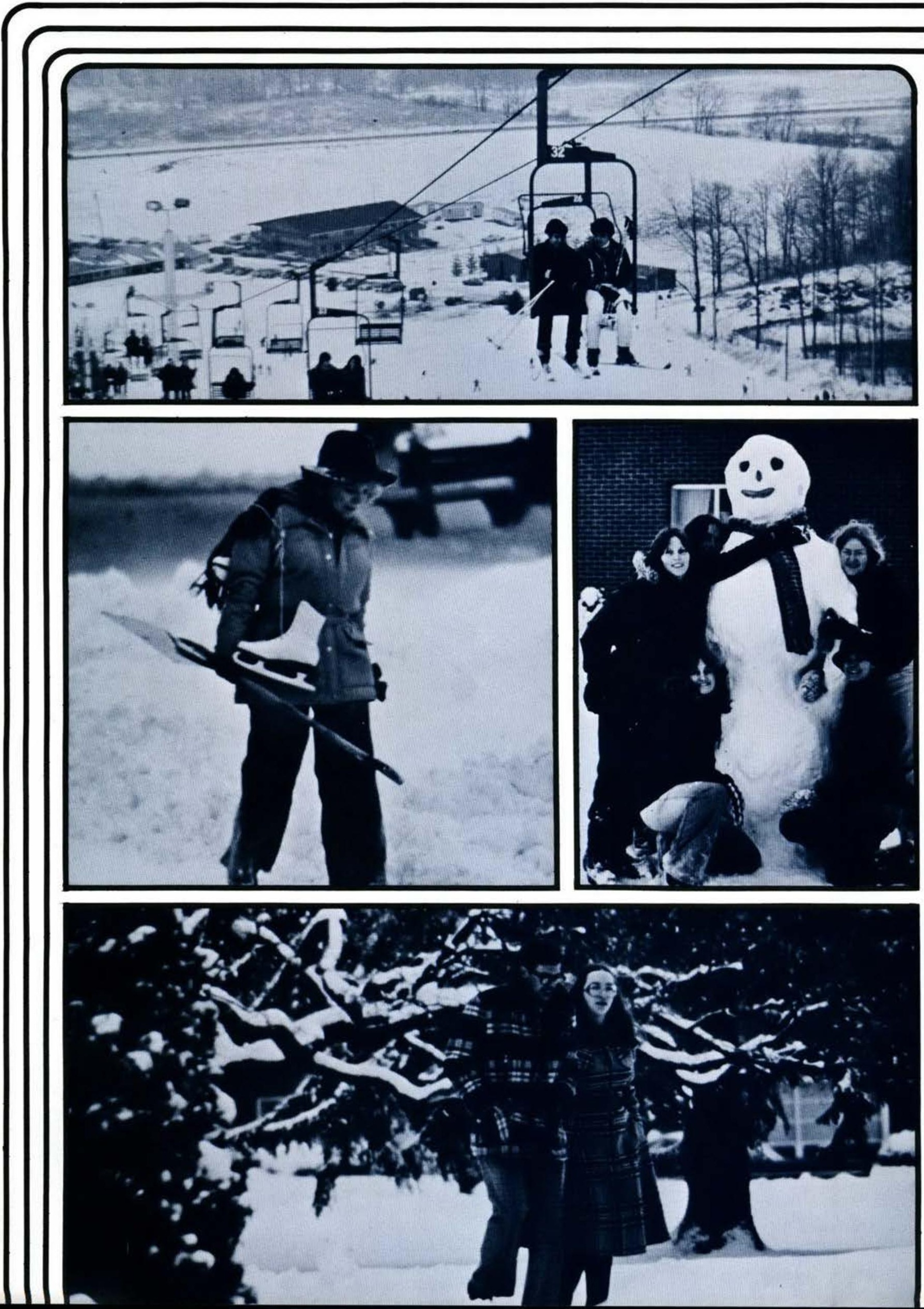


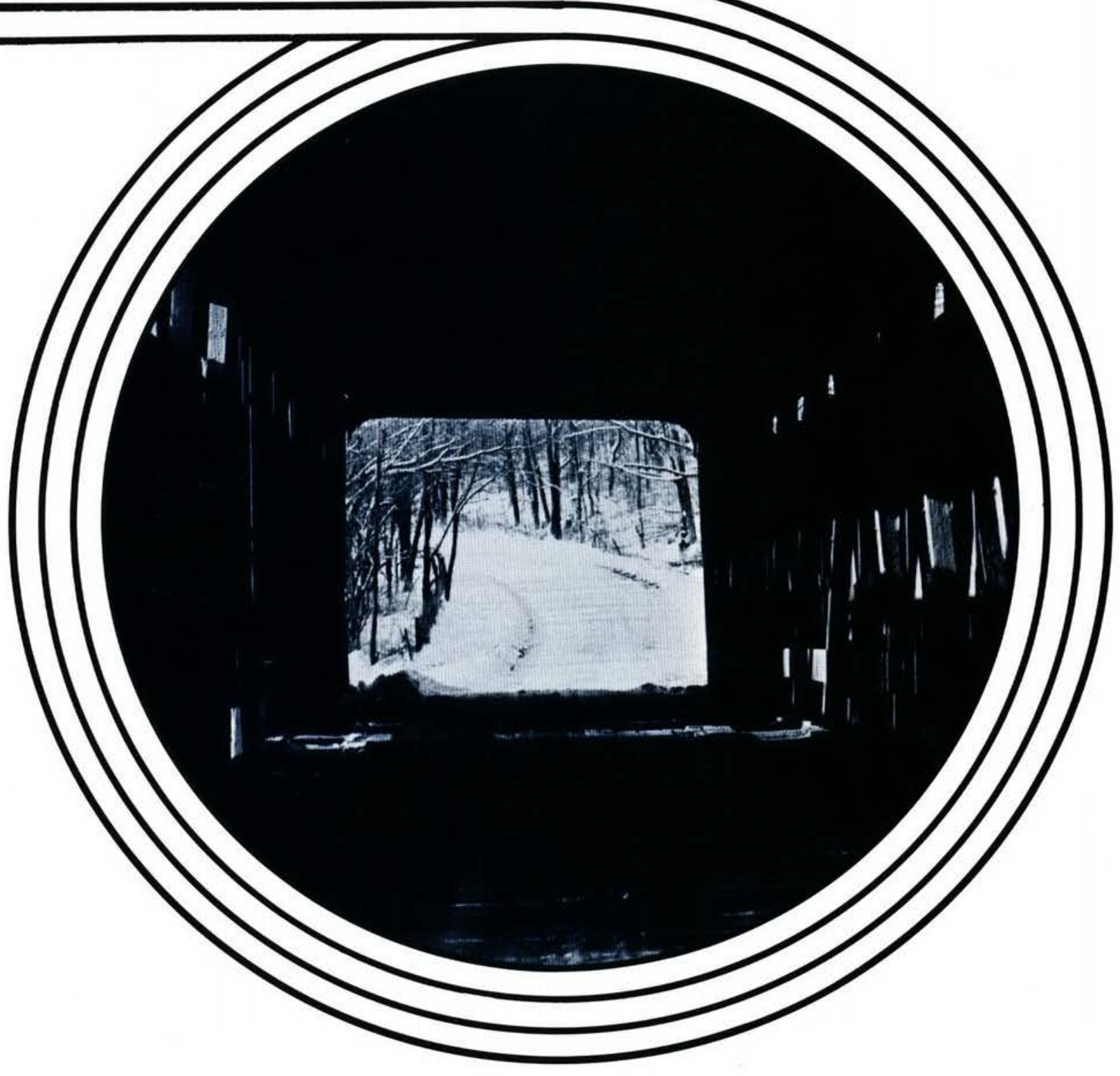

WJN $\mathcal{E} \mathcal{R}$ 


\section{Being Earnest Is Important}

"The Importance of Being Earnest," a hilarious farce written by Oscar Wilde, is performed on January 13,14 , and 15 . An all-freshman cast under the direction of Myron Youngman strive to produce the satire of the Victorian period, stressing the witty scenes and dialogue. Included in the cast are: Jim Leightenheimer, John Briggs, Gregory Howe, Guthrie Chamberlain, Mike O'Quinn, Ginny Decker, Katie Osborne, Lori LaHaye, and Patty Slusher.

1. Ginny Decker enters with a sweep of the hand and a twist of the bustle.

2. Katie Osborne whispers to Jim Leightenheimer: "Do you wear contacts?"

3. Only John Briggs' hairdresser knows for sure

4. John Briggs and Lori LaHaye discuss "Earnest's" life in the city.

5. Jim Leightenheimer and John Briggs argue over the one teacake that is left.

6. Guthrie Chamberlain sets for tea.

7. Myron Youngman, director, gives last minute instructions to the cast.

8. Even Miss Prism finds love in the play, "The Importance of Being Earnest".
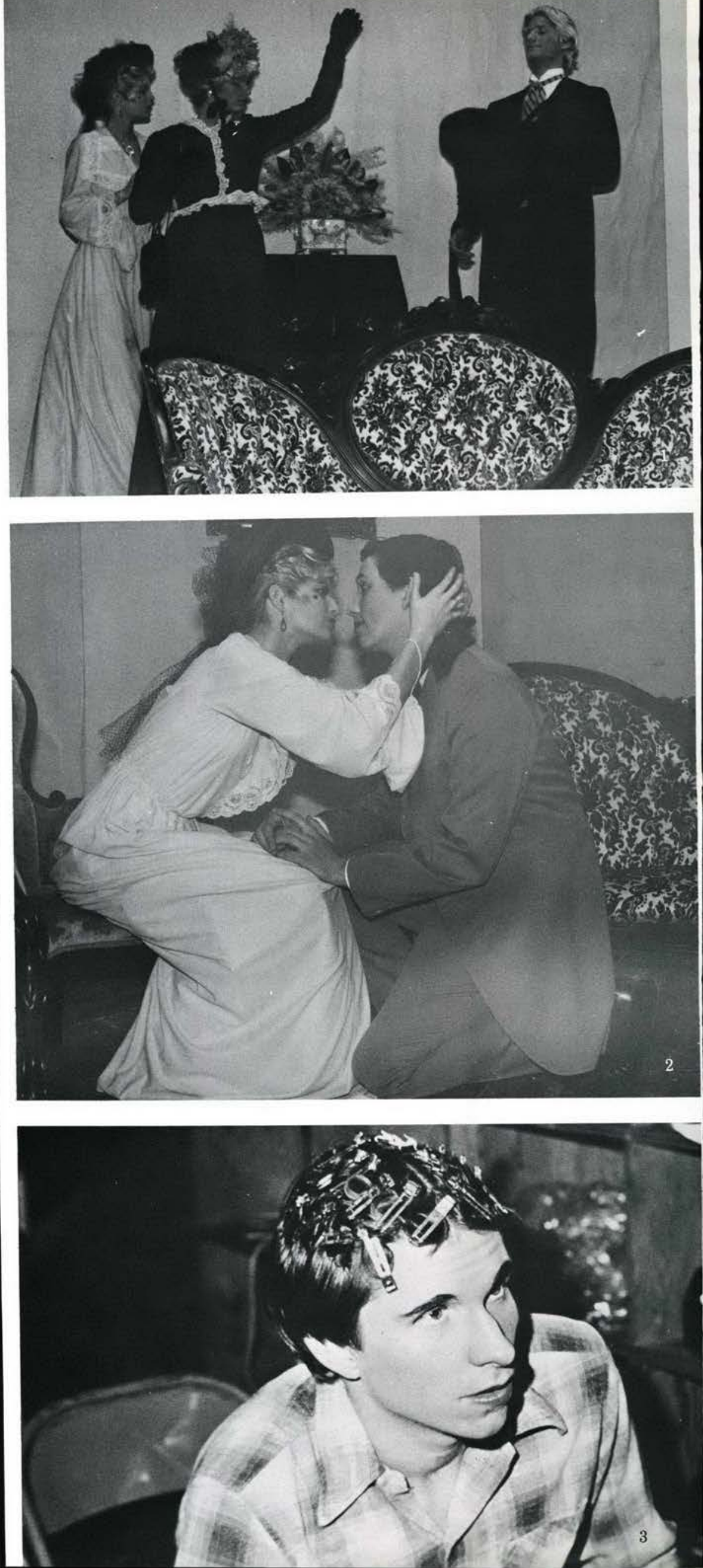

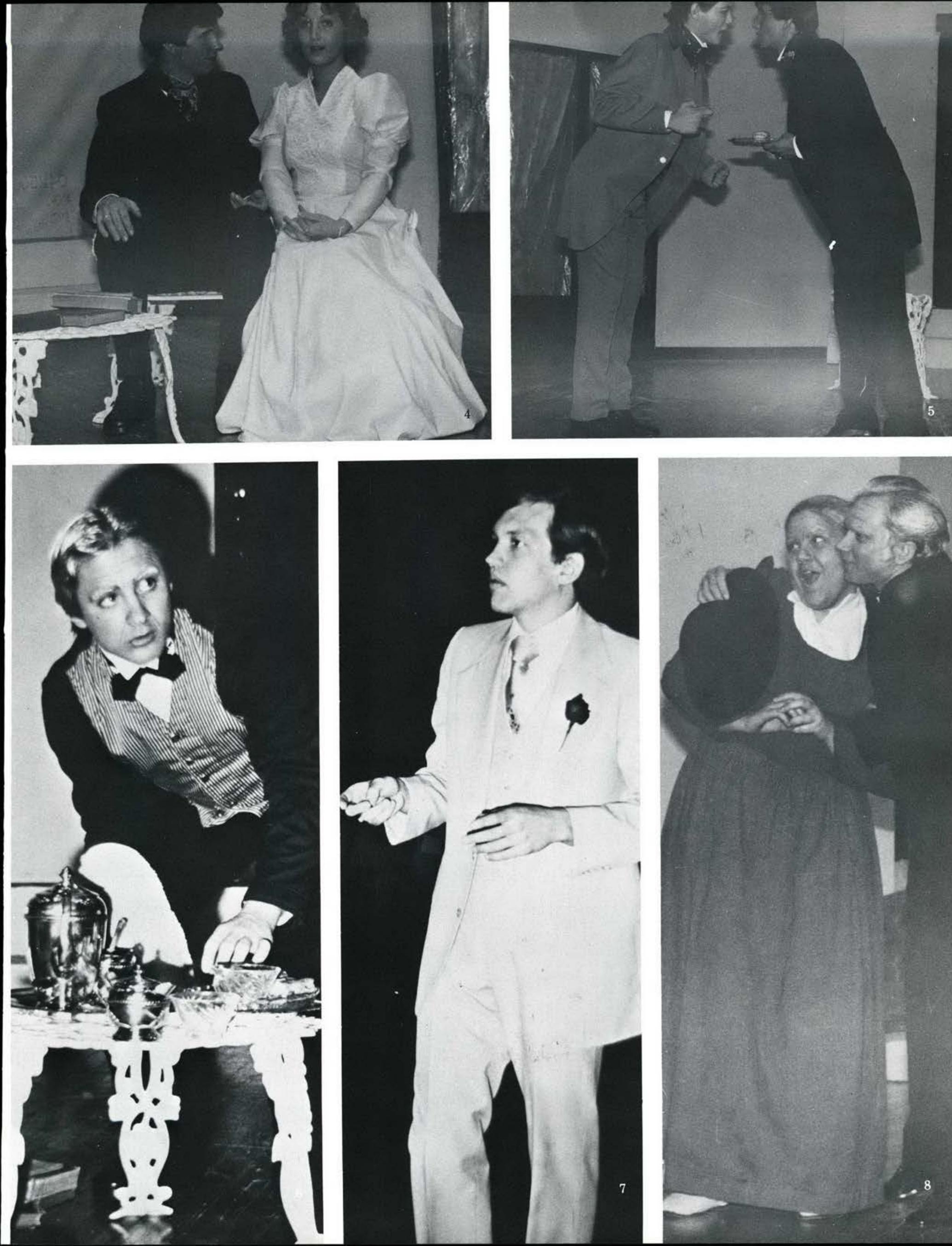


\section{Conference Is Held Despite Weather}

Each year the missionary conference is organized by Fellowship of World Missions, a campus group praying specifically for missionaries.

During the week of January 16-20, the temperature drops to a low of $21^{\circ}$, and for the first time in Cedarville's history girls wear slacks to the conference. Ninety-six percent of Cedarville's student body voluntarily sacrifices breakfast and lunch in the college cafeteria on Hunger Day to aid victims of the recent flood in Assam, India.

The conference hosts four speakers, including Kay Lamb of Campus Bible Fellowship; Dan Lacey, missionary to the Spanish-speaking people in Florida, and Vernon Weber, missionary in the Dominican Republic. All are from B.M.M. William Hopewell represents A.B.W.E. as Deputation Secretary.

1. Kay Lamb exchanges a few words with a passing student.

2. "Reaching Those Who Have Not Heard" is the theme of this year's conference, which is carried out by a chorus written by Dennis Hinks.

3. Kay Lamb chats with students in the library.

4. Is Vernon Webber telling Judi Riter and Jeff Warix a joke?

5. Dan Lacey gets acquainted with Dr. Callan.

6. F.W.M.: FRONT ROW: S. Holma, L. McClure, C. Lofgren, D. Radcliff, C. Mull, D. LaRue, M. Nauta; SECOND ROW: B. Segerstrom, D. Hinks, M. Seger, L. Patton, D. Gierhart, W. Rife, D. Spicer; BACK ROW: J. Veldt, B. Waggoner, J. Metzler, K. Glassey, R. Kline, M. Castellani, M. Nelson. 7. The conference is highlighted by a Swordbearers cantata, "Go Tell Your World", which is directed by Kathy Howell. 8. One of this year's speakers is William Hopewell.

9. During his stay, Dan Lacey speaks to Dr. Monroe's geography class.

10. Craig Colas enjoys a chat with William Hopewell.
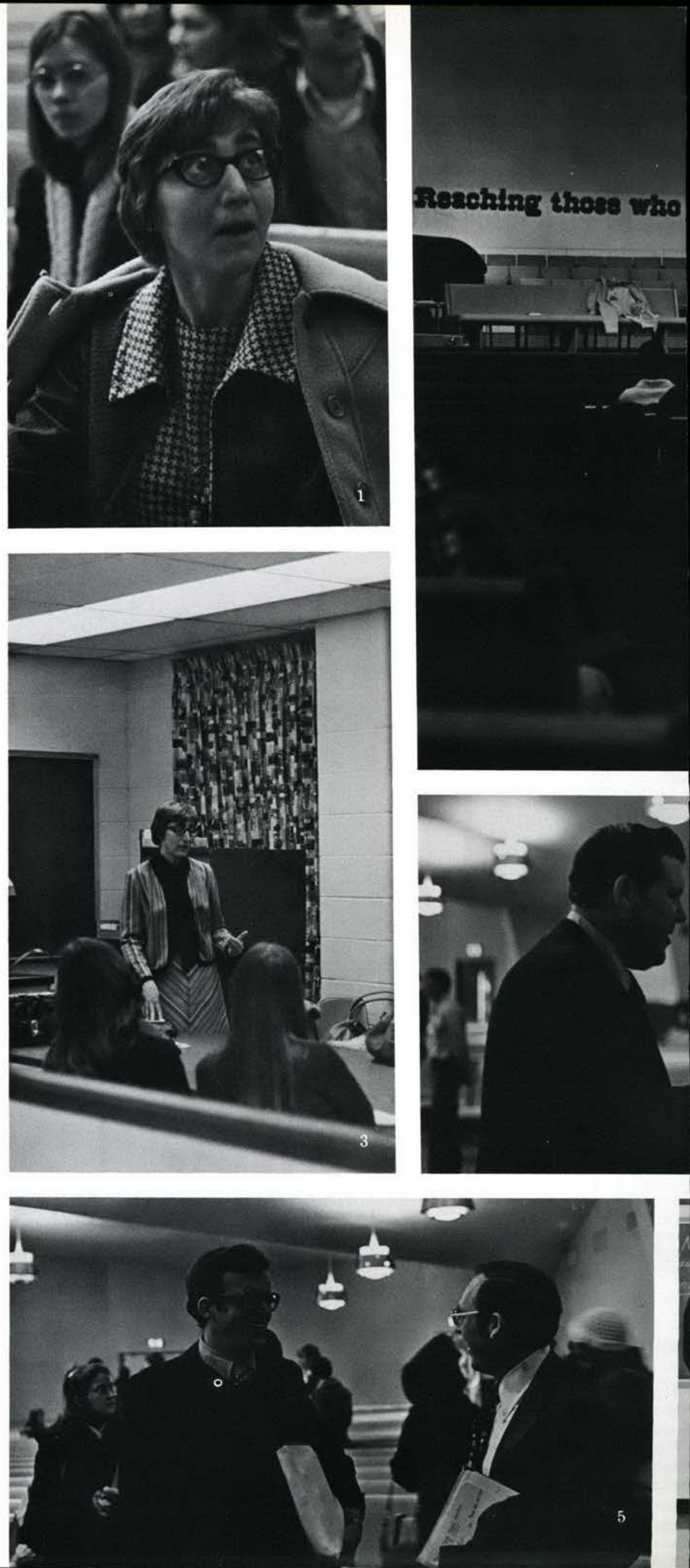


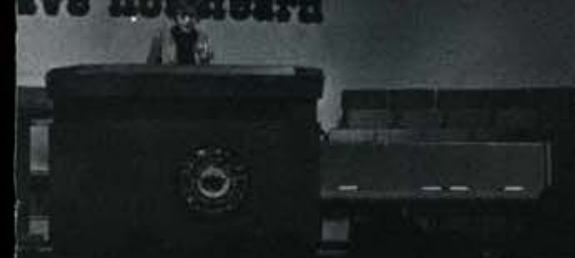

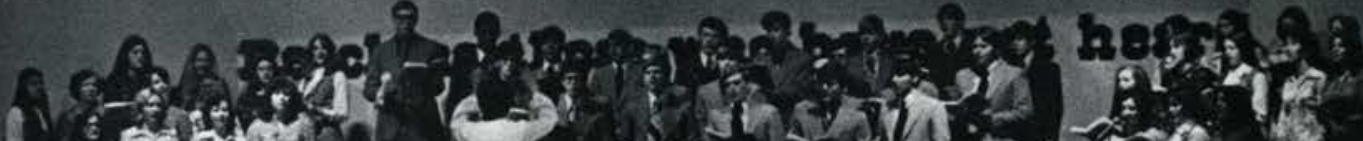

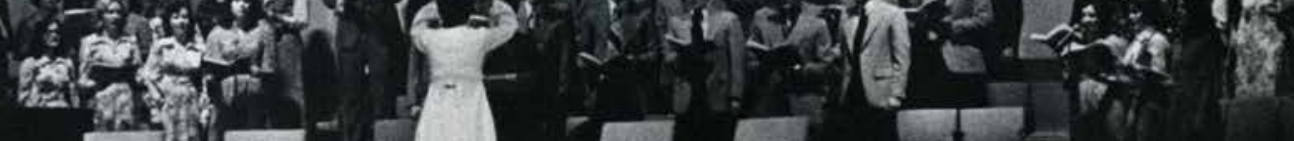

12.
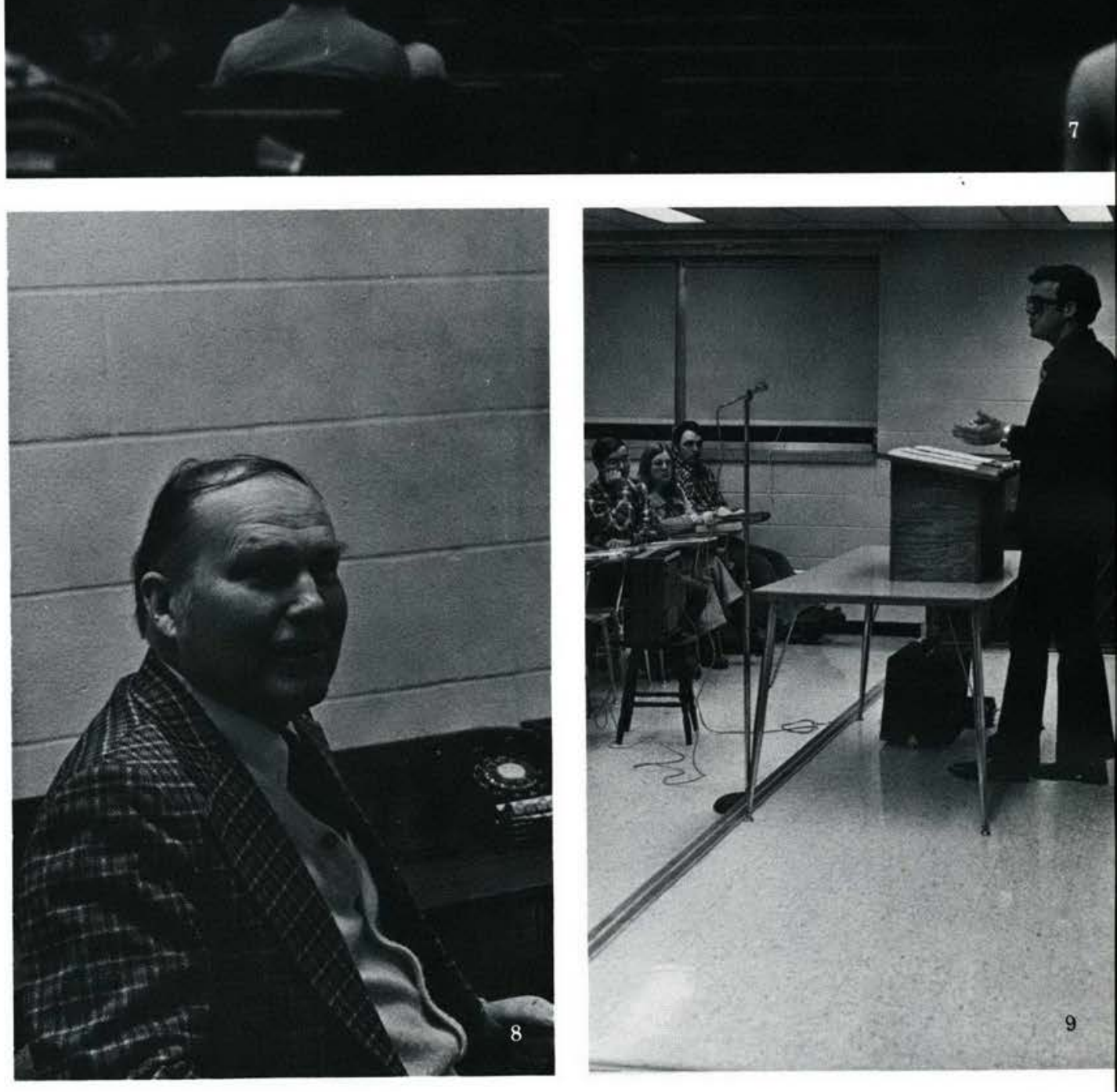

\section{3}

4

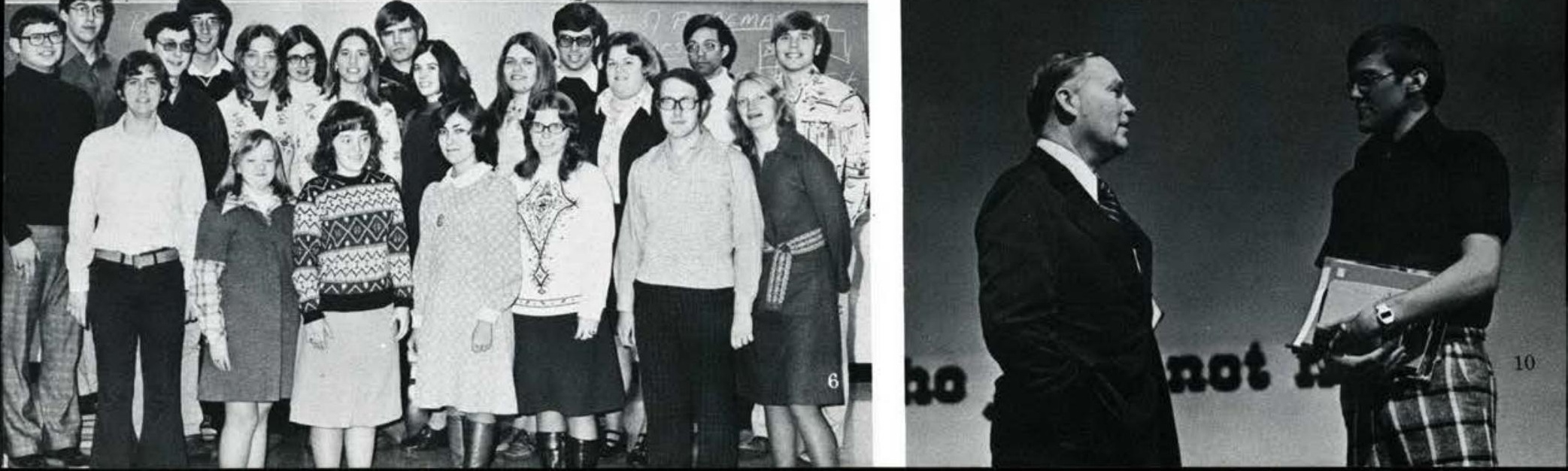



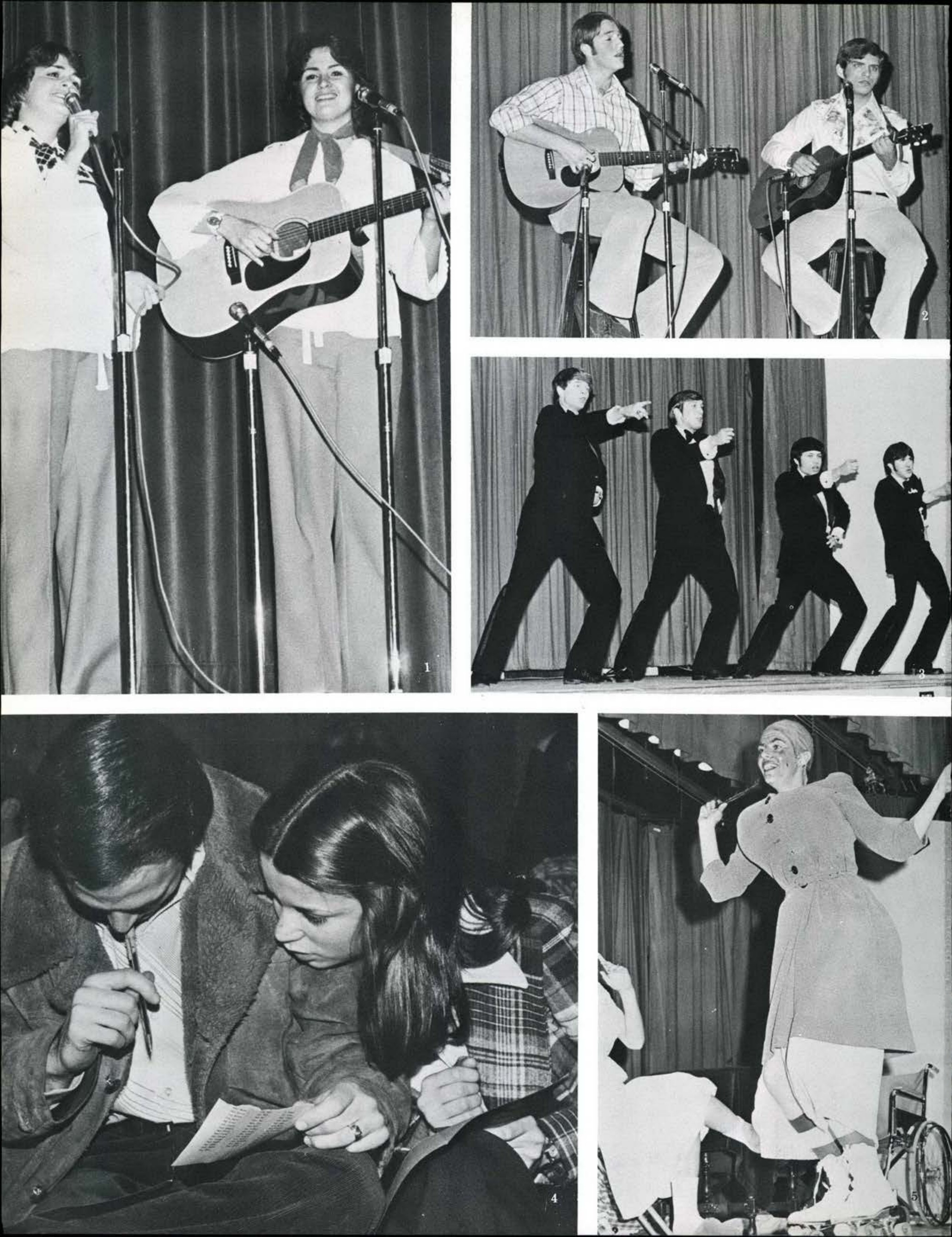


\section{AX Selects Sweetheart Her Court}

Each year, Alpha Chi, a campus organization of "Men for Christ," chooses the Alpha Chi Sweetheart Queen and her court. On Saturday, February 12, 1977, Mary Humbert was crowned Alpha Chi Sweetheart. Cherie Watts, Diane DeNicola, and Ruth Sprague made up the court. Alpha Chi, one of the most prominent organizations at Cedarville College, sponsors many events which include the annual Alpha Chi banquet, the Alpha Chi retreat, the Alpha Chi talent show, and Cedar Day. The responsibilities of the Sweetheart Queen and her court include representing $\mathrm{Al}$ pha Chi at the various activities sponsored by Alpha Chi and in the homecoming parade. They are called upon to give ideas and suggestions from a woman's point of view, and to represent the organization in Christian testimony.

1. Alpha Chi: FRONT ROW: S. Hoy, M. Highman, D. Burns, M. Cowell, C. Elliott, T. Altimus, M. Cayton, A. Morgan, G. Bowser; SECOND ROW: M. Peters, P. Schmutzler, A. Grenier, D. Burns, M. Kessel, B. Whitaker, D. Scott, M. Bentley, R. Stickelman, D. Wickman; THIRD ROW: R. Kaufman, C. Sarver, M. Schuchard, R. McClendon, R. Douglass, P. Godby, J. Dannenberg, J. Rohde, L. Twigg; BACK ROW: M. Shaw, S. Thompson, G. Gross, G. Brace, M. Jones, P. Budnik, W. Felmlee, D. Francis, L. Bunker.

2. Newly-crowned Mary Humbert listens to the sweetheart song of Alpha Chi.

3. Mary seems delighted with the outcome. 4. Court attendant Ruth Sprague with her escort Tim Altimus watch as Chuck Elliott introduces the new sweetheart to the audience.

5. A smiling face and a look of repsonsibility tell their own stories.

6. Cherie Watts with her escort Dan Hicks look on as Mary is crowned.

7. Diane DeNicola with escort Mark Highman smiles into the camera.
$2 \pi$

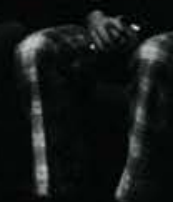

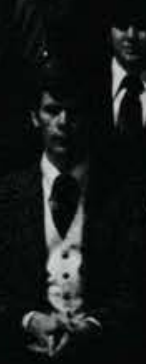
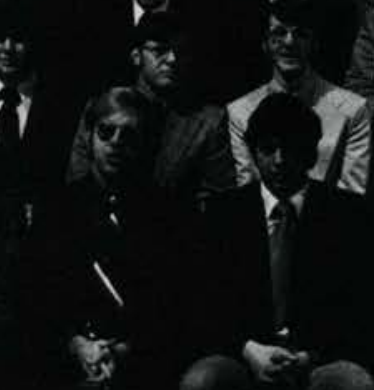

(1)

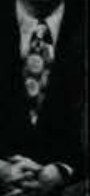

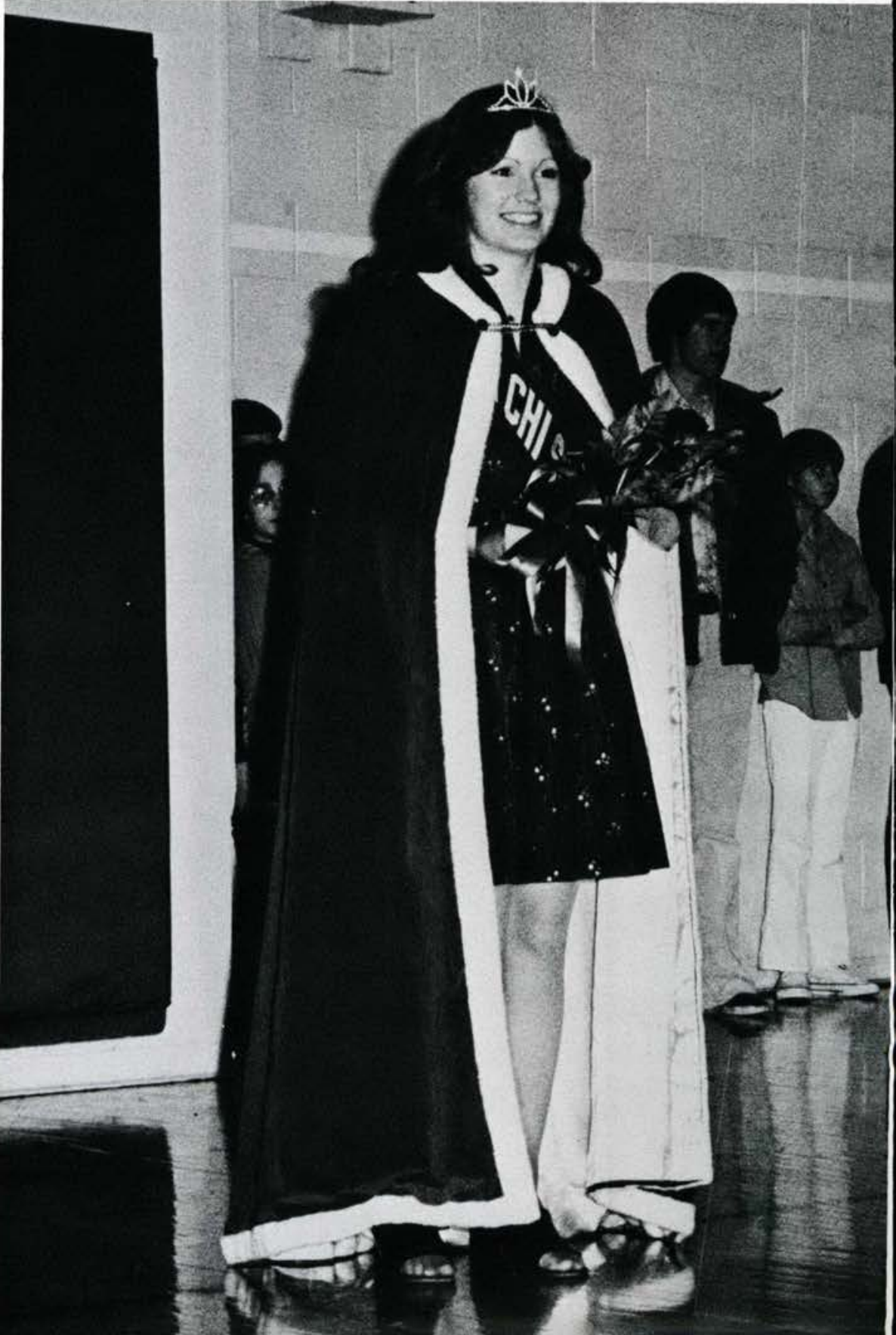




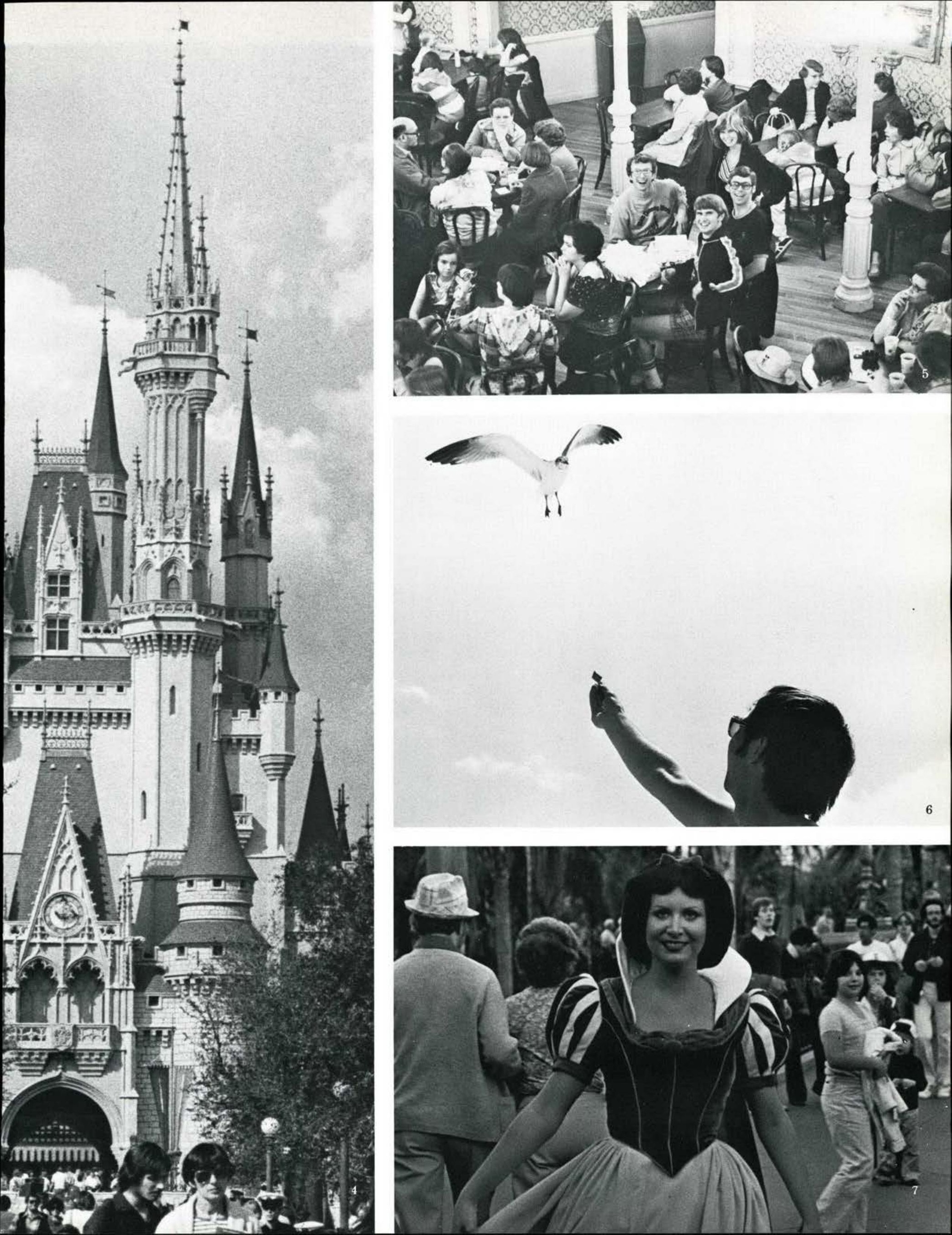



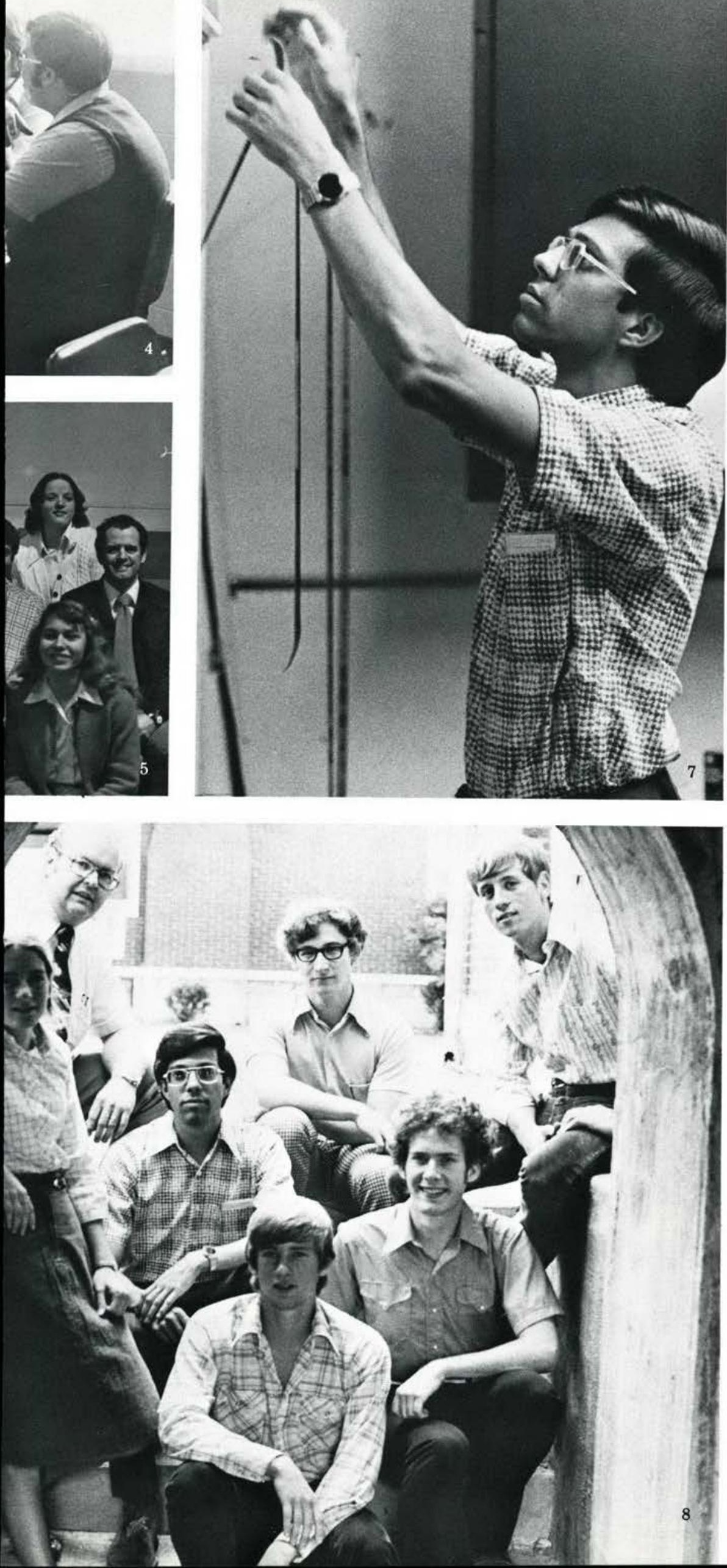

Organizations Provide

\section{Journalistic Training}

A relatively new Christian service offered at Cedarville is LIVING SPRINGS. LIVING SPRINGS is a magazine that is aimed at reaching elderly people across the world. In this organization, college students write devotionals, articles of personal interest, puzzles, and poems. Along with these workers are students who labor on laying out the magazine, typing, and drawing.

Working closely with the newspaper and the yearbook is the Camera Club. They provide most of the pictures for these publications. Under the direction of Roy Kern, they learn the techniques and skills involved in professional photography. The club not only provides a service to the school, but is a useful learning experience to its members. They are involved in the total process of picture taking from rolling their own film to printing the final picture.

1. Deep in thought, Pat Farmwald listens as the next magazine issue is planned.

2. John Dannenberg puts his negative in place as he prepares to print a picture.

3. Jim Barrett takes aim as he raises the camera.

4. A "meeting of the minds" work on the next issue for LIVING SPRINGS.

5. Living Springs: FRONT ROW: G. Gross (Assistant Editor), M. Highman (Editor), J. Ebel, P. Farmwald, B. Gilbert, C. Denny; SECOND ROW: R. Douglass, R. Connors, G. Bennett, D. Woodall, D. Burns, Pastor Green; BACK ROW: C. McLane, C. Lofgren, J. Coleman, D. Bond, D. Jansen, B. Guenther.

6. Mark Highman takes his turn as LIVING SPRINGS prepares for a bake sale.

7. Mark Castellani places a new batch of negatives out to dry.

8. Camera Club: Roy Kern, D. Denny, M. McDougal, A. Ross, M. Castellani, J. Dannenberg, J. Barrett. 

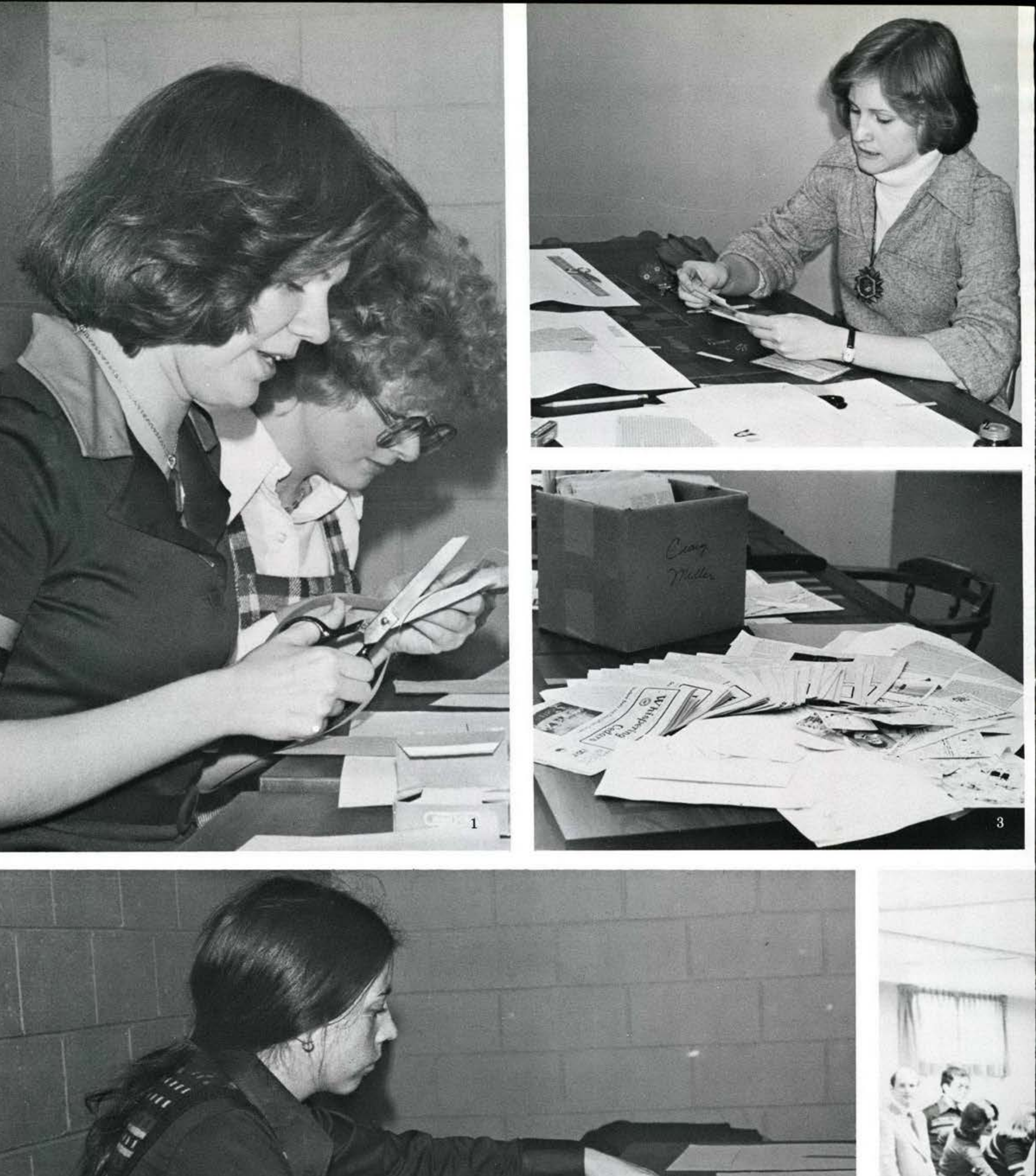


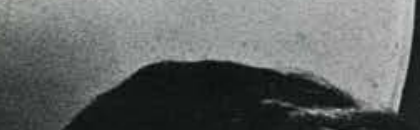

82

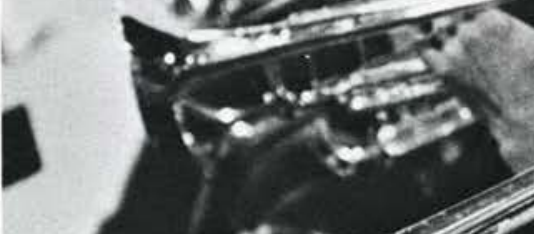

1..5.

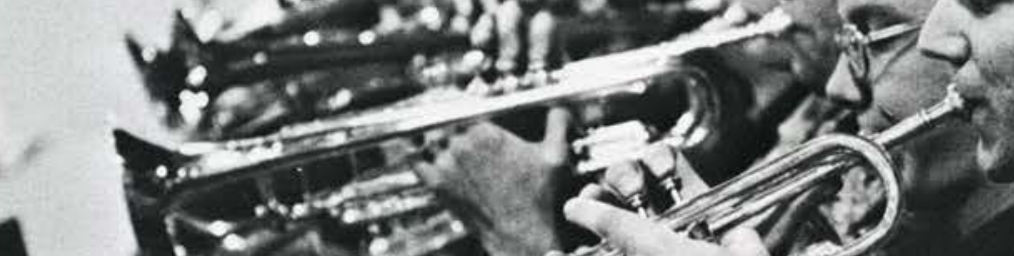

(i) ye?

D) 1

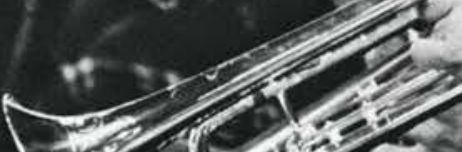

$<0$

\&2)

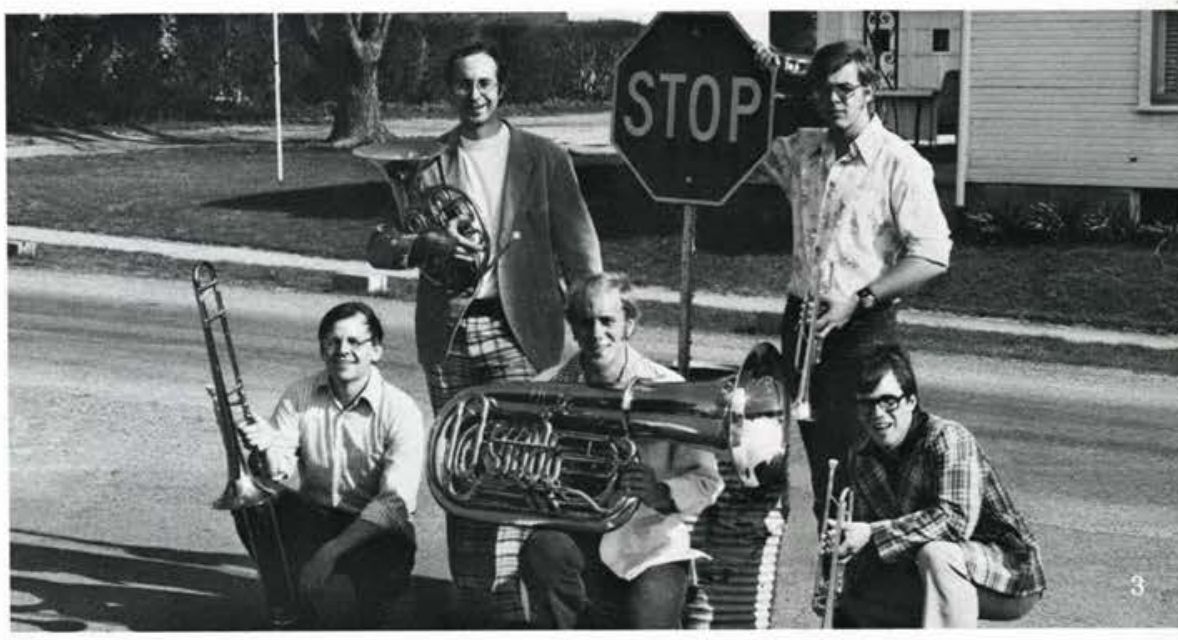

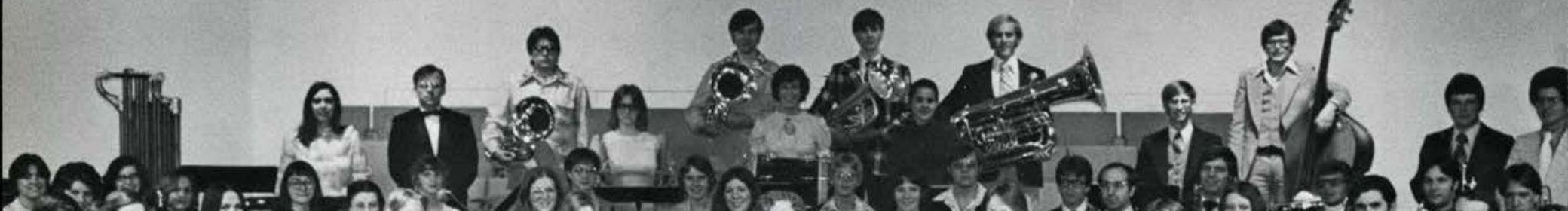
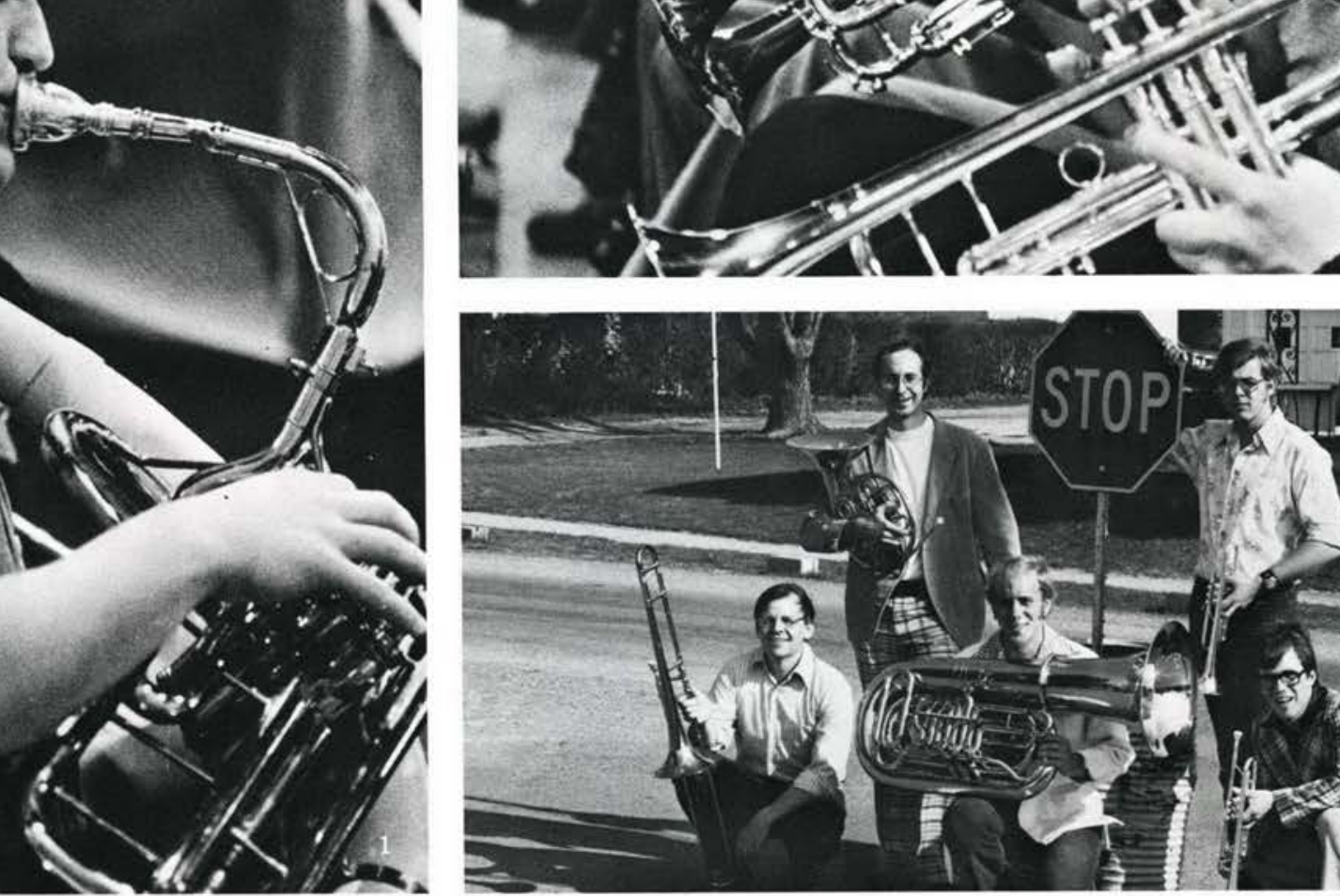
4
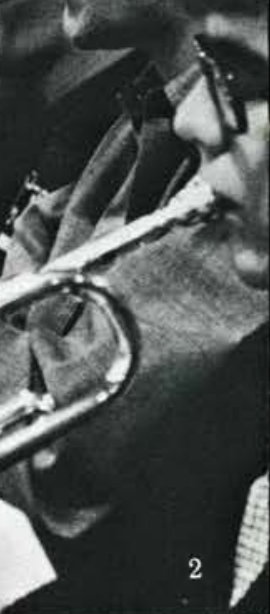

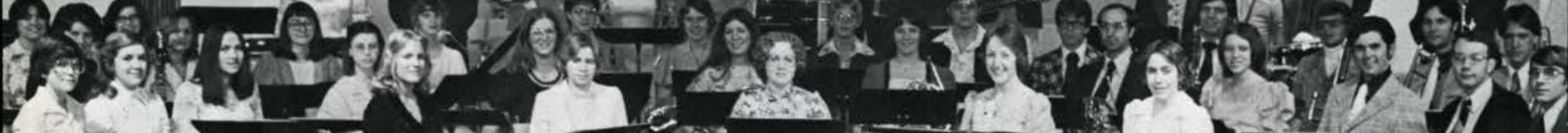
5 (1) 


\section{Lending Assistance To Others}

Phi Epsilon Kappa is better translated "Light in the World". Those students who believe that they are called into some area of fulltime Christian work meet together for instruction from guest speakers and fellowship with one another. A volunteer honorary student group whose purpose is to host campus visitors describes Pi Delta. They conduct campus tours; make sure that guests have lodging; and show good ole Cedarville hospitality.

Assisting churches in the general area is the main purpose of the canvassing ministry. Students accomplish this by going door-todoor taking a survey of a specific church's surrounding community.

Cedarville's chapter of Music Educators National Conference seeks to acquaint its members with the most effective techniques and resources in music education. Their newest undertaking is the spring musical, "You're A Good Man, Charlie Brown."

1. Could it be that Linus "kisses the girls and makes them cry?"

2. Tim Pasma, playing the part of Charlie Brown, pauses to sign an autograph for an adoring fan.

3. Phi Epsilon Kappa: M. Davenport, A. Ternak, K. Browne, D. Storch.

4. Canvassing: G. Bennett, D. Woodall, A. Simpson, C. Miller, D. VanLoan, K. Seymour, B. Kessler, B. Guenther, K. Lapp, R. Kinkle, N. Crandall, C. Keller, M. Johnson. 5. MENC: FRONT ROW: B. Klimek, R. Eaton, C. Hulsman, R. Luedeke, D. Spencer; BACK ROW: J. Mohler, J. Riter, K. Seymour, C. Sprunger, A. Henning.

6. Pi Delta: C. Miller, C. Phillips, R. Yoder, B. Begley.
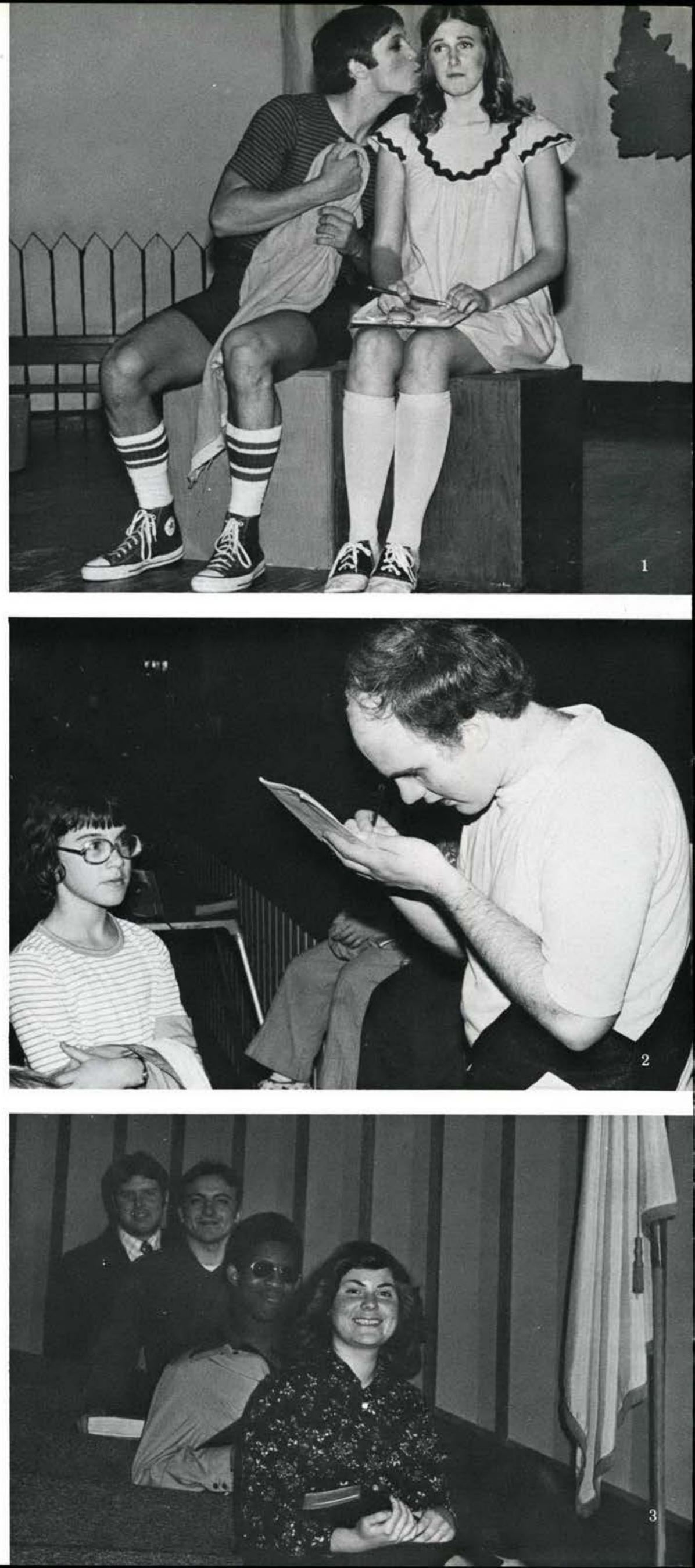

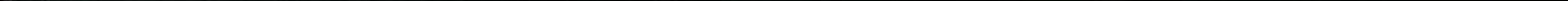


\section{Brains Is The Name Of The Game}

Highlighting the year for Timalathians involves a trip to Indianapolis to hear the well-known Dr. Francis Schaeffer lecture. Other activities of the club include reading books, viewing Francis Schaeffer movies, and participating in panel discussions. All members of Timalathians are given the opportunity to broaden their knowledge and voice their own opinions on current philosophical trends.

Cedarville's Chess Club provides an opportunity for chessmen to improve their game. Members are encouraged to read up on chess skills. Several flea markets are held to earn money for their tournaments.

1. Timalathians take notes at the Schaeffer lectures.

2. Ron Miller leads in a short devotional before the group leaves for Indianapolis.

3. Timalathians: M. Seeley, R. Miller, R. Park, W. Johnson, B. Miller.

4. Chess Club: R. Conners, M. Vincent, T. Davis, P. McCullough, C. Starbuck, D. Quinn, K. Kerrigan, Dr. Scott, Mrs. Scott, R. Yoder, K. Andrus.

5. Francis Schaeffer poses the question: "How Should We Then Live?"

6. Answering questions after the lecture is Edith Schaeffer.
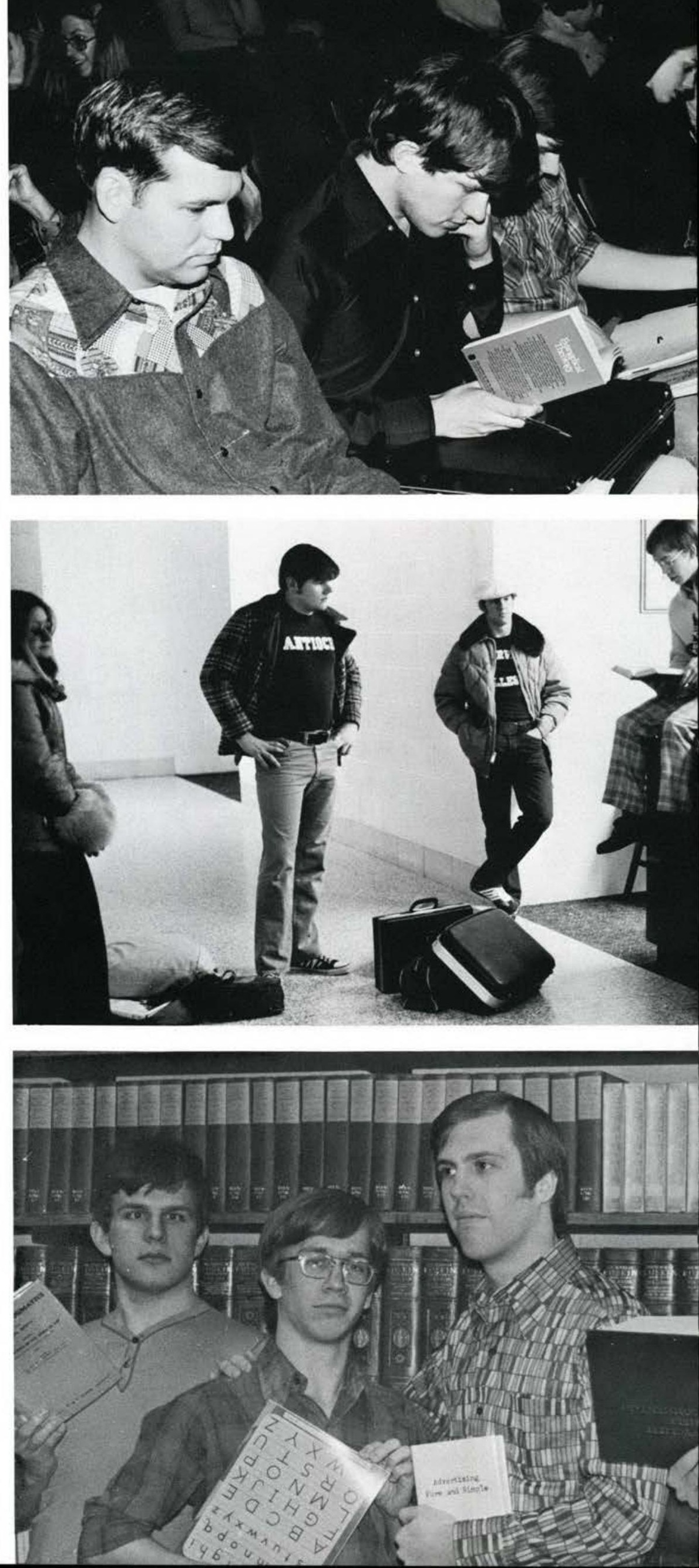


\section{Fun, Food And Fellowship}

A men's organization that offers services to the campus of Cedarville College and fellowship for its members is Pi Sigma Nu. Each year fifteen members are initiated into the organization. The initiation is its most noted activity. Ranking second is the shovelling of snow from the school's sidewalks during the winter.

Varsity $\mathrm{C}$ is a club for men who have lettered in sports at Cedarville. They are responsible for the church tournaments held on campus during the winter, and also for the food sold to spectators at the basketball games.

1. A visiting coach is awarded a trophy for his team's placing in the church tournaments sponsored by Varsity C.

2. Steve Uyenshi, Joe Harkleroad, and Jon Wyman work hard selling popcorn at basketball games.

3. VARSITY C: FRONT ROW: W. Rowe, T. Williams, K. Waiters, D. Chesser, D. Self, D. Stoner, J. Wyman, M. Ziegler, D. Jarvis; SECOND ROW: P. Budnik, J. Harkleroad, R. Cagwin, B. Henslin, B. Hull, J. Potter, P. Slusher, W. Gifford; THIRD ROW: R. Thomas, T. Benefiel, K. Erny, B. Fleming, R. Thacker, W. Gerber, D. Wood. 4. Dan Dedic keeps score for the tournaments.

5. A stolen $\mathrm{Pi}$ Sigma $\mathrm{Nu}$ bell is now property of Alpha Chi.

6. PI SIGMA NU: FRONT ROW: D. Stoner, W. Gerber, D. Bartemus, K. Harding, B. Hull; SECOND ROW: G. Spencer, D. Evans, M. Mignard, R. DePriest, M. Ziegler, S. Stairs, D. Bresson, D. Harkleroad; THIRD ROW: S. Uyenshi, D. Mattox, R. Commeville, D. Colburn, R. Cagwin, P. Slusher. 


\section{Pe) \\ (2) \\ (2) \\ 웅}

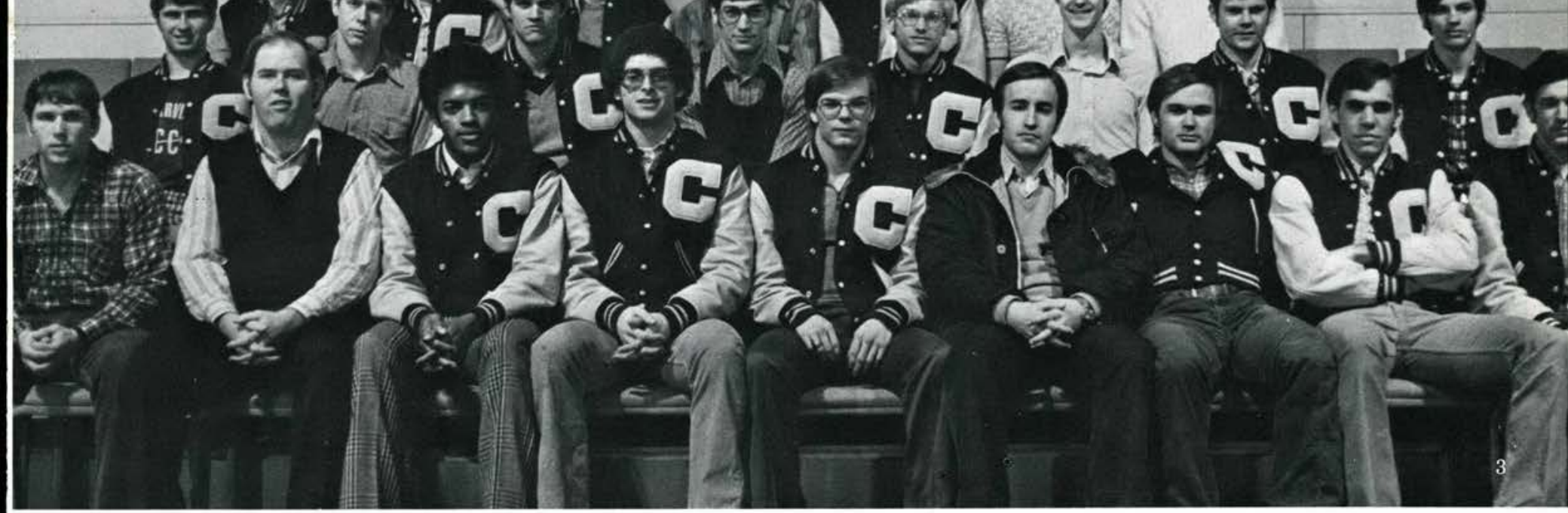

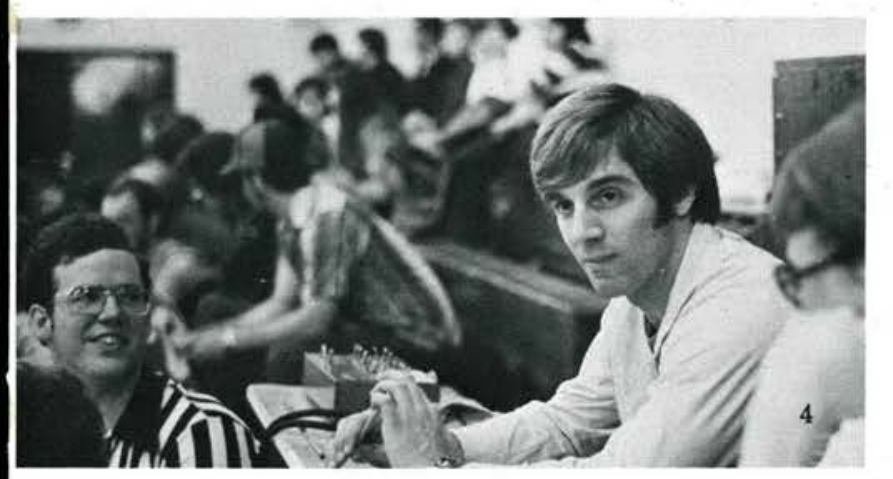

$\theta$

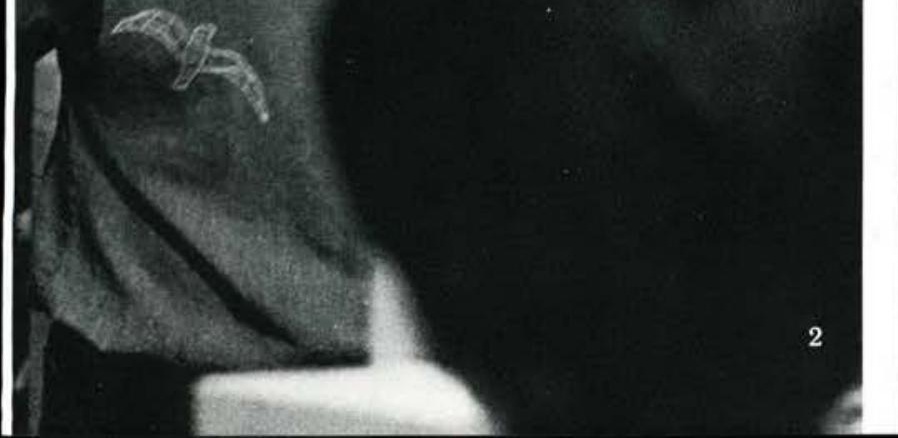

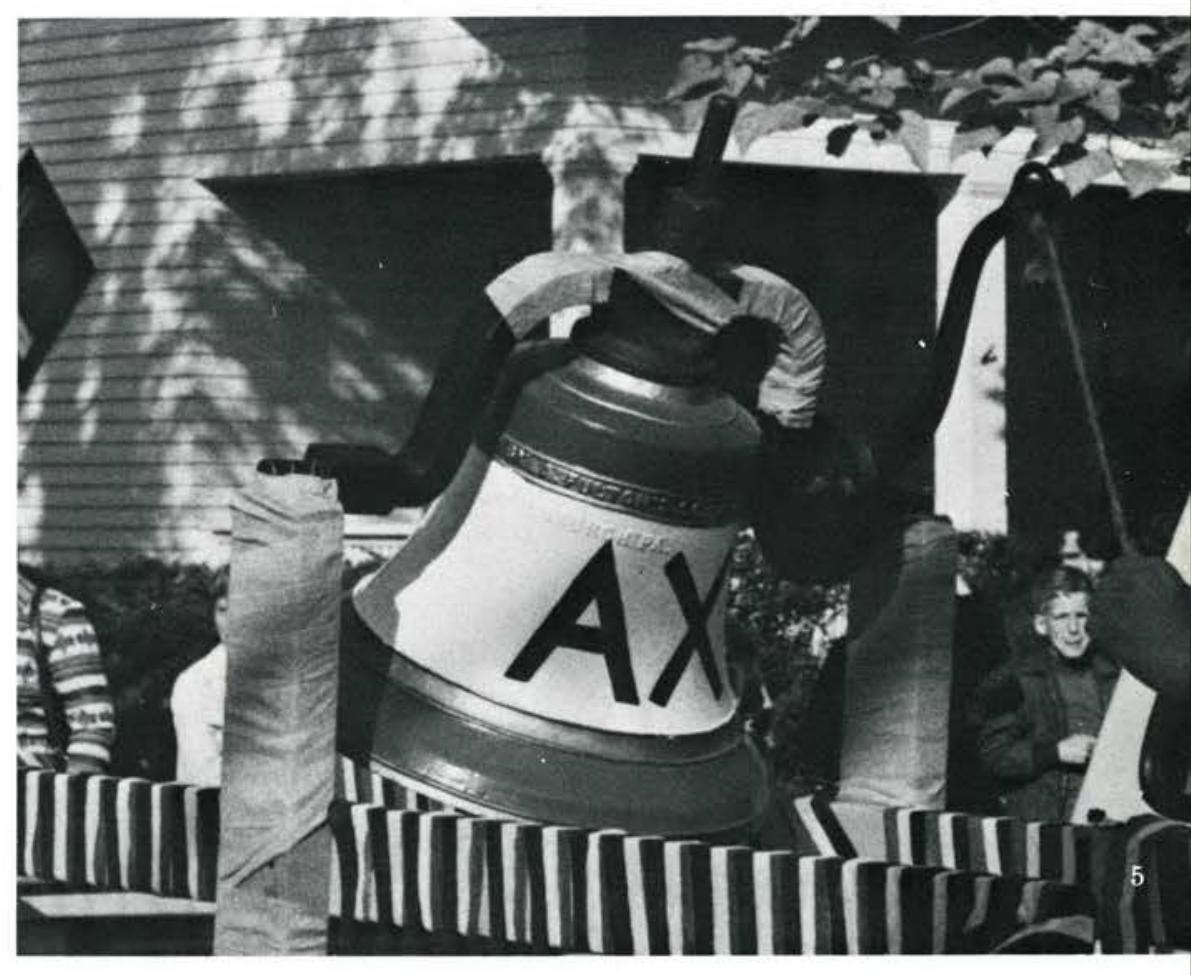

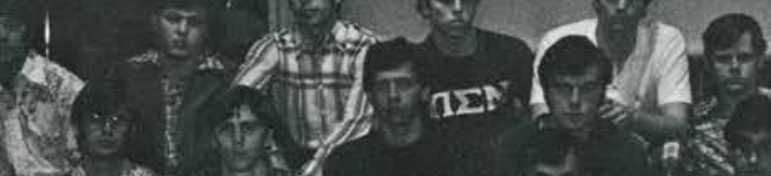

(2) 


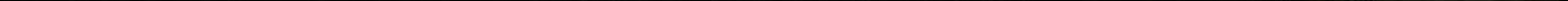




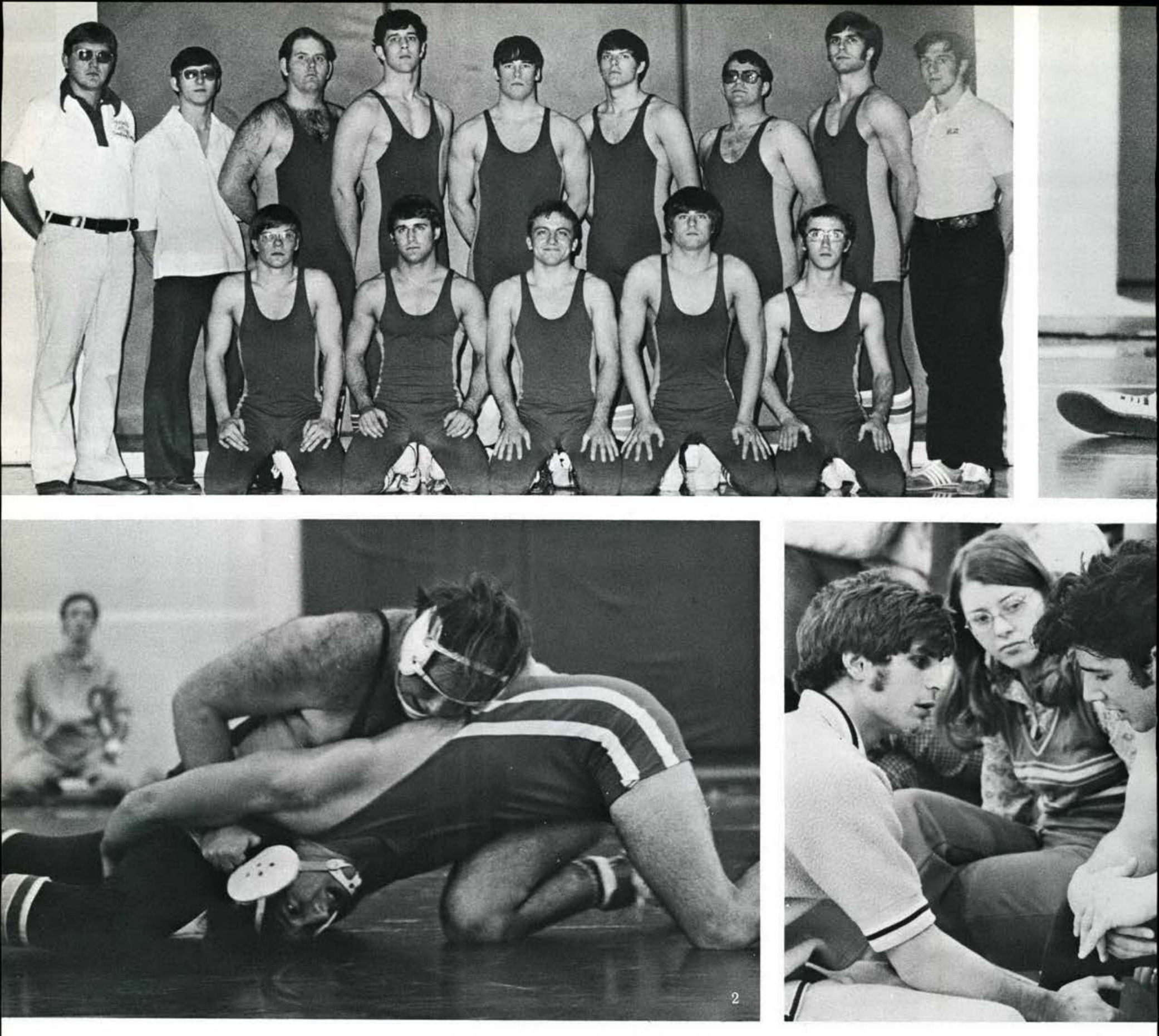



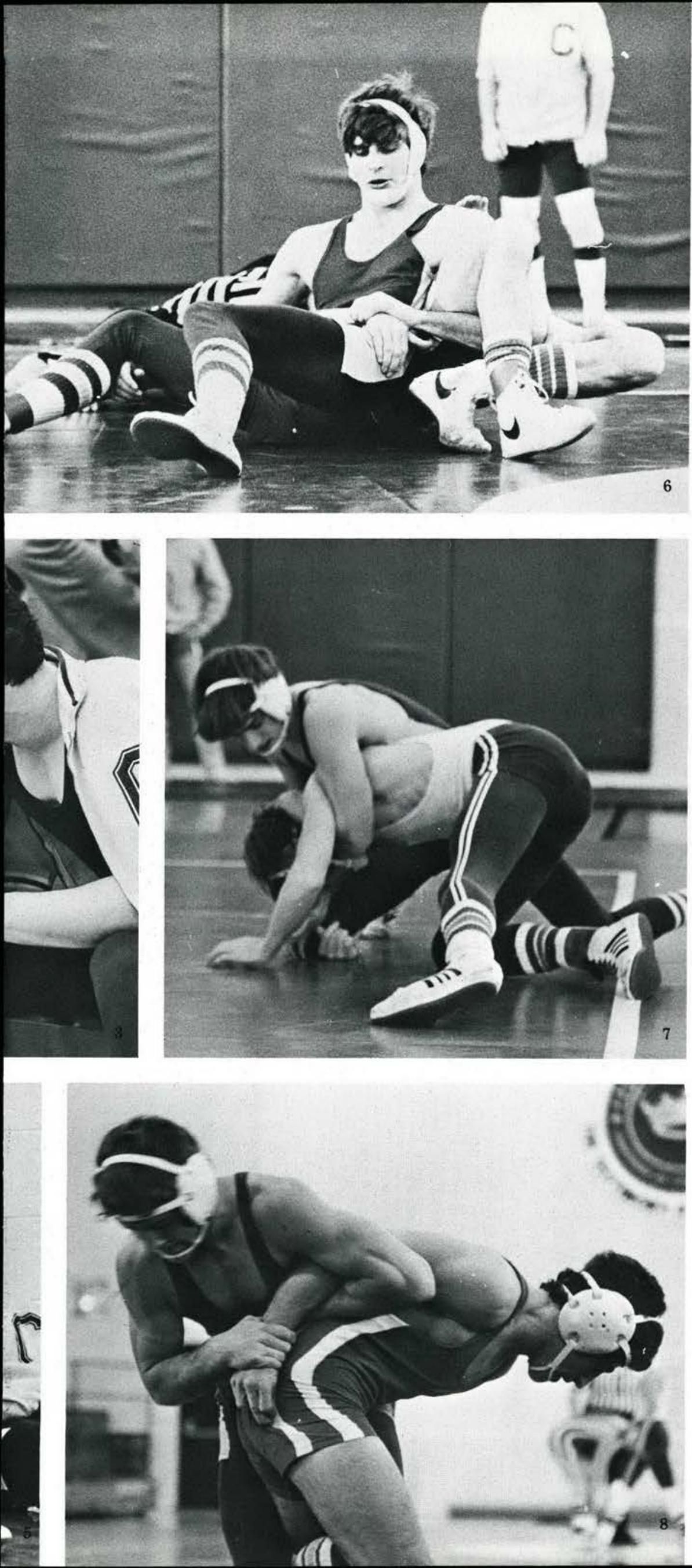

\section{Nationals Berth Highlights Season}

The Jacket grapplers turn in a 5-82 season this winter as they are plagued once again by injuries and a lack of wrestlers. Their strength is shown in matches such as the overwhelming of Bluffton, 48-6. Undoubtedly, the highlight comes as Cedarville stuns an NCAA major university, Georgia Tech, 3023. Four matmen take MOC top honors as the team finishes 3rd. Two of the Jackets, Dale West and Armand Ternak, make the long trip to Nationals with their second place showing in District \#22 competition.

1. Wrestling Team: FRONT ROW: D. Self, D. West, A. Ternak, D. Pippin, K. Hathaway; BACK ROW: Coach Gary Storm, M. Barnett, T. Williams, P. Gardner, J. Conklin, D. McGhee, J. Shaner, J. Kollar, D. Fields.

2. Senior Tom Williams wrestles well in his first season.

3. Jim Kollar listens to Pete Gardner's version of his match.

4. Most Valuable Wrestler Armand Ternak has his man just about pinned.

5. Coach Dernlan's son tries to give Dale West a few "needed" pointers.

6. His man behind him, Jim Kollar plots his next move.

7. Most Improved Wrestler Don Pippin tries to break his man down.

8. Dale West shows the form that took him to the Nationals in Spokane, Washington. 


\section{Cold Weather Spurs Heated Competition}

Men's and women's basketball highlight Cedarville's winter intramural program, providing a means of exercising to stay warm in this year's sub-zero weather. Although it is cold outside, the action is hot and heavy in the gym. In women's basketball, Patterson dorm romps through the opposition for the top prize. Men's basketball proves to be a hotly contested issue as Upper Williams beats Off-Campus twice during the regular season, but finally succombs by a close margin in the championship.

1. Opponents stretch to gain control of the jump ball in intramural action.

2. The ball is "the one that almost got away."

3. Behind every successful BB program are those people who are responsible for keeping records and statistics.

4. Action under the bucket is intense.

5 . This is the proper technique for a set shot.

6. John Briggs takes special care to mark this lay-up.

7. Members of the faculty and staff are shown here taking a "break from the action".

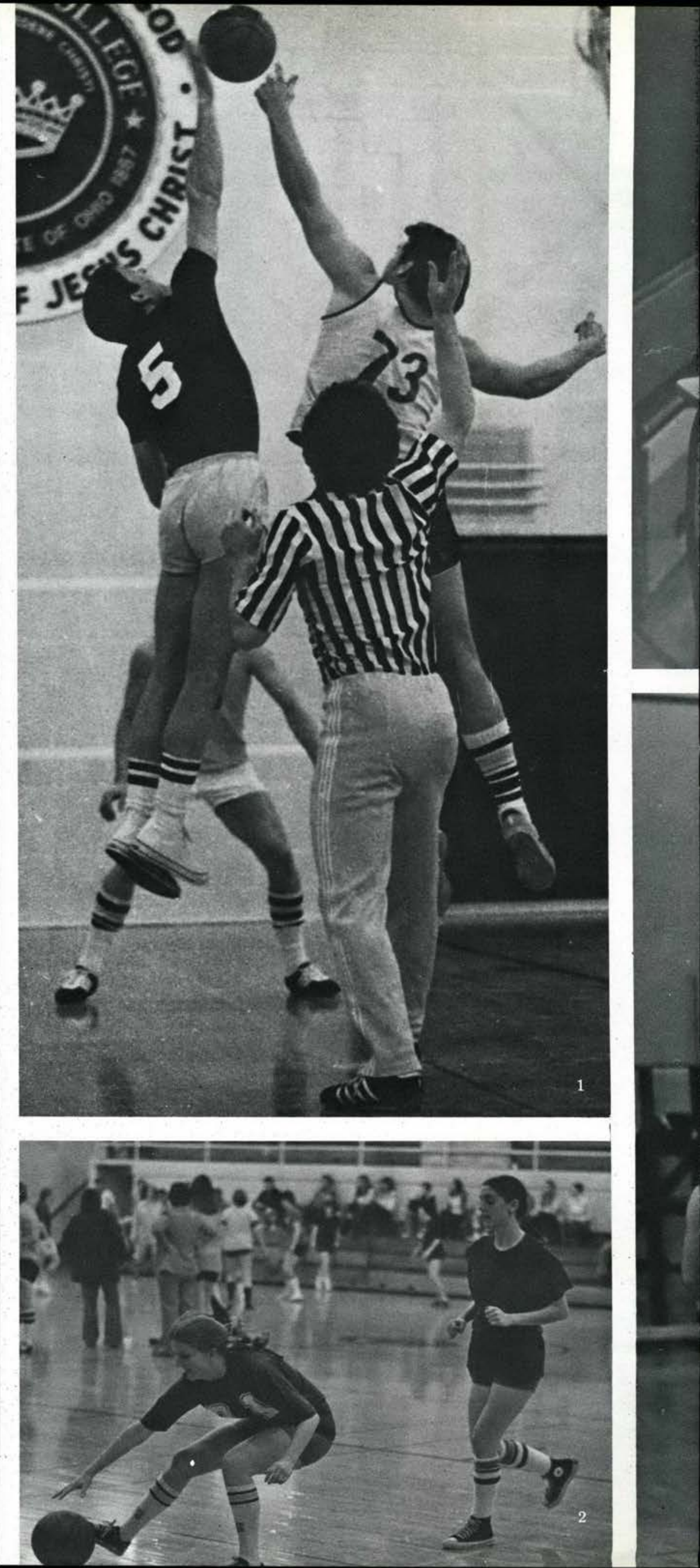




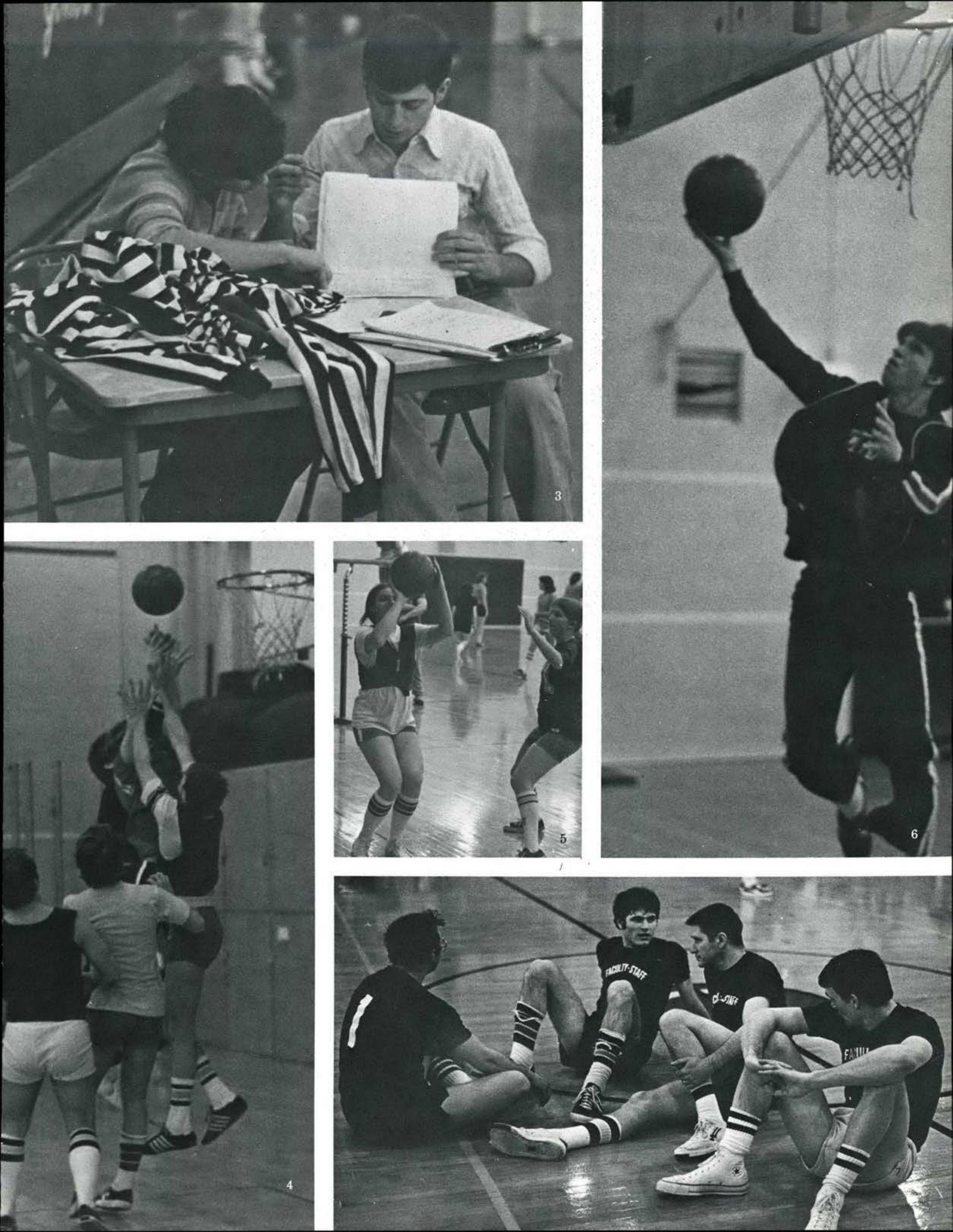




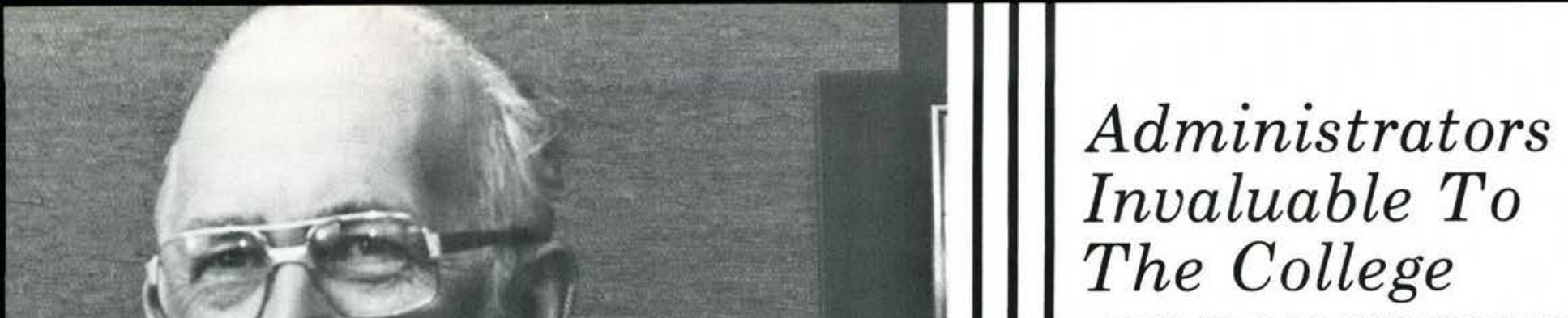

1. TRUSTEES OF CEDARVILLE COLLEGE:

Charles A. Barth

Francis Bresson

George O'Bryon

Gerald Smelser

Rudy Bedford

Paul Tassell

Jack Jacobs

J. Dale Murphy

James B. Carraher

George Engelmann

James T. Jeremiah

Galen Call

Donald Tyler

Donald Sewel

William Brock

Roy Guenin

Earl Willetts

Jack Cline

Paul Vernier

(Not pictured):

Glenn H. Davis

John Draxler

Arthur Dyke

Willard Eidson

Irwin Olson

William Patterson

Robert Sumner

Earl Umbaugh

2. Clifford W. Johnson, D.Ed.,

Academic Dean

3. Donald Rickard, M.A.,

Dean of Students

4. Kenneth St. Clair, M.A., C.P.A.,

Business Manager

5. James T. Jeremiah, D.D.

President of the College

6. Lee Turner, M. Div.,

Director of Development 
Industrious Employees Promote
School
Relations

1. Henry Phillips, B.A., Assistant Director of Development, Estate Planning 2. Dan Stevens, B.A., Th.M. Assistant Director of Development Alumni Coordinator 3. DEVELOPMENT OFFICE

Linda Benson, Graphic Artist Carla Humm, Composer Operator Barbara Bernstein

Secretary to Estate Planning and Alumni Coordinator Debra Clough,

Admissions Counselor Nancy Case, Assistant to Director of Public Relations 4. Roy Kern, B.A., Director of Public Relations and Student Recruitment 5. MAILING ROOM Wilma Conklin, Supervisor Marion Payne Jill Williamson

6. Pastor Harold Green, Th.B., Director of Christian Service 7. WCDR RADIO STATION Jacqueline Payne, Secretary

David Boston, 1st Class FCC License, Chief Engineer Kathleen Howell, Music Coordinator James Peer,

Program Operations Director Paul Gathany, 1st Class FCC License, WCDR General Manager, Christian Education Publications Director 8. CHRISTIAN SERVICE Patty Birkenholtz, Receptionist Margaret Green, Secretary to Director of Christian Service 9. Lois Gillespie, Secretary to Director of Development
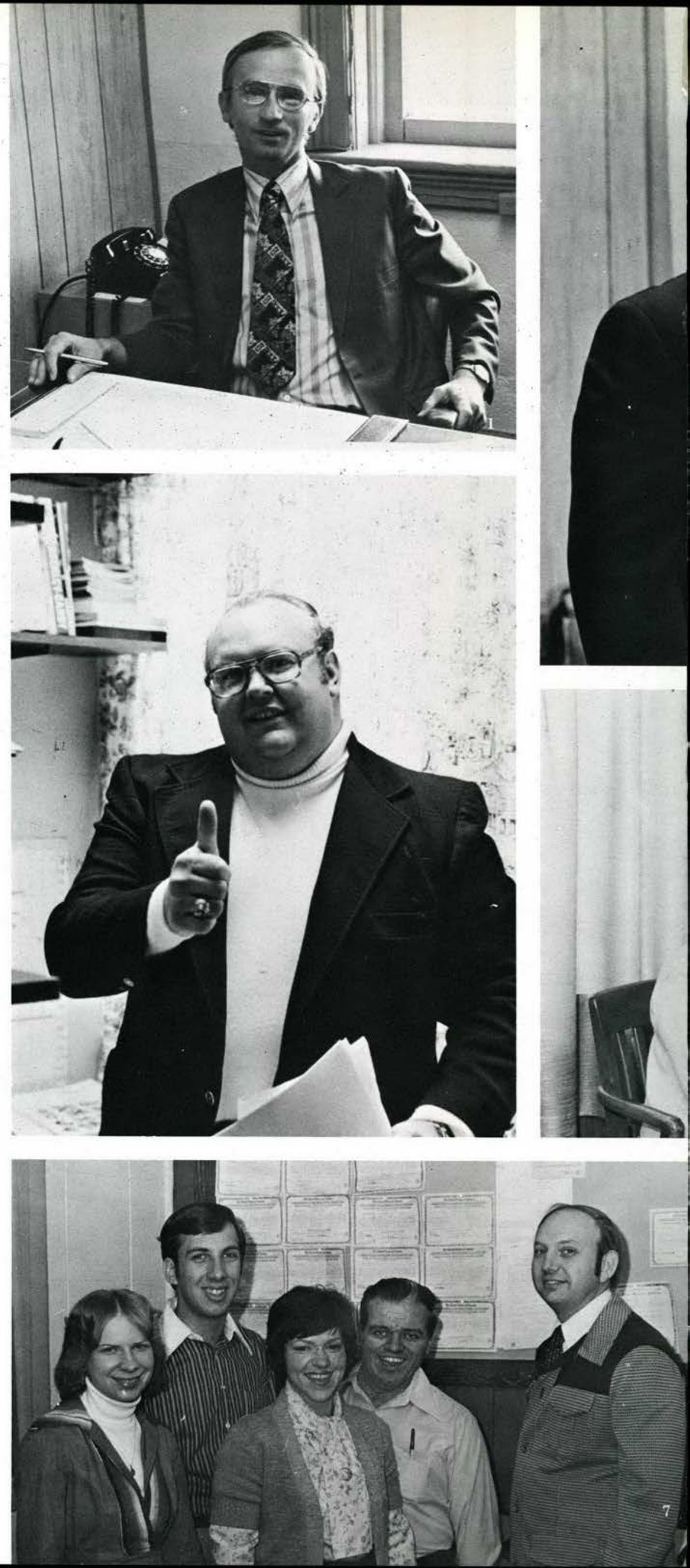


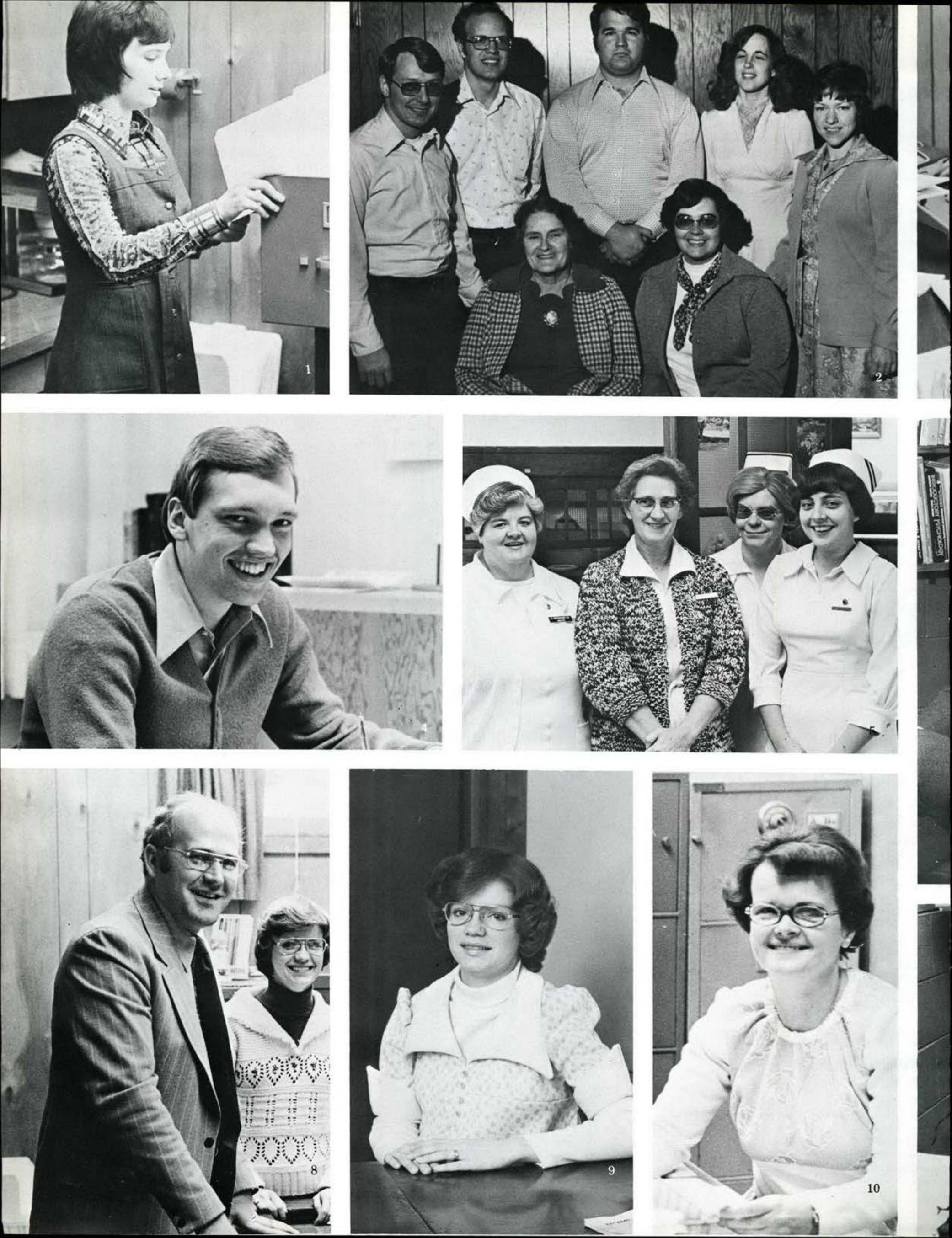




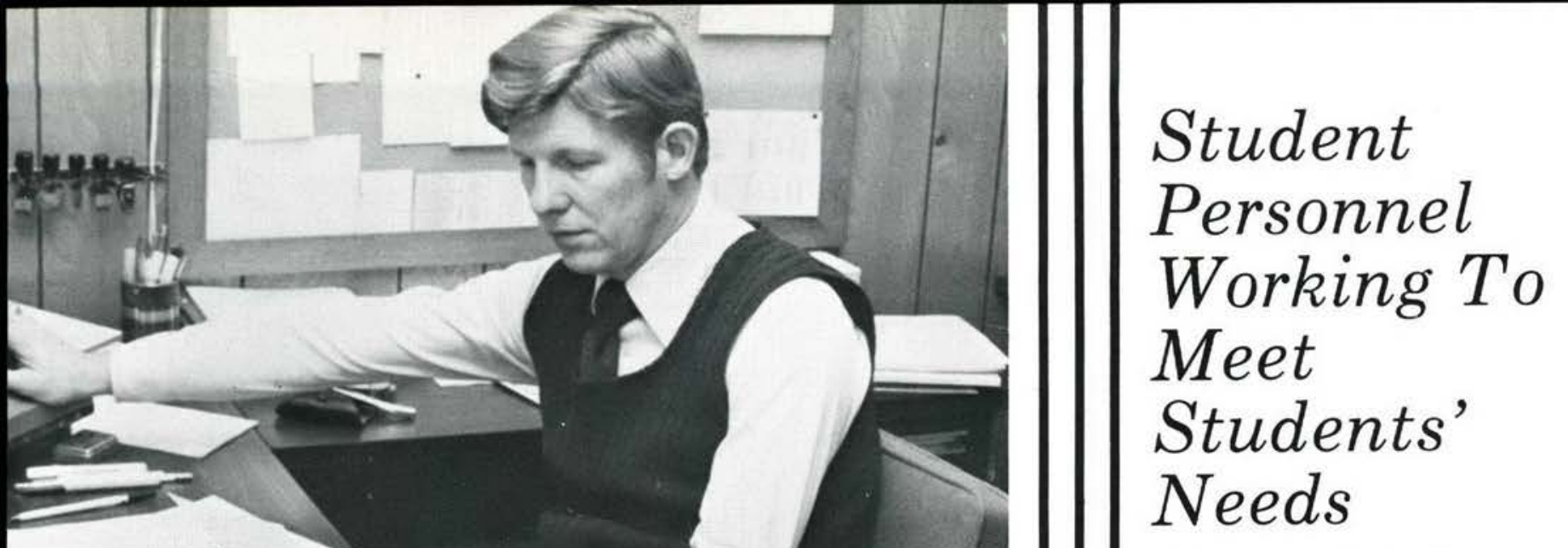

1. Patricia Bates, B.S., M.S.,

Dean of Women

2. RESIDENT HALL SUPERVISORS

David Dernlan

David Carroll

Robert Seymour

Christine Rufener

Kathy Howell

Beatrice Printy

Tawn Jutton

(Not pictured - John Bole)

3. David Gidley, B.A.

Director of Financial Aid

4. Myron Youngman, B.A.,

Director of Student Activities

5. HEALTH SERVICE

Betty Bertschinger,

Director of Health Service

Lucia Strobridge,

Secretary to Director of Health Service

Elaine Schulte,

Nurse

Joanne Cook,

Nurse

6. Martin Clark, B.A., M.A., Ed. D.,

Director of Counseling Services

7. Nancy Seymour,

Secretary to Director of Financial Aid

8. Richard Walker, B.A.

Dean of Men

9. Barbara Jeffords,

Receptionist

10. Virginia Kirchner,

Secretary to Dean of Students

11. Sheryl Wing,

Secretary to Director of Counseling

Services 


\section{Academic Assistance Provided By Staff}

1. Patricia Monroe, Typist

2. May Greenwood,

Secretary to Academic Dean 3. Lynn Brock, B.A., M.L.S.

Director of Library Services 4. Barbara North,

Athletic Director's Secretary 5. Stephen Brown, B.S., M.L.S., Associate Director of Library Services 6. Mary Mitchell,

Music Department Secretary 7. Irene Gidley,

Secretary to the President 8. L. Robert White, B.S., M.Ed., Registrar and Director of Admissions 9. ADMISSIONS AND REGISTRAR Toinette King,

Secretary - Admissions and Testing Sharon Floyd, Records Clerk Barbara McIntosh, Secretary to Registrar 10. LIBRARY Lois Gillette,

Technical Processing Clerk Christine Rufener,

Circulation Supervisor Lorelei Auwarter,

Assistant Circulation Supervisor Esther Ruder, Serials Library Merilee Shank, Acquisitions Clerk Ethel Rayburn, Secretary to Director of Library Services

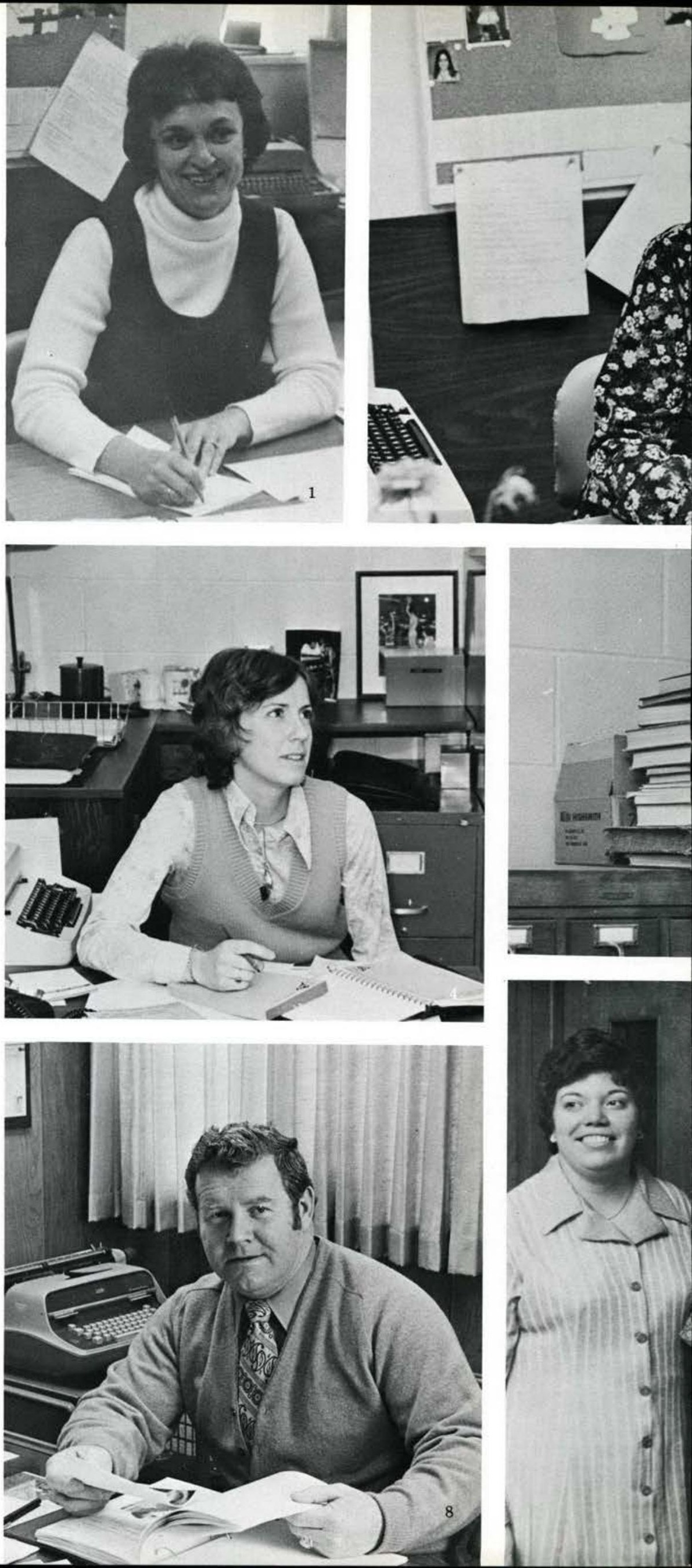




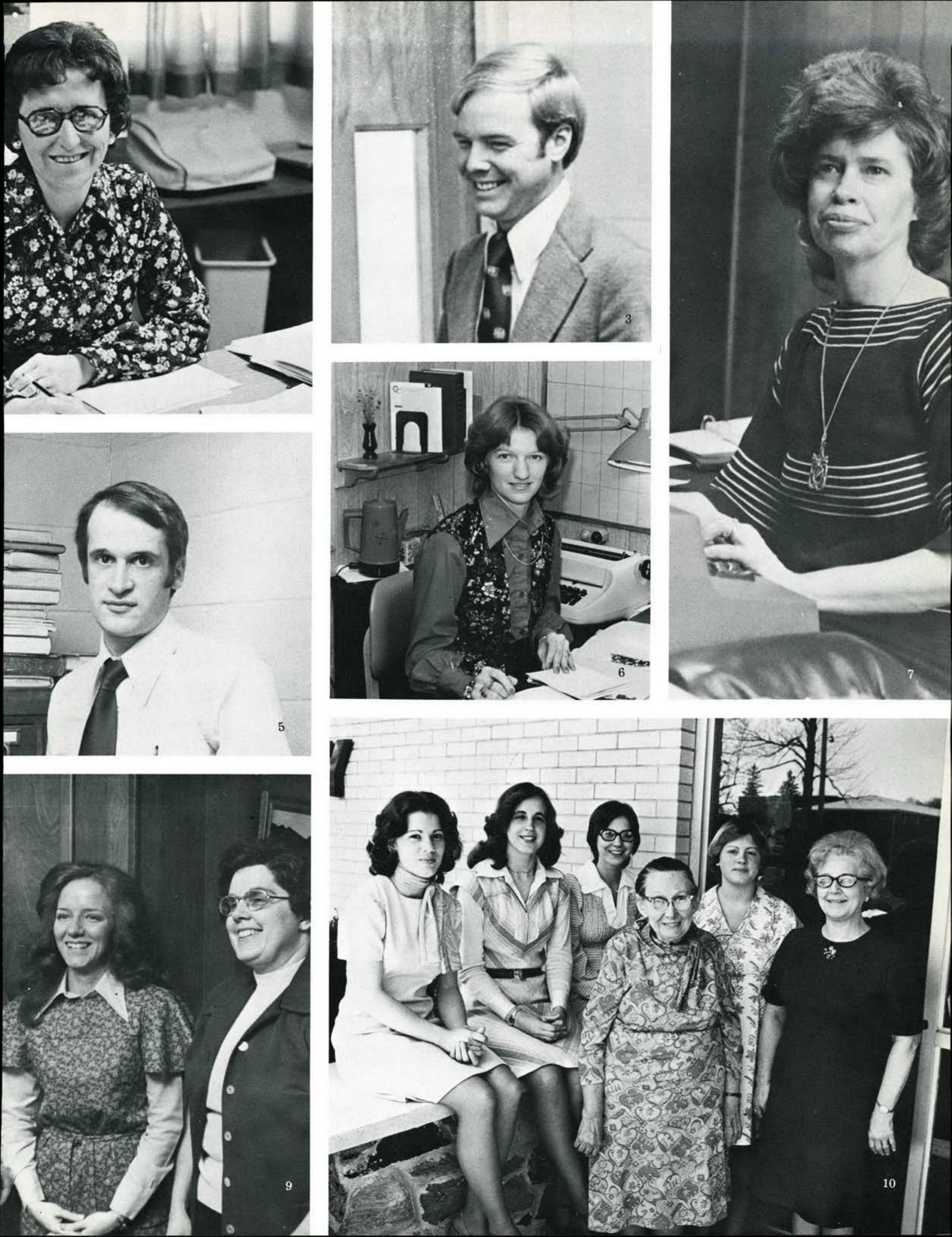




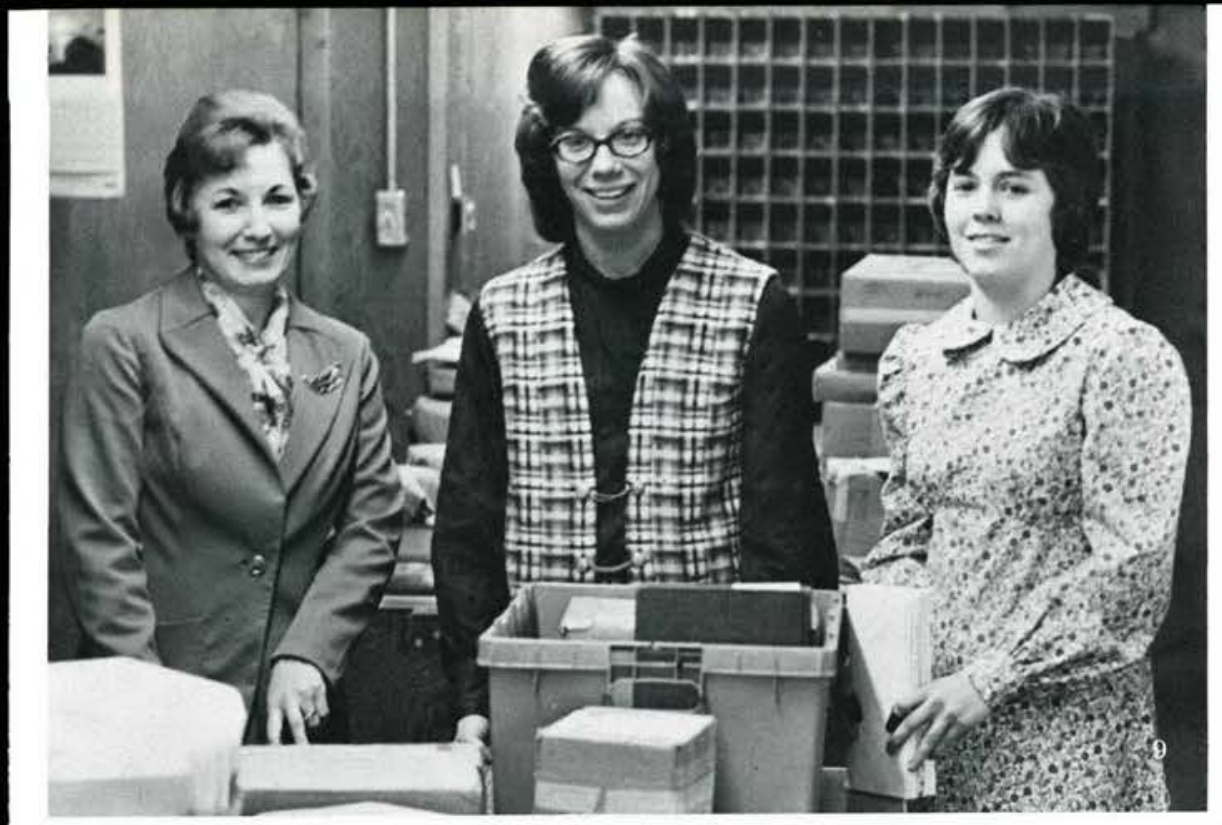

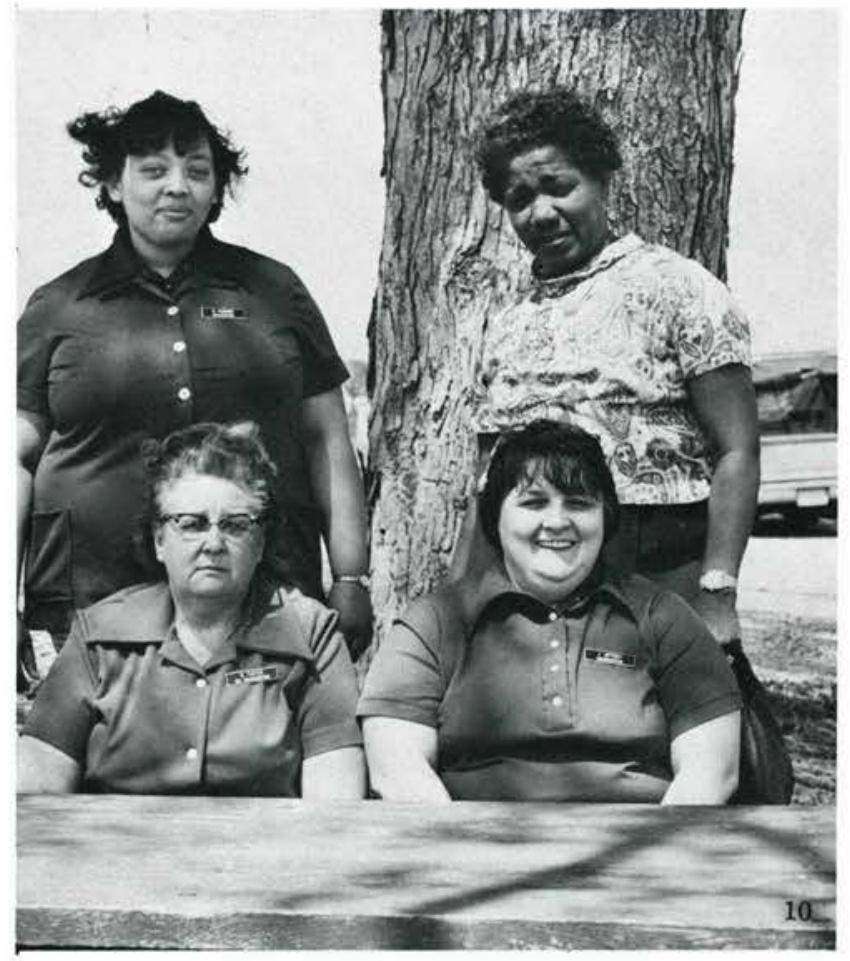

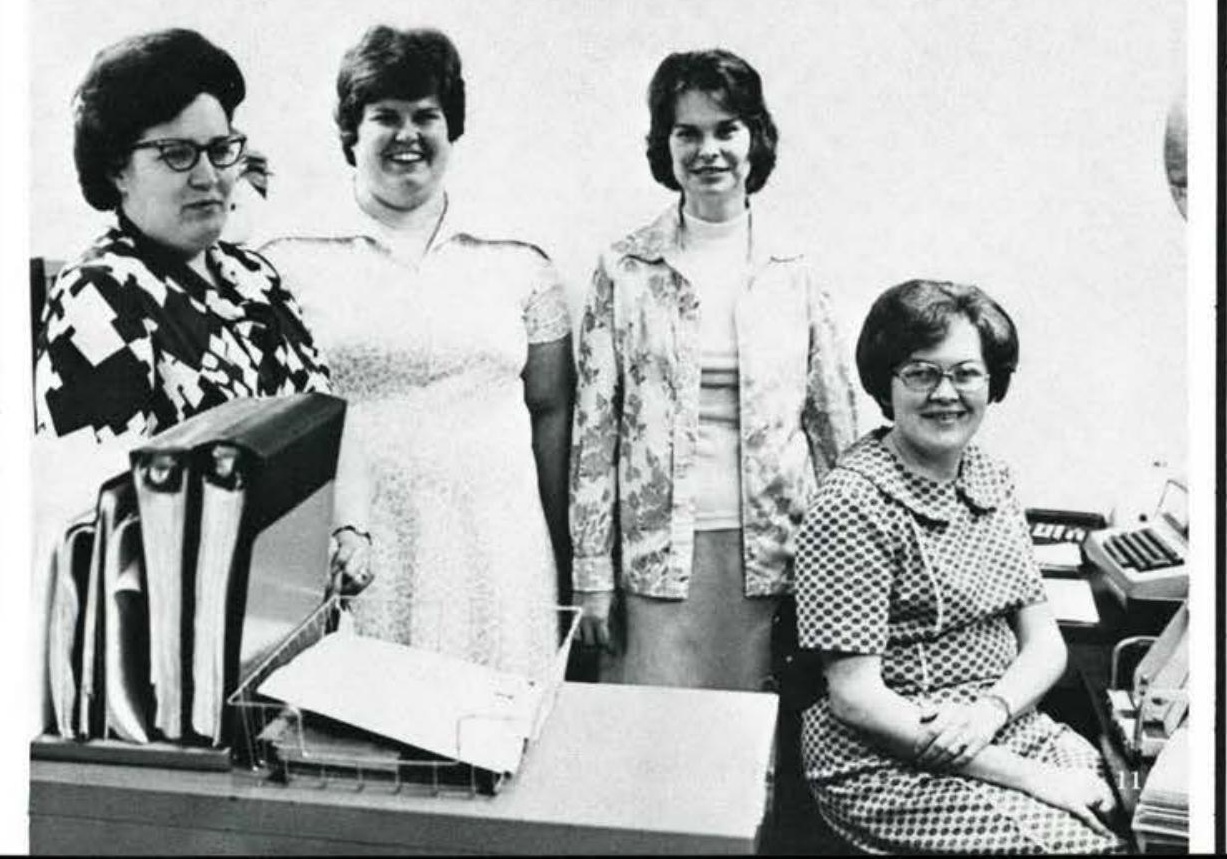

1. BOOKSTORE

Harry Cole

Assistant Manager

Audrey Bergen

Martha Baldwin

Constance Kriel

Maxine Benefiel

2. Marabeth Elmore,

Receptionist

3. Ida St. Clair,

Receptionist

4. FOOD SERVICE

BACK ROW: Y. Story, P. Fudge, M.

Ellis, A. Terwilleger, M. Hall, S. Ackley,

P. Depp, C. Reynolds; THIRD ROW: L.

Pollack, B. Behrend, M. Long, E.

Monroe, J. Travis, D. Reed, M. Miller;

SECOND ROW: S. Johnson, M. Pollack,

W. Thomas, B. Hawes, B. Fenner,

FRONT ROW: N. Linamen, J. St. Clair. 5. PHYSICAL PLANT

BACK ROW: L. Filson, M. Halk, E.

Filson, G. Storm, C. Bates, D. Mitchell,

M. McIntosh, J. Chambers, A. Grisham;

FRONT ROW: P. Kaufman, T.

Wineberg, D. Dillon, R. Dillon.

6. Dorothy Spencer,

Secretary to Business Manager

7. Eldon Sarver,

Accountant

8. Lori Rossi,

Copy Center Operator

9. POST OFFICE

Betty Grisham,

Supervisor

Lynda Shenefield

Faith Whitelaw

10. HOUSEKEEPING:

BACK ROW: B. Hubbard, C. Bruce;

FRONT ROW: B. Tartar, J. Jeffery.

11. BUSINESS OFFICE

Eileen Kaufman,

Accounts Payable

Nancy Fissel,

Cashier

Karen Harris,

Payroll \& Accounting Machine Operator Margaret Burrichter.

Bookkeeper 


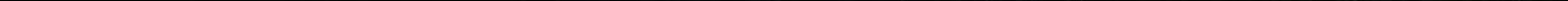




\section{Enriching The Whole Man}

1. HEALTH AND PHYSICAL EDUCATION DEPARTMENT: 2. JUNE KEARNEY, Ph.D.

Professor of Physical Education 3. ELVIN KING, M.Ed., Assistant Professor of Physical Education 4. MARYALYCE JEREMIAH, Ph.D.

Associate Professor of Physical Education 5. JOHN McGILLIVRAY, M.S., Instructor of Physical Education 6. DONALD CALLAN, Ph.D., Professor of Physical Education, Chairman

7. PAMELA DIEHL, Ph.D. Assistant Professor of Physical Education 8. MUSIC DEPARTMENT: 9. DEAN A. KOOL, M.Ed. Assistant Professor of Music (Instrumental) 10. CHARLES ELLINGTON, Ph.D., Associate Professor of Music (Vocal) 11. PHILIP McCLURE, M.M., Instructor of Music (Piano) 12. DAVID MATSON, M.A., Associate Professor of Music (Vocal),

Chairman

13. ROBERT MONROE, Ph.D.

Professor of Music (Instrumental)

14. LYLE ANDERSON, M.A.,

Assistant Professor of Music (Vocal) 15. JACK PAYNE, M.M.,

Assistant Professor of Music (Organ, Piano)
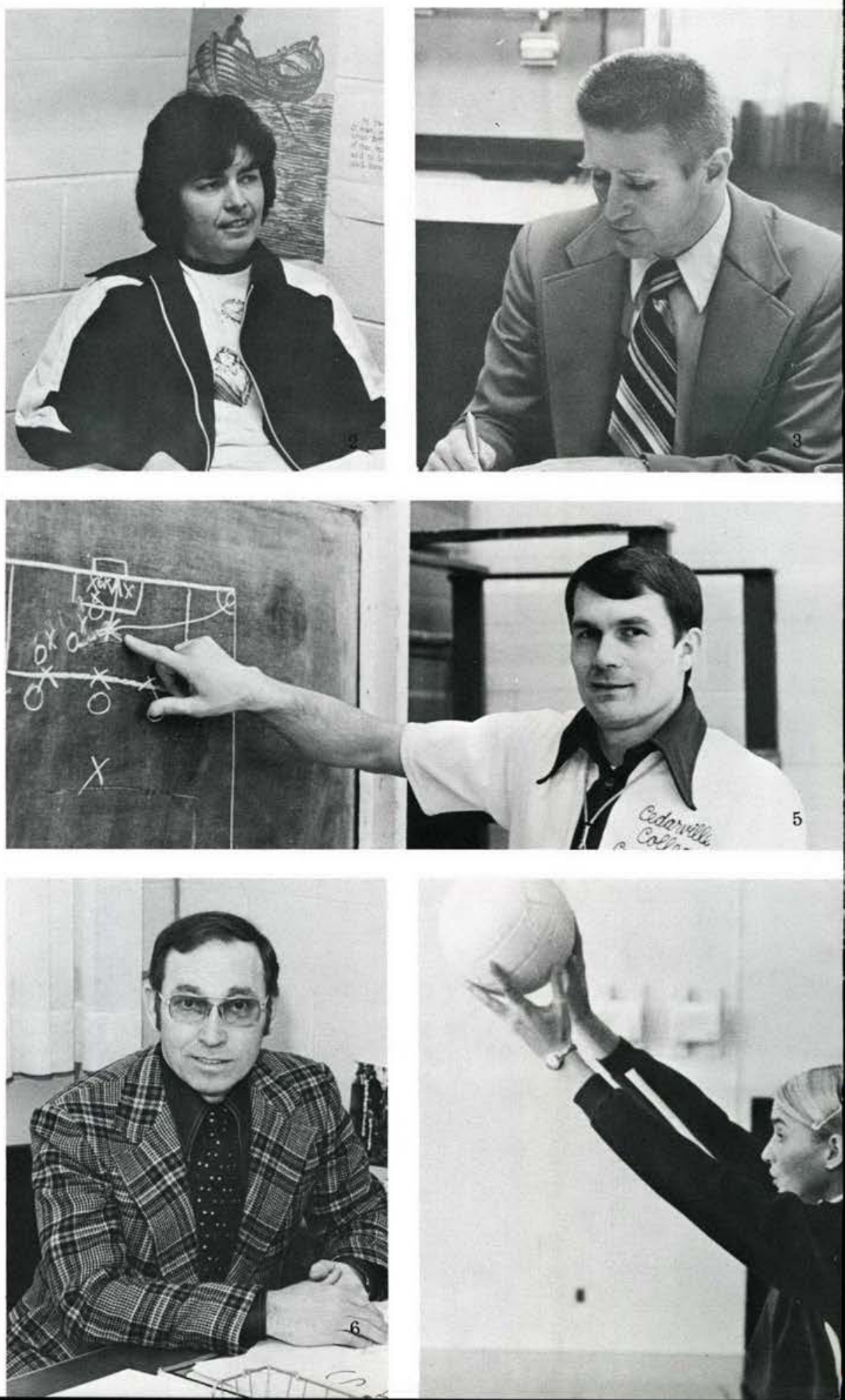

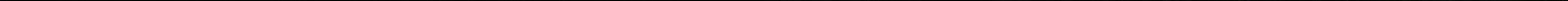


\section{Improving Man's World Through The Sciences}

1. SOCIAL SCIENCE DEPARTMENT:

2. J. MURRAY MURDOCH, Ph.D.

Professor of History, Chairman

3. JAMES McGOLDRICK, Ph.D.

Professor of History

4. JOSEPH HALSEY, M.Ed.

Associate Professor of Social Science

5. ALLEN MONROE, Ph.D.,

Professor of Social Science

6. PAT BRYANT, B.A.

7. BERNICE BOWERSOX, M.A.

8. SCIENCE AND MATHEMATICS DEPARTMENT:

9. DANIEL WETZEL, Ph.D.,

Professor of Physics \& Mathematics

10. AUSTIN ELMORE, M.A.T.

Professor of Biological Science

11. EDWIN BRAITHWAITE, Ph.D.,

Assistant Professor of Mathematics

12. DANE HARVEY, M.S.,

Assistant Professor of Physics \&

Mathematics

13. LARRY KILLIAN, M.S.,

Associate Professor of Biological Science

14. BERT FRYE, M.A.T.,

Associate Professor of Physical Science

15. DONALD BAUMANN, Ph.D.,

Professor of Biology \& Chemistry,

Chairman

16. LARRY HELMICK, Ph.D.,

Professor of Chemistry
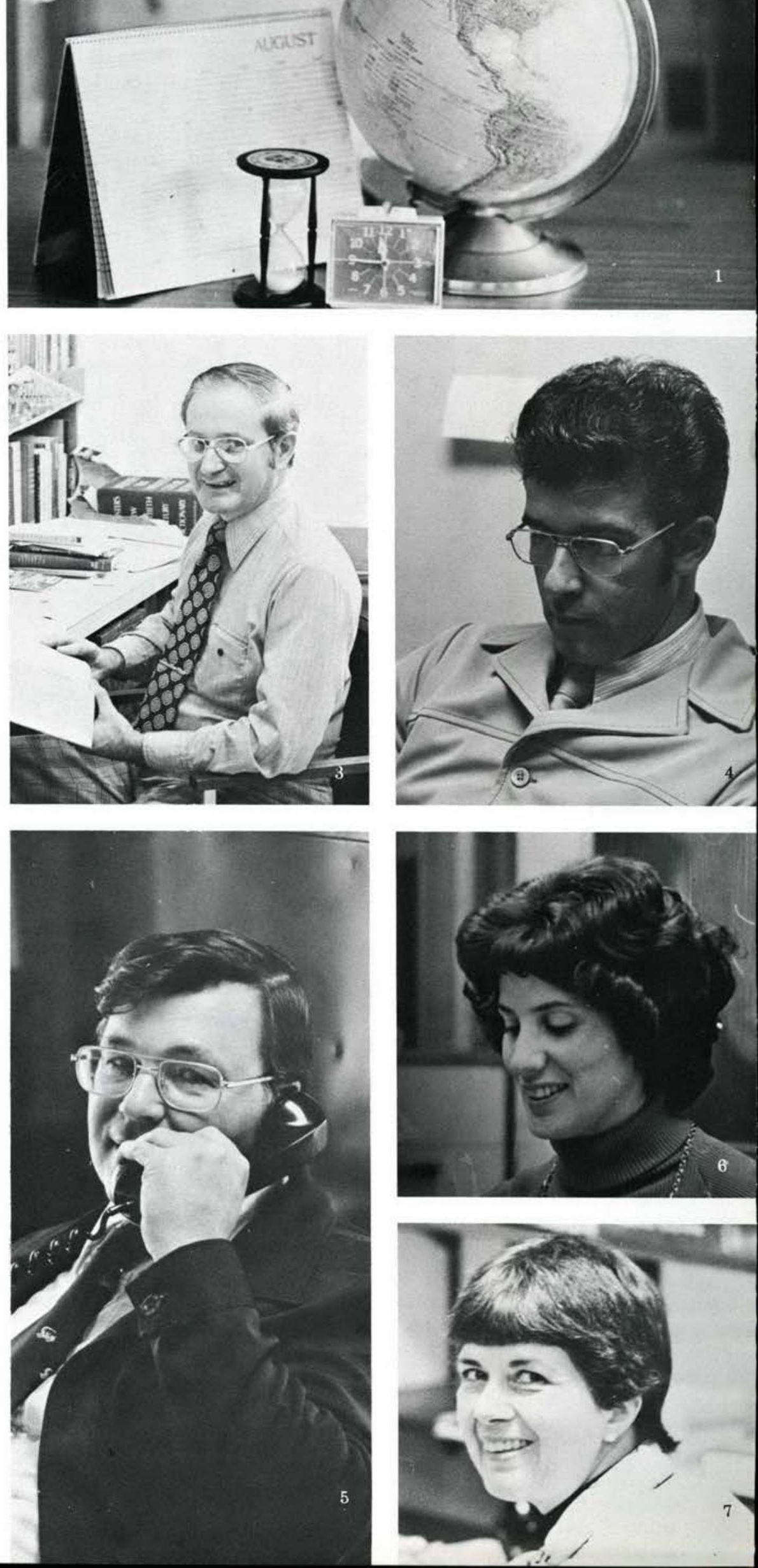


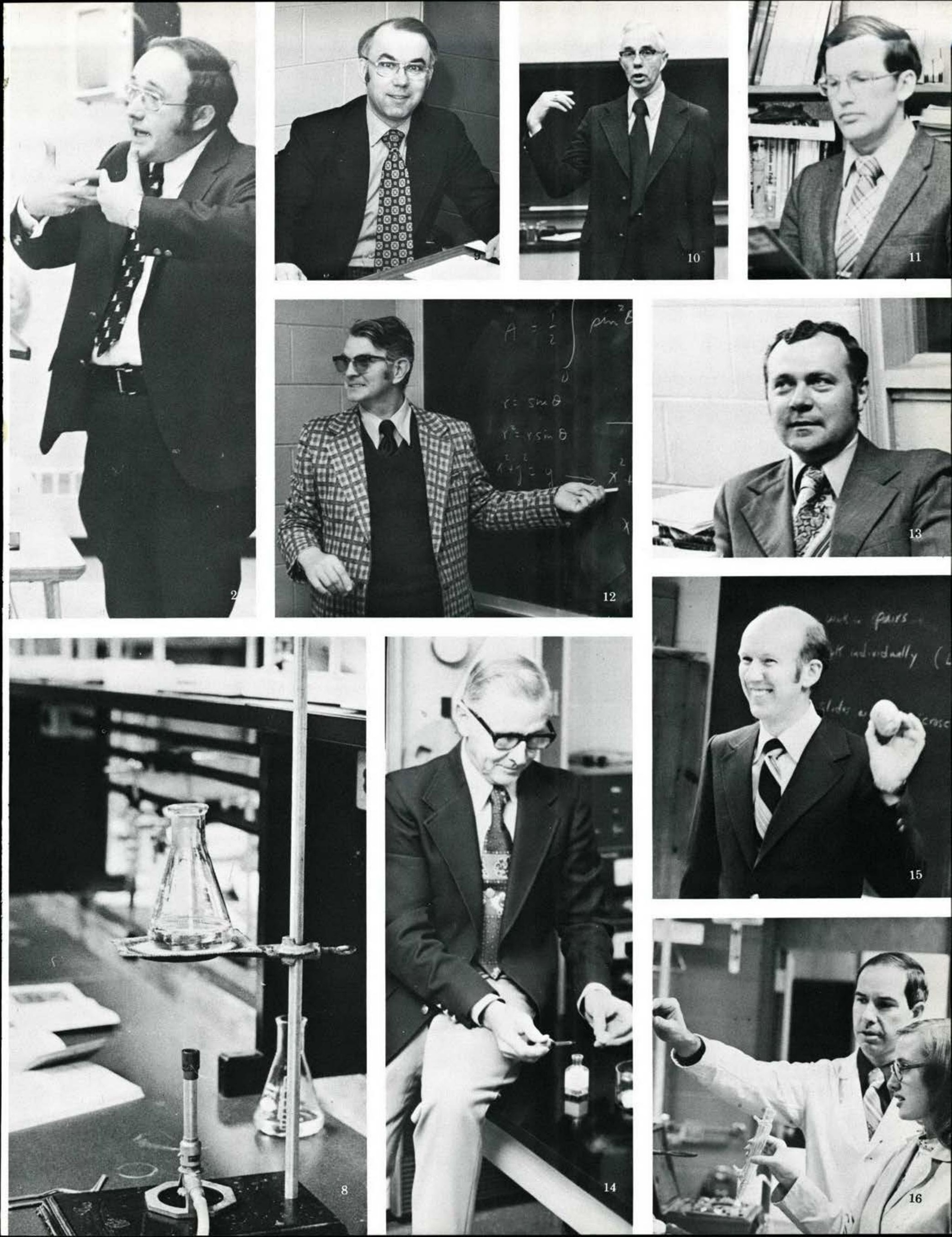




\section{Students Care About School's Functioning}

Each department chooses one student to represent it on the Academic Advisory Board. It meets with Dr. Johnson twice a month to discuss concerns students may have regarding different academic programs.

The Advisory Twelve, comprised of three men from each class and Pastor Green, is responsible for the spiritual concerns of the student body. They act as deacons of the college chapel.

Residing in West Hall is Alpha Chi Resque Squad. They are on call 24 hours a day for any campus emergency that may arise.

The Personnel Assistants are hired by the school in order that the rules will be enforced in the dorms. These people are leaders because they are in charge of a group of students; they are friends because they reach out and help those needing encouragement.

1. RESQUE SQUAD: S. Terlouw, D. Drozak, L. Bunker, D. Francis, G. Felmlee, T. O'Neal, D. Wishart, E. DeLange.

2. This poor battered soul is actually a member of the Alpha Chi Resque Squad! 3 . Soaking one's feet is one of the many tasks provided by the Health Service. 4. PERSONNEL ASSISTANTS: BACK ROW: B. Sininger, D. Blackburn, M. Bentley, D. Rae, R. Yoder, F. Dallis, S. Browne, D. Hunn, L. Summerlin, P. Dersham, S. Browning; SECOND ROW: K. Anderson, L. Neal, J. Harkless, N. Reu, D. Shumaker, J. Ebel, J. Leeke, C. Watts, B. Giles, D. Butcher; FRONT ROW: W. Throckmorton, D. Evens, B. Street, W. Johnson, D. Burns, C. Hulsman, M. Humbert.

5. ADVISORY 12: P. DeLange, D. Atkinson, M. Seeley, M. Highman, R. Campbell, J. Footman, S. Browne, Pastor Green, F. Dallis.

6. STUDENT ACADEMIC ADVISORY BOARD: FRONT ROW: T. Pasma, J. Cross, D. DeNicola, D. Radcliffe; BACK ROW: T. Lutz, R. Kline, D. Stoner, T. Detwiler, Dr. Johnson.
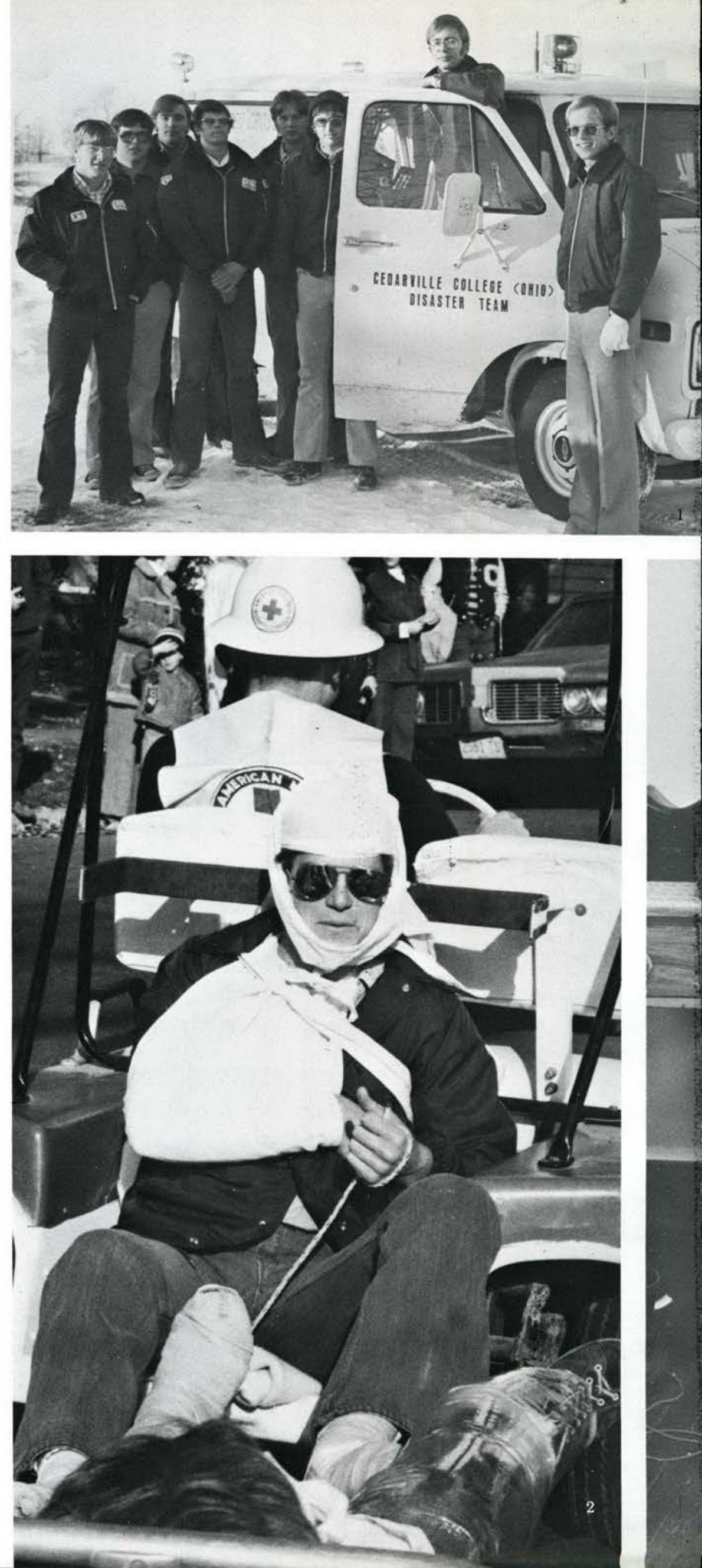

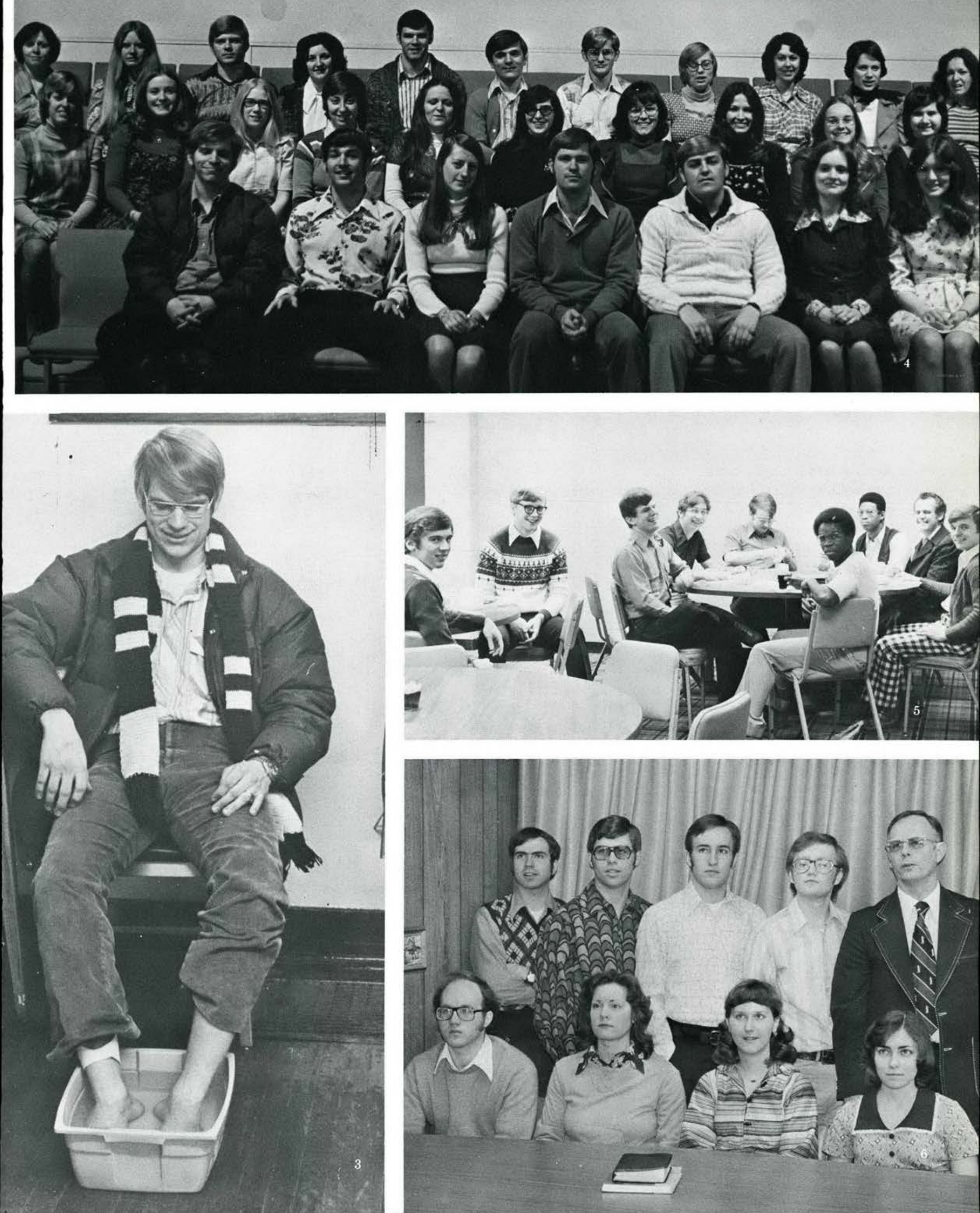


\section{In Memory Of Thomas Smith}

C. Thomas Smith, 47, manager of food service at Cedarville College, died early Saturday morning, February 25 . He had suffered a heart attack Friday evening while in his home and was taken to Greene Memorial Hospital. Smith had been manager of food service since September, 1964.

During his supervision, the cafeteria has seen marked improvements throughout the years. This year, new trays were purchased for use in the cafeteria. The addition of a salad bar/drink center at the start of the cafeteria line created more seating space in the dining room.

Smith is survived by his widow, Nancy; his mother (consultant manager for the food service); two sons, Michael (now acting as food service manager), and Timothy; a sister, Mary Jane Parker of Bowling Green; and a brother, David C. of Cleveland.

1. Ken Erny helps himself at the salad bar, a new addition this year.

2. One Sunday night students are treated to tacos.

3. Amy Lamb finds the cafeteria a great place to share her ideas.

4. The snack shop is a favorite spot for the kids from the town, as well as Cedarville College students.

5. The late Mr. Thomas Smith, head of cafeteria services.

6. Dave Messenger "digs in".

7. Pam Harrison looks determined to win her argument with Jack. 


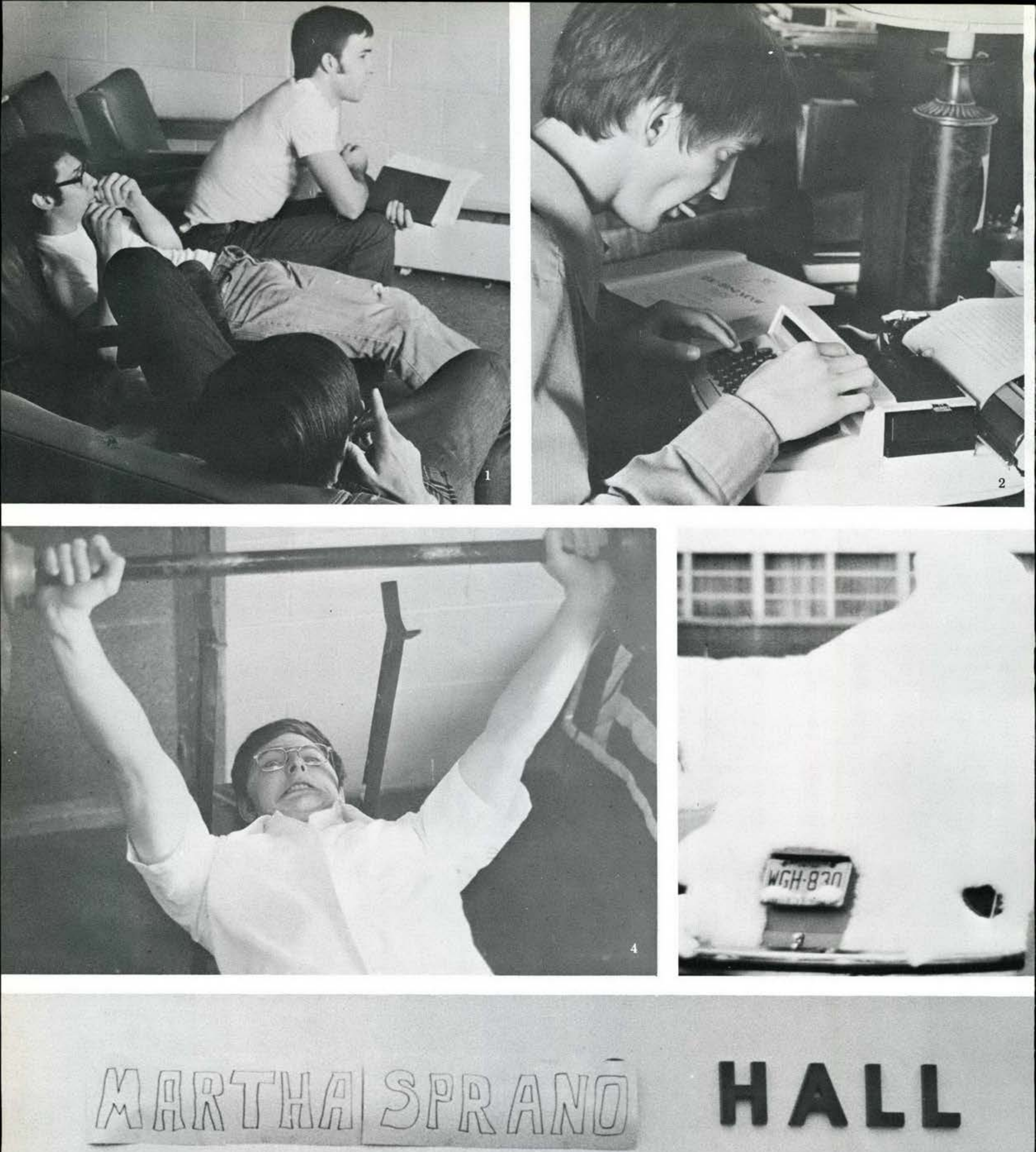




\section{More Women Per Square Feet}

Residents of the largest dorm on Cedarville's campus, Maddox girls lead an interesting life, under the watchful eye of Mrs. Printy, (Ma). Many of the activities these girls participate in take place in the courtyard. Midnight jogs around the courtyard (twelve laps equal one mile) help the girls keep in shape. Building snowmen in the courtyard is a favorite wintertime activity, while sunbathing is popular in the spring. Parties in $\mathrm{Ma}$ Printy's apartment provide a change from the usual entertainment. A "holy" snake produced excitement this year, when it was discovered in the prayer room. Freshmen girls find life in Maddox an interesting place to begin college life, as they adjust to living three to a room. Upperclassmen usually manage to have only two to a room, but there still is a problem when five girls try to use one mirror all at the same time!

1. Many late nights are spent over the typewriter.

2. A typical Maddox room is not exactly what you would find in GOOD HOUSEKEEPING.

3. A rare treat is male visitors during open house.

4. Lonely bikes wait for the snow to melt. 5. Margaret Stairs tells a new joke to plants. 6. A female astronomy student tries a new means of contacting outer space.

7. After raiding the refrigerator, Amy Ross proves that there is no chocolate mess. 8. Karen Price waits up for Paula to find out how the big date went.

9. During the winter months Maddox girls retreat to the warmth of their rooms.
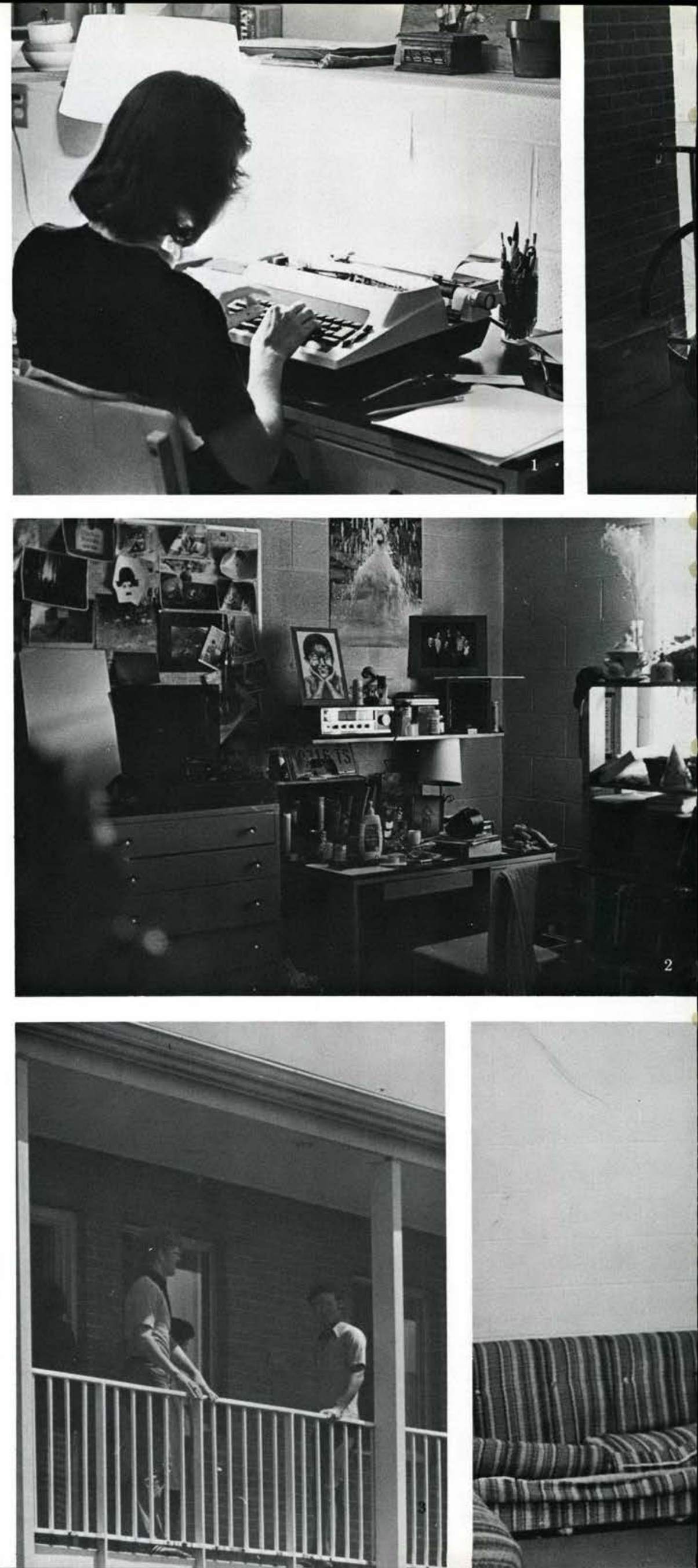

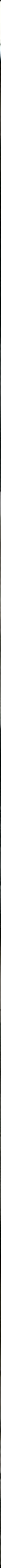


\section{Home, Sweet Home}

Although it is often ignored by passersby on their journey to Marshall and Carr, Rogers Dorm is definitely a part of Cedarville's campus. Since it was just converted from apartments into a mens' dorm, one wonders how to fit six guys into a bathroom reported to be somewhat comparable in size to a telephone booth. With the RA living right below them, many of the guys are also faced with trying to live a reasonably normal life as a college student, while maintaining complete silence.

Marshall, the twin brother of Carr, is known for extremes in individuality. Each unit has its own unique personality, with the residents of the unit forming close friendships with each other. The dorm as a whole cannot be classified as either studious or rowdy, but rather there are a few studious units, and many rowdy ones. (A factor contributing to this may be the recreation available in the basement of Marshall.)

1. Al Woodruff's acrobats make you wonder if the picture is upside down.

2. A speedy exit seems in store for this Roger resident.

3. Taking a leisurely pose, Keith Namy chats with a friend.

4. "Ready, Aim ..." Phil Smith looks menacingly toward a nearby friend.

5. Dick Krewson practices his downhill form in anticipation of the weekend.

6. Keith Glassey leads the men's choir of Marshall as he sings into a jumprope microphone.

7. The photographer is kept dizzy as he tries to snap this fellow's picture.

8. Dave Denny tries his hand at table top shuffleboard.

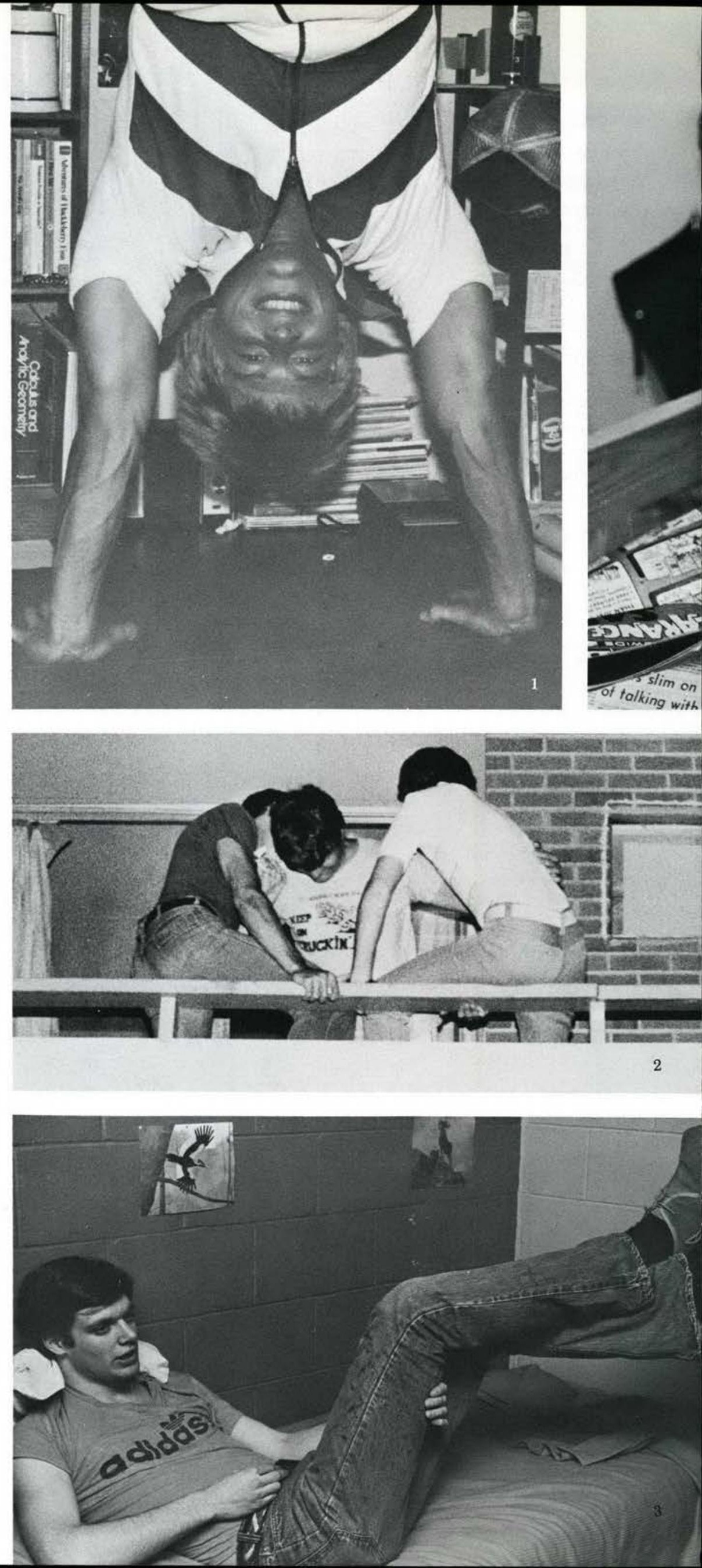




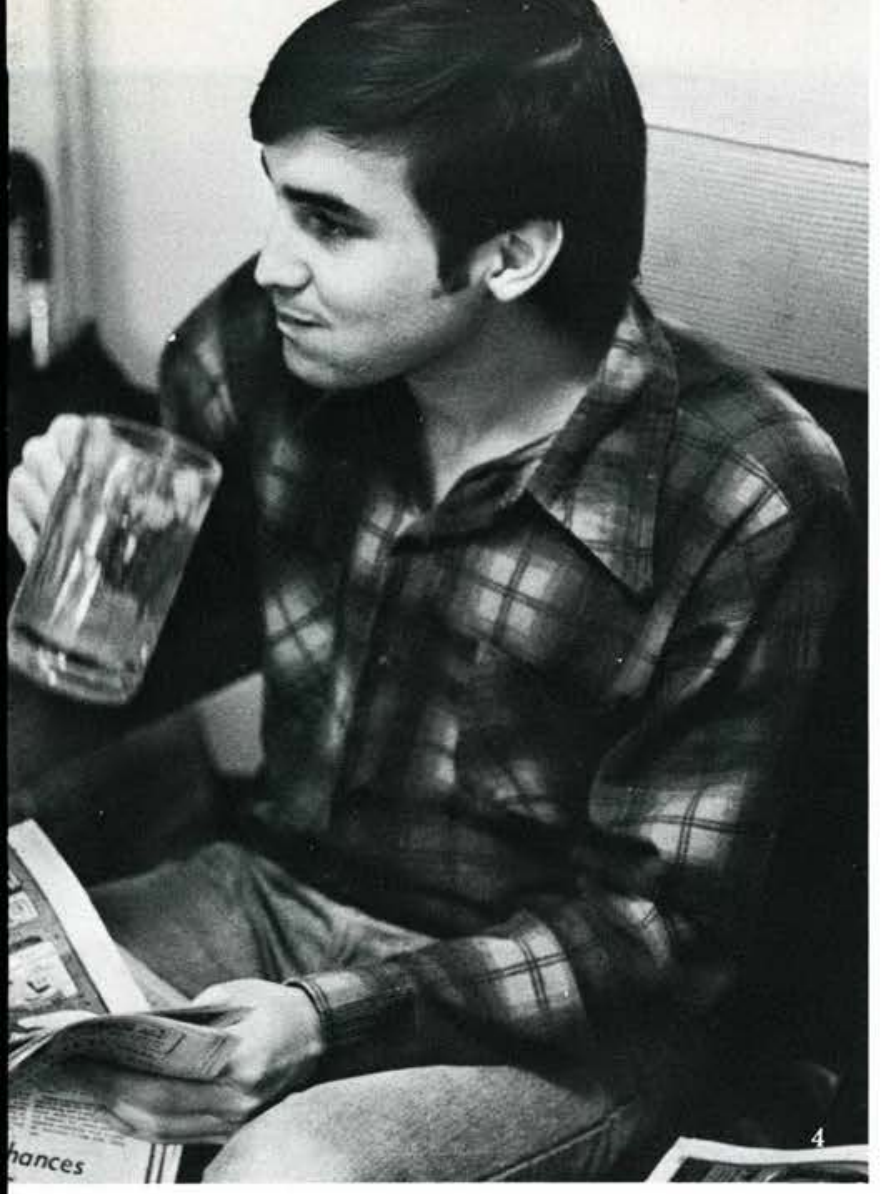

$E$

: 8 a है

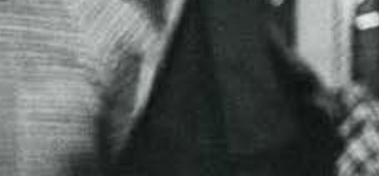

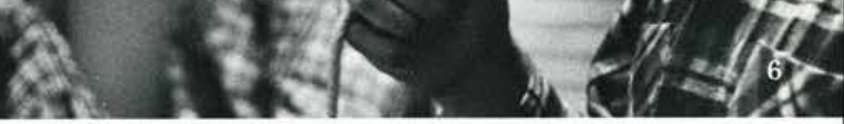
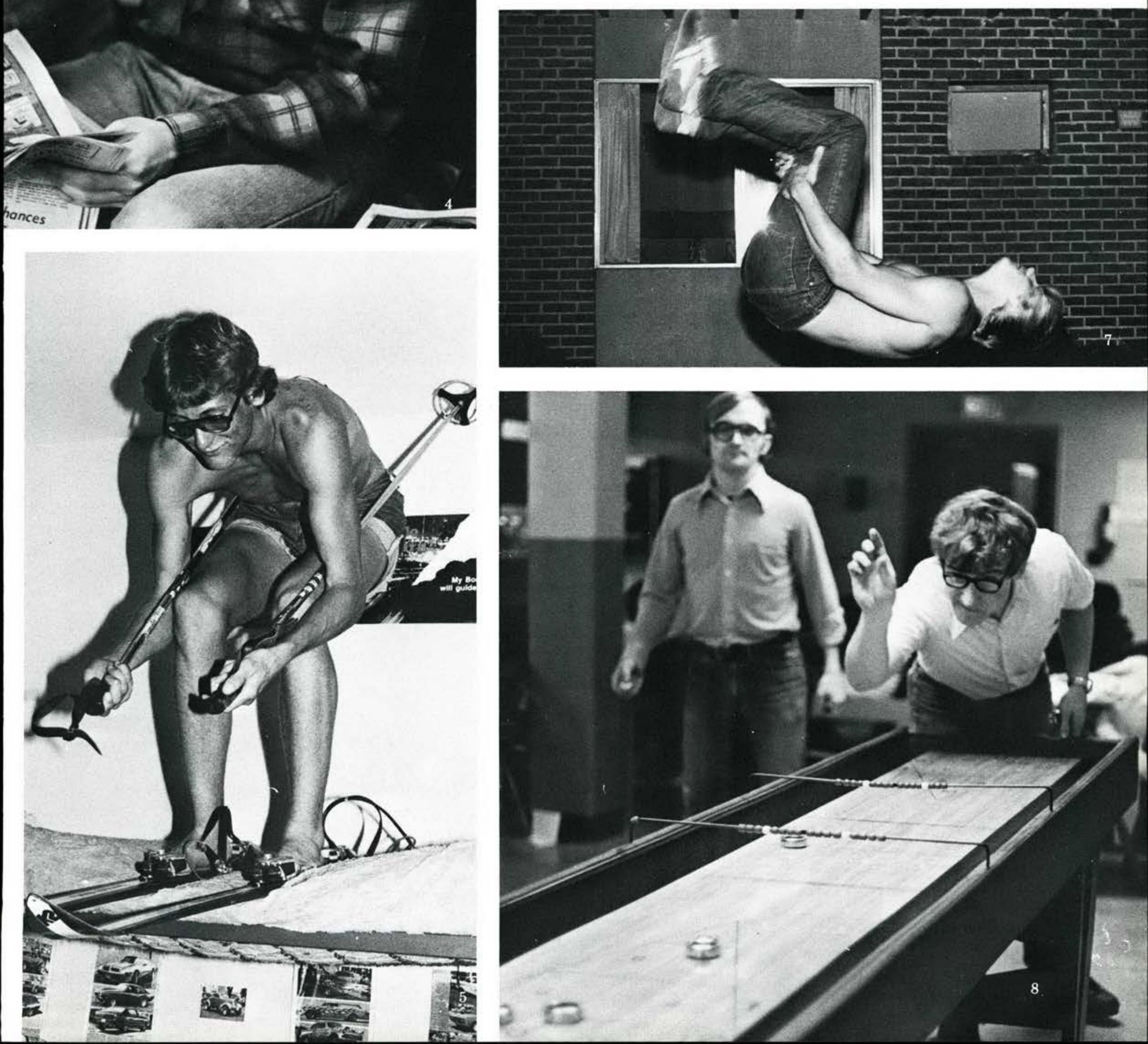


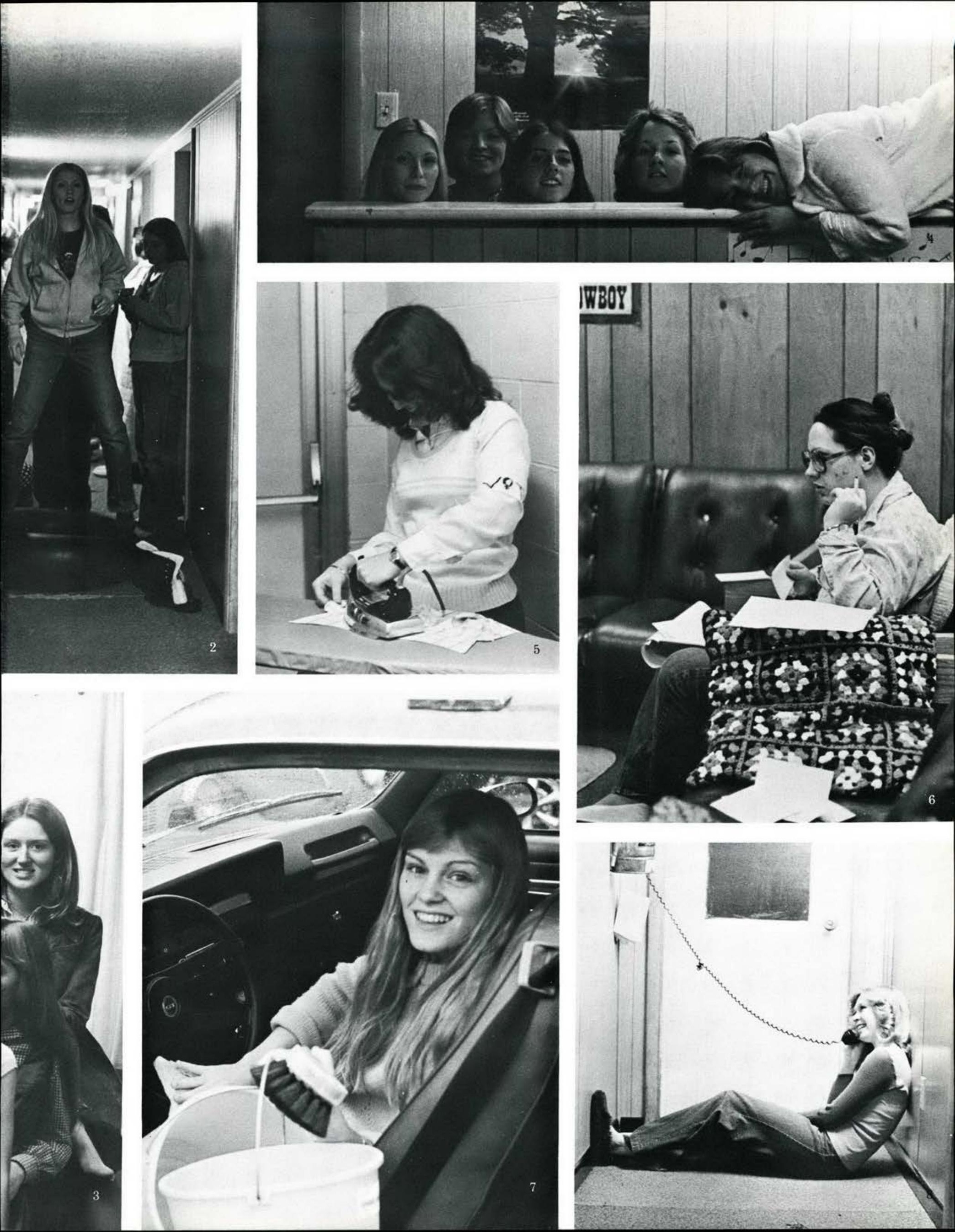




\section{Three Dorms Share Same Resident Adviser}

Rumored by its occupants to have various obnoxious vermin crawling the floors of its dark basement is West Hall - the old white house hidden behind the Science Center. Housing the members of the Alpha Chi Rescue Squad, West Hall consists of two stories, boasting a balcony, kitchen, and garage for the Squad's ambulance. West shares a Resident Adviser with Carr Dorm, located approximately 100 yards to its south. One of the few carpeted dorms on campus, Carr is divided into units with four rooms per unit and two guys per room. Carr is Marshall's identical twin in exterior appearance. Marshall's basement is a recreation room while Carr's is more rooms. Known for the altruism of its residents, Carr also shares the R.A. belonging to itself and West with Palmer Dorm which lies directly behind Carr. Just opened up this year, Palmer is composed of two buildings and a duplex house.

1. It is a fact that Floyd Dallis is engaged but is this his fiancee?

2. Jerry Lantz burns the midnight oil. 3. Jack Caufield exemplifies good study habits.

4. John Andrew appears to have given up his mischieviousness and is resigned to undo what he did - or maybe he was just practicing!

5. Life at West Hall includes lively chats on the way to the ball diamond.

6. West Hall is a testing ground for future homemakers, as Dave Rich and Tim O'Neal demonstrate.

7. Is the flying debris going in or coming out of Mark Streitmatter's mouth?

8. Is Dave Drozeck getting his hair trimmed - or trying to read an eye chart? 


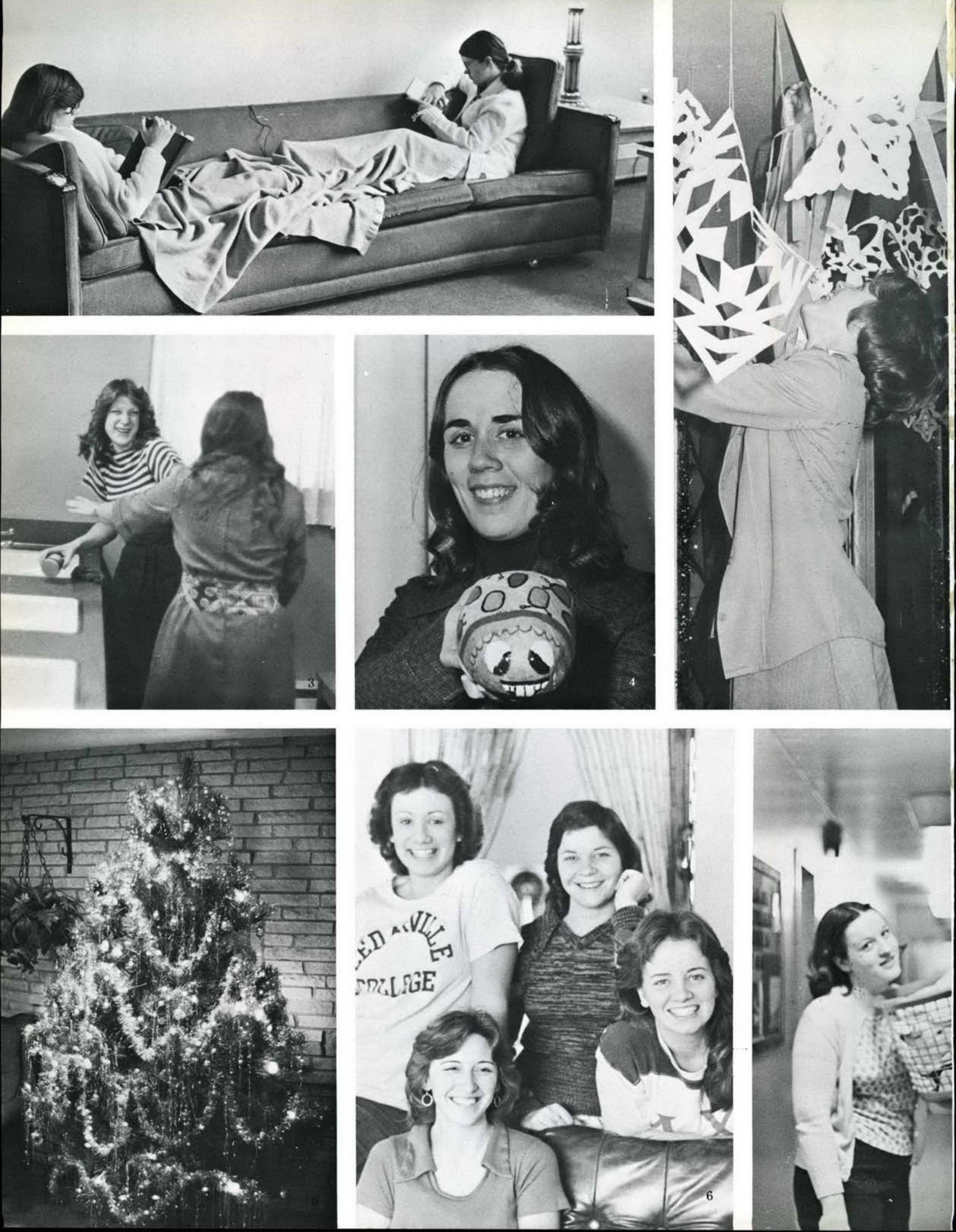




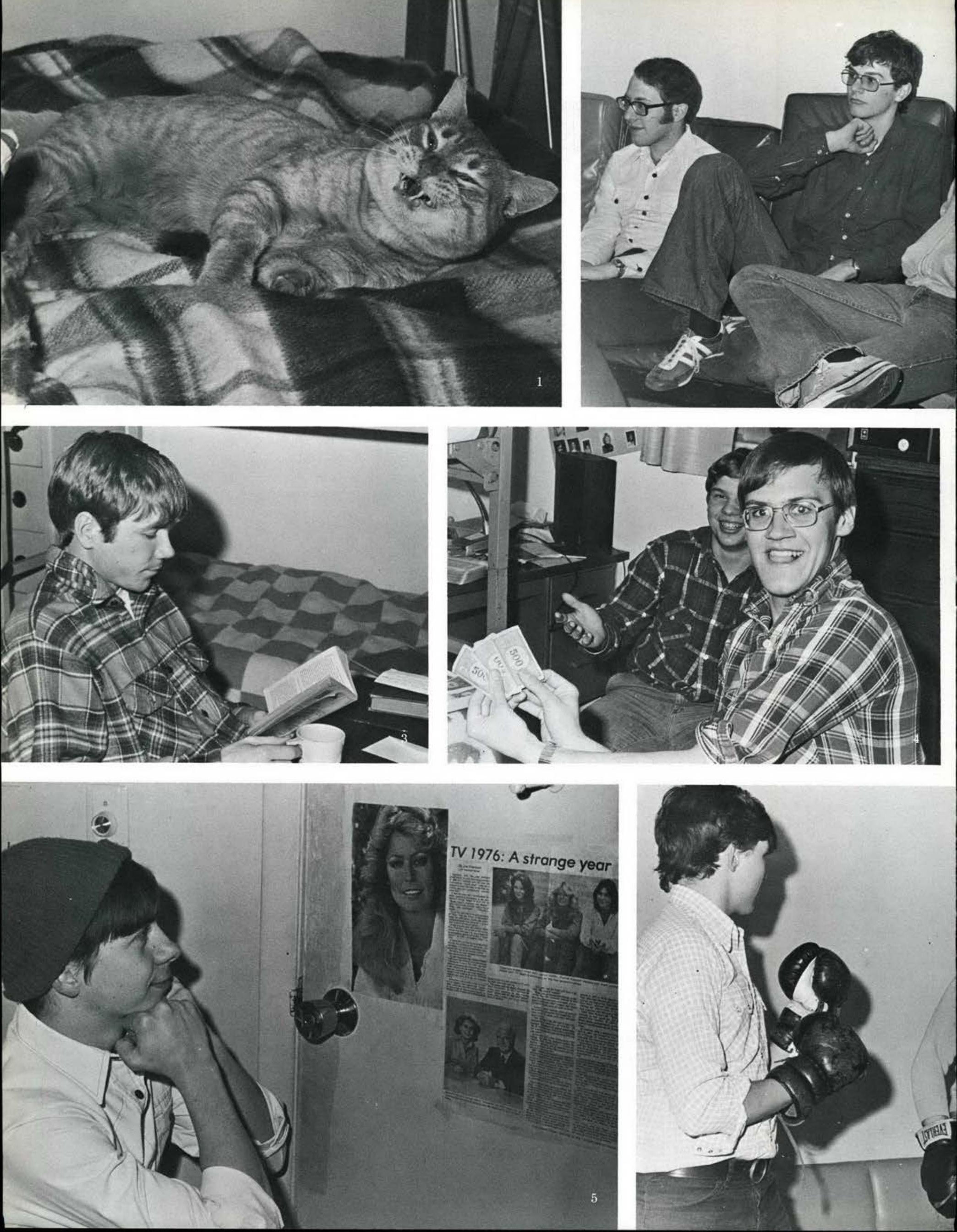




\section{Luxury Living Provided By Three Dorms}

Cedarville's showcases of antiquity, Hartman, Harriman and South, stand tall and stout as they remind the college of yesterday's past. The residents of these houses experience a more homey situation of warmth and closeness than in the dorms. There is a sense of freedom reigning within these three relics because of their exclusion from the college campus. The three noble fossils add to the college's sophistication and heritage.

1. Escaping to the lounge in Harriman, Martha Schneeberger studies for a New Testament test.

2. Kathy Price wonders if there is any resemblance between herself and a snowman friend.

3. Doesn't Karen Webster know that writing papers is no joking matter!

4. A beautician from the Pink Parlor in South Charleston demonstrates hair styling for the eager girls of Hartman, Harriman, and South.

5. Who else but Sally Ott would own Snoopy slippers!?

6. With plunger in hand, Cherie Watts does her impersonation of maintenance.

7. Becky Brown relaxes from studies by strumming her guitar.

8 . Someone very interesting must be at the top of the stairs to attract the attention of the girls at South.

9. Lydia West seems engrossed in Baptist History - it's obviously a posed picture! 10. Carol Williams gets ready for a big date. 11. Charlotte Olson shows off her new play toy.
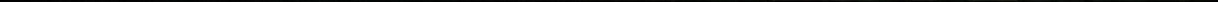


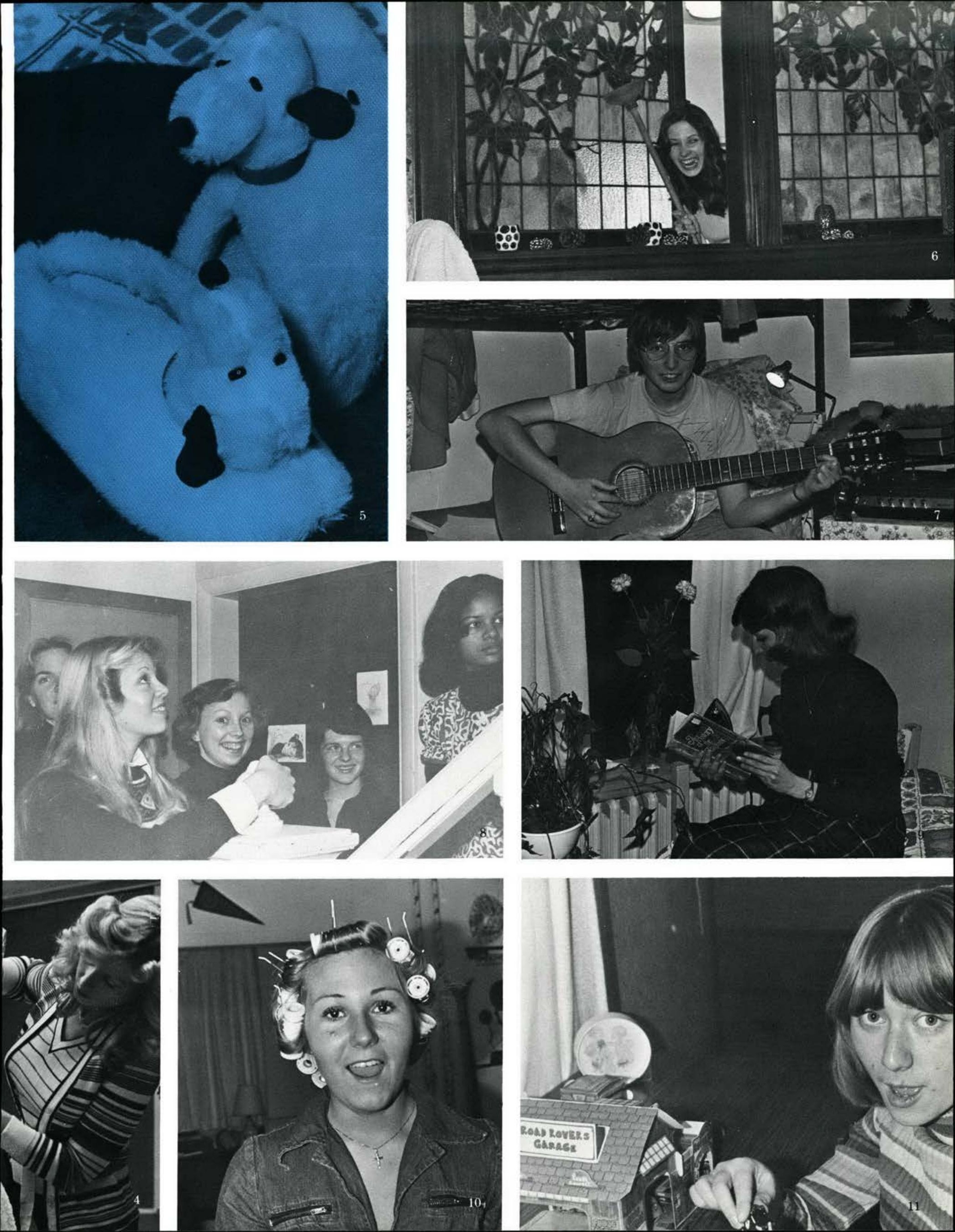




\section{The Cold Drives Them Inside}

The wind whips persistently, causing huge snow drifts to block roads and sidewalks. Temperature records are broken by the freezing weather that hits Cedarville. Campused students seek refuge from the cold and relief from their bleak attitudes. With energy consumption advised at a bare minimum, students gather en masse at the Student Gymnasium Center for recreation. Many others are found taking advantage of their plight by using their time wisely, in study.

Spirits ebb, but perservere, with the hope "it can't last forever!" In the back of everyone's mind are thoughts of ... SPRING!!

1. Janice Croy spends the long winter day looking up terminology for use in her research paper.

2. If only Joel Hunter's mother could see his new bonnet!

3. A game of tiddlywinks is enjoyed by Keith Glassey and Debbie Gierhart.

4. What would you rate this hand?

5. Craig Stephens seems about to accept her proposal!

6. Dianne Muirhead and Fred Laxton relax in the Marshall basement.

7. During the cold weather much time is spent inside playing rook, as Mark Keough, Dan Hicks, Darlene Repp, and Dan Self demonstrate.

8. Is Dale Mattox as deeply engrossed in his studies as he appears to be?

9. With their radiant smiles Janet Bubel and Janet Van Ryn add a little sunshine to the bleak winter.

10. There's always time for good fellowship and songs, especially in the dead of winter.
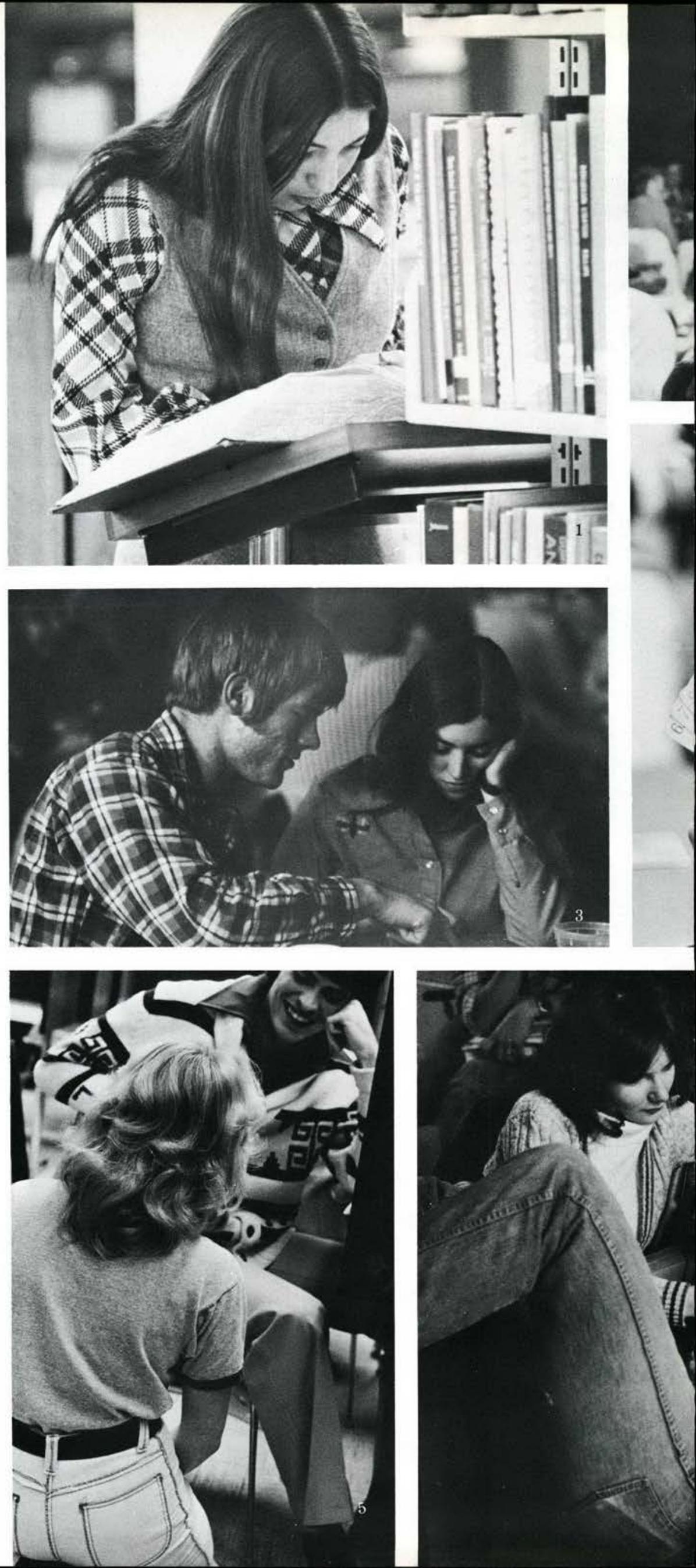

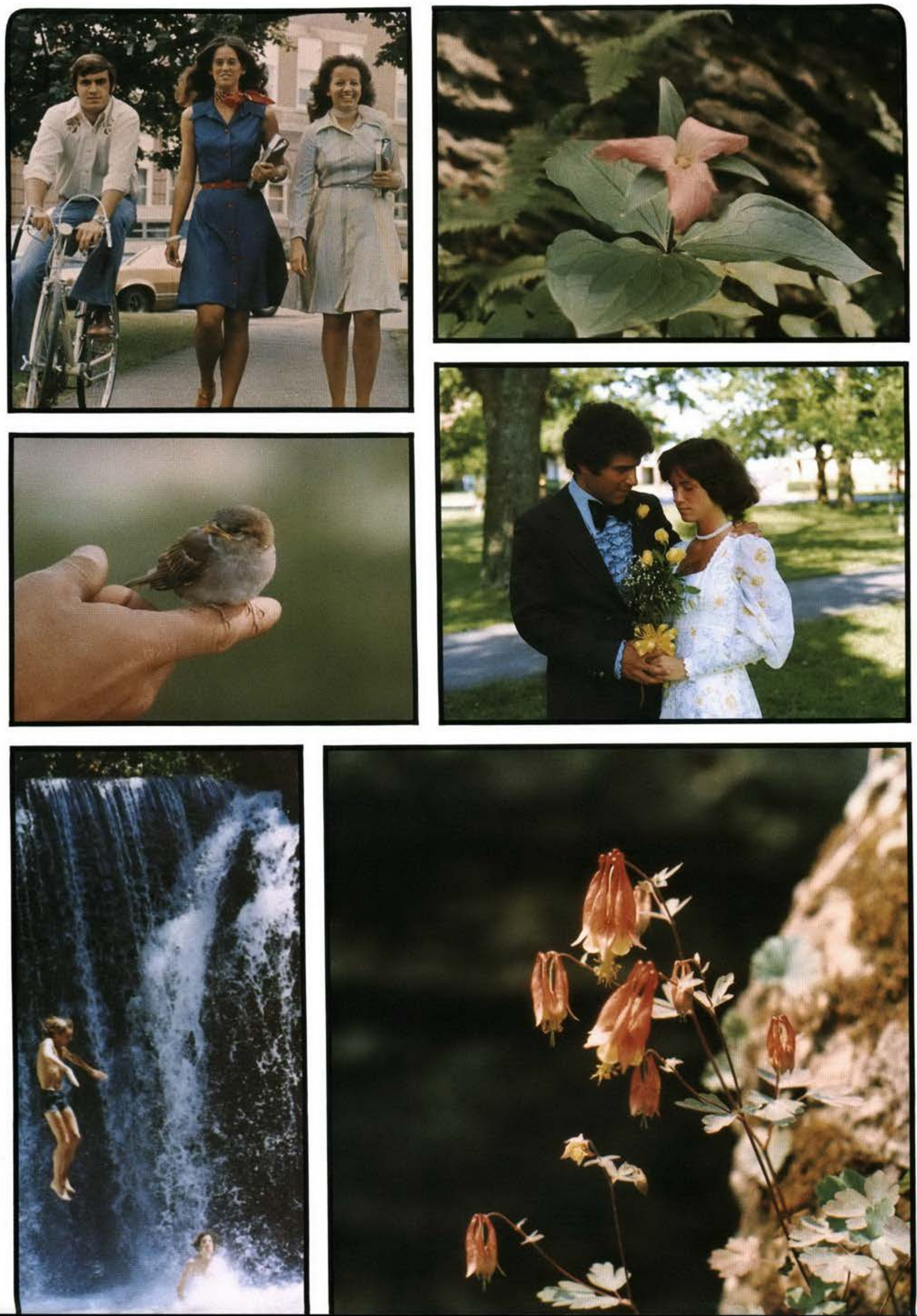


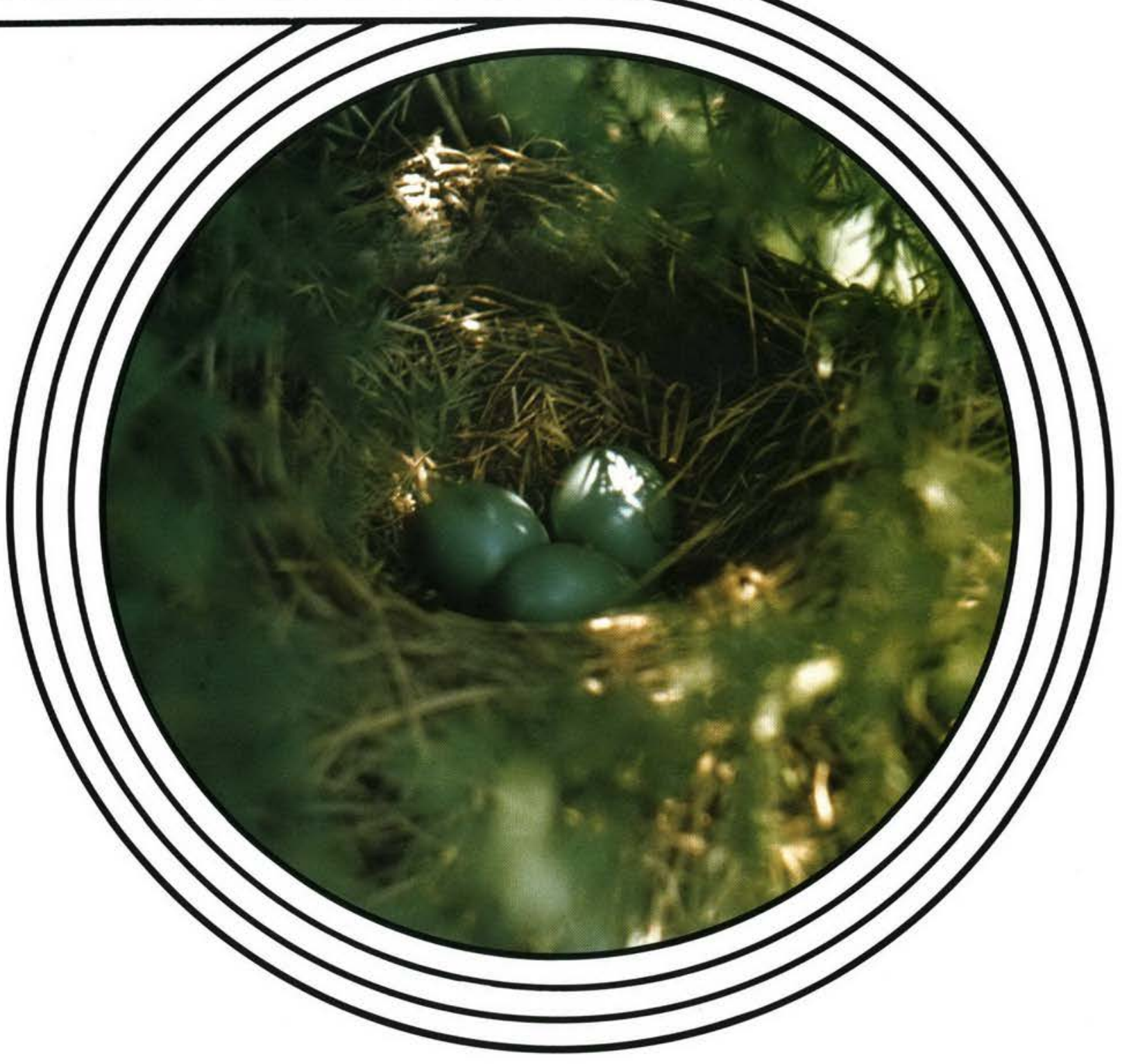

SPRJNG 


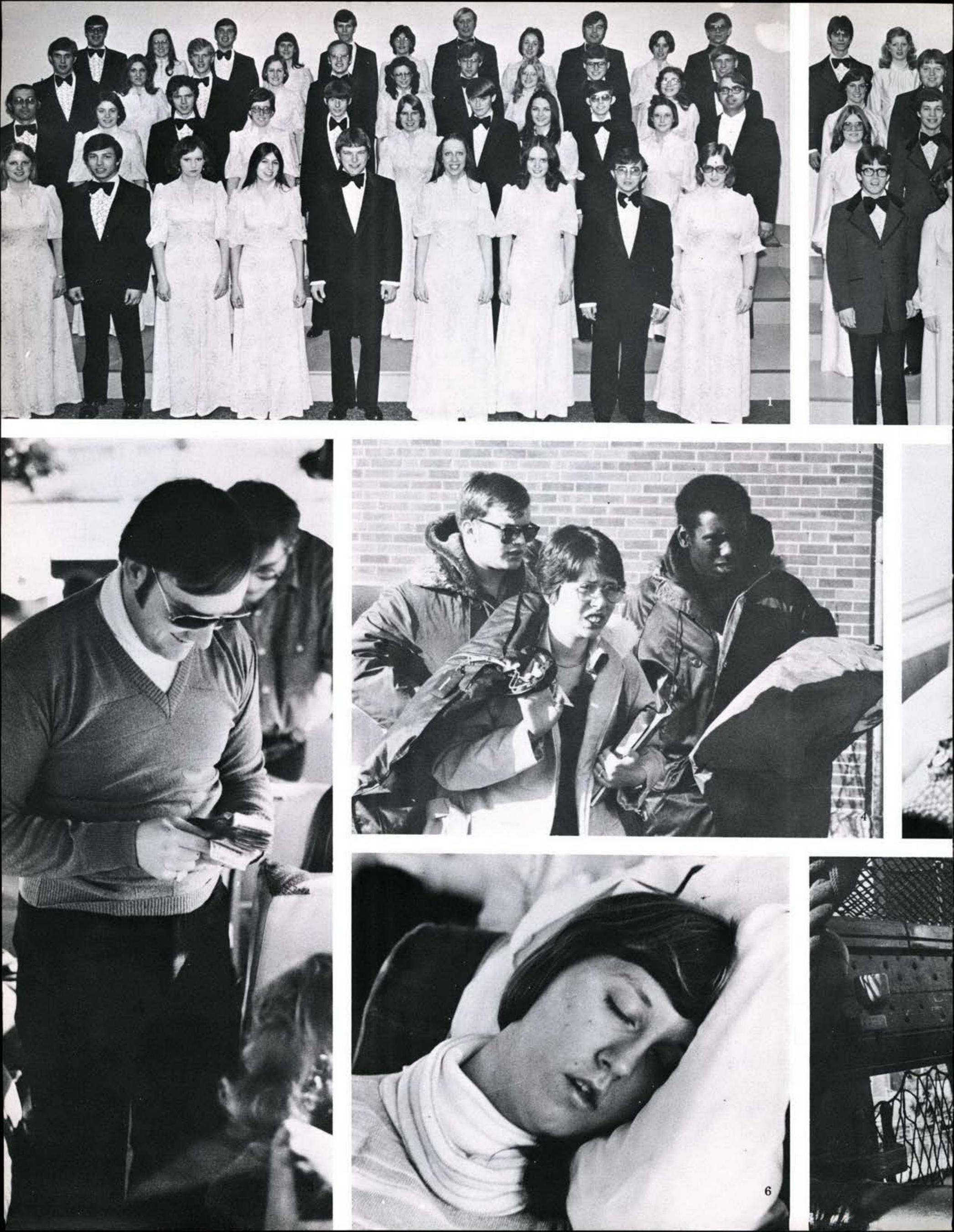



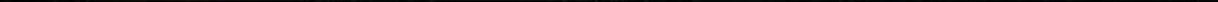

Music

\section{Groups Keep Busy}

"Active" certainly describes this year's Concert Choir and Choralaires. Spring break, finds Concert Choir, under the leadership of Director David Matson, travelling southward, eventually hitting sunny Florida. The Choralaires and leader Lyle Anderson head northward to cold New England, where they, for a day, find themselves snowbound. Travelling for the groups is not restricted to spring break - many weekends in both winter and spring quarters are spent in musical ministry with churches throughout the MidWest.

1. Concert Choir, BACK ROW: D. Ellis, S. Perry, R. Douglass, D. DeNicola, M. Cowell, K. Lapp, B. Rogers, J. Riter, R. Wagner, D. Spencer, L. Avery; THIRD ROW: M. Warren, D. Reid, D. Betts, C. Phillips, D. Carroll, S. Jenkins, M. Sigmon, K. Seymour, D. Hicks, P. Reynolds, A. Webber; SECOND ROW: P. Kauffman, B. Adams, D. Abbott, C. Whitestine, J. Neely, G. Ward, D. Gregory, D. Wetzel, K. Woods, L. Stauffer, Director David Matson; FIRST ROW: P. Gardner, E. England, D. Curtis, B. Harrison, D. Wagner, J. Surso, C. Porter, D.

Wickman, K. Faull.

2. Choralaires, BACK ROW: J. Kobalka, D. Elmore, C. Miller, L. DeYoung, J. Mohler, D. Storch, J. Raber, S. Levin, D. Ellington, R. Eaton, D. Parvin; THIRD ROW: D. Jones, B. Hayes, K. Jones, B. Miller, S. Browne, C. Hulsman, C. McLane, D. Grooms, R. Kinkle; SECOND ROW: N. Unroe, P. Miller, B. Selden, M. Horne, G.

Howe, C. Huffman, J. Willetts, B. Foreman, C. Sprunger; FIRST ROW: D. McMurray, M. McClure, K. McMurray, G. Nicholl, C. Salzman, F. Grahl, Director Lyle Anderson. 3. Choralaire director Anderson distributes everyone's favorite - money.

4. Choralaires Dewayne Grooms, Rosalie Eaton, Bob Foreman arrive wearily at another concert stop.

5. Lyn Stauffer and Mark Cowell share an "intimate" moment on the bus.

6. Diane DeNicola knows how to make the most of her travelling time.

7. On their spring tour, Marilyn Horne defiantly claims the U.S.S. Constitution for her group. 


\section{Beach Is The Setting For Evangelism}

Ft. Lauderdale is the ideal destination for college students over spring break - fun and sun being their main goal. But thirty students from Cedarville College, along with Pastor Green, head for the southlands with a different goal in mind - that of sharing their faith with other college kids. This year's Beach Evangelism Team works with two churches, Grace Baptist of Ft. Lauderdale, and Westgate Baptist of Plantation. They sing in these churches on the weekends, and witness at the beach during the week. The team also is in charge of two youth rallies. Several promising contacts are made during the week. The team not only develops a unity among its members, but grows in the Lord as they learn to trust in Him.

1. Members of the team minister in a church service.

2. Sheik Steve Poling and a beacher talk before the breakers.

3. Taking time out, Jim Jamison reads from his Bible.

4. Ocean surf breaks on the ragged rocks near shore.

5. Pastor Green involuntarily takes a flying dunk.

6. Finding a seat on the beach, Bruce, Steve and a sunner chat.

7. Beach Evangelism: BACK ROW: S. Poling, S. Isaacs, D. Reidel, S. Browne, C. Zelonis, J. Jamison, M. Shaw, R. Yoder; SECOND ROW: J. Smith, B. Keizer, D. Cobb, S. Hoy, R. Smith, L. Gilliland, H. Vassari, M. Humbart, N. Reu, T. Rowland, G. Bushong, D. Dunn, D. Radcliffe, M. Cuffman, Pastor Green; FRONT ROW: L. Stuenzi, J. Erickson, K. Anderson, L. West, L. Terlouw, M. Harris.

8. Unable to resist studies, Bruce Keizer sits beneath a palm tree reading a book.
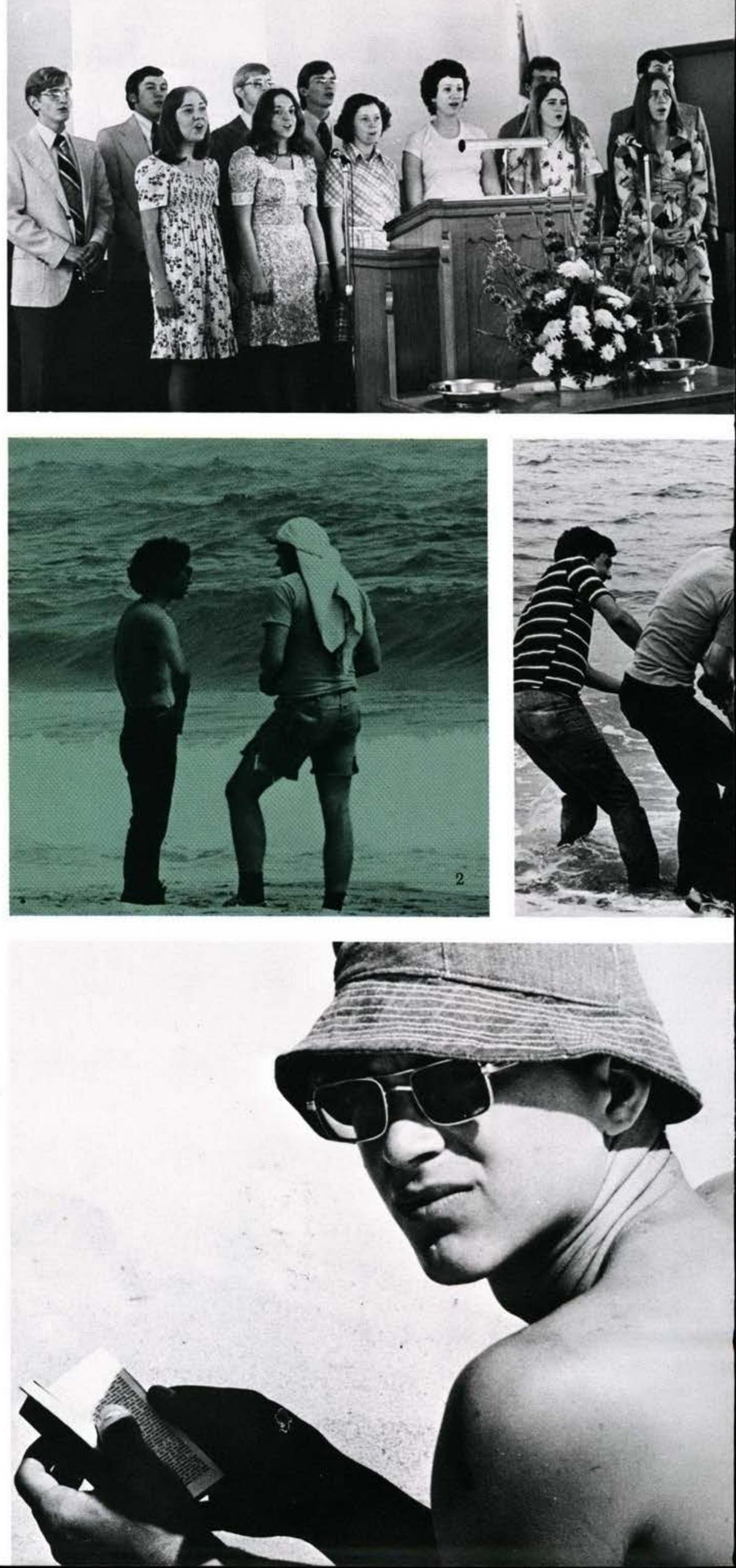

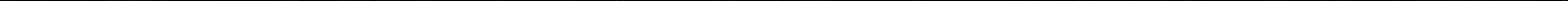


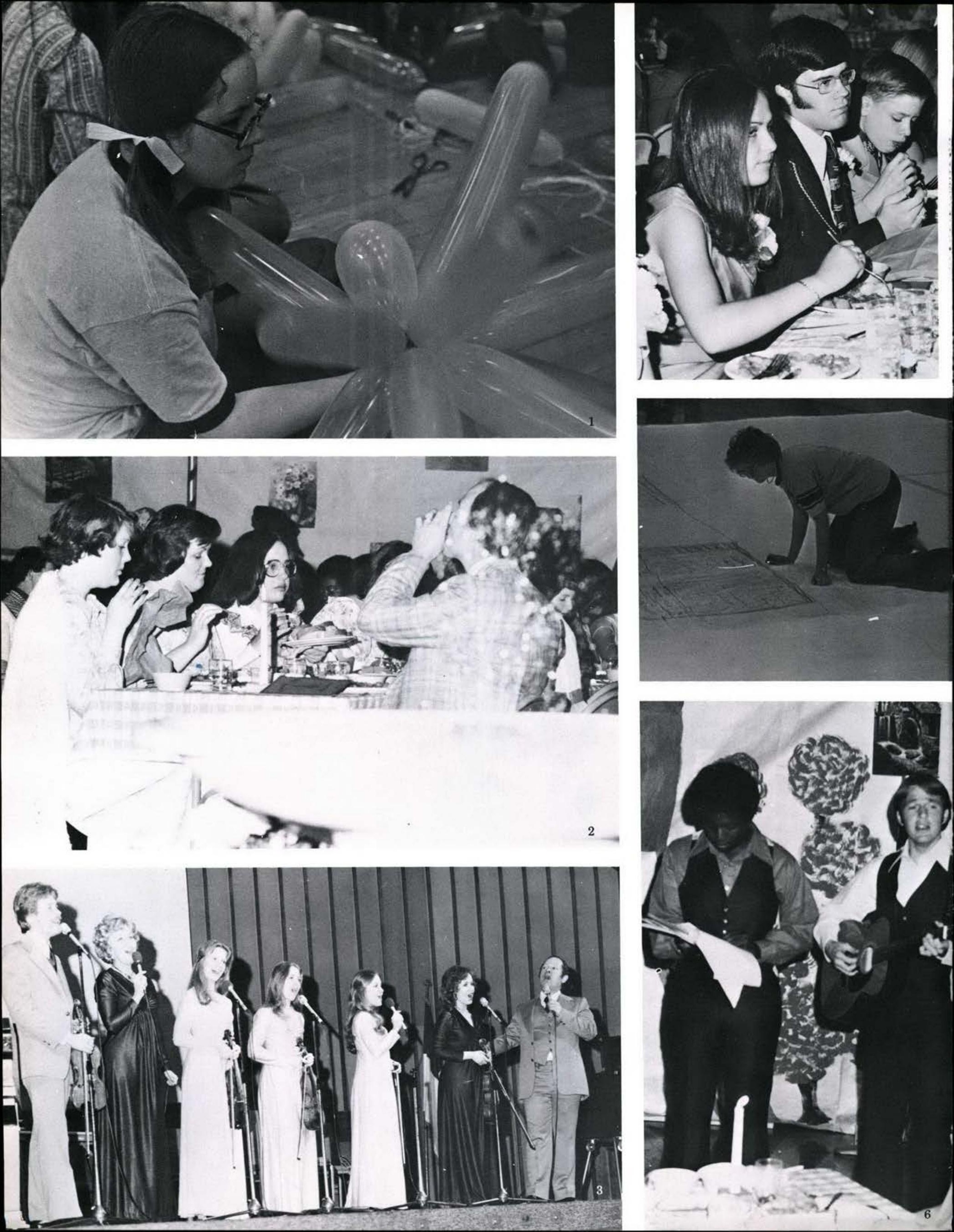




\section{Charlie Brown Visits Cedarville}

MENC gives a thoroughly entertaining musical in the spring. Tim Pasma, Lou Ann DeYoung, Byron Major, John Mohler, Ron Bigelow, and Lila Terlouw star in Charles Schultz's "You're A Good Man, Charlie Brown." The musical is directed by Rich Luedeke. The performance recaptures memories from every student's childhood.

1. Fear grips Charlie Brown as he notices the little red-haired girl looking his way. 2. Patty and Lucy come face to face with vampire Linus.

3. Snoopy and Patty engage in an early morning rabbit hunt.

4. There is nothing more special than first love - Lucy for Schroeder and Schroeder for Beethoven.

5. Sometimes a brother's consoling shoulder becomes a necessity.

6. The World War I Flying Ace scans the sky in search of the Red Baron.

7. The crowd-and Snoopy-pleaser has to be "Suppertime".

8. Lucy polls Charlie Brown on her crabbiness quotient as Snoopy obviously displays his response.

9. Charlie Brown unburdens his problems to a caring, concerned Lucy. 


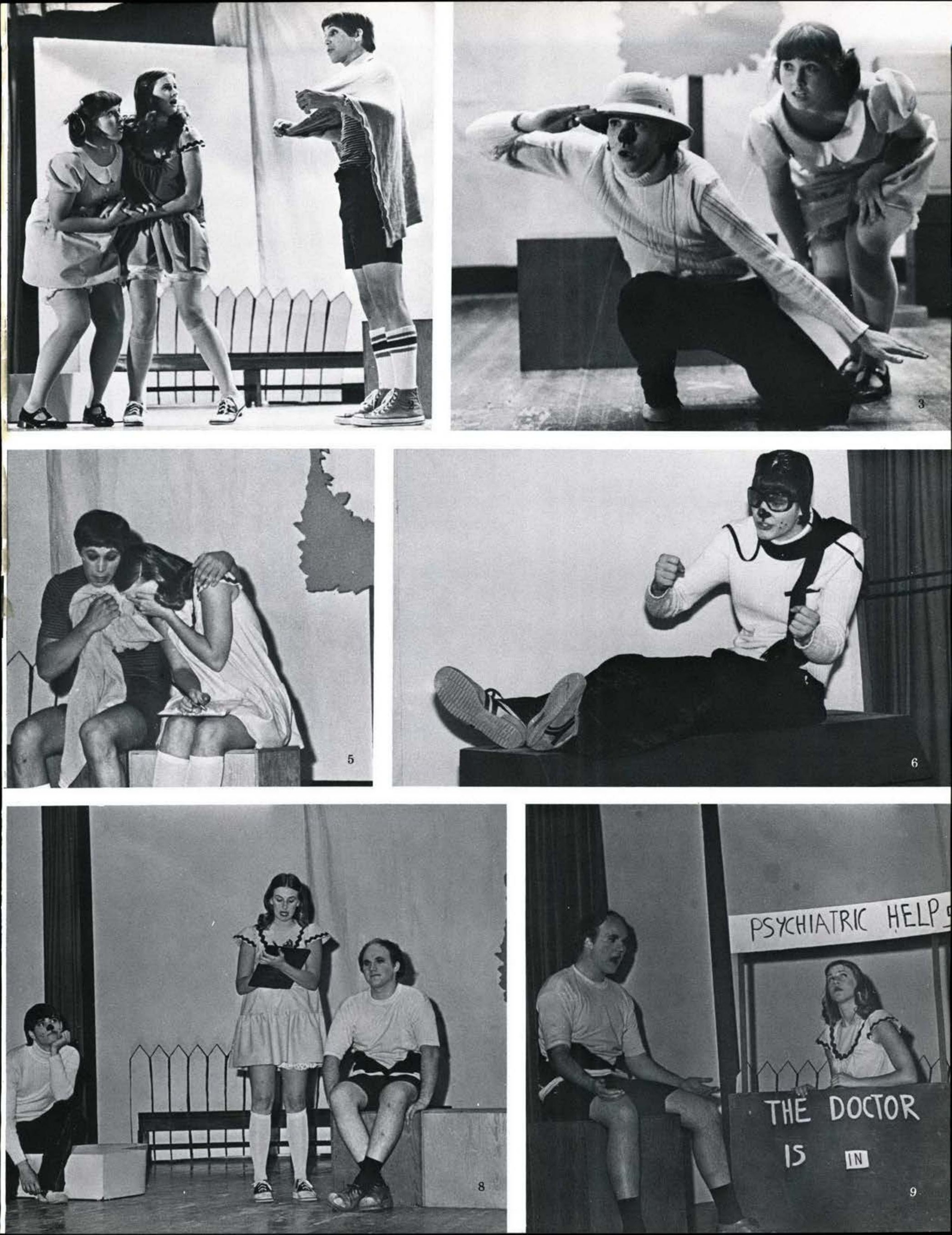




\section{Work-A-Thon Draws Student Participation}

Student Senate is a governmental body composed of elected members from either a class or an organization. Each participant is involved in helping the college to function properly. Their responsibilities range from organizing major events held on campus, such as Homecoming, to handing out student loans and grants. The Senate is the acting go-beteen for the students and the Administration. The biggest project undertaken by the whole student body this year is the Work-A-Thon, organized by Student Body Project. May 4 is the day in which Cedarville College students work in the city park, the Cedar Cliff High School football field, the Indian Mound, and other areas in the town and on campus. The project has a twofold purpose: to show concern for and interest in the surrounding community of $\mathrm{Ce}$ darville, and to raise money for the new chapel organ.

1. The chipping paint on Bethel Hall is a project for students in the Work-A-Thon. 2. Debris is removed from the wooded areas adjacent to Cedarville.

3. Dawn Shumaker plants marigolds to beautify the walkways.

4. A lonely wheelbarrel waits to be filled. 5. Student Body Project Committee: BACK ROW: M. Kessel, T. Bos, B. Heagy, P. Miller, J. Veldt, J. Gehrke, D. Scott, D. Blackburn; SECOND ROW: D. Zaller, C. Hammond, J. Vogel; FRONT ROW: J. Graham, C. Jacobs, D. Jansen, R. Moore.

6. Cedarville College students "fetch the stick" from the river.

7. A mask is needed to sweep the heavily dusted attic in the old opera house.

8. Student Senate: BACK ROW: D. Wickman, B. Keizer, B. Henslin, S. Bahorik, S. Anderson, C. Miller, S. Scoggins, C. Douglass, R. Harley, B. Abernathy, M. Jackson; SECOND ROW: K. Amstutz, B. Heagy, L. Hanson, S. Poling, M. Sigmon, M. Seeley, V. Cline, J. Kiser, D. Thomas; FRONT ROW: C. May, M. Biggs, C. Radcliff, Dean Rickard, D. Dixon, B. Reid, D. Zaller.
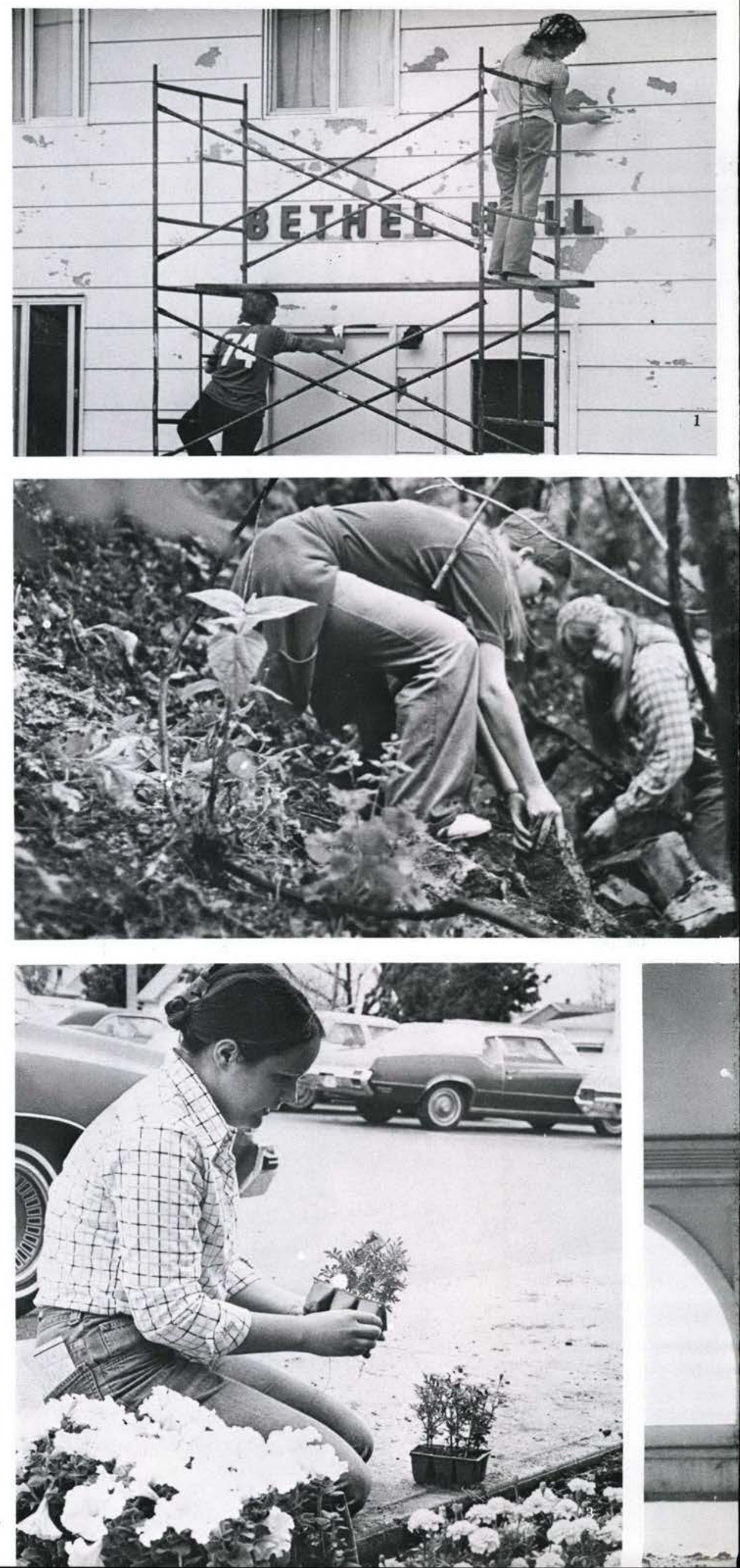


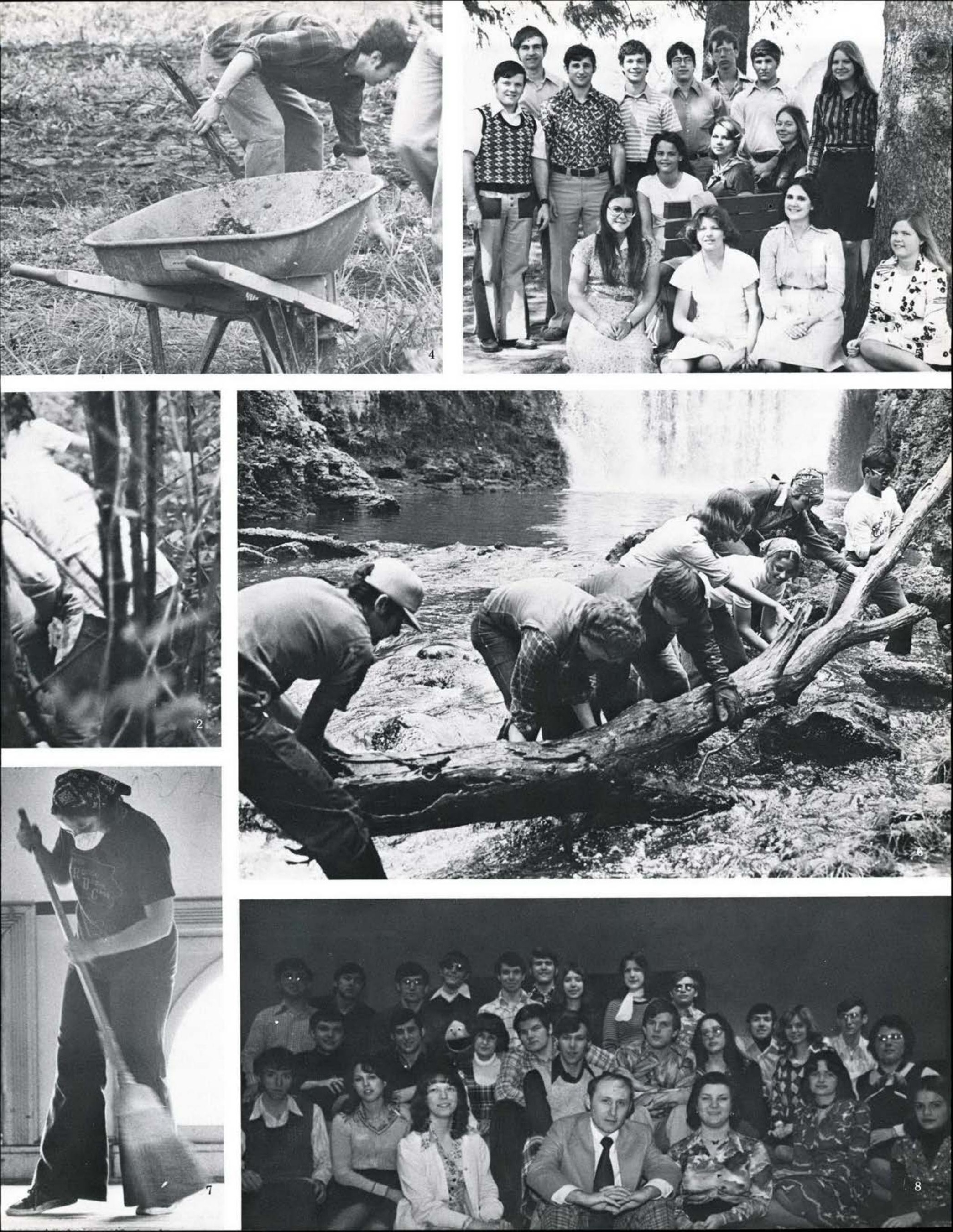



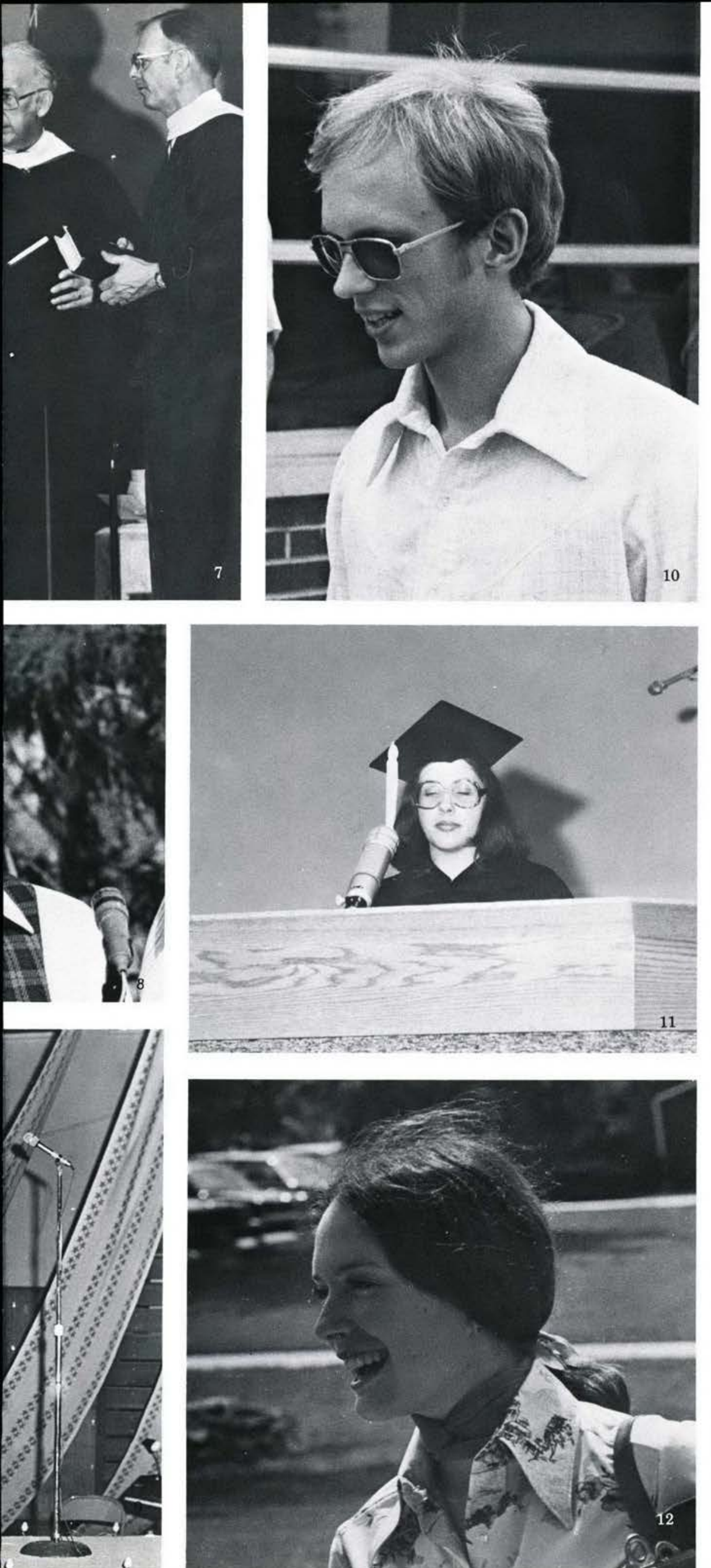
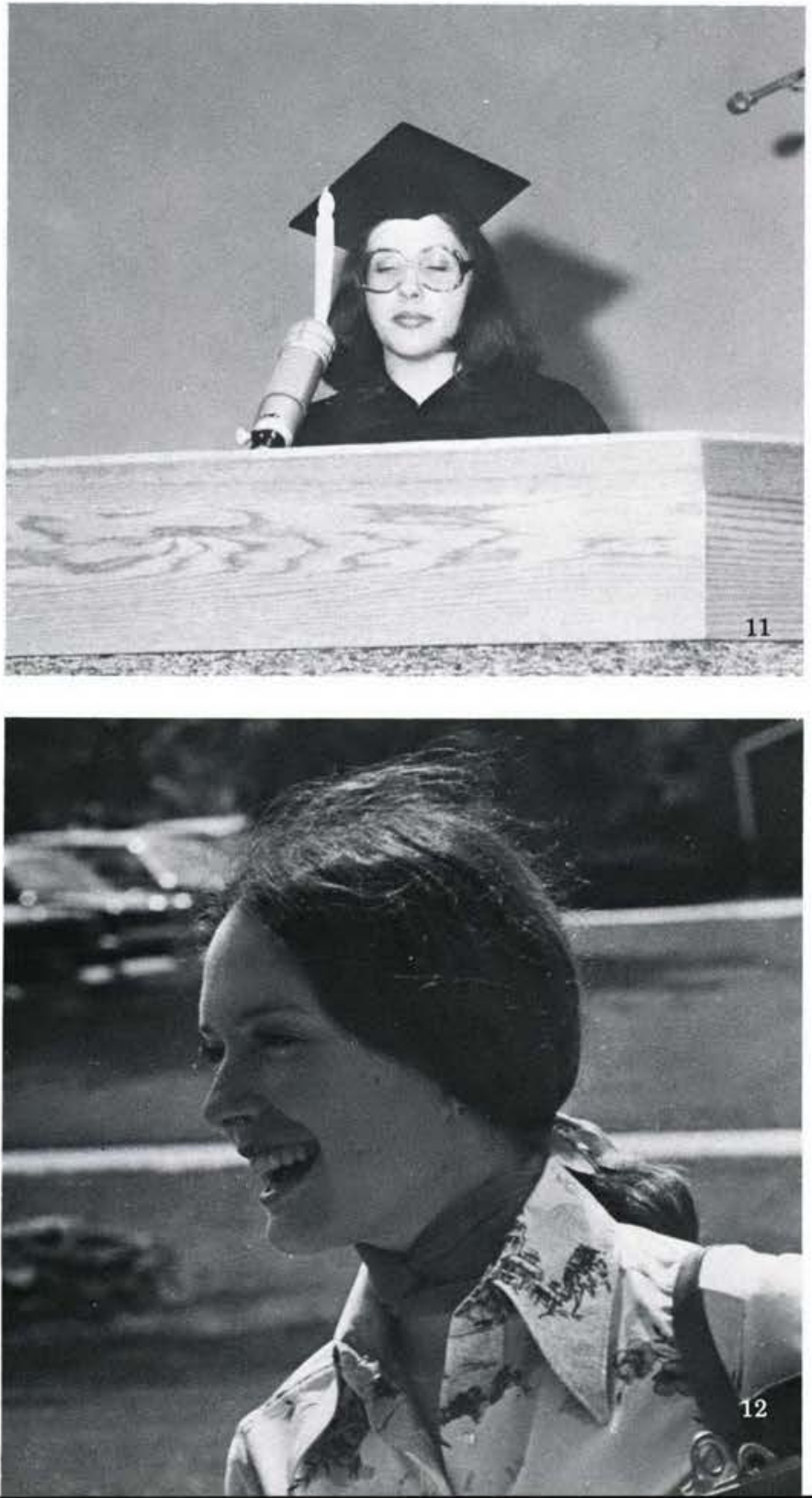

\section{Students}

\section{Selected For Honors}

On May 6 Honor's Day recognizes students who excell academically. The 1977 program is different from former years in that the emphasis is placed on the spiritual aspect of academics. The service includes music and special speakers. Students on the Dean's List and the Dean's Honor List are noted as a group. Awards are given to faculty members and students during other chapel services.

Twenty-three students from Cedarville College are honored by Who's Who in American Colleges for the 1977-78 year.

1. Wynn Gerber, SR

Business Administration

2. Kent Amstutz, JR

Biology

3. Don Hare, SR

Pre-Seminary

Penny Linger, SR

Elementary Education

4. Helen Vassari, SR

Business

5. Wes Johnson, SR

Pre-Seminary/Bible

6. Tim Hager, SR

Social Science

(Salutatorian)

7. Honor's Day speakers include Dr. James T. Jeremiah, Dr. Clifford W.

Johnson, and guest speaker, Dr. W.

Wilbert Welch, President of Grand

Rapids Baptist College and Seminary.

8. Doug Wing, SR

Math

9. Bruce Keizer, SR

Pre-Seminary/History

10. Ed DeLange, JR

Biology

11. Vicki Cline, SR

History/Pol. Sci./IDS

(Valedictorian)

12. Cindi Porter, SR

Psychology 


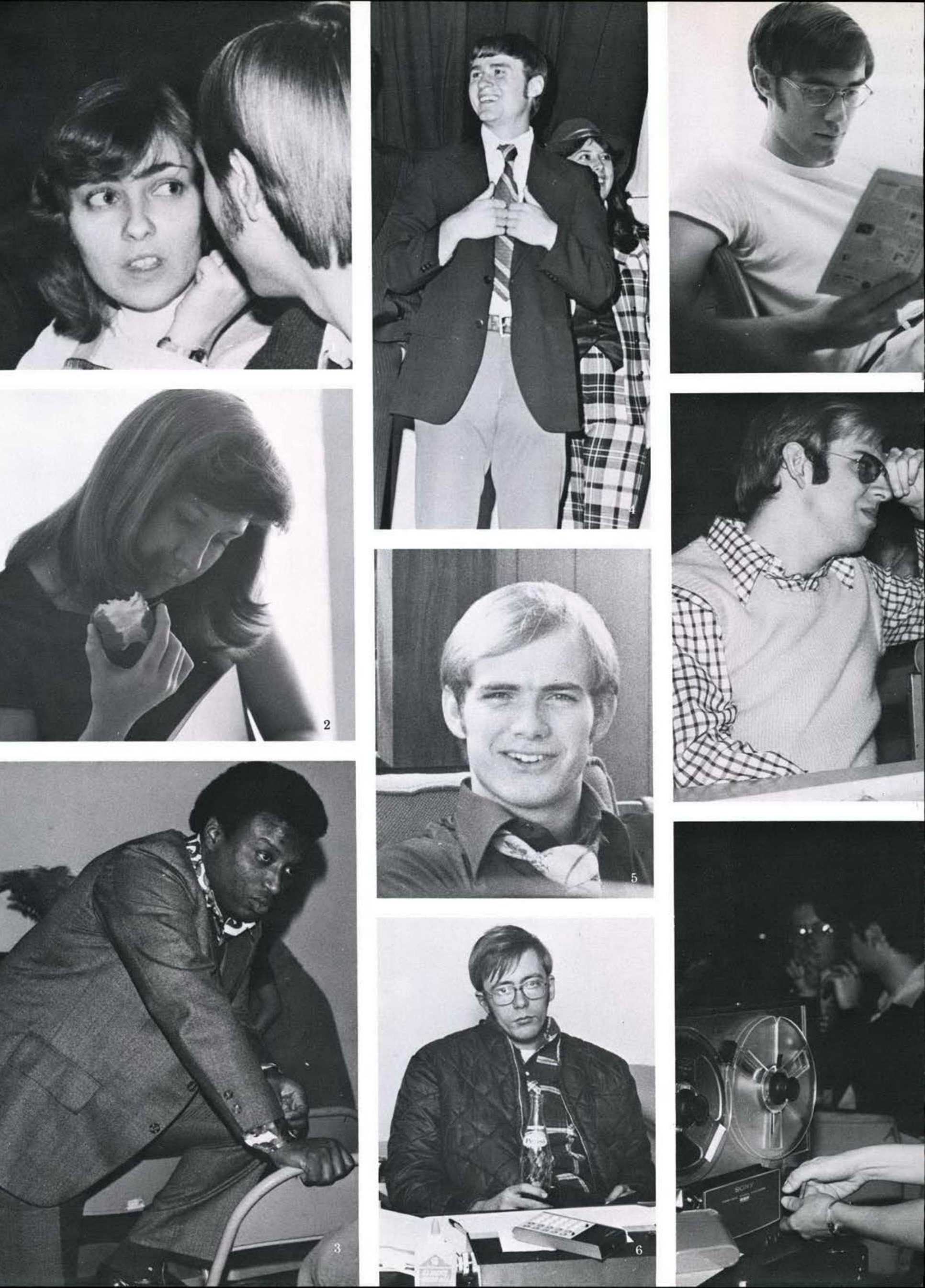




\section{Cedar Day Ushers In Springtime}

The men of Alpha Chi help to make spring an even more exciting time of year by celebrating Cedar Day. Cedar Day as well as the entire weekend is a tradition from the early days of the college. More importantly Cedar Weekend affords a special opportunity for prospective students to learn in a unique way what Cedarville has to offer. The sublime (artist-lecture series, College Choir concert, challenging sports events) as well as the ridiculous (road rallies, raft races, relay races) are all a part of Cedar weekend.

Cedar Weekend is indeed a festive occasion as well as a homecoming. It's a great way to start and enjoy springtime in Cedarville.

1. Charlotte Olson and Nate Rehn give thanks before they indulge in Cedar Day's picnic.

2. Cedar Day usually brings out a variety of lake creatures!

3. The candy apples are too inviting for Keith Willhite.

4. Any resemblance to a Chinese rickshaw is purely coincidental!

5. An old tire provides entertainment for these two Cedarville lads.

6. Canoe races are the highlight of the day for water lovers.

7. One of the survivors makes it to shore.

8. This ship is about to lose her crew!
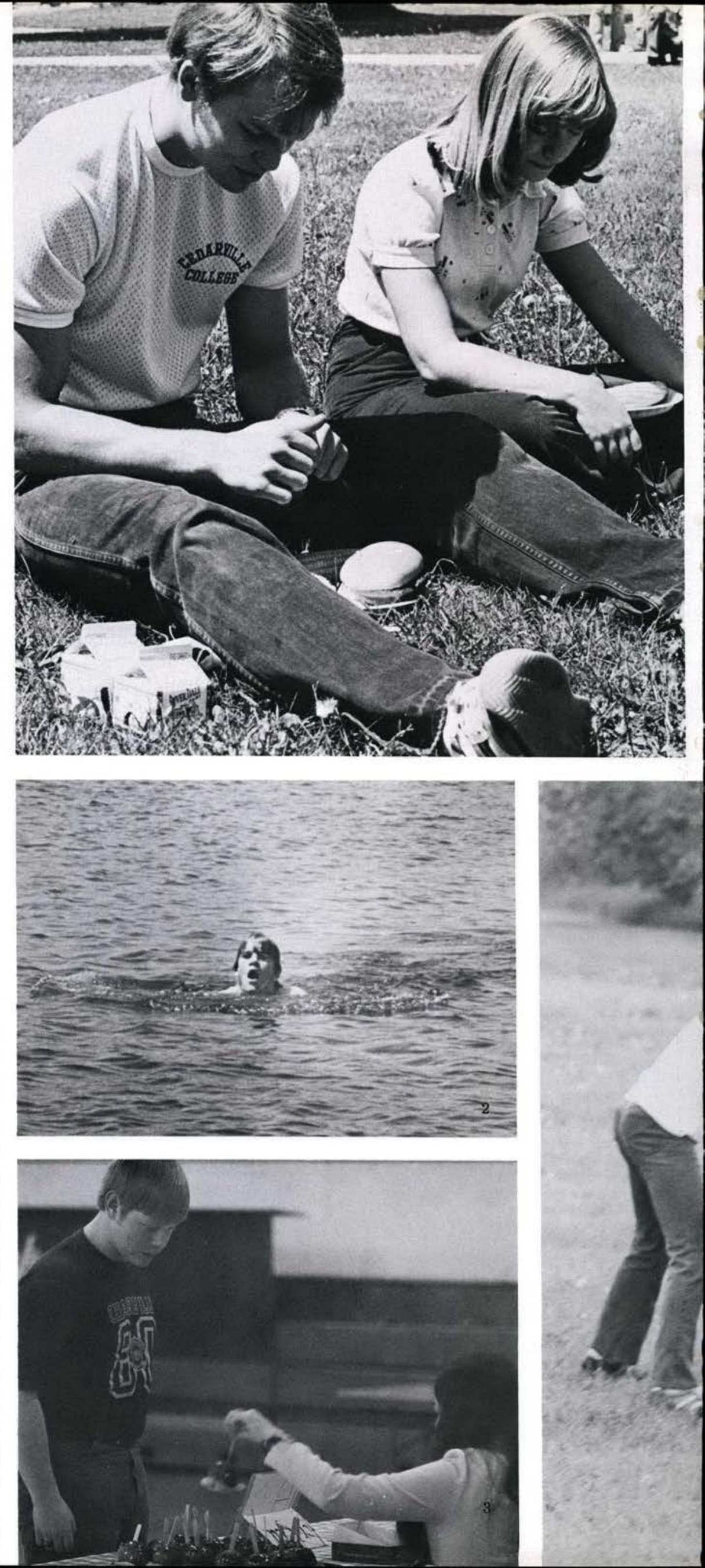


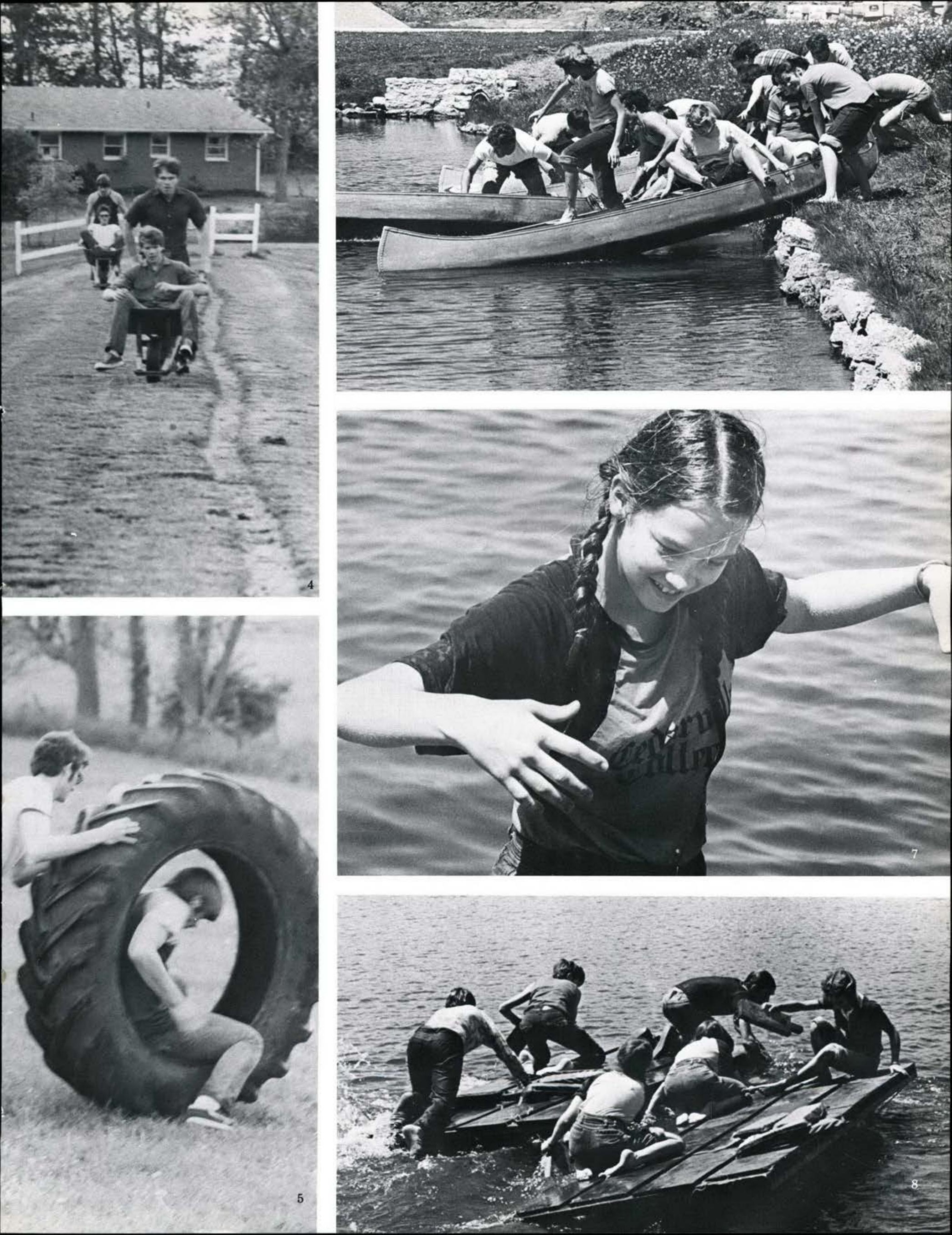



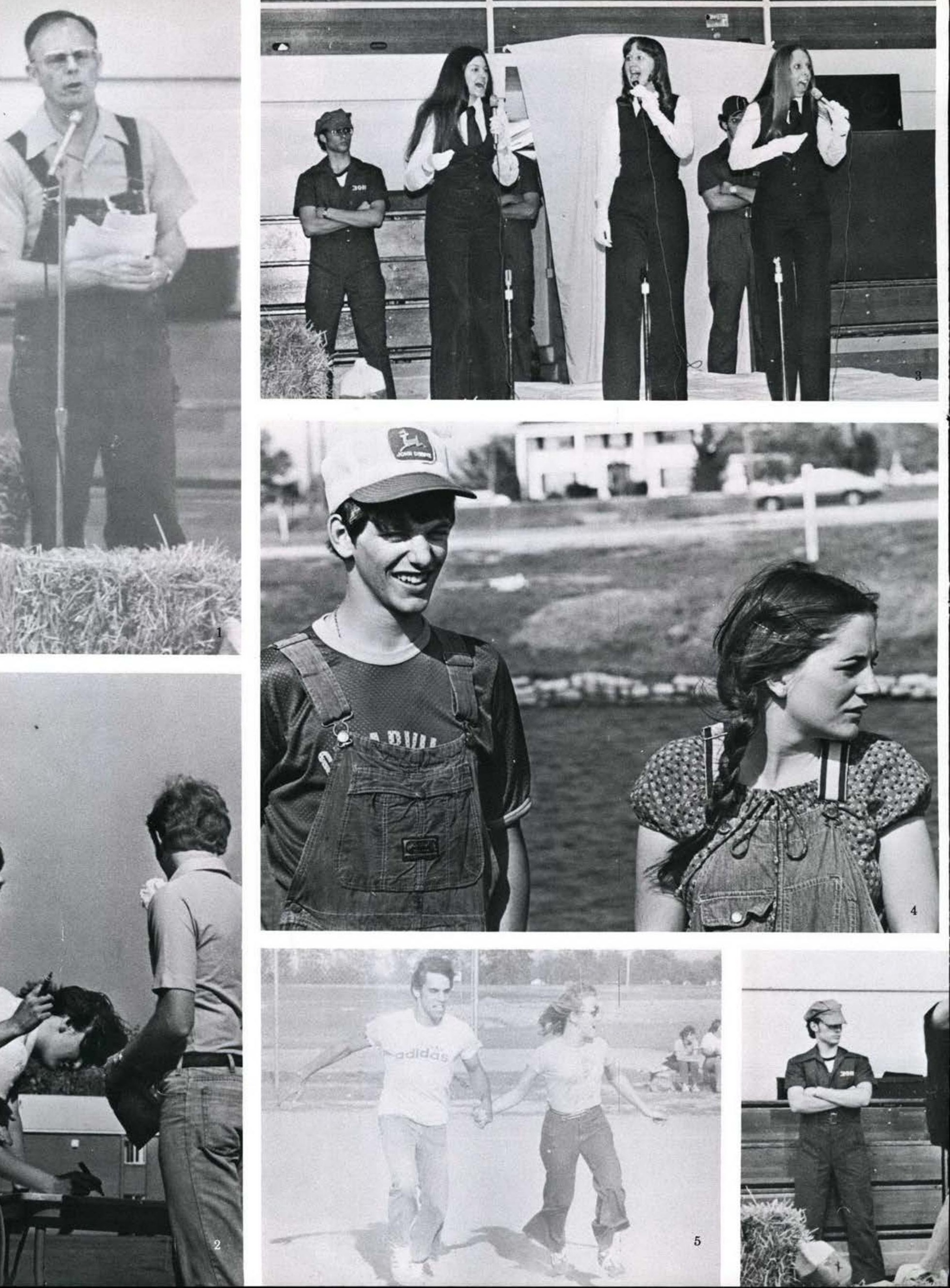

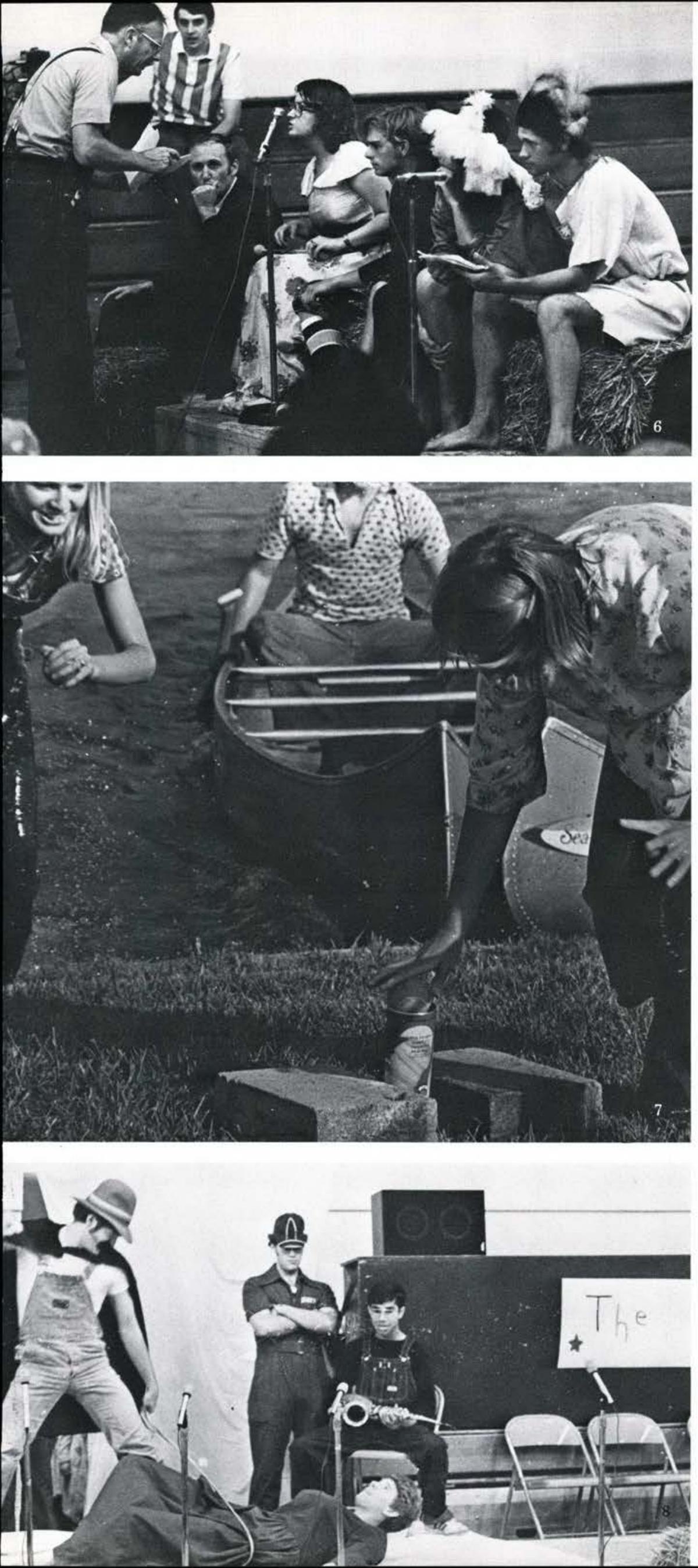

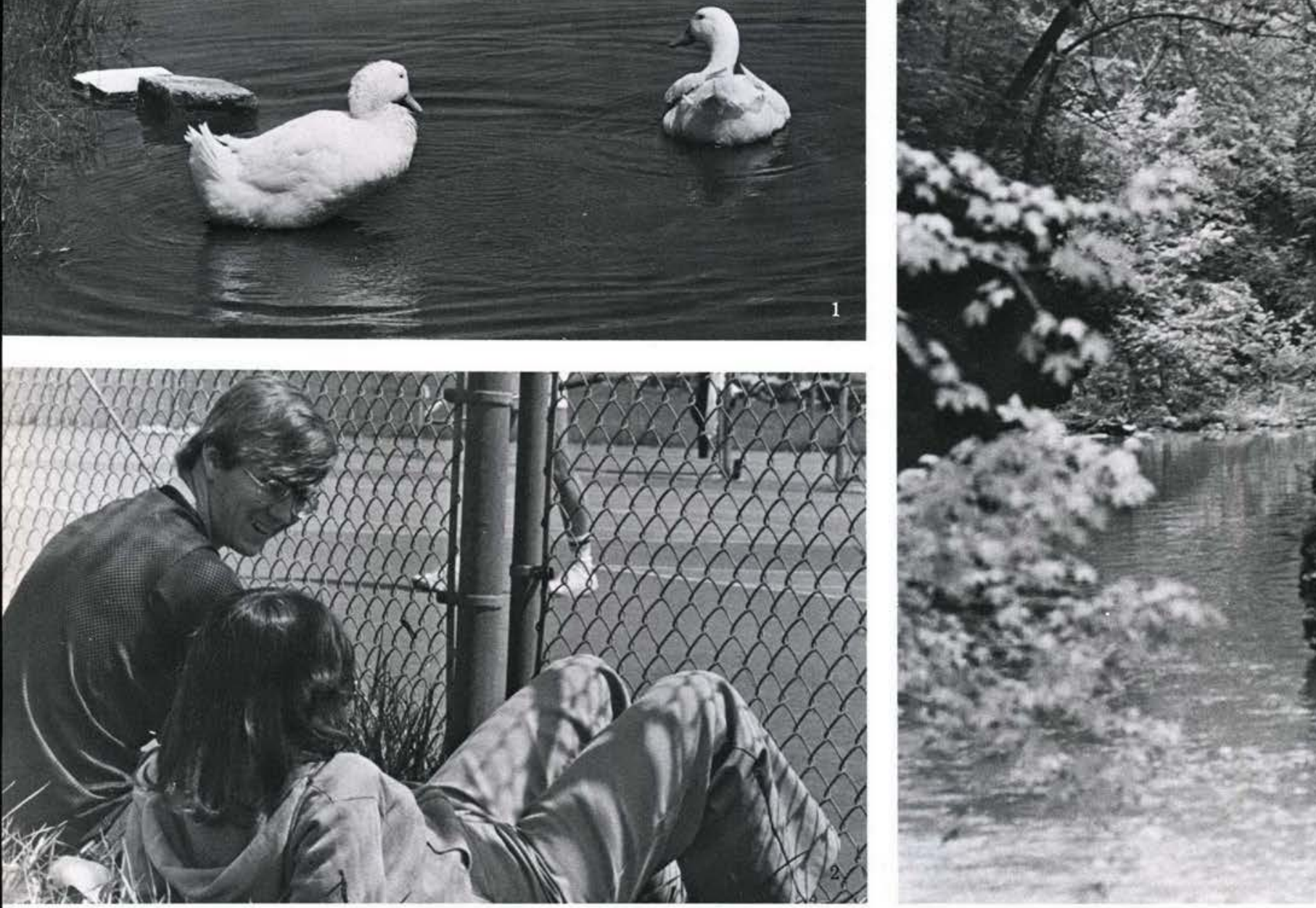

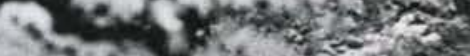

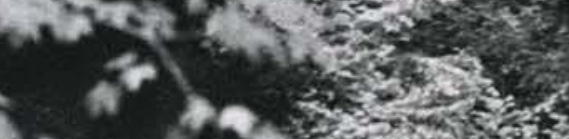

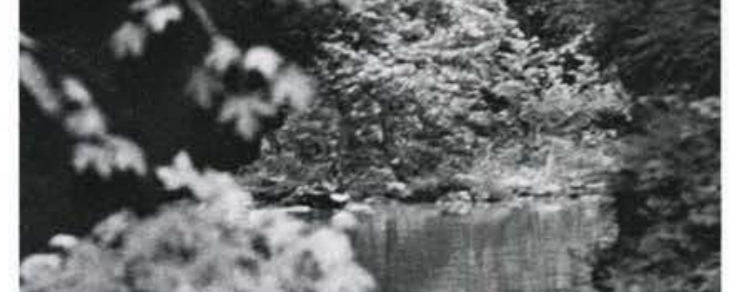

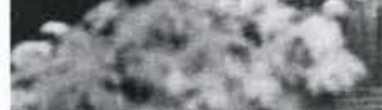

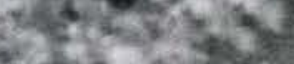

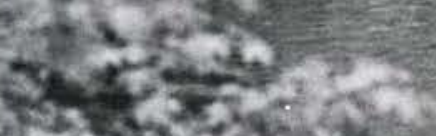

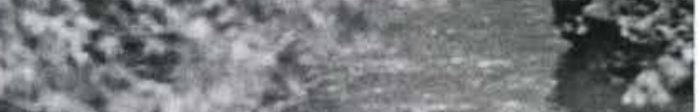

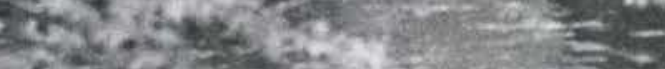

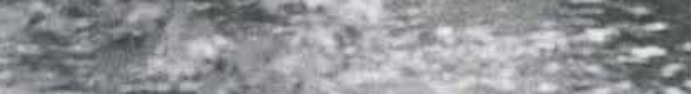

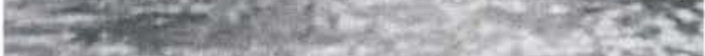

$(6)$

silne

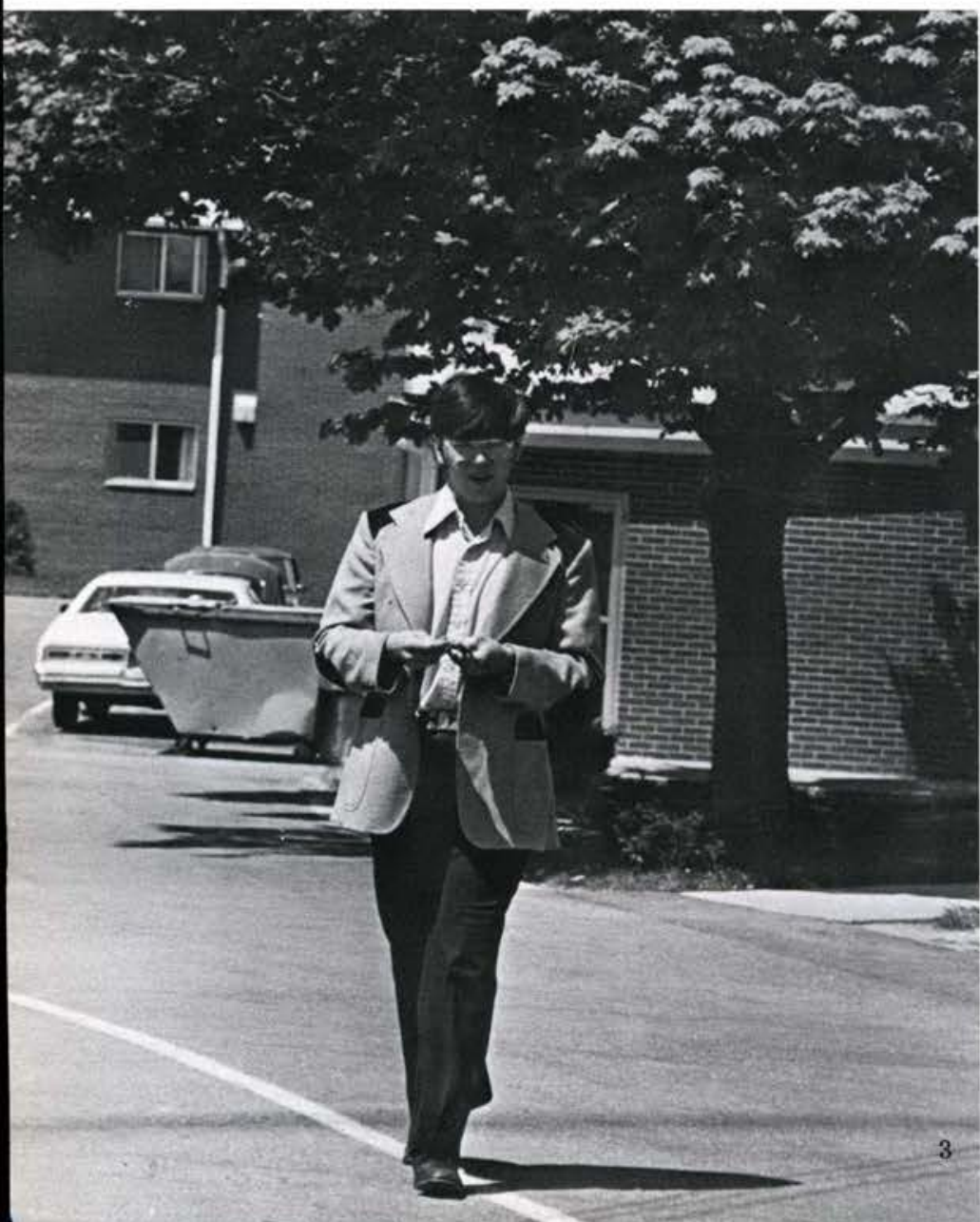

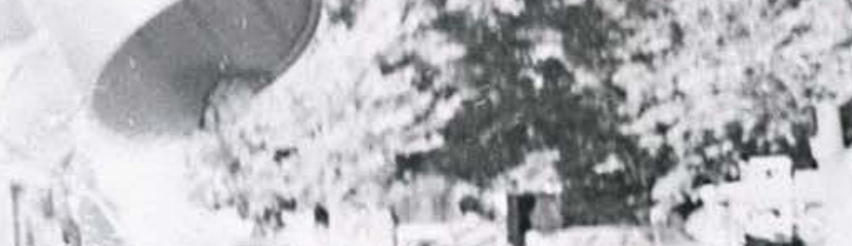

2. Wx.

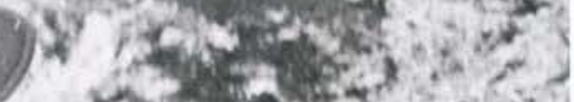

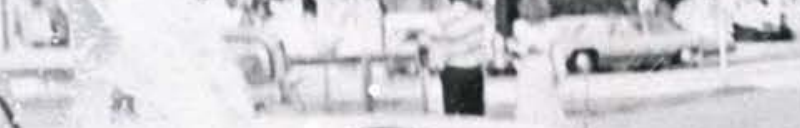

it: in

aringen ant $x^{2}$
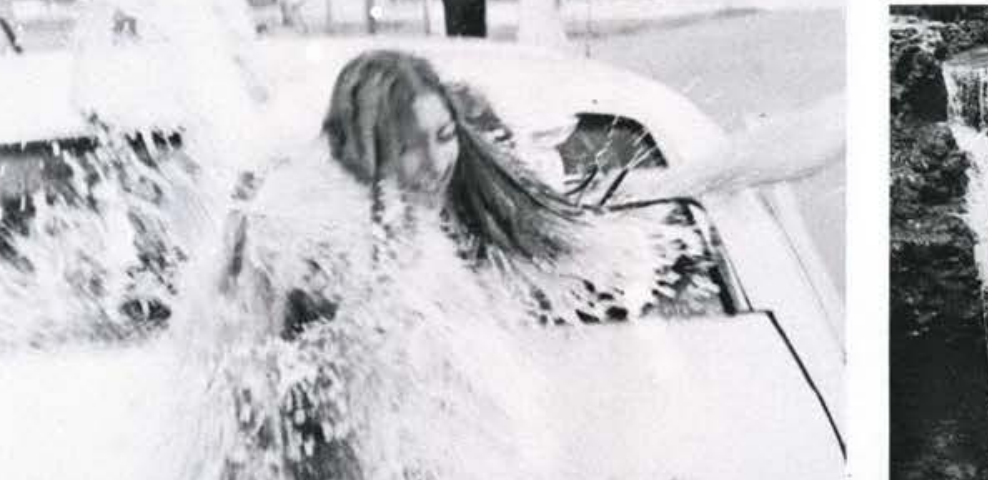

2 ats

ty?

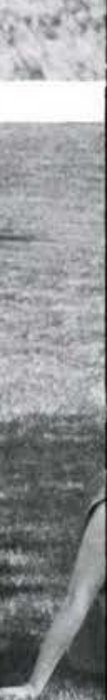

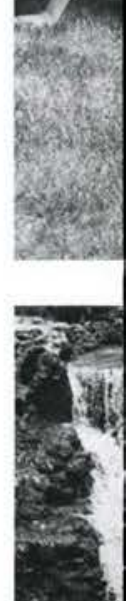




\section{Young Squad Posts} Winning Season

After mopping up in Florida, winning five straight, Cedarville appears to have their artillery ready to "gun" down their Northern opponents. It is not to be, however, as they proceed to drop twelve of their next nineteen games. At the season's end, they straighten out to cop the NCCAA area playoffs from Bethel College, ending at 1412.

The team hits for a .317 average, but cannot seem to keep their opponents from averaging over six runs a game.

Individually there are several standouts. Senior Captain Wynn Gerber is best defenseman, and makes the All-District team. Fred Greetham leads the team in batting average and RBI's, as well as being voted MVP and making the first team All-District. Mike Ratzlaff breaks a school record with five home runs and is also on first team All-District, and first team All Area VI for NAIA.

1. This conference on the mound could mean a possible pitching change.

2. A view from behind home plate shows bat and ball about to meet.

3. A Jacket hitter connects on this pitch. 4. Catcher Wynn Gerber heads for the dugout.

5. The Jackets take time out to ask for Divine guidance before a game.

6. A Jacket baserunner safely slides into second base.

7. Baseball Team: FRONT ROW: Coach Callan, J. Luce, S. Uyenishi, W. Rowe, S. Hancock, D. Fullmer, F. Greetham, C. Fullmer, B. Baldwin, W. Gerber; BACK ROW: D. Cremean, D. Stewart, M. Devine, M. Ratzlaff, R. Floyd, K. Jones, R. Cagwin, C. Burnette, C. Searles, D. Hill, D. Coomes.

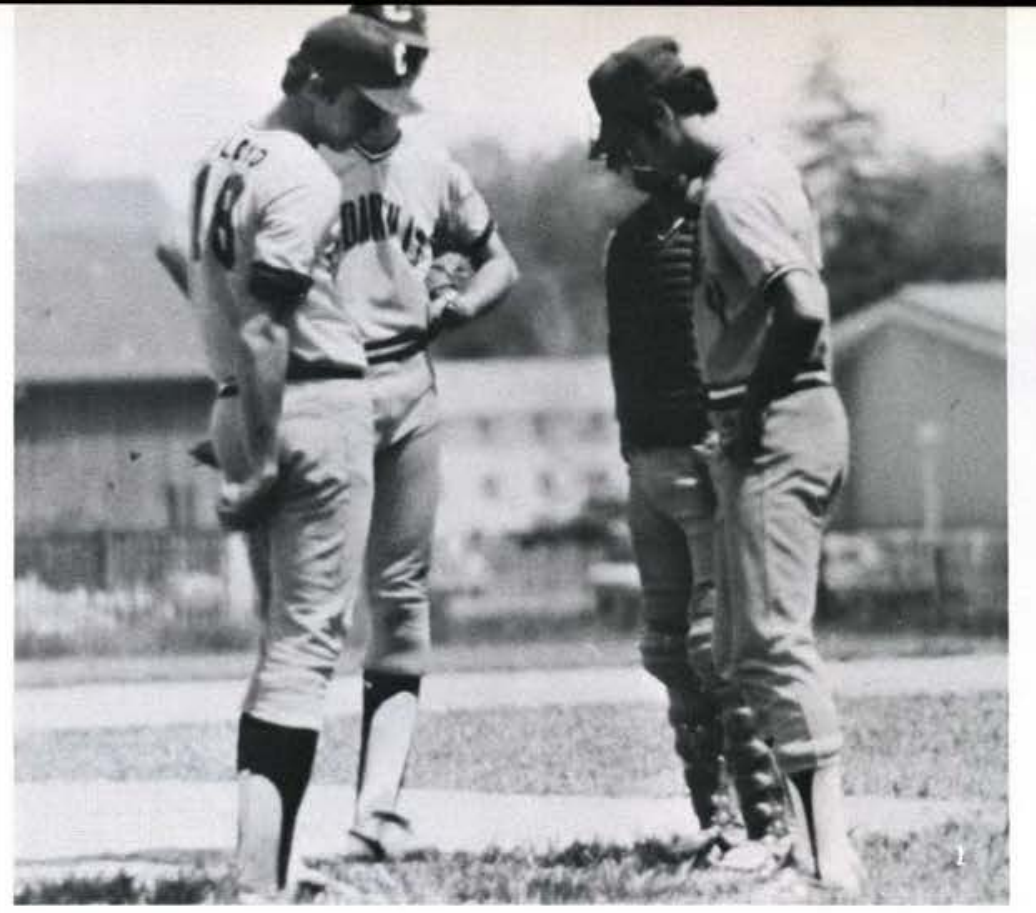




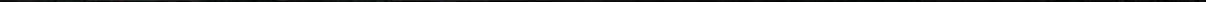

1. Coach Callan is deep in thought as he plots his team's next move.

2. Ron Floyd delivers a pitch to the plate. 3. A group of jubilant Jackets celebrate after a victory.

4. Mike Ratzlaff, Fred Greetham, and Wynn Gerber represent the Jackets on the All-NAIA District \#22 Team.

5 . Wes Rowe follows through after a healthy swing.

6. Randy Cagwin shows true determination as he releases his pitch.

7. Mike Ratzlaff receives a little coaching advice from Dan Coomes. 

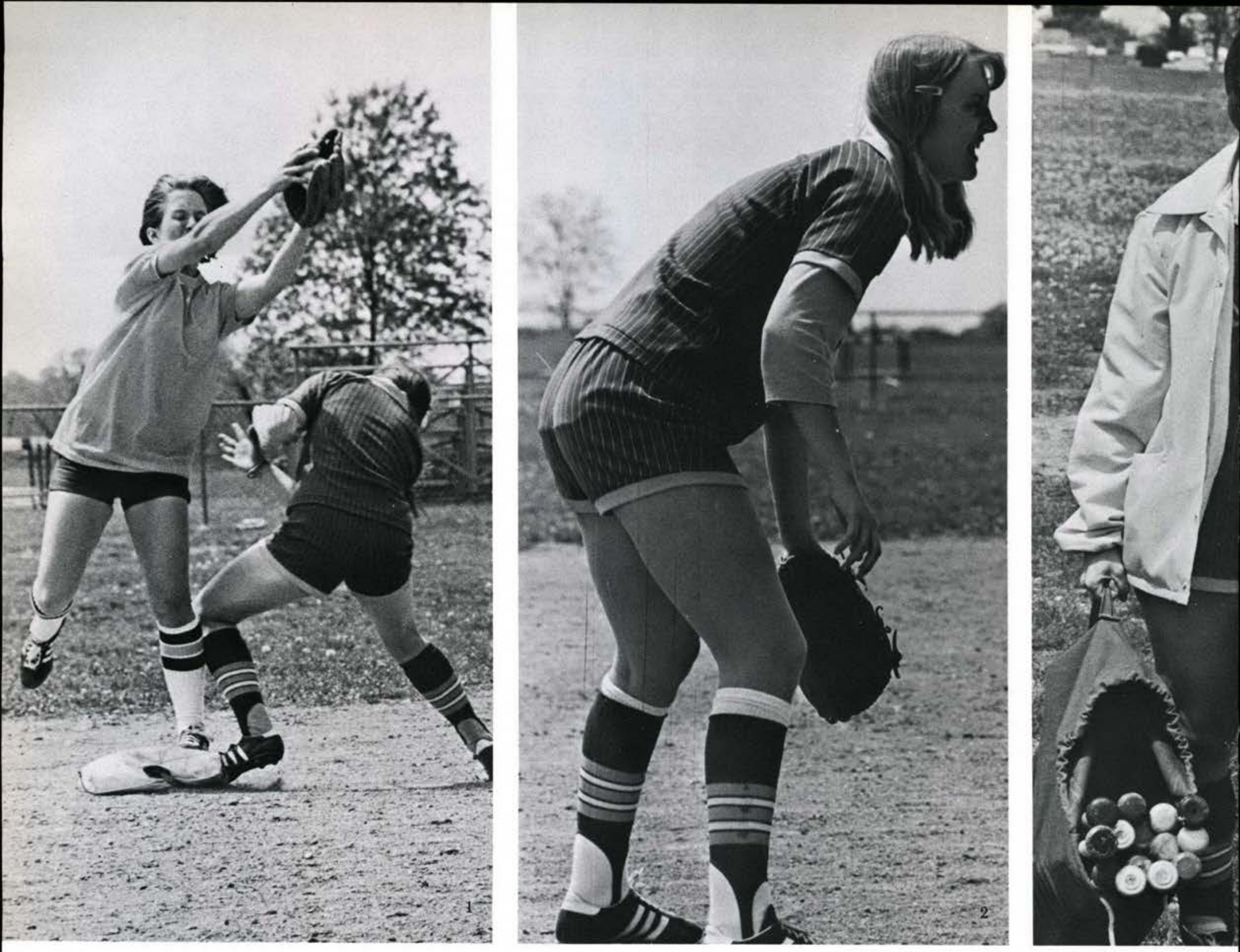

3

C-7.

whe

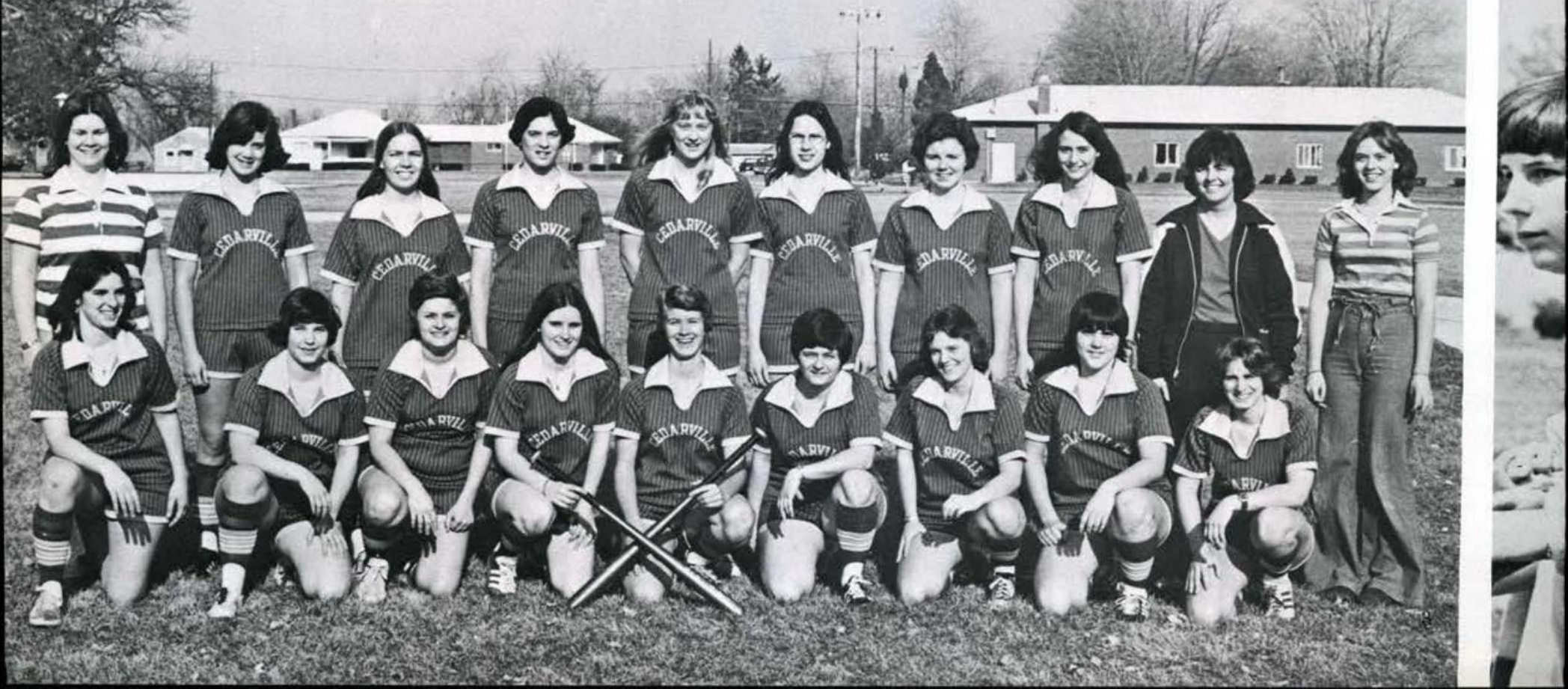




\section{Distance Men Excel For Thinclads}

The Cedarville thinclads establish another record-breaking season as their long distance and field events hold them through many meets. Brian Hull never ceases to create excitement with come-from-behind victories and with four school records to his credit: the mile, 2mile, 3-mile, and steeplechase. Brian also journeys to Nationals where he places fourth in the steeplechase. Dale Shaw also competes in Nationals in the 3-mile event. Mark Peters ties Coach McGillivray's record in the pole vault as he has a good season. Cedarville loses several Seniors, such as all-around Warren Gifford and long-distance man Paul Budnik, but young talent appears to be plenteous for several seasons ahead.

1. After a job well done, Coach King heads to the bench for a rest.

2. While contemplating a good jump, Warren Gifford waves to the cameraman.

3. Dale Shaw sets a new record in the six mile.

4. After pulling a muscle in the race, Dale Shaw gets encouragement from the coach.

5. Bryan Smith loosens-up before a workout.

6. Track Team: FRONT ROW: R. Glidden, B. Henslin, B. Balais, B. Smith, D. Shaw, J. Hunter, P. Schmutzler, S. Anderson; SECOND ROW: M. Jackson, P. Budnik, B. Hull, W. Gifford, D. Rowe, A. Woodruff, T. Hutchison, M. Peters; BACK ROW: Coach Elvin King, T. Yater, S. Lones, M. Streitmatter, D. Rogers, J. Kauffman, W. Gifford, Coach John McGillivray.

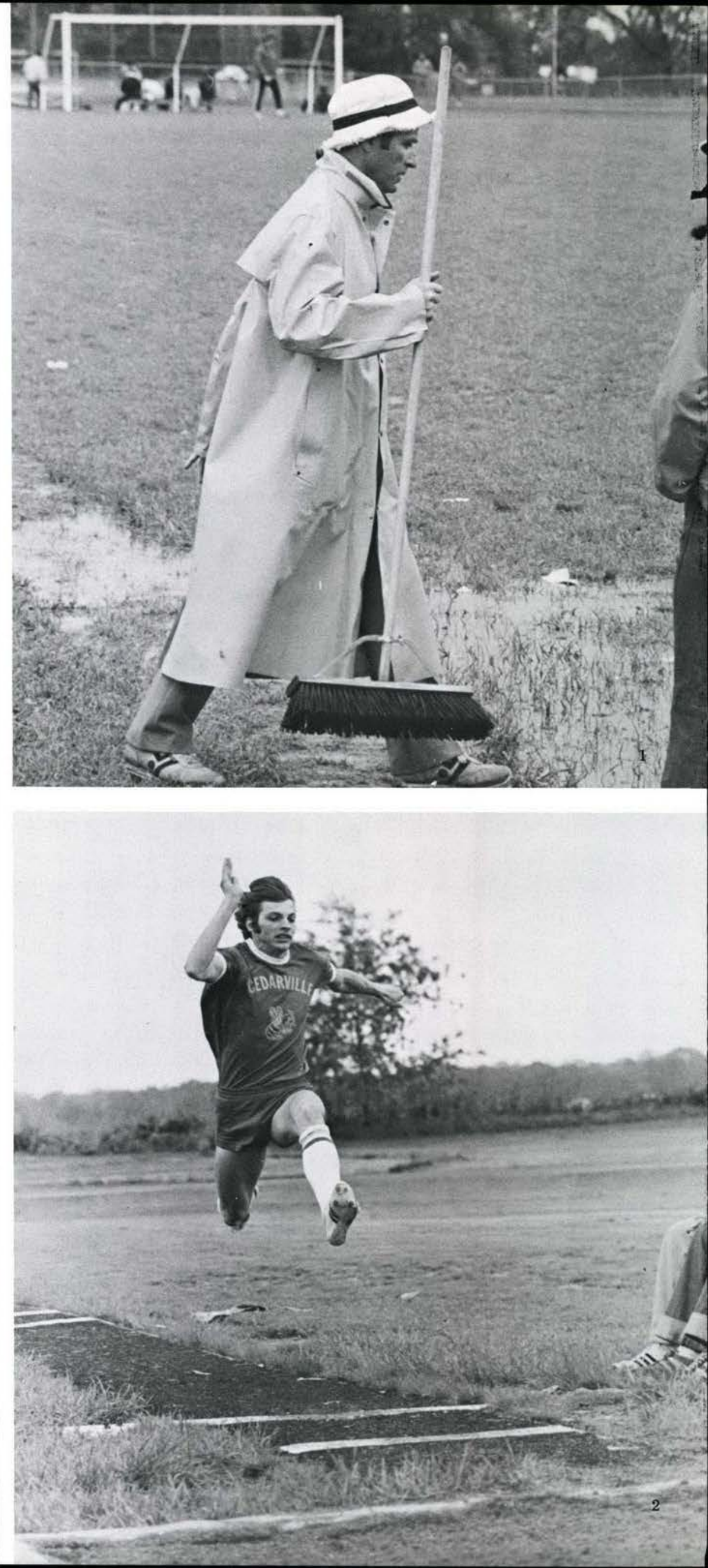




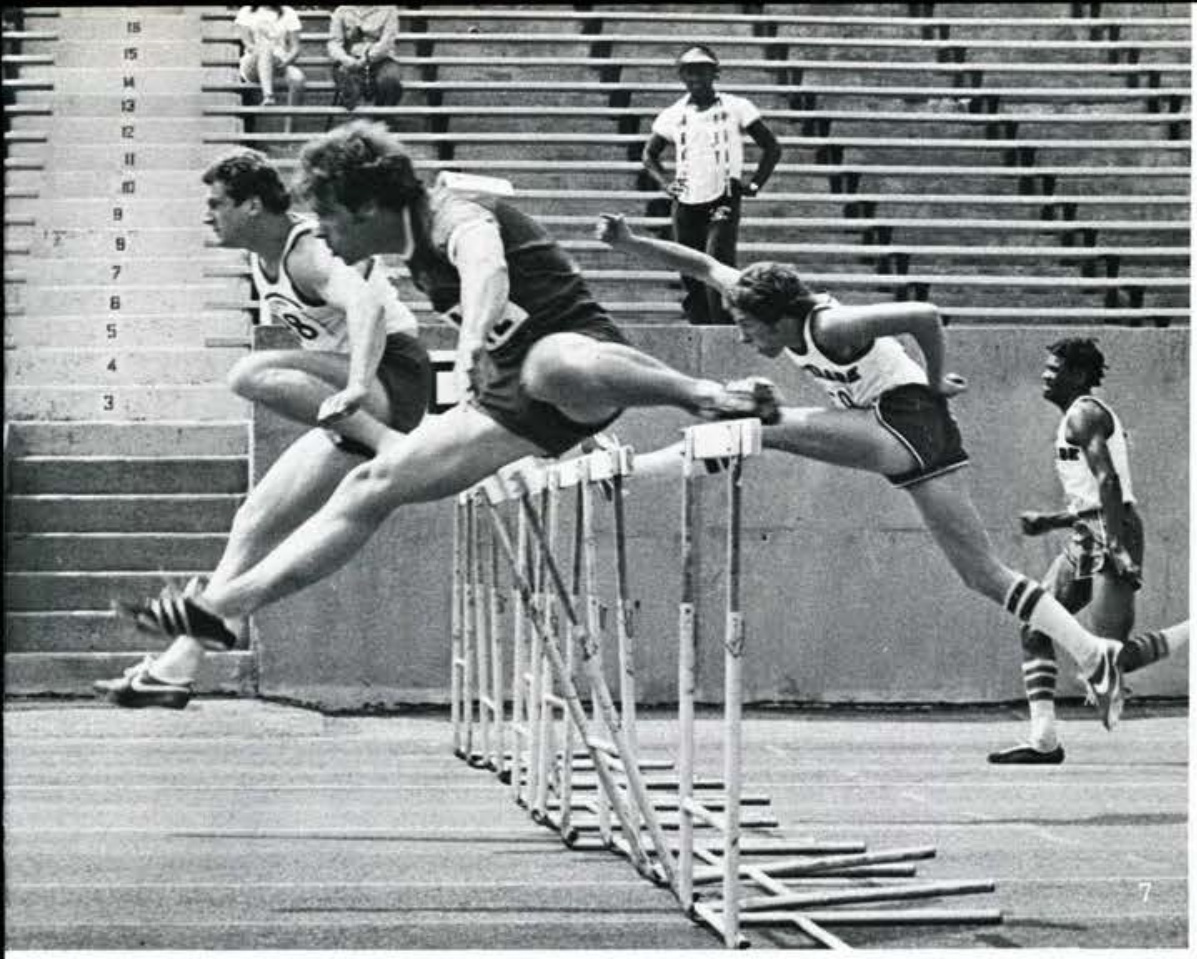

1. Coach McGillivray figures things out for the pole vaulters.

2. Planting hard, Mark Peters stretches for the bar.

3. Sometimes Mark Peters has rope problems, but Scott Anderson manages this tieup.

4. Dave Rogers puts his whole body into it. 5. Brian Hull is tough, no matter how rough the going gets.

6. Joel Hunter will do anything to beat the opponent - maybe even "fly".

7 . Stretching for every inch he can get, Bryan Smith attempts to overtake his opponent.

8. Tom Hutchison concentrates on the gun for the first leg of the mile relay.

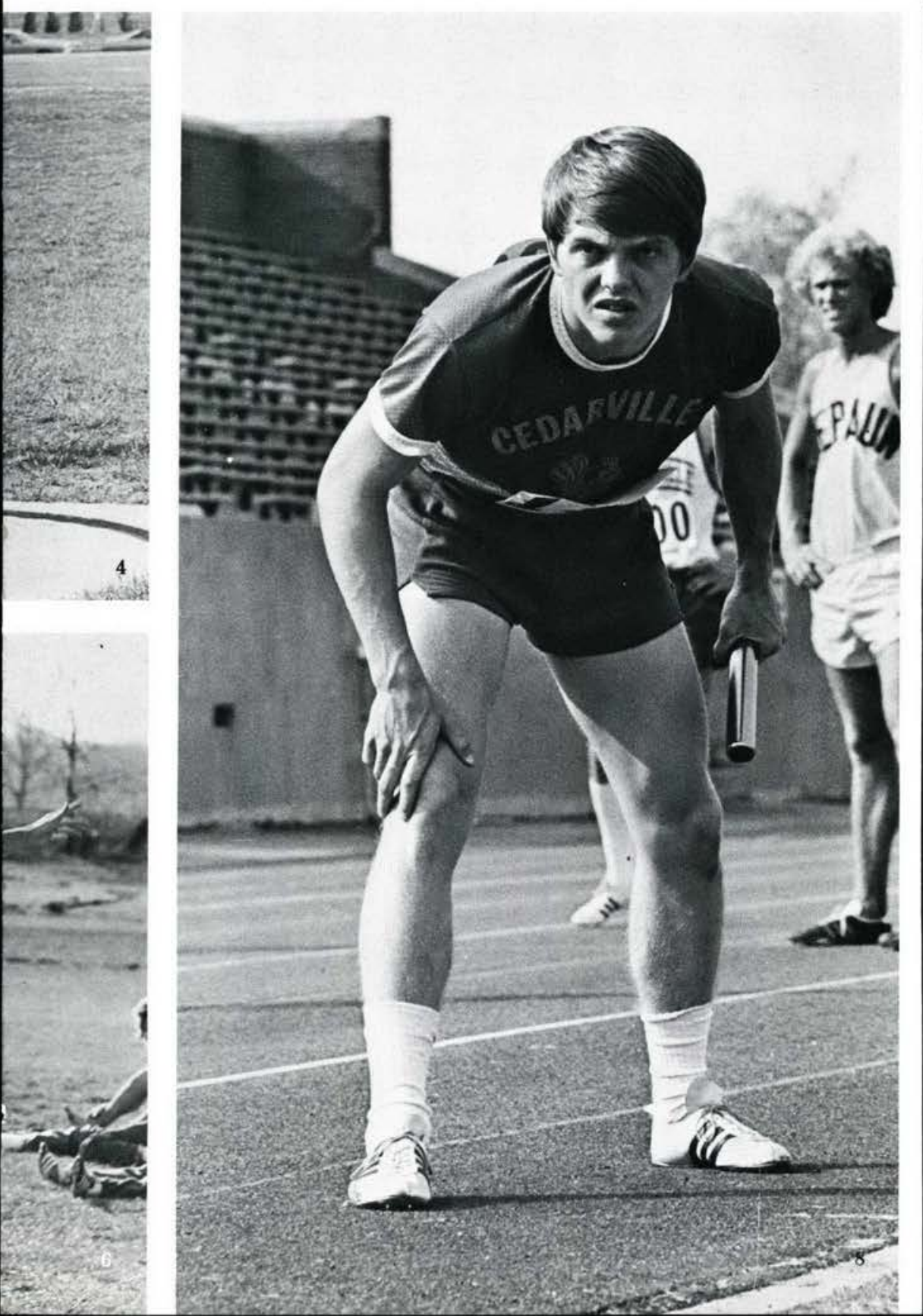




\section{Net Champs Again!}

That Cedarville men's tennis team just keeps on winning ... and winning ... and winning! The "racqueteers" are 18-3 this season, taking first in their own Invitational, at the MOC Tournament, and at the District Tournament (capturing all six top berths!).

Freshman Gary Gallian has a tough job in the No. 1 Singles position, but fulfills it more than adequately, compiling a 21-4 record for the season. And for the umpteenth time in a row, the squad traveled to Nationals representing NAIA District \#22.

1. Dave Lynch (18-6), No. 5 Singles, approaches the net.

2. No. 2 Man Ken Erny (20-6) hits a backhand as he warms up prior to a match. 3 . Coach Murdoch records another Cedarville win in the NAIA Dist \#22 tourney. 4. Cedarville's No. 1 Singles tennis player, Gary Gallian (21-4), reaches back for something extra on his serve.

5. The two-handed backhand becomes a Gallian trademark in route to his Dist \#22 Singles championship.

6. A powerful forehand helps Steve Stairs advance to the finals in the NAIA tournament.

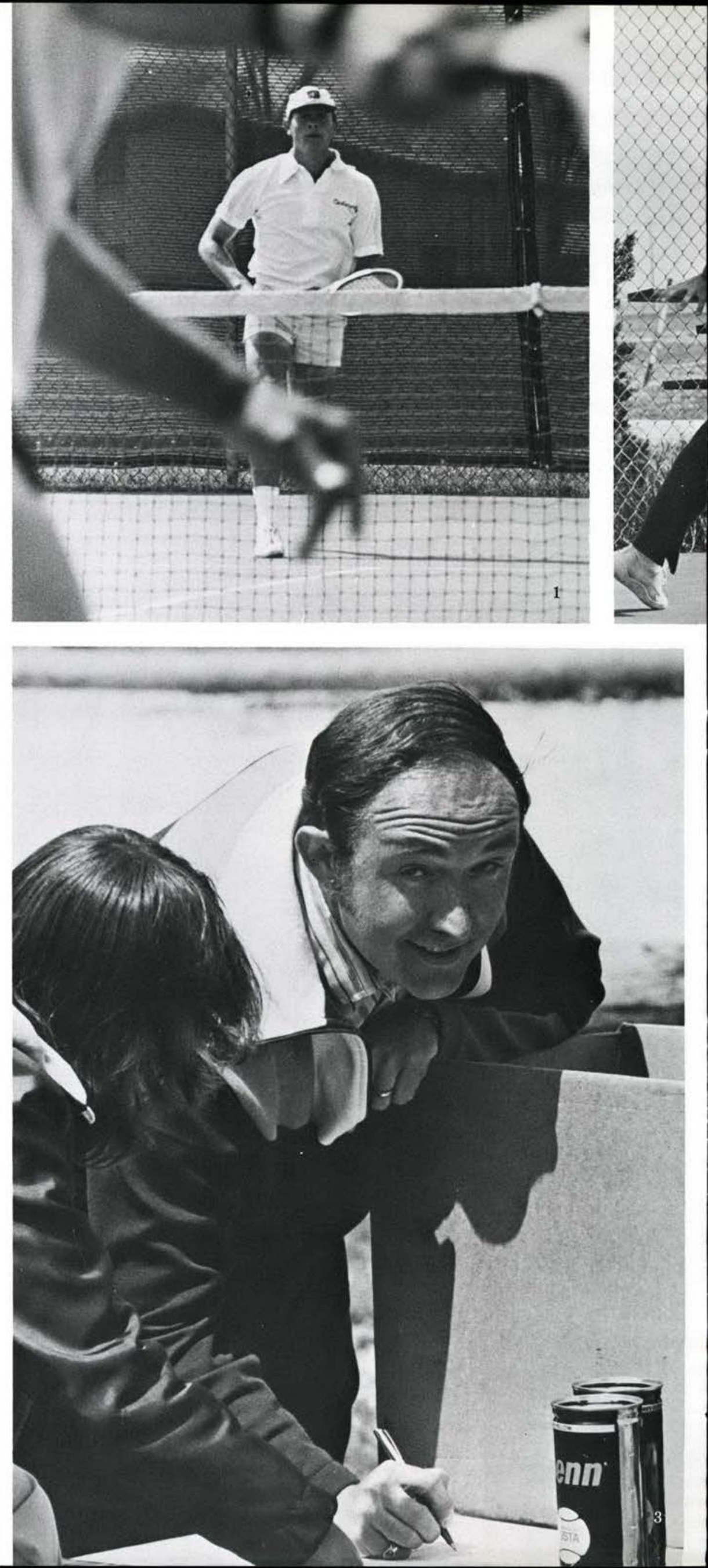




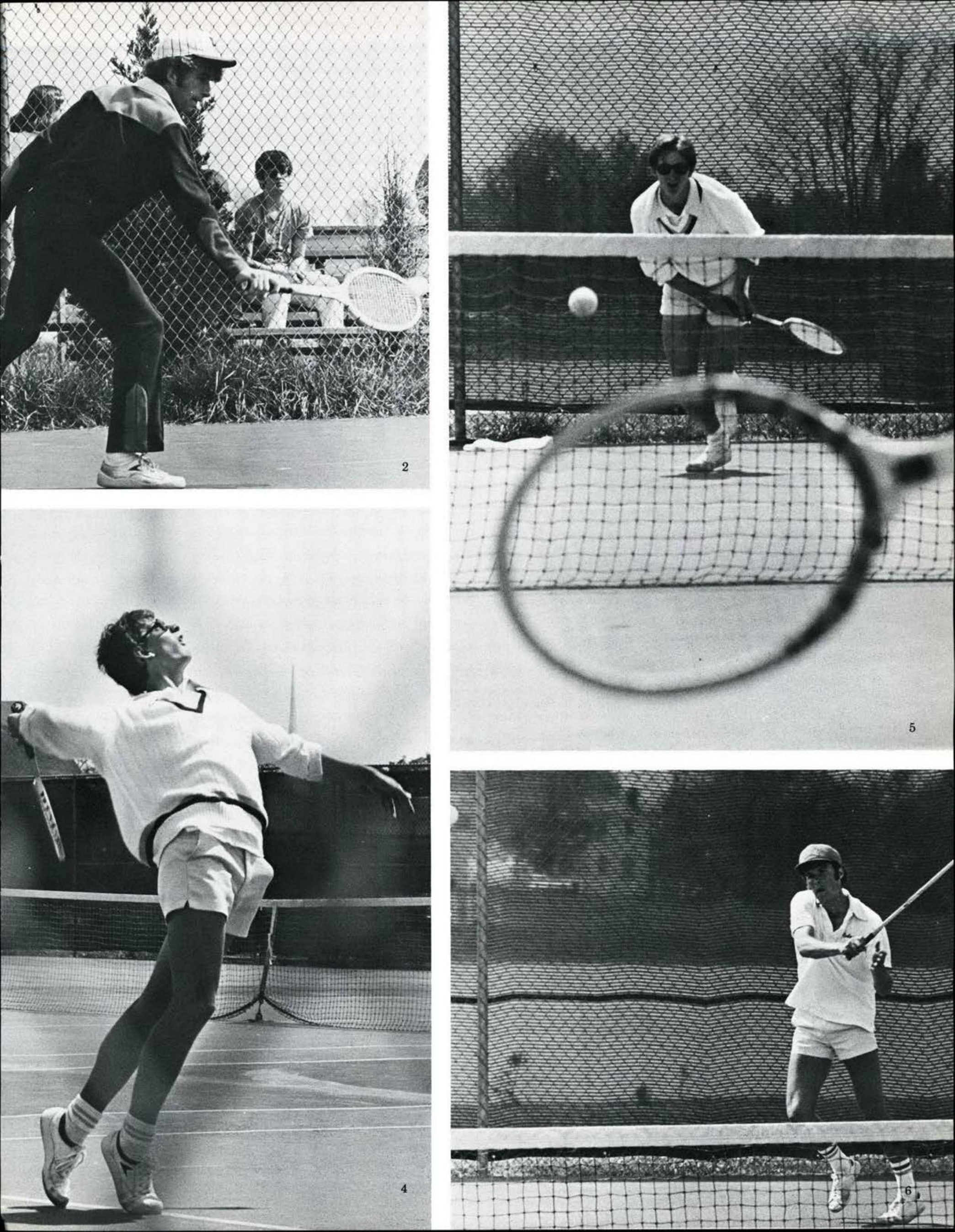




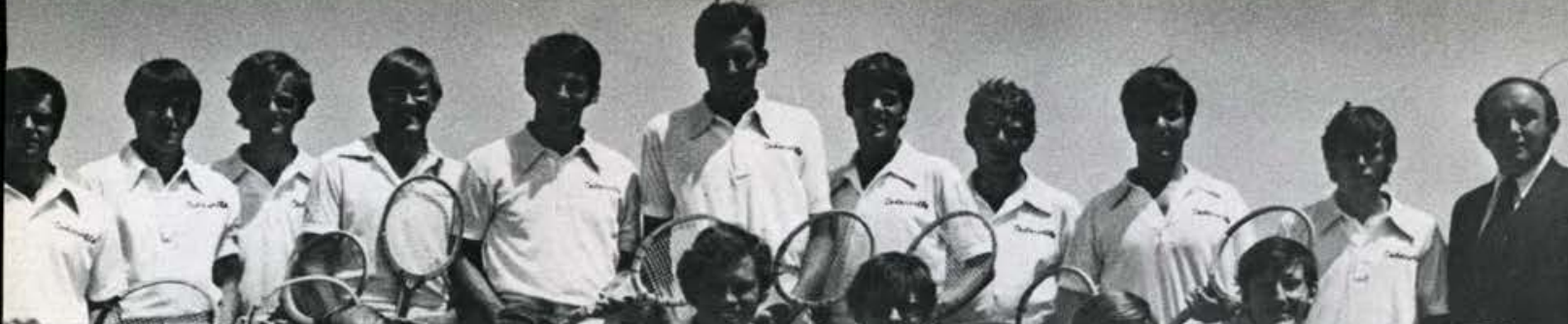

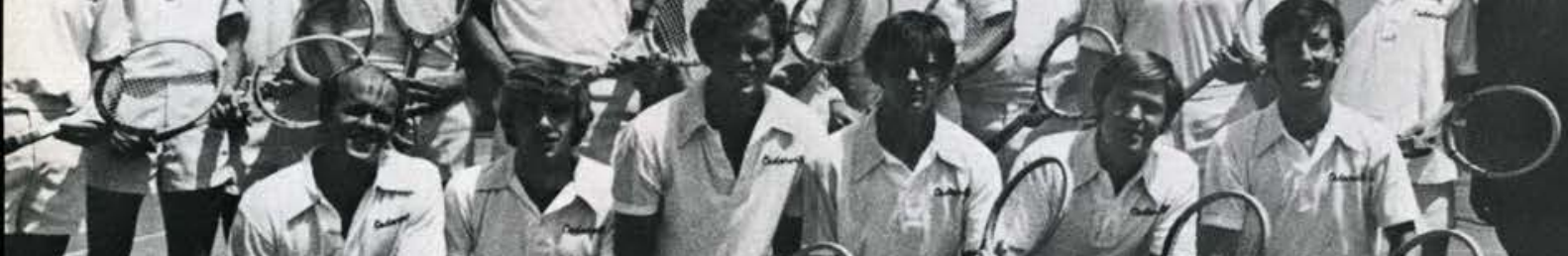
$710 \times 20$

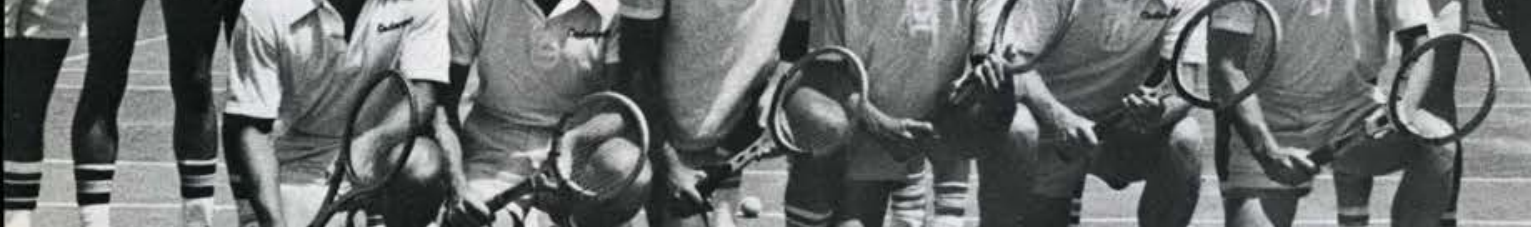
30 n. 

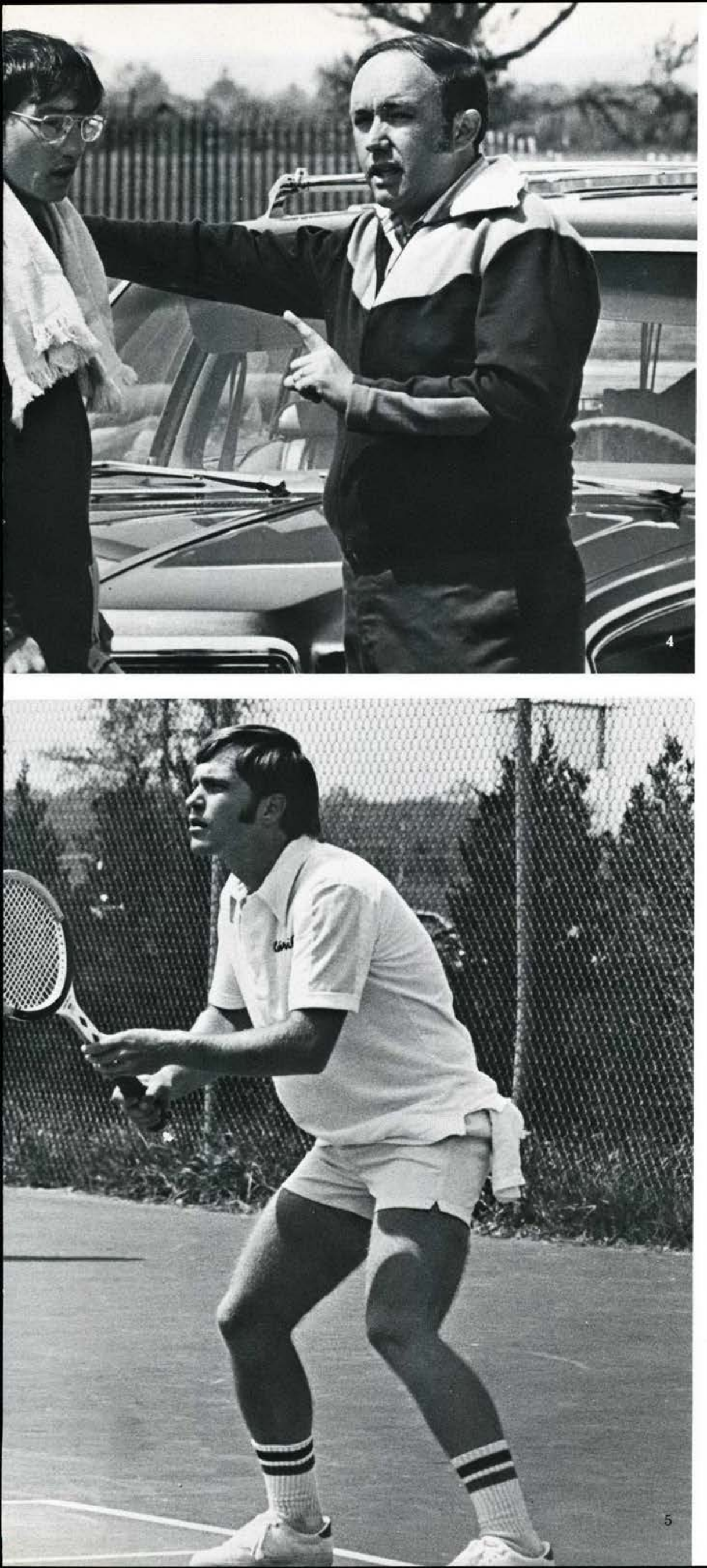


\section{Netters' New Schedule A Success}

The Jackettes tennis team switched this year from a fall schedule to a spring schedule, allowing for much better weather for the netters.

They lose three straight matches at the start of the season, but pick themselves up and sweep five of their final eight. At the state tournament they surprise many by finishing 22 nd and show that they are here to stay.

Amy Ross has a difficult task at the No. 1 Singles position, meeting many outstanding opponents, but she fairs well nonetheless. Laura Palmer is voted Most Improved Player as she comes on strong toward the end of the season.

1. Pairing up in doubles competition are Marilyn Nauta and Debbie Storch.

2. Amy Ross intently awaits her opponent's serve.

3. Storch and Nauta keep posted on the action.

4. Becky DeLancey follows through on a forehand shot.

5. Tennis Team: FRONT ROW: L. Palmer, B. DeLancey, J. Jacobitz, L. Penquite, S. Taylor; BACK ROW: Coach Pamela Diehl, M. Chipukits, D. Storch, E. Banks, M. Nauta, A. Ross.

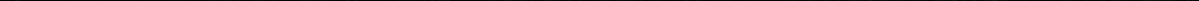




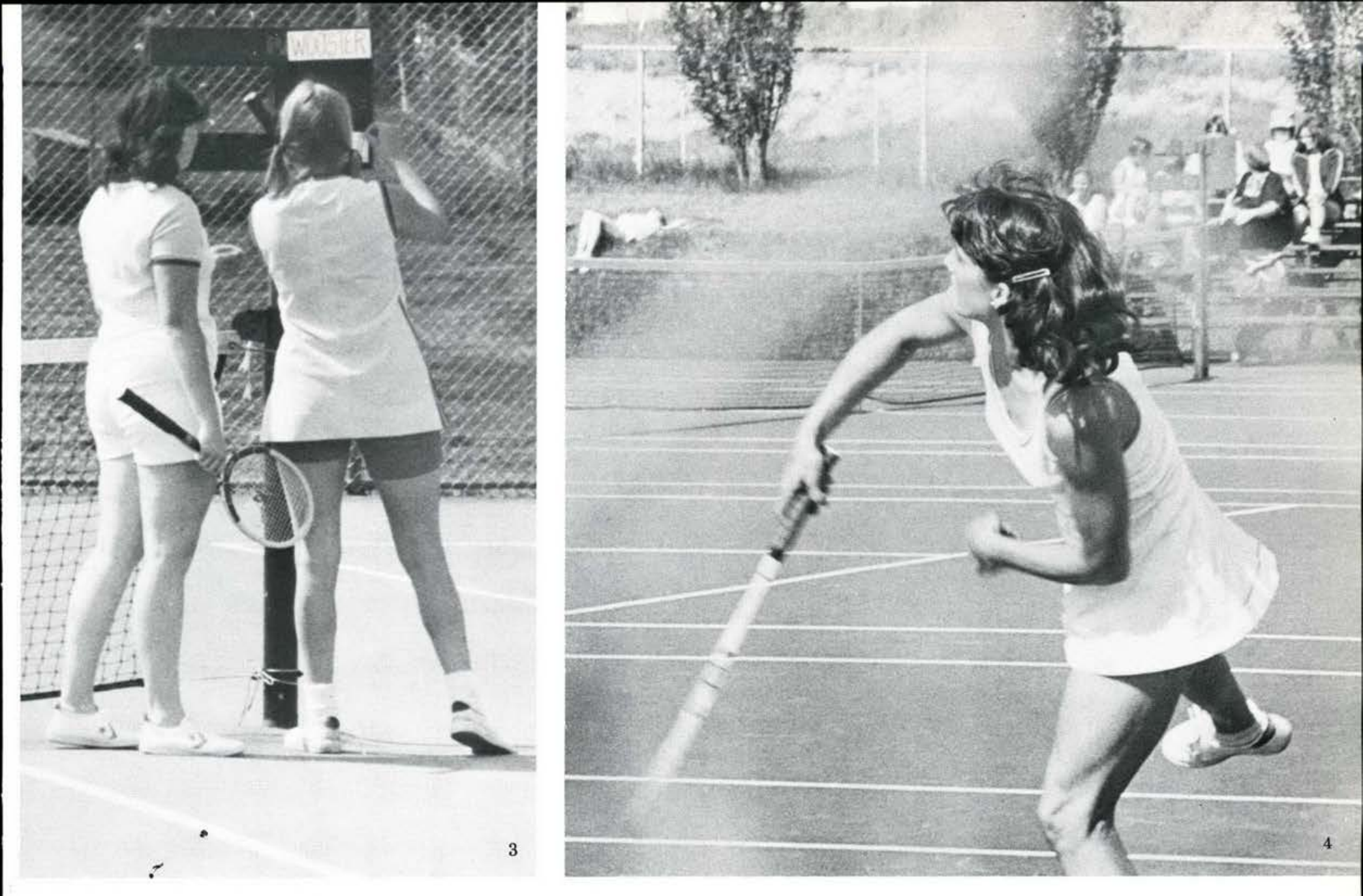


Close Matches Prove Golfers'
Downfall

Losing seasons are never ones to be thrilled about, but this year's team has many good moments to look back upon. Several matches are decided by only one stroke, victories are a putt or drive out of their grasp. Having a very young team means a better season next spring. All but Tim Reder will return. Freshman Dave Ellis proves to be a real addition to the squad as he ends up as first man and compiles the lowest stroke average.

1. Golf Team: FRONT ROW: G. Gromacki, D. Taylor; BACK ROW: P. Slusher, D. Ellis, Coach Al Monroe, D. Riddle, K. Rice. 2. Junior Pete Slusher finds the range with the right iron.

3. Coach Monroe uses just the proper amount of "English".

4. Keith Rice drops a putt for the Jackets. 5. Dave Riddle putts for his par.

6. Dan Taylor, a sophomore, helps considerably this season.

7. "Go in, or I'll put the Polish curse on you!" says Gary Gromacki.
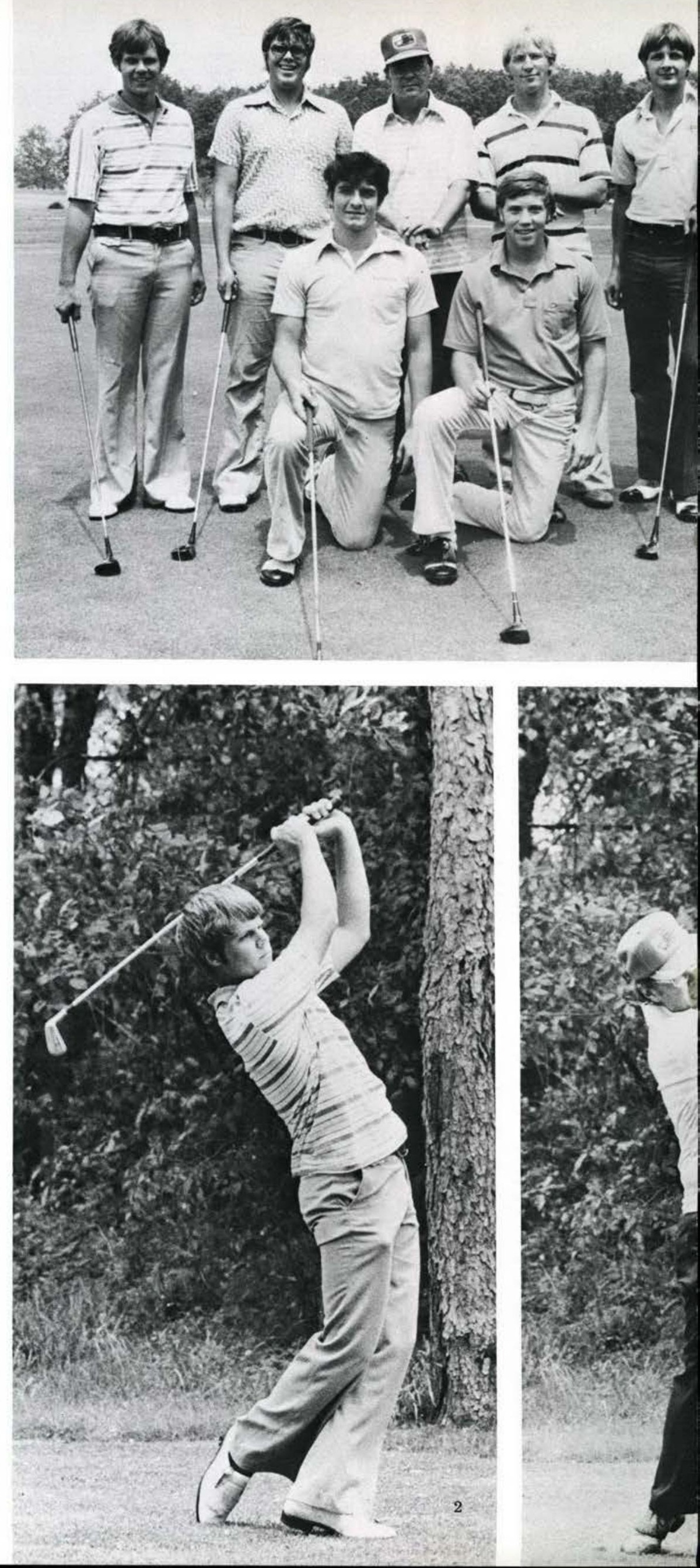


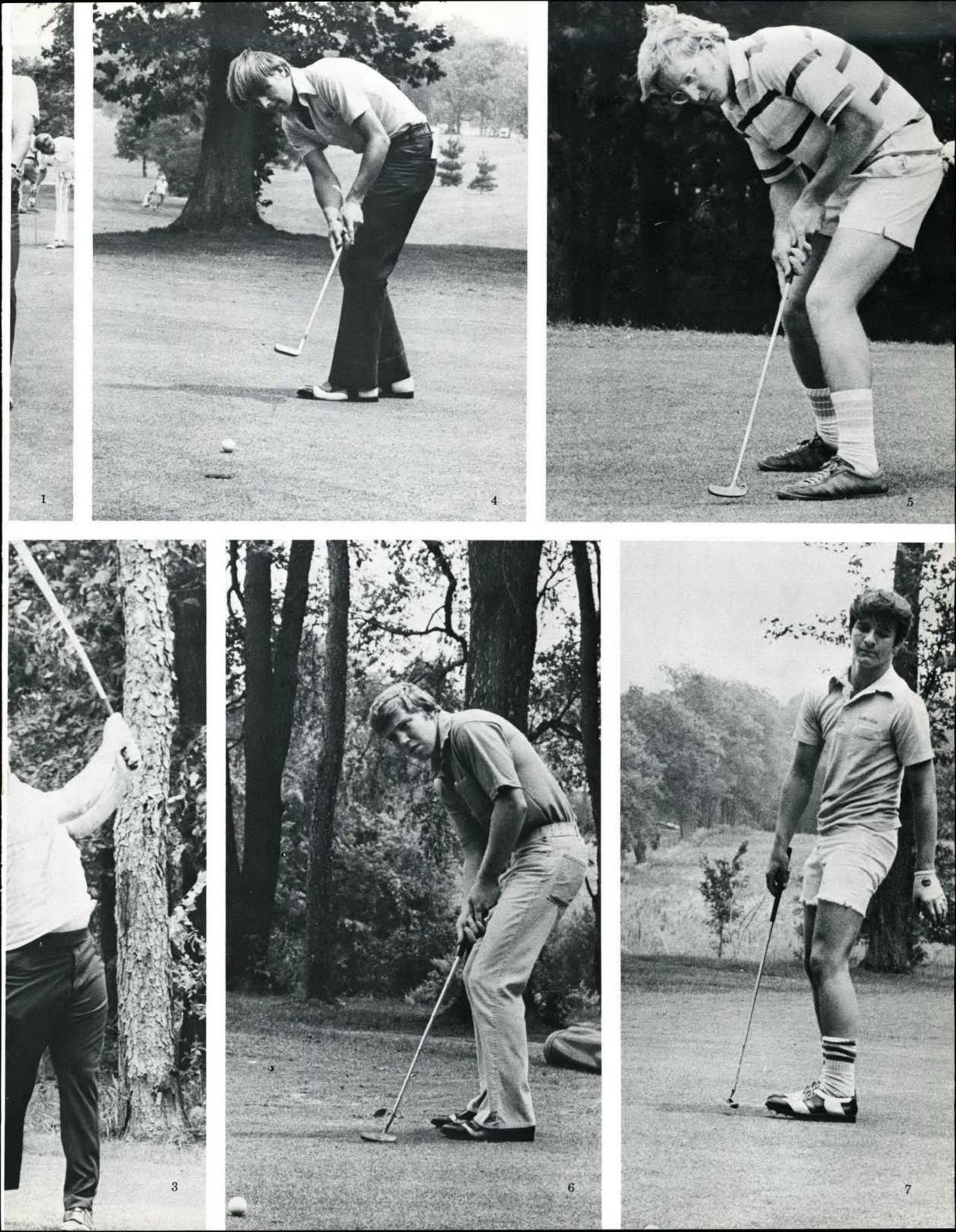




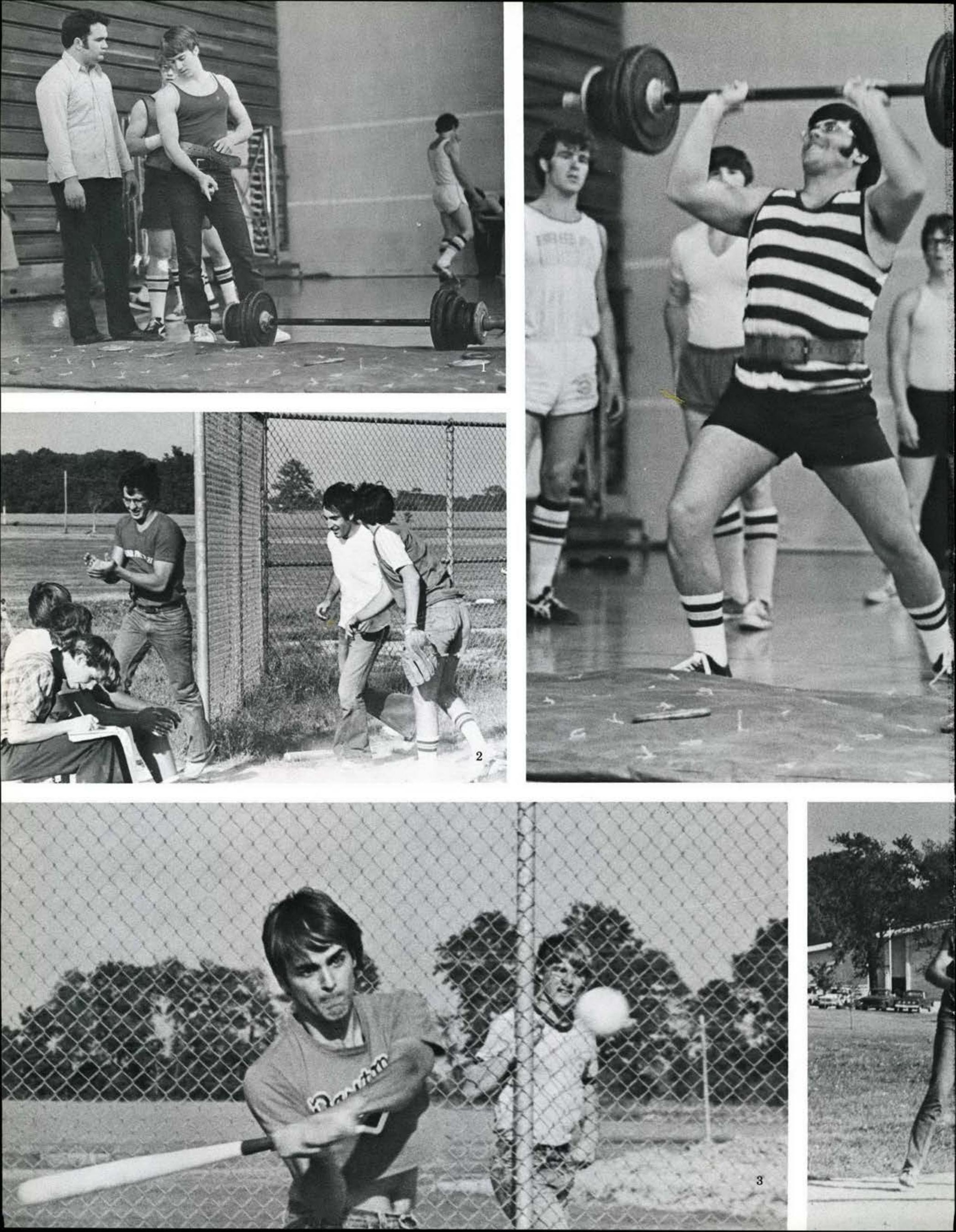


WRESTLING

Ohio Northern

Olivet Nazarene

Bluffton

Sinclair

Urbana

Dayton

Bluffton

Findlay

Central State

Wilmington

Xavier

Georgia Tech

Wright State

Huntington

Hanover

MOC - 3rd

NAIA Dist \#22 - 6th

1st in MOC - Armand Ternak

Dale West

Jim Kollar

Jeff Conklin Dale West Dale West

\section{CROSS COUNTRY}

Penn-Ohio Meet 7th of 8

NCCAA Dist \#3 1st of 3

NCCAA Nationals 3rd of 13
VOLLEYBALL

Cincinnati Bible

Milligan

Ohio Northern

Wooster

Wilmington

Cincinnati Bible

Mt. St. Joseph

Cincinnati

Central State

Bluffton

Capitol

Urbana

Defiance

Miami

Ashland

Marshall

Lakeland

Wittenberg

Ohio Dominican

Wright State

Rio Grande

Ohio U.

Xavier

Muskingum

Ohio Dominican

Wright State

NAIA Nationals - Armand Ternak

Most Valuable Wrestler - Armand Ternak

Most Improved Wrestler - Don Pippin

\begin{tabular}{|c|c|c|c|c|}
\hline $\begin{array}{l}\text { Hanover } \\
\text { Earlham }\end{array}$ & $\begin{array}{l}27 \\
69\end{array}$ & Cedarville & 40 & \\
\hline Defiance & 101 & & & \\
\hline $\begin{array}{l}\text { Wittenberg } \\
\text { Invitationals }\end{array}$ & 35 & Cedarville & 20 & W \\
\hline $\begin{array}{l}\text { Earlham } \\
\text { Hanover } \\
\text { Findlay }\end{array}$ & & $\begin{array}{l}\text { 1st of } 5 \\
5 \text { th of } 7 \\
4 \text { th of } 7\end{array}$ & & \\
\hline
\end{tabular}

Bowling Green

IUPUI

Earlham

DePauw

Hanover

Ohio State

Dayton

12-15,15-3,15-1

$15-10,16-14$

7-15,15-9,21-19

14-11,15-5

15-5,15-7

$15-9,15-11$

15-13,1-15,3-15

$11-15,5-15$

15-6,15-1

$15-6,14-16,15-10$

$8-15,15-11,4-15$

15-2,15-3

9-15,3-15

9-15,15-7,14-16

15-10,5-15,10-15

15-11,15-6

15-10,15-9

9-15,15-7,15-6

$15-3,15-3$

$7-15,10-15$

$13-15,15-6,15-11$

$14-16,15-8,2-15$

$15-1,16-14$

$15-4,15-6$

$14-16,15-4,15-7$

$2-15,7-15$

$7-15,12-15$

$15-12,15-2$

15-6,15-7

$15-6,14-16,15-4$

$15-10,15-8$

$2-15,7-15$

$6-15,2-15$

MVP - Denise DeMars

MV Hitter - Denise DeMars

MV Setter - Judie Cross

Most Improved Players - JoEllyn Priola Valerie Tot-

All-Ohio Meet Brian Hull 1st in College 3rd overall

NAIA District \#22 Brian Hull 1st

NAIA Nationals Brian Hull 20th

$$
\begin{array}{r}
\text { NCCAA All-American - Paul Budnik } \\
\text { Ron Thomas }
\end{array}
$$

NAIA All- American - Brian Hull

\section{GOLF}

Wilmington

Wittenberg $\quad 304$

Bluffton

Tiffin

Clark Tech

Wright State

Sinclair

Malone

Walsh

Mt. Vernon

Mt. Vernon

Ohio Dominican

Urbana

Wilmington

Ohio Dominican

304 CC 375

$\begin{array}{lll}\text { CC } & 324\end{array}$

311 CC 348

345 CC 344

406 CC 445

316 CC 343

$\begin{array}{lll}316 & \mathrm{CC} & 343 \\ 315 & \mathrm{CC} & 334\end{array}$

$\begin{array}{lll}315 & \text { CC } & 334 \\ 288 & \text { CC } & 322\end{array}$

298 CC 322

317

306

332

355

344

$\mathrm{CC}$

$\mathrm{CC}$
$\mathrm{CC}$
$\mathrm{CC}$

CC

MOC - tied for 5 th of 7

NAIA Dist \# $22-6$ th of 11

Low Avg. - Dave Ellis, 82.6

\section{MEN'S BASKETBALL}

Marion

Grace College Tournament

\section{Biola}

Geneva

Bryan

Wilmington

Kentucky Christian

Walsh

Greenville

Malone

Findlay College Tournament
Indian Tech

Findlay

Rio Grande

Tiffin

Mt. Vernon Nazarene

Ohio Dominican

Rio Grande

Urbana

Malone

Ohio Dominican

Tiffin

Mt. Vernon Nazarene

Urbana

Walsh

Central State

Grace
W
W
W
W
W
W
L
L
W
W
L
W
L
L
L
W
W
W
W
L
W
L
W
W
W
W
L
L
W
W
W
W
L
L man

W
W
W
W
W
L
L
W
W
L
W
L
L
L
W
W
W
W
L
W
L
W
W
W
L
L
W
W
W
W
L
L
MVP, Highest Field Goal Pct. - Jeff

Reep

Most Rebounds, Leading Scorer - Steve

Lones

JV MVP - Kim Kauffman 


\section{MEN'S TENNIS}

$\begin{array}{lllll}\text { Bluffton } & 1 & \text { CC } & 8 & \text { W } \\ \text { Thomas More } & 0 & \text { CC } & 9 & \text { W } \\ \text { Hillsdale } & 5 & \text { CC } & 4 & \text { L } \\ \text { Tri State } & 3 & \text { CC } & 6 & \text { W } \\ \text { Olivet Nazarene } & 4 & \text { CC } & 5 & \text { W } \\ \text { Mt. Vernon Nazarene } & 0 & \text { CC } & 9 & \text { W } \\ \text { Rio Grande } & 0 & \text { CC } & 9 & \text { W } \\ \text { Walsh } & 1 & \text { CC } & 8 & \text { W } \\ \text { Wilmington } & 3 & \text { CC } & 6 & \text { W } \\ \text { Wittenberg } & 7 & \text { CC } & 2 & \text { L } \\ \text { Thomas More } & 0 & \text { CC } & 9 & \text { W } \\ \text { Malone } & 0 & \text { CC } & 9 & \text { W } \\ \text { Rio Grande } & 0 & \text { CC } & 9 & \text { W } \\ \text { Ashland } & 2 & \text { CC } & 5 & \text { W } \\ \text { Wilmington } & 1 & \text { CC } & 8 & \text { W } \\ \text { Wright State } & 4 & \text { CC } & 5 & \text { W } \\ \text { Spring Arbor } & 5 & \text { CC } & 4 & \text { L } \\ \text { Central State } & 1 & \text { CC } & 8 & \text { W }\end{array}$

Cedarville Invitational - 1st

MOC--1st

NAIA - 1st

NAIA Dist. \#22 Singles Champion - Gary Gallion

Tennis Team competed at Nationals

MVP - Wes Johnson (22-2)

\section{TRACK}

$\begin{array}{lllll}\text { Wittenberg } & 69 & \mathrm{CC} & 76 & \text { W }\end{array}$

Invitationals

Earlham Relays - 1st

Cedarville Relays - 1st

NCCAA Nationals - 2nd

MOC - 2nd

NAIA Nationals - Brian Hull, 4th in Steeplechase

High Point Man - Brian Hull, 58 pts. Outstanding

Performance - Brian Hull, 8:55.4

Record in Steeplechase

All-MOC - Dale Shaw Bryan Smith

All-NAIA Dist \#22 - Joel Hunter

All-American NCCAA - Brian Hull

Mark Peters

Dale Shaw

Bryan Smith

Records--Dale Shaw

6-Mile $\quad 30: 30.2$

Mark Peters

Pole Vault 14'0"

Brian Hull

Mile

2-Mile $\quad 9: 14.8$

3-Mile 14:01

Steeplechase 8:55.4

\section{WOMEN'S TENNIS}

Ohio Wesleyan

$\begin{array}{rlll}5 & \mathrm{CC} & 0 & \mathrm{~L} \\ 5 & \mathrm{CC} & 0 & \mathrm{~L} \\ 5 & \mathrm{CC} & 0 & \mathrm{~L} \\ 1 & \mathrm{CC} & 4 & \mathrm{~W} \\ 0 & \mathrm{CC} & 5 & \mathrm{~W} \\ \text { Forfeit } & \mathrm{CC} & & \mathrm{W} \\ 0 & \mathrm{CC} & 5 & \mathrm{~W} \\ 4 & \mathrm{CC} & 1 & \mathrm{~L} \\ 9 & \mathrm{CC} & 0 & \mathrm{~L} \\ 0 & \mathrm{CC} & 5 & \mathrm{~W} \\ 4 & \mathrm{CC} & 1 & \mathrm{~L}\end{array}$

Toledo

Central State

Clark Tech

Kent State

Ohio Dominican

Otterbein

Wright State

Findlay

Sinclair

4 CC 1 L

State Tournament - 22nd of 27

Most Improved Player - Laura Palmer

\section{SOCCER}

Ohio U.

Wittenberg

Cincinnati

Bluffton

Ohio Wesleyan

Denison

Wilmington

Walsh

Malone

Kent State

Dayton

NAIA Dist \#22 Championship

Walsh

NAIA Regional Playoffs

Indiana Tech

Spring Arbor

$\begin{array}{llll}2 & \mathrm{CC} & 4 & \mathrm{~W} \\ 2 & \mathrm{CC} & 1 & \mathrm{~L}\end{array}$

(6OT)

MVP - Ken Howard

$\begin{array}{llll}1 & \mathrm{CC} & 2 & \mathrm{~W}\end{array}$

1 CC 3 W

$\begin{array}{llll}0 & \mathrm{CC} & 3 & \mathrm{~W}\end{array}$

$\begin{array}{llll}0 & \mathrm{CC} & 9 & \mathrm{~W}\end{array}$

3 CC 2 I

$\begin{array}{llll}0 & \mathrm{CC} & 0 & \mathrm{~T}\end{array}$

2 CC 7 W

1 CC 00 L

$\begin{array}{llll}0 & \mathrm{CC} & 3 & \mathrm{~W}\end{array}$

$\begin{array}{llll}0 & \mathrm{CC} & 1 & \mathrm{~W}\end{array}$

$\begin{array}{llll}3 & \mathrm{CC} & 1 & \mathrm{~L}\end{array}$

$\begin{array}{llll}0 & \mathrm{CC} & 2 & \mathrm{~W}\end{array}$

MV Defense - Ken Howard

Most Improved Player - Warren Allen

High Point - Tom Benefiel

All- MOC - Tom Benefiel

Ken Howard

Don Bartemus

Merle Ziegler

Evandro Batista

All-NAIA Dist \#22 - Ken Howard

Don Bartemus

Merle Ziegler

Evandro Batista

All-Ohio 2nd Team - Evandro Batista

All-Ohio Hon. Ment. - Ken Howard

All-Midwest Hon. Ment. - Evandro Batista

All- NAIA - Evandro Batista

WOMEN'S BASKETBALL

Morehead State

Greenville

Wilmington

Capitol

Wittenberg

Wooster

N. Kentucky

Wright State

Miami

Ohio Valley Tournament

Wilmington

Capitol

Cincinnati

Ohio Dominican

Central State

Ohio U.

Malone

Cincinnati

Ashland

Dayton

Mt. St. Joseph

State Tournament

Findlay

Ohio Northern

$\begin{array}{llll}87 & \mathrm{CC} & 55 & \mathrm{~L}\end{array}$

$40 \quad$ CC $53 \quad$ W

22 CC 76 W

43 CC 46 W

$\begin{array}{llll}27 & \mathrm{CC} & 97 & \mathrm{~W}\end{array}$

44 CC 48 W

$\begin{array}{llll}101 & \mathrm{CC} & 46 & \mathrm{~L}\end{array}$

49 CC 63 W

$\begin{array}{llll}65 & \mathrm{CC} & 41 & \mathrm{~L}\end{array}$

20 CC $90 \quad \mathrm{~W}$

60 CC 65 W

$\begin{array}{llll}59 & \mathrm{CC} & 48 & \mathrm{~L}\end{array}$

$\begin{array}{llll}57 & \mathrm{CC} & 75 & \mathrm{~W}\end{array}$

$\begin{array}{llll}47 & \mathrm{CC} & 48 & \mathrm{~W}\end{array}$

$\begin{array}{llll}71 & \mathrm{CC} & 64 & \mathrm{~L}\end{array}$

$\begin{array}{llll}60 & \text { CC } & 64 & \text { W }\end{array}$

76 CC 62 L

$\begin{array}{llll}59 & \text { CC } & 52 & \text { L }\end{array}$

72 CC $55 \quad \mathrm{~L}$

$\begin{array}{llll}64 & \mathrm{CC} & 67 & \mathrm{~W}\end{array}$

$\begin{array}{llll}32 & \mathrm{CC} & 76 & \mathrm{~W}\end{array}$

60 CC 50 L

State Tournament Free Throw Champion Dorene Sands, 47 of 50

MVP - Cathy Bunton

Leading Scorer, Rebounder, Field Goal

Percentage - Vickie Butler
BASEBALL

Southeastern Bible College 0 CC 11 W

Clearwater Bible College 5 CC 11 W

Southeastern Bible College 2 CC 8 W

Warner Southern College 2 CC 8 W

Warner Southern College 3 CC 17 W

$\begin{array}{lllll}\text { Mt. Vernon Nazarene } & 6 & \text { CC } & 2 & \text { L }\end{array}$

Mt. Vernon Nazarene $\quad 4$ CC 2 L

Urbana

Urbana

Rio Grande

Rio Grande

Ohio Dominican

Ohio Dominican

Central State

Central State

Wilmington

Wilmington

Ohio Dominican

Ohio Dominican

Urbana

Urbana

Central State

Central State

Wright State

NCCAA Area Playoffs

Bethel

Bethel

2 CC 8 W

11 CC 9 L

$\begin{array}{llll}17 & \mathrm{CC} & 4 & \mathrm{~L}\end{array}$

8 CC 11 L

$\begin{array}{llll}11 & \mathrm{CC} & 8 & \mathrm{~L}\end{array}$

5 C

10 CC 14 W

$\begin{array}{llll}4 & \mathrm{CC} & 7 & \mathrm{~W}\end{array}$

6 CC 10 W

16 CC 6 L

$\begin{array}{llll}2 & \mathrm{CC} & 3 & \mathrm{~W}\end{array}$

$\begin{array}{llll}11 & \mathrm{CC} & 7 & \mathrm{~L}\end{array}$

12 CC 9 L

4 CC 18 W

$\begin{array}{llll}11 & \text { CC } & 9 & \text { L }\end{array}$

$\begin{array}{llll}7 & \mathrm{CC} & 1 & \mathrm{~L}\end{array}$

$\begin{array}{llll}8 & \mathrm{CC} & 0 & \mathrm{~L}\end{array}$

4 CC 6 W

$\begin{array}{llll}5 & \mathrm{CC} & 6 & \mathrm{~W}\end{array}$

MVP, Highest Batting Avg., Most RBI's Fred Greetham

All-NAIA Dist \#22 - Fred Greetham Mike Ratzlaff

Wynn Gerber, Hon. Mention

All-NAIA Area VI - Mike Ratzlaff

Best Defensive Player - Wynn Gerber

WOMEN'S SOFTBALL

Wright State 4 CC 3 L

$\begin{array}{lllll}\text { Edgecliff } & 1 & \text { CC } & 14 & \text { W }\end{array}$

$\begin{array}{lllll}\text { Sinclair } & 5 & \text { CC } & 17 & \text { W }\end{array}$

Sinclair $\quad 2$ CC 3 W

Miami $\quad 11$ CC 4 L

Wooster $\quad 1$ CC 3 W

Wooster $\quad 1$ CC 4 W

Dayton $\quad 5$ CC 2 L

Dayton 6 CC 1 L

$\begin{array}{lllll}\text { Wittenberg } & 3 & \mathrm{CC} & 7 & \mathrm{~W}\end{array}$

Ohio Wesleyan 5 CC 10 W

$\begin{array}{lllll}\text { Lakeland } & 12 & \text { CC } & 13 & \text { W }\end{array}$

Kent State $\quad 11$ CC 1 L

MVP - Kim Gall

Best Defense - Kim Gall

Most RBI's - Sue Kulp

Highest Batting Avg. - Sue Kulp

FIELD HOCKEY

Miami

Wittenberg

$3 \mathrm{CC} 2 \mathrm{~L}$

Ohio Wesleyan

4 CC 5 W

Ohio Valley League Tournament -2 nd

Cincinnati

$1 \mathrm{CC} 4 \mathrm{~W}$

Dayton

$1 \mathrm{CC} 2 \mathrm{~W}$

MVP - Mary Harris

High Scorer - Debbie Selden

Most Improved Player - Sue Kulp 


\section{Organizations Geared Toward The Future}

A long-established organization on Cedarville's campus is Alpha $\mathrm{Mu}$ Chi, advised by Ma Printy. It provides advice and helpful hints to engaged women for making their marriage a success. Meetings include hosting special speakers, viewing newest bridal fashions, and planning weddings. The year's final get-together is a club shower.

Chi Theta $\mathrm{Pi}$ is a group for students interested in health professions. The variety of career opportunities for the Christian professional are many, and the organization seeks to make the students aware of them. The group spends much of its time planning for the annual Science Fair held on Cedar Day.

1. Each spring the S.C.G. bulletin board fills up with a multitude of wedding invitations.

2. Dr. Helmick shows the students how it's done!

3. Chi Theta Pi: BACK ROW: D. Johnson, K. Harding, K. Amstutz, Dr. Helmick; SECOND ROW: M. Nelson, B. Carroll, M. Nauta, D. Richardson; FRONT ROW: D. Radcliffe, D. Schweitzer, S. Paradiso, L. Overturf, J. Surso, A. Ross.

4. Kent Amstutz tries to blame the shot on a warped cue stick!

5. Everyone seems ready to chip in their advice as to how the game is played!

6. One of the requirements for Alpha Mu Chi's membership.

7. Alpha Mu Chi: Mrs. Printy (Adviser), W Freeburger, K. Spencer, S. Chamblin, B. Begley.

8. With all eyes on her, Donna Radcliffe ponders her next move.

9. On Cedar Day Chi Theta Pi sponsors a booth to inform interested persons of their blood type.
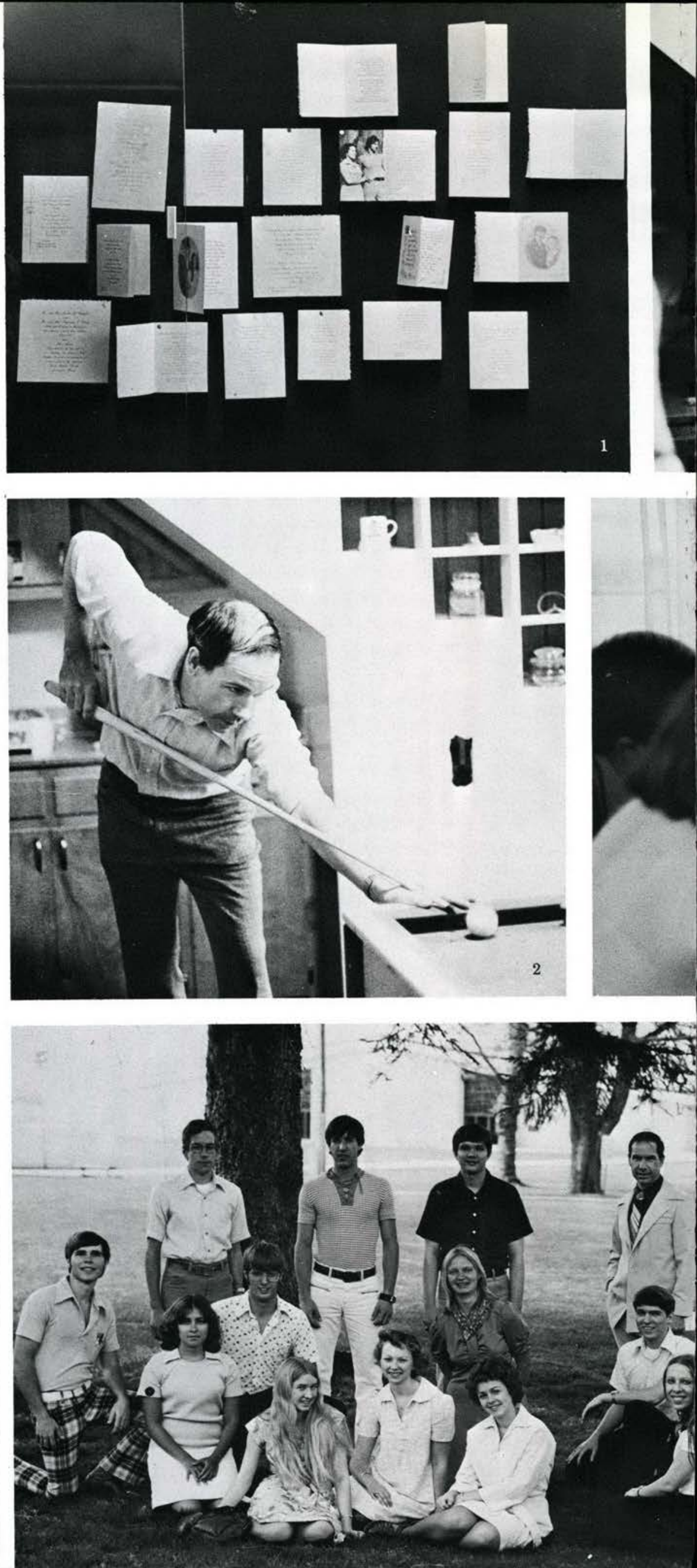


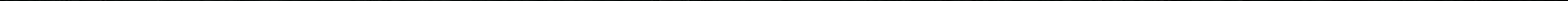




\section{Students Share Their Faith}

Each week the Campus Evangeiism members visit nearby college campuses to share their faith in Jesus Christ with fellow students. They go to Wright State, Wittenberg and Antioch, where they meet students from many walks of life and various religious backgrounds and beliefs.

The first Sunday of each month, students from Cedarville College have the opportunity to travel to Cincinnati to work in a rescue mission. Many people from the inner city come to the mission for food, shelter, and clothing. There, our students have the privilege of sharing their faith in Christ.

Cedarville College students have the privilege of ministering at the Bethesda Rehabilitation Center in Springfield. Bethesda is a Biblebased home for juvenile offenders. Here, our students have ample opportunity to witness to these kids to set a Christian example before them and to share with them Jesus and His love.

1. Ross Livingood leafs through his Bible, finding verses to share.

2. Jim Carrington converses with one of the men at the Rescue Mission.

3. Bethesda Rehabilitation: D. Riddle, J. Riter, J. Zachary, M. Danube, I. Taylor.

4. Helping in the kitchen is one way of showing God's love, as Dave Riddle demonstrates.

5. Campus Evangelism: R. Young, S. Champlin, C. Miller, N. Crandall, K. Payne, D. Poole.

6. Dan Poole and Linda Ernst share their faith on Campus Evangelism.

7. Rescue Mission: M. Nauta, J. Carrington, D. Smith, J. Yhap, J. Dannenberg.

8. Preaching for the Rescue Mission is Don Smith.
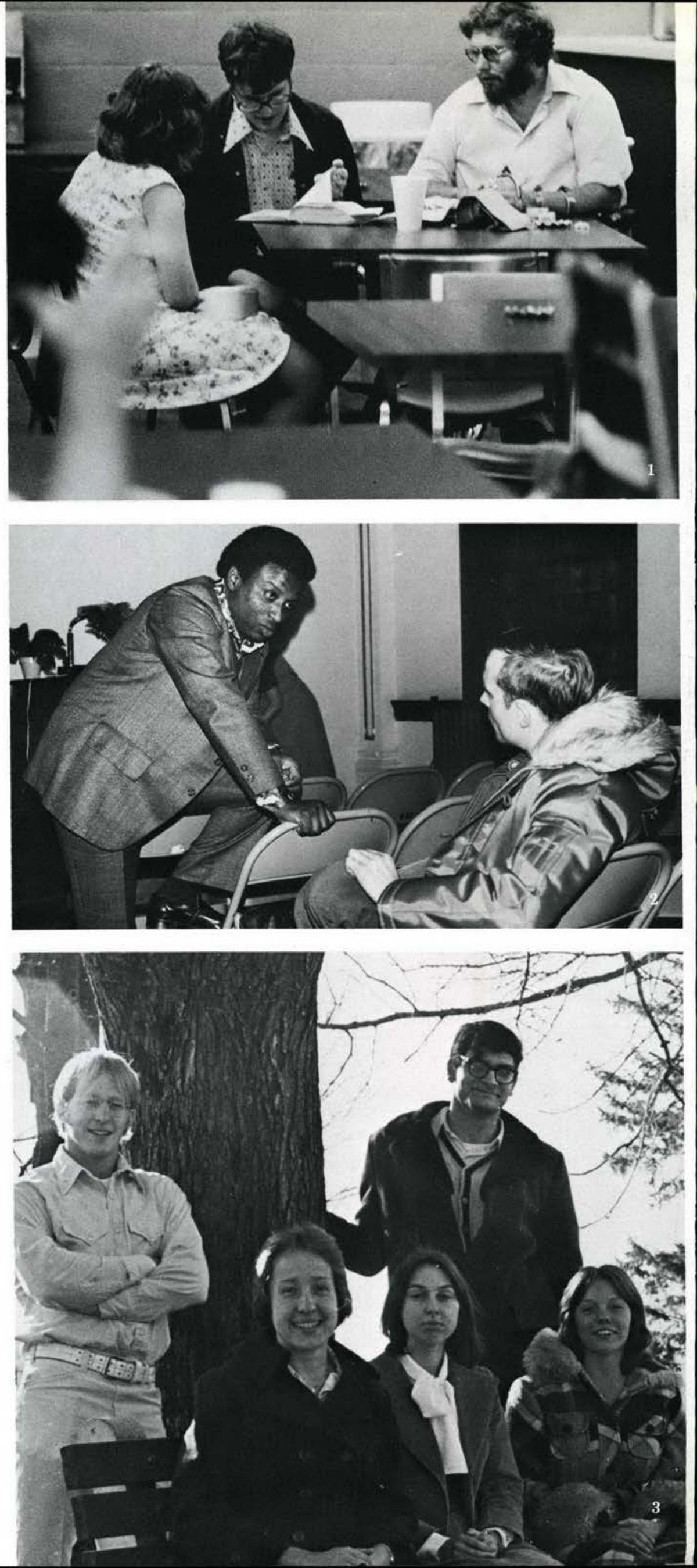

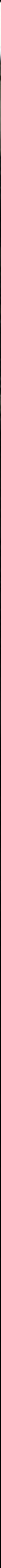


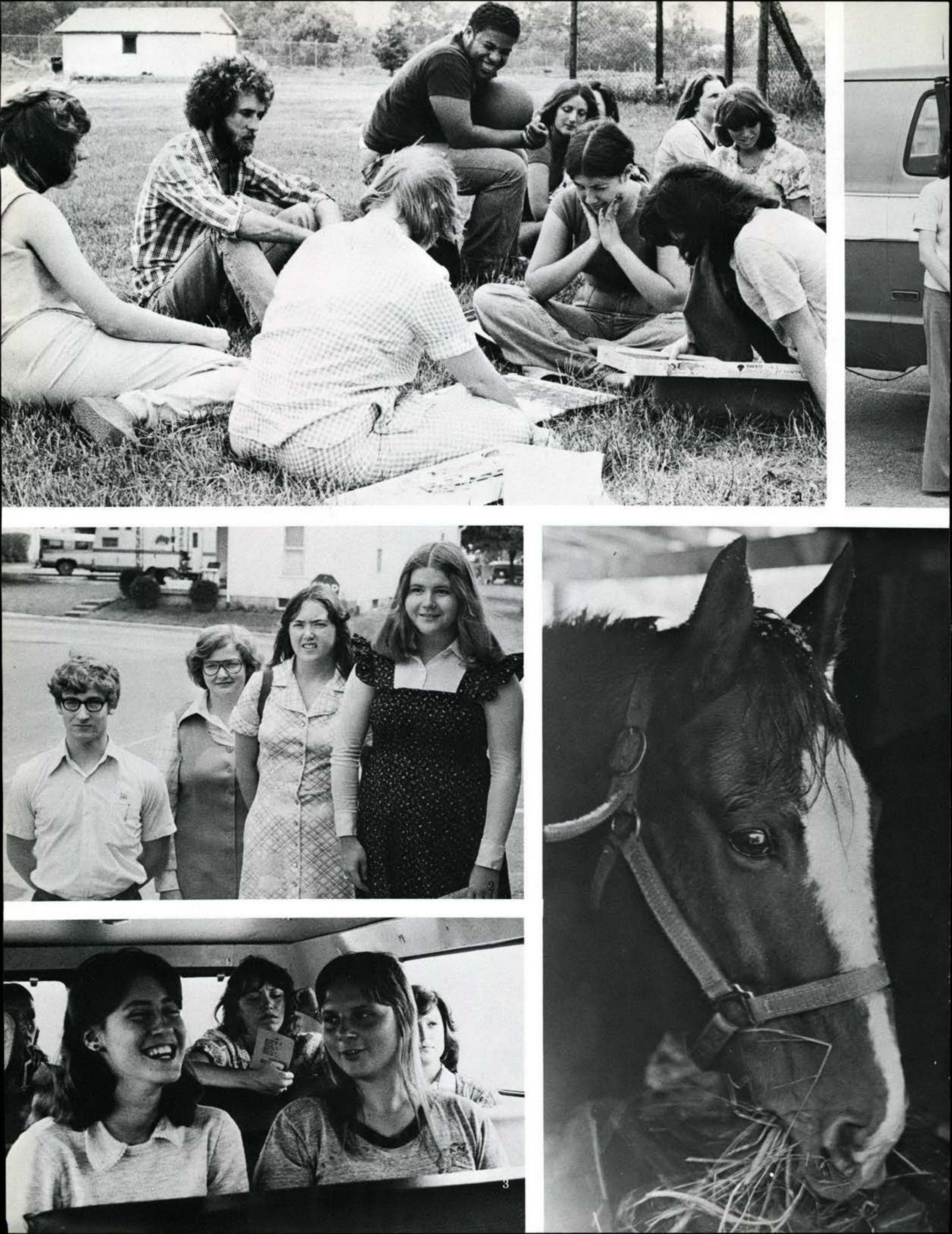




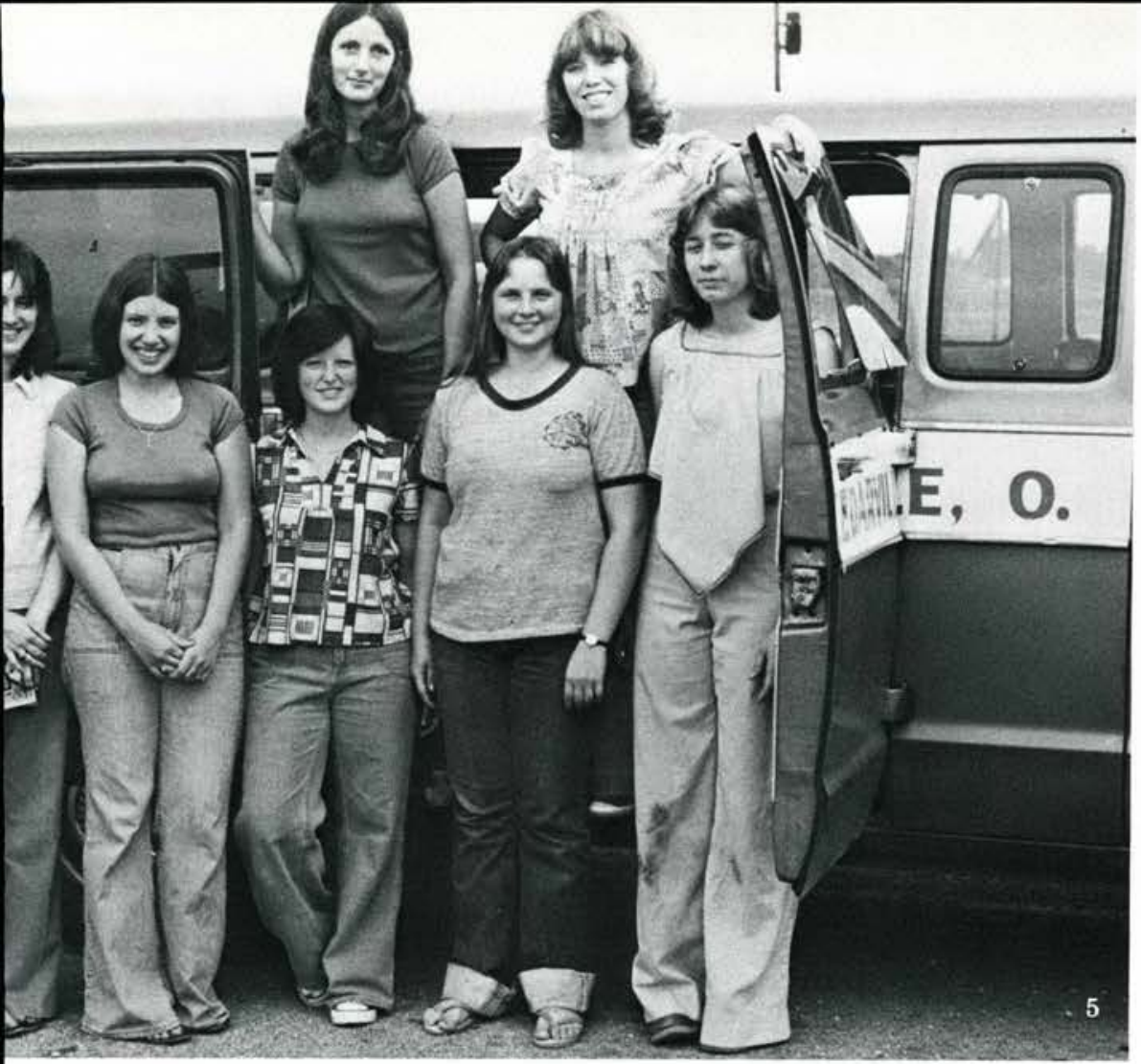

A Time For
Sharing Christ

Four Oaks, formally Happy Timers, is a Christian Service which gives students an opportunity to have camp-outs, activity times, and Bible studies with mentally retarded children. Sometimes students care for these youngsters during parent-teacher activities.

The Yellow Springs Riding Group gives students time to talk and possibly witness to others while walking their horses.

1. As the excitement of the game becomes more intense, the players draw a crowd of supporters.

2. Yellow Springs Riding Group: D. Denny, J. Arthur, K. Gray, T. Combs.

3 . The van rides provide a chance for workers to learn and share with each other. 4. One of the animal friends isn't about to stop what he's doing to get his picture taken

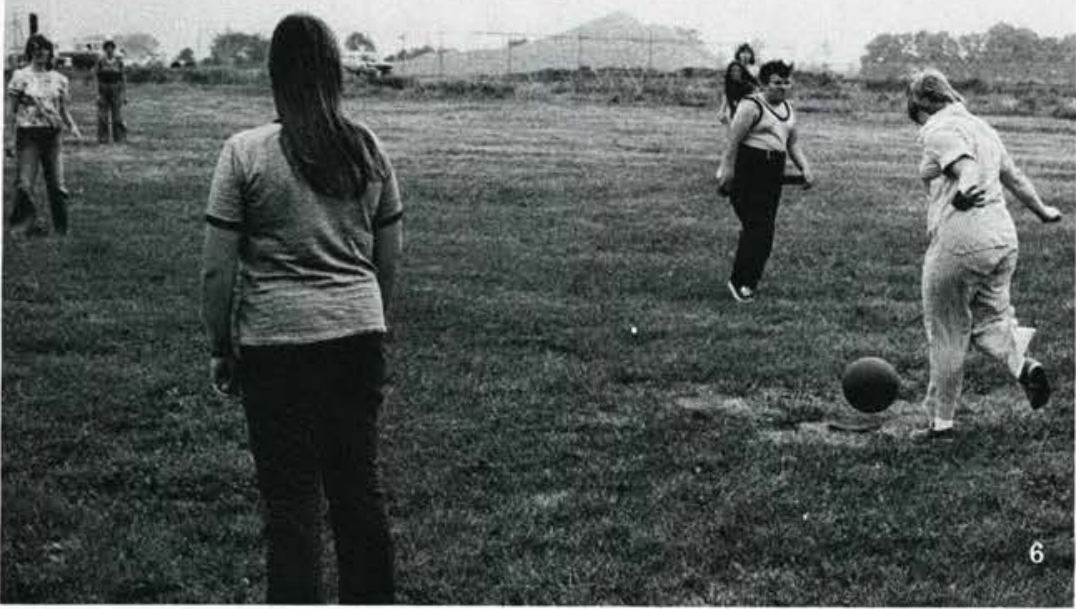

5. Four Oaks: FRONT ROW: D. Mast, S. Scoggins, P. Gilbert, D. Miller, C. Brown; BACK ROW: J. Prugh, J. Bubel.

6. A game of kickball is enjoyed by all. 7. Darlene Miller realizes that individual attention is very important in building friendships.

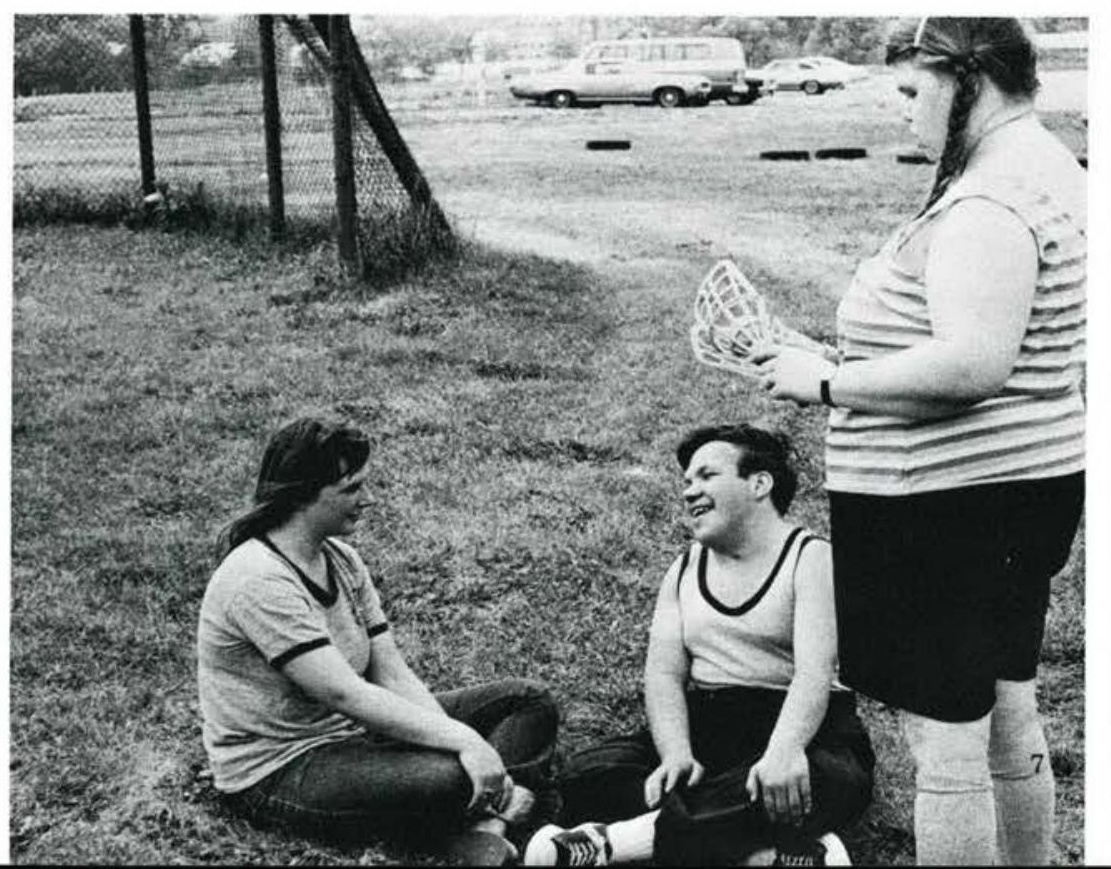




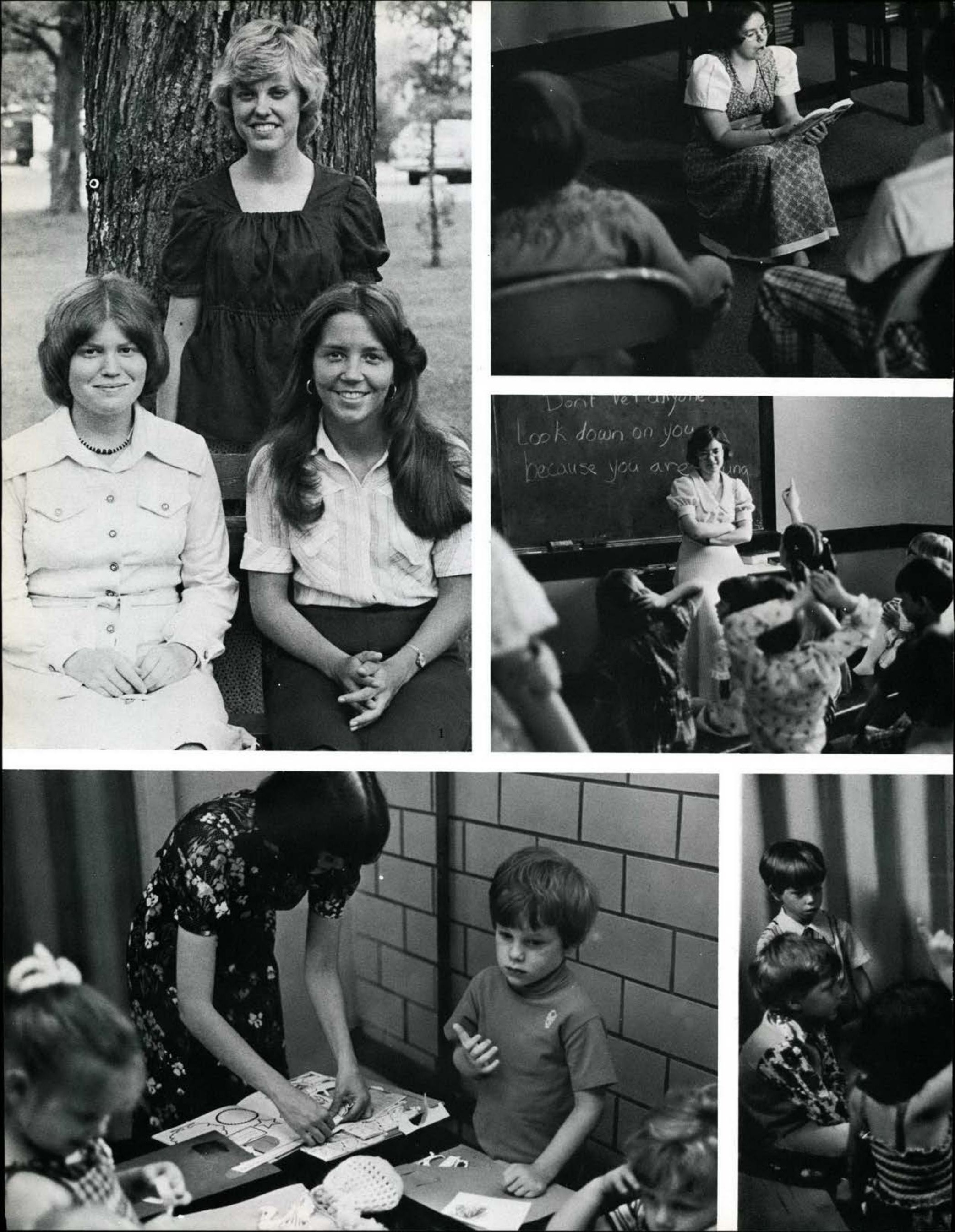




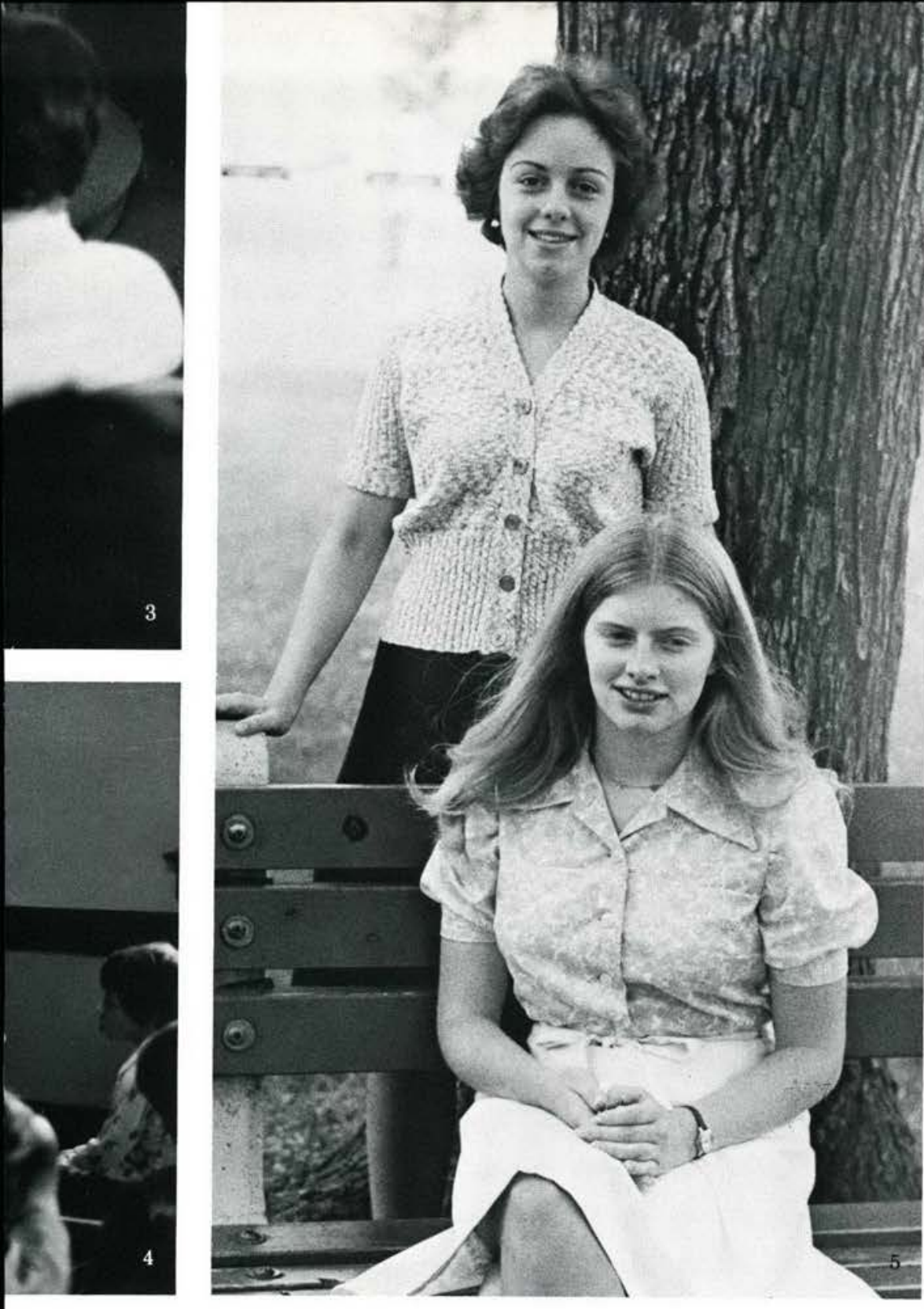

\section{Ministering To Children}

At Barney Children's Hospital volunteer groups talk with youngsters in their rooms and in the game room. Contacts with parents are often made in this Christian Service.

Children's church or junior church programs are held at two churches, First Reformed and Emmanuel Baptist. Students are involved in this program which meets every Sunday to conduct the singing or teaching.

1. Children's Church: K. Anderson, S. Shaw, D. Gawthrop.

2. Through handcraft projects Debbie Gierhart utilizes a means of reaching children. 3. A story of our Savior's love is read to eager listeners.

4. The children tell Melissa Shugars what they have learned.

5. Children's Hospital workers are Lisa Overturf and Vicki Burleson.

6. Chris Taylor teaches the children a new song.

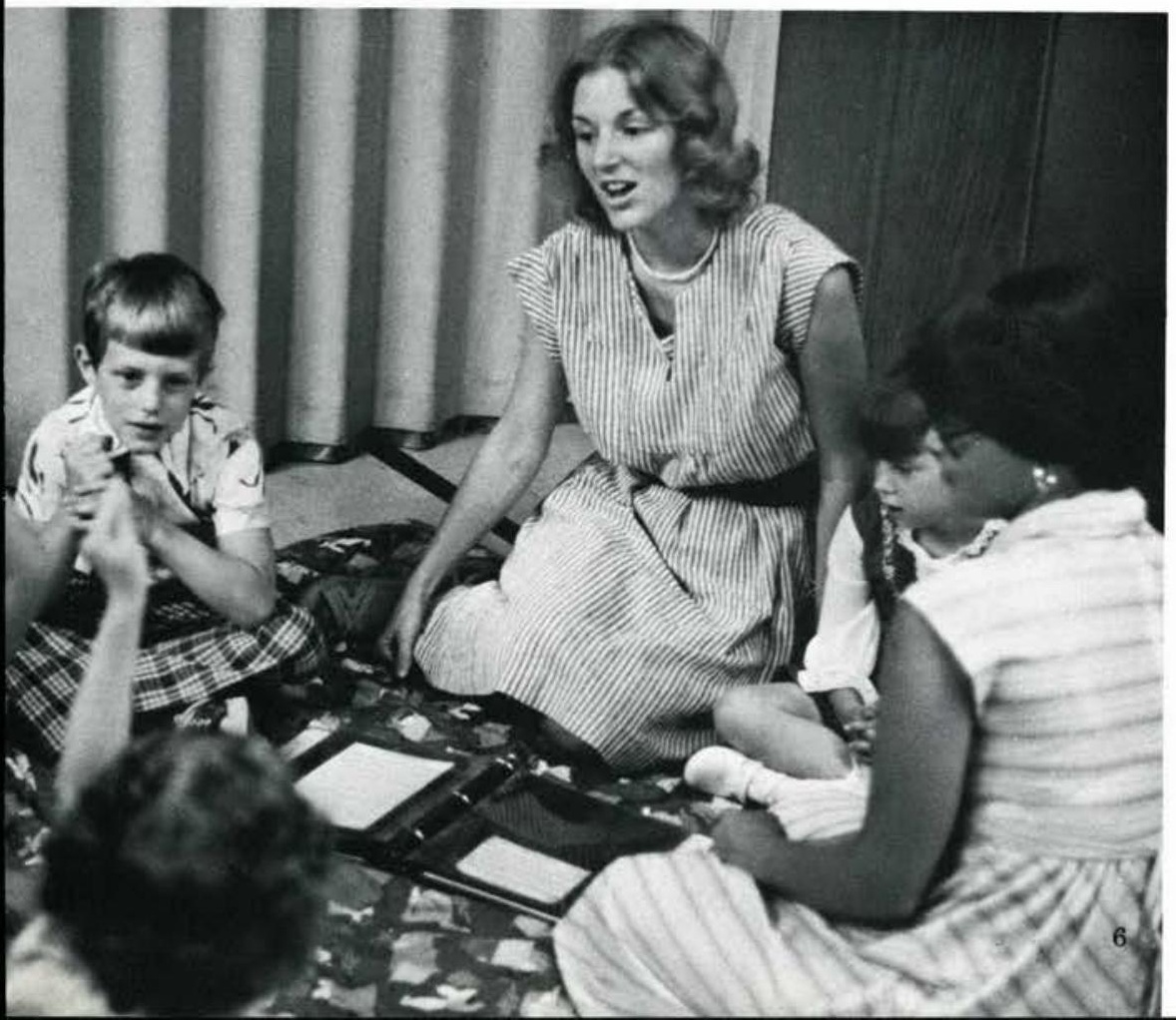



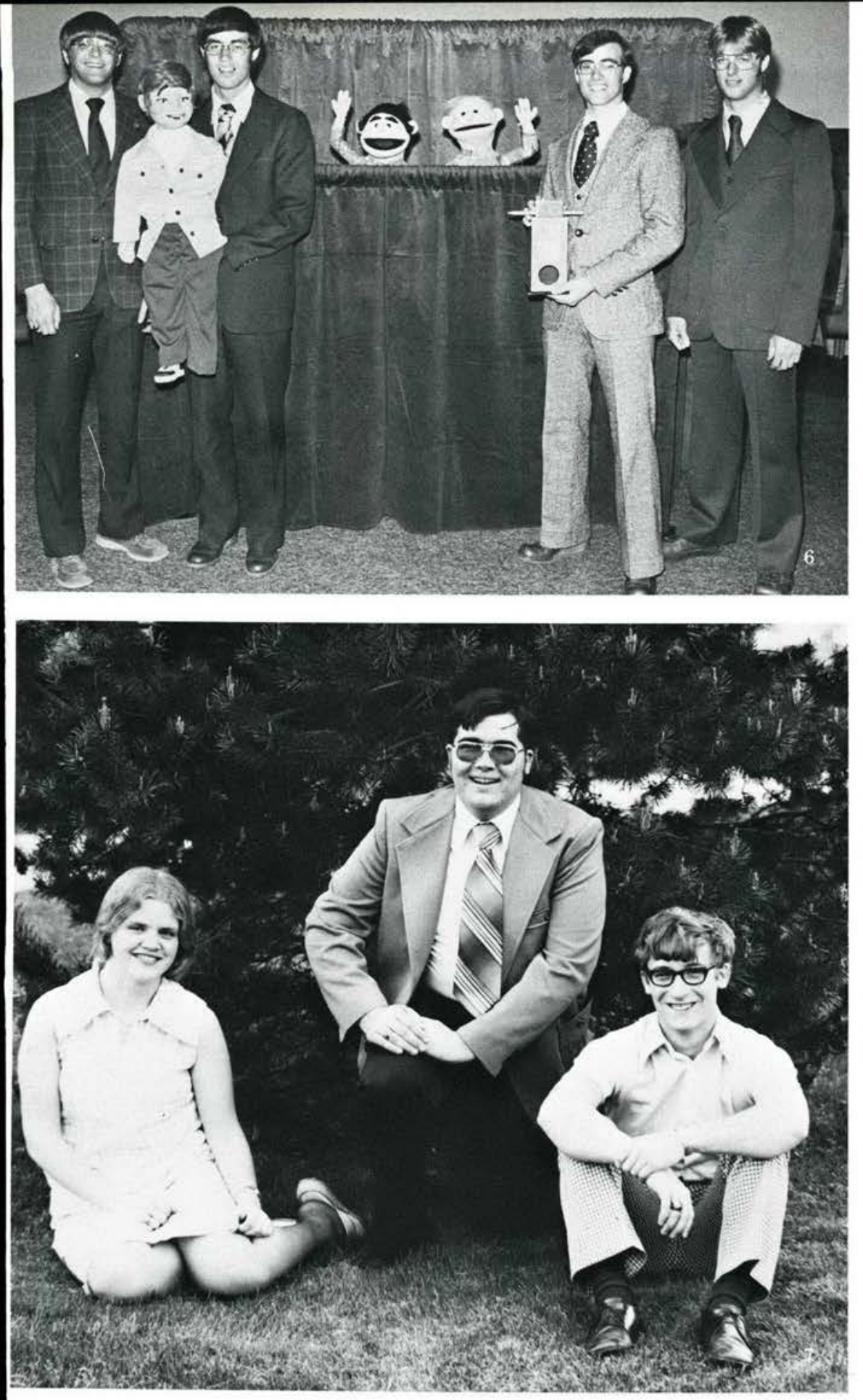

\section{Summer}

\section{Is No Time To Quit}

The summer brings with it many opportunities for Cedarville students to take an active role in Christian service and missions. Abundant Life, Summer Swordbearers, and The Master's Muppets travel the United States spreading the Good News of Jesus Christ; and, through the Missionary Internship Program, students assist missionaries in eighteen different parts of the country and the world.

1. Summer Swordbearers: FRONT ROW: D. DeNicola, C. Phillips; SECOND ROW:

D. Green, B. Taylor, S. Miller, M. Bleeker, D. Ormsbee; BACK ROW: L. Kuschel, D. Stoner, P. Henry, C. Miller.

2. Scotland: A. Henning, T. Gibbons, K. Haga.

3. Israel: FRONT ROW: D. Radcliffe, B Beikert, J. Smith; BACK ROW: M. Kessel, J. Vogel.

4. Australia: FRONT ROW: E. Roberts, M. Bentley, D. Jackson, K. Howell, B. Hobar, D. Jackson, Pastor Green, S. Ott; BACK ROW: M. Norne, D. Wickman, S. Brown, R. Eaton, K. Amstutz, S. Perry.

5. Bonaire: D. Monts; Mexico: K. Gray. 6. Master's Muppets: C. Colas, B. Waggoner, D. Christian, B. Carroll.

7. Utah: G. Longnecker; West Virginia: R. Connors; Utah: D. Denny.

8. Philippines: FRONT ROW: M. McDougal, D. Green, D. Chesser; BACK ROW: R. Carr, R. Floyd, J. Potter, K. Kauffman, M. Streitmatter, C. Searles, Coach Callan.

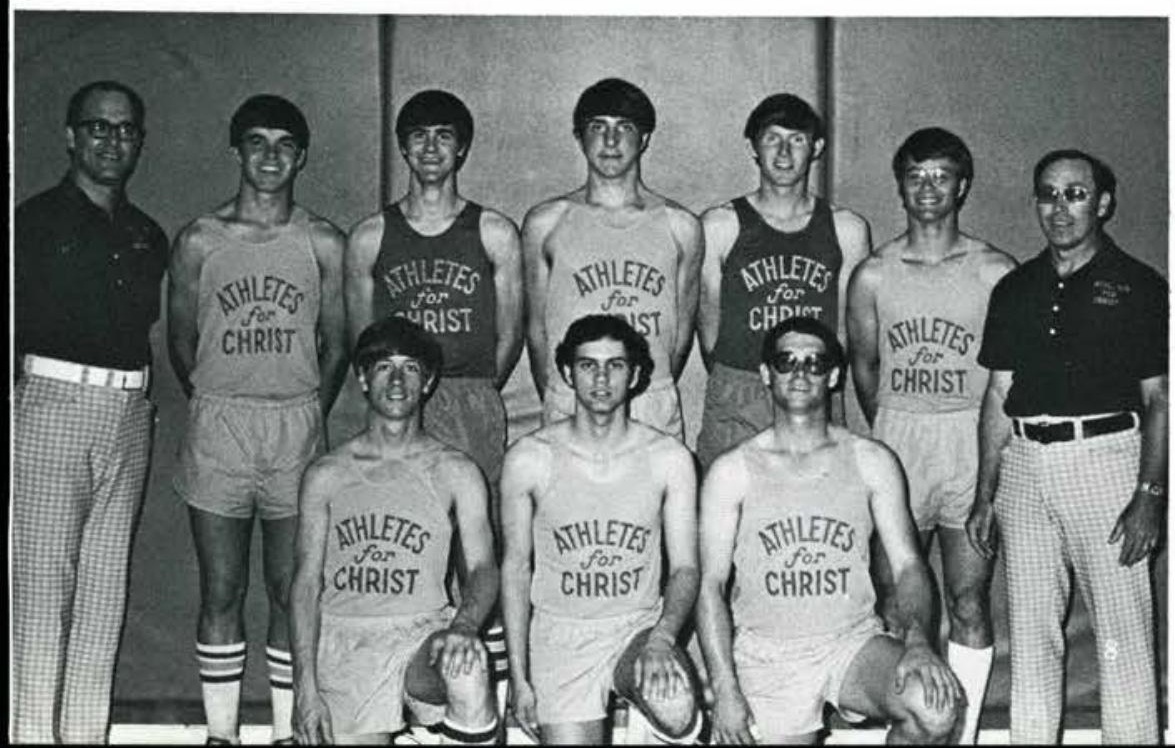




\section{Understanding And Knowing God}

James Murray Grier was born July 23, 1932 in Staten Island, New York. He came to a saving knowledge of Jesus Christ at the age of 14. Following high school, he attended Brooklyn Polytechnical Institute for electrical engineering. Upon his father's urging, Mr. Grier transferred to Baptist Bible College Seminary in Johnson City, New York. After completing the five-year program for the Bachelor of Theology Degree, he still felt unprepared for the Lord's work. Therefore, he went on to Grace Theological Seminary and remained there for the next three years, receiving his Master's of Divinity at the end of the period.

James M. Grier was ordained in 1961 from his home church in Staten Island, New York. He pastored two churches - one in North Adams, Michigan, and the other in Taylor, Michigan. He then came to Cedarville College where he became employed as a fulltime teacher. He has recently completed his Master's of Theology which he obtained from Westminster Theological Seminary.

Jeremiah 9:23, 24 is the goal of Mr. Grier's life which says: "Thus saith the LORD, Let not the wise man glory in his wisdom, neither let the mighty man glory in his might, let not the rich man glory in his riches: But let him that glorieth glory in this, that he understandeth and knoweth me." We who have been under the instruction of this man know this verse to be true in his life. God has given him an understanding and knowledge that he imparts to his students so that they, too, may know God exalt Him. Daily lectures consist of exhorting the students to a better understanding of the Creator of the universe. We come to know God and are stilled and awed by what has been revealed to us. We thank this teacher for bringing us to a relization of Who god is. For this reason, we of the yearbook staff dedicate the 1977 Miracle to Mr. James M. Grier. 


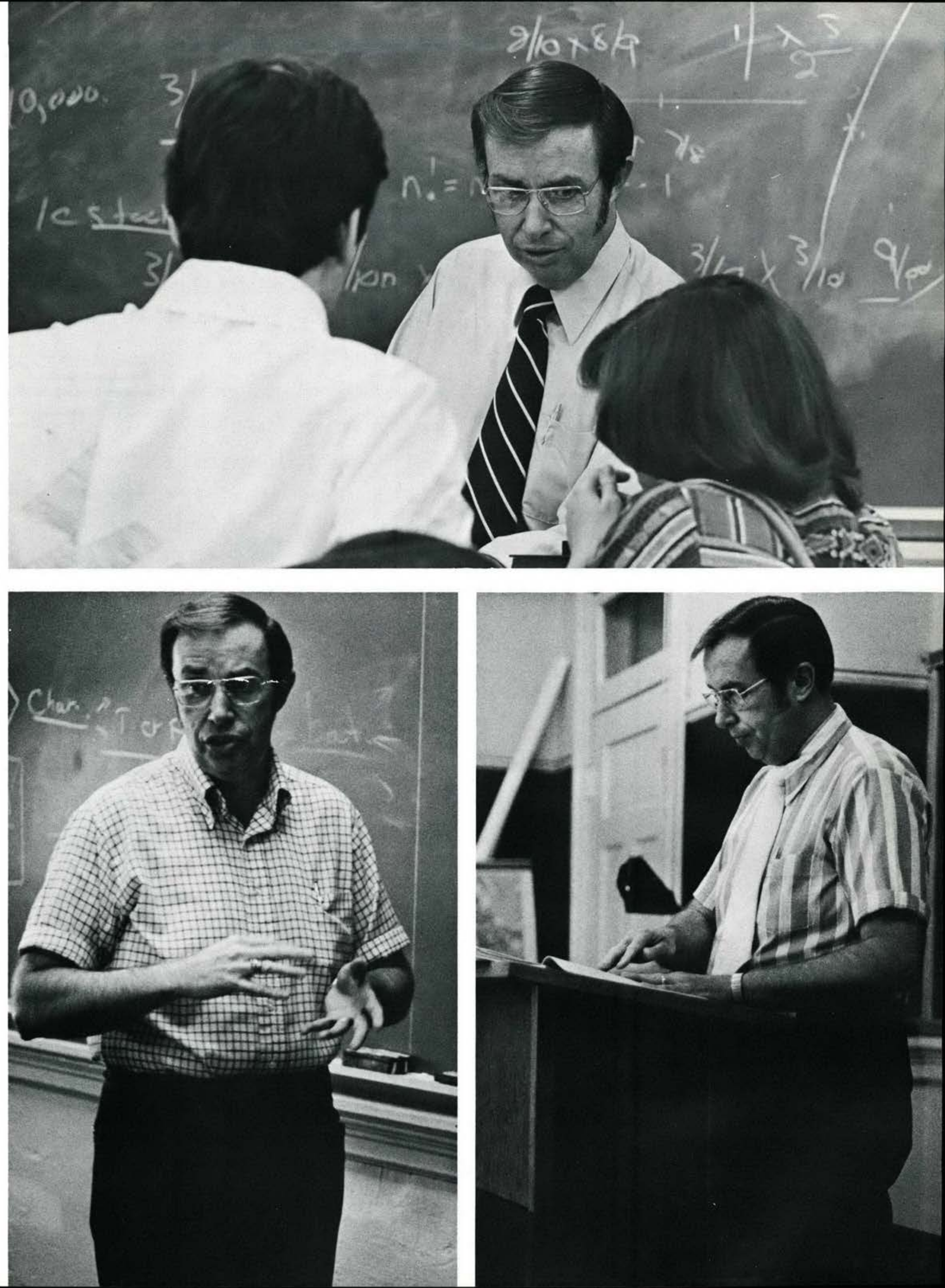




\section{It's $A$ Miracle}

The common phrase around the workroom in reference to the yearbook's completion is ... it's a miracle! And It's true - when one considers the hours spent in putting the yearbook together, it is a miracle when the final deadline is met. But we of the 1977 Miracle Staff give the glory to God in respect to the work accomplished for this is His book, to be used for His purpose. It was $\mathrm{He}$ Who gave the ideas for the theme and how it was to be carried out; it was $\mathrm{He}$ Who saw that everything went according as He planned.

As we read this yearbook now, we the staff can sit back and reflect upon the message that is being conveyed.

We hope that you, too, can see that God is exalted in its pages.

1. Assistant Editor Lynn Beck crops the pictures that correspond to her witty captions.

2. The ladder is changed once again by Editor Carla Morley.

3. Sales of old yearbook pictures are always a success.

4. The door to the yearbook room is a friendly greeting to the staff.

5. Photographer Mark McDougal takes a break from his busy picture schedule to catch up on studies.

6. Miracle Staff: V. Pristera, P. Hayes, J. Acker, L. Beck, P. Arvay, C. Danielson, C. Morley, R. Wuebben, Charlie Miller, J. Harriman, Marlin Rayburn.

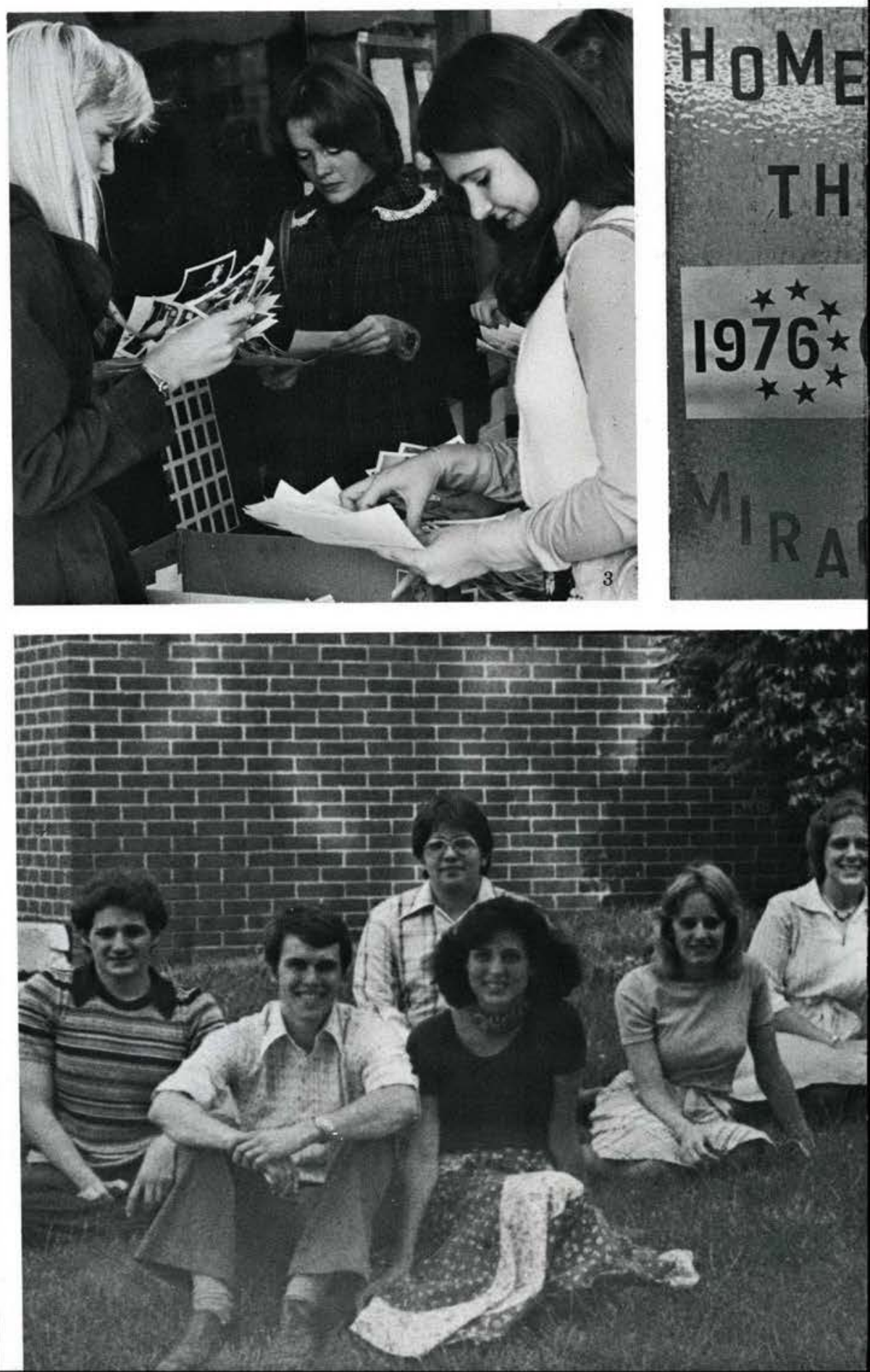



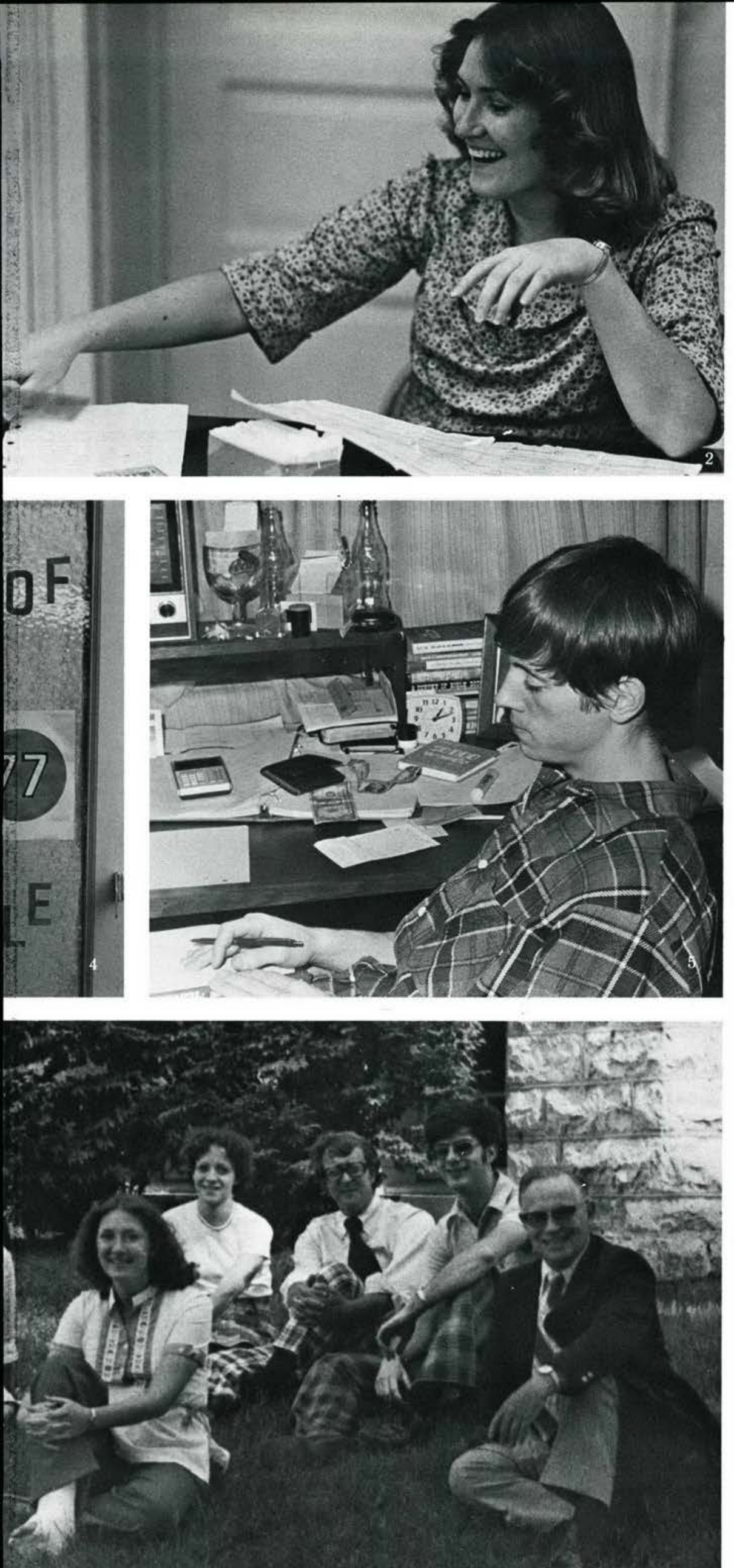

\section{7 \\ Staff}

Adviser

Marlin Rayburn

Josten's American Representative Charlie Miller

\section{Editor}

Carla Morley

Assistant Editor

Lynn Beck

Business Manager

Debbie Clough

Staff

Jeff Acker

Paula Arvay

Kathy Brower

Cheryl Danielson

Pat Farmwald

Carole Green

Phil Hayes

Connie McLane

Cindy Orrick

Karen Price

Val Pristera

Rose Ricker

Renee Wuebben

Photographers

Jim Barrett

Mark Castellani

John Dannenberg

Dave Denny

Joel Harriman

Mark McDougal

Amy Ross

Special Thanks To ............

Brinker Beck

Austin Elmore

Roy Kern

Dana Kyle

Wendy McNiece

Jack Nace

Jim Neely

New Life Media

Dan Stevens

Darlene Tillson

Myron Youngman

For Photographs Used 


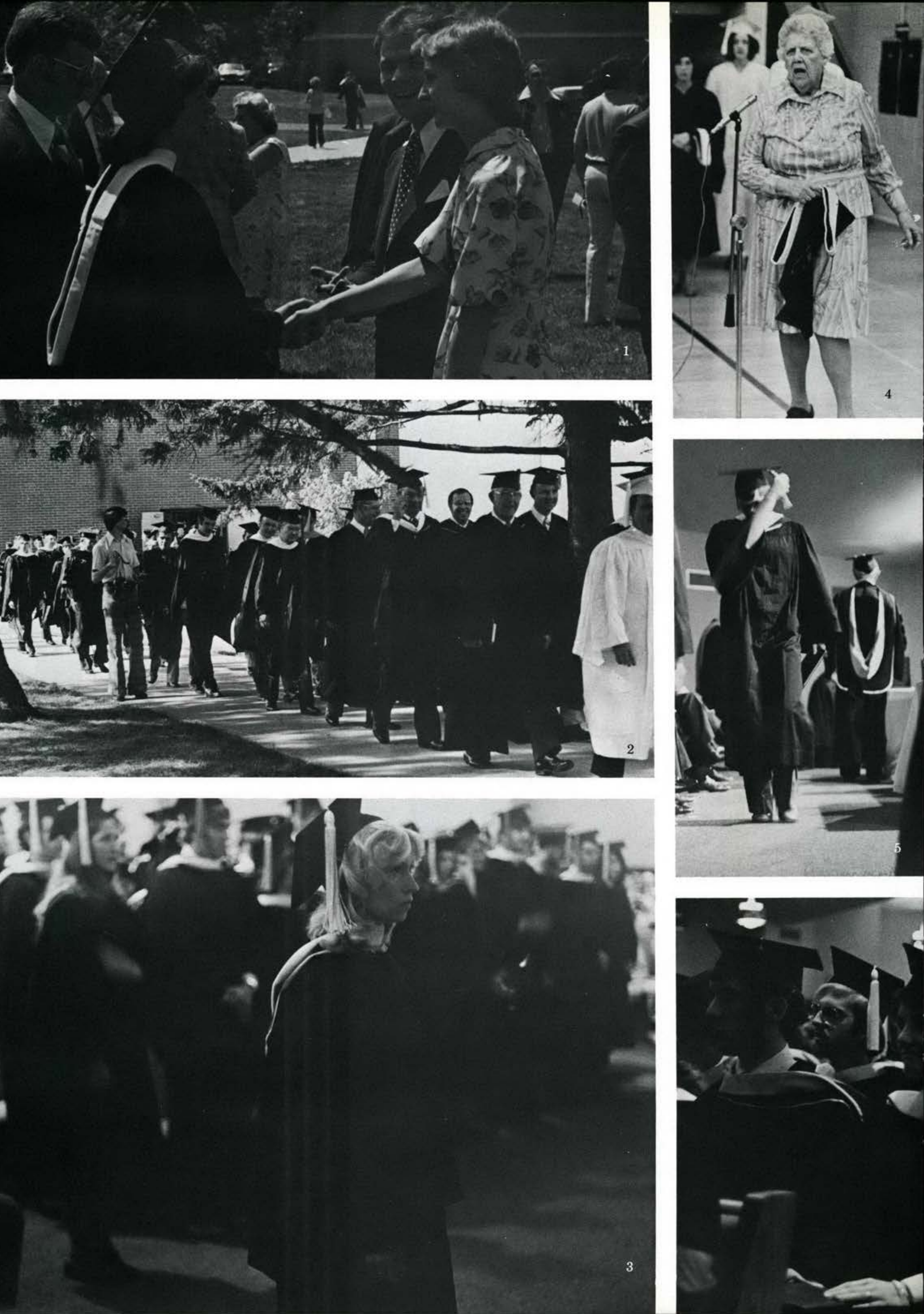



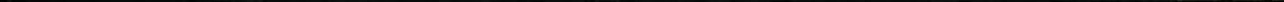

\section{The End; Yet The Beginning}

Graduation day is warm and sunny as the 1977 graduating Seniors march to receive their diplomas. Commencement exercises are held in the College Chapel on June 4. During the service, Miriam Maddox is honored for her 20 years of serving as director of the procession; honorary degrees are conferred upon Donald Leslie Tyler and Gerald V. Smelser; and Dr. James T. Jeremiah, President of Cedarville College, announces that the school year for 1977-78 is to be his last at the college.

Being a graduating Senior is the end of one's days at college - but it is the beginning of new experiences in the area that the Lord has chosen for each student. It is our hope as the Class of 1977 that we will truly live "For the Word of God and the Testimony of Jesus Christ".

1. Lydia West gives Barb Barrett a hearty handshake after the exercises.

2. The procession begins for the 1977 graduates.

3. Waiting for her name to be read, Margo Axiotis Barnett reflects the seriousness of the ceremony.

4. Miriam Maddox, in charge of graduation for the past twenty years, gives final instructions to this year's grads.

5. Rick Kline remembers to move his taswel.

6. Dwight Evens seems doubtful as to the truth of the story being told.

7. Receiving her diploma is Paulette Donalson.

8. The speakers of the day keep the graduates' attention. 


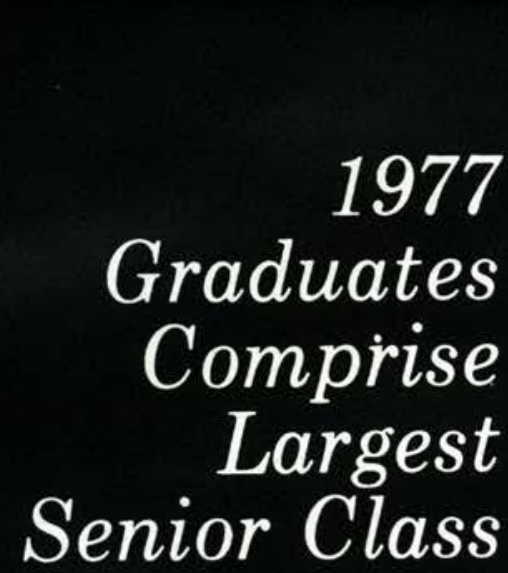

The 1977 graduating Senior Class is the largest such class in the history of Cedarville College. Its members consist of approximately 245 men and women. In February, while Cedarville was buried in the snow of the worst winter in many years, thirty-three members of the Senior Class boarded a chartered bus and departed for Florida, the land of sun and fun. Originally choosing Toronto, Canada as their destination, the class later changed its plans to journey to Disney World and Daytona Beach.

One of the projects that the class used to raise money for the trip was the selling of family portraits through New Life Media, a photography studio staffed by Cedarville College alumni.

Rescue Kits were also essential in providing the means for the trip.

1. "You're kidding! The test has been cancelled?!" laments Merle Zeigler.

2. Marlin Cayton pouts: "But I want to play Cowboys and Indians!"

3. Impatient for her turkey, Debbie Biggs begins to nibble on her menu.

4. Pick your own caption:

a. Dan Riedel calls the masses to repentance.

b. "If I have to wear this silly robe, then why can't girls wear pants?"

c. "Is an 'A' in Fundamentals of Speech worth all this fuss?"

5. Drastic measures have been employed by the Senior Class Officers to insure graduation for all Seniors. The officers are: Becky Reid (Student Senate), Paulette Donalson (Treasurer), Wes Johnson (Chaplain), Val Pristera (Vice President), Barb Beikert (Secretary), and Phil Hayes (President). Not pictured is Bruce Keizer (Student Senate).
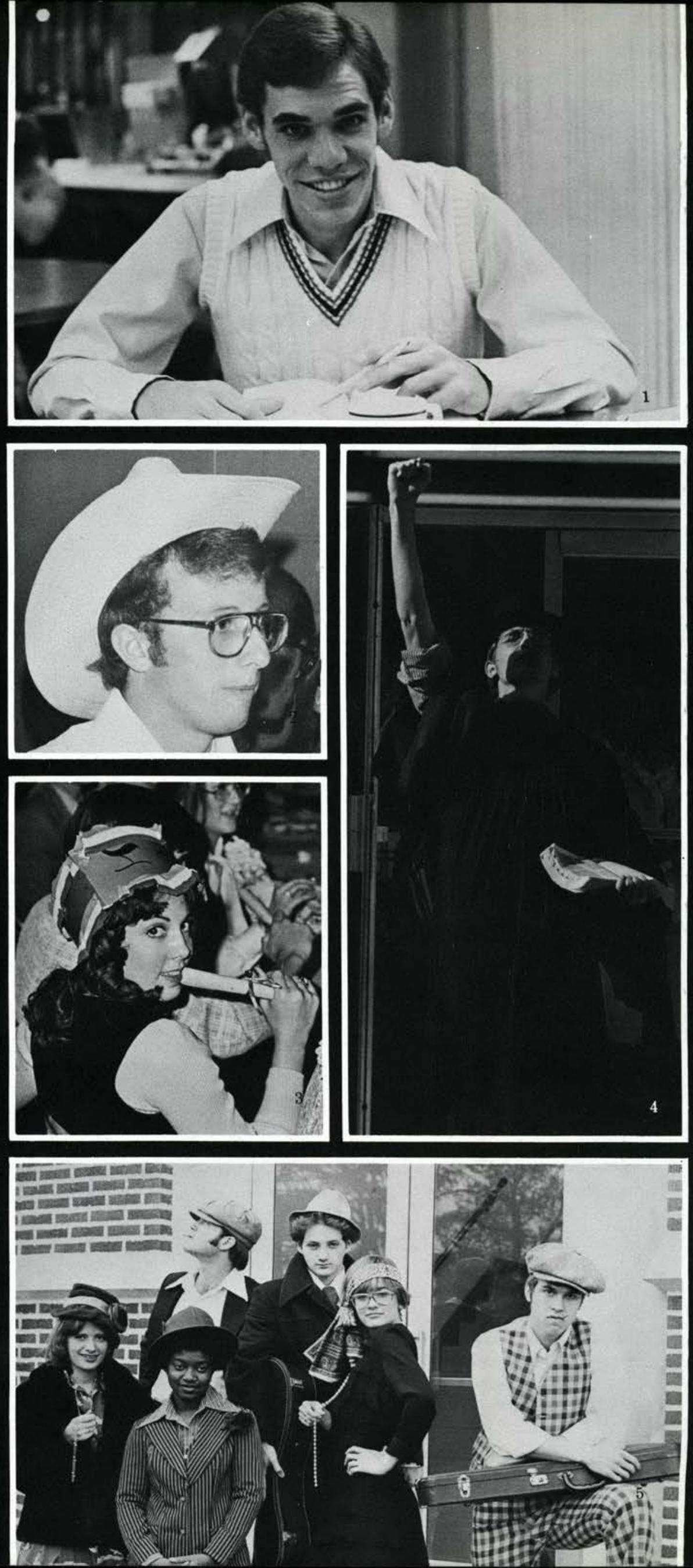

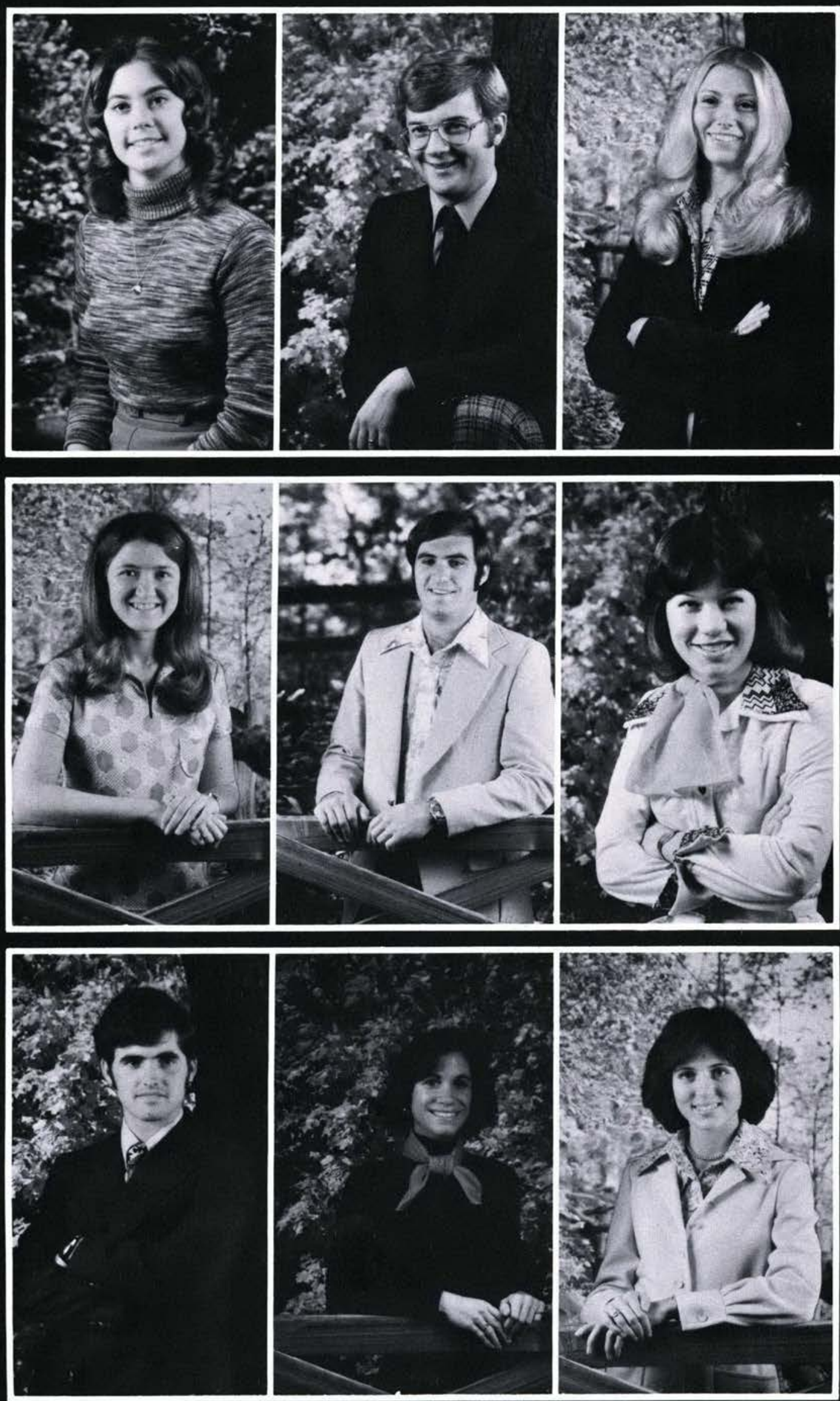

Patty Andes

Music

Pottstown, PA

Richard Auwarter

Physical Education

Cedarville, $\mathrm{OH}$

Margo Axiotis

Elementary Education

Silvis, IL
Terry Baker

Elementary Education Northfield, $\mathrm{OH}$

Robert Balais

Pre-Seminary

Boca Raton, FL

Barbara Barrett

Elementary Education Amherst, $\mathrm{OH}$
Don Bartemus

Bible

Pasadena, MD

Leah Bathurst

Behav. Sci./Psychology

Dalton, PA

Lynn Beck

Biology

Saugerties, NY 
Beverly Begley Biology North Tonawanda, NY

Barbara Beikert IDS-Philosophy/History Manila, Phillippines

Debbie Benedict Elementary Education Huntington, NY

William Bernhard Pre-Seminary Toledo, $\mathrm{OH}$

Deborah Biggs Elementary Education Hudson, IA

Marlene Bleeker Speech Ames, IA

Dan Bowman Pre-Seminary Brownsbury, IN

Valerie Bowser Elementary Education Worthington, PA Juanita Brock Broadcasting Xenia, $\mathrm{OH}$
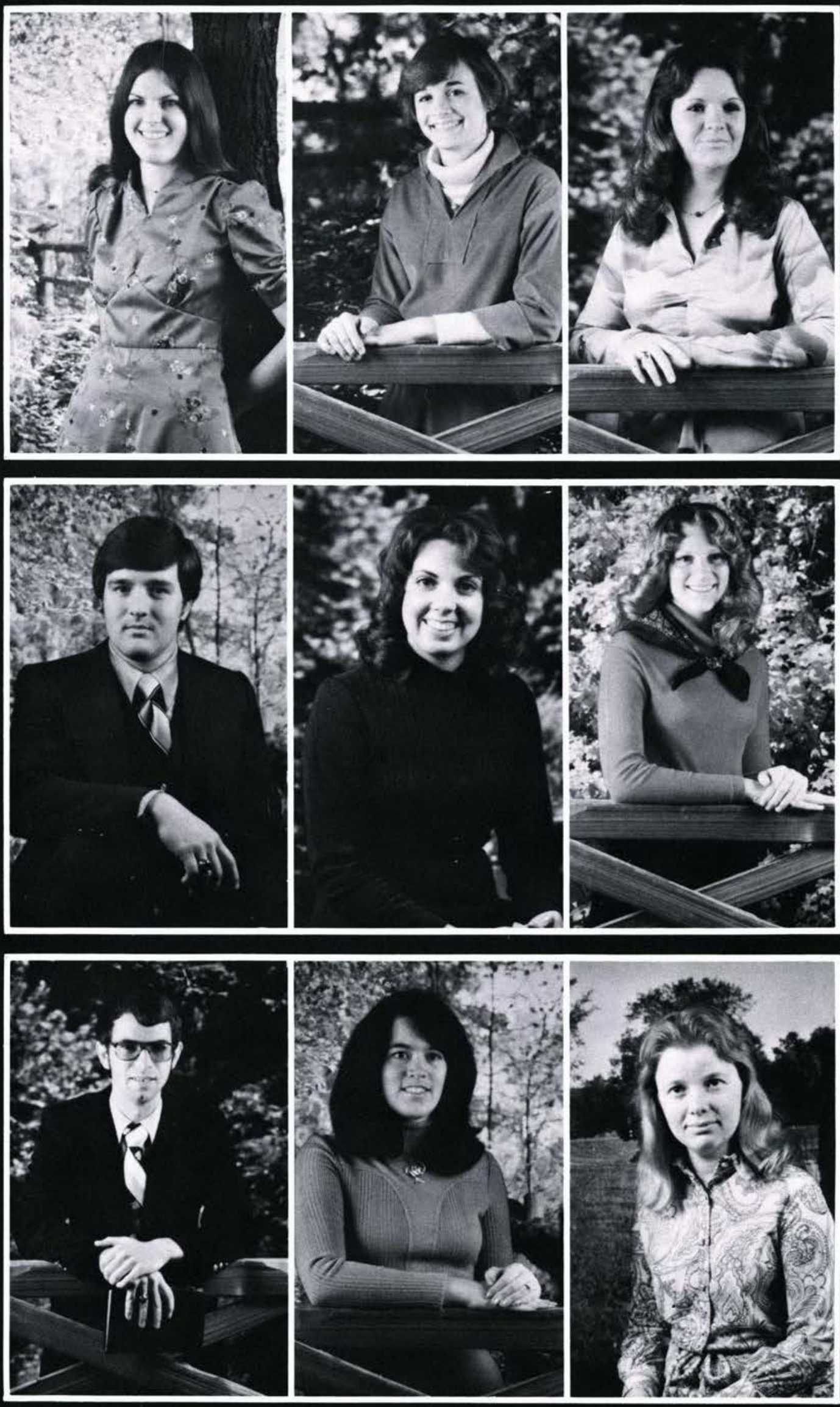
Sherry Chamblin Biology McLeana, VA

Marilee Clark Elementary Education Springfield, $\mathrm{OH}$

Ron Clark Bible Ft. Wayne, IN

History/Pol. Sci./IDS Rockbridge, $\mathrm{OH}$

Connie Clithero Elementary Education Portsmouth, $\mathrm{OH}$

Steve Combs Pre-Seminary Fairborn, $\mathrm{OH}$

Rick Commeville Pre-Seminary Brownsburg, IN

Robert Cook Pol. Sci./Broadcasting Cedarville, $\mathrm{OH}$

Dennis Crady Psychology Springfield, IL
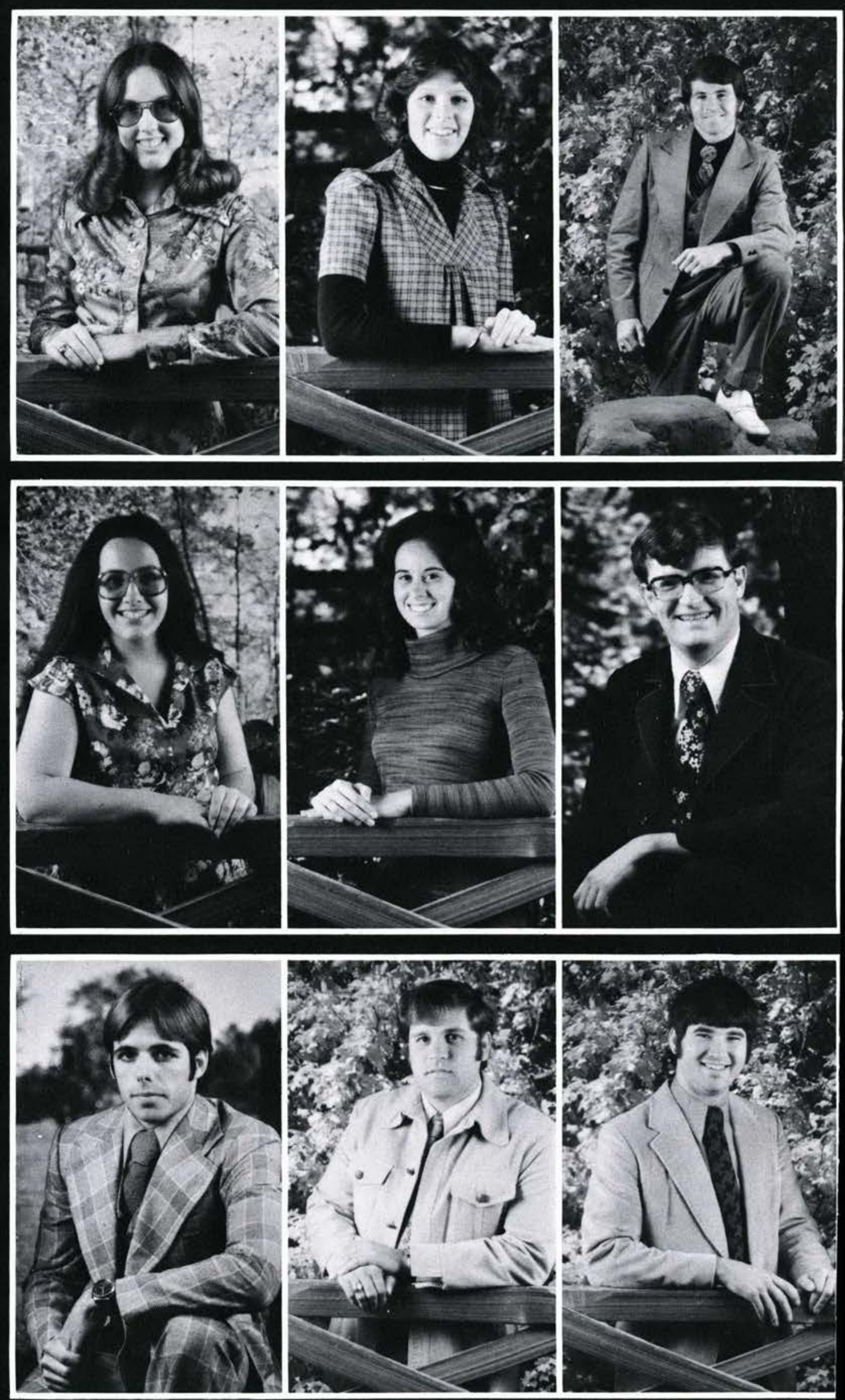
David Dernlan

Pre-Seminary/Bible

Toledo, $\mathrm{OH}$

Paula Dersham

Bible

Elyria, $\mathrm{OH}$

Tim Detwiler

Broadcasting

Bristol, IN

Mike Dolph

Broadcasting/Speech

Bellefontaine, $\mathrm{OH}$

Paulette Donalson

Communications

Hyannis, MA

Randall Douglass

Pre-Seminary/Bible

Youngstown, $\mathrm{OH}$

Bill Dunham

Business Administration

Springfield, $\mathrm{OH}$

Chuck Elliott

Comp. Social Science

Barrington, NJ

Floyd Elmore

Pre-Seminary/Bible

Xenia, $\mathrm{OH}$
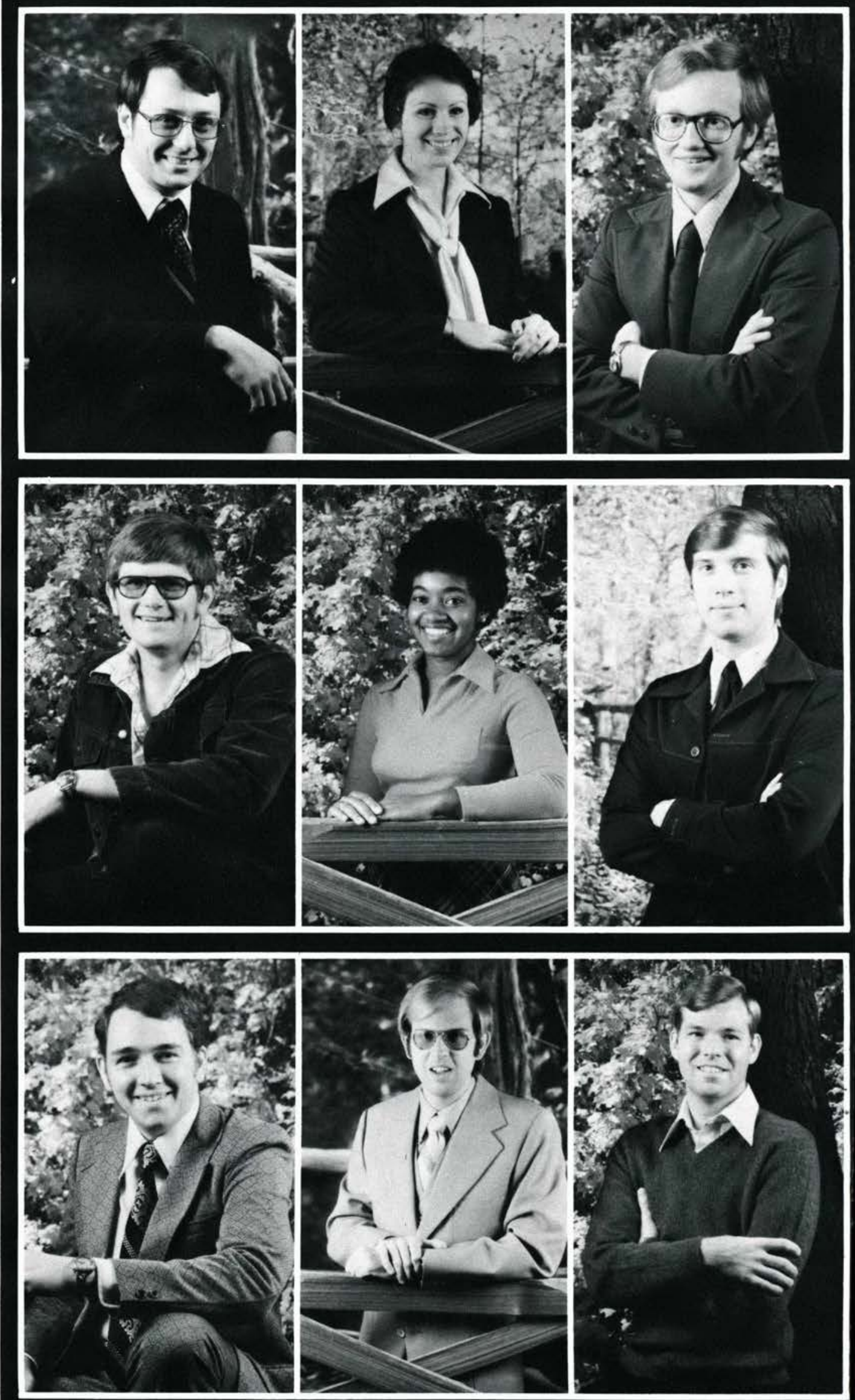
Steve Gidley

Biology

Cedarville, $\mathrm{OH}$

Deborah Gierhart

Elementary Education

Phillipsburg, KS

Warren Gifford Biology

Rockville, MD

Pennie Gilbert

Bible

Troy, MI

Brenda Giles

Elementary Education Homewood, IL

Robert Gillespie

Pre-Seminary

Cedarville, $\mathrm{OH}$

Staranna Glover

Bible

White Cloud, MI

Karen Grace

Behavioral Science

Cincinnati, $\mathrm{OH}$

Pat Grimmett

Elementary Education

Akron, $\mathrm{OH}$
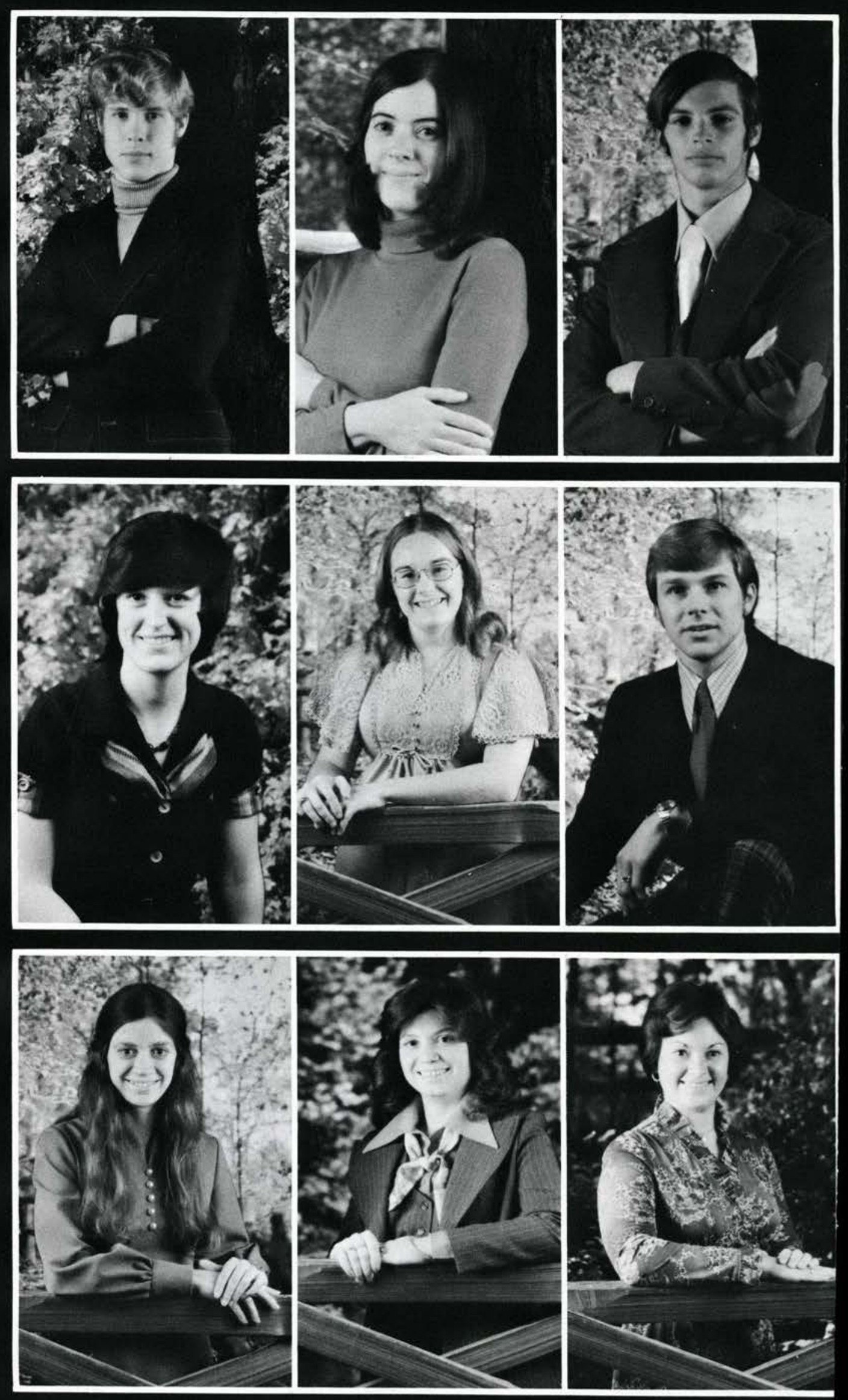
Angie Hilmes Business

Salem, AR

Jana Hoffer

Elementary Education

Portsmouth, $\mathrm{OH}$

Laurene Hollister Elementary Education Mobile, AL

Stephen Holman

IDS-Philosophy

Rives Junction, MI

Sharon Hopkins Elementary Education Holly, MI

Karla Houmes

Behav. Sci./Psychology

Hoopeston, IL

Elaine Howard Elementary Education Dubois, PA

Ken Howard Physical Education Niagra Falls, NY

Cathy Hulsman Music Education Eastlake, $\mathrm{OH}$
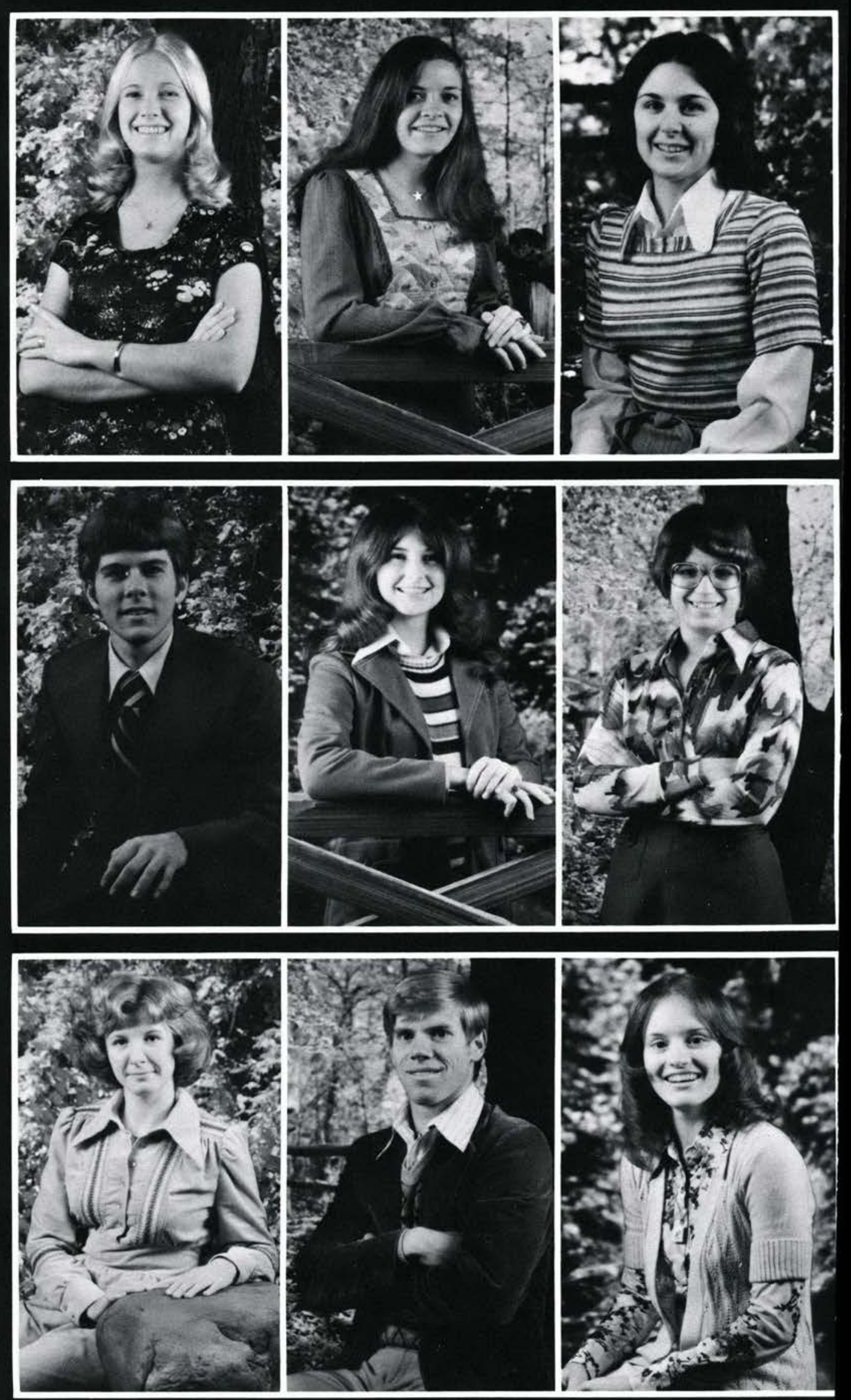

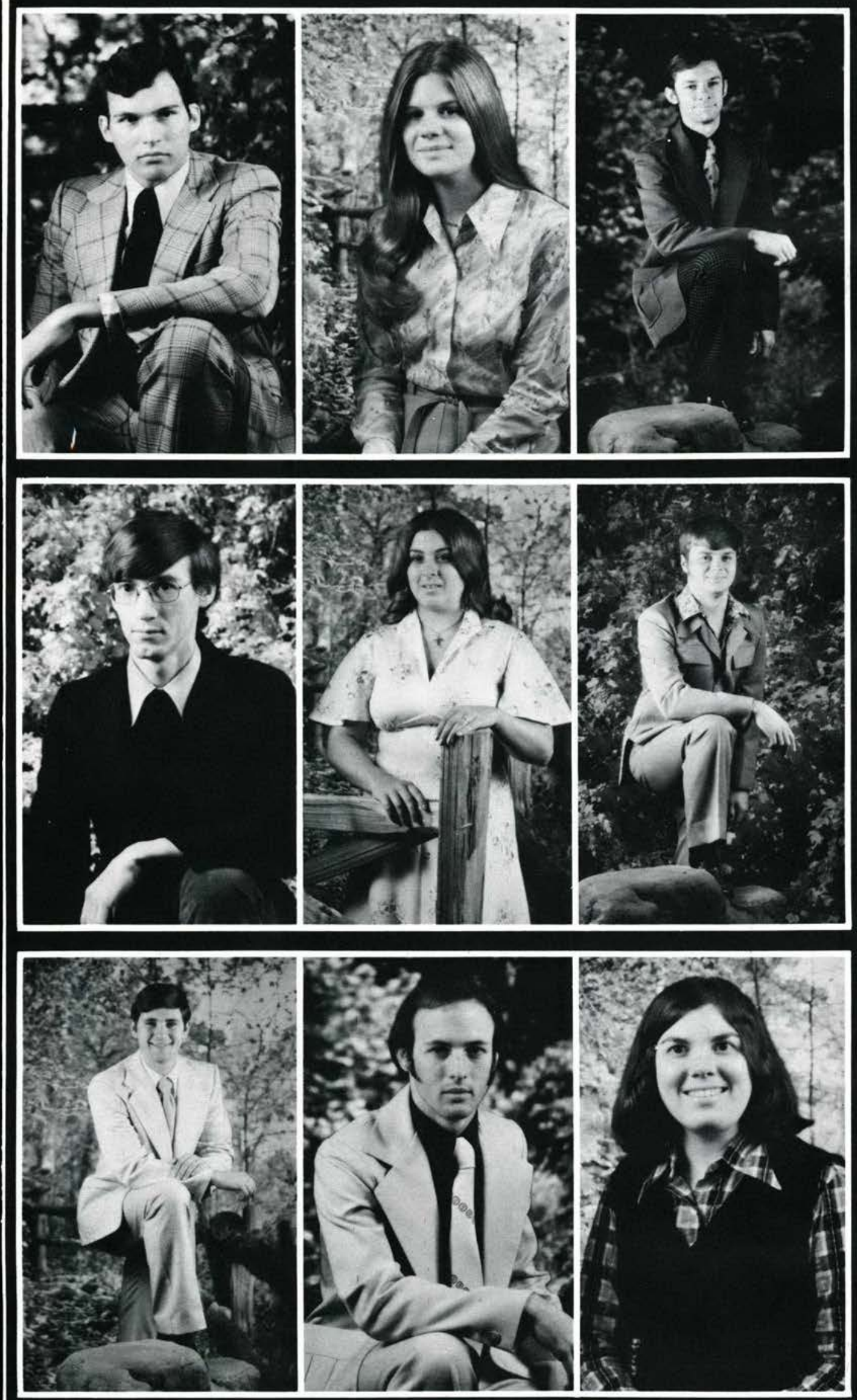

William Humphrey

Business Administration

Owosso, MI

Sue Isaacs

Social Science Education Roxana, IL

John Iseminger

Physical Education

Funkstown, MD
Michael Jackson

Business/Comp.Soc. Sci.

Bloomfield, IA

Janet Jacobitz

Behavioral Science

Flushing, MI

Keith Jant

Chemistry/Math

Erie, PA
John Jeffords

Business Administration Cedarville, $\mathrm{OH}$

Joe Jenkins

Business Administration McLean, VA

Lynn Johnson

Elementary Education

Medinah, IL 
Wes Johnson

Pre-Seminary/Bible

Medinah, IL

Tawn Jutton

Elementary Education

Cedarville, $\mathrm{OH}$

Bruce Keizer

Pre-Seminary/History

Ketchikan, AK

Loretta Keysor

Speech/English

Lima, $\mathrm{OH}$

Rebecca Klimek Music

North Jackson, OH

Rick Kline

Pre-Seminary

Nescopeck, PA

Camilla Koons

Phycial Education

Zainesville, $\mathrm{OH}$

Debra Krull

Elementary Education

Williamsville, NY

David LaBelle

Math

Akron, $\mathrm{OH}$
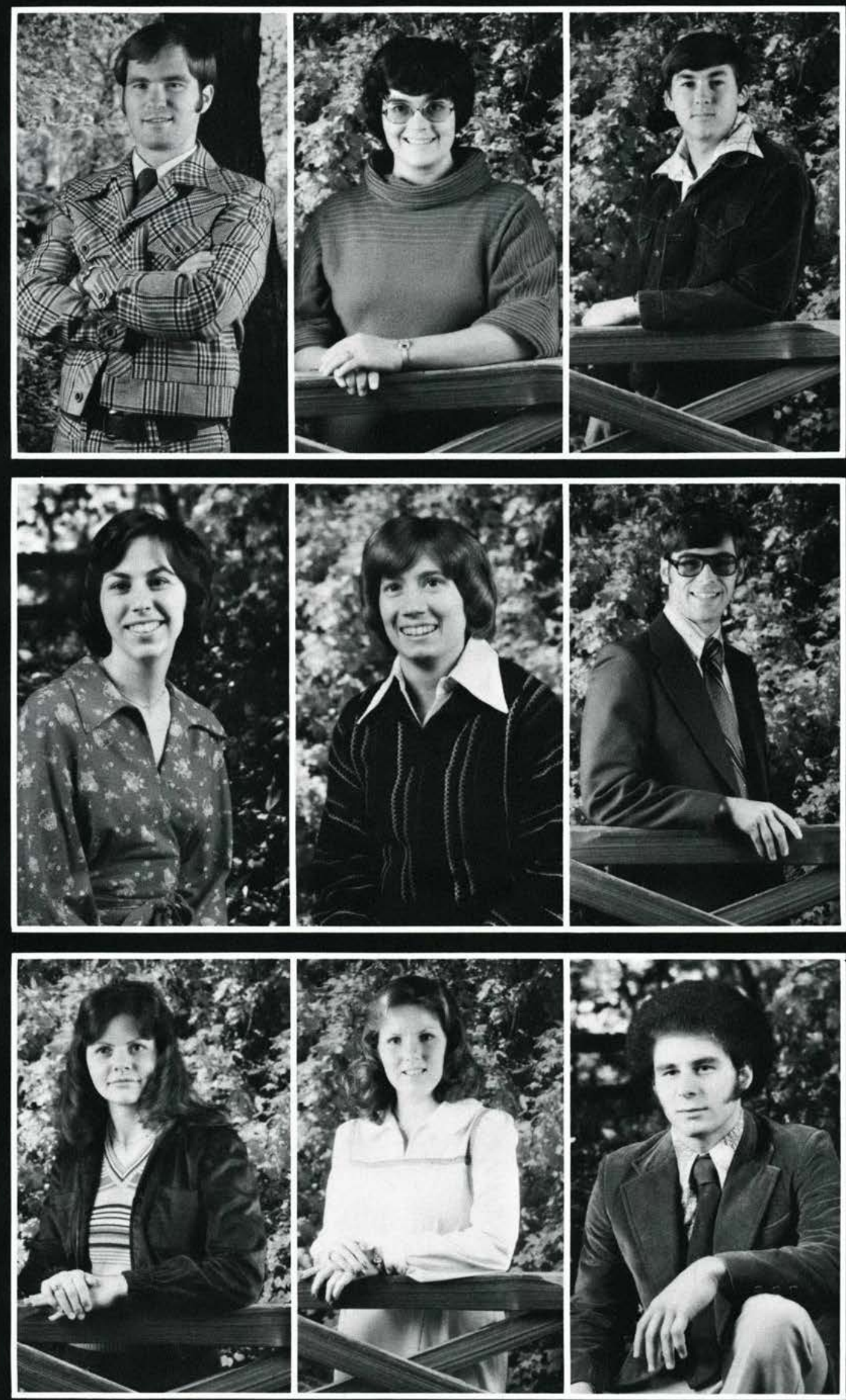

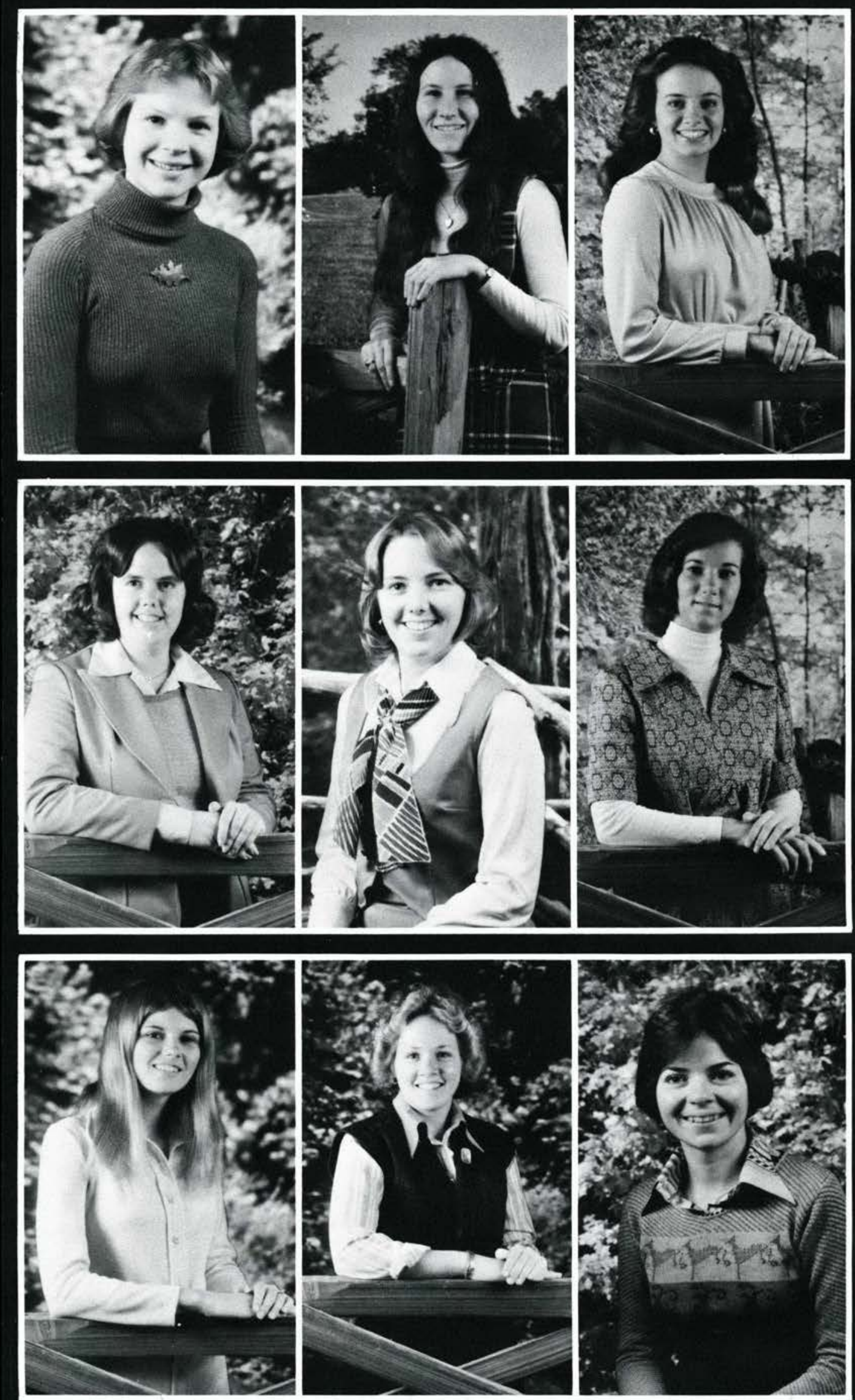

Amy Lamb

History

Springfield, $\mathrm{OH}$

Debra Leeke

Chemistry

St. Charles, MO

Mia Leisure

Elementary Education

Cambridge City, IN

Denise Lenox

Elementary Education

Columbus, $\mathrm{OH}$

Penny Linger

Elementary Education

East Liverpool, $\mathrm{OH}$

Deborah Lones

Elementary Education

Prosperity, WV

Ruth Lotz

Behavioral Science

Oxford, MI

Brenda Madeen

Biology

Jamestown, NY

Brenda Mangum

Physical Education

Stow, $\mathrm{OH}$ 
Michael Mariage

Pre-Seminary

Cedarville, $\mathrm{OH}$

Debby Martin

Behav. Sci/Psychology

Davison, MI

Sheree Martin

Elementary Education Pern, IL

Michael Mary

Physical Education Xenia, $\mathrm{OH}$

Carlton McCracken Chemistry

Curwensville, PA

Carol McFarland

Speech/English Education

Springfield, $\mathrm{OH}$

Barb McKe€

English

Kingsley, MI

Wendy McNiece

Pre-Seminary

Valparaiso, IN

Alice Miller

Speech

Lebanon, In
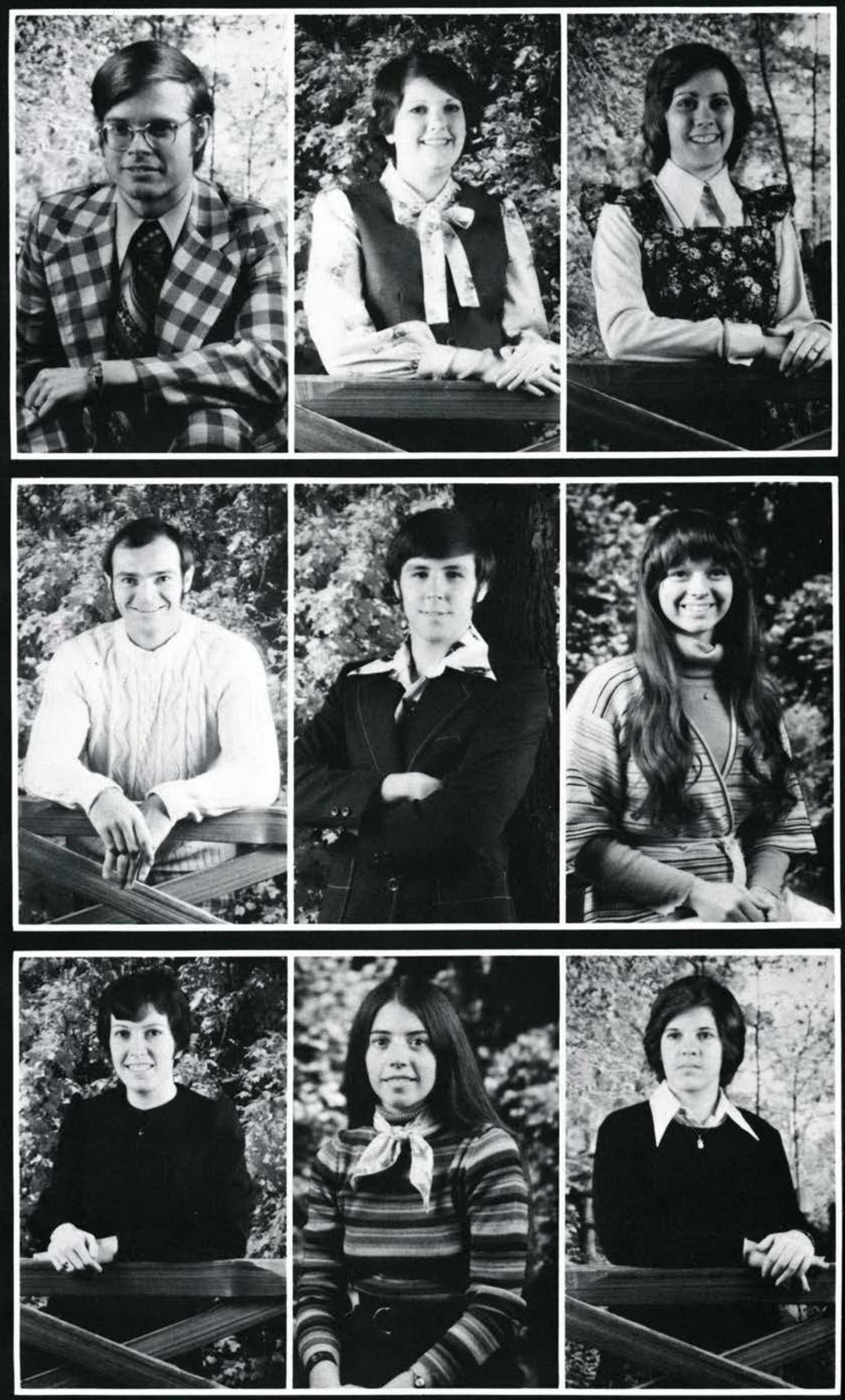


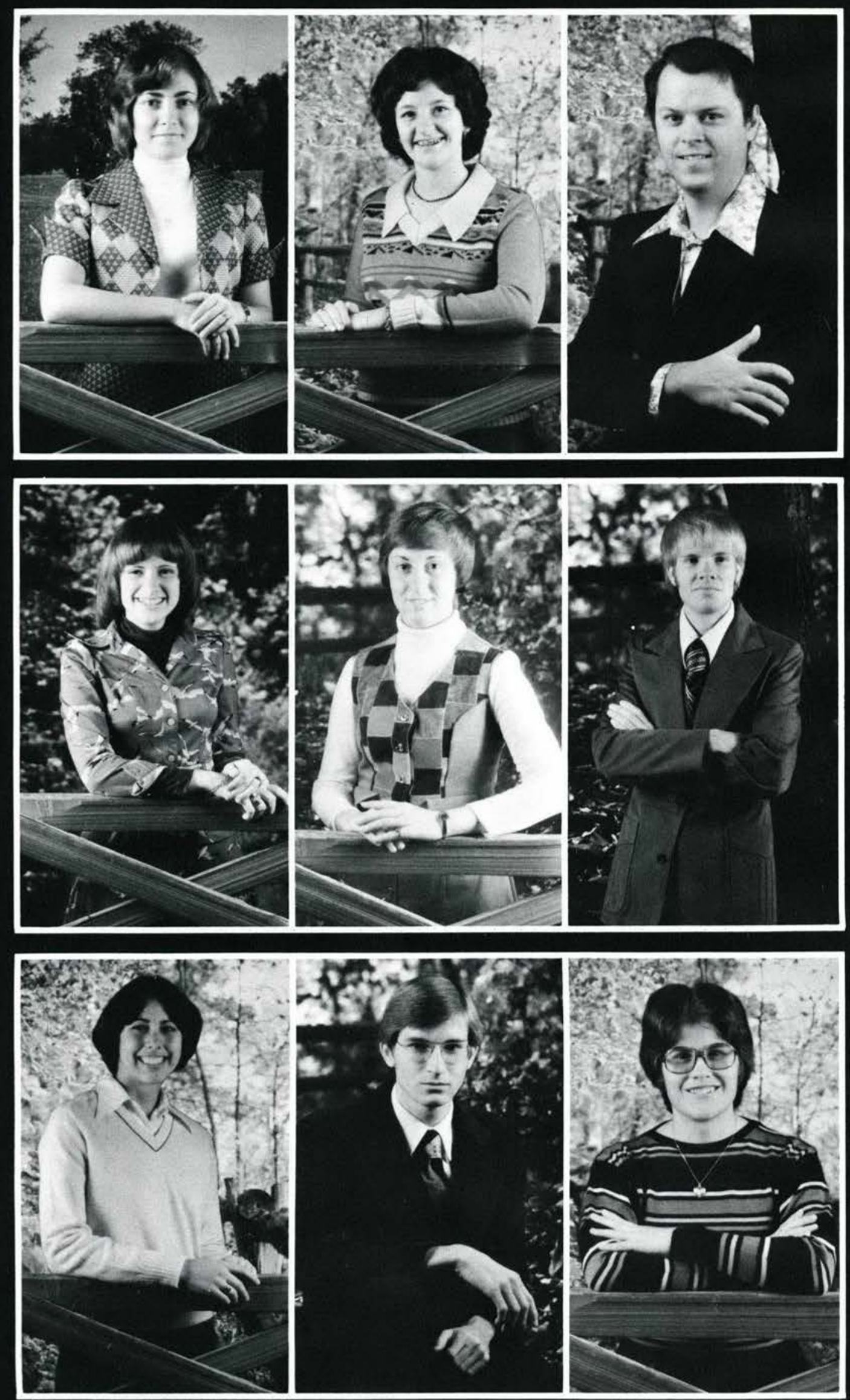

Donna Radcliffe

Biology

Adamsville, $\mathrm{OH}$

Diana Rae

Elementary Education

Eastlake, $\mathrm{OH}$

Tim Reder

Comprehensive Bible

Xenia, $\mathrm{OH}$

Becky Reid

Psychology

Romeo, MI

Nancy Reu

Business Administration

Villa Park, IN

Kenneth Rhodes

History/Political Science

Harbor Creek, PA

Rose Ricker

English Education

Tonawanda, NY

Dan Riedel

IDS-Philosophy

Fairview Park, OH

Karen Robb

Bible

New Castle, PA 
Eddie Roberts

Bible

Spencer, $\mathrm{OH}$

Bob Rogers

History

Fairview Park, OH

Charolette Rowland

Broadcasting

Litchfield, $\mathrm{OH}$

Steve Rowland

Elementary Education

Greenwood, IN

Karen Sawyer

Elementary Education

Milwaukee, WI

Jeff Schlesinger

Broadcasting

Woolrich, PA

Kay Schneider

Elementary Education

Rantoule, IL

Paul Schnell

Pre-Seminary

Alpena, MI

Calvin Searles

Business

Wakeman, $\mathrm{OH}$
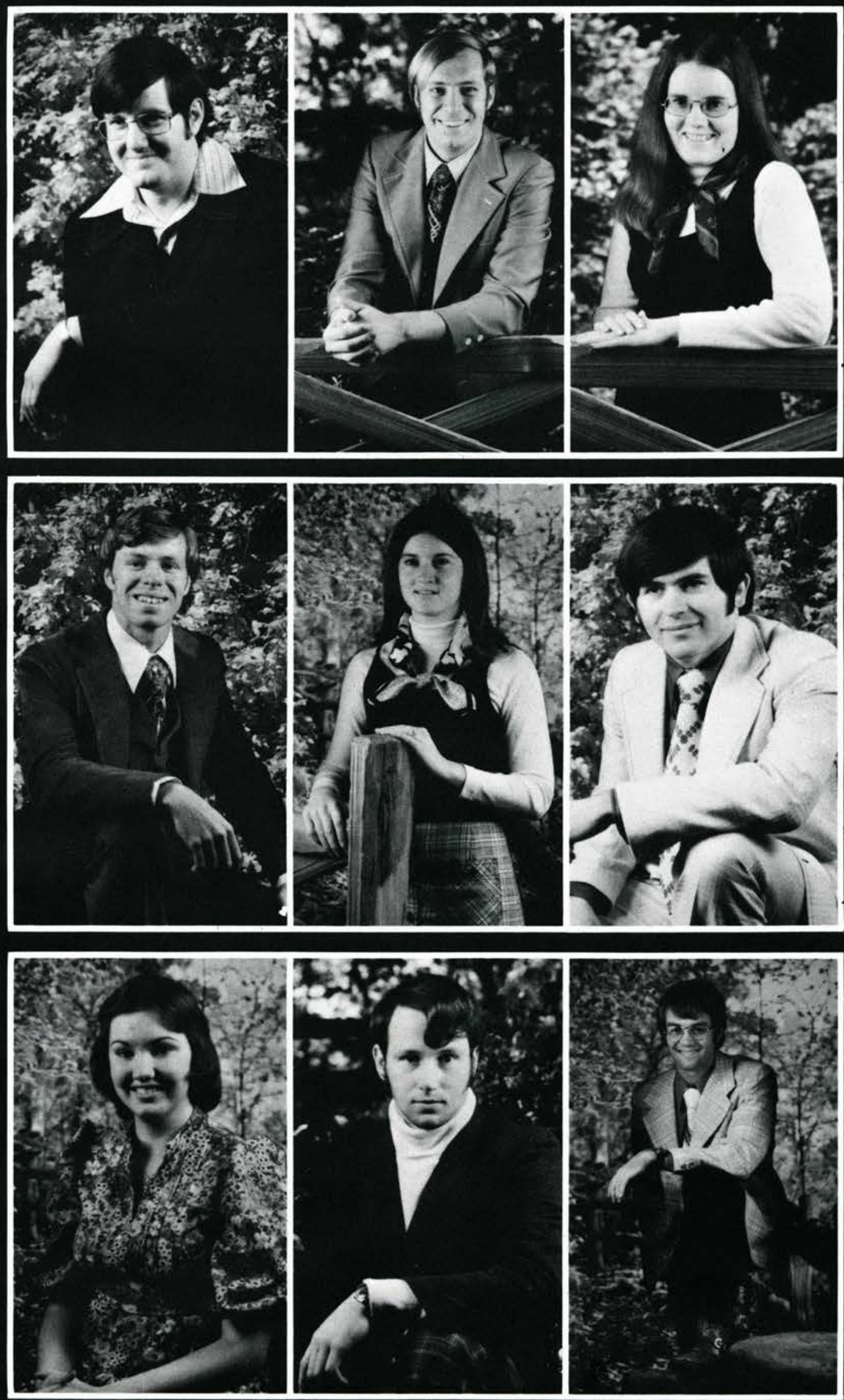
Philip K. Smith

Pre-Seminary

Brooklyn, MI

Phillip G. Smith Speech

Ann Arbor, MI

Terri Smith

Elementary Education

Terre Haute, IN

Ginny Smoot

Mount Vernon, OH

Karen Sollenne

Physical Education

Parma, OH

Gaylord Spencer

Business Administration

Hopedale, $\mathrm{OH}$

Karen Spencer

Biology

Akron, $\mathrm{OH}$

Deb Stahl

Biology

Findlay, $\mathrm{OH}$

Stephen Stairs

Business

Columbus, $\mathrm{OH}$
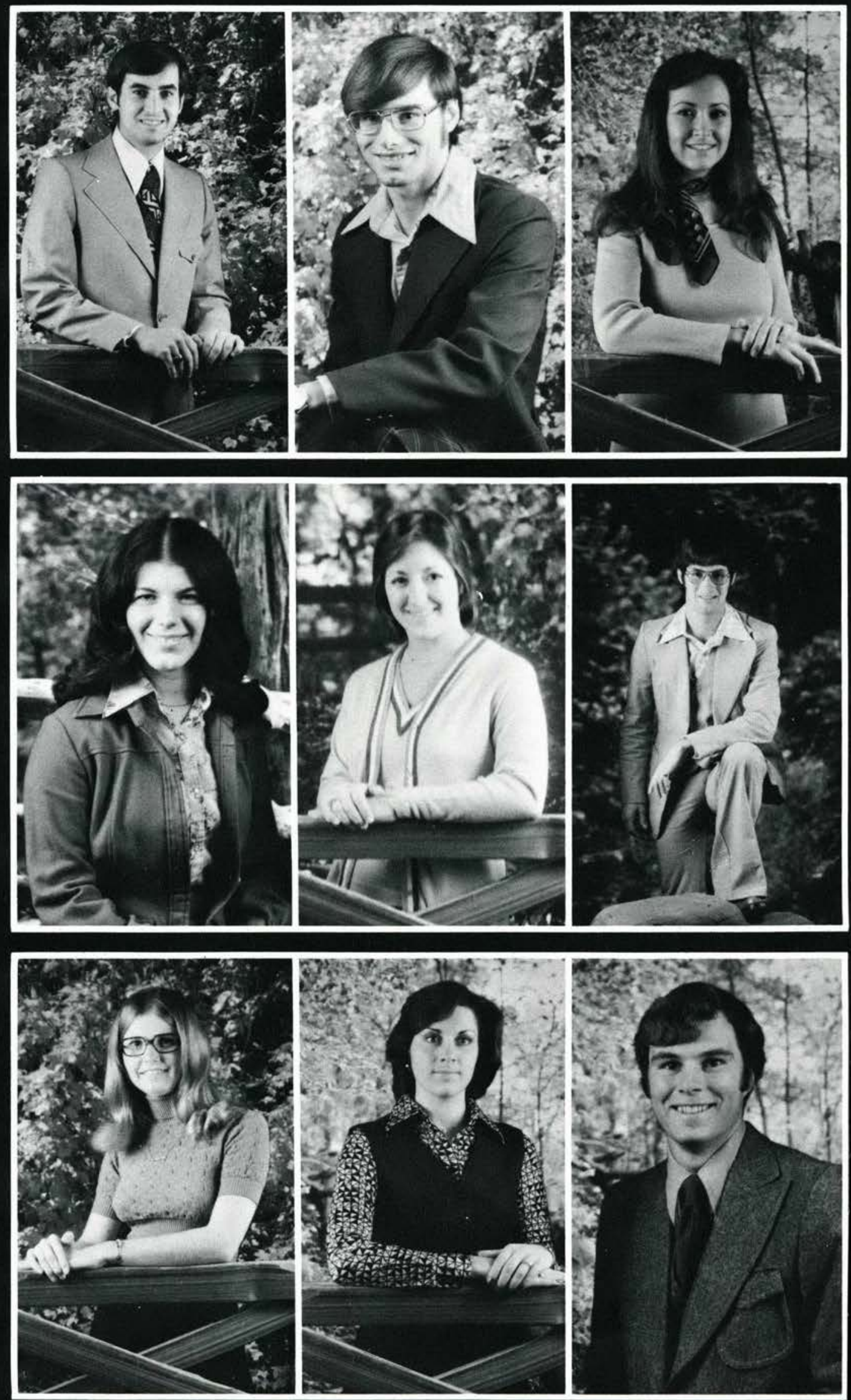

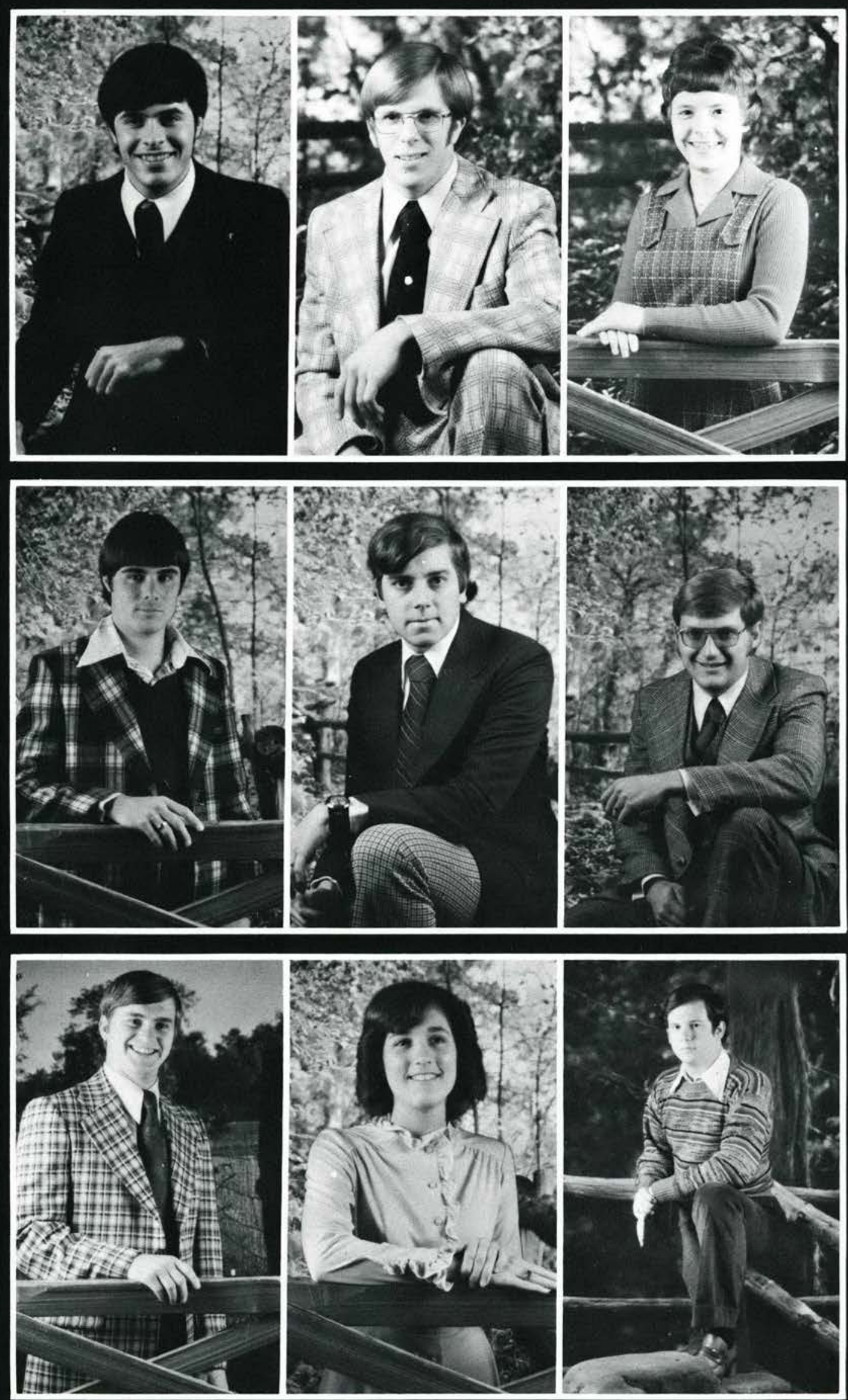

Craig Stephens

Business

Columbus, $\mathrm{OH}$

Steve Stewart

Speech/Broadcasting

Caldwell, $\mathrm{OH}$

Teresa Stewart

Elementary Education

Bradford, $\mathrm{OH}$
Dave Storch

Psychology

Joliet, IL

Bob Storey

Bible

Xenia, $\mathrm{OH}$

Gary Storm

Bible

Cedarville, $\mathrm{OH}$
Dwight Strickland

Pre-Seminary

Cedarville, $\mathrm{OH}$

Audrey Sutliff

Elementary Education

Huntingdon Valley, PA

Dave Tawney

Bible

Clendenie, WV 
Bonnie Taylor

Psychology

Chardon, $\mathrm{OH}$

Chris Taylor

Elementary Education Bellefontaine, $\mathrm{OH}$

Armand Ternak

Physical Education

Tecumseh, MI

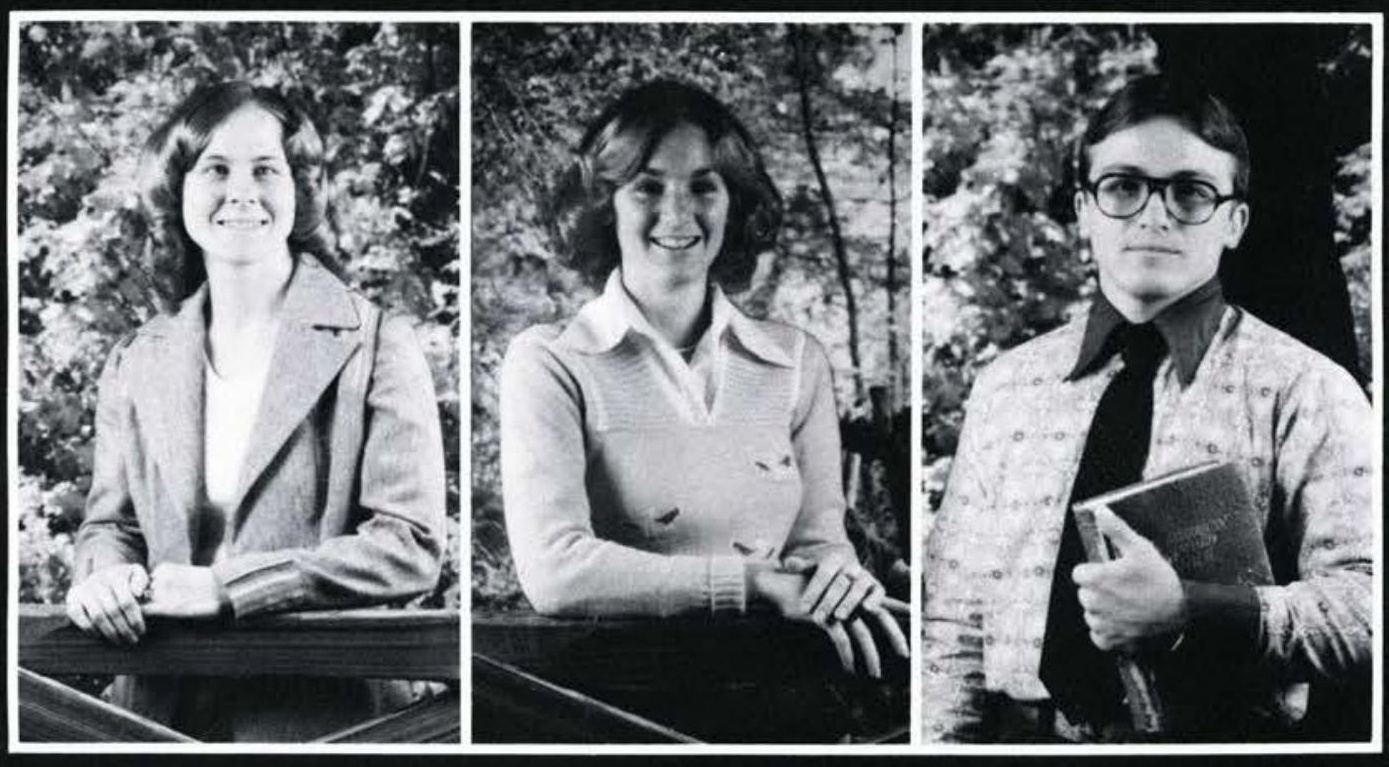

Joseph Terrell

IDS-Bible

Barboursville, WV

Rock Thacker

Business Administration

Cincinnati, $\mathrm{OH}$

John Thomas

Pre-Seminary

Cedarville, $\mathrm{OH}$

Ron Thomas

IDS-Bible

Columbus, $\mathrm{OH}$

Sue Thomas

Behavioral Science

Doylestown, $\mathrm{OH}$

Pat Townsend

Physical Education

Roanoke, VA

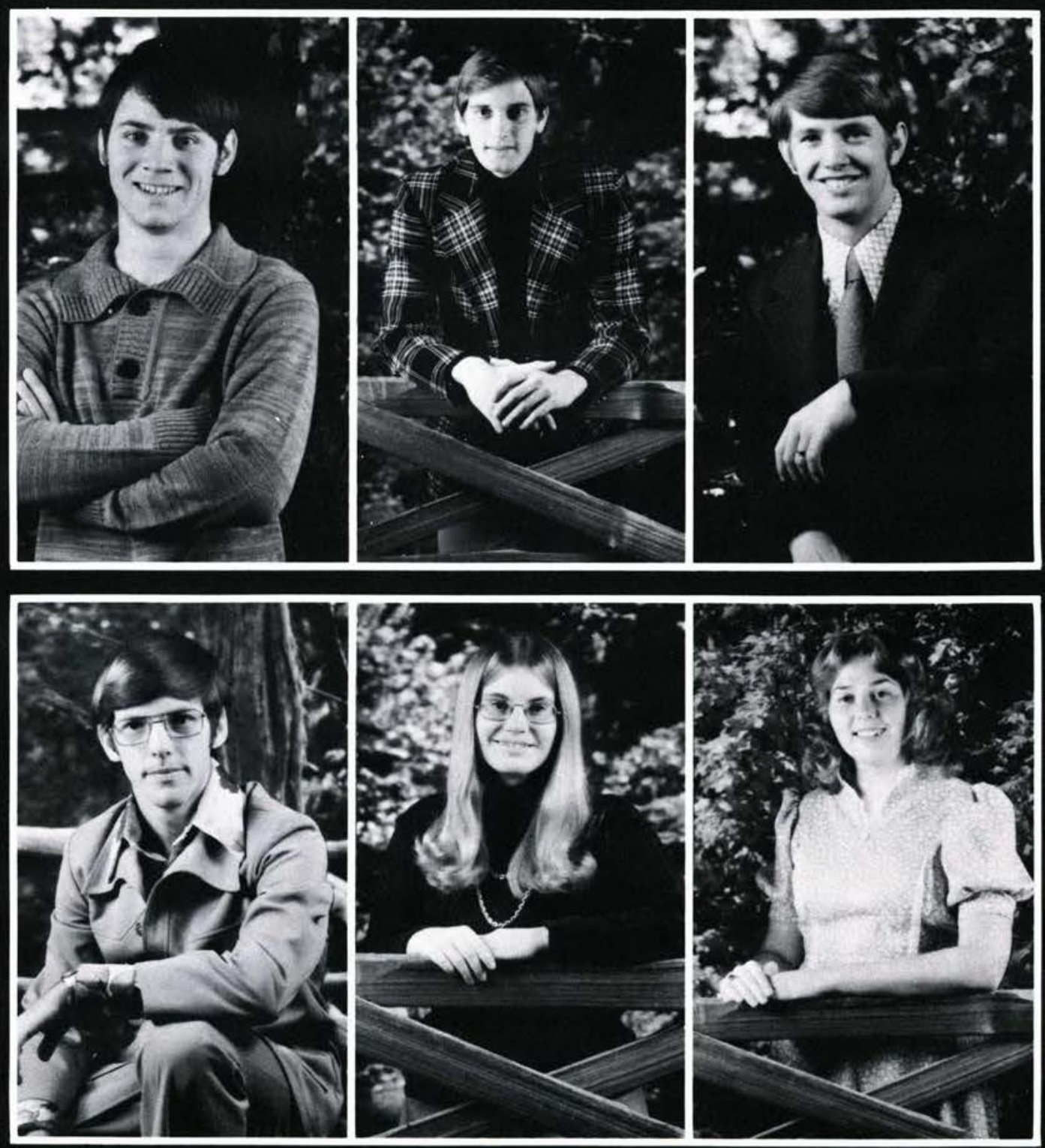


Jennifer Wagner

Elementary Eduacation

Fostoria, $\mathrm{OH}$

Marilyn White

Elementary Education

Pontiac, MI

Lorna Wigton

Elementary Education

Mt. Gilead, $\mathrm{OH}$

Bill Williams
Biology
Cedarville, OH

Bruce Williams

Biology

Cedarville, $\mathrm{OH}$

Ruth Battaglia Williams

Elementary Education

Cedarville, $\mathrm{OH}$

Sheri Cowell Williams

Elementary Education

Cedarville, $\mathrm{OH}$

Jay Williamson

Comprehensive Bible

Cedarville, $\mathrm{OH}$

Steve Wilson

Business

Cincinnati, $\mathrm{OH}$
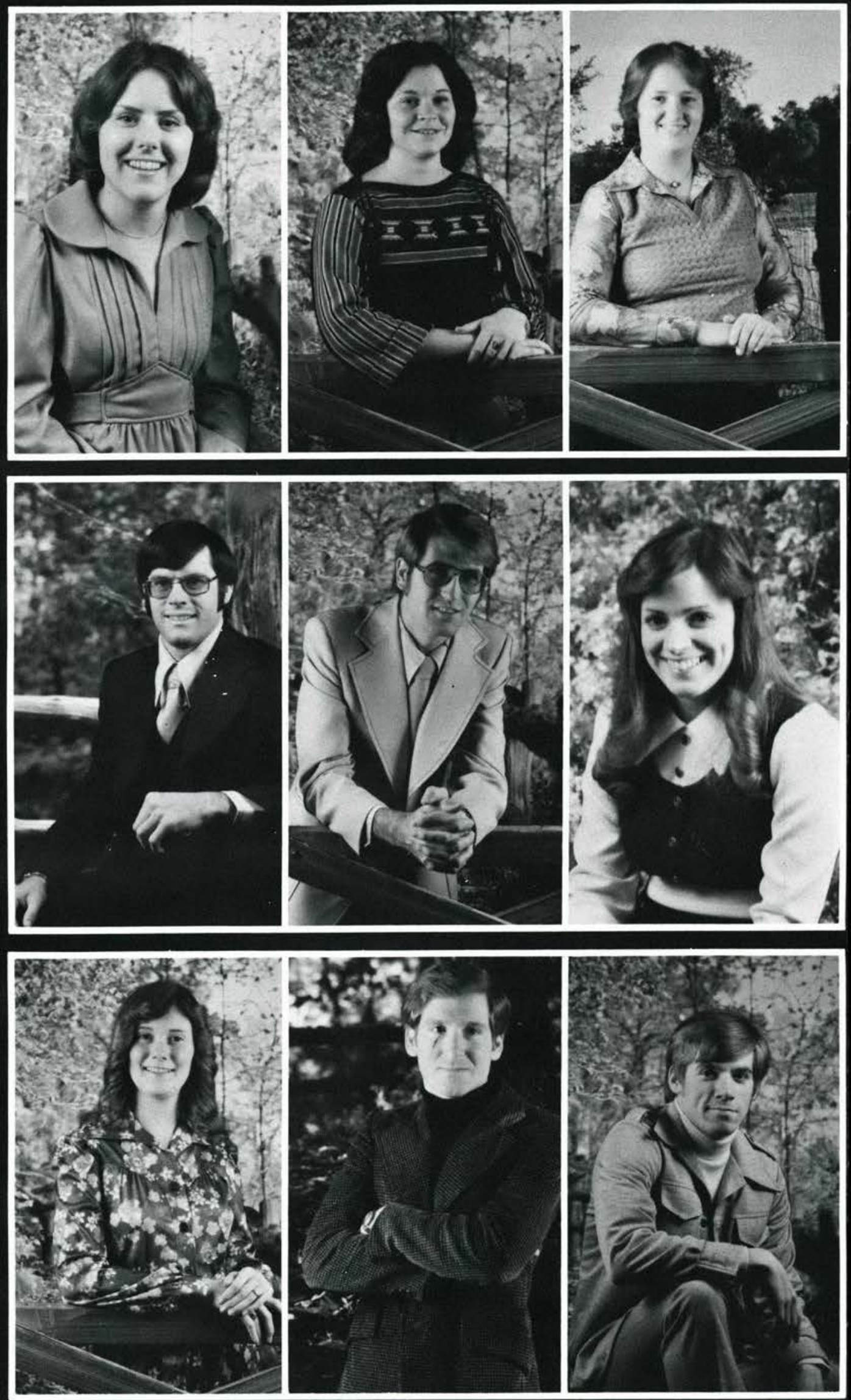

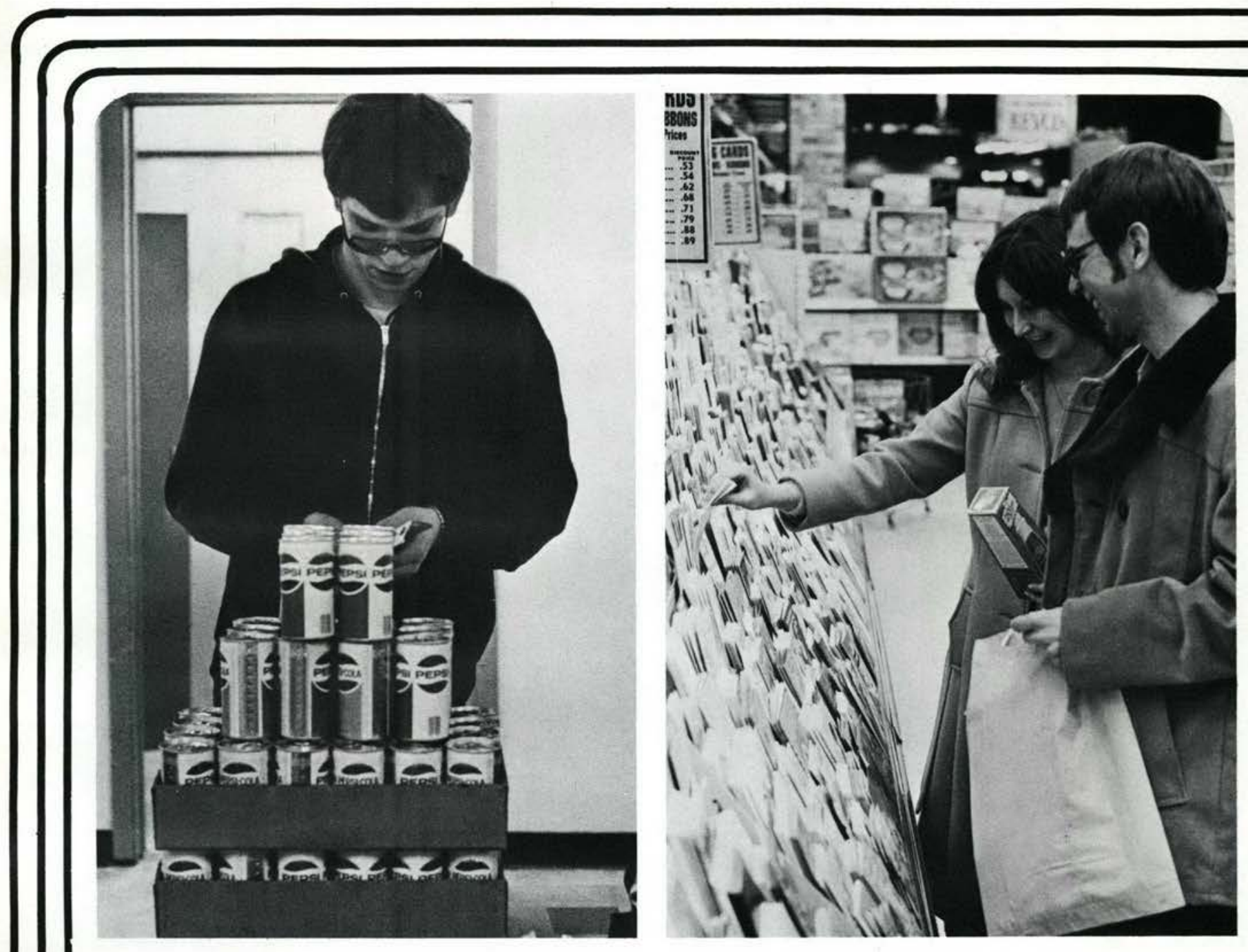

A II. II
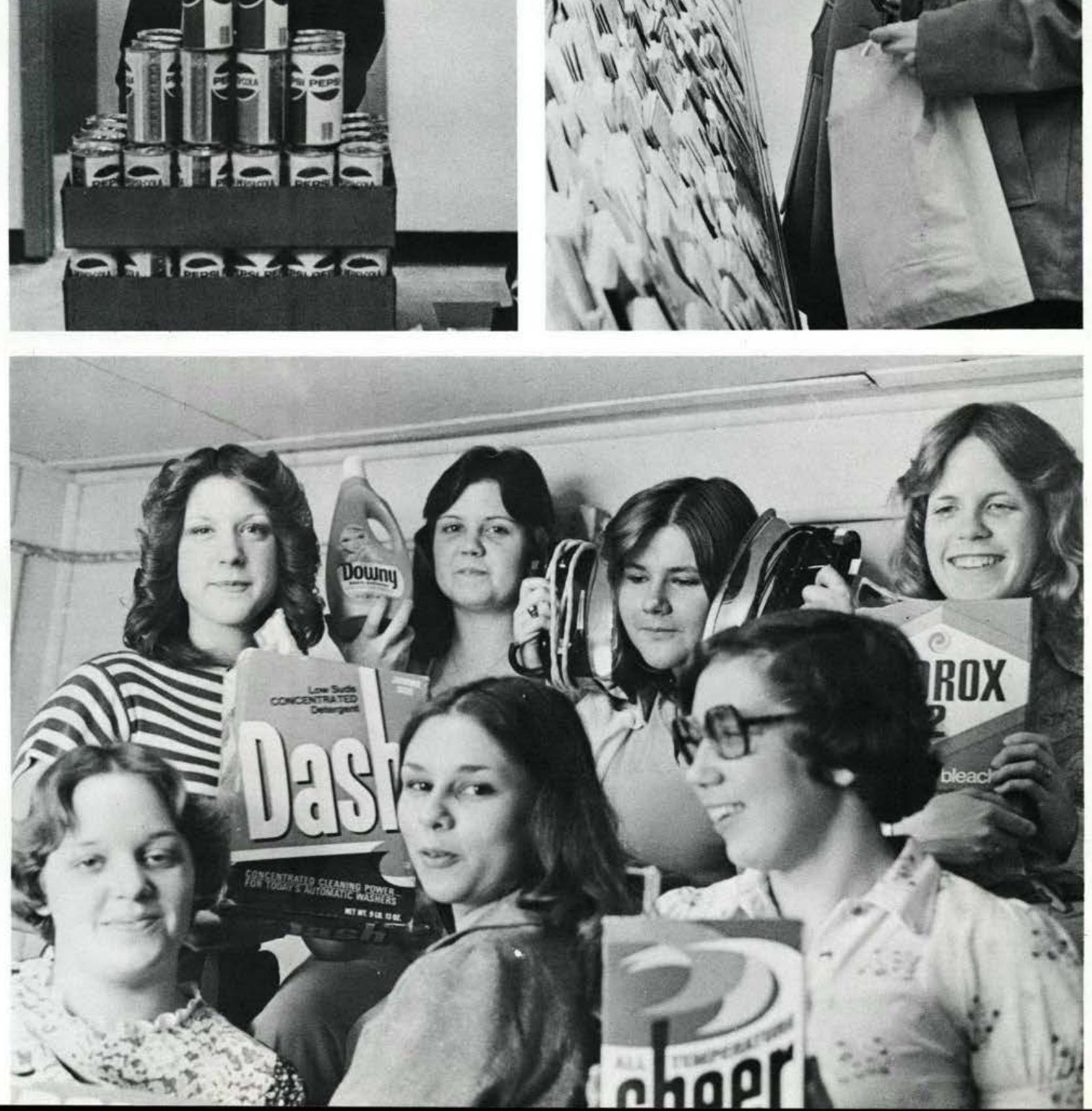


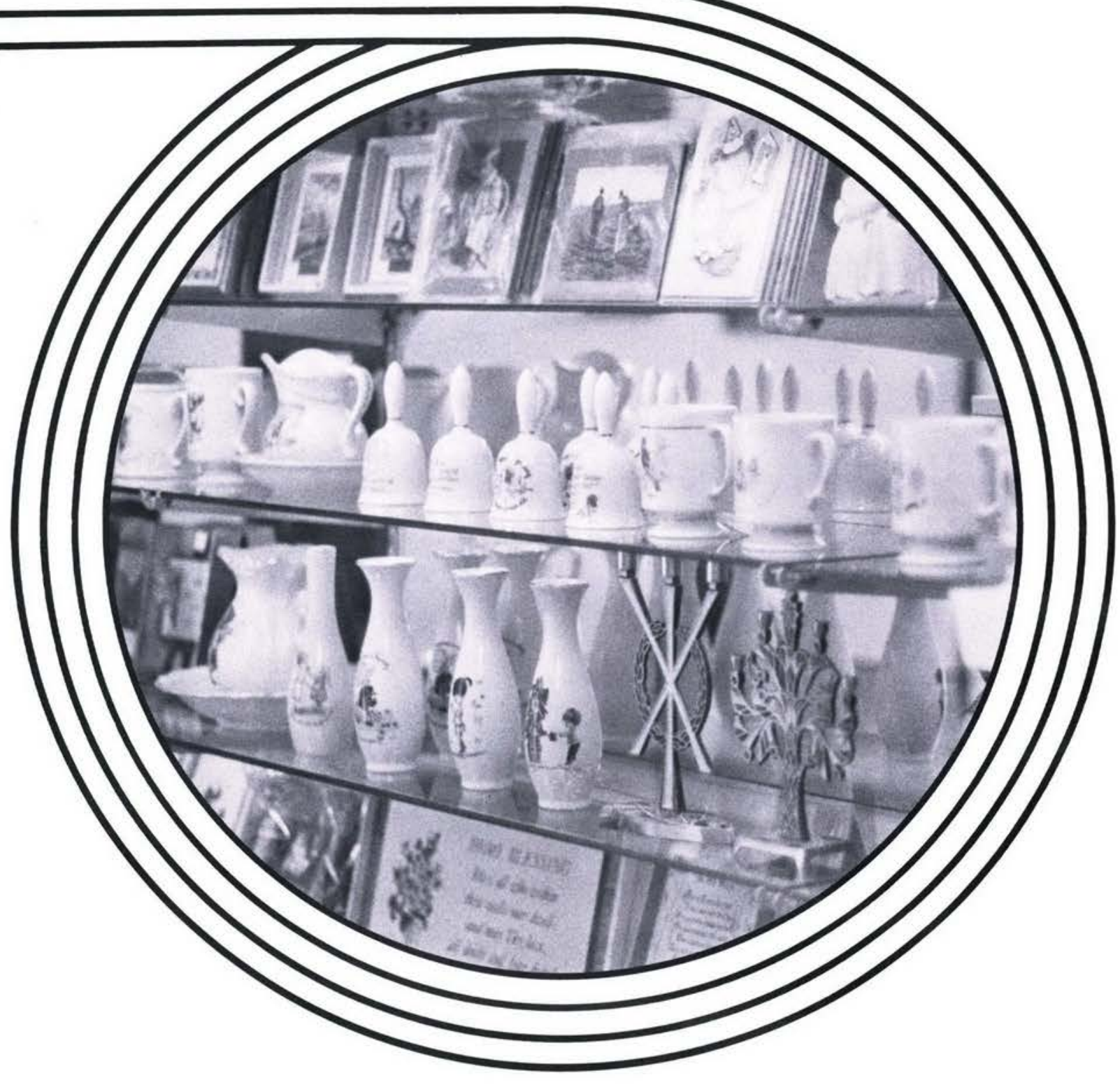

ADVER TJSE MENTS 


\section{Parent Patrons}

Mr. \& Mrs. James Abercrombie 27212 W. Huron R. Dr. Flatrock, MI

Mrs. John Aitken 319 Ottawa Avenue Hasbrouck Hts., N $J$

Mr. \& Mrs. William Aitken 203 Du Bois Rd. Glassboro, NJ

Dr. \& Mrs. John S. Alvey 7356 East 100 South Marion, IN

Robert Balais 298 NW 45th St. Boca Raton, FL

Mr. \& Mrs. William Basye 1055 Monmouth Dr. Akron, $\mathrm{OH}$

Mr. \& Mrs. William D. Bathurst R.D. 2, White Birch Road Dalton, PA

Immanuel Baptist Church

3417 Palmetto Street Columbus, Ohio

BEST WISHES TO THE CLASS OF 1977

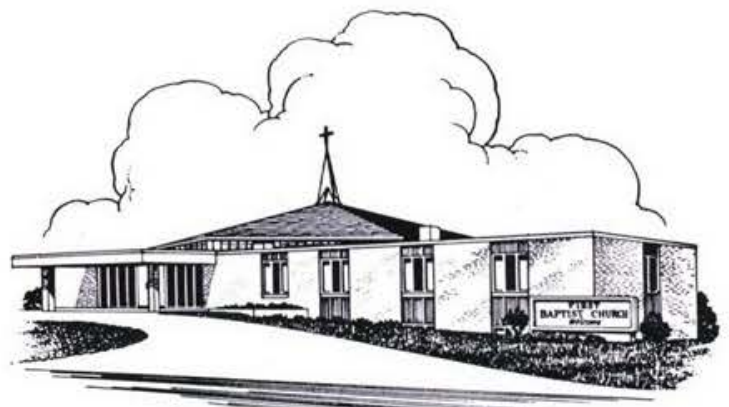

\section{FIRST BAPTIST CHURCH}

1001 N. Lincoln Street

Creston, Iowa 50801

Norman Hoag, Pastor

Thomas Strong, Associate Pastor

Rebecca Tallmon, Sr

Martha Johnson, Fr.

Tamara Christensen, Fr.

\section{FIRST BAPTIST CHURCH} OF SILVIS

11019 th Avenue

Silvis, Illinois 61282

Rev. John Lineberry, Pastor

Rev. John Clark, Youth Pastor

"The All Family Church"

Greetings to Margo and Pam Axiotis from all the folks at First Baptist Church

\section{FAITH BAPTIST CHURCH}

2201 Park Avenue

Lynchburg, Virginia 24501

Ronald C. Laube, Pastor

"The Family Centered Church"

Our Student - Miss Brenda James 


\section{CEDARVILLE}

\section{FEDERAL}

\section{SAVINGS \& LOAN}

Telephone 513-766-2141

Cedarville, Ohio 45314

Congratulations

to the

Class of ' 77

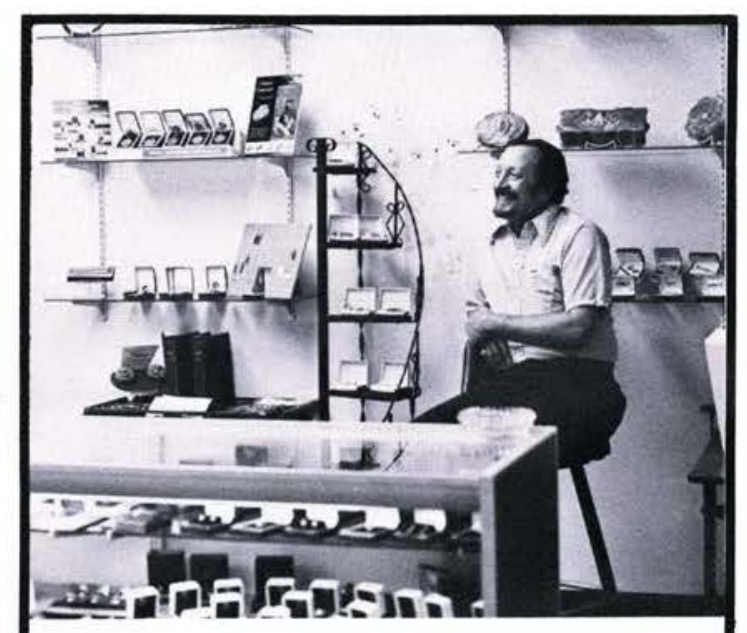

Diamonds • Watches • Jewelry

\section{WILLIAM'S \\ JEWELERS}

Suite 2W - 2nd Floor

Peoples Savings \& Loan Bldg.

100 West Main St. Xenia, Ohio

BILL BLOCK Phone 372-1444

"Bless you one and all"

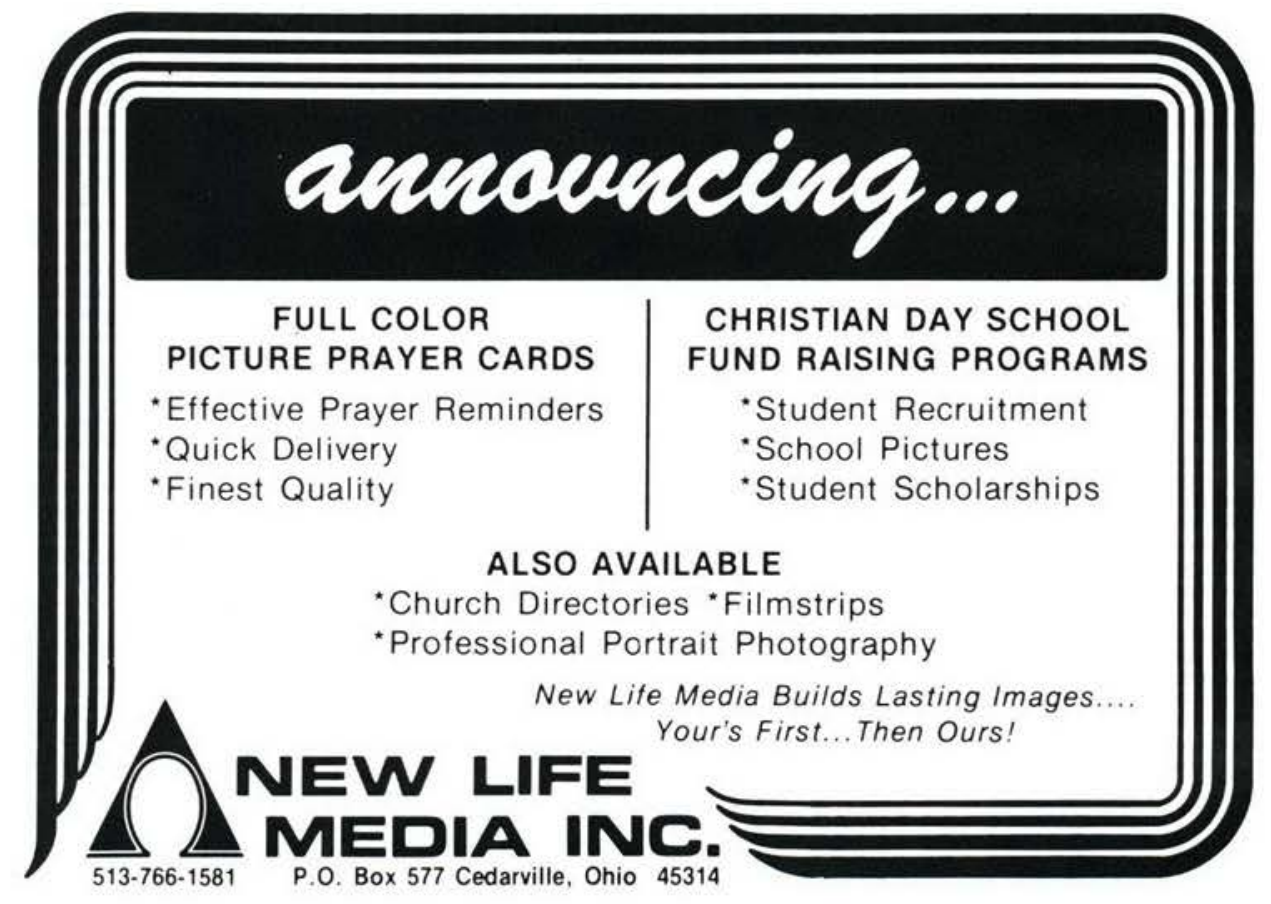

Mr. \& Mrs. Edward A. Book

154 Long Hill Road

Little Falls, NJ

Lee E. Brady

203 Sparling Dr.

Rochester, NY

Mr. \& Mrs. Robert J. Brower 267 Voorhis Ave.

River Edge, NJ

Mrs. Doris A. Browne

780 Columbia Rd NW

Washington, D.C. 
Norbert \& Ann Budnik 7721 S. Rutherford Ave. Burbank, IL

Mr. \& Mrs. George Butler $\mathrm{R} \# 1$ Steamboat Rock, IA

Mr. \& Mrs. Raymond Cagwin, Sr. 9961 Jennings $\mathrm{Rd}$. Eden, NY

Mr. \& Mrs. Peter W. Campbell 78 Holden St. Holden, MA

Mr. \& Mrs. John S. Chamblin 7018 Capitol View Dr. McLean, VA

Mr. \& Mrs. S.M. Conrad 1928 Berna Road Akron, $\mathrm{OH}$

Mr. \& Mrs. Charles R. Coombs 909 Plainview Drive Campbellsville, KY

Mr. \& Mrs. George Crompton 16 Burlington Avenue Vourhee, NJ
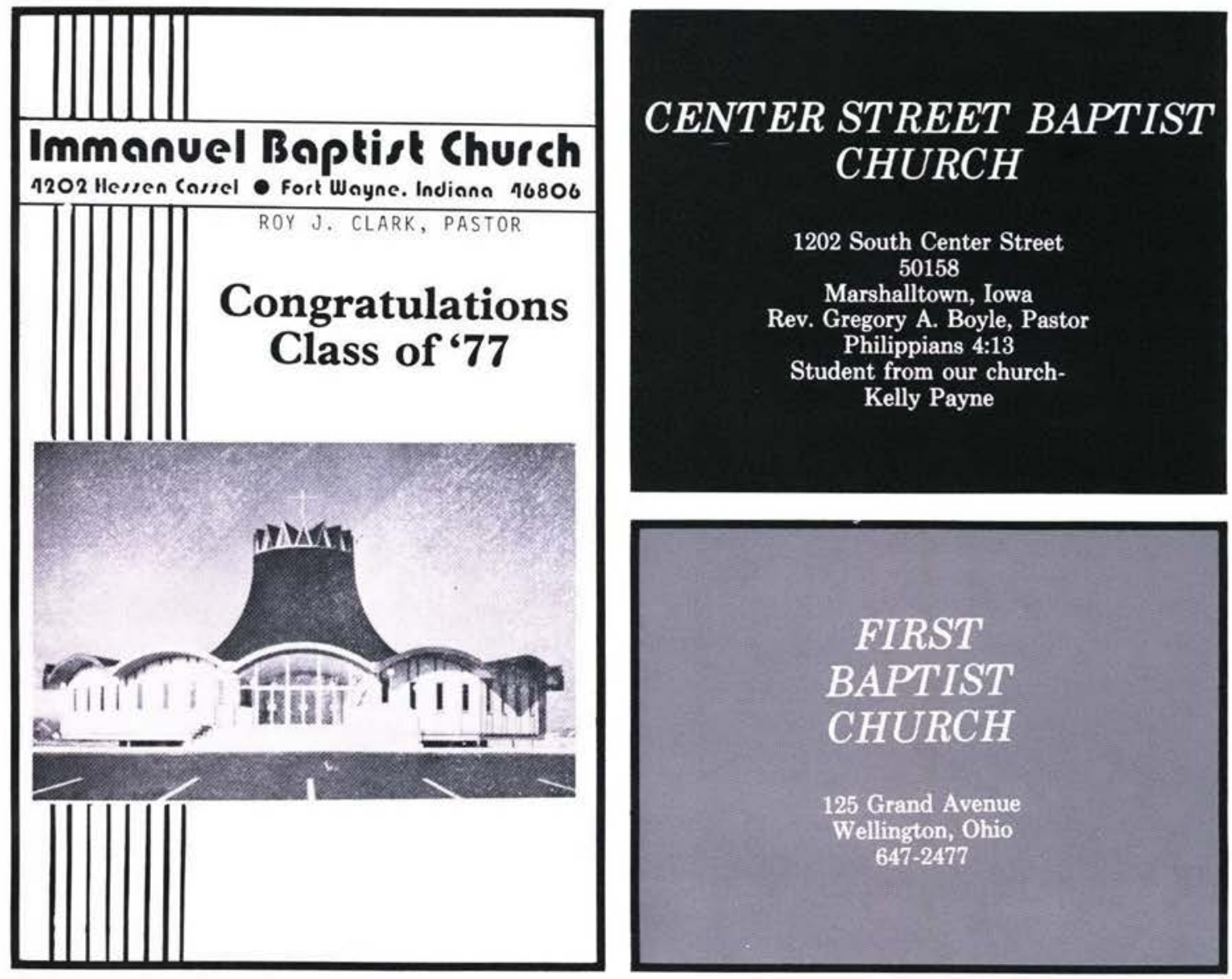

congratulations to the class of 1977

\section{BETHEL} BAPTIST CHURCH

212 North "I"

Oskaloosa, Iowa 52577

Pastor Jim T. Smith

"The Church with a Vision"

\section{Congratulations Class of 1977 from}

\section{HUNTSBURG BAPTIST CHURCH}

16401 Mayfield Road

Huntsburg, Ohio Ben H. Garlich, Pastor

"But seek ye rirst the kingdom of God, and his rightousness; and all these things shall be added unto you." Matt. 6:33

God's Best

to the

Class of '77

\section{Perry Baptist}

Church of the Good News

\section{Perry Drive, SW}

Canton, Ohio

Gordon H. Roloff,

Pastor 


\section{"Fundamental \\ Fervent}

$$
\text { Friendly ..." }
$$

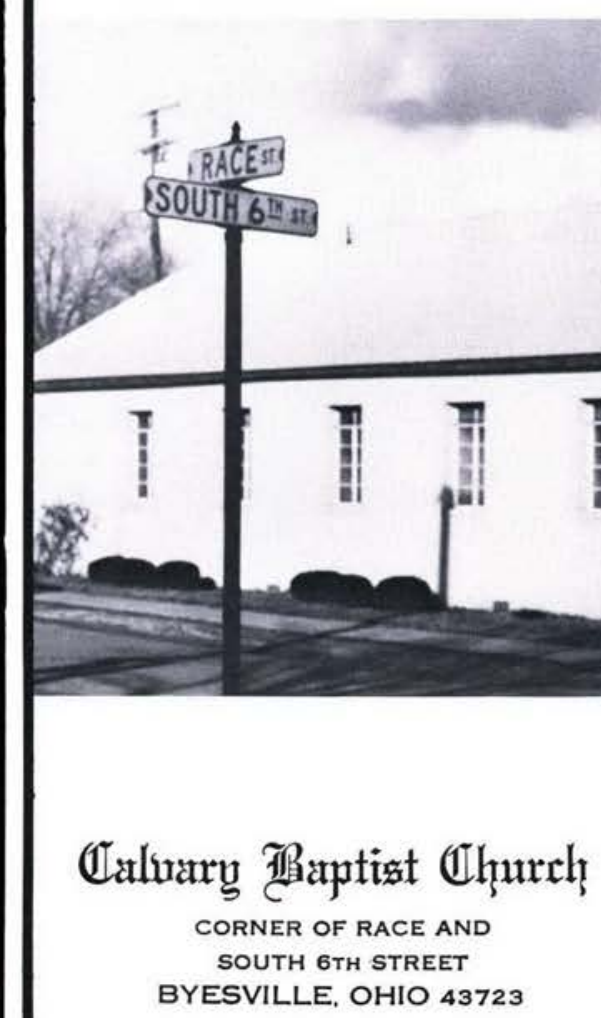

Rev. Kenneth L. Pugh, Pastor

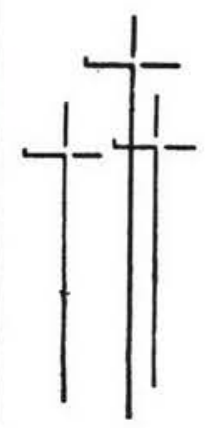

Miss Nancy Abels

Miss Jessilon English

Mr. David Rich

Miss Rhonda Rogers

(Oppently setting forth the (Thrist of the Uross
Mr. \& Mrs. Wayne Crum

315 N. Elmwood

Medina, $\mathrm{OH}$

Edna C. Cunningham

410 West Ave.

Northvale, NJ

Raymond G. Dailey $439 \mathrm{~W}$. Willow St.

Lombard, IL

Mr. \& Mrs. Ernest H. Detwiller 19693 Co. Rd. 6

Bristol, IN

Mr. \& Mrs. Merle F. Dixon 4318 Cleveland Hgts. Blvd. Lakeland, FL

Richmond Donaldson

Box 322

Geigertown, PA

Mr. \& Mrs. Henry Duncan 7314 Yellow River Rd.

Ft. Wayne, IN
Mrs. Lexter H. Edelin 780 Columbia Rd NW

Washington, D.C. 
Mr. \& Mrs. Jim Ellis 121 Michelle Dr. Hudson, IA

Mr. \& Mrs. Richard Emery 30209 Forest Grove Rd. Willowick, $\mathrm{OH}$

Mr. \& Mrs. Richard Erickson 166 Park St. Jamestown, NY

Paul Esham Rt. 3 Salisbury, MD

Mr. \& Mrs. Donald E. Felts 50 Willow Way Parsippany, NJ

Mr. \& Mrs. Howard Foster 8616 Crossbank Dr. Ft. Wayne, IN

Rev. \& Mrs. Graham Freeman 404 S. Main Street Muncy, PA

Alfred H. Galbraith 4101 Braddock Road Alexandria, VA
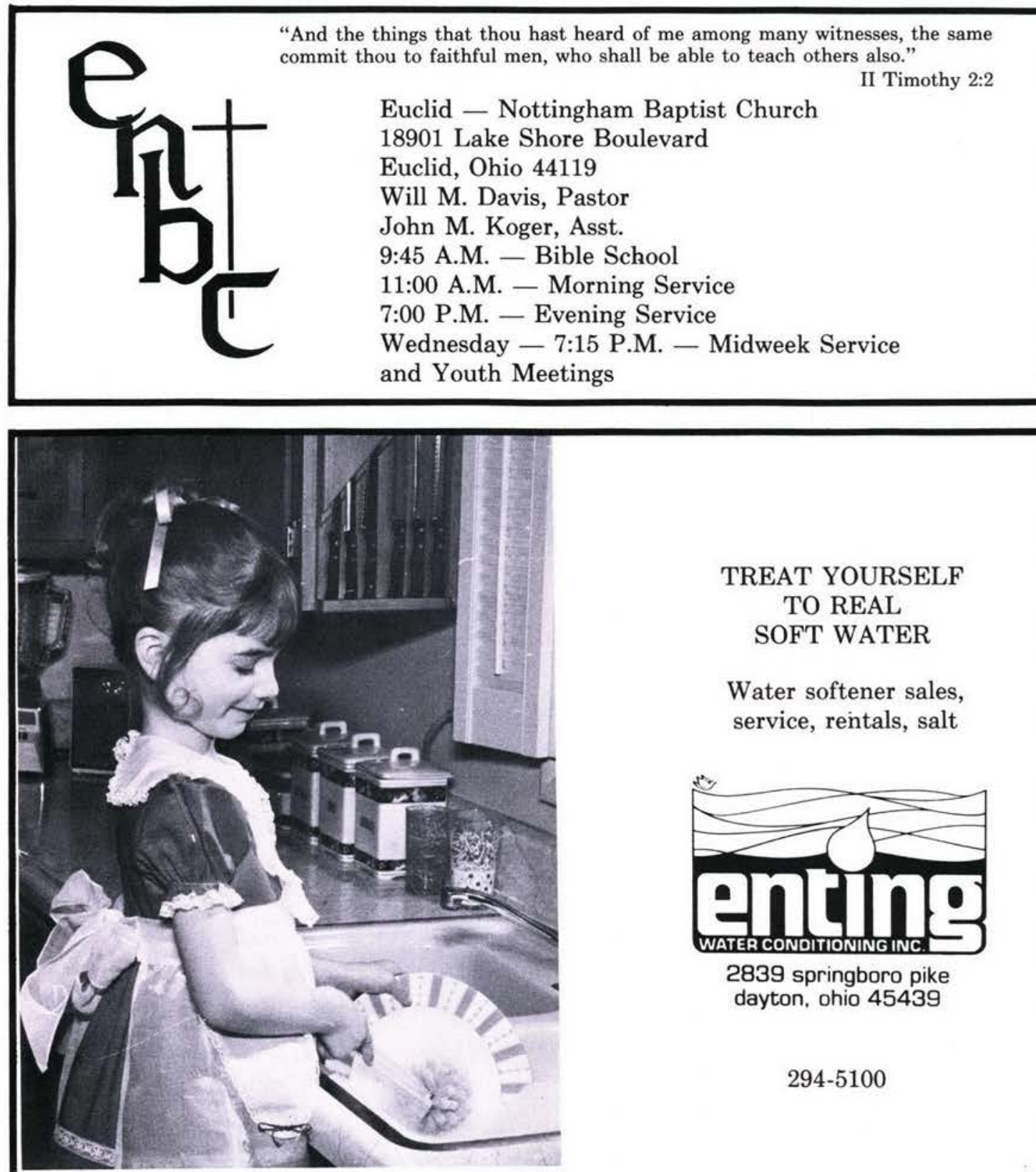

TREAT YOURSELF

TO REAL

SOFT WATER

Water softener sales, service, rentals, salt

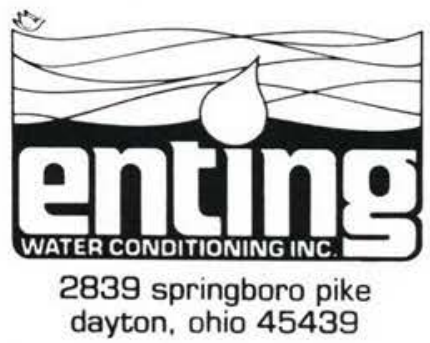

294-5100
Little Girls Love Soft Water ...

So Do Mommies and Daddies!

\section{FIRST BAPTIST $\mathrm{CHURCH}$}

221 New Castle Street

Butler, Pennsylvania 16001

\section{OUR POSITION}

We are a Separated, Gospel Preaching New Testament Baptist Church, Standing for the Inspired, Inerrant Word of God, the Deity of Christ, the Blood Atonement and Bodily Resurrection of Christ, Salvation by Grace through Faith in Christ, and Pre-Tribulational, Pre-Millennial Coming of Christ.
OUR SERVICES
Clarion Broadcast

Bible School

Morning Worship

Live Broadcast

Eager Beavers

Jr. Astronauts

Pro-Teens

Evening Worship

Prayer Meeting

Visitation
9:30 AM

9:45 AM 11:00 AM

utler, PA

6:30 PM

6:30 PM

6:30 PM

7:30 PM Wednesday

Thursday

7:30 PM

7:00 PM 

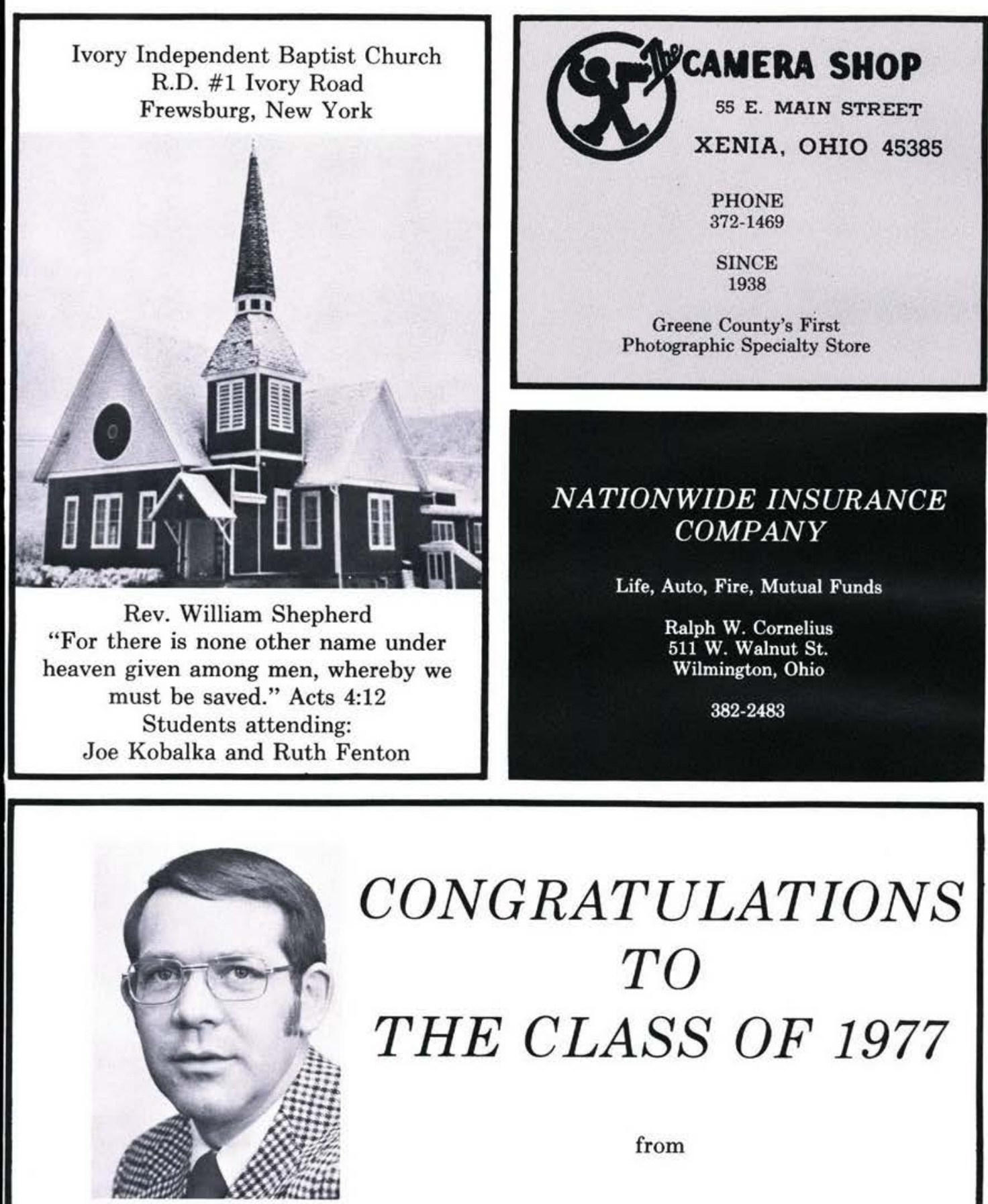

\section{CONGRATULATIONS} TO

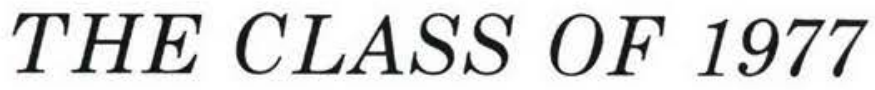

from

The Bethel Baptist Church in Beautiful Cherry Hill, New Jersey

Rev. Virgil Stoneking Pastor

Rev. Daniel Pascucci

Assistant to the Pastor

"Your soul is our sole business"
Mr. \& Mrs. Lauren E. Gall 3463 Palmer Highway

Britton, MI

Mr. \& Mrs. Rodney Gardner 7 Gerkins Street

Topsham, ME

Mr. \& Mrs. Carl Gawthrop Rt. 9, Box 273

Fairmont, WV

Mr. \& Mrs. Walter Gettle 20117 Cameron Mill Rd. Bentley Springs, MD

Mr. \& Mrs. Glen Gierhart 152 8th

Phillipsburg, KS

Mr. \& Mrs. Calvin A. Gilbert 210 Habrand

Troy, MI

Mr. \& Mrs. Dellas C. Gilbert

R.R. 2, Box 157

Bunker Hill, IL

Dorotha Grace

1695 Sherman Ave.

Cincinnati, $\mathrm{OH}$ 
Mr. \& Mrs. Charles Grafton 13462 Villa D'Est Highland, MD

F. Grigsby 225A, South Blvd. Boynton Beach, FL

Duane \& Elaine Hansen 3761 Carson City Rd Sheridan, MI

Mr. \& Mrs. Donald D. Harkless 408 Bear Creek Road Sarver, PA

..r. \& Mrs. Clarence R. Harkness R.D. \# 2 Troy, PA

Mr. \& Mrs. Paul Harrison 787 Harrison St. Lincoln Park, MI

Mr. \& Mrs. Glenn A. Hathaway 2154 Green Road Madison, $\mathrm{OH}$

Rev. \& Mrs. Charles Hawkins 208 South Grant Crawfordsville, IN
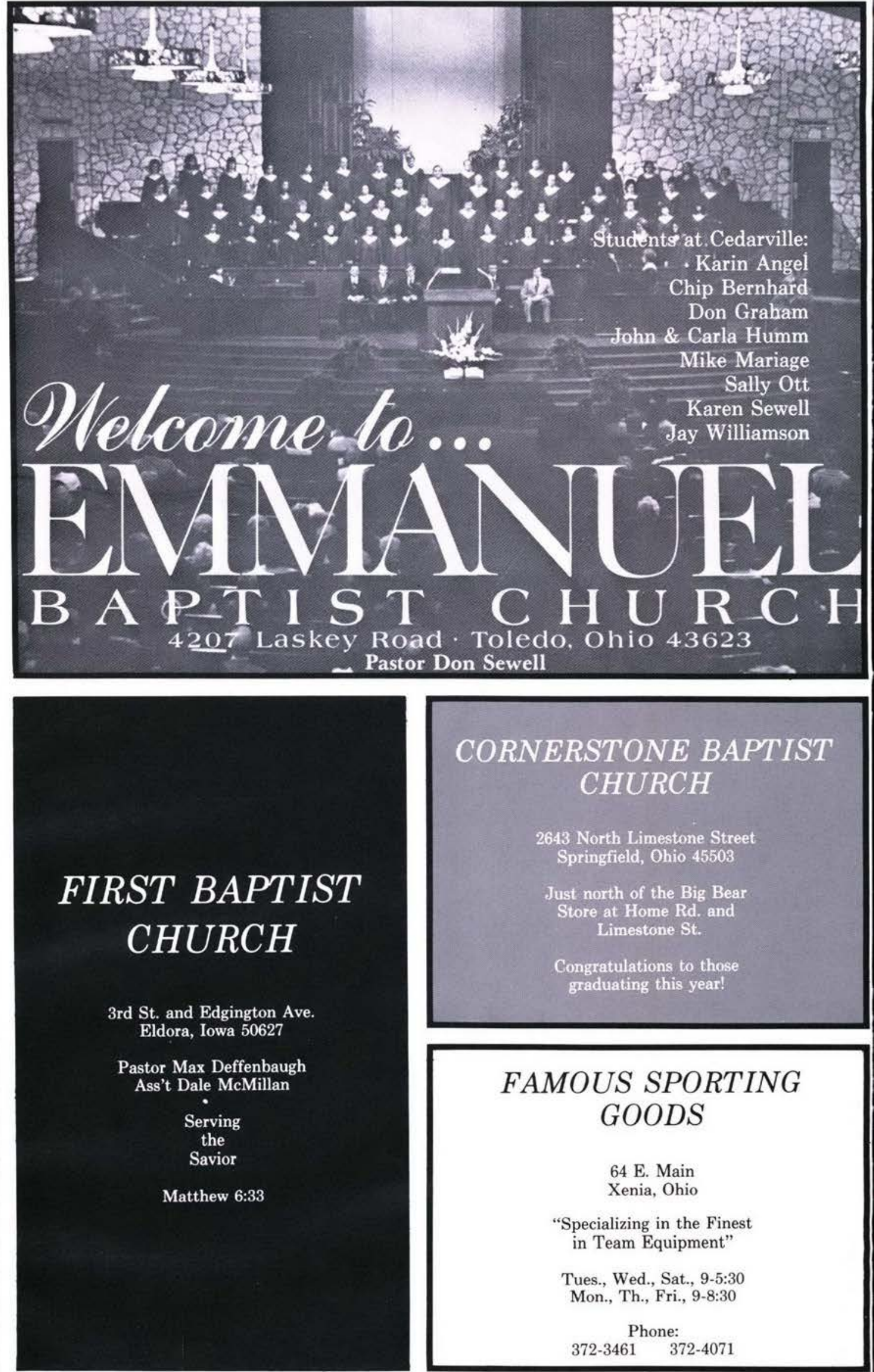

\section{CORNERSTONE BAPTIST CHURCH \\ 2643 North Limestone Street Springfield, Ohio 45503 \\ Just north of the Big Bear Store at Home Rd. and Limestone St. \\ Congratulations to those graduating this year!}

\section{FAMOUS SPORTING GOODS}

64 E. Main

Xenia, Ohio

"Specializing in the Finest in Team Equipment"

Tues., Wed., Sat., 9-5:30

Mon., Th., Fri., 9-8:30

Phone:

372-3461 372-4071 


\section{CLINTONVILLE BAPTIST $\mathrm{CHURCH}$}

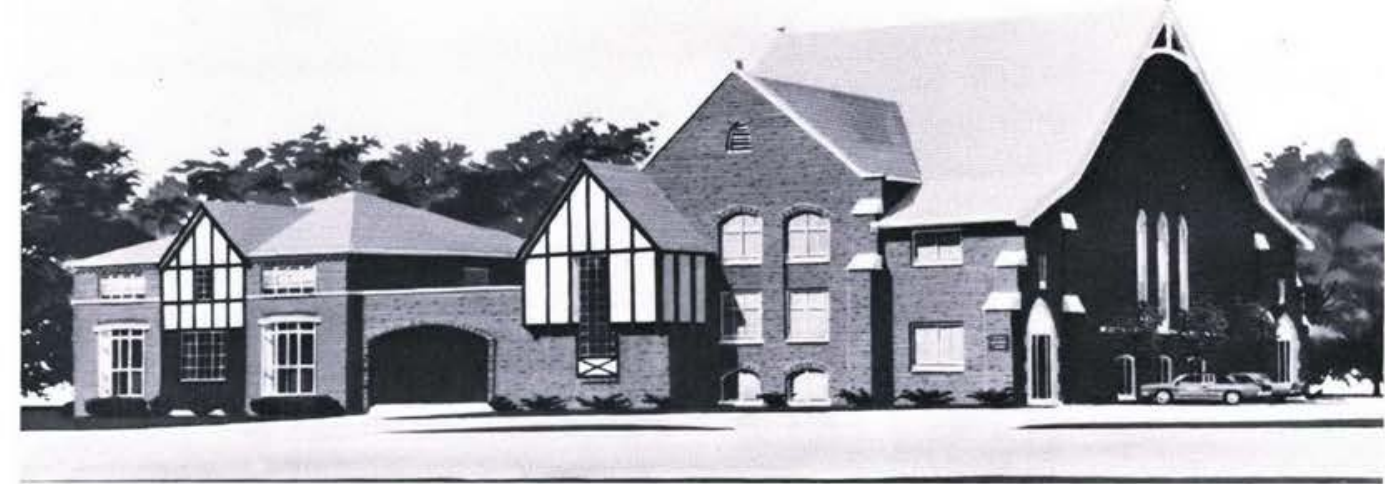

35 Oakland Park

Columbus, Ohio 43214

Graduating Senior: Steve Stairs

\section{GRANDVIEW PARK BAPTIST CHURCH}

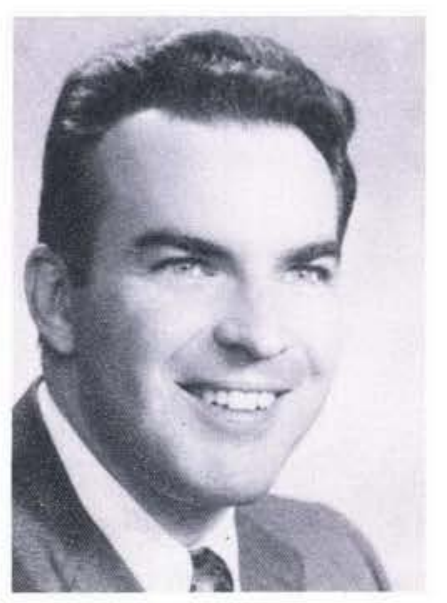

1701 East 33rd Street

Des Moines, Iowa 50317

Dr. Paul Tassell, Pastor

"For the Word of God and Testimony of Jesus Christ"
Mr. \& Mrs. Cecil Hayes

Route \#1, Box 95F

Brownsburg, IN

Bill \& Mary Heatly

2390 Tamara Rd, Rt. 3

Kalkaska, MI

Mr. \& Mrs. C.T. Henderson

110 Vernon Dr.

Ft. Mitchell, KY

Mrs. LaVonne Henson 1379 Williamsburg $\mathrm{Ct}$.

Flint, MI

Carl \& June Hermansky 433 Washington $\mathrm{Pl}$.

Hasbrouck Heights, NJ

Mr. \& Mrs. William Howe 420 Nevada St.

East Alton, IL

Francis L. Hoy

R.D. \#1

Halifax, PA

Mr. \& Mrs. Earl Haga

R.R. \#3, Box 133

Covington, IN 
Mr. \& Mrs. Russell Hull 926 Hunt Road Lakewood, NY

Mr. \& Mrs. Franklin C. Hunt Rt. 1, Box 8 Sprakers, NY

Lilian Hutchison 14260 Knox Warren, MI

Mr. \& Mrs. John L. Iseminger P.O. Box 321 Funkstown, MD

Italian Village Restaurant 112 E. Logan St. Tecumseh, MI

Mr. \& Mrs. Harvey Jacobitz 5070 Tahquamenon Flushing, MI

Mr. \& Mrs. Russell W. Jenkins, Jr. 6817 Baron Road McLean, VA

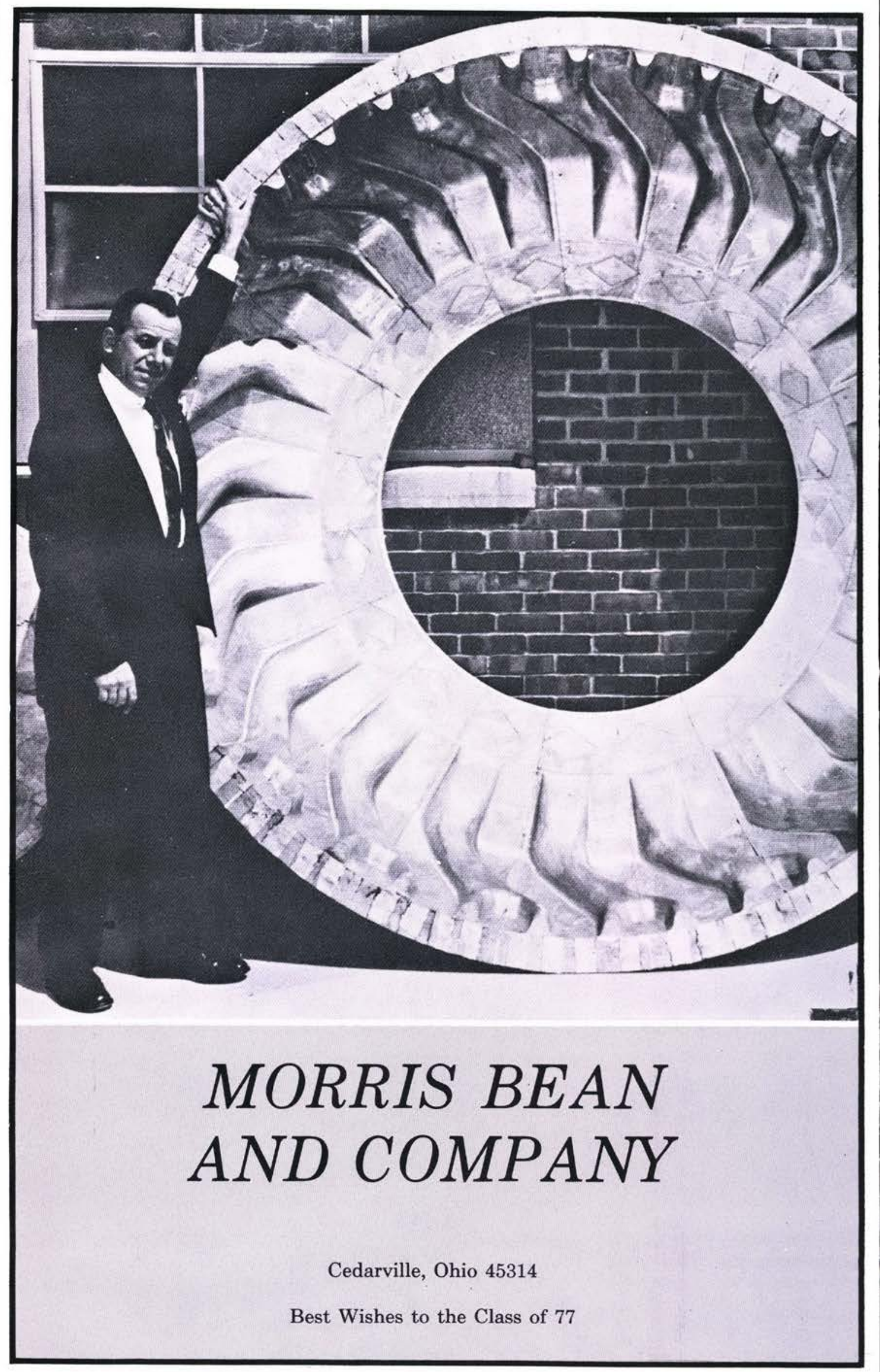



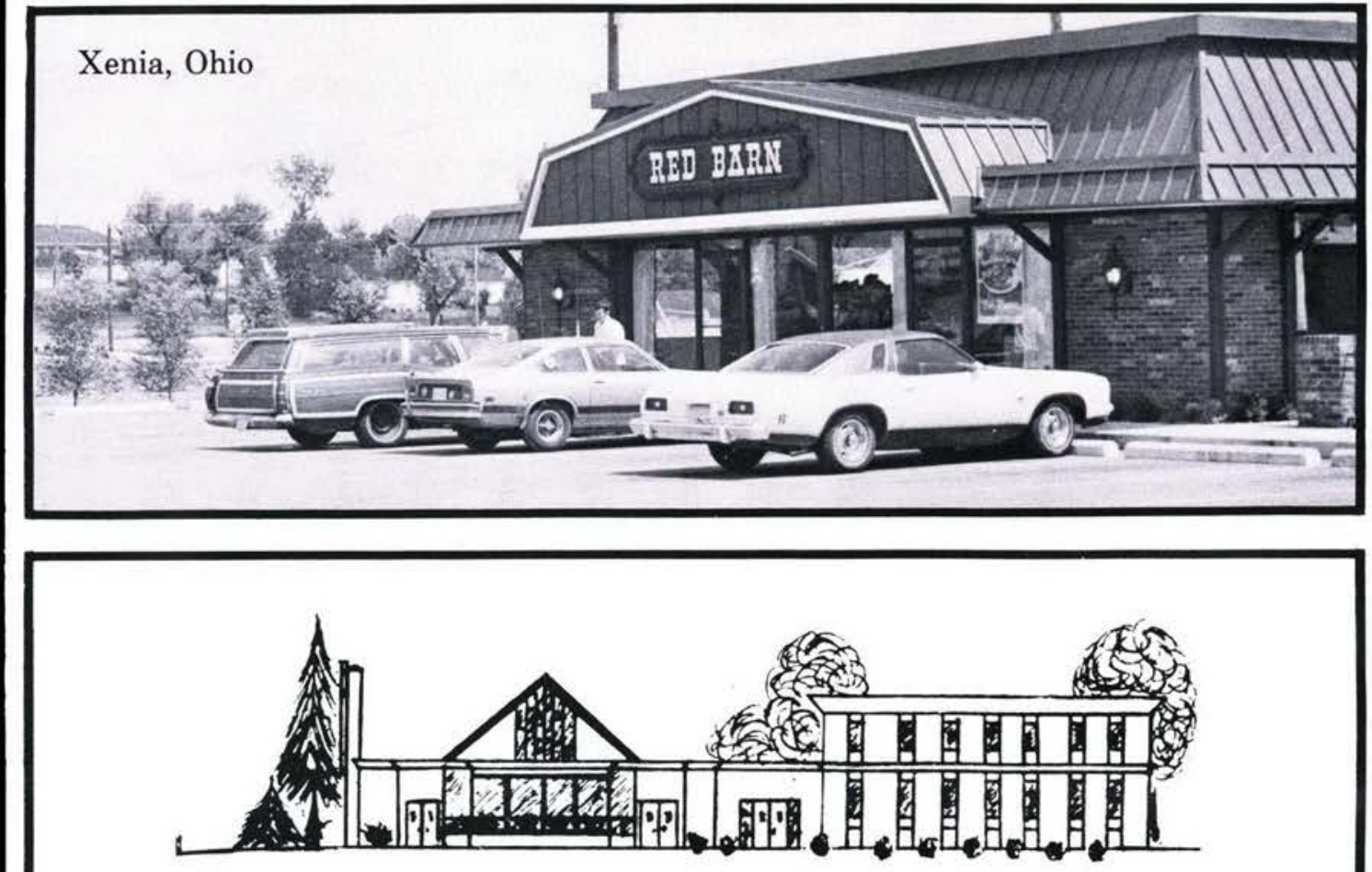

\section{Unian Lake Baptist Church}

8390 COMMERCE ROAD

UNION LAKE, MICHIGAN 48085

\section{COLONIAL PIZZA}

87 N. Main Street

Cedarville, Ohio

\subsection{9}

Tues - Thurs 11:00 am $-11: 00 \mathrm{pm}$

Fri-Sat $11: 00 \mathrm{am}-12: 00 \mathrm{pm}$

Sunday $\quad 5: 00 \mathrm{pm}-11: 00 \mathrm{pm}$

Closed Mondays
242 N: Detroit St.

Xenia, Ohio

Congratulations to the Class of ' 77

\section{ANDERSON INSURANCE AGENCY}

Mrs. Eva Johns

17265 Mayfield Rd.

Windsor, $\mathrm{OH}$

Mr. \& Mrs. Ed Johnson 22W262 Spring Valley Dr. Medinah, IL

Mr. \& Mrs. Norman E. Johnson 1255 th Ave. West

West Fargo, ND

Mr. \& Mrs. Dean Jones

E. 1162224 th

Spokane, WA

Mr. \& Mrs. Henry Karki 1730 Harlansburg Rd.

New Castle, PA

Mr. \& Mrs. Dillon Karsian 269 Poplar Avenue

Hackensack, NJ

Mrs. Neva Kauffman

R.R. \#2, Box $176 Q$

Brownsburg, IN

\section{Roseville Avenue}

\section{Newark, New Jersey 07107}

The Reverend Frank J. Kolk, A.B., N.J.L.A., Administrator
Mr. \& Mrs. Roger F. Keough 8659 Orchard Hill Ct.

Cincinnati, OH 
Mr. \& Mrs. Olen A. Kessel Box 239A, Rt. 2 Keyser, WV

Mr. \& Mrs. Joseph Klimek 342 S. Warren Rd.

N. Jackson, $\mathrm{OH}$

Rev. \& Mrs. Frank J. Kolk 295 Roseville Ave.

Newark, NJ

Mr. \& Mrs. Robert H. Lane 741 Lenox St. New Lenox, IL

Mr. \& Mrs. Bill Lanphier

Box 143

Tracy, IA

Mr. \& Mrs. Arthur E. Larson Box 144, Ogden Dunes Portage, IN

Mr. \& Mrs. James Larson 12551 Blue Spruce Dr., R.D. 3 Edinboro, PA

Mr. \& Mrs. Fred Laxton 935 Squire Lane Milford, MI

\section{GRACE BAPTIST CHURCH}

North Main Street Cedarville, Ohio

Paul Jackson, Pastor

Wishing an Abundant Life to the 1977 Grads

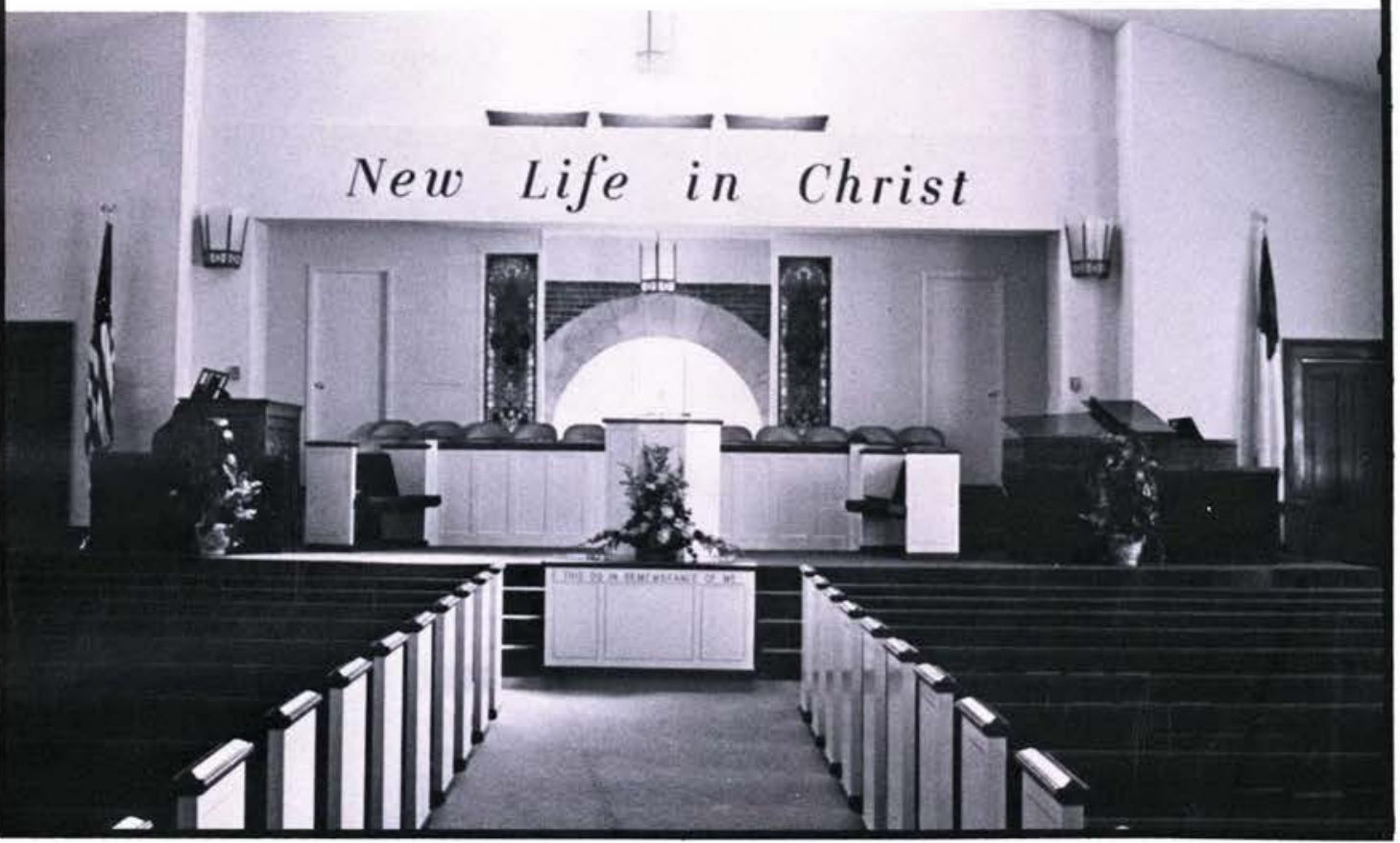

For Your

Best Deal In

General

Electric

Appliances

Housewares

and Gifts

Free Gift

Wrapping

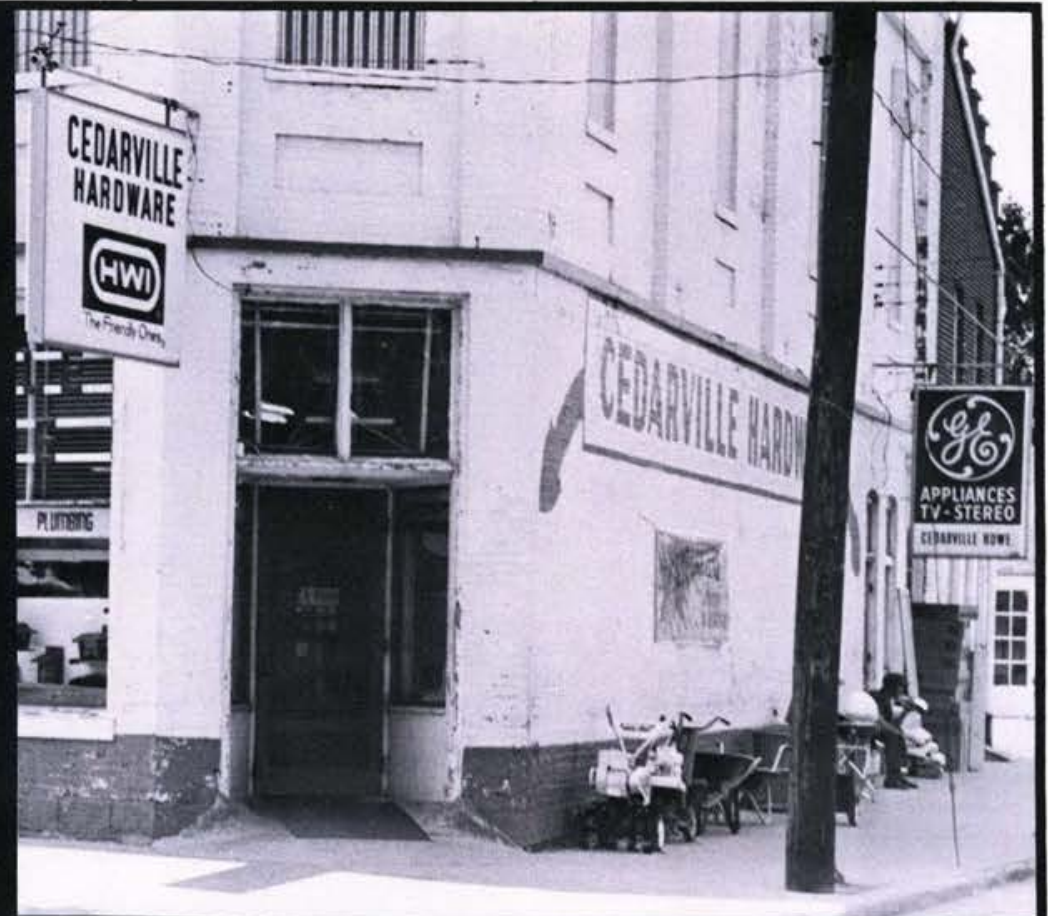

Congratulations to the Class of 1977 


\begin{tabular}{|cc|}
\hline$S$ & \\
$P$ & \\
$O$ & "Everything For The \\
$R$ & Sportsman" \\
$T$ & Converse Shoes \\
$S$ & Athletic Equipment \\
$M$ & Fishing Rods \& Reels \\
$A$ & Bowling Balls \\
$N$ & Weekdays 12 to 9 \\
$S$, & Saturday 10 to 9 \\
1201 Sunset Ave. \\
Springfield, Ohio \\
\hline$O P S$ & 325-6587 \\
\hline
\end{tabular}

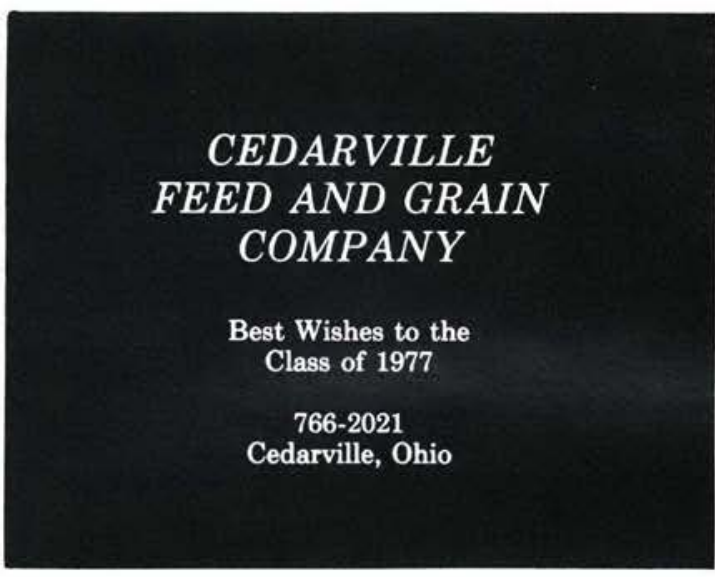

Kennedy's

Supermarket

Xenia Plaza Shopping Center

Xenia, Ohio

Congratulations Class of ' 77

\section{Linda's Flower and Gift Shoppe}

\section{flowers.}

lowers for every occasion designed just for you!

75 N. Main St.
Clayton H. Lewis

1429 N. Woodlawn

Griffith, IN

Dr. \& Mrs. Robert Lightner 2449 Wildrah Ct.

Dallas, TX

Richard Livingood

307 Cypress Ave., Apt. \#12

Trenton, $\mathrm{OH}$

Mr. \& Mrs. Robert McBride

10223 Dodge Lane

Louisville, KY
Cedarville, Ohio

766-5768

\section{Miami Deposit Bank}

"Here to Serve You"

Deposit Insured Up To $\$ 40,000$
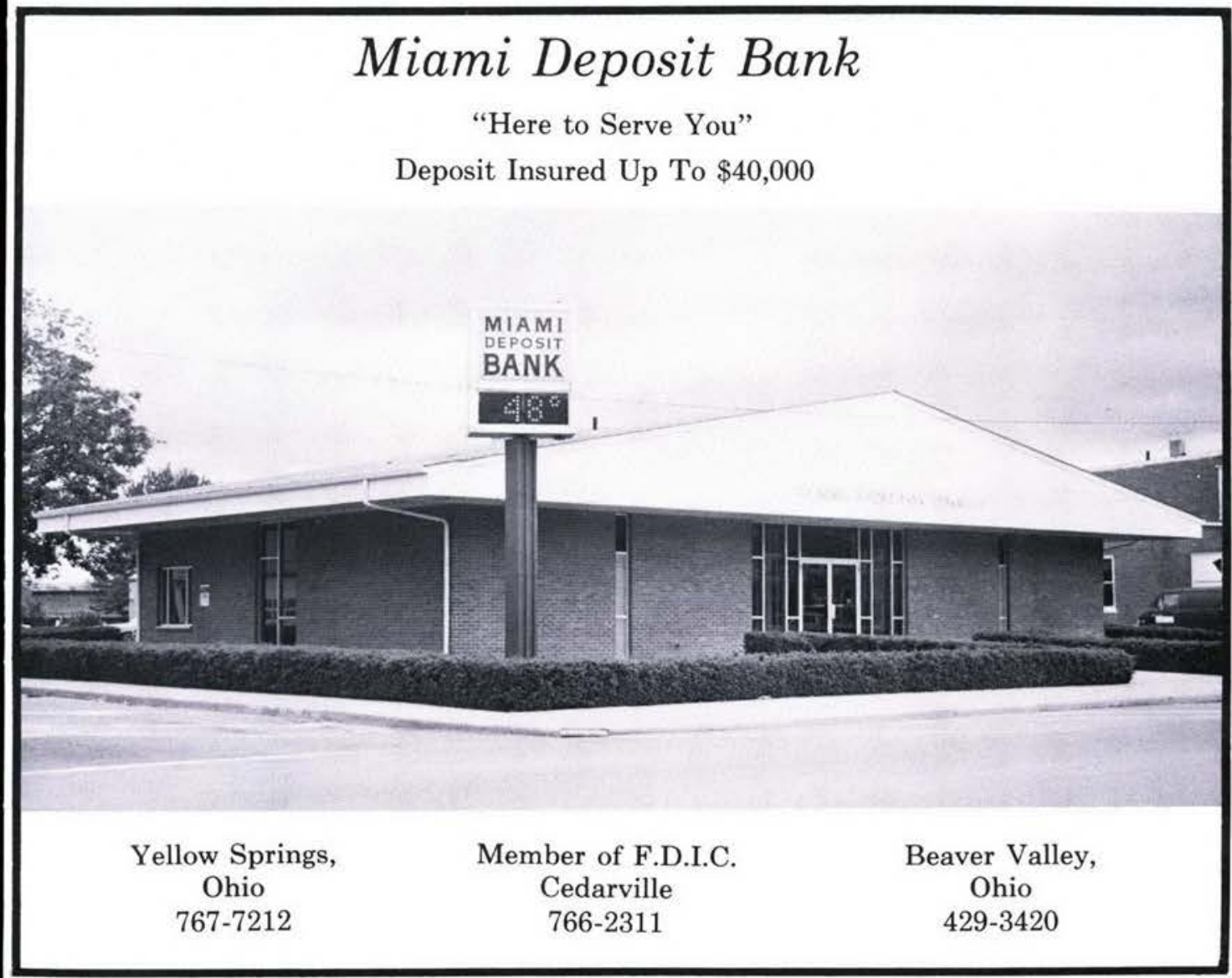

Mr. \& Mrs. Robert E. McCullough 4085 Townview Dr.

Flint, MI

Mr. \& Mrs. Jacob McDonald 721 Lakeview Dr.

Noblesville, IN

Mr. \& Mrs. Harold McLouth 5419 N. State Road

Davison, MI

Mr. \& Mrs. Donald C. Maloney 3474 Frewsburg Rd., Box 208 Kennedy. NY 
Mr. \& Mrs. Nelson A. Marland 948 N. Princeton Ave. Villa Park, II

Mr. \& Mrs. Elmer G. Martin Rt. \#2, Box \#70 Grethel, KY

Mr. \& Mrs. R.L. Medlock 3420 No. 37 th Tacoma, WA

Dr. \& Mrs. Robert Michel 144 Turner $\mathrm{Pk}$. Montour Falls, NY

Mr. \& Mrs. Don Milbauer 3508 Shadyside Dr. Erlamber, KY

George \& Doris Miller 457 Ridge $\mathrm{Rd}$

Horseheads, NY

Mr. \& Mrs. Robert W. Miller R.D. \#2, Box 245 New Providence, PA

Mr. \& Mrs. Russell A. Miller, Jr. 7020 Redmiles Road Laurel, MD
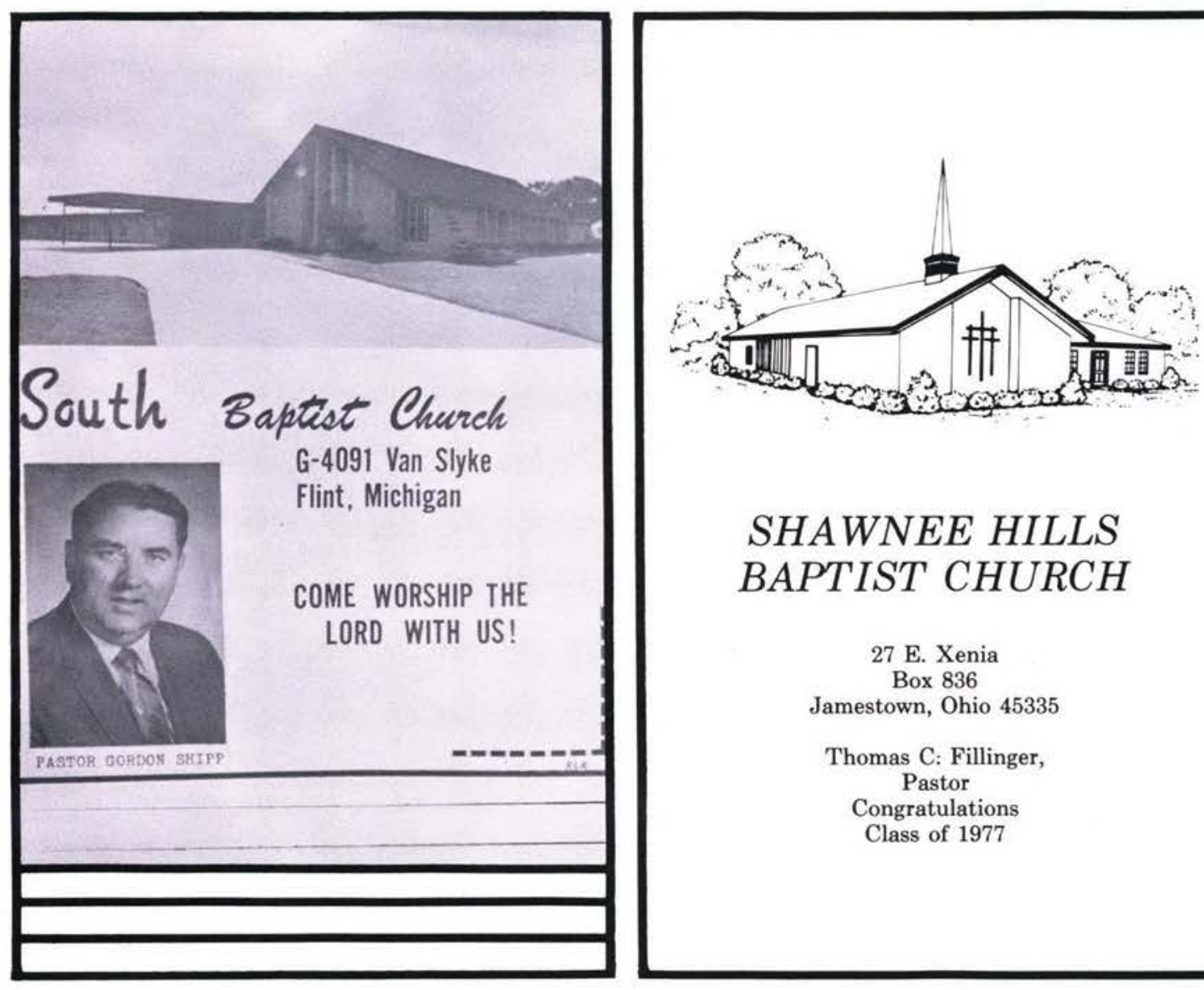

\section{SHAWNEE HILLS BAPTIST CHURCH}

27 E. Xenia

Box 836

Jamestown, Ohio 45335

Thomas C: Fillinger, Pastor

Congratulations

Class of 1977

\section{JOHNNY'S AUTO PARTS}

A Society Corporation Bank

\section{LOCATIONS TO BETTER}

MAIN OFFICE: $161 \mathrm{E}$. Main PLAZA OFFICE:

82 N. Allison Ave

$372-9211$ or $426-6049$

... Over 45 banking services Member FDIC 


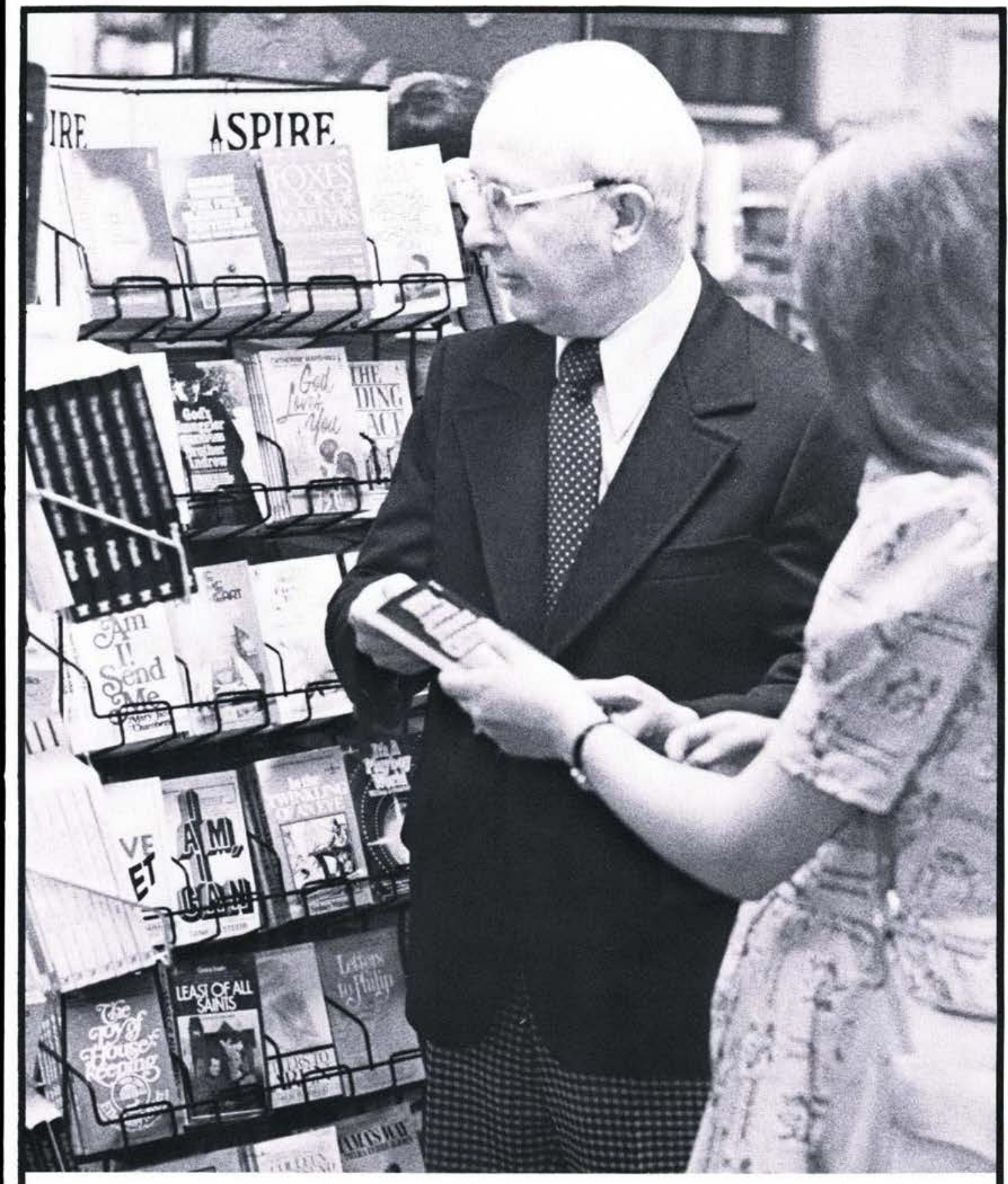

Reignold A. Miner, Jr.

1250 E. Cross

Ypsilanti, MI

Mr. \& Mrs. George Mitchell 315 Broadway

Brooklaun, NJ

Mr. \& Mrs. Louis N. Moberly, Jr. 105 Lesdale

Troy, MI

Dr. \& Mrs. John Molin

2181 Firwood Drive

Davison, MI

Mr. \& Mrs. Amos W. Moore 2489 Avondale Ave.

Roslyn, PA

Mr. \& Mrs. Judson Moore 76 W. Main Street

Port Norris, NJ

Melvin Morley

R.R. \#1

Edna, KS

Mr. \& Mrs. Stephen M. Mucha P.O. Box 106

St. John, IN

\section{CEDARVILLE COLLEGE BOOKSTORE}


Mr. \& Mrs. R.J. Myers 724 Evelyn N.E. Grand Rapids, MI

William H. Napier 804 Avenue E Fort Madison, IA

Mr. \& Mrs. LaVerne Olson 3769 Kansas Drive Santa Rosa, CA

Mr. \& Mrs. George E. Osborne 2415 Royal Dr. Cedar Falls, IA

Rev. William R. Pack 80 Meadow Lane Kenmore, NY

Mr. \& Mrs. Ralph Parke Woodlea Rd., R.D. 2 Dalton, PA

Mr. \& Mrs. Clayton Partridge 67 Miriam Ave. Blasdell, NY

\section{Young's Jersey Dairy}

"the dairy with cows"

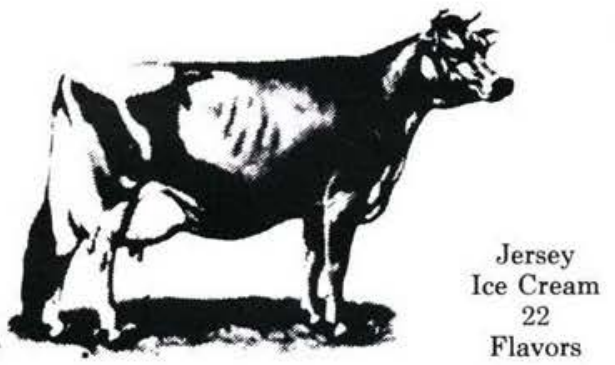

Cones - Sundaes - Shakes

$\begin{array}{ll}\text { donuts } & \text { hamburgers } \\ \text { cookies } & \text { french fries } \\ \text { cakes } & \text { sausage }\end{array}$

open 24 hours everyday

1 mile north of Yellow Springs

\section{Today ... \\ Tomorrow ... \\ Forever}

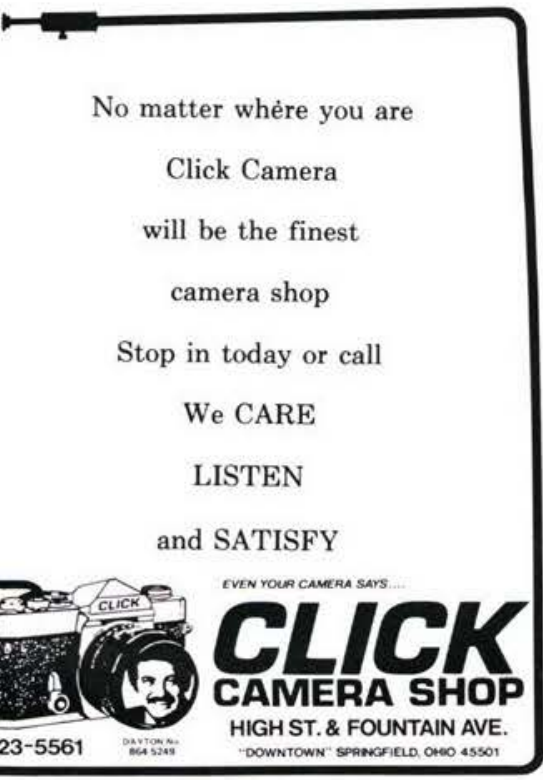

"Let your light so shine before men, that they may see your good works, and glorify your Father which is in heaven."

- Matthew 5:16

\section{YELLOW SPRINGS}

\section{NEWS}

May God's grace lift us all into the glory of His Kingdom

Best Wishes

from the Staff of the

Yellow Springs News

Feel At Home At ...

\section{THE VILLAGE INN}

Cedarville, Ohio

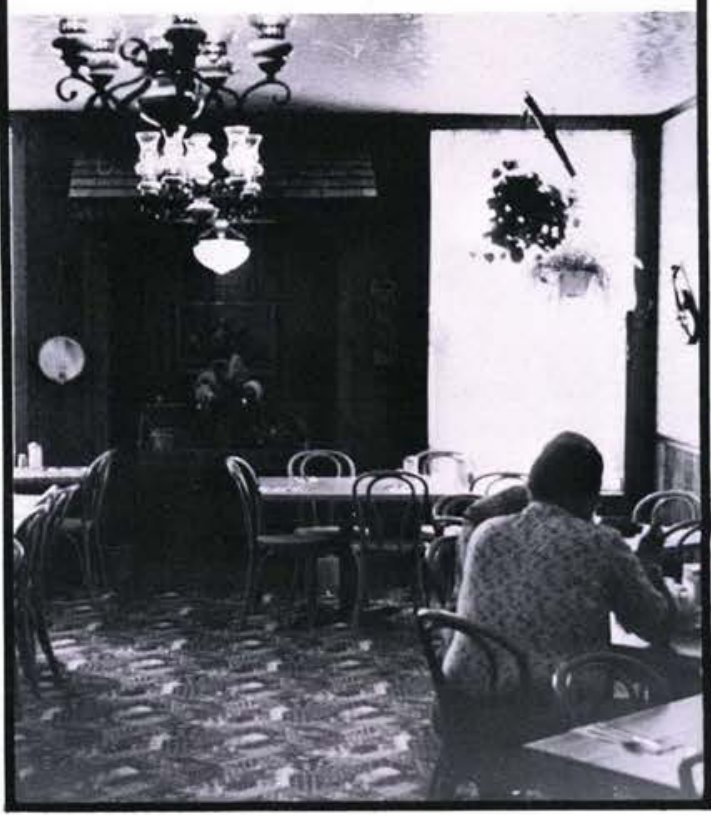




\section{Ed's Tire and Auto} Service, Inc.

Complete Automotive Repair State Rt. 42

Cedarville, Ohio 766-2761

Special Prices on Tires to Students and Faculty
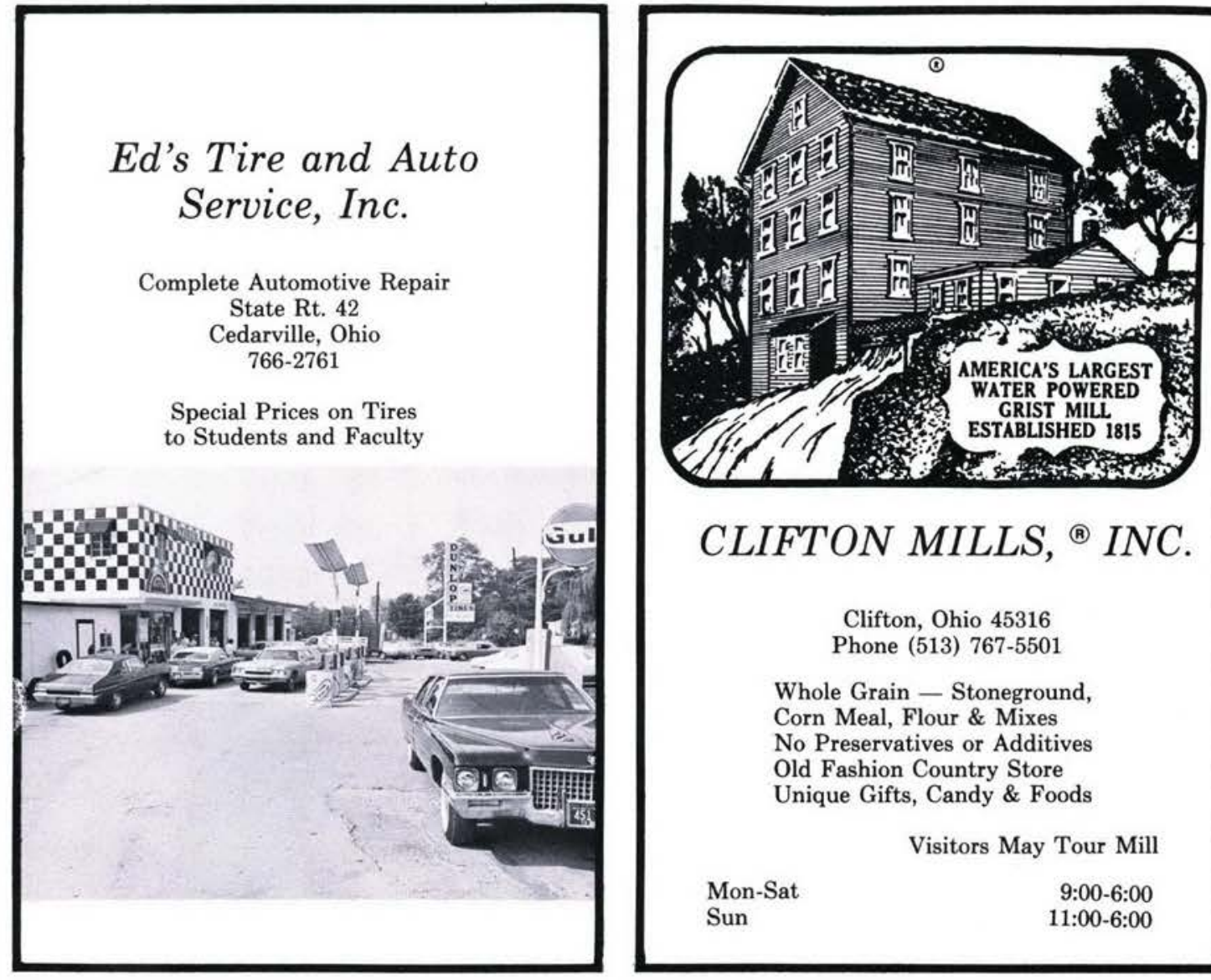

Clifton, Ohio 45316

Phone (513) 767-5501

Whole Grain - Stoneground, Corn Meal, Flour \& Mixes

No Preservatives or Additives

Old Fashion Country Store

Unique Gifts, Candy \& Foods

Visitors May Tour Mill

Mon-Sat

Sun

9:00-6:00

11:00-6:00
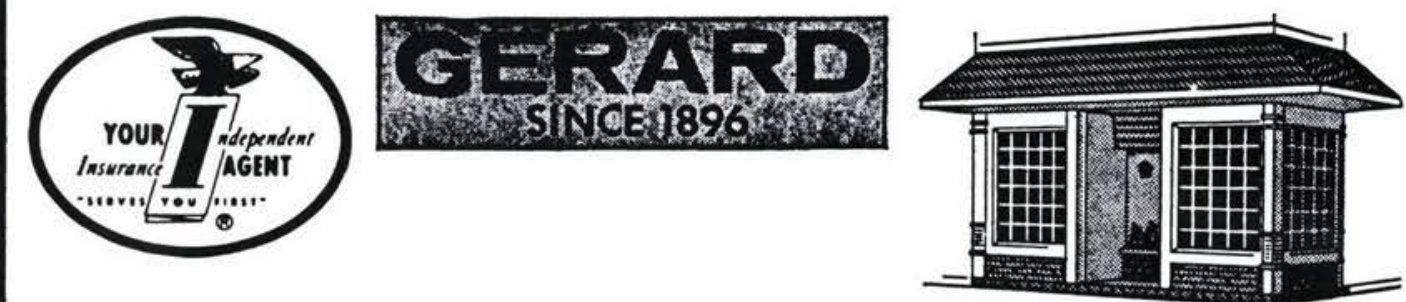

Life

Auto

Fire

Boat

Bonds

Home Owners

Health

Pension Programs
"Insure with Confidence"

\section{A FULL SERVICE AGENCY}

$1 \mathrm{~W}$. Washington

Jamestown, Ohio

Earl Gerard - Res. 372-2600

Dick Baker - Res. 426-2920

Business - Farm - Industrial -

Commercial
Dr. \& Mrs. Charles N. Patton 2509 Sunrise Ave.

Lafayette, IN

Mr. \& Mrs. Clifford M. Peterson R.D. \#2, Box 180

Cuba, NY

Mr. \& Mrs. Don Peterson

Box 156

Haines, AK

Mr. \& Mrs. Norman B. Polley P.O. Box 133

Brownsburg, IN

Gail Poole

26613 Townley

Madison Hts., MI

Mr. \& Mrs. Leneal R. Potter

R.D. \#2

Allegany, NY

Mr. \& Mrs. George A. Price 1550A, US 19 North

Port Richey, FL

Mr. \& Mrs. Harry Price

67 Florence Ave.

Sharon Hill, PA 
Mrs. Stella Pristera 1605 University Ferndale, MI

Mr. \& Mrs. William Pruitt 20378 Bonniebank Blvd. Rocky River, $\mathrm{OH}$

Mr. \& Mrs. Doyle Putman R.R. \#1 Argos, IN

Mr. \& Mrs. Marlin L. Rayburn Cedarville College Cedarville, $\mathrm{OH}$

Mr. \& Mrs. Karl M. Reitnauer 38 E. Washington St. Hornell, NY

E. Reu 225 S. Michigan Villa Park, IL

Rev. \& Mrs. Merle Richardson Missionary Acres, Box 72

Greenville, MO

Mr. \& Mrs. Louis Ricker 18 Mosher Dr. Tonawanda, NY
Rubber Stamps

All Types And

Made To Order

Engraved Signs and Badges

Plastic, Wood, Metal

We Make Our Own!

\section{COMMERCIAL RUBBER STAMP CO.}

2953 S. Yellow Springs St.

Springfield, Ohio 45506

513-322-1924

Bring A

Friend To
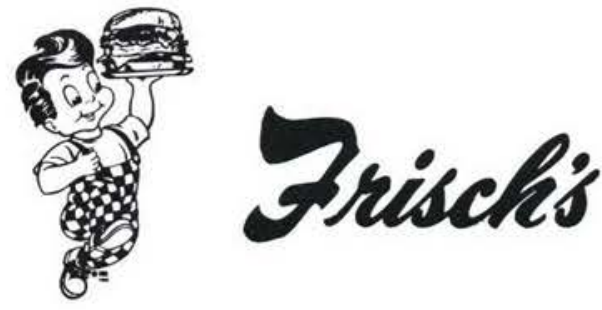

Enjoy Frisch's Famous Big Boy After Any Campus Activity

We've Been Serving You

Since 1955

Plenty of Free Parking and Faster Car Service

26 S. Allison Avenue Xenia, Ohio

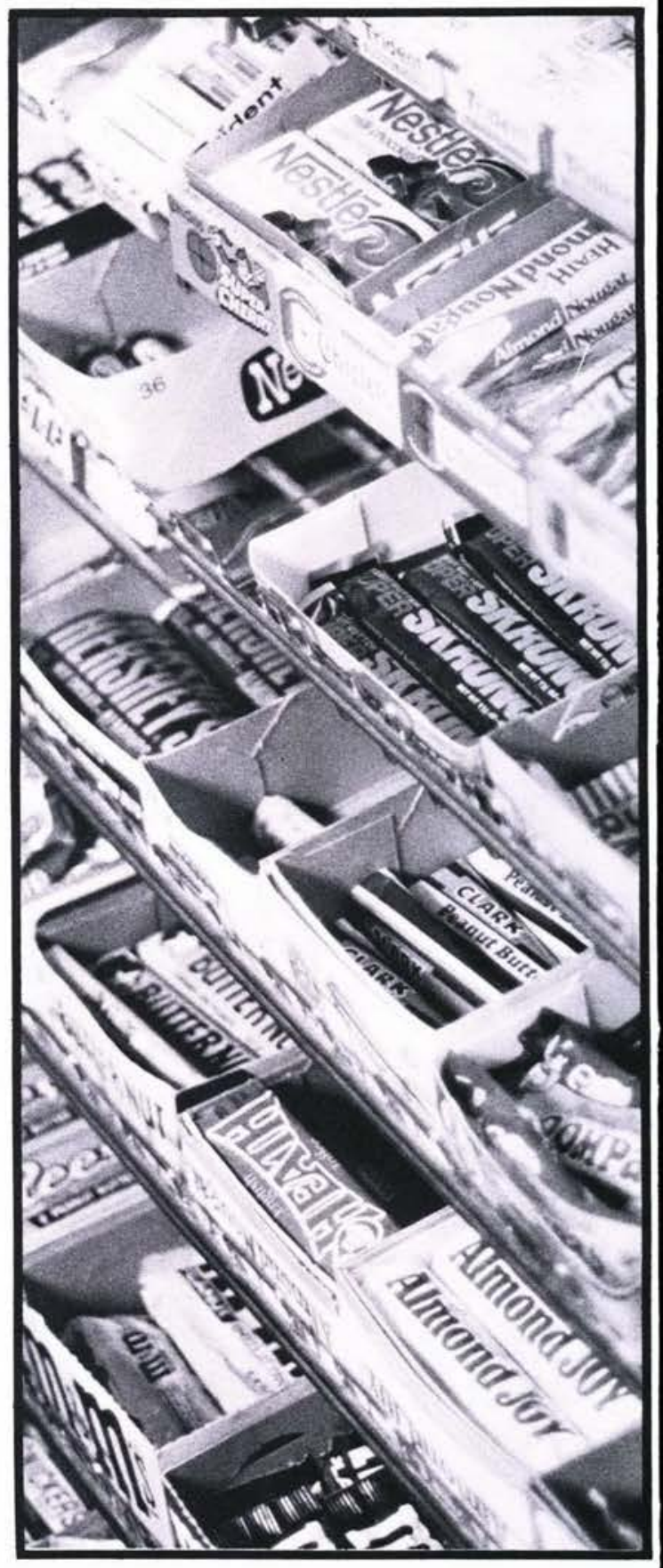

\section{VILLAGE LANES}

Yellow Springs, Ohio

1475 Xenia Ave.

Phone 767-1730

- 10 Lanes Are More Fun Bill Brooks, Mgr. 


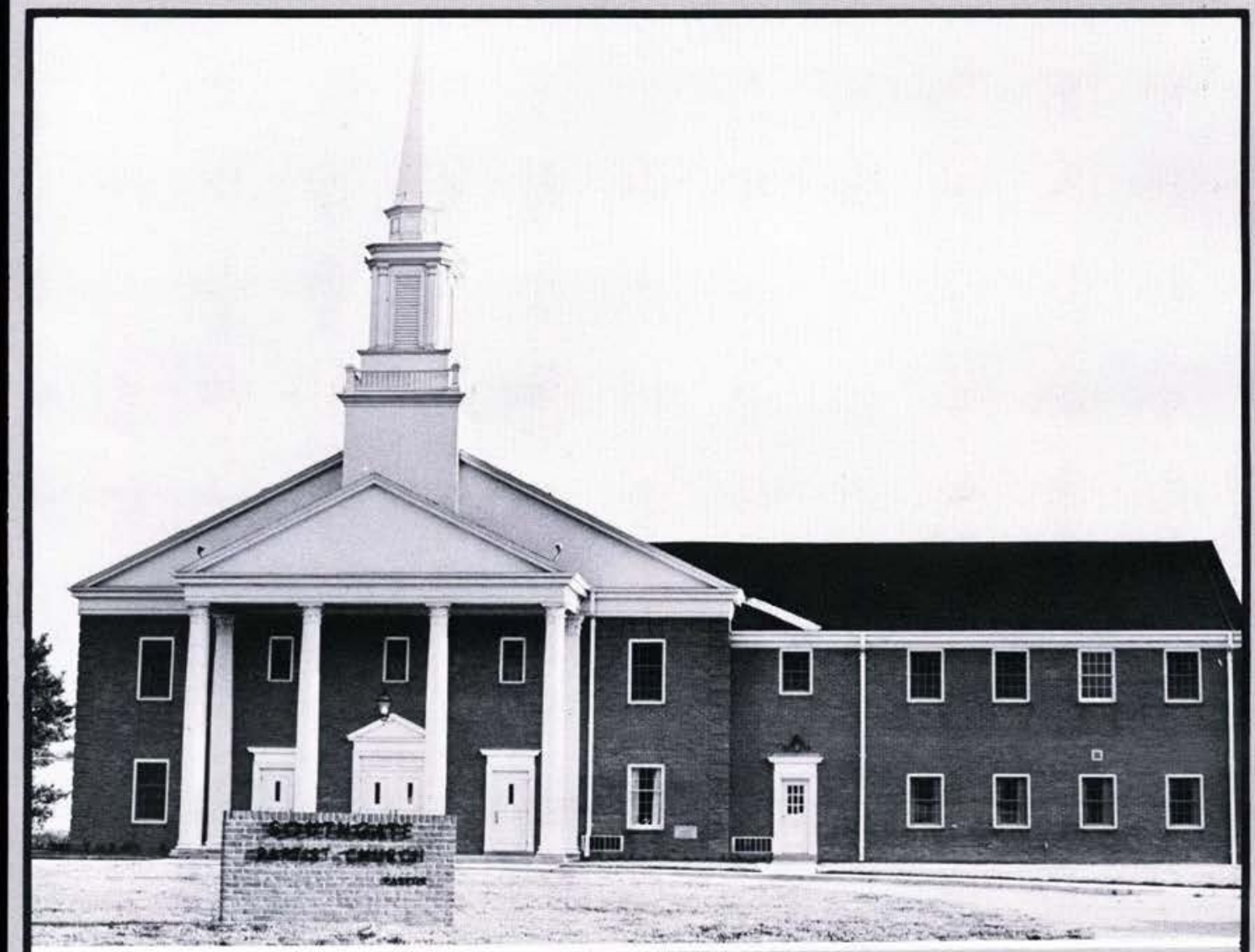

\section{SOUTHGATE BAPTIST CHURCH}

Mrs. Esther M. Riggs

6001 Falcon Lane

Indianapolis, IN

Mr. \& Mrs. Fred Roberts

R.R. \#1, Box 1

Bunker Hill, IN

Mr. \& Mrs. Irvin A. Rollman 225 Clifton Ave.

Reading, PA

Rev. and Mrs. Gordon H. Roloff 156 Aultman Avenue, N.W.

Canton, $\mathrm{OH}$

Mr. \& Mrs. Raymond Romein R. 2, Box 125

Delphi, IN

Mr. \& Mrs. Joe Salyer 305 W. N.Y. St.

Knox, IN

Glenn E. Sawyer

2434 N. Terrace Ave.

Milwaukee, WI

Mr. \& Mrs. Vincent Sayre

R.D. \#2

Carthage, NY
Behold, the fear of the Lord, that is wisdom; and to depart from evil is understanding.

JOB 28:28 
Fred Schieber 31 Penn Ave. Rockledge, PA

Mr. \& Mrs. A. Schierwagen 33 Chestnut St. Pearl River, NY

Mr. \& Mrs. K. Ardell Schlesinger Woolrich, PA

Mr. \& Mrs. Donald Schuchard 3524 Adair Ave. No. Crystal, MN

Mr. \& Mrs. John R. Scoggins 729 Ridge Lane East Alton, IL

Mr. \& Mrs. A.D. Searles R.D. \#3 Wakeman, $\mathrm{OH}$

Quinten Seeley P.O. Box 63

Medina, $\mathrm{OH}$

Mr. \& Mrs. Charles E. Segerstrom 1207 Williston Avenue Waterloo, IA

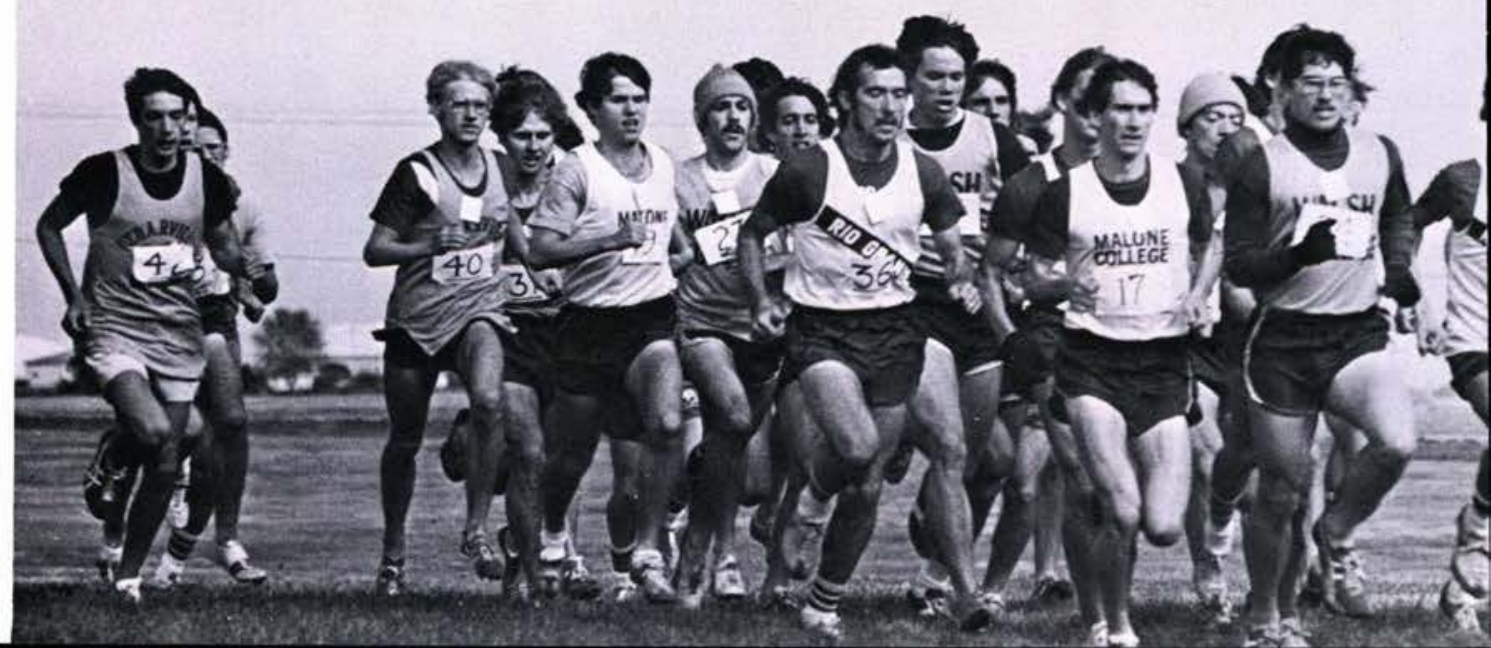




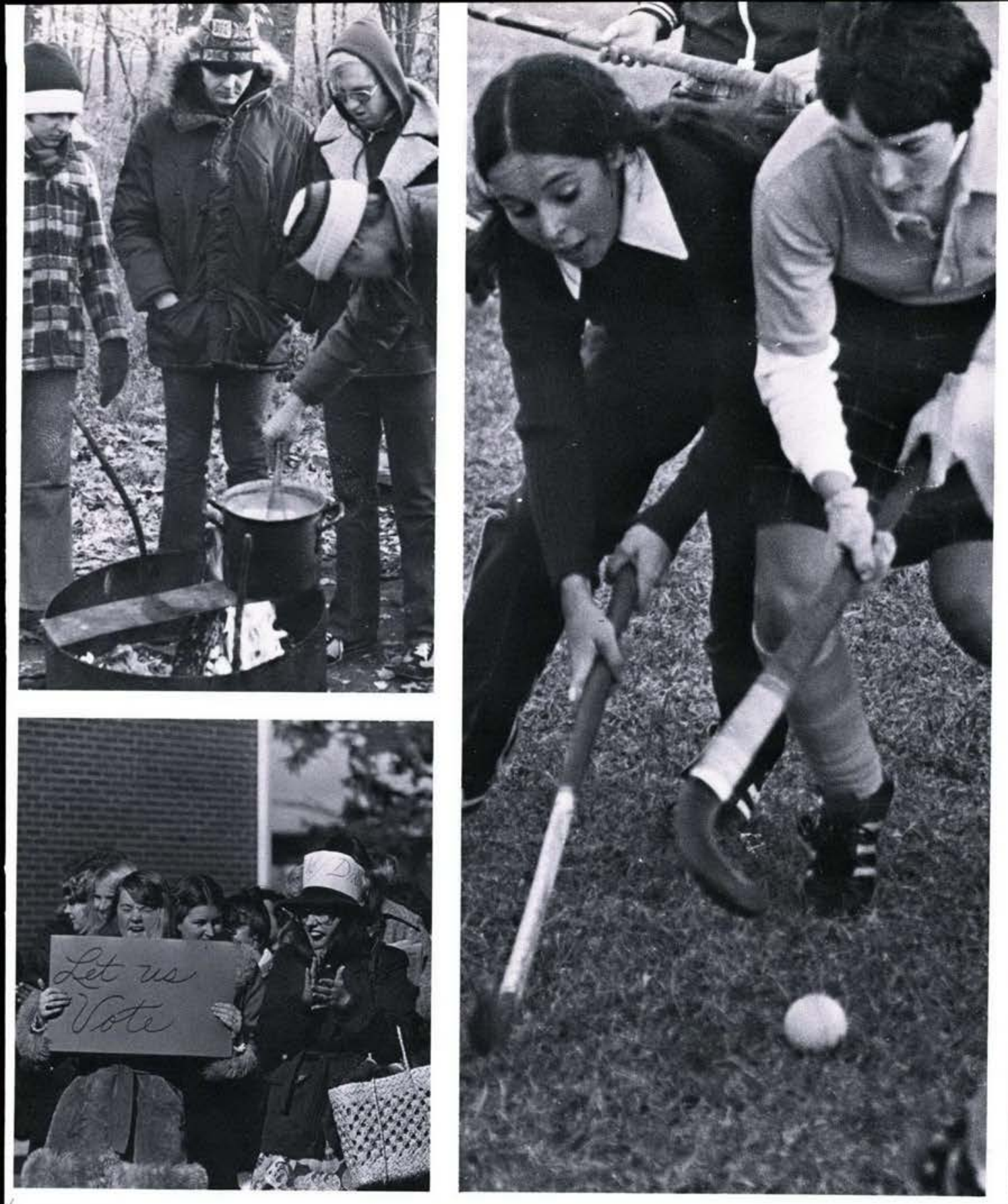

Mr. \& Mrs. Roy L. Shumaker

1620 Exeter Rd.

Westminster, MD

Mr. \& Mrs. William W. Sirka

7911 Meadowbrook Drive

Indianapolis, IN

Mr. \& Mrs. Floyd Sliker

R.D. \#2

Worthington, PA

Eric H. Smith

3765 E. Omaha Drive

Grandville, MI

Richard \& Jean Steinhofer

310 Lacey Drive

New Milford, NJ

Mr. \& Mrs. Keith Streitmatter

R. 5, Box 33

Rensselaer, IN

James \& Rhea Sullivan

15621 Camden

East Detroit, MI

Mrs. Betty Jane Sweeney

R.D. \#3

Jersey Shore, PA 
Mr. \& Mrs. James E. Tawney 108 Koontz Avenue Clendenin, WV

Kenneth Taylor P.O. Box 20 Williston, ND

Mr. \& Mrs. Raymond Taylor 2623 Wedgewood Rd.

Des Moines, IA

Mr. \& Mrs. Louis Terlouw Rt. 1, Box 153 Prairie City, IA

Mr. \& Mrs. Raymond L. Terrell 222 Bartow Dr. Barboursville, WV

Mr. \& Mrs. Corbin Tillman 3211 W. Maple Rd. Wixom, MI

Jack \& Marjary Tindall 5866 Hosner Rd. Oxford, MI

Mr. \& Mrs. Clarence Totman Box 172 Cincinnatus, NY

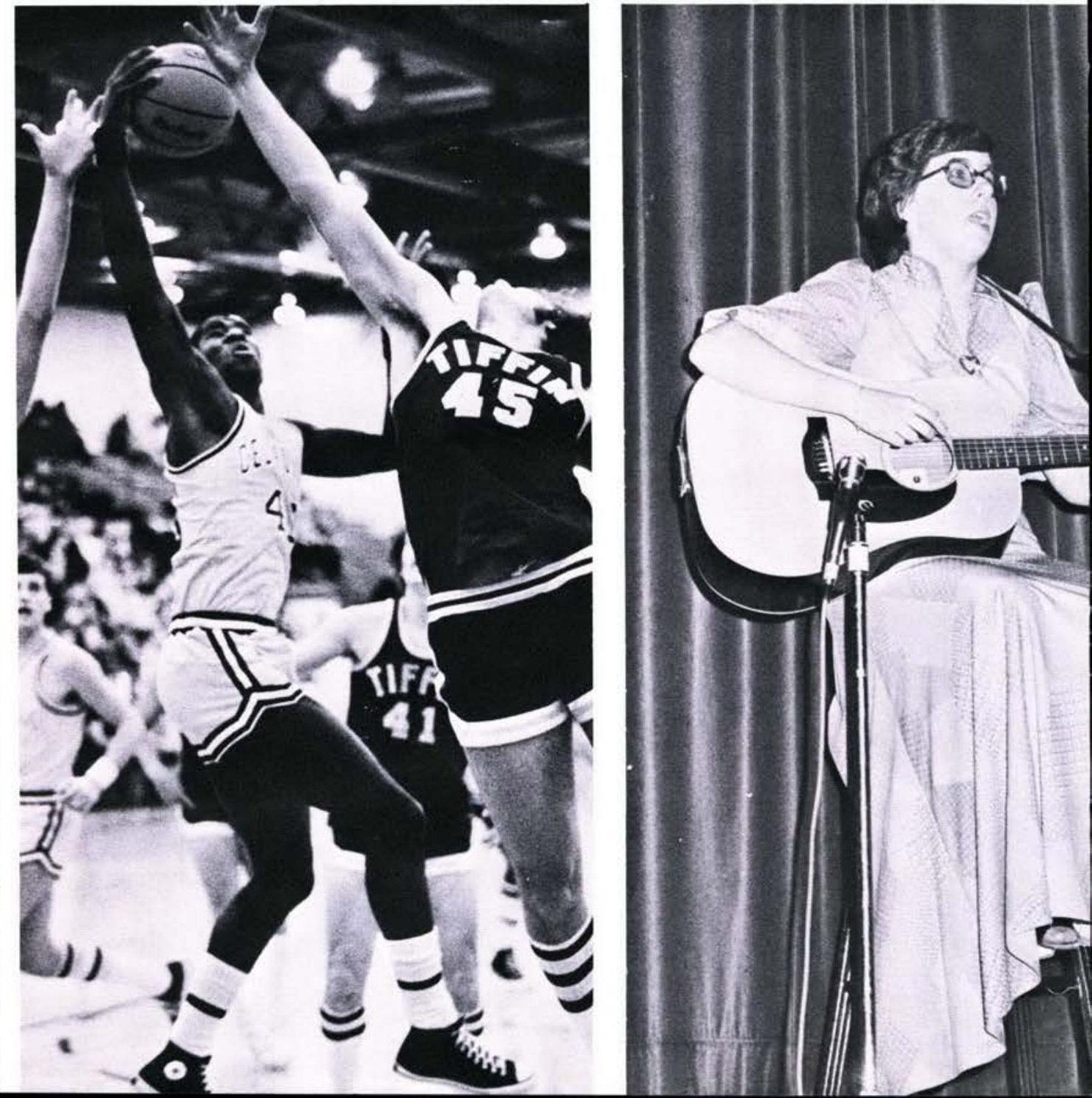


Mr. \& Mrs. C. Russell Wildermuth 3320 Upland Avenue Boothwyn, PA

John \& Freida Wilson 2142 Berrypatch Dr. Cincinnati, $\mathrm{OH}$

Mr. \& Mrs. Thomas A. Wittlinger 7071 Tonawanda Creek Road Lockport, NY

Mr. \& Mrs. Gordon Wood R.D. \#2, Box 135

Curwensville, PA

Mr. \& Mrs. Francis A. Wozniak 3102 Johnson Cr. Rd. Middleport, NY

Rev. \& Mrs. Edwin Wyman 1902 54th Street East Bradenton, FL

Mr. \& Mrs. Richard Yater R.R. \# 3 Crawfordsville, IN

Mr. \& Mrs. Forest R. Yoder 1525 Monter Ave. Louisville, $\mathrm{OH}$

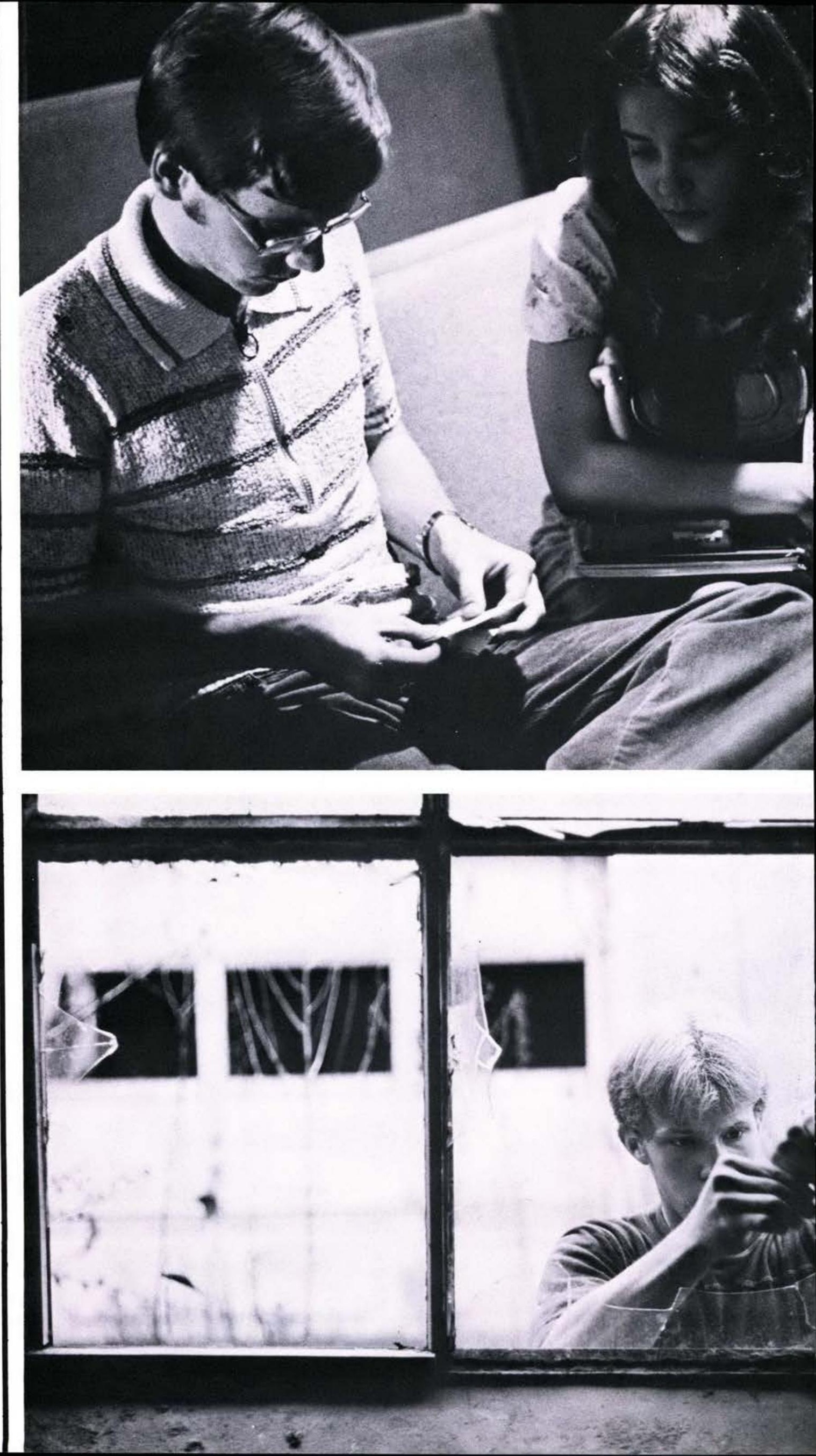


We know that God has revealed Himself in three ways: (1) by His Word, the Bible, which we at Cedarville are taught; (2) by His creation, which we in stillness view as an expression of the glory of God; and (3) by His Son, who Himself was perfect and whose humble and godly spirit showed us the way to Heaven. It was by His willing obedience to the Father's command that He submitted to death on the cross. This death was a substitute to take our place as a result of our sin. It is belief in the Person and the Work of the Savior that brings one into a saving relationship with God. We are no longer doomed to spend eternity in Hell.

Jesus' exaltation will come - and we as believers will be united with Him to exalt Him forever.
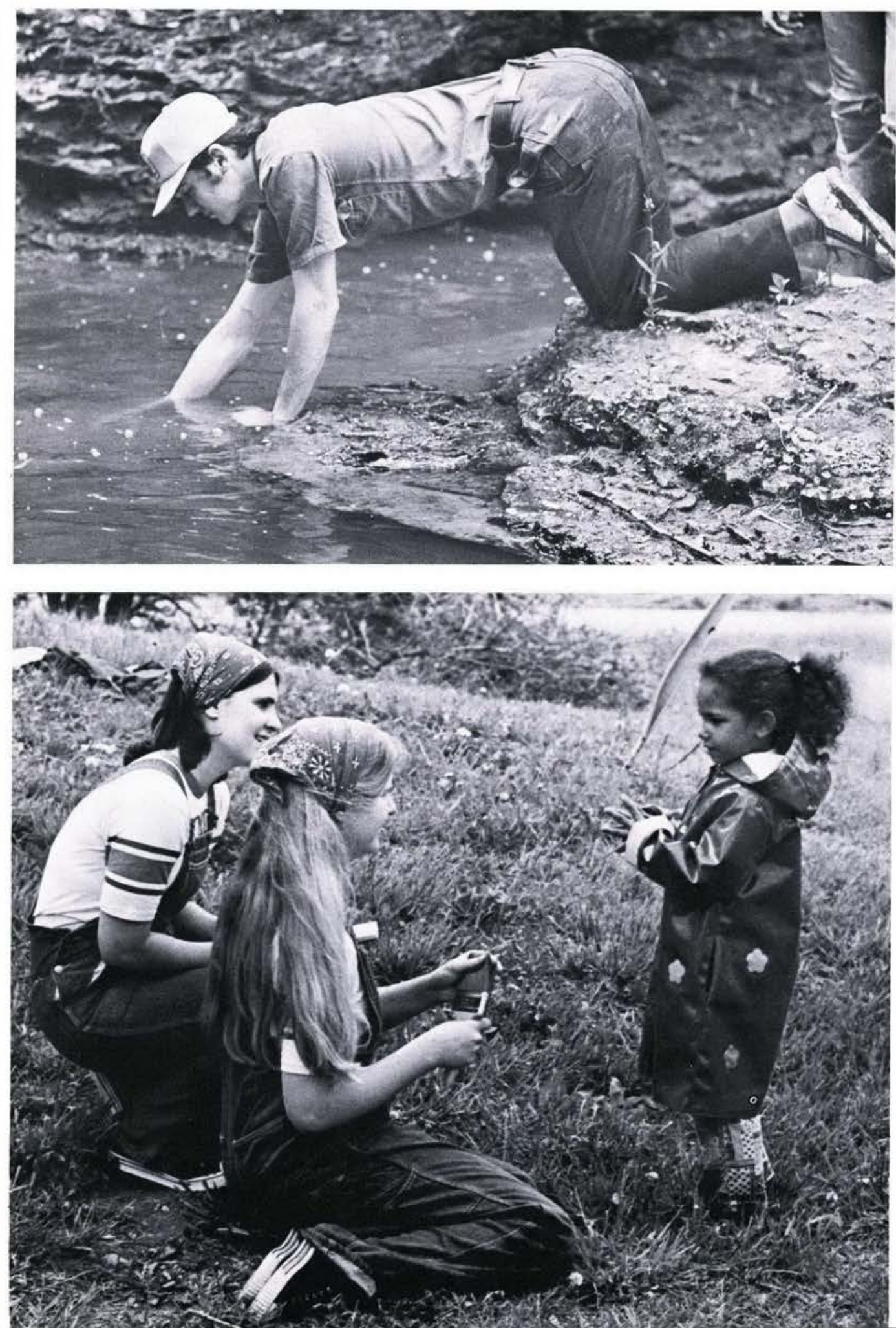

Mildred B. Zachary 226 Oak Park Dr.

Brevard, NC

Mr. \& Mrs. Louis Zaller 771 East 348th Street Eastlake, $\mathrm{OH}$

Mr. \& Mrs. William Zelonis 721 22nd St. N.W. Canton, $\mathrm{OH}$

Rev. Joseph E. Lewis

4506 Moore Rd.

Middletown, $\mathrm{OH}$ 
Let this mind be in you, which was also in Christ Jesus: Who, being in the form of God, thought it not robbery to be equal with God: But made himself of no reputation, and took upon him the form of a servant, and was made in the likeness of men: And being found in fashion as a man, he humbled himself, and became obedient unto death, even the death of the cross. Wherefore God also hath highly EXALTED him, and given him a name which is above every name: That at the name of Jesus every knee should bow, of things in heaven, and things in earth, and things under the earth; and that every tongue should confess that Jesus Christ is Lord, to the glory of God the Father. 
Abbott, Dan, 52, 154

Abels, Nancy, 41, 68

Abercrombie, Jim, 52

Abernathy, William, 52, 163

Acker, Jeff, 41, 88, 210 Ackley, Steve

Adams, Barbara, 41, 103, 154

Addison, Nanette, 52, 59 Adkins, Cathy, 41

Aeshleman, Deborah, 22, 41 Aitken, Leslie, 70

Aitken, Thomas, 41

Allan, Warren, 29, 30, 52 Allen, John, 52 Allen, Michael, 98

Alspaugh, Cheryl, 52, 59 Altimus, Tim, 52, 59, 80, 81 Alvey, John, 52 Amsden, Diana, 41

Amstutz, Kent, 52, 59, 70, 163, $164,198,199,206$

Anderson, Crystal, 34, 52, 104 Anderson, Dean, 52 Anderson, Joy, 18, 52

Anderson, Kim, 52, 59

Anderson, Kris, 8, 52, 130, 157,

204

Anderson, Scott, 163, 183, 184

Anderson, William, 87

Andes, Patrice, 215

Andrew, John, 52, 142

Andrus, Kenneth, 41, 95

Angel, Karin, 24, 52, 170

Apple, Brenda, 52, 59, 88

Armstrong, Kathleen, 52

Arthur, Jane, 52, 70, 202 Arthur, Sarah

Arvay, Paula, 52, 210 Ashley, Roger

Atkinson, Bryce, 24

Atkinson, Richard, 25, 41, 130

Auwarter, Clay, 30, 52, 59

Auwarter, Richard, 30, 215

Avery, Lee, 52, 59, 91, 154

Axiotis, Margo, 141, 212, 215

Axiotis, Pamela, 18, 41

Babcock, Edward, 52 Babcock, Lana

Bahorik, Scott, 21, 22, 41, 163 Bailey, Tom, 52

Baker, Pamela, 52, 68

Baker, Terry, 68, 215

Balais, Robert, 183, 215 Baldwin, Martha Baldwin, Richard

Baldwin, William, 41, 89, 177

Banks, Elizabeth, 191

Banner, Cythia, 52

Barnett, Michael, 41, 106

Barrett, Barbara, 212, 215

Barrett, Jim, 52, 84, 85

Barrett, Sharon, 41 Barror, Clarence

Bartemus, Donald, 30, 97, 173,

215

Bartley, Ronald, 194 Basye, Daniel, 59 Bates, Patricia

Bathurst, Leah, 215

Batista, Evandro, 29, 30

Battaglia, Michael

Baumann, Carol

Bean, Jeffrey, 52, 68 Bearss, John

Beck, Lynn, 11, 210, 215
Becker, Becky, 41

Begley, Beverly, 93, 199, 216

Beight, Scott, 41, 66

Beikert, Barbara, 82, 206, 214,

216

Beikert, Beth, 41

Bell, Daniel

Belleman, Benny, 30

Benedict, Deborah, 216

Benefiel, Tom, 29, 30, 59, 97

Bennett, Gene, 59, 84, 92

Benson, Linda, 22

Benson, Norman, 22, 52

Bentley, Mike, 21, 23, 52, 80,

130, 206

Bentley, Rita, 59

Berger, Daniel

Bernhard, William, 24, 25, 100,

173,216

Bernstein, Barbara, 41

Betts, Daniel, 41, 154

Betts, Donnie

Bibeau, Donna

Bigelow, Ronald, 160

Biggs, Deborah, 214, 216

Biggs, Mala, 40, 41, 163

Birkenholtz, Patricia, 59, 91,

113

Blackburn, Beth, 52

Blackburn, Debra, 9, 22, 24, 52,

130, 163

Blackstone, Pamela

Bleeker, Marlene, 22,

Bleeker, 9, 22, 206, 216

Blue, Richard

Board, Suetta, 18, 52

Bond, Denise, 52, 66, 84

Bonzo, Sandra, 18, 41

Book, Ruth, 41

Borck, Jay, 52

Bos, Suzanne

Bos, Timothy, 88, 89, 163

Boston, David

Bowers, John, 41

Bowers, Richard

Bowman, Daniel, 82, 216

Bowser, George, 59, 80

Bowser, Valerie, 216

Brace, Greg, 41, 80

Bremmer, Terrill, 41

Braun, Daniel

Brazelton, April, 14, 41

Brentlinger, John

Bresson, Daniel, 66, 97

Bresson, Michael, 41

Brewer, Joseph, 41

Briggs, John, 21, 41, 74, 75, 108

Broach, Terry, 8, 52, 66, 78, 91, 158

Brock, Juanita, 216

Brower, Kathleen, 41, 66

Brown, Cheryl

Brown, Coessa, 203

Brown, Elaine, 36, 180, 217

Brown, Judy, 41, 66, 103

Brown, Rebecca, 52, 149

Brown, Steven, 41, 66, 206

Browne, Kevin, 22, 41, 92

Browne, Scott, 52, 91, 130, 154,

157,172

Browning, Sara, 19, 66, 130,

141, 217

Bruening, Laurie, 36, 41

Bubel, Janet, 52, 151, 203

Budnik, Paul, 32, 80, 82, 97, 183,217
Buettell, Paul, 50

Bunker, Louis, 41, 80, 130

Bunton, Cathy, 34, 59, 104, 105

Burleson, Vicki, 52, 66, 205

Burnette, Charles, 59, 177

Burns, David, 22, 59, 78, 80, 84

Burns, Dennis, 22, 130

Burns, Donald, $41,66,78,80$ Burtner, David

Burtner, Pam, 19, 217

Bushong, Gloria, 59, 70, 157

Butcher, Debra, 130, 217

Butcher, Joyce, 22, 41

Butcher, Judi

Butler, Michael, 41

Butler, Vicki, 41, 104, 180

Byers, Janice, 51, 52

Cafferty, Brian, 41

Cagwin, Randy, 52, 97, 177, 179 Calhoun, Ron

Callan, Jan, 41, 66 Callan, Nedra

Campbell, Randy, 52, 70, 130 Campbell, Steven, 59

Carey, Cheryl, 34, 52, 180 Carr, Janet, 217

Carr, Loraine, 41 Carr, Scott.

Carrington, James, 166, 200, 201,217

Carroll, David, 59, 114, 154

Carroll, William, 21, 42, 66, 198, 207

Cartan, Sharon, 52

Cartwright, Joyce, 42, 88 Case, Barton, 9, 59

Castellani, Mark, 77, 85 Castellano, August

Castle, Cindy, 34, 35, 42, 104 Caulfield, Jack, 141

Cavey, John, 217 Caylor, Sandra

Cayton, Marlin, 80, 82, 91, 214, 217

Chamberlain, Guthrie, 21, 52,

Chambers, Rachel, 59

Chamblin, Sherry, 19, 199, 218

Champlin, Sandra, 18, 52, 201

Chandler, Scott, 42

Chesser, Dennis, 29, 97, 98, 100, 135,207

Chipukits, Marie, 191

Chmura, Thomas, 22

Christian, Dale, 42, 66, 207

Churchward, Kenneth, 42

Clark, Marilee, 218

Clark, Ronald, 29, 30, 218

Clark, Russ

Clarke, Victoria, 42

Cline, Vicki, 18, 141, 158, 163, 165,218

Clithero, Connie, 218

Clough, Debra, 59, 113

Coates, Pamela, 42

Cobb, David, 59, 157

Cobb, Judy, 19, 59, 66

Cobb, Rebecca, 19, 59, 91 Cody, Theresa

Colas, Craig, 21, 32, 40, 42, 77, 146, 188, 207

Colburn, David, 97

Coleman, Joyce, 84

Collingsworth, Rita, 42

Combs, Stephen, 218

Combs, Tammy, 42, 202

Commeville, Richard, 97, 218

Compton, Bruce, 59

Conklin, Jeff, 52, 106

Connors, Gary, 52

Connors, Richard, 42, 66, 84, 95, 207

Conrad, David, 42, 66

Conrad, Diane, 59

Cook, Robert, 218

Cook, Thomas B., 29, 30

Cook, Thomas G.

Coombs, Stephen, 42

Cooper, Daniel

Cope, Merrilee

Cornell, Ruth

Cornwell, Ralph

Courtsal, Peter, 59

Courtsal, Rachel, 59

Couture, Jonathan

Cowell, Mark, 59, 80, 154, 155

Cowell, Sheri, 238

Cowen, Cheryl

Cowen, Jeffery, 59

Crady, Dennis, 218

Craig, Kent, 42

Crain, Pat, 219

Crandall, Nora, 42, 93, 201

Creeger, Stephen

Cremean, David, 42, 177

Crompton, Richard

Crone, Micheal, 219

Cross, Judith, 36, 59, 130

Croy, Janice, 42, 68, 150

Crum, Roni, 36, 180, 219

Crymble, Steven, 31, 219

Cuffman, Mike, 15, 59, 157, 166

Culver, Carolyn, 219

Cunningham, Audrey

Curtis, Dawn, 21, 154

Dailey, John, 14, 53

Dalby, Pamela, 59

Dallis, Floyd, 51, 53, 66, 130,

142

Dalton, Kathleen, 53

Danec, Tami, 18, 42, 66

Danielson, Cheryl, 53, 210

Dannenberg, John, 59, 80, 84,

85, 201

Danube, Thomas, 42, 200

Dariano, Joseph, 42

Darnell, Kevin, 219

Dautel, Debbie, 42

Davenport, Michael, 59, 92

Davey, Terea, 42

Davis, Janet, 53

Davis, Jeffrey, 59

Davis, Linda

Davis, Timothy, 42, 66, 95

Dawson, Sandy, 59

Dean, Nancy, 53

Dear, Nancy, 212, 219

Decker, Rebecca

Decker, Virginia, 42, 66, 74

Dedic, Dan, 59, 97

DeLancey, Rebekah, 36, 53, 191

DeLange, Ed, 59, 130, 165 
DePriest, Roger, 97, 219

Dernlan, David, 114, 220 Dernlan, Susan

Dersham, Paula, 68, 130, 220 Detwiler, Tim, 130, 220

Devine, Marty, 53, 177

DeYoung, Janice, 53

DeYoung, Lou Ann, 91, 53, 155 160,161

Dillsworth, Debbie Dillsworth, Gale

Dixon, Debra, 9, 53, 163 Dobson, Kenneth Dolph, Mike, 200

Donahue, Brian Donahue, Maria

Donaldson, Gordon, 30, 53

Donalson, Paulette, 11, 212, 214,220

Donnelly, Lynne, 34, 53, 180 Dorrington, Harold Douglas, Cassie, 18 Douglass, Cheryl, 42, 66, 163 Douglass, Randall, 78, 80, 84 , 154,220

Dowd, Timothy, 42, 100, 188 Drake, Nancy, 60, 158 Driscoll, Rebecca, 53

Drozek, David, 53, 130, 143 Dugan, Eileen, 53, 87 Duncan, Karen, 66

Dunham, William, 220

Dunn, Daniel, 58, 60, 91, 157 Durham, Cathy Dyer, Karen, 53

Earnhart, Lori, 53

Eaton, Rosalie, 60, 91, 93, 154 155,206

Ebel, Janet, 53, 66, 84, 130 Edlund, Alan

Edwards, Paul, 51, 53 Ehrman, Ida, 42, 66 Eissens, John, 146

Eissens, Linda, 50, 53 Ellington, Dave, 30, 53, 70, 155

Geoffrey, Ellington, 30, 42

Elliott, Charles, 80, 81, 167, 220 Ellis, David, 43, 154, 192

Elmore, Deborah, 50, 155 Elmore, Floyd, 220 Elmore, Marabeth Emery, Mary, 60

Engdahl, Elizabeth, 60 Engdahl, Jonathan

England, Erech, 43, 70, 154

English, Jessilon, 60, 68

Erickson, Judy, 60, 157

Ernst, Linda, 60, 201

Erny, Ken, 60, 70, 97, 132, 187,

Esham, Vernon, 60

Evans, David, 97, 221

Evans, Donna, 53

Evens, Dwight, 22, 130, 212, 221

Everett, Laura, 60

Farmwald, Patricia, 43, 84

Faull, Kim, 43, 88, 154 Fava, Ann, 43

Felmlee, William, 14, 53, 80,

Felts, Susan, 43

Fenstermaker, Ronald

Fenton, George

Fenton, Ruth, 18, 43

Fertig, Ned, 53

Festag, Deborah, 18, 60, 68
Fetzer, Karen, 60

Few, Bryan, 60

Few, Dennis, 60

Fields, Donald

Fields, Duncan, 106

Filmer, Marjorie, 18, 43, 68

Fleming, Bruce, 60, 97, 188, 189

Fletcher, Rita, 43

Flint, Paula, 53

Flood, Lawrence, 43

Flowers, Tom, 38, 221

Floyd, Kenneth, 43, 221

Floyd, Ron, 177, 178, 207

Fogle, Sallie, 60

Footman, James, 53, 130

Foreman, Robert, 60, 87, 154, 155

Forrest, Darla, 43

Forsten, Mary, 60, 70

Foulis, Glenda, 221

Francis, David, 53, 80, 130

Frederick, Jane, 53

Freeburger, Wendy, 60, 199

Freeman, Paul, 53

French, Suzanne, 61

Freshney, Merry, 24, 53

Frey, Kristen, 34, 43

Frost, Russell

Fuller, Elizabeth, 43, 89

Fullmer, Carey, 54, 177

Fullmer, Daniel, 43, 177

Fumbah, Amanda, 221

Funtik, Jan, 43

Gabler, Timothy, 221

Gabriel, James

Gaines, Kenneth

Galbraith, Elizabeth, 43

Galbreath, Teresa, 43,88

Gale, Janet

Gall, Kimberly, 34, 104, 180

Gallian, Gary, 43, 187, 188

Galt, Deborah

Gardner, Patricia, 61, 154

Gardener, Peter, 60, 106

Gardener, Venessa, 43

Gawthrop, Denise, 18, 61, 204

Gehrke, Joel, 31, 43, 163

Gerber, Wynn, 97, 176, 177,

178, 221

German, James

Geshay, Barbara, 54

Gettle, Paulette, 43, 68

Gibbons, Tawanna, 206

Gidley, Deborah, 221

Gidley, Steven, 222

Gierhart, Deborah, 77, 150, 204, 222

Gifford, Warren, 29, 30, 97, 182,

183,222

Gifford, Wynn, 43, 183

Gilbert, Allen, 43, 147

Gilbert, Brenda, 43, 68, 84

Gilbert, David, 61

Gilbert, Pennie, 68, 203, 222

Giles, Brenda, 130, 145, 222

Gillenwater, Deborah, 43

Gillenwater, Dennis

Gillespie, Frank, 43

Gillespie, Robert, 222

Gillette, Dan

Gilliland, Lana, 157

Gilmour, Bonnie, 43

Gilmour, William, 61

Given, Dennis

Glassey, Keith, 61, 68, 77, 139 , 150
Glenney, David, 61

Glenney, Sandra, 61

Glidden, Roger, 43, 146, 183 Globig, Renee

Glover, Staranna, 66, 222 Godby, Paul, 61, 80

Godby, Wayne, 61 Godby, William

Grace, Karen, 222

Gradish, Linda, 61

Grafton, Linda, 43

Graham, Donald

Graham, Joy, 88, 163

Grahl, Faith, 21, 43, 155 Graves, William

Gray, Karen, 18, 61, 202, 206

Green, Carole, 36, 61

Green, Daniel, 22, 40, 43, 87, 206

Green, Dann, 43, 188, 207

Green, Kathy, 24, 25, 180 Green, Sharon

Greetham, Fred, 54, 177, 178 Gregory, David, 53, 154 Gregory, Elaine, 53

Grenier, James, 43, 78, 80

Greve, Marsha, 18, 43 Grier, Kevin, 54

Grimmett, Patricia, 19, 222 Grisham, Betty

Grisham, Cynthia, 43 Grisham, Mark, 43

Gromacki, Gary, 43, 89, 192 , 193

Grooms, Dewayne, 53, 154, 155

Gross, Gary, 53, 80, 84

Groves, Deborah, 43, 66

Guenther, Bonnie, 43, 66, 84, 93,144

Haga, Karen, 18, 69, 86, 87; 158,206

Hager, Timothy, 164, 223

Hall, Cynthia, 51, 54, 66

Hamer, Rebecca, 61 Hamilton, Tim

Hammond, Cathy, 163, 223

Hammond, Pamela, 43, 180, 181

Hammond, Robert

Hancock, Stephen, 43, 177

Handyside, Ken, 223

Hansen, Mary Jane, 54

Hanson, David, 44

Hanson, Joel, 44

Hanson, Lois, 163, 223

Hanson, Robert, 54

Harding, Kurt, 58, 61, 97, 198

Hare, Donald, 29, 30, 164, 223

Hargis, Carla, 19, 61, 88, 89

Hargis, Randi, 44

Harkleroad, Daniel, 61, 97, 100

Harkleroad, Mason, 96, 97, 223

Harkless, Judith, 54, 130

Harkness, Dean

Harley, Rick, 44, 163

Harriman, Joel, 210, 223 Harris, James Harris, Karen

Harris, Mary, 34, 157

Harrison, Bonnie, 44, 154

Harrison, Denise, 44

Harrison, Pam, 61, 68, 133 Hartzell, Brooks Hartzell, Harry Hartzell, Janet Hatfield, Charles

Hathaway, Kevin, 44, 106

Hattenfield, Debra, 18, 19, 61

Hawkins, Cecilia, 44

Hayes, Philip, 172, 210, 214,

Hayes, Steven, 44

Hayes, William, 22, 44, 155

Hazel, Dona, 18, 54

Hazel, Douglas, 61

Hazzard, Linda

Heagy, Barry, 9, 21, 61, 147, 163

Heatly, Cathy, 44, 88, 89

Heffernan, David, 44

Henderson, Kim, 24, 44, 88

Henderson, Timothy, 44

Henning, Ann, 61, 88, 89, 93, 206

Henry, Pat, 91, 223, 206

Henslin, Bruce, 23, 31, 32, 58,

$61,97,163,183$

Henson, Judy, 44, 102, 103

Hermansky, Kim, 44

Hernandez, Michael

Herron, Cheryl, 44, 66

Herzberger, Dwight

Heslep, Cheryl

Hicks, Daniel, 61, 79, 81, 88,

151, 154

Hicks, Lester

Higbee, Sara, 19, 44

Highman, Mark, 54, 80, 81, 84,

130

Hill, Dwain, 177

Hill, Elaine

Hill, Paul, 44

Hill, William

Hilmes, Angela, 21, 70, 224

Hinkle, Gary, 54, 66

Hinks, Dennis, 61, 77

Hinks, Judith, 61

Hinks, Richard

Hinks, Scott, 44

Hitchcock, John, 44

Hitchcock, Melodee

Hobar, Brenda, 36, 44, 180, 206

Hoffer, Jana, 22, 224

Holler, Bert, 61

Hollister, Laurene, 224

Hollopeter, Mark

Holman, Stephen, 77, 224

Holmes, Patricia, 36, 61

Hopkins, Sharon, 224

Horne, Marilyn, 24, 61, 155, 206

Hornsby, Gary

Houmes, Karla, 68, 224

Howard, Brenda, 44

Howard, Deborah, 19, 61

Howard, Elaine, 224

Howard, Kenneth, 29, 30, 224

Howard, Timothy, 44

Howe, Gregory, 44, 75, 155

Hoy, Steven, 61, 70, 80, 157

Hudson, Terrell, 61

Huffman, Carolyn, 21, 44, 155

Huffman, Donald, 54

Hufzinger, Leslie 
Hunn, Denise, 61, 68, 130

Hunt, Margaret, 44

Hunter, Joel, 54, 150, 183, 184 Hunter, Mark, 61

Hutchison, Tom, 24, 183, 185

Isaacs, Susan, 157, 225

Iseminger, John, 38, 225

Jackson, Debbie, 78, 206

Jackson, Dorothy, 78, 206

Jackson, Micheal, 163, 183, 225

Jacobitz, Janet, 34, 104, 225

Jacobs, Cindy, 44, 163

James, Brenda 44, 66

James, Catherine, 61, 70

James, Deborah, 18, 61

Jamison, James, 54, 156, 157

Jansen, Dawn, 18, 40, 44, 66,

84,163

Jant, Keith, 225

Jarvis, David, 30, 97 Jeffery, Joyce

Jeffords, John, 225

Jenkins, Joe, 10, 30, 78, 225

Jenkins, Robin, 44

Jenkins, Susan, 44, 66, 154 Jenson, John

Jerisk, Francine, 44

Johnson, Brad, 44

Johnson, Charlene, 44, 66

Johnson, David, 44, 66, 198 Johnson, Jill, 44, 66

Johnson, Lynn, 225

Johnson, Marilynn, 44

Johnson, Martha, 44, 66, 93 Johnson, Russell

Johnson, Wes, 94, 130, 164, 188 , $189,214,226$ Jones, Alice Jones, Carman Jones, Cindy, 44

Jones, Cynthia, 66

Jones, Dianne, 54, 155

Jones, Kenneth, 155, 177, 195

Jones, Linda, 61, 68

Jones, Mark, 44, 80

Jones, Mary Kathleen, 61 Jones, Rick

Jones, Sherri, 8, 54, 141

Joseph, David, 62

Jutton, Tawn, 114, 226

Kaffenbarger, Dan, 54

Kamphausen, Margaret, 45 Karki, Mark

Karsian, Kris, 45

Kauffman, Kim, 45, 98, 100, 207

Kauffman, Paul, 62, 154

Kaufman, Jack, 183

Kaufman, Janice, 54, 70

Kaufman, Robert, 22, 45, 80

Kearbey, Kathy, 38, 54

Kearbey, Tamera

Keener, Jsoeph

Kehus, Ruth

Keizer, Bruce, 147. 157, 163, 164,226

Keller, Cheryl, 18, 45, 88, 93

Kelso, Denise, 18, 54, 66

Keough, Mark, 105, 151

Kerrigan, Kenneth, 62, 95

Kerrigan, Susan, 45

Kessel, Michael, 54, 80, 163, 206

Kessler, William, 54, 93

Kester, Paul, 30

Keys, Deborah, 45
Keysor, Loretta, 226

Kimball, Kristi, 18, 45

King, Alan, 62

King, Beth

Kinkade, Russell

Kinkle, Rochelle, 62, 93, 155

Kinney, Colleen, 19, 45

Kirby, Keith, 195

Kirby, Mark, 54

Kirk, Desiree, 22, 54

Kiser, JoAnn, 18, 45, 68, 163

Kisner, David, 62, 166

Kitchen, Debbie, 54

Klamm, Joyce, 38, 45, 102

Klimek, Rebecca, 93, 167, 226

Kline, Rick, 82, 77, 130, 212 , 226

Knowles, Phil, 79

Knudsen, Judy, 62

Kobalka, Joe, 45, 155

Koch, Anna

Kolk, David, 45

Kollar, James, 106, 107

Koons, Camilla, 226

Kozma, Paula, 45

Krause, Gladys, 45, 88

Krejci, Rick, 54

Krewson, Richard, 45, 139

Krick, Mary, 45

Kriel, Patricia, 54

Krull, Debra, 226

Kuhn, Catherine, 18, 45, 66

Kuhn, John, 45

Kulp, Susan, 34, 45, 180

Kuntzelman, Susan, 34, 55, 70

Kuschel, Linda, 24, 45, 206

Kyle, Dana

LaBelle, David, 38, 226

LaHaye, Lori, 15, 45, 70, 75

Lamb, Amy, 132, 227

Lambert, Jayne, 62

Lambert, Keith, 62

Lancaster, Carol, 36, 62, 180

Landis, Mark, 38, 55

Lane, Betsy, 45, 68

Langford, Karen, 18, 46, 66

Lanphier, Bill, 55

Lantz, Jerry, 55, 98, 100, 101, 142

Lapp, Karen, 19, 46, 66, 154, 93

Larson, Mark, 55

Larson, Valerie, 18, 46

LaRue, David, 46, 70, 77

Lathrop, Lorita, 70

Lawrence, Deborah, 46, 70

Laxton, Frederick, 55, 88, 89 ,

150,172

Lazar, David

Leach, Fonda, 46

Leatherman, Daniel

Lee, Kevin

Lee, Michael

Leeke, Debra, 227

Leeke, Jo, 55, 68, 130

Lehnhart, Kenneth

Leightenheimer, James, 46, 76,

75,146

Leisure, Mia, 144, 227

Lenox, Denise, 46, 227

Lenox, Doretta

Leston, Philip, 62

Levering, Fran, 46

Levin, Sharon, 22, 46, 88, 89,

155

Lewis, Donald

Lewis, Tim, 46
Leyland, Leslie, 55

Lightner, Nancy, 46, 91

Lillback, Doug, 46

Linamen, Nick, 46, 66, 118

Linger, Penelope, 164, 227

Livingood, Ross, 62, 200

Lloyd, Guy, 62

Loach, Barb

Lloyd, Roger

Lofgren, Christine, 62, 68, 69, $77,84,87$

Logsdon, Sally, 55, 88

Lones, Deborah, 19, 227

Lones, Mark, 46

Lones, Steve, 98, 183

Longnecker, Grace, 62, 207

Longnecker, Joel, 55

Longnecker, Nathan, 46

Lord, Kathleen, 62 Lotz, Ruth, 227

Lough, Deborah

Lowis, Janet, 55

Lowrey, Randall

Luce, Jim, 46, 88, 89, 177 Lucht, Joyce

Luedeke, Richard, 62, 79, 91, 93

Luers, LuAnn, 18, 55 Lufkin, Linda

Lutman, Vernon, 62

Lutz, Thomas, 62, 130

Lynch, Dave, 186, 188

Lyons, David, 22, 62, 167

MacDermaid, Andrea, 34, 62,

102

Madeen, Brenda, 227

Major, Byron, 46, 70, 161

Malakar, Promode, 46

Maloney, Vance, 55

Mangum, Brenda, 227

Mariage, Michael, 228

Marihugh, Julie, 46, 66

Marland, Donna, 55, 141

Martens, Margot, 68

Martin, Cynthia, 46

Martin, Debby, 18, 158, 228

Martin, Ruth, 46, 68

Martin, Sheree, 228

Marvin, Dawn, 34, 55

Mary, Michael, 38, 228

Mason, Lydia, 62

Mast, Deborah, 46, 203

Masters, Kevin, 46

Matheny, Lisa, 22, 46

Matthews, Stanley, 46

Mattox, Dale, 62, 97, 151

Maust, Dan

May, Calvin, 163

Mayo, Margie, 46

Mayo, Michelle, 18, 62

McBride, Brenda, 19, 47 McCardle, Glenn

McClendon, Richard, 55, 80

McClure, Lisa, 55, 77

McClure, Michelle, 47, 68, 155

McCracken, Carlton, 38, 228

McCracken, Gerald, 47

McCrorey, Bradley

McCullough, Paul, 47, 95

McDonald, Debra, 47

McDonald, Edwin, 47

McDougal, Kent, 21

McDougal, Mark, 62, 85, 207,

McFadden, 211

McFarland, Carol, 228

McGhee, Daniel, 47, 106

McKee, Barbara, 68, 228

McLane, Connie, 47, 85, 155

McLouth, Edwin, 47

McMillan, Gene, 22, 62, 173

McMillan, Ronald

McMillen, Susan, 62

McMurray, David, 62, 88, 89,

155

McMurray, Karen, 47, 88, 155

McNiece, Wendy, 86, 173, 228

Medlock, Brian, 55, 188

Medlock, Ron, 55, 188

Meeker, Renee, 62, 66

Melford, Donald

Menninger, Leah, 47

Merchant, Mahlon

Merchant, Robert

Mesner, Stephanie, 19, 22, 62

Messenger, David, 22, 55, 66,

88, 132

Metzger, Karen, 62

Metzler, Joyce, 55, 77

Michaels, Ethel

Michalski, Patricia, 47

Michel, Roger, 47, 188

Mignard, Michael, 30, 55, 97

Milbauer, Brad, 21, 47, 66

Miller, Alice, 228

Miller, Brenda, 155

Miller, Brian, 55, 94

Miller, Craig, 22, 51, 55, 87, 93,

$155,163,206$

Miller, Cynthia, 47, 88, 93, 201

Miller, Darlene, 55, 203

Miller, Karen, 229

Miller, Leah, 47, 68

Miller, Philip, 51, 55, 155, 163

Miller, Ronald, 94, 229

Miller, Stephan, 23, 62, 206

Miner, Albert

Miner, Kathryn, 229

Mitchell, Douglas, 47

Mitchell, George

Moberly, Sharon, 55

Modica, Virginia, 229

Mohler, John, 55, 93, 155, 160,

161

Mohler, Thomas, 62, 88, 89, 172

Molin, Patti, 18, 23, 47

Monday, Pamela, 62

Monroe, Charles

Monroe, Linda

Monts, Diane, 62, 87, 206

Moore, Diane, 34, 35, 47

Moore, Jane, 55, 66

Moore, Lisa, 229

Moore, Martha, 19

Moore, Paul, 47

Moore, Rayanne, 47, 163

Moore, Tim

Morgan, Alan, 55, 70, 80

Morley, Carla, 70, 210, 211, 229

Morris, Cheryl, 55, 70

Morris, David, 47

Norton, Douglas, 23, 47

Mosbacker, Barret 
Nace, Jack, 62, 70

Namy, Karen

Namy, Keith, 62, 138

Napier, Carolyn, 47, 180

Nauta, Marilyn, 77, 159, 190,

191, 198, 201, 229

Neal, Lori, 55, 130

Neally, Brenda, 55, 70

Neely, James, 47

Neely, Janie, 62, 154 Neff, Randy

Nelson, Michael, 62, 70, 77, 167, 198

Nelson, Samuel, 47

Nicholl, Gary, 62, 155 Nichols, James

Nichols, Joyce, 229

Noble, Dewey, 30, 62 North, Barbara

North, Paul, 62, 88, 89

Northcutt, Ruth, 19, 47, 66

Norton, Rachel, 36, 55, 104

Oakes, Kathy, 47

Ockert, Judith, 47 Odom, Terry

Olden, Renae, 47

Oliver, Leslie, 47

Olson, Charlotte, 19, 63, 66, 87, 149,168

Ometz, Farris

O'Neal, Tim, 55, 103, 143 O'Quinn, Cindy

O'Quinn, Mike, 40, 47, 87

Ormsbee, David, 63, 167, 206

Orrick, Cynthia, 55, 66, 104

Osborne, Kathr 47, 74

Ott, Sally, 82, ? 230 Otto, D. $\quad 47$

Overturf, Lisa, 55, 1לo, _J5 Pack, William, 47

Palmer, Laura, 63, 104, 191

Paradiso, Susan, 198

Park, Michele, 36, 63 Park, Russell, 94 Parke, Linda, 55

Parker, Evelyn, 63, 70 Parlier, Timothy

Partridge, Donna, 47, 66

Parvin, Donald, 24, 47, 155 Pasma, Andrew

Pasma, Timothy, 15, 92, 130, $160,161,230$

Passmore, Burdette

Patterson, Mark, 56

Patton, Jay, 63, 66

Patton, Lynda, 18, 47, 68, 77 Payne, John

Payne, Karen, 47, 66

Payne, Kathy, 47, 88

Payne, Kelly, 48

Payne, Nancy, 56

Pearce, Sally, 63

Penquite, Landa, 36, 48, 191

Perry, James

Perry, Roxanne, 63

Perry, Susan, 63, 154, 206

Peters, Mark, 48, 70, 80, 183,

Peterson, Judy, 48

Peterson, Mark, 63

Peterson, Martha, 230

Peterson, Richard, 48, 68

Petry, Stephen Phillips, Ann

Phillips, Claire, 22, 56, 86, 87, $98,154,206$
Phillips, Glendolyn

Pickard, Kimberly

Pierce, Mark, 48

Pinson, Jeff, 56, 146

Pippin, Donald, 48, 106, 107

Pippin, Jeanne, 63, 79, 91

Poling, 63, 87, 156, 157, 163

Polley, Franklin, 48, 66

Poole, Daniel, 48, 201

Porter, Cindi, 10, 154, 165, 230

Porter, Georgette

Poskey, Cynthia, 56

Potter, John, 51, 56, 97, 98, 99 , 207

Powers, Cynthia, 22, 230

Prentice, Beth, 56, 66, 89

Pressau, Martin, 56, 66

Price, Karen, 56, 87, 137

Price, Kathy, 48, 148

Price, Sally, 144, 230

Price, Vera, 56

Pringle, Kevin

Priola, Jo Ellen, 36, 105, 180,

230

Pristera, Val, 210, 214, 230

Prugh, Jane, 56, 203

Pruitt, Jocelyn, 48

Putman, Gaye, 56

Qualls, Quentin

Quinn, Donald, 63, 95

Raber, Jon, 63, 88, 89, 155

Radcliff, Carol, 68, 163, 172,

230

Radcliff, Charles, 48

Radcliff, Jeff

Radcliffe, Donna, 77, 130, 157,

$166,198,199,206,231$

Rae, Diana, 8, 23, 130, 173, 231

Raye, Michael

Randall, Lee, 48, 188

Ransom, Deborah, 63

Rapinchuk, Debbie, 48

Rarick, Edward, 56

Rasmussen, Cindy, 48

Ratzlaff, Michael, 56, 177, 178,

179

Ray, Cheryl, 22

Rayburn, Marilyn, 56

Reder, Tim, 231

Redinger, Ellen, 51, 56

Reed, Cynthia, 56

Reep, Jeff, 98, 100

Rees, Chris, 63

Regling, Richard

Regling, Susanne, 63

Rehn, Nathan, 48, 168

Reid, Deborah, 48, 154, 231

Reid, Rebecca, 18, 19, 163, 167, 214,231

Reinhart, Rick, 48

Reitnauer, Nancy, 19, 63

Reno, William

Repp, Darlene, 11, 23, 48, 151

Reu, Janice, 48

Reu, Nancy, 130, 157, 231

Reynolds, Patricia, 56, 154

Reynolds, Sandy, 88

Rhines, Lorelei

Rhodes, Joan, 48

Rhodes, Kenneth, 231

Rice, Keith, 192, 193

Rich, David, 63, 143

Richards, Janice, 63

Richards, Lee, 48

Richardson, Douglas, 48, 198

Ricker, Rose, 82, 231
Riddle, David, 68, 70, 192, 193,

200,201

Riedel, Daniel, 70, 157, 214, 231

Rife, Wanda, 48, 77

Riggs, Brian, 48, 100

Risser, Laura, 34, 63, 104 Ritchie, Sharon

Riter, Judith, 11, 51, 56, 76, 88, $91,93,154,200$

Robb, Karen, 231

Roberts, Eddie, 206, 232

Roberts, Lloyd, 56, 88, 89

Robery, Deborah, 18, 63, 70

Robinson, Christine, 48 Rock, David, 63

Rogers, David, 56, 68, 183, 184

Rogers, Rhonda, 19, 22, 63

Rogers, Robert, 10, 154, 232

Rohde, Joseph, 56, 80

Rohm, Cathy, 63

Rollman, Irvin, 48

Roloff, William, 22, 64

Romein, Marcia, 56

Ross, Amy, 64, 70, 85, 137, 190, 191,198

Ross, Julie, 180 Rossi, David Rossi, Lori

Roth, Barbara, 18, 34, 56 Roush, Betty, 56

Rowe, Danny, 183

Rowe, Wes, 38, 64, 70, 97, 177 , 178

Rowland, Charolette, 232

Rowland, Steven, 71, 232

Rowland, Tim, 64, 71, 157

Ruh, Clark, 56, 134 Ruiz, Tomas, 56

Rupe, Rebecca, 48 Sabados, Bruce

Sagraves, Joyce, 48

Salmonas, Tate, 57

Salter, Robert, 48

Salyer, Larry, 64

Salzman, Christine, 48, 155

Sanderlin, Debbie, 56, 68

Sands, Dorene, 36, 56, 104

Sarver, Clyde, 48, 180 Saunders, Jim

Sawyer, Karen, 232 Schatz, Dawn

Schatz, Rhoda, 48 Schatz, Twila, 48

Schieber, Debbie, 48, 68

Schierwagen, Elizbeth, 64

Schlesinger, Jeffrey, 232

Schmutzler, Paul, 48, 80, 183

Schneeberger, Beverly

Schneeberger, Martha, 148

Schnell, Paul, 66, 232

Schneider, Kay, 68, 232

Schofield, Terri, 48

Schuchard, Mark, 48, 68, 80

Schweitzer, Debbie, 64, 198

Schwerthofer, JoAnn, 48

Scoggins, Sheryl, 18, 40, 48, 66, 163,203

Scott, Dean, 21, 30, 55, 80, 163 Scott, Peggy, 64 Scott, Susan, 56

Searles, Calvin, 66, 177, 207,

232

Seeley, Mark, 94, 130, 163, 233

Seger, Marcia, 48, 77

Segerstrom, Bryan, 64, 77

Selden, Debbie, 34, 104, 180

Selden, Rebecca, 11, 34, 64, 102, 155

Self, Dan, 97, 106, 151, 233

Sewell, Karen, 22, 49

Seymour, Karen, 56, 93, 154

Seymour, Nancy

Seymour, Robert John

Seymour, Robert Judson, 233

Shaffer, Earl, 66, 233

Shaner, Jim, 106

Shanks, Kathy

Shaver, Michael, 32, 51

Shaw, Dale, 32, 49, 134, 183

Shaw, Martin, $58,64,71,80$, 157

Shaw, Sharon, 18, 56, 204

Shedden, Rachael, 49, 68

Sheldon, Ronald, 49

Shelton, Linda, 233

Shenefield, Lynda

Shenefield, Paul, 65

Sherwood, Janice, 48

Shubert, Timothy, 49, 66

Shugars, Melissa, 64, 204

Shumaker, Dawn, 19, 64, 130, 162

Sigmon, Mark, 10, 22, 154, 163, 233

Sikora, Janet

Sikora, Michael, 233

Simmons, Kim 145

Simpson, Andrew, 24, 49, 93

Sininger, Rebecca, 68, 130, 233

Sirka, Colleen, 49

Slicker, Susan, 235

Slusher, Patty, 49, 75

Slusher, Pete, 64, 97, 192

Smart, Kathleen

Smith, Bryan, 183, 185

Smith, Cathy, 18, 64

Smith, Dennis

Smith, Donald, 98, 100, 201

Smith, Eric, 22, 49

Smith, George

Smith, Jack, 49

Smith, Judith, 18, 64, 157, 206

Smith, Kim, 49, 66, 103

Smith, Melanie, 56

Smith, Michael

Smith, Paul

Smith, Philip K., 139, 234

Smith, Philiip G., 234

Smith, Rachel, 56, 157

Smith, Randell

Smith, Richard, 49, 194

Smith, Ronda, 56

Smith, Terri, 234

Smooth, Ginny, 234

Snook, Nancy, 36, 49

Snyder, Karen, 49, 88

Snyder, Stephen, 49

Sollenne, Karen, 22, 70, 140,

234

Sorber, Dan, 49

Spencer, Dawn, 64, 93, 154 
Stahl, Debra, 36, 234

Stairs, Margaret, 49, 137

Stairs, Stephen, $38,70,97,187$, 188,234

Stanaway, Terry, 56, 100, 194 Starback, Christopher, 49, 87,

95

Stauffer, Lynette, 64, 154, 155 Stebner, Regina Stehlik, Lorie, 49

Steinhofer, Karen, 49, 66

Stephens, Craig, 38, 150, 235 Stephens, Michael, 49 Stephenson, Susan, 49

Stewart, David, 49, 177

Stewart, Steven, 235

Stewart, Teresa, 235

Stickel, Dennis, 64

Stickelman, Ron, 49, 80

Stigers, Loyd, 64, 88, 89 Stone, Lewis

Stone, Virginia, 23, 49

Stoner, David, 24, 29, 30, 64, $97,130,134,206$

Stoner, Timothy, 22, 30, 65

Storch, David, 23, 155, 235

Storch, Deborah, 65, 92, 190 ,

Storer, Charlene, 49

Storey, Robert, 235

Storm, Gary, 106, 118, 235 Storm, Nancy

Street, Rebecca, 65, 130

Streitmatter, Mark, 56, 98, 100, $143,183,207$

Streitmatter, Marla, 18

Strickland, Cynthia, 56

Strickland, Dwight, 235

Strock, Steve, 22, 24, 49

Stuenzi, Linda, 65, 157

Stump, Steven, 38, 65 Sullivan, Jenet, 65

Summerlin, Beth, 49

Summerlin, Leigh, 65, 130

Surso, Joan, 56, 66, 91, 154, 198

Sutliff, Audrey, 235

Swank, Calvin, 49

Swayze, Steve, 50, 88, 89, 188

Sweeney, Gwena, 57, 78

Tacderan, Sheryl, 50

Tallmon, Rebecca

Tanner, Judith, 65

Tawney, David, 235

Taylor, Bonnie, 23, 206, 236

Taylor, Christine, 144, 205, 236

Taylor, Daniel, 57, 192, 193

Taylor, Irene, 65, 70, 200

Taylor, Priscilla, 57

Taylor, Rhonda, 18, 65, 66, 88 ,

Taylor, Shawn, 36, 50, 105, 191

Tedeschi, Jane, 50, 87

Terkildsen, Nayda, 50, 87

Terlouw, Lila, 58, 65, 68, 157,

161

Terlouw, Steven, 50, 130

Ternak, Armand, 92, 106, 236

Terrell, Joseph, 89, 236

Terwilleger, Alan, 65, 118

Thacker, Zachary, 97, 98, 236

Thomas, Deborah, 65, 163

Thomas, John, 236

Thomas, Ron, 32, 97, 236

Thomas, Sherri, 57

Thomas, Susan, 236

Thompson, Stephen, 57, 80
Throckmorton, Warren, 57, 68, $78,91,130,172$

Tichenor, Sheryle, 9, 57

Tillman, Nancy, 50

Tillson, Darlene, 50, 103

Tindall, Barry, 50

Titus, Kathy, 50

Titus, Stephen, 57, 88, 89

Toelcke, Dorothy, 65

Toro, Beverly

Toro, Debbie, 57

Totman, Valerie, 36,65

Towle, Nancy, 24, 34, 35

Towle, Stacy, 25, 50

Townsend, James, 65

Townsend, Pat, 19, 65, 88, 89, 236

Tresse, Dana

Tresse, David, 50

Turner, Kathleen, 36, 50

Turner, Virginia

Twigg, Larry, 57, 80

Twigg, Terry, 237

Ulrich, Robert, 57

Ulsh, Cay, 237

Unroe, Nancy, 50, 155

Utley, Sheralee, 57

Uyenishi, Stephen, 38, 96, 97,

177

Uzzel, Rodney

Vail, Marienne, 50, 180

Valentine, David

VanCompernolle, Valerie, 65

Van der Hoeven, Peggy, 23, 57

Van Ryn, Debra, 50, 151

Varner, Sherry

Vassari, Helen, 19, 68, 144, 157, 164,237

Veldt, Joel, 21, 50, 77, 163

Vernon, Diane, 50, 68

Vincent, Matt, 50, 88, 89, 95

Vinson, Michael, 237

Vitt, Ellen, 237

Vitt, Frank, 38, 237

Vogel, Julie, 57, 163, 206

Waddell, Allen

Waddle, Mischelle, 70, 237

Waggoner, Bryan, 77, 87, 167, 207, 237

Wagner, Barb, 144, 237

Wagner, David, 65, 88, 89, 154

Wagner, Glenna, 65, 88

Wagner, Jennifer, 18, 68, 238

Wagner, Joyce

Wagner, Randy, 57, 88, 89, 154

Wagner, Ruth, 57, 87

Wagner, Tina, 57,87

Waiters, Kevin, 65, 97, 98, 101

Waites, Kimberly, 50

Walborn, John, 10

Waldo, Jeff, 40

Waldo, Pam

Walker, Carol, 57

Walker, Catherine, 57

Walker, Dixie

Wall, Terry, 194

Ward, Jearl, 50, 66, 91, 158

Ward, Virginia, 50, 88, 154

Warix, Jeff, 57, 76

Warren, Mark, 154

Washburn, Perry

Watson, Paul

Watts, Cherie, $18,58,65,81$, 130, 149

Webber, Allen, 57, 88, 89, 154

Webster, Karen, 57, 148
Weimer, Douglas, 50 Weller, Barry, 65

Weller, Kathy, 50, 180

West, Bradley, 50

West, Dale, 51, 57, 106, 107

West, Lydia, 15, 65, 91, 149 157,212

Wetzel, Danette, 50, 70, 88, 154

Wheeler, Joyce, 19, 65

Whitaker, Brian, 65, 80

White, Marilyn, 144, 238

Whitelaw, Faith, 65, 119

Whitestine, Claudia, 57, 154

Whiting, Thomas, 50

Wickham, Gregory

Wickman, Daniel, 65, 80, 154,

163,206

Wigton, Lorna, 238

Wildermuth, Karen, 57

Willetts, Jan, 65, 91

Willetts, Joyce, 50, 155

Willhite, Keith, 23, 40, 50, 168

Williams, Bill, 188, 238

Williams, Bruce, 38, 238

Williams, Carol, 50, 149

Williams, Evelyn

Williams, John, 50

Williams, Kathleen

Williams, Lynn, 50

Williams, Ruth, 238

Williams, Thomas, $58,65,66$, 97,106

Williamson, John, 238

Willsey, Steven, 57

Wilson, Steven, 238 Wind, Connie Wing, Sheryl

Wing, Douglas, 10, 164, 239

Winward, Robert, 57 Wise, Robyn, 65

Wishart, David, 130, 166, 239 Wittlinger, Bradley Wood, Dave G.

Wood, David L., 65, 97, 98, 195

Woodall, David, 57, 84, 88, 89 ,

Woodcock, Patricia, 239 Woodhouse, Susan

Woodruff, Allen, 21, 50, 138,

Woods, Kenneth, 50, 154

Wozniak, Michelle, 50

Wright, Cynthia, 57

Wright, Edwin, 65

Wuebben, Renee, 57, 210

Wurstner, Dale, 50

Wurstner, Sharon, 50

Wyman, Jonathan, 70, 96, 97,

Wyse, Eric, 23, 50

Yater, Leona, 57, 70

Yater, Thomas, 50, 66, 100, 183

Yhap, Joy, 50, 201

Yoder, Janice, 50, 66

Yoder, Russell, 21, 65, 68, 93, 95, 130, 135, 157

Young, Amy, 50, 68, 103

Young, Rhonda, 65, 102

Young, Richard, 58, 65, 66, 201

Youngman, Gary, 65

Youngman, Myron

Zachary, Janice, 57, 200

Zaller, Deborah, 65, 163

Zelonis, Carl, 21, 38, 65, 70, 71,

157

Ziegler, Merle, 30, 97, 170, 214, 239

Ziemer, Becky, 65, 104

Zink, Susan, 18, 57, 86, 87

Abbas, Robert, 122

Anderson, Lyle, 125, 154, 155

Armstrong, Mead, 120

Auwarter, Lorelei, 117

Baldwin, Martha, 118

Baldwin, Richard, 120

Ballard, Stanley, 22, 122

Barth, Charles, 110

Bates, Carolyn, 118

Bates, Patricia, 114

Baumann, Donald, 129

Bedford, Rudy, 110

Benefiel, Maxine, 118

Benson, Linda, 113

Bergen, Audrey, 118

Bergen, Harmon, 126

Bernstein, Barbara, 113

Bertschinger, Betty, 114

Biddle, Jim, 122

Biddle, Sharon, 15, 16, 127

Bole, John

Booth, Roger, 127

Boston, David, 112

Bowersox, Bernice, 128

Braithwaite, Edwin, 129

Bresson, Francis, 110

Brock, Lynn, 117

Brock, William, 110

Brown, Stephen, 117

Bruce, Connie, 119

Bryant, Pat, 128

Burrichter, Margaret, 119

Call, Galen, 110

Callah, Donald, 32, 124, 177, 178, 207

Carlson, Paul, 123

Carraher, James, 110

Case, Nancy, 113

Chambers, James, 118

Clark, Martin, 115

Cline, Jack, 110

Cole, Harry, 118

Conklin, Wilma, 113

Cook, Joanne, 114

Coomes, Dan, 177, 179

Coriell, Ronald, 122

Diehl, Pamela, 124, 191

Dillon, Dallas, 118

Dillon, Robert, 118

Dixon, Pat, 15, 79, 126

Dodson, Irma, 123

Dunn, Martha, 123

Durham, Richard, 121

Ellington, Charles, 125

Elmore, Austin, 129

Elmore, Marabeth, 118

Engelmann, George, 110

Fillinger, Peggy

Filson, Earl, 118

Filson, Lyle, 118

Filson, Mary

Fisher, Jean, 121

Fissel, Nancy, 119

Floyd, Sharon, 117 
Green, Harold, 22, 84, 113, 130 . 156, 206 Green, Margaret, 113 Greenwood, Edward, 126 Greenwood, May, 116

Grier, James, 121, 208, 209 Grisham, Albert, 118 Grisham, Betty, 119

Gromacki, Robert, 121 Grosh, Jody, 11, 126

Grosh, Ronald, 87, 126 Guenin, Roy, 110 Haffey, David, 120 Haffey, Debbie, 126 Halk, Michael, 118

Halsey, Joseph, 128 Harris, Karen, 119 Harvey, Dane, 129

Helmick, Larry, 129, 198 Howard, Elayne

Howell, Kathleen, 77, 112, 114,

Humm, Carla, 113 Jacobs, Jack, 110 Jeffery, Joyce, 119 Jeffords, Barbara, 114 Jeremiah, James, 8, 9, 111, 164 ,

Jeremiah, Maryalyce, 34,35 , 104,125

Johnson, Clifford, 17, 79, 110 $130,164,170$

Kaufman, Eileen, 119 Kaufman, Phil, 118

Kearney, June, 36, 124, 180, 181

Kern, Rebecca, 122

Kern, Roy, 85, 112

Killian, Larry, 129

King, Elvin, 32, 124, 182, 183 King, Toinette, 117

Kirchner, Virginia, 114 Kool, Dean, 125 Kriel, Audrey

Kriel, Constance, 118

Lawlor, George, 121

Maddox, Miriam, 126, 212

Matson, David, 125, 154

McClure, Philip, 125

McGillivray, John, 29, 30, 124, 183,184

McGoldrick, James, 128

McIntosh, Barbara, 117

McIntosh, Michael, 118

McIntosh, Richard, 121 Matson, Rebecca Mick, Bernice Mitchell, Mary, 117

Monroe, Allen, 14, 16, 128, 192

Monroe, Patricia, 116

Monroe, Robert, 88, 89, 125

Murdoch, J. Murray, 129, 186, 188,189

Murphy, J. Dale, 110

North, Barbara, 116

O'Bryon, George, 110

Orihood, Sally, 110

Parvin, Donald, 120 Payne, Jack, 125

Payne, Jacqueline, 112

Payne, Marion, 113 Peer, James, 112

Phillips, Henry, 112

Phipps, James, 15, 17, 127

Printy, Beatrice, 114, 199

Rayburn, Ethel, 117

Rayburn, Marlin, 127, 210
Rickard, Donald, 110, 163

Riggs, Jack, 15, 121

Riter, William, 120

Rossi, Lori, 118

Ruder, Esther, 117

Rufener, Christine, 114, 117

Sarver, Eldon, 118

Schulte, Elaine, 114

Scott, Jack, 95, 122

Seaman, James, 121

Seaman, Lila, 123

Sewell, Donald, 110

Seymour, Nancy, 115

Seymour, Robert, 114

Shank, Merilee, 117

Shenefield, Lynda, 119

Shirk, Carmen, 126

Smelser, Gerald, 110

Smith, Michael, 174

Smith, Stella

Smith, Thomas, 133

Spencer, Dorothy, 118

Spencer, Edward, 126

St. Clair, Ida, 118

St. Clair, Jeff, 118

St. Clair, Kenneth, 110

Stevens, Dan, 113

Strobridge, Lucia, 114

Tarter, Betty, 119

Tarter, Charles

Tassell, Paul, 110

Taylor, Virginia

Turner, Lee, 111

Tyler, Donald, 110

Vernier, Paul, 110

Walker, Richard, 114

Wetzel, Daniel, 128

White, Robert, 116

Willetts, Earl, 110

Williamson, Jay

Williamson, Jill, 113

Wineberg, Tom, 118

Wing, Sheryl, 115

Youngman, Myron, 75, 114

Zickefoose, Vicki, 123

Abundant Life, 90, 91

Academic Advisory Board, 130, 131

Advisory Twelve, 130, 131

Aletheia, 90, 91

Alpha Chi, 80, 8

Alpha Chi Resque Squad, 130, 131

Alpha Mu Chi, 198, 199

Beach Evangelism, 156, 157

Bethesda Rehabilitation, 200,

201

Bible Club, 68, 69

Brass Choir, 88, 89

Brass Quintet, 88, 89

Camera Club, 84, 85

Campus Evangelism, 200, 201

Canvassing, 92, 93

Chess Club, 94, 95

Chi Theta Pi, 198, 199

Children's Church, 204, 205

Children's Hospital, 204, 205

Choralaires, 154, 155

Concert Choir, 154, 155

Detention Home, 70, 71

Four Oaks, 202, 203

FWM, 76, 77

Gamma Chi, 18, 19

Gamma Zeta Theta, 18, 19

Jail Service, 70, 71
Joyful Sounds Trio, 90, 91

Living Hope Trio, 90, 91

Living Springs, 84, 85 MENC, 92,93

Miracle Staff, 210, 211 MIS, 206, 207 O.S.S.O., 66,67

Pep Band, 88, 89

Personnel Assistants, 130, 131

Phi Epsilon Kappa, 92, 93 Pi Delta, 92, 93

Pi Sigma Nu, 96, 97

Puppet Ministry, 66, 67, 206,

207

Rescue Mission, 200, 201

Rest Homes, 68, 69

Student Body Project, 162, 163

Student Senate, 162, 163

Swordbearers, 22, 23, 24, 25, 206, 207

Timalathians, 94, 95

Varsity C, 96, 97

Whispering Cedars, 86, 87

Wind Ensemble, 88, 89

Yellow Springs Riding Group, 202, 203 



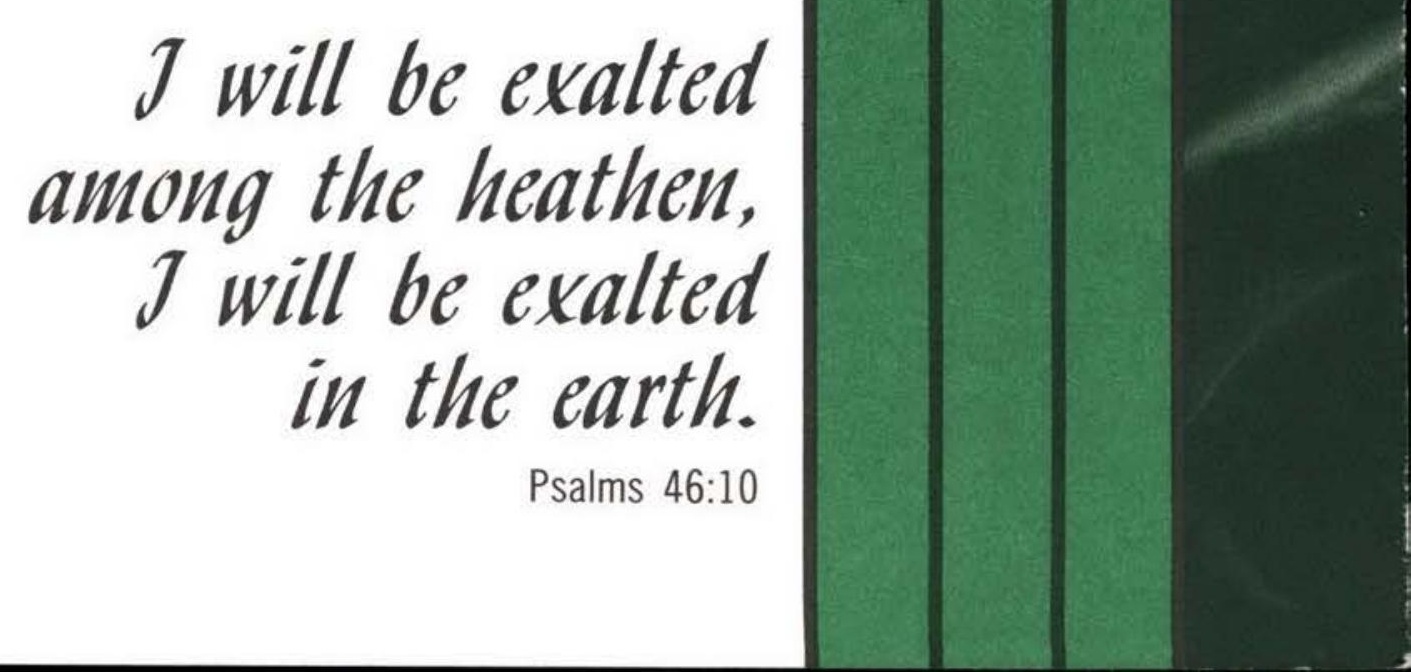




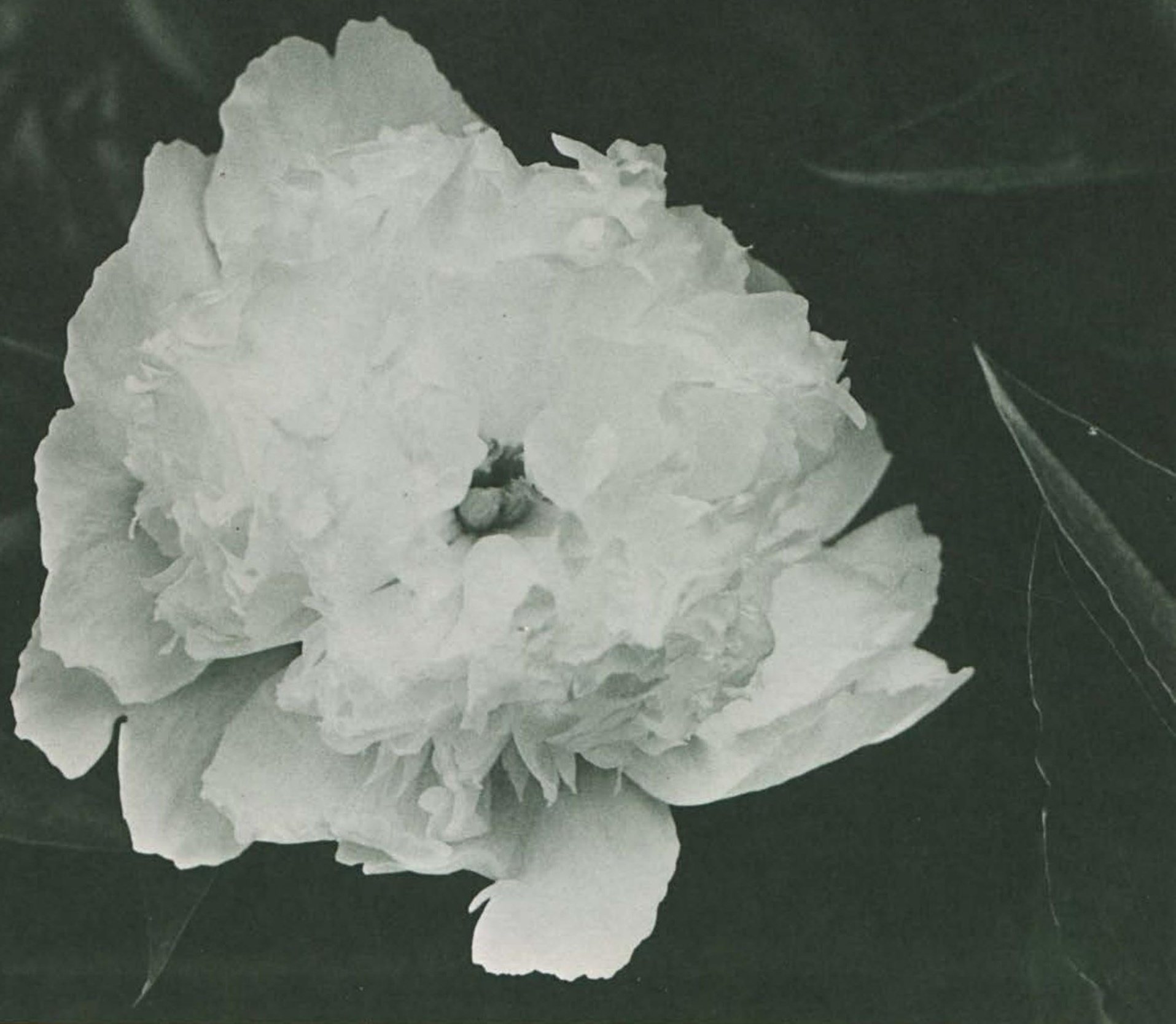


